\author{
UNIVERSIDADE DE SÃO PAULO \\ ESCOLA DE COMUNICAÇÃO E ARTES \\ DEPARTAMENTO DE MÚSICA
}

\title{
ESTUDOS INTERPRETATIVOS PARA A CONSTRUÇÃO DE UMA EDIÇÃO CRÍTICA DO CONCERTINO PARA CLARINETE DE FRANCISCO MIGNONE
}

\begin{abstract}
Dissertação apresentada ao Programa de Pósgraduação em Música, Área de Concentração: Processos de Criação Musical, Linha de Pesquisa: Técnicas Composicionais e Questões Interpretativas, da Escola de Comunicação e Artes da Universidade de São Paulo, como exigência parcial para a obtenção do Título de Mestre em Artes, sob a orientação do Prof. Dr. Gilmar Roberto Jardim.
\end{abstract}

Henrique Villas Boas de Alencar

São Paulo

2014 


\section{FOLHA DE APROVAÇÃO}

\section{ESTUDOS INTERPRETATIVOS PARA A CONSTRUÇÃO DE UMA EDIÇÃO CRÍTICA DO CONCERTINO PARA CLARINETE DE FRANCISCO MIGNONE}

Dissertação apresentada ao Programa de Pósgraduação em Música, Área de Concentração: Processos de Criação Musical, Linha de Pesquisa: Técnicas Composicionais e Questões Interpretativas, da Escola de Comunicação e Artes da Universidade de São Paulo, como exigência parcial para a obtenção do Título de Mestre em Artes, sob a orientação do Prof. Dr. Gilmar Roberto Jardim.

Henrique Villas Boas de Alencar

\section{BANCA EXAMINADORA}

Prof. Dr.

Instituição: Assinatura:

Prof. Dr.

Instituição: Assinatura:

Prof. Dr.

Instituição: Assinatura: de de 2014 
À minha esposa Mariane, à minha família, aos meus professores e alunos, a todos os músicos que se dedicam à arte com verdade no coração. 


\section{AGRADECIMENTOS}

Aos amigos Bruno Menegatti, Giovanni Matarazzo, Bruno Sanches, Ivan Vilela e, em especial, a Diogo Maia e Gil Jardim, por acreditarem neste projeto. À Josephina Mignone, à Anette Mignone, à Valéria Peixoto e à Academia Brasileira de Música. À José Botelho. À Orquestra Sinfônica da Unicamp, ao Furio e à Virgínia Damiani. 


\section{RESUMO}

O presente trabalho trata da investigação dos procedimentos composicionais utilizados no Concertino para Clarineta, de Francisco Mignone, por meio da identificação e da comparação das diversas fontes da obra em diálogo com a "tradição oral". Tem como objetivo elucidar questões técnicas observadas na partitura orquestral manuscrita e suas possíveis resoluções em virtude da performance. Para tanto, desenvolve conteúdo com vistas à produção de uma edição crítica da obra.

Palavras chaves: Mignone - Concertino - Clarineta - Clarinete - Edição Crítica - Música Brasileira - Orquestra de Câmara. 


\begin{abstract}
The present work deals with the investigation of compositional procedures used in the Concertino for Clarinet by Francisco Mignone through the identification and comparison of different sources of the work in dialogue with the "oral tradition". Aims to clarify technical issues observed in handwritten orchestral score and their possible resolutions to the performance. For that, develops content in order to produce a critical edition of the work.
\end{abstract}

Key words: Mignone - Concertino - Clarinet - Critical Edition - Brazilian Music - Chamber Orchestra. 


\section{SUMÁRIO}

AGRADECIMENTOS

RESUMO

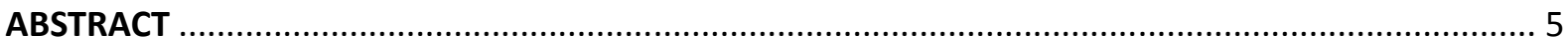

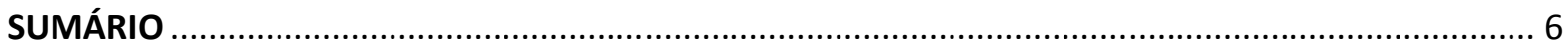

INTRODUÇÃO

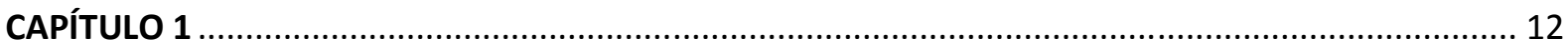

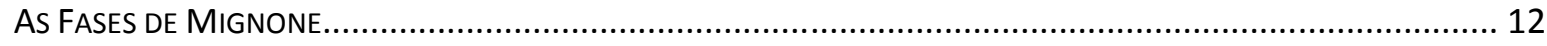

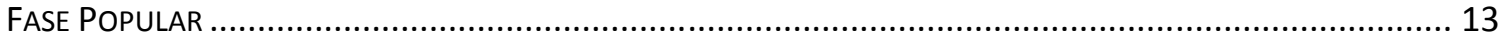

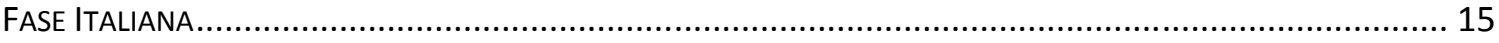

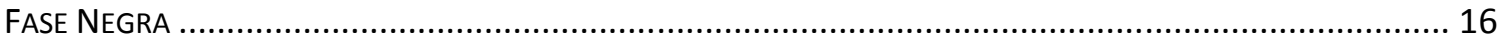

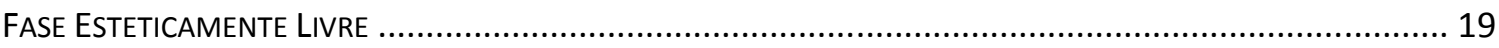

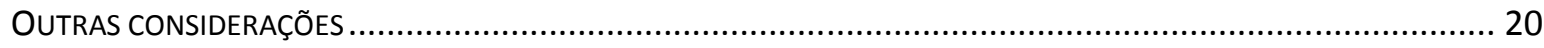

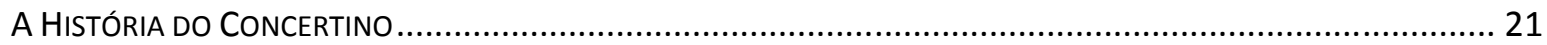

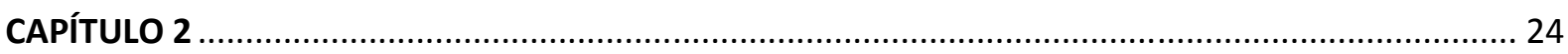

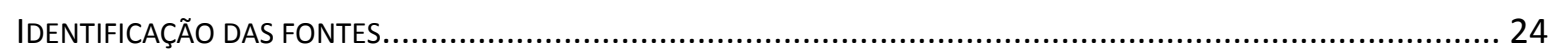

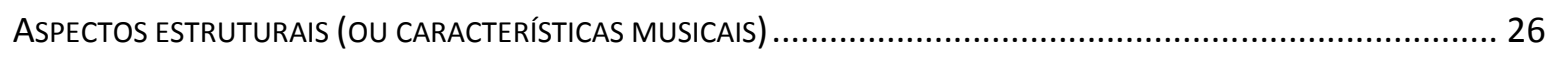

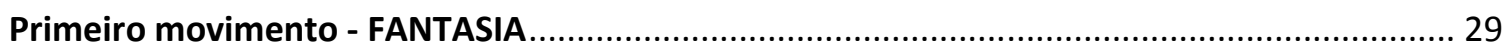

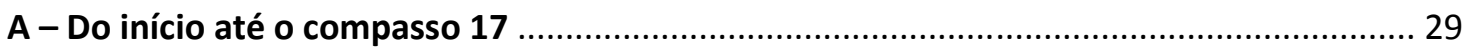

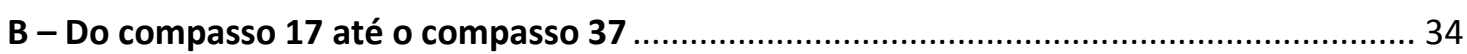

C - Do compasso 38 até o 52

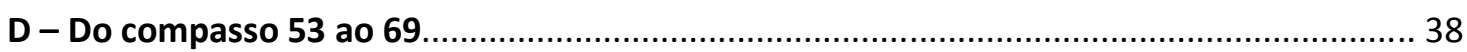

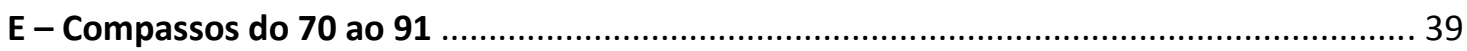

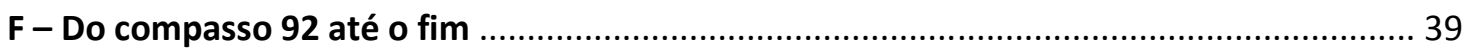

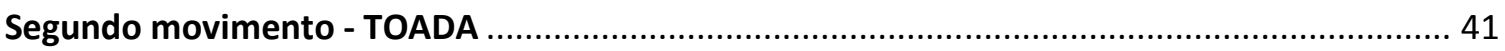

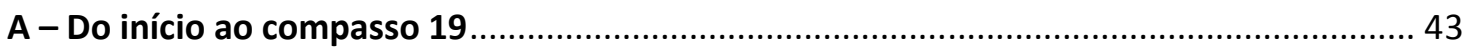

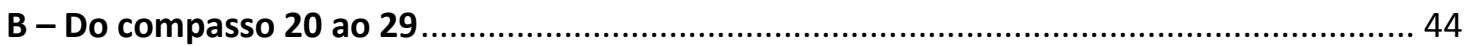

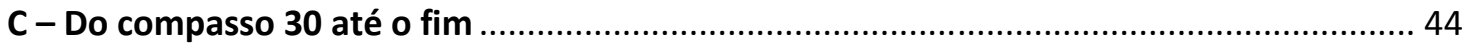

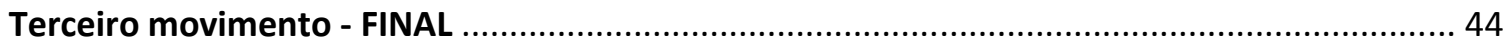

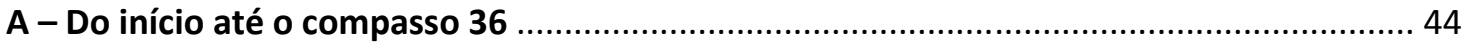

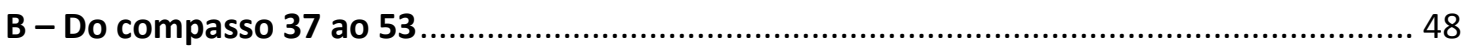

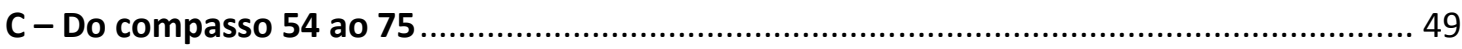

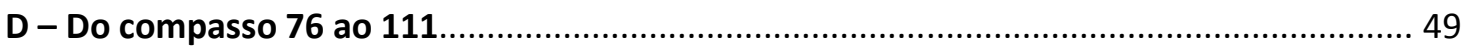




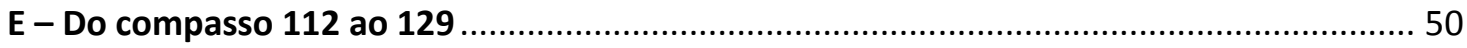

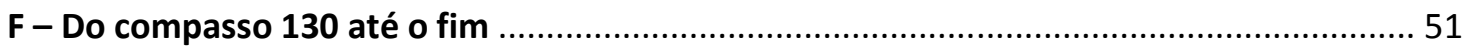

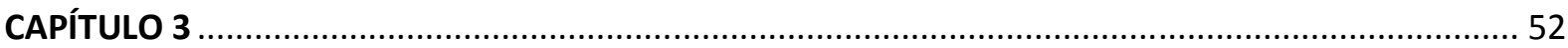

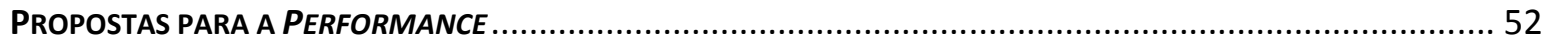

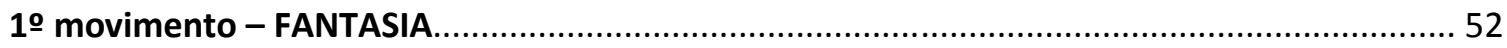

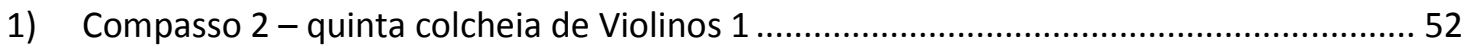

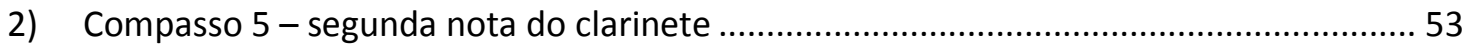

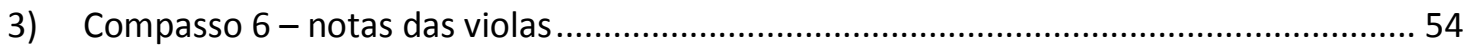

4) Compasso 9 - primeira nota do clarinete e do contrabaixo ............................................ 56

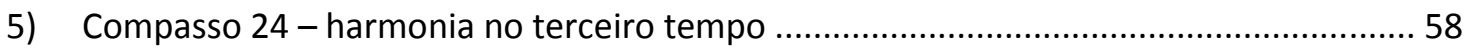

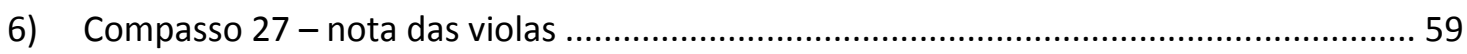

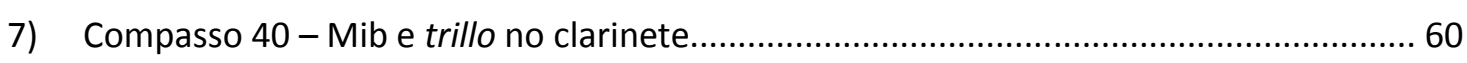

8) Compasso 44 - nota da segunda semicolcheia do terceiro tempo ................................... 62

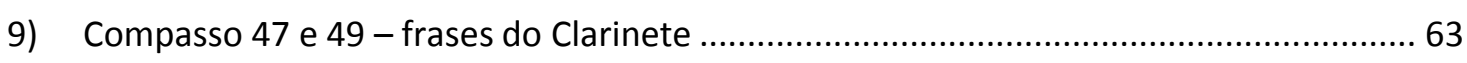

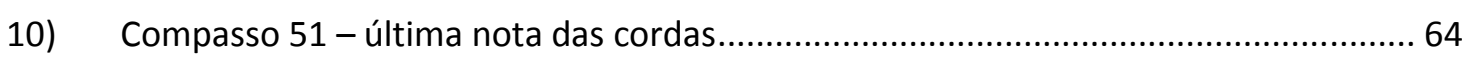

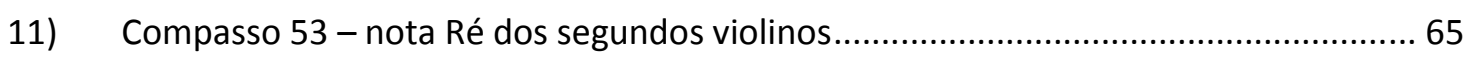

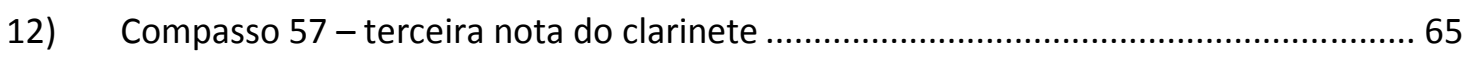

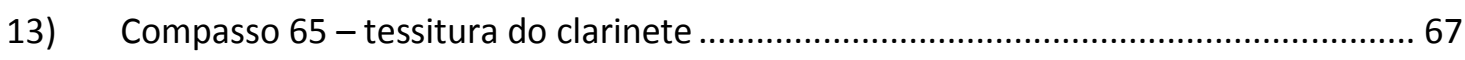

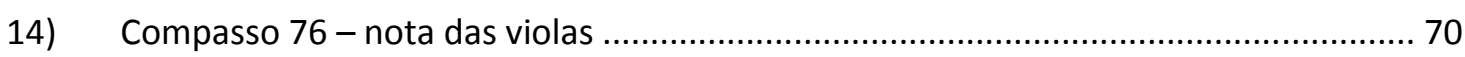

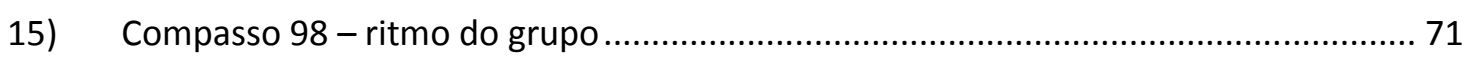

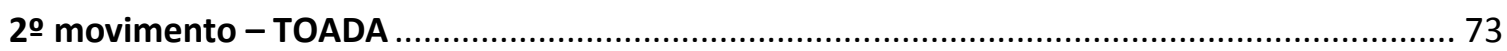

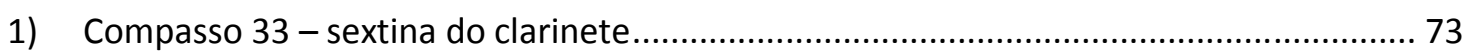

2) Compasso 36 - melodia do fagote e ausência dos contrabaixos....................................... 75

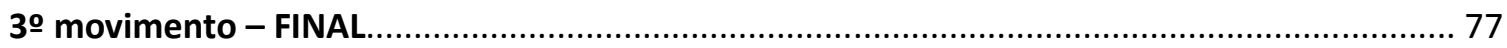

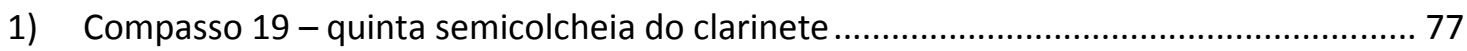

2) Compasso 59 - ritmo de violinos 2 e violas .................................................................. 78

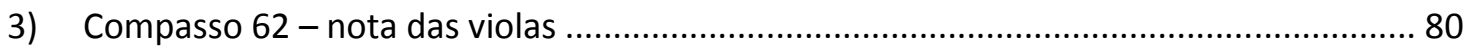

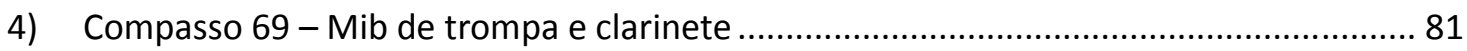

5) Compassos 85 e 90 - nota das violas e ausência da frase de primeiros violinos............... 82

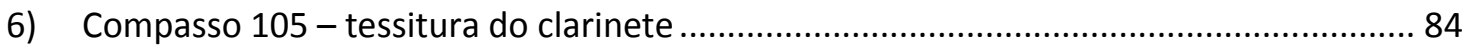

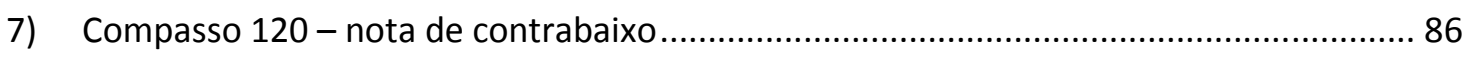

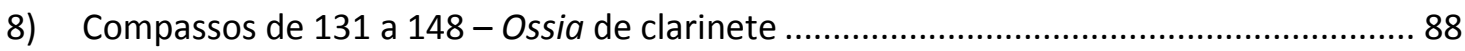

9) Compassos 148 - ausência das notas de violino 1 no final do compasso ......................... 90

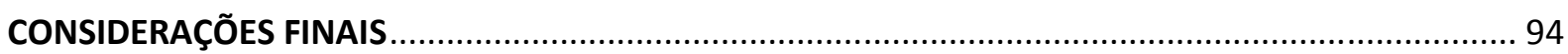

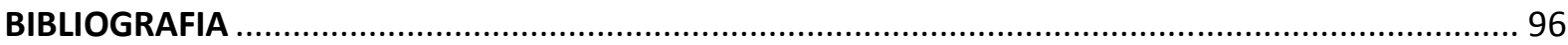


MANUSCRITO AUTÓGRAFO DA VERSÃO ORQUESTRAL PERTENCENTE À BIBLIOTECA NACIONAL DO RIO DE JANEIRO 99

MANUSCRITO AUTÓGRAFO DA REDUÇÃO PIANÍSTICA PERTENCENTE À BIBLIOTECA NACIONAL DO RIO DE JANEIRO. 100 MANUSCRITO AUTÓGRAFO DO ESBOÇO DA OBRA PERTENCENTE À BIBLIOTECA NACIONAL DO RIO DE JANEIRO 


\section{INTRODUÇÃO}

O trabalho apresentado a seguir busca elucidar pontos incertos do manuscrito orquestral em justaposição às outras fontes escritas do Concertino para Clarinete e Orquestra, obra de Francisco Mignone, de 1957.

O Concertino conta com três movimentos que seguem a estrutura clássica: rápido lento - rápido, cujos títulos são, respectivamente, Fantasia - Ponteio - Final. Durante os trinta primeiros anos que se seguem à data de sua composição, o Concertino foi executado exclusivamente pelo clarinetista carioca José Botelho (1931) - para quem a obra foi escrita em concertos à frente de orquestras ou em recitais acompanhado por piano. Nessas ocasiões, Botelho fazia adaptações e alterações dada a grande quantidade de incertezas em ambas as versões (orquestra e piano). No início da década de 1990, outros clarinetistas, além de Botelho, passaram a incluir a obra em seus repertórios, mas sempre enfrentando dificuldades nesse sentido. ${ }^{1}$

Dada a importância da obra para a música brasileira e para a história e o desenvolvimento do clarinete no Brasil, entendemos ser pertinente o estudo dos processos composicionais envolvidos na realização do Concertino a fim de resgatar a estética e a técnica do compositor e discutir com maior acuidade as questões editoriais, interpretativas e históricas que a obra demanda. Pretendemos, de maneira transparente, facilitar a difusão de uma das mais importantes obras da história do clarinete no Brasil e da música de um dos maiores compositores brasileiros do século XX.

Em maio de 2012 pudemos realizar essa obra com a Orquestra Sinfônica da Unicamp, tendo como solista o clarinetista Diogo Maia. No confronto com o manuscrito, descobrimos que haviam inúmeras questões técnicas e composicionais a serem resolvidas para a performance, assunto que abordaremos detalhadamente no terceiro capítulo deste trabalho. Como intérpretes, promovemos as resoluções necessárias à performance iminente da peça. Todavia, a necessidade de defender essas medidas levou-nos a entrevistar José Botelho, o que fizemos em setembro desse mesmo ano. Botelho lembrava-se de muitos detalhes da partitura e da história que envolvia a obra e sua estreia sob a batuta do compositor - como compassos e frases desdobradas, respirações fraseológicas, andamentos escolhidos, etc. - a "tradição oral" da obra.

\footnotetext{
${ }^{1}$ Ao longo de sua carreira, José Botelho dedicou-se ao ensino da clarineta no Brasil, formando diversos clarinetistas profissionais. Vários deles têm o Concertino em seu repertório: (N. A.).
} 
Em abril de 2012, a primeira gravação profissional do Concertino tinha sido realizada pela Orquestra Sinfônica de São Paulo sob regência da maestrina americana Marin Alsop, tendo como solista o clarinetista Sérgio Burgani. A partitura orquestral utilizada para isso não sofreu nenhuma revisão musicológica, e a parte da clarineta foi revisada pelo solista.

A insuficiência de informações no manuscrito orquestral provavelmente veio do fato de a obra ter sido executada pelo mesmo intérprete durante as três primeiras décadas a partir da data de sua composição. Essa situação só se estabeleceu possivelmente porque essa insuficiência era suprida pelos conhecimentos de Botelho adquiridos diretamente do compositor por ocasião da estreia da obra. A "tradição escrita" (mesmo que insuficiente, em parte) agregada a "tradição oral” da obra tornava possível uma execução fiel aos preceitos do autor.

No caso da Orquestra Sinfônica de São Paulo, por exemplo, que demanda uma produção musical volumosa, muitas vezes não há tempo para um olhar mais acurado sobre a partitura a ser executada. As grandes orquestras do Brasil e do mundo também estão incluídas nesse contexto de produção artística e necessitam de uma partitura minuciosamente discutida. Na maior parte das vezes, a tomada de contato com a tradição oral das obras executadas figura apenas como uma possibilidade remota. Também orquestras de menor porte do cenário musical brasileiro e internacional dependem de partituras confiáveis. Em especial, a partitura do Concertino encontra-se ao alcance técnico de numerosas orquestras, podendo gerar as mais diversas execuções e interpretações.

Nessas circunstâncias, entendemos que a produção de uma partitura que contenha o resultado do cruzamento entre as tradições oral e escrita da obra e, ao mesmo tempo, discuta as questões do manuscrito em justaposição com as outras fontes existentes seja importante para a conservação da história da música brasileira, em especial a desse compositor que teve grande atuação na corrente nacionalista brasileira no século XX. Ao lado de Villa-Lobos e de Camargo Guarnieri, Francisco Mignone contribuiu generosamente para que a música popular de seu tempo alcançasse as salas de concerto, quebrando paradigmas e preconceitos da sociedade brasileira.

Propomo-nos, portanto, a investigar mais profundamente os procedimentos composicionais que envolvem o Concertino, contrapondo as principais informações sobre a obra escrita e sua tradição oral. Para isso, apoiamo-nos na experiência da performance e 
levantamos os pontos mais importantes da partitura a fim de vislumbrar a intenção do autor ${ }^{2}$.

\footnotetext{
${ }^{2}$ Uma versão parcial desta pesquisa, intitulada "Concertino Con's'certado: um olhar sobre a partitura do Concertino para Clarineta de Francisco Mignone", foi apresentada como artigo por ocasião da I Jornada Discente do PPGMUS/USP. Nela ressaltamos alguns dos principais pontos a serem discutidos no primeiro movimento da obra, Fantasia. Ver: http://www.pos.eca.usp.br/index.php?q=pt-br/ppgmus/jornada discente/2012/5402/paper.
} 


\section{CAPÍTULO 1}

\section{As FASES DE Mignone}

Para compreender as fases artísticas pelas quais Mignone passou durante sua vida, será necessário confrontar os dados biográficos do autor e os traços estéticos de sua obra. Ainda assim, o risco de incorrer em erros de julgamento estará sempre presente, já que a complexidade dessa tarefa é digna de um trabalho exclusivo sobre o tema, num volume que não caberia nesta dissertação. Muitos já se lançaram a esse desafio e contribuíram significativamente nesse sentido: Bruno Kiefer publicou, em 1983 (três anos antes da morte de Mignone), a biografia intitulada "Mignone: Vida e Obra"; José Maria Neves cita Mignone diversas vezes em seu livro, "Música contemporânea brasileira", de 1981; e o próprio Mignone nos oferece os fatos importantes de sua vida até aquele momento em seu livro, “A Parte do Anjo: autocrítica de um cinquentenário", de 1947. Antes disso, o nome de Mignone apareceu regularmente em periódicos, como a Revista Brasileira de Música, na década de 1930, e nos textos de Mario de Andrade para a revista Klaxon, na década de 1920.

Nos últimos 30 anos (a partir da década de 1980), trabalhos como artigos, dissertações e teses acadêmicas sobre Mignone ou que citam sua obra e sua importância estética na cultura brasileira vêm sendo elaborados por pesquisadores do mundo todo. Podemos citar: African and Brazilian Pathways to Francisco Mignone's Brazilian Fantasies for Piano and Orchestra, de Gisele Nacif Witkowski; "Choro: A Social History of a Brasilian Popular Music", de Tamara Elena Livingston e Thomas George Caracas Garcia; "Villa Kyrial: Crônica da Belle Époque Paulistana”, de Marcia Camargos; "A música popular brasileira na vitrola de Mário de Andrade", textos de vários autores organizados por Flávia Camargo Toni; "Chico Bororó Mignone", de Arnaldo D. Contier; "O Anjo e suas Metas-Morfoses”, de José Eduardo Martins, etc. Além desses, outros textos dessa natureza poderão ser referenciados em nossa bibliografia.

$\mathrm{Na}$ busca por compreender melhor o que envolveu a composição do Concertino para Clarinete, partiremos para um estudo não estritamente biográfico do autor, mas estilístico. Dados familiares ou da carreira do compositor que não tangenciam ou influenciam o seu estilo terão, para nós, portanto, um papel secundário. Francisco Mignone nasceu em São Paulo, em 3 de setembro de 1897, quase na virada do século. Sua mãe, Virgínia Canonico Mignone, era de Tirreni (sul da Itália) e seu pai, Alferio Mignone (flautista), nasceu em 
Salerno. A família Mignone veio para o Brasil antes de Francisco nascer, mas para Mignone filho a ascendência italiana foi determinante na constituição de seus traços estilísticos como compositor. Já aos seis anos de idade assistiu a uma apresentação de La Bohème, uma de suas primeiras memórias musicais.

Guiado pelo pai, Mignone teve quatro professores italianos no início de sua formação, a começar pelo próprio Alferio, seguindo-se Sílvio Motto, Agostino Cantù e Savino de Benedictis. Com estes estudou piano, flauta, violoncelo, contraponto e composição. Ao lado desses estudos, devemos considerar a vida profissional precoce de Mignone, que o colocou em contato com orquestras jovens (como as organizadas no Conservatório Dramático Musical de São Paulo) e com operetas, atuando ao lado do pai como segundo flautista. Mas a música popular paulistana teve espaço de honra no coração de Francisco, como destacou Maria Josephina Mignone, segunda esposa e viúva de Francisco: "Ele sempre me dizia que a verdadeira música dele era a da juventude, porque vinha do coração". A isso, Mignone acrescentava: "a flauta era o meu instrumento predileto nos choros e serestas noturnas na antiga Paulicéia" (KIEFER, Bruno. Mignone: Vida e obra. p. 11).

\section{FASE POPULAR}

Aos 15 anos (1912) Mignone ingressou no Conservatório Dramático Musical de São Paulo, época em que foi colega de Mario de Andrade. Sua primeira obra conhecida oficialmente foi a Danse du Paysan para piano, pequena peça que também foi incluída com o título de "Dança" na "Suíte Campestre" (em 1918, na versão orquestral, e 1931 na versão para 2 pianos) e nas "Peças para Pequena Orquestra de Cordas" (Quatro), de 1984. É interessante notar como Francisco lidava com a própria obra, já que é comum observar pequenos trechos ou movimentos completos de uma obra incluídos em outras obras numa constante renovação e resgate de seu estilo. Nesse caso especial, a "Danse du Paysan" aparece no tenro início de sua carreira como obra vinda do coração (como comentou Josephina) e no final de sua vida ${ }^{3}$, em 1984, confirmando seu amor pelas obras da juventude.

Foi nesse período em que estudou no CDMSP que Mignone tocava flauta nas serestas e nos choros nas esquinas da Paulicéia com seus colegas, dentre eles Mário de Andrade. Mais tarde, já compositor reconhecido, compôs três ciclos de valsas sob a influência dessa

\footnotetext{
${ }^{3}$ Mignone morreu em 19 de fevereiro de 1986. Seus dois últimos anos foram de luta intensa contra a sua doença.
} 
memória, composições que levaram o título de "Valsas de Esquina", "pois naquela época os rapazes não se aproximavam das janelas das moças com receio de ser repreendidos por um pai ou irmão" (Francisco Mignone); tocavam então nas esquinas. Nesse mesmo período, Mignone foi pianista de cinema mudo, quando, segundo o próprio compositor ${ }^{4}$, improvisava, criava composições e tocava outras de memória e, transformando-as à sua maneira, re-harmonizava melodias. "Foi daí que surgiu a necessidade de escrever o que tocava" (Francisco Mignone). Essas primeiras obras, oriundas da sua atividade no cinema mudo, carregam uma estética erudita; Mignone admitia as influências da música italiana, da música portuguesa e de compositores, como Mendelssohn, por exemplo. Mais tarde começou a tocar obras de Ernesto Nazareth: "Às vezes imitando ou parodiando Nazareth, compunha minhas obras"5.

A precocidade do talento de Francisco colocou-o em lugar de destaque no cenário musical paulistano. Com 16 anos obteve os primeiros lugares nos concursos da revista A Cigarra e da Casa Levy com a valsa "Manon" e com o tango "Não se Impressione", respectivamente. Aos 20 anos, já diplomado pelo CDMSP, teve suas primeiras obras editadas pela casa A. Di Franco. Foi nessa ocasião que Francisco usou seu apelido entre os colegas de conservatório como pseudônimo: assinou Chico Bororó e publicou suas primeiras obras populares. No mesmo ano, Mignone conheceu pessoalmente Ernesto Nazareth na casa de piano Eduardo Solto. Um ano depois, com 21 anos, Mignone foi nomeado professor no CDMSP.

Exímio pianista, Francisco rapidamente chegou ao palco do recém-inaugurado (1911) Theatro Municipal de São Paulo, solando o primeiro movimento do concerto para piano de Grieg e apresentando algumas de suas obras, como o poema sinfônico "Caramuru", a "Suíte Campestre" (da qual o primeiro movimento é a Danse du Paysan, sua primeira composição), a "Romanza in Lá", o "Andante", a "Farândola das Horas", a "Alma Adorada" e o primeiro movimento da "Sonata em Sol menor para violino e piano".

Aos 22 anos, Francisco tomou contato com o teatro, participando da estreia de "O Contratador de Diamantes", peça teatral de Afonso Arinos. Vestido a caráter, regeu um minueto para que 16 pares de atores dançassem em cena, experiência fundamental para o desenrolar da carreira do jovem compositor, que teve a ideia de transformar a peça teatral em uma ópera. Essa ideia se desenvolveu nos anos seguintes e marcou o início da chamada fase italiana de Mignone. Ainda nesse mesmo ano, Mignone teve outras obras tocadas no Theatro

\footnotetext{
${ }^{4}$ Documentário "Lição de Piano", gravado pela FUNARTE em 1978.

${ }^{5}$ Idem
} 
Municipal, todas recém-compostas. ${ }^{6}$

\section{FASE ITALIANA}

Em 1920, exonerado do CDMSP, Mignone viajou para Milão com bolsa de estudos concedida pelo governo brasileiro; nesse período, estudou com Vicenzo Ferroni no Conservatório Giuseppe Verdi e, guiado pelo professor, compôs sua primeira ópera, O "Contratador dos Diamantes". O marco principal do início dessa chamada fase italiana de Mignone se deu curiosamente por meio de uma obra cujas características composicionais se aproximam mais da música francesa do que da italiana. Isso se deve ao fato de Vicenzo Ferroni ter sido aluno de Jules Massenet (compositor operístico francês). Essa influência pode ser notada no "Contratador dos Diamantes", de Mignone, na "Gavotta" e no "Menuette", da ária "Datti Pace ao Mio Cuore", e no "Dueto" do segundo ato, nos quais se pode perceber a estética da obra de Massenet, mais precisamente da ópera Werther.

Mignone residiu na Itália até o ano de 1927, período em que fez poucas viagens ao Brasil. Estava na Itália durante a Semana de Arte Moderna de 1922, mas mesmo distante pôde compreender o significado desse marco histórico: “A partir daí, valorizou-se muito o músico de obras populares" (F. Mignone). Em 15 de agosto de 1923, a obra "Cenas da Roça” obteve o primeiro lugar em concurso instituído pela Sociedade de Concertos Sinfônicos de São Paulo; e em 1924, quando Mignone tinha 27 anos, a ópera "O Contratador dos Diamantes" estreou no Theatro Municipal do Rio de Janeiro. Dois anos depois (1926) o compositor obteve, com o poema sinfônico "No Sertão", o primeiro lugar no mesmo concurso da Sociedade de Concertos Sinfônicos de São Paulo.

A mudança de Mignone para a Espanha em 1927 ampliou seus horizontes artísticos, o que o fez trabalhar imerso na cultura estética daquele país. Obras como "Cantos Populares Espanhóis", "Êxtase", "Interlúdio Sinfônico" e "Suíte Asturiana” fazem parte desse período, além das canções "Marinero por qué no has venido?", "Las Mujeres son las moscas" e "Noche clara y estrellada". Outra obra significativa dessa época foi "O Inocente" (L'Innocente), de 1927, que carrega traços do modalismo da música popular espanhola percebidos especialmente na $2^{\mathrm{a}}$ “Ária de Andrea” e na “Ária Final”. Essa obra, de temática

\footnotetext{
${ }^{6}$ Fragmento Id́líico, Intermezzo Lírico, Paráfrase sobre o Hino dos Cavalheiros da Kyrial, Égloga e Dança das Bruxas.
} 
espanhola, nasceu, como relata o próprio compositor, de sua paixão por uma escritora daquele país. Outro fato curioso que corrobora a absorção da estética espanhola por Mignone se dá na correlação entre seus "Cantos Populares Espanhóis", de 1928, e as "Canciones Populares Españolas” que Manuel De Falla compôs no mesmo ano. Sabe-se que Mignone conheceu De Falla e Segovia durante os dois anos que manteve residência em Madri.

Um ano depois (1929) Mignone volta ao Brasil para residir em São Paulo, onde se torna professor de harmonia do CDMSP. Ao mesmo tempo assume a direção local da gravadora de discos Parlophon e, nessa empresa, cria a Orquestra Paulistana, responsável, entre outros, por pelo menos 15 registros sonoros de obras de Chico Bororó realizados no período de 1930 a 1932, alguns dos quais com solos de flauta de seu pai.

Embora a cunha "italiana" apregoada à essa fase de Mignone por Arnaldo D. Contier em seu artigo "Chico Bororó Mignone" encontre respaldo na permanência do compositor como aluno no Conservatório Giuseppe Verdi, notamos que a estética praticada em suas obras durante esse período não se apoia exclusivamente na cultura italiana. Suas duas obras mais expressivas nessa fase têm influências francesas e espanholas, não obstante, a composição de obras com temáticas nacionais brasileiras foi volumosa: "No Sertão" (1920), "Cenas da Roça" e "Lendas Sertanejas” (1923, 1924 e 1927), “Ao Anoitecer", “Cantiga de Ninar" (1925), “Canto Nostálgico do Sertanejo" (1925) e "Maxixe" (1927). Portanto, nomear essa fase de "italiana" pode parecer uma redução de sua abrangência estética, e podemos até dizer que o termo que Mario de Andrade utilizou, em 1928 para criticar Mignone, seja mais fiel à descrição dessa fase.

"Mignone [...] recebe crítica contundente de Mário de Andrade por seu internacionalismo" (Catálogo de obras de Francisco Mignone, Academia Brasileira de Música, pg.164)

\section{FASE NEGRA}

É conhecida a influência que Mario de Andrade exerceu sobre os artistas brasileiros de sua época, e Mignone é um caso que mereceu especial atenção do autor de Macunaíma: “[...] dentre os compositores vivos brasileiros, Francisco Mignone é talvez o problema mais complexo pelas causas raciais e pela unilateralidade de cultura que muito o despaísam e desencaminham. Além disso, minha impressão é que o compositor inda não teve coragem 
para colocar bem os seus problemas espirituais. Ele inda está excessivamente atraído pela chamada 'música universal', sem reparar que a verdadeira universalidade, senão a mais aplaudida, pelo menos a mais fecunda e enobrecedora, é a dos artistas nacionais por excelência. Nunca um Tchaikovsky universal terá o valor nem a importância dum Mussorgsky nacional, nem um Saint Saëns a importância dum Debussy" (ANDRADE, Mário de. Luta pelo sinfonismo. XI. Sociedade Sinfônica de São Paulo. In: MDM. P. 239.). A relação que nasceu na juventude entre esses dois artistas se transformou em uma amizade rica e duradoura, marcada por diversas discussões acerca da estética nacionalista. Na música, o movimento nacionalista inaugurado por Alberto Nepomuceno tem como principais representantes: Heitor Villa-Lobos, Camargo Guarnieri e Francisco Mignone na primeira geração.

As críticas contundentes de Mario de Andrade em relação a Mignone surgiram ainda em 1920, quando Mignone tinha 23 anos e estava na Itália. Durante o período em que Mignone esteve fora do país, a influência de Mario não o alcançava com tanta veemência; contudo, no momento de sua volta ao Brasil e com a aproximação do amigo, Mignone sentiu necessidade de tomar uma posição estética diante das expectativas de Mario.

A composição da Primeira Fantasia Brasileira, para piano, estreada em 1931, marcou a adesão de Mignone ao Nacionalismo nos moldes de Mario de Andrade. Na peça, que dura cerca de dez minutos, "predominam [...] os elementos brasileiros procedentes das raízes africanas" (Mignone: Vida e Obra, Bruno Kiefer, pag. 20). A partir de então, a produção musical de Mignone foi guiada pelos preceitos do Nacionalismo. No entanto, apenas em 1942 o termo "Negra", que foi cunhado por Mario de Andrade, passou a designar a fase de Mignone que compreende os anos de 1929 até 1947. Esse termo designa uma identificação com os elementos negros da cultura musical brasileira - ritmos, harmonias modais, instrumentação, forma musical - e "pode ir até o uso de textos africanos, como na canção 'Uandala lê', composição de 1932" (Bruno Kiefer, p. 24).

Esse período foi promissor para Mignone, então com 33 anos e com o velho pseudônimo. O "maestro Chico Bororó" fez a música para o filme "O Babão", primeiro filme sonoro brasileiro e que estreou em São Paulo em 12/01/1930. Embora em 1932/33 a Parlophon, empresa fonográfica que Mignone dirigia, tenha sido incorporada à Odeon, o que encerrou sua ligação com o compositor, Mignone compôs em abundância. Na década de 1930 foram mais de 150 títulos, além da gravação de diversos discos com suas obras. A partir daí, as técnicas composicionais de Mignone se ampliaram; em 1933, por exemplo, ele compôs, 
sobre versos de Suzana Campos, a canção para soprano e piano intitulada "O Vento Balançava Aquela Rosa Tão de Leve", utilizando-se pela primeira vez da estética composicional do Atonalismo.

No mesmo ano o compositor mudou-se para o Rio de Janeiro, onde se casou com Liddy Chiaffareli, separada há algum tempo de Agostino Cantù, seu antigo professor. Nesse ano Mignone também compôs o bailado "Maracatu do Chico-Rei", com argumento de Mario de Andrade, que "representa um dos pontos culminantes da estética Nacionalista de Mignone" (Bruno Kiefer, p. 21), sua terceira obra de envergadura, sucedendo as duas óperas anteriores. Em "A parte do Anjo", Mignone comenta as influências estéticas de seu Bailado: "[...] é incontestável que me aproveitei das obsessões rítmicas de Stravinsky e De Falla no Maracatu do Chico Rei [...]”. É curioso notar que essas influências e sua confissão não geraram uma crítica negativa por parte de Mário de Andrade. No ano seguinte, 1934, Mignone assumiu a cadeira de regência do então Instituto Nacional de Música (INM), atual Escola de Música da UFRJ, sucedendo Walter Burle Marx. Em 1935 assumiu também o coro da mesma instituição. No ano seguinte, após reger um concerto alusivo ao centenário de Carlos Gomes, Mignone foi convidado pelo embaixador da Alemanha a se apresentar naquele país. Em 1937, viajou para a Alemanha, onde regeu a Orquestra Filarmônica de Berlim executando obras suas e de outros autores brasileiros. A viagem se repetiu no ano seguinte, quando Mignone regeu em Berlim, Hamburgo e Frankfurt. A pequena turnê se estendeu até a Itália, onde regeu em Roma o "Maracatu do Chico Rei” com a Academia Santa Cecília. No final do mesmo ano, organizou uma série de gravações para a feira mundial de Nova Iorque de 1939. Fizeram parte do repertório desses discos as obras: "Cateretê", "Congada", "Cucumbizinho", "Fantasia Brasileira n"3", "Lenda Sertaneja n'7", "Miudinho", "Nazareth e Toada", entre outras. Também gravou, de Camargo Guarnieri, o "Ponteio no1" e a "Toada à moda Paulistana"; e de Heitor Villa-Lobos, “A Lenda do Caboclo". Nesse ano ainda foi efetivado por concurso na Cátedra de regência do Instituto Nacional de Música e compôs "O Espantalho" e o bailado "Leilão", última obra considerada integrante da fase negra.

A influência de Mario de Andrade sempre determinou, a partir da volta de Mignone ao Brasil em 1929, os caminhos estéticos que a obra desse último tomou. Em 1942 Mario de Andrade criticou as duas últimas obras citadas acima como excessivamente carregadas de características da cultura negra e arrematou dizendo que estava "convencido de que é preciso de fato abandonar o excesso de folclore e a sua utilização documental". (CONTIER, Arnaldo. Chico Bororó Mignone, p. 26) 


\section{FASE ESTETICAMENTE LIVRE}

A fase mais longa da obra de Mignone, que vai de meados da década de 1940 até sua morte em $1986^{7}$, foi marcada por fatos que situam Mignone como um dos maiores e mais importantes compositores brasileiros do século XX. Além de manter intensamente sua atividade como compositor, somando mais de seiscentas obras catalogadas apenas nesse período, Mignone se dedicou ao ensino da regência na EM/UFRJ e particularmente em sua casa; também se dedicou à gravação de discos de música erudita, à regência de orquestras nacionais e internacionais e à composição e gravação de trilhas sonoras para o cinema brasileiro, além de transcrições, arranjos e orquestrações. Mignone também atuou como pianista, compondo para esse instrumento farta quantidade de obras solo, para dois pianos e para duas e quatro mãos.

Do ponto de vista estético, notamos que, nesse período embora Mignone tenha se permitido cruzar fronteiras, a preocupação com o Nacionalismo musical brasileiro norteou a maior parte de sua produção, e em especial a música popular e folclórica. Apesar disso, obras dodecafônicas, seriais ou atonais fizeram parte de sua produção. Em carta a Bruno Kiefer, em 1983 (Mignone com 80 anos), narrou uma de suas imersões na música atonal: "Somente em 1960, assim que acabei de compor e apresentar o meu único concerto para piano e orquestra e também tendo ensaiado e dirigido a 'Missa de São Marcos' de Stravinsky, é que surgiu em mim a necessidade de enriquecer minha técnica de composição com outros processos. Partindo da obra de Stravinsky, li e escutei tudo o que estava ao meu alcance a respeito do Dodecafonismo e do Serialismo. Escrevi muitas obras, entre elas dois quintetos para instrumentos de sopro (madeiras), a "Segunda Sonata para piano", a "Terceira Sonata para piano" e o "Pequeno Oratório de Santa Clara" (versos de Cecília Meireles) para solistas, coro misto e orquestra. Mas, chegado nesse ponto, me perguntei: e a música nacionalista? E também começava a achar minha música dodecafônica e serial muito parecida com centenas de outras que iam no mesmo caminho. Depois de muito pensar e maturar, cheguei à conclusão de que podia, se minha contribuição pessoal me permitisse, chegar a uma linha do meio. Afinal, o Serialismo, ou melhor, o Dodecafonismo, não atrapalha; ao contrário, estimula liberdades atonais e cromáticas inesperadas que o bom gosto deve controlar".

Em relação à composição do Pequeno Oratório de Santa Clara, Mignone confirma o

\footnotetext{
${ }^{7}$ É interessante notar que o início da fase de Mignone chamada de Esteticamente Livre tenha coincidido com o falecimento, em 1945, de Mario de Andrade.
} 
pensamento exposto na carta a Bruno Kiefer: "Nessa peça eu mudo quase completamente de estilo; eu vou pelo dodecafonismo, serialismo, atonalismo e mignonismo também, muitas coisas de minha invenção". O Oratório é de 1962, mesmo ano em que faleceu Liddy Mignone em um desastre de avião, ano também em que Mignone compôs a "Sonata n² para piano", outra peça serial.

Essas ampliações de suas técnicas de composição levaram-no a repensar sua produção nacionalista ao ponto de publicar, em 1968, no Jornal do Brasil, o artigo "Do Nacionalismo à música pela música", no qual criticou as ideias de Mario de Andrade e declarou que "não andava contente com o que produzia" em sua fase nacionalista. Em 1977, por ocasião de uma entrevista cedida ao mesmo jornal, Mignone confirmou sua volta ao Nacionalismo, "pois nele há uma mensagem de riqueza, de variedade, de ambiente e de cor local”.

\section{OUTRAS CONSIDERAÇÕES}

Mignone foi coautor do livro "A Parte do Anjo", lançado em comemoração ao seu cinquentenário (1947). Também foi membro da Academia Brasileira de Música, ocupando a cadeira 17 e sucedendo Arthur Perier, sendo recepcionado por Heitor Villa-Lobos na cerimônia.

Em 1964, casou-se pela segunda vez, numa cerimônia em Santa Cruz de La Sierra, na Bolívia, com Maria Josephina, que o acompanhou até sua morte. Durante o período em que estiveram juntos, Maria Josephina tornou-se companheira na música e testemunha ocular dos processos composicionais de Mignone. Sobre o Dodecafonismo, ela descreve: "Ele queria provar que podia fazer essa música tão bem quanto qualquer outro, só que não era a música dele. Tanto que deixou depois e voltou à música nacionalista". Sobre o hábito da composição, ela nos relata: "Isso me impressionava muito, ele não ia ao piano. Ele escrevia sem ir ao piano. A duas óperas eu assisti, 'O Sargento de Milícias' e 'O Chalaça', ele escrevia a partitura da orquestra inteira sem ir ao piano. Ficava horas e horas ali, completamente concentrado na composição. Mas como é que você consegue escrever tudo isso sem ouvir? eu perguntei - foi quando ele me respondeu: quando você escreve uma carta, você precisa pegar a gramática? Você já sabe todas as regras. A mesma coisa eu, eu tenho os sons todos na cabeça".

$\mathrm{Na}$ sua busca estética uma fonte se revelou preciosa: a juventude. Maria Josephina relata que ele sempre dizia: "Os jovens é que têm a verdade" - e arremata: "Ele sempre 
procurava ouvir os jovens, ele gostava muito dos jovens". Outro fator que alimentava sua criação artística era o ambiente no qual vivia ordinariamente. Maria Josephina nos conta que Mignone era um grande cozinheiro, sendo sua grande especialidade o "macarrão do pobre", uma receita autoral que atraía os paladares de pessoas como Mario de Andrade, Carlos Drumond, Manuel Bandeira, Bruno Jorge, Gilberto Figueiredo, Jacques Klein, Issac Karabtchevsky, Heitor Alimonda, Nelson Freire, entre outros. Segundo Josephina "todo sábado eles jantavam na casa de Mignone. Era um ambiente de muita cultura".

Em 1967 Mignone se aposentou da cátedra de regência da EM/UFRJ e em 1982 recebeu o Prêmio Shell, num concerto em sua homenagem no Teatro Municipal do Rio de Janeiro.

\section{A HistóRIA DO CONCERTINO}

O Concertino para Clarinete, de Francisco Mignone, faz parte das obras compostas em sua fase esteticamente livre. Foi composto em 1957 e dedicado ao então jovem (24 anos) clarinetista português naturalizado brasileiro, José Botelho. A ideia da composição foi de Alferio Mignone, pai do compositor, que, ao escutar no rádio um solo do jovem clarinetista executando um concerto de Carl Maria von Weber, impressionou-se com a qualidade técnica e sonora do instrumentista. Alferio viu em Botelho a figura de um raro virtuose daquele instrumento naquela época e a possibilidade de valorizá-lo por meio da composição de uma obra exclusiva. Alferio não tardou em sugerir a Francisco que compusesse algo especificamente para Botelho. Mignone, que na época dirigia a Orquestra Sinfônica da Rádio Gazeta, encontrou então a oportunidade de escrever um concerto para esse instrumento.

Apenas em 1919, sob a estética de sua fase chamada italiana, Mignone havia composto um Fragmento Lírico para clarinete solista e orquestra sinfônica. A oportunidade de ver realizada uma segunda obra para clarinete solista e orquestra e tendo como solista um virtuose (o que significava maior liberdade criativa) encantou Mignone, que se lançou à composição com tamanha dedicação que, num período de três meses já estava de posse da versão orquestral. Nesse período ele produziu um esboço ao piano da obra e a já mencionada versão orquestral. Após os três meses de composição, Mignone, que morava então no Rio de Janeiro, viajou para São Paulo a fim de se encontrar com Botelho e apresentar-lhe a peça.

Botelho relata, em entrevista exclusiva, que, ao receber a partitura, ficou 
impressionado com a dificuldade técnica que a obra apresentava. Solicitou então a Mignone que deixasse com ele o manuscrito para que pudesse estudar. "Pra mim tudo era fácil" (José Botelho). Algumas semanas depois Botelho recebeu uma ligação de Mignone dizendo que estaria em São Paulo pelos próximos dias para assuntos particulares e sugerindo mais um encontro entre os dois. "Pois bem, ficamos ali aquela semana inteira agarrados no Concertino, discutindo e estudando juntos" (José Botelho).

É fruto desse estudo e dessa discussão entre os dois artistas uma série de alterações na parte de clarinete do Concertino; a mais expressiva alteração tornou-se, por sugestão de Botelho, uma Ossia na parte final do último movimento. Apesar de membro da Academia Brasileira de Música e do prestígio alcançado como compositor, Mignone esteve sempre aberto às sugestões dos músicos com os quais trabalhava, como descreve Botelho: "Mignone disse: a gente escreve, mas sabe que de maneira geral o intérprete vai melhorar aquilo que eu escrevi". Ao mesmo tempo Botelho nos relata "Mignone dificilmente errava; escrevia todas as partes de próprio punho". Apesar de Mignone ter aceitado as alterações propostas por Botelho, não as incluiu em sua partitura orquestral nem tampouco em uma redução para piano que produziu mais tarde.

A estreia da obra se deu naquele mesmo ano com a Orquestra da Rádio Gazeta e regência do compositor. Sobre a ocasião, Botelho nos conta que "Na estreia, os músicos dos sopros eram quase todos músicos populares. Foi na rádio gazeta em 1957”. Isso contribuiu, segundo Botelho, para que as características populares da obra fossem bem realizadas, já que ela contém ritmos, harmonias e melodias típicas da música popular brasileira. Os três movimentos dos quais a obra é composta, Fantasia - Ponteio - Final, dialogam intensamente com a nossa música popular. A Fantasia apresenta uma sucessão de ritmos brasileiros unidos por gestos mais líricos, típicos do estilo Fantasia; a Toada contém um único movimento rítmico que permeia todo o movimento. Segundo Botelho, Mignone falou de sua admiração pela "Toada pra Você", de Lorenzo Fernandez, e a intenção de homenagear essa obra. De fato, em 1948 Mignone tinha gravado essa toada de Lorenzo Fernandez com a soprano Alice Ribeiro. O movimento Final é um baião com característica de Rondó e muito ritmado para a orquestra, especialmente para os músicos de instrumentos de sopro.

O Concertino de Mignone foi muito bem recebido pelo público, alcançando uma notoriedade dentro do repertório sinfônico para clarinete solista. Botelho incorporou-o ao seu repertório pessoal, executando-o em recitais com piano e em outras ocasiões com orquestra. Contudo, a primeira gravação em estúdio ocorreu apenas na década de 1970, com Botelho 
como solista, Vicente Fittipaldi como regente e com a Orquestra Nacional. Mignone acompanhou o processo, mas não ficou satisfeito com o resultado. Botelho conta que Mignone achou a gravação lenta demais. Essa gravação acabou não sendo lançada, e o registro sonoro que chegou até nós e que também foi acompanhado por Mignone foi realizado por esses mesmos músicos ao vivo no Teatro Municipal do Rio de Janeiro.

Apesar do sucesso alcançado com o Concertino, Mignone voltou a escrever para clarinete solista e orquestra apenas em 1980 e mesmo assim dividindo a parte de solista entre o clarinete e o fagote. Trata-se do "Concertino para Clarinete, Fagote e Orquestra", encomendado pela Orquestra Sinfônica Brasileira e estreado no Teatro Municipal do Rio de Janeiro contando com José Botelho e Noel Devos nos solos e Isaac Karabtchevsky na regência. Essa encomenda se deu em razão do quadragésimo aniversário dessa orquestra. Ainda assim, trata-se de uma transcrição do próprio autor de uma obra dodecafônica de 1930 intitulada "Cateretê" para coro misto a capela. 


\section{CAPÍTULO 2}

\section{IDENTIFICAÇÃO DAS FONTES}

Um dos pontos-chave para a compreensão e a organização do pensamento interpretativo de um editor é a identificação das fontes a serem utilizadas (GRIER, 1996, p. 19). Essa identificação ajuda a comunicar o campo semântico e torná-lo inteligível, já que cada obra é um caso singular, cada fonte é distinta e, por conseguinte, cada edição é única. Neste trabalho de investigação, utilizaremos fontes primárias, aquelas que registram as notas originais manuscritas do autor, e fontes secundárias, aquelas que não são manuscritas do autor, mas que carregam uma correspondência clara com a obra.

São três as fontes primárias:

Nossa primeira fonte - esboço manuscrito da partitura para piano e clarinete que originou a orquestração, de 1957 (Fp1) - é uma cópia xerografada do original pertencente à Biblioteca Nacional do Rio de Janeiro. Na capa, encontra-se a data: 19 de fevereiro de 1957, Rio de Janeiro. O documento apresenta diversas rasuras, tais como substituição de notas, subtração de compassos inteiros, alterações de ritmo, além de pedaços de papel colados em pentagramas inteiros, substituindo trechos completos. Anotações de orquestração também são encontradas em diversos trechos, além de arcadas de instrumentos de cordas. Outro ponto interessante diz respeito à parte do método composicional de Mignone: a presença da escrita de caneta sobre o lápis. Ao que parece, Mignone esboçou com grafite e depois, quando teve certeza dos trechos, confirmou com tinta. Esse mesmo procedimento é encontrado em seu “Concertino para Clarineta, Fagote e Orquestra”, de 1980 (SILVEIRA, 2004, p. 25).

A segunda fonte que utilizamos - o manuscrito da versão orquestral do autor, datado de 1957 (Fp2) - é uma cópia xerografada do autógrafo pertencente à Biblioteca Nacional do Rio de Janeiro. Na capa, pode-se ler o título pretendido, “Concertino para clarinete sib com orquestra", além da data de 27 de fevereiro de 1957 e do carimbo da Musicoteca da Rádio Gazeta. Pode-se também notar a escrita precisa da instrumentação desejada pelo autor (12 primeiros violinos, 10 segundos violinos, 8 violas, 6 violoncelos e 6 contrabaixos, além de 2 
flautas, 2 oboés, 2 fagotes, 2 trompas e 2 trompetes $^{8}$ ) e a dedicatória a José Botelho. No decorrer das páginas, encontram-se o texto musical manuscrito e anotações de regência.

A terceira fonte - o manuscrito da redução para piano e clarinete de 1957 (Fp3) - é outra cópia xerografada do autógrafo pertencente à mesma biblioteca, documento posterior à versão orquestral acima descrita. Na primeira página da partitura, encontra-se o carimbo da Biblioteca Nacional do Rio de Janeiro; depois, no decorrer das páginas, o texto musical claro e bem legível. A análise comparativa dessas duas primeiras fontes e o levantamento histórico confirma suas características de redução orquestral. José Botelho declarou, em 1999, que tal documento lhe foi entregue alguns meses após a primeira execução da obra, datada de nove de junho de 1957 (SILVEIRA, 2004, p.23).

Para este estudo utilizaremos apenas uma fonte secundária - o material orquestral (partes individuais) de 1957. São cópias xerografadas de materiais extraídos por copista da partitura original e autorizadas por Mignone para a estreia do Concertino (SILVEIRA, 2004, p. 24). Esse material se encontra na Biblioteca Nacional do Rio de Janeiro e apresenta também o carimbo da Musicoteca da Rádio Gazeta, além de anotações dos músicos que o utilizaram, como algumas correções de notas, compassos e arcadas. Há também anotações de datas, como de 1957 (época da estreia) e 1959 (possivelmente uma outra performance da obra).

Esta pesquisa não ignorou a existência de outros registros da obra. Ainda assim, preferimos nos ater aos materiais que tiveram contato real e direto com o compositor e excluir os seus derivados ${ }^{9}$. A saber:

- Uma partitura orquestral e uma redução para piano produzidas digitalmente por Fernando José Silva Rodrigues da Silveira, respectivamente em 2004 e 2005,

\footnotetext{
${ }^{8}$ No catálogo de obras do autor, publicado pela Academia Brasileira de Música em 2007, o Concertinho aparece com o título de "Concertino para Clarineta e Pequena Orquestra"; o mesmo acontece no catálogo mais recente da Editora Criadores do Brasil, de 2011/2012. Ambos apontam a duração de 18 minutos para a obra, sendo que, se respeitados aproximadamente os andamentos escritos, a obra dura cerca de 12 minutos. De fato, a denominação "Pequena Orquestra" nesses catálogos não está equivocada, embora não apareça no título original. A instrumentação determinada por Mignone enquadra como "Orquestra de Câmara" o conjunto de músicos requisitados. A ausência de tímpanos e clarinetes impede a classificação de "Orquestra Clássica". Ver DICIONÁRIO DE TERMOS E EXPREÇÕES DA MÚSICA, 2004, p. 239.

${ }^{9}$ A razão para essa distinção está na busca de um diálogo próximo e íntimo entre o editor e o autor. Considerar os materiais derivados seria considerar "atravessadores" nessa relação. Não que os atravessadores não pudessem constituir uma experiência enriquecedora, mas o caráter concreto deste trabalho será alcançado quanto mais nos concentrarmos no campo semântico singular do autor. Buscamos a descrição do processo mais puro do autor, e não uma historiografia do texto musical impresso.
} 
mas não publicada.

- Uma partitura completa do material produzida pela Editora Criadores do Brasil, igualmente não publicada - OSESP, de $2012^{10}$.

Dessa forma, esperamos contribuir significativamente para a busca de um texto musical fidedigno e que se apresente de maneira a atender às exigências de um mercado internacional de partituras de música erudita, isto é, com todas as possíveis questões interpretativas e técnicas abordadas.

Como material de apoio, utilizaremos a tese que gerou a edição de Silveira e duas entrevistas exclusivas: a primeira, concedida por Maria Josephina Mignone, viúva do autor, em São Paulo, no ano de 2010; a segunda, concedida por José Botelho - clarinetista para quem o Concertino é dedicado e que foi também o estreante da obra sob a batuta do autor - no Rio de Janeiro em 2012.

\section{ASPECTOS ESTRUTURAIS (OU CARACTERÍSTICAS MUSICAIS)}

A análise a que procederemos consiste na observação de características composicionais empregadas na obra, como tipologias harmônicas, emprego de ritmos idiomáticos, peculiaridades melódicas, orquestrais e de forma, etc. A apreensão dessas características e a comparação entre elas servirão para delinear o que podemos chamar de perfil composicional da obra. Esse perfil constitui parte fundamental da elaboração do nosso projeto e nos ajudará a justificar as escolhas editoriais finais deste trabalho. Para a análise, utilizaremos as três fontes primárias da obra. A versão orquestral assume um papel hierárquico predominante sobre as outras; contudo, nenhuma decisão analítica será tomada desconsiderando alguma das fontes, pois acreditamos que cada fonte primária carrega um teor de dados musicais particular ao seu momento histórico e meio de expressão. A cronologia de suas aparições poderá abalizar pontos importantes de análise. Podemos dizer que a fonte primária 3 (a última partitura dessa obra produzida por Mignone), por exemplo, carrega o senso revisor do autor de maneira mais explícita.

O Concertino apresenta uma escrita clara e objetiva, os materiais temáticos são

\footnotetext{
${ }^{10}$ Essa edição contém: a partitura orquestral; a partitura para clarinete solista; o material da orquestra.
} 
facilmente identificáveis. O papel de acompanhamento que a orquestra assume durante quase toda a obra torna cristalina a distribuição das funções de cada parte formal e de cada material temático. Durante os três movimentos formalmente distribuídos (Fantasia - Toada - Final) o autor imprime seu estilo descomplicado e natural por meio da simplicidade harmônica da maioria dos trechos, da austeridade da escrita rítmica e melódica e da fluência na conexão entre as partes de cada movimento. Julgamos que essas características sejam fruto de seu convívio íntimo com a música popular brasileira durante parte de sua formação musical. Ritmos típicos de música popular brasileira são exercidos durante toda a obra, além da utilização de elementos populares na linha melódica da clarineta solista e seus ornamentos, temas que serão abordados mais adiante. Por outro lado, as influências da escola italiana e do aprendizado formal de música são percebidas como parte importante da instrução musical do autor, principalmente em relação à orquestração, como, por exemplo, o uso sistemático das famílias da orquestra (cordas, madeiras e metais) respeitando o equilíbrio das forças acústicas entre elas. Raramente os metais são utilizados sem o auxílio das madeiras, e as cordas são predominantemente requisitadas como base da orquestração. As disposições dos acordes da harmonia também são guiadas pelas diretrizes clássicas da orquestração, e praticamente não há montagens de acordes realizadas através das diferentes famílias: a tríade ou tétrade não é construída pelos violoncelos com oboés e trompetes, mas sim dentro das famílias ou com as famílias combinadas em blocos dobrados.

A harmonia apresenta características fortes do tonalismo, e as relações de atração entre as subdominantes e dominantes são extensamente aplicadas. Outras características, como cadências, campos harmônicos e procedimentos de baixo pedal, estão presentes na composição, reforçando o tonalismo. Mesmo assim, percebe-se em alguns pontos a presença do politonalismo, principalmente no primeiro movimento, por meio da sobreposição de tríades ou tétrades. A presença de ritmos brasileiros é constante, e a identificação de suas origens nos ajudará a compreender melhor o material de base da composição. Do ponto de vista da identificação das formas musicais utilizadas, notamos que o espírito livre do autor se manifesta: as formas clássicas parecem guiar o pensamento contudo, não aparecem de maneira explícita. O terceiro movimento, por exemplo, assemelha-se a um Rondó, dada a reiteração constante do tema principal, mas a aplicação da forma não se dá de maneira clássica; e o segundo movimento assemelha-se a uma canção mais por suas características melódicas e de acompanhamento do que por sua disposição formal. O primeiro movimento é de natureza mais inventiva e, embora exista certo senso de "recapitulação", os 
materiais temáticos resultam sempre como novidade ao ouvinte.

$\mathrm{Na}$ busca por um discurso mais simples, dada a natureza técnica evidente nesta parte do texto, e de uma explanação mais franca e aberta dos dados analíticos, não nos fixaremos em ferramentas analíticas herméticas. Em favor da fluência do texto e por uma facilidade de compreensão do enunciado, tomaremos algumas resoluções: não utilizaremos as letras maiúsculas para definição de forma (por exemplo, em ABACAD, pode haver o significado de Rondó); para a harmonia, utilizaremos o sistema de cifragem de origem americana com adaptações ao uso brasileiro $\left(\mathrm{C}^{\text {maj7 }}\right.$ será $\mathrm{C}^{7+}$, acordes aumentados poderão aparecer como $\mathrm{C}^{\text {aum }}$ ou $\mathrm{C}^{5+}$, os de sexta aumentada poderão aparecer como $\mathrm{C}^{6 \mathrm{aum}}$ ou $\mathrm{C}^{6+}$ ); e as discussões sobre a funcionalidade dos acordes estarão presentes no corpo do texto para que não seja necessária a utilização da simbologia correspondente. Além disso, o uso das figuras apoiará o pensamento analítico e a descrição da obra. 


\section{Primeiro movimento - FANTASIA}

A escrita pianística que podemos perceber na construção da versão orquestral de Fantasia mostra indícios do método de composição do autor, como, por exemplo, acordes montados à maneira do piano. De maneira idêntica podemos situar as melodias do clarinete solista, que, por sua vez, realiza cromatismos e arpejos típicos do piano. O caráter de Fantasia é percebido pela variação constante de andamento, pela riqueza melódica e por uma agógica que vai de encontro à rigidez formal, o que torna o texto musical rico e, ao mesmo tempo, diáfano. Mesmo assim, podemos perceber técnicas de construção melódica baseadas nos fundamentos matemáticos de espelhamento e retrogradação por exemplo, considerados parâmetros rígidos. Os ritmos brasileiros marcantes alternam sua presença com trechos rubato, como o recitativo. Há diálogo entre a orquestra e o solista; contudo, na maior parte do tempo a orquestra exerce a função de acompanhamento.

A FANTASIA apresenta as seguintes partes:

\section{A - Do início até o compasso 17}

Nessa primeira parte são observados alguns procedimentos que estarão presentes durante toda a obra. No primeiro compasso, observamos o acorde de $\mathrm{C} \#^{\circ(13)} / \mathrm{D}$, que insere a sonoridade estática (pela falta de resolução) utilizada em vários trechos da obra, ao mesmo tempo em que sugere a sobreposição de acordes (ou funções harmônicas, no caso do primeiro compasso) que verificar-se-á mais adiante.

Figura 1 - Fantasia, compasso 1

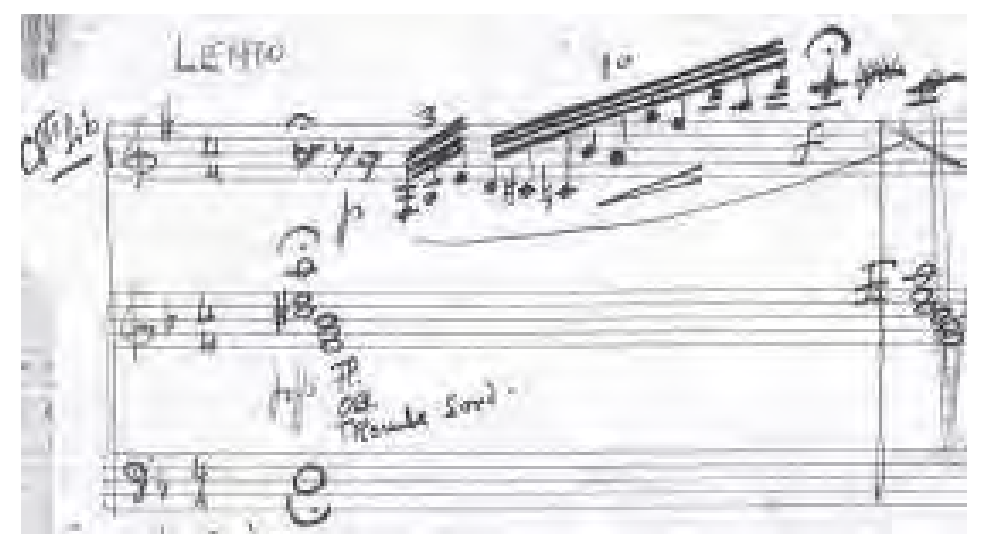

Fp1 (esboço) 
Figura 2 - Fantasia, compasso 1

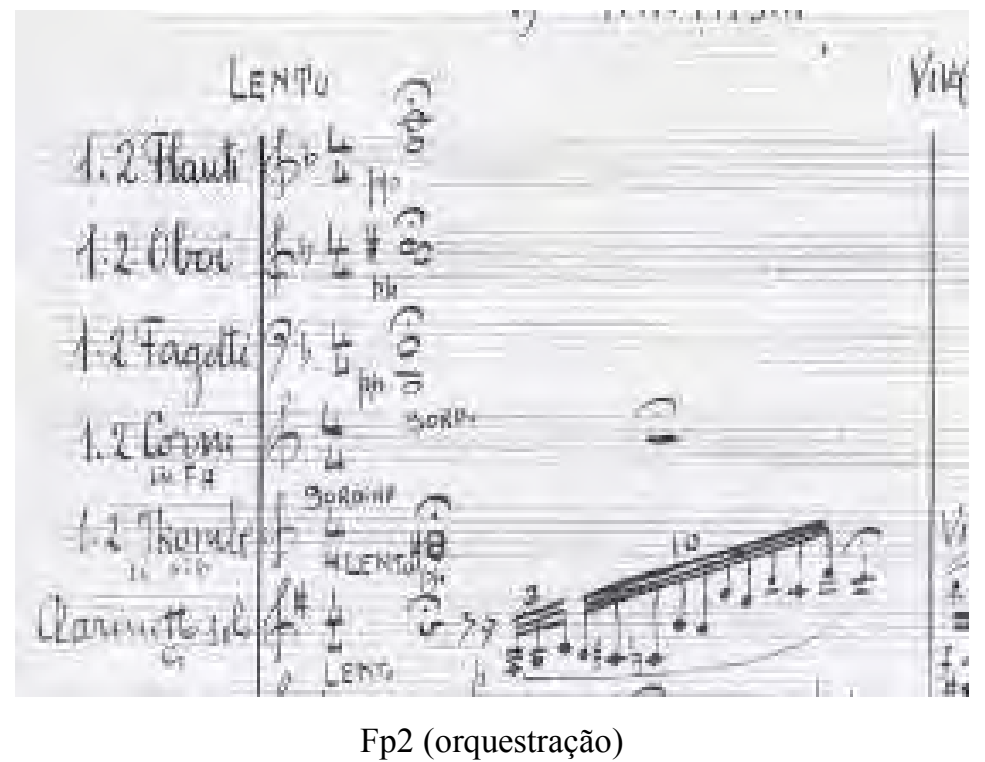

Figura 3 - Fantasia, compasso 1

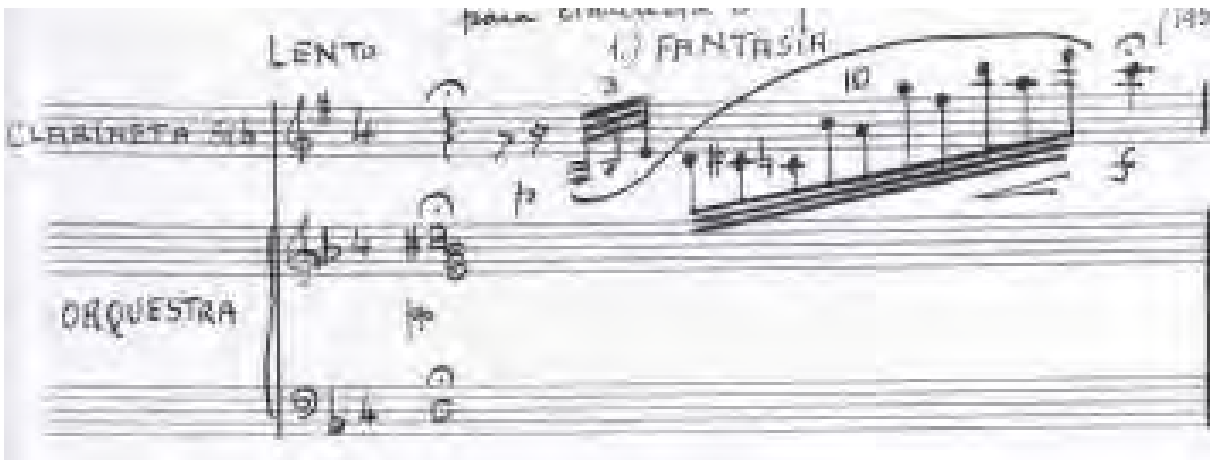

Fp3 (redução)

No esboço (Fp1) e na orquestração (Fp2) está presente a décima terceira nota do acorde (Lá). Já na redução (Fp3) essa nota foi suprimida, possivelmente para facilitar a execução dessa abertura ao teclado. Não sabemos se Mignone pretendia que a obra fosse executada publicamente na versão pianística, mas como se percebe frequentemente nas partituras para piano indicações para orquestra como meio de expressão desejado, podemos assumir que a elaboração da redução pianística tinha como objetivo o estudo da obra e não sua execução pública. Isso corrobora a ideia da facilitação da parte pianística em desvantagem da integridade total da obra.

$\mathrm{Na}$ sequência observamos os sucessivos intervalos de segunda paralela, material composicional de uso assíduo pelo autor durante a obra. 
Figura 4 - Fantasia, compasso 2

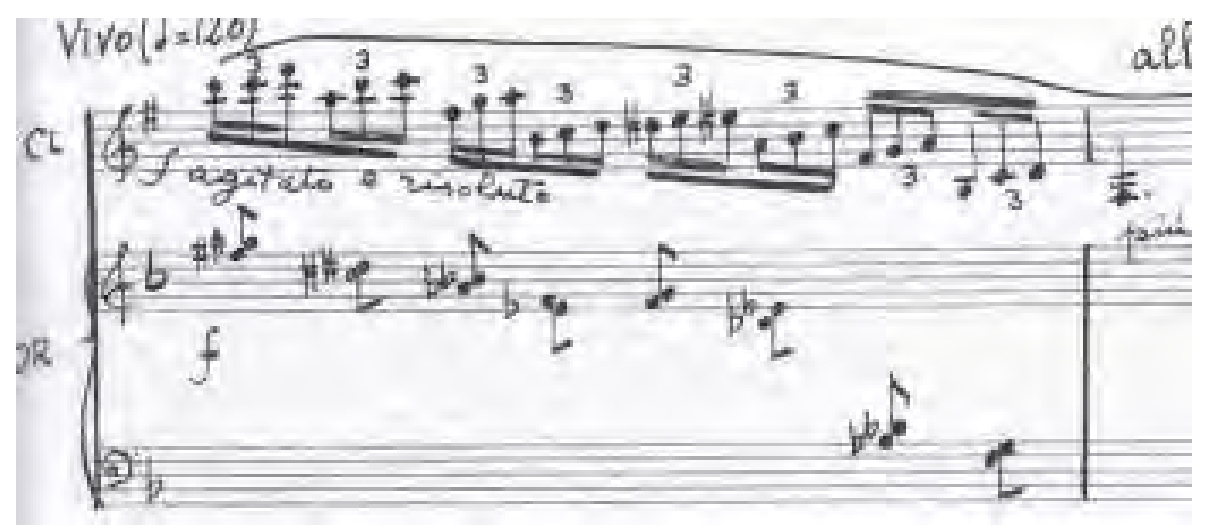

Fp3 (redução)

Um pouco mais à frente notamos o procedimento de movimento contrário entre o acorde da harmonia e o baixo, encaminhando os acordes de $\mathrm{Em}^{7+} / \mathrm{F}, \mathrm{F}^{7+} / \mathrm{E}$ e $\mathrm{Dm}^{7}$ [esse último com uma apogiatura na nona nota do acorde (Mi)] nos compassos 5, 6 e 7. Esse movimento contrário será amplamente utilizado pelo autor, principalmente no primeiro e no terceiro movimentos da obra (Fantasia e Final).

Figura 5 - Fantasia, compassos de 4 a 7
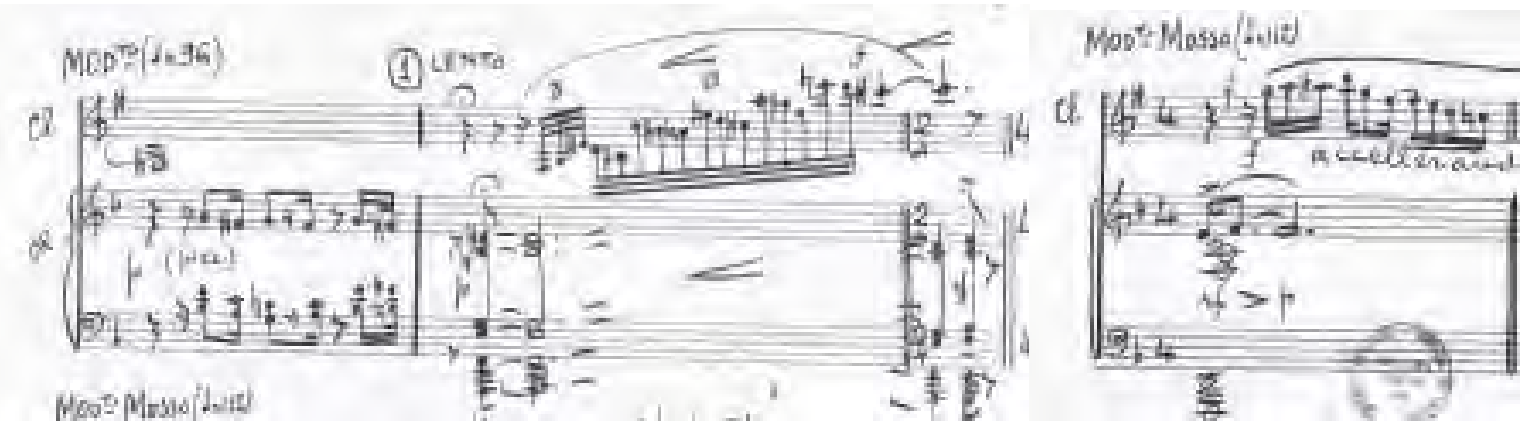

Fp3 (redução)

A maneira como Mignone utiliza os campos harmônicos como material composicional aponta na direção de uma busca pela simplicidade do discurso musical. Despido de procedimentos excessivamente rebuscados ou complexos, o compositor alcança genialmente uma transparência estilística, aproveitando-se da funcionalidade desse material. 
Figura 6 - Fantasia, compassos de 5 a 9

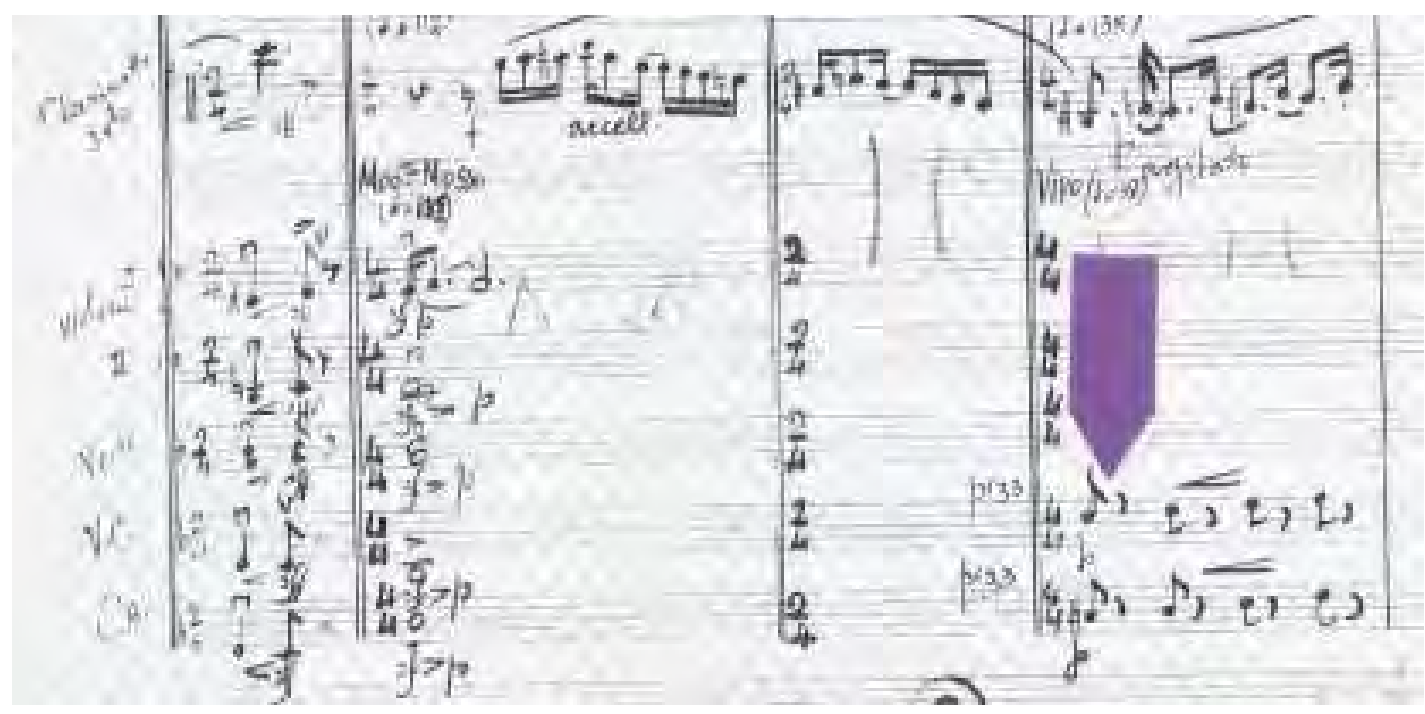

Fp2 (orquestração)

Figura 7 - Fantasia, compassos de 10 a 12

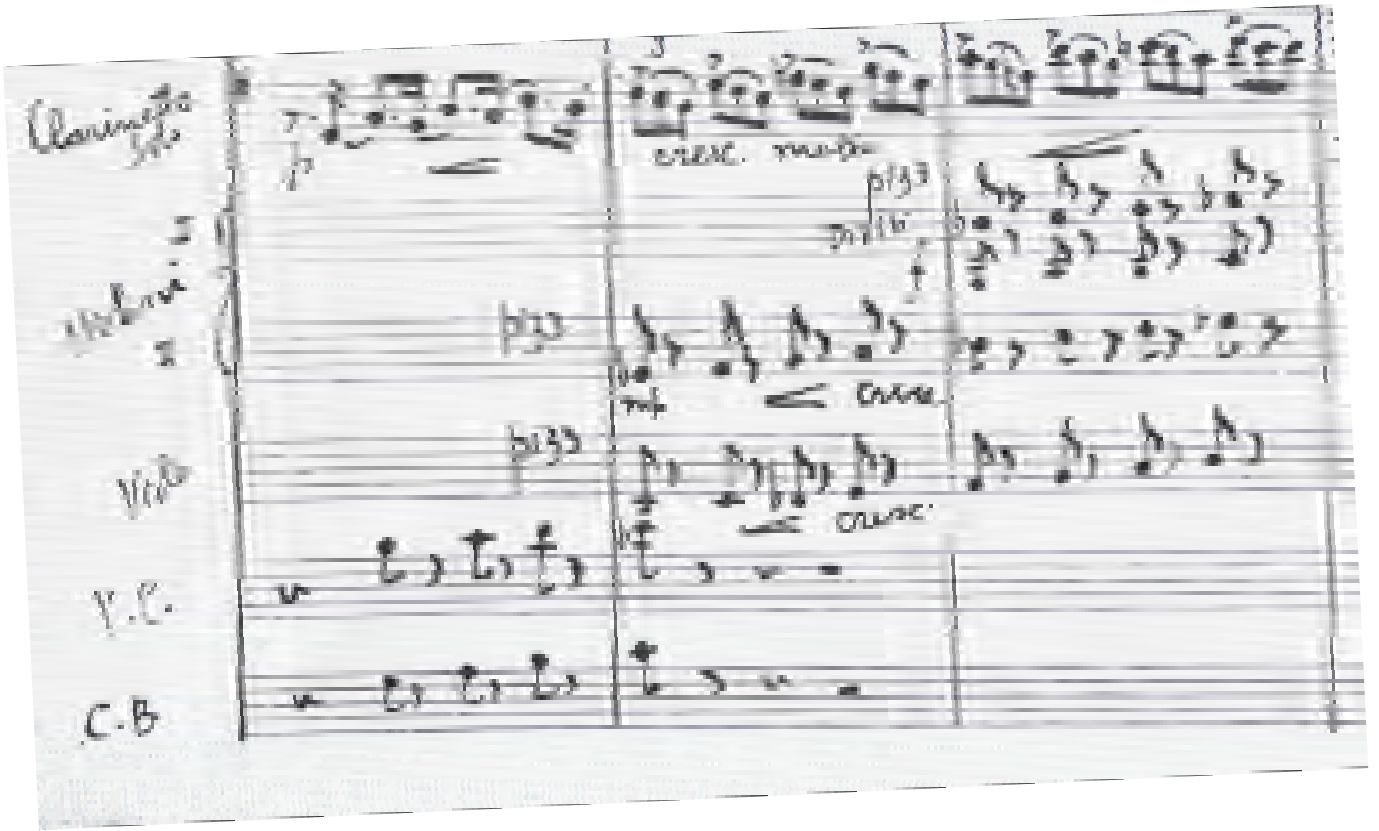

Fp2 (orquestração)

Nos compassos de 9 a 12, a exploração do campo harmônico de Ré menor por intervalos de décimas paralelas em grau conjunto resulta no campo harmônico de Si bemol Maior por meio da inserção de Mib, conduzindo e preparando a chegada de uma harmonia mais intensa nos compassos de 13 a 16. Primeiro, o acorde de $E b_{4+}{ }^{(7+)}$, depois a sobreposição

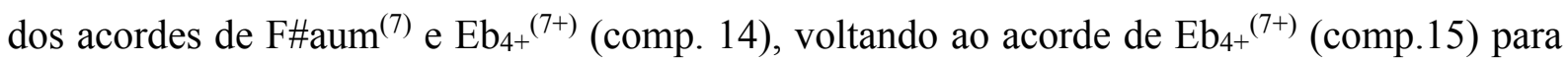
então finalizar o trecho com o acorde de sexta napolitana (sexta aumentada) de Eb (aquele 
composto por dois trítonos ${ }^{11}$ distanciados por um tom inteiro, comp. 16).

Figura 8 - Fantasia, compassos de 10 a 14

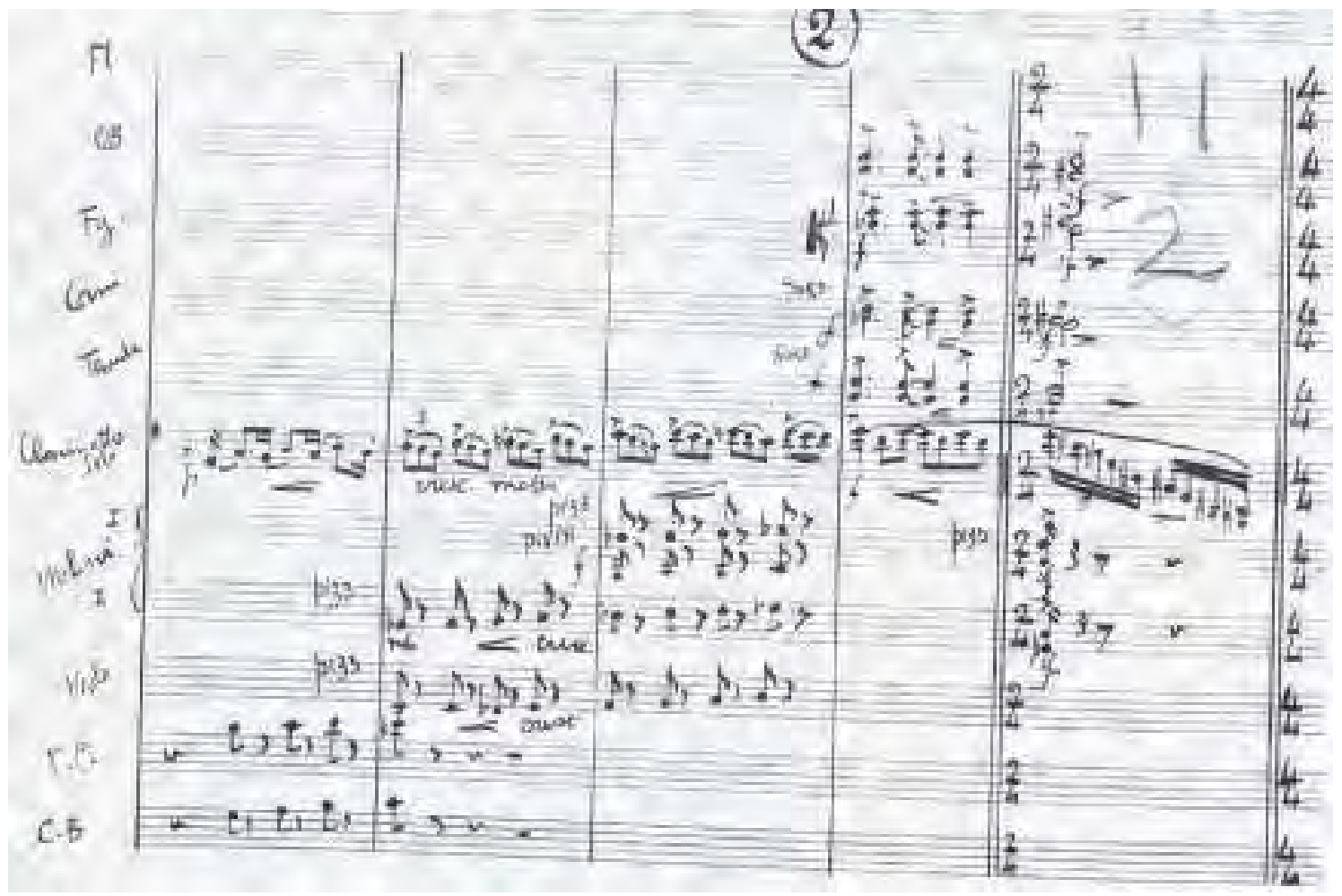

Fp2 (orquestração)

Figura 9 - Fantasia, compassos 15 e 16

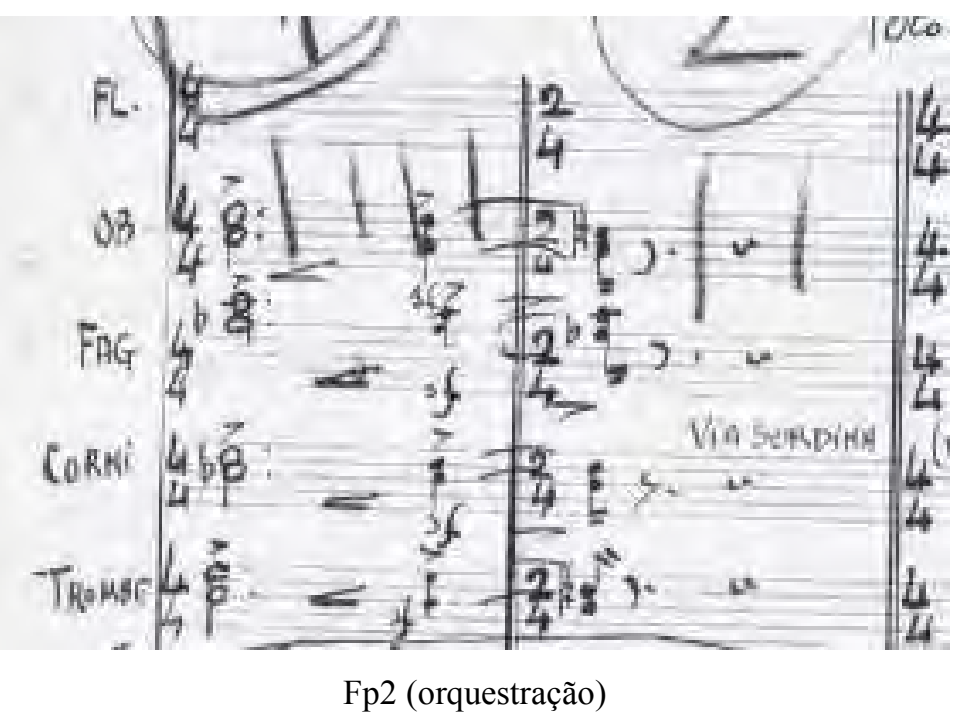

${ }^{11}$ Ver SCHOEMBERG, Tratado de Harmonia, 1999, p. 357 
É interessante notar a ausência da sobreposição dos acordes no compasso 14 nas versões para piano, já que tanto no esboço quanto na redução está anotado apenas o acorde de F\#aum ${ }^{7}$. A decisão sobre a sobreposição ocorreu ao autor durante o processo de orquestração da obra como um reforço timbrístico à articulação, já que o acorde de $\mathrm{Eb}_{4+}{ }^{(7+)}$ está presente no pizz. das cordas e não tem tanta força quanto o acorde dos sopros e metais. Mignone estava em constante revisão e reinvenção de sua obra, e suas decisões apontam para uma consciência profunda da escrita pianística e orquestral. A sobreposição acontece, na orquestra, no espaço da mesma oitava e resulta sonoramente graças à diversidade timbrística entre as famílias da orquestra e o tipo de técnica de execução utilizada. Se estivesse transcrita a mesma sobreposição ao piano, a força do acorde principal ficaria comprometida, soando mais como um cluster do que como um acorde funcional da esfera do Tonalismo. A saída seria então ampliar o contexto para duas oitavas; contudo, a fluência do discurso dos acordes seria também prejudicada.

Figura 10 - Fantasia, compassos de 13 a 16

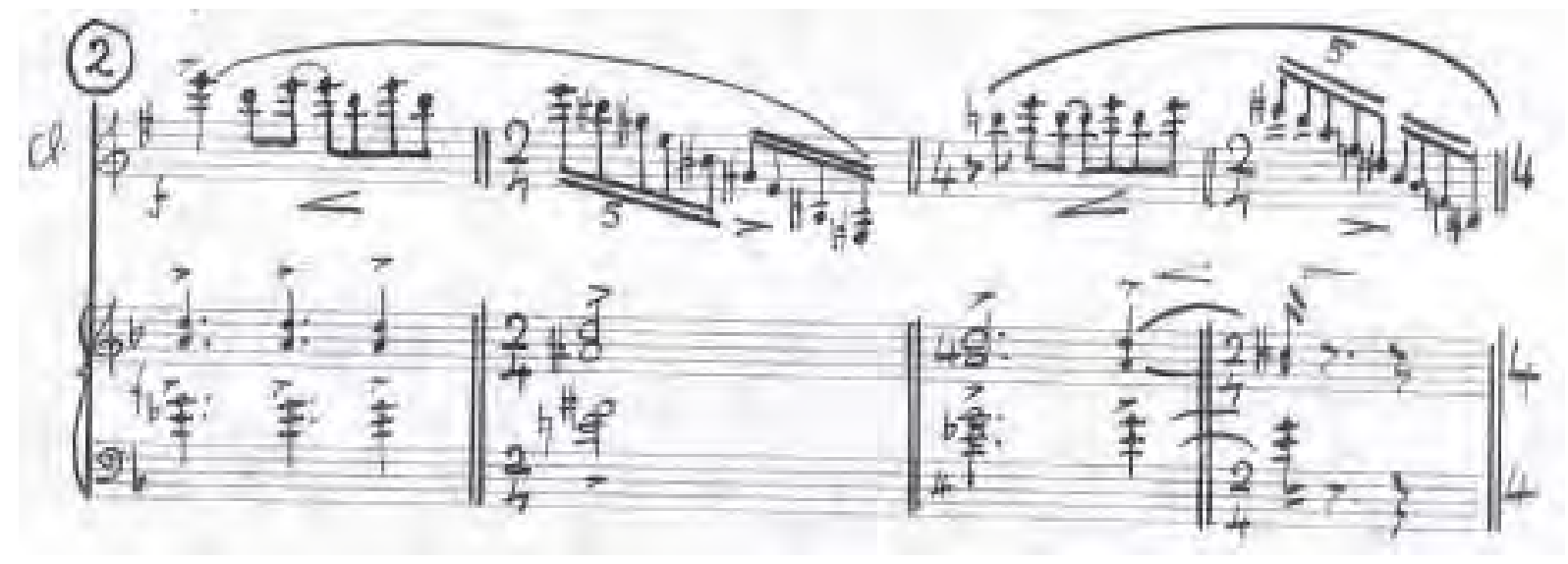

Fp3 (redução)

\section{B - Do compasso 17 até o compasso 37}

Aqui se inicia um trecho de acompanhamento mais ritmado na orquestra, o diálogo do clarinete solista com os cellos e baixos é predominante, e as violas e os violinos são responsáveis pela manutenção do ostinato. São dois os ritmos principais do trecho: 
Figura 11 - ritmos característicos

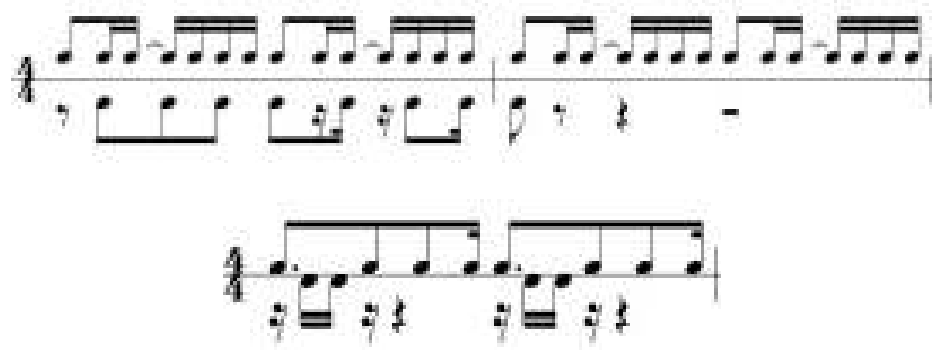

É difícil estabelecer uma única origem para cada um dos ritmos que Mignone imprime nesse seu Concertino; contudo, há de se notar a semelhança do primeiro ritmo da figura 11 com o ritmo da Modinha de Batuque, uma espécie de Batuque praticado no interior do estado de São Paulo, precisamente nas cidades de Capivarí, Tietê, Laranjal Paulista, Porto Feliz, Piracicaba e Jundiaí. Pode também ser encontrado na cidade de São Paulo.

Figura 12 - Modinha de Batuque - No dia quando eu morrê

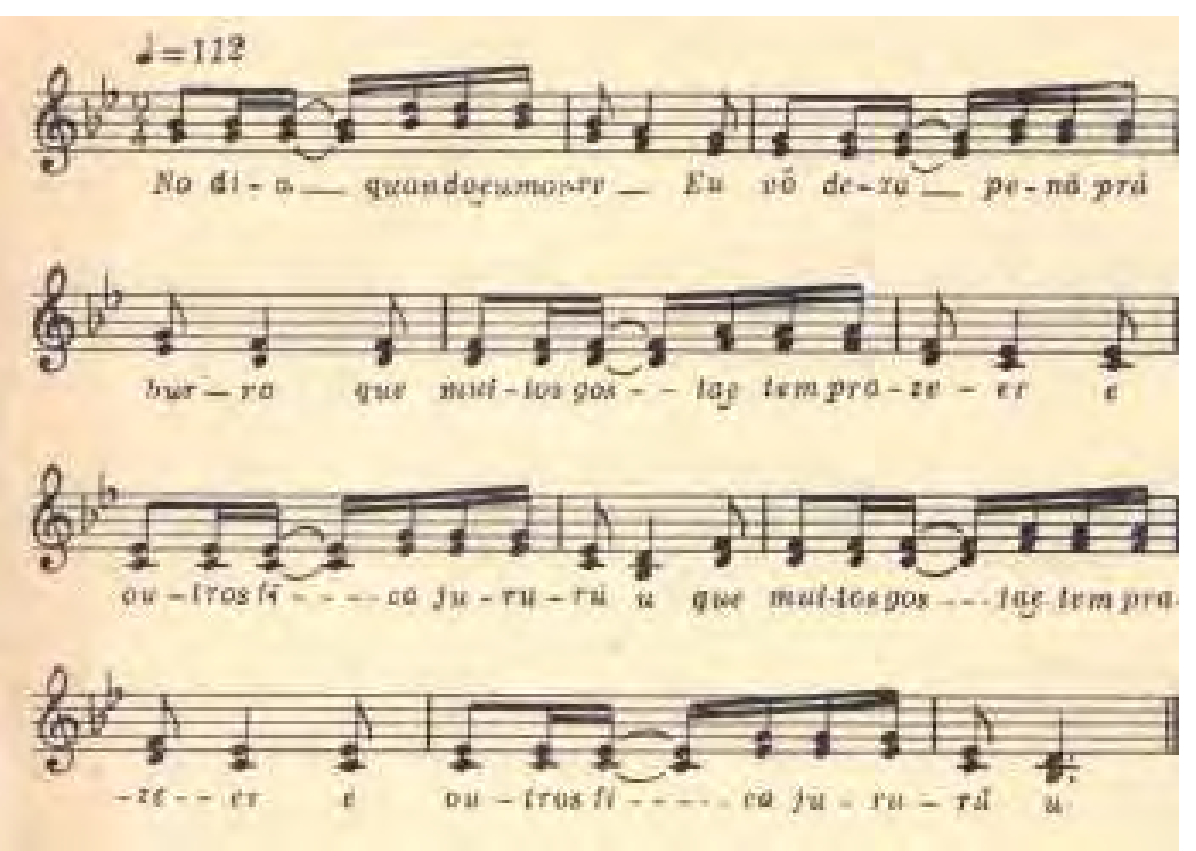

Fonte: MELODIA E RITMO NO FOLCLORE DE SÃO PAULO; Rossini Tavarez de Lima, Ed. Ricordi, São Paulo, 1954, pg. 67

Esse tipo de associação visa enriquecer as informações que se relacionam ao compositor e à obra em questão, e não buscar uma correlação estrita entre a Modinha de Batuque e o Concertino. Não pretendemos comprovar que Mignone se utilizou do ritmo da modinha, mas podemos dizer que esse ritmo, como tantos outros, esteve presente na memória 
do autor. Segundo o Prof. Dr. Ivan Vilela, em entrevista concedida em 2014: “[...] Mignone era um conhecedor da cultura popular paulista. [...] foi ele e o Radamés quem orquestraram as Xácaras ${ }^{12}$ que o Braguinha fez sobre as histórias infantis: O Macaco e a Velha, Da. Baratinha. Lobo Mau e os Três Porquinhos".

Harmonicamente esse trecho do Concertino é simples: as regiões predominantes são Ré menor até o compasso 29 e Lá menor, do compasso 30 ao 37. As tipologias dos acordes são facilmente identificáveis: tríades em posição fundamental, primeiras e segundas inversões; tétrades com sétimas maiores e menores; acordes de quarta suspensa, nona menor e maior, décimas terceiras; acordes diminutos com sétimas maiores e diminutas. A sequência modulatória que Mignone usa no trecho está na figura seguinte:

Figura 13 - Fantasia, sequência modulatória: compassos de 17 a 37

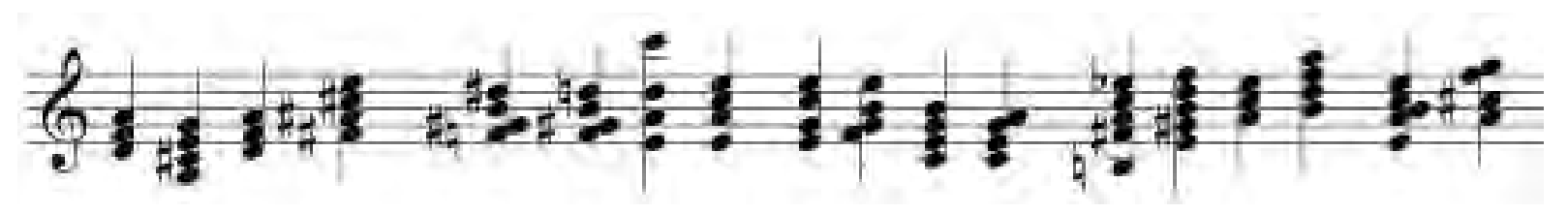

\section{C - Do compasso 38 até o 52}

A exploração do campo harmônico de $\mathrm{Bb}$ - compassos de 38 a 40 - se assemelha ao procedimento demonstrado acima nos compassos de 9 a 12 . O acorde dominante único na peça com formação por sobreposição de tons inteiros 13 no compasso 41 prepara a utilização dos procedimentos de espelhamento e retrogradação do material cromático nos compassos de 42 a 49. O uníssono na orquestra de cordas e a ambiguidade do Dó natural e do Dó\# nos compassos de 50 até 52 finalizam o trecho.

\footnotetext{
${ }^{12}$ Xácara (esp. jácara): Gênero de poema de origem espanhola que era cantado por TROVADORES, no Brasil sofreu influência de tradições populares locais como a MODINHA. (DOURADO, Henrique Autran. DICIONÁRIO DE TERMOS E EXPRESSÕES DA MÚSICA. Editora 34, São Paulo, 2004)

${ }^{13}$ Ver SCHOEMBERG, Tratado de Harmonia, 1999, p. 537/538
} 
Figura 14 - Fantasia, compassos de 36 a 41

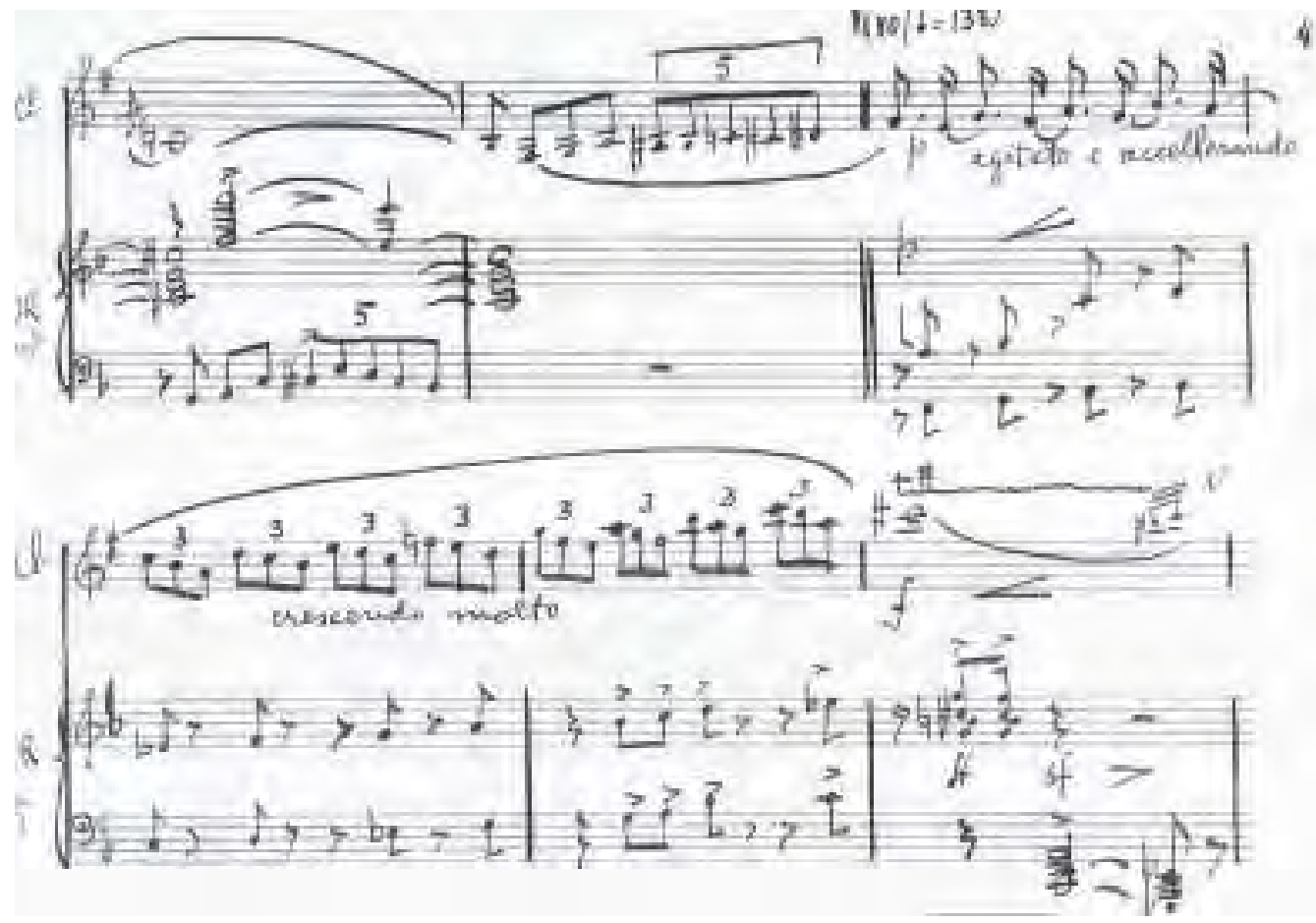

Fp3 (redução)

Figura 15 - Fantasia, compassos de 42 a 45
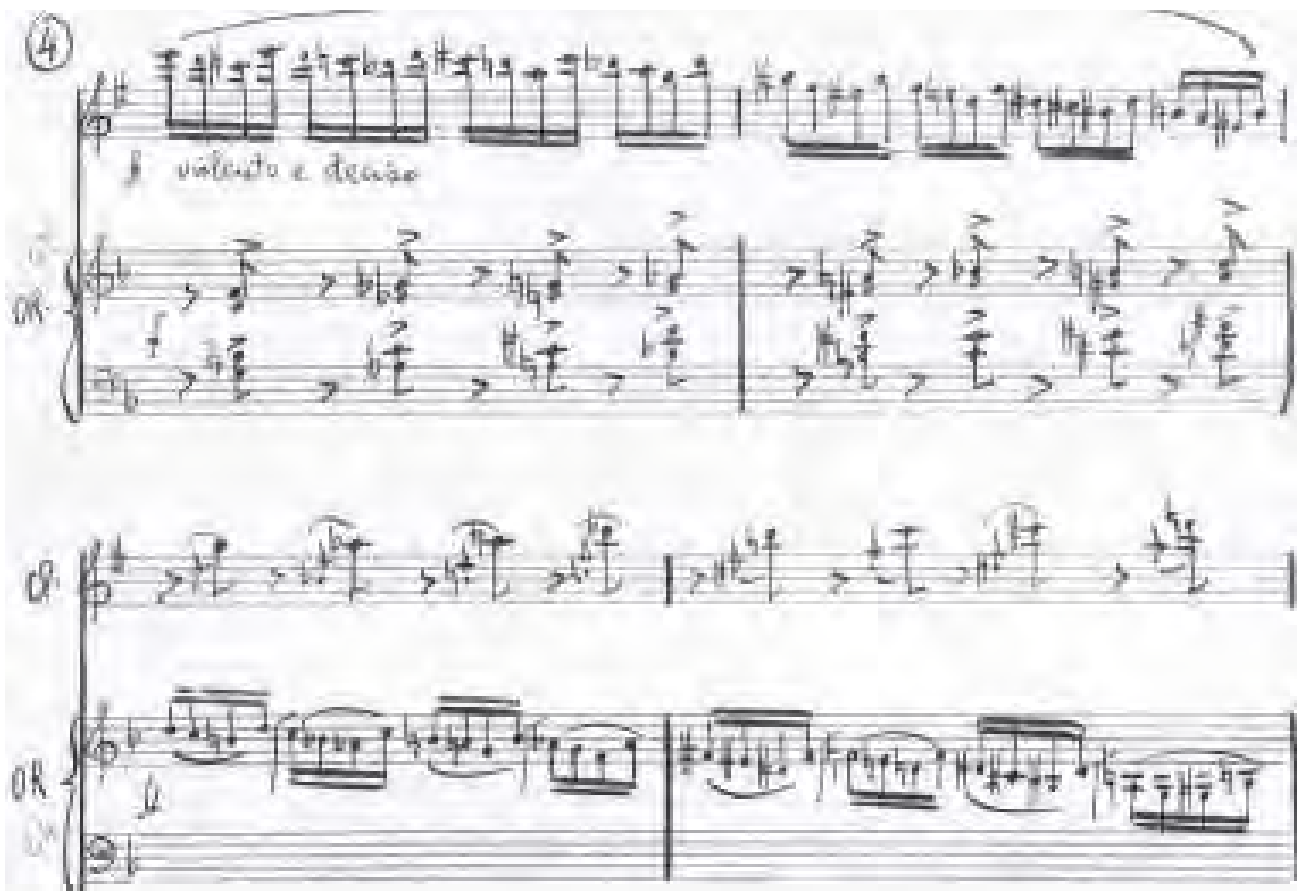

Fp3 (redução) 
Figura 16 - Fantasia, compassos de 46 a 52

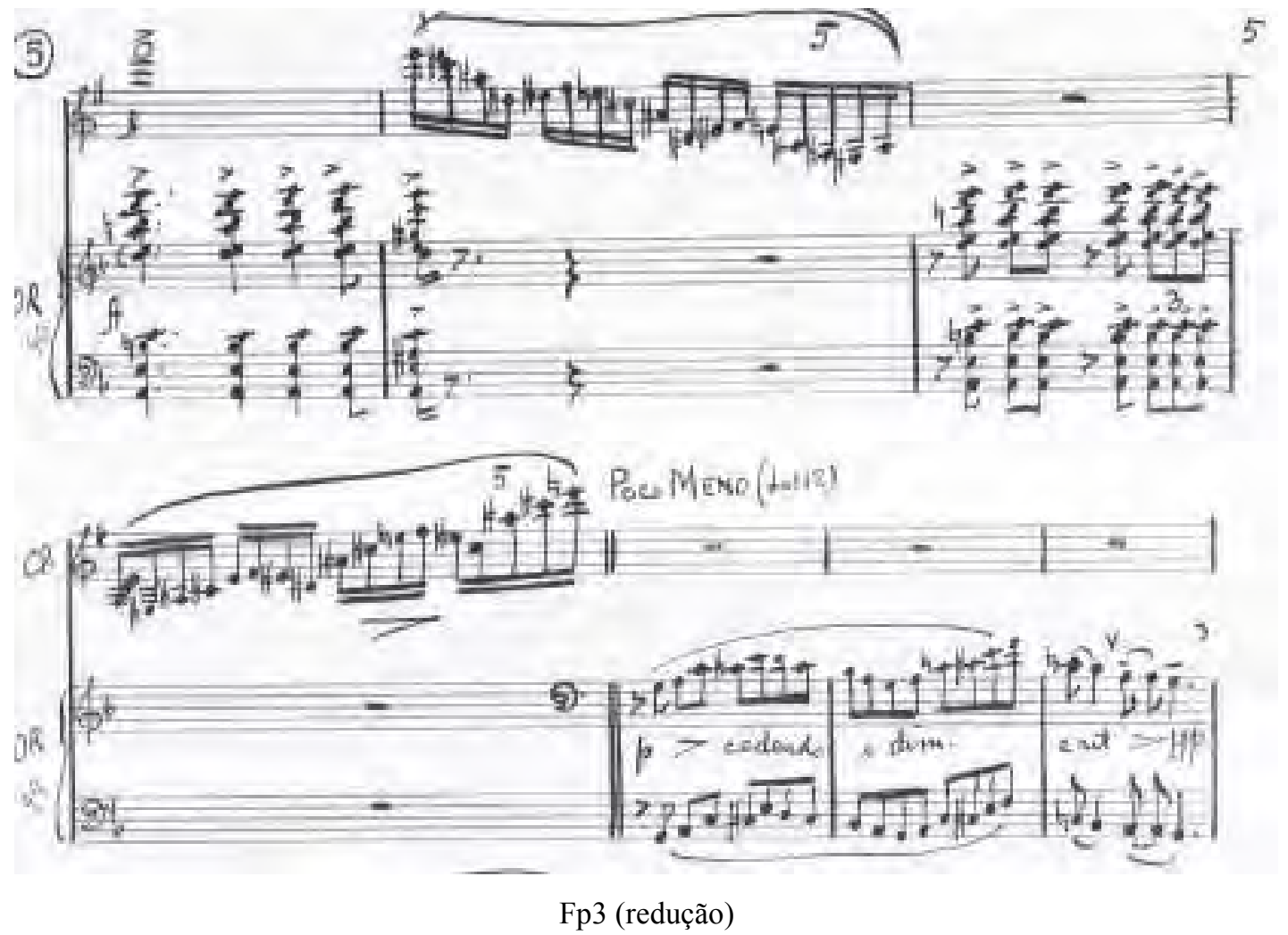

A retrogradação se dá na linha do clarinete nos compassos 47 e 49 (fig. 15), enquanto a inversão se dá entre as partes de solista e de acompanhamento (fig. 14).

\section{D - Do compasso 53 ao 69}

O momento do recitativo é peculiar pelo uso de uma sequência de acordes sobrepostos recriando a sonoridade estática do primeiro compasso da obra. O clarinete solista aproveita-se das notas da harmonia para construir sua melodia, e, embora existam conflitos entre as fontes, os acordes das sobreposições são facilmente identificáveis na sequência do compasso 53 até o 64 (fig. 17). 
Figura 17 - Sequência de acordes de sobreposição

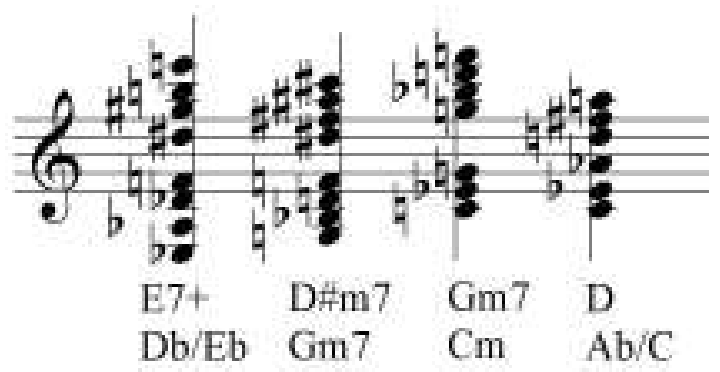

O recitativo termina no compasso 58. No compasso 59 a orquestra responde agressivamente às melodias do clarinete por meio de um adensamento rítmico que se esvai nos compassos 68 e 69 . O trecho finaliza com a utilização do material de exploração do campo harmônico por intervalos de décima, desta vez de Lá Maior e com a orquestra realizando a melodia já apresentada pelo clarinete.

\section{E - Compassos do 70 ao 91}

A partir desse ponto, inicia-se um trecho que podemos compreender como uma recapitulação dos materiais composicionais. Há a repetição do material melódico de B no clarinete, agora com a orquestra acompanhando num ritmo um pouco diferente do apresentado anteriormente (fig. 11, primeiro ritmo), compassos de 70 ao 77 . A presença de um baixo pedal de ritmo similar ao de surdo de samba (ataques nos tempos 2 e 4 do compasso) na nota Sol pode se observada nos compassos de 78 a 84. Os acordes sobre esse baixo pedal apontam para o campo harmônico de Si menor, encaminhando-se, através do Mi menor, para o campo harmônico de Ré menor que conduz ao final do movimento. No compasso 89 Mignone se utiliza do mesmo acorde napolitano montado sobre Mib para alcançar o pedal na nota Ré que se manterá do compasso 90 até o fim do movimento.

\section{F - Do compasso 92 até o fim}

Esses compassos finais funcionam como uma pequena Coda que traz em suas cadências os acordes de Dm, C, Eb, Ebm e E. A mistura das funções harmônicas por meio da utilização desses acordes como dominante e subdominante corrobora a sonoridade do acorde napolitano usado anteriormente nos modos Maior e menor. Embora não seja essa uma cadência final comumente utilizada, cumpre sua função de revelar e contextualizar as 
circunstâncias que permearam o movimento como um todo. Podemos notar ainda a presença do material de exploração dos campos harmônicos por meio de intervalos de décima diatônicos e cromáticos e da região harmônica do quinto grau da tonalidade do movimento. 


\section{Segundo movimento - TOADA}

A Toada apresenta pouca ou nenhuma variação de andamento: o pulso perpassa todo o movimento sem nenhuma indicação de ritenuto, accelerando ou de mudança súbita de marcação metronômica. O movimento rítmico principal apresentado no compasso quaternário é obtido por meio da sobreposição das células: mínima pontuada e semínima, semínima pontuada e colcheia ligada à mínima seguinte, mínima ligada à concheia e semínima pontuada.

Figura 18 - Toada, ritmo característico

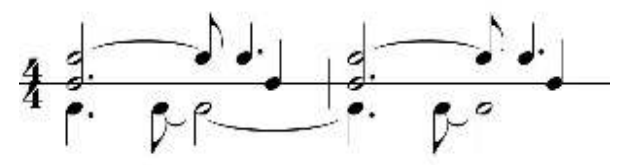

Ritmo base para a construção do movimento

Esse ritmo também é o material de base da Toada pra Você, de Lorenzo Fernandez, em parceria com Mário de Andrade, uma das canções mais famosas daquele compositor na década de vinte. O material harmônico composto pela alternância constante de tônica e subdominante também é semelhante. Contudo, a Toada de Mignone não parece uma citação da Toada de Lorenzo Fernandez ${ }^{14}$. Segundo o Prof. Dr. Ivan Vilela “[...] a Toada pode ser entendida como um maxixe lento, lânguido e dolente. Sua origem possivelmente é portuguesa e normalmente é escrita em 4 por 4 . Espalha-se por todo o Brasil. Na música caipira há a Toada histórica, ligada ao romance, contando um acontecido, imaginado ou sonhado".

A Toada pode ser também um Baião lento, como é o caso da Toada de Mignone, ou da Toada de Baixão e Maião ${ }^{15}$, ambas advindas do Cururu Paulista.

\footnotetext{
${ }^{14}$ Em 1948, Mignone gravou ao piano a Toada pra Você de Lorenzo Fernandez, com Alice Ribeiro realizando a parte do canto, pela gravadora Odeon.

15 "O Cururu apresenta música vocal e instrumental. A vocal, geralmente em falsete, possui duas partes: o canto silábico de introdução e de encerramento e o canto versificado na 'carreira' ou rima. O primeiro [...] hoje denomina-se 'Baixão'; o segundo chama-se 'Maião'. [...]. Ambas as partes são conhecidas por 'Toadas"' (Fonte: MELODIA E RITMO NO FOLCLORE DE SÃO PAULO; Rossini Tavarez de Lima, Ed. Ricordi, São Paulo, 1954, pg. 20).
} 
Figura 19 - Toada de Baixão e Maião, Meu rico Povo

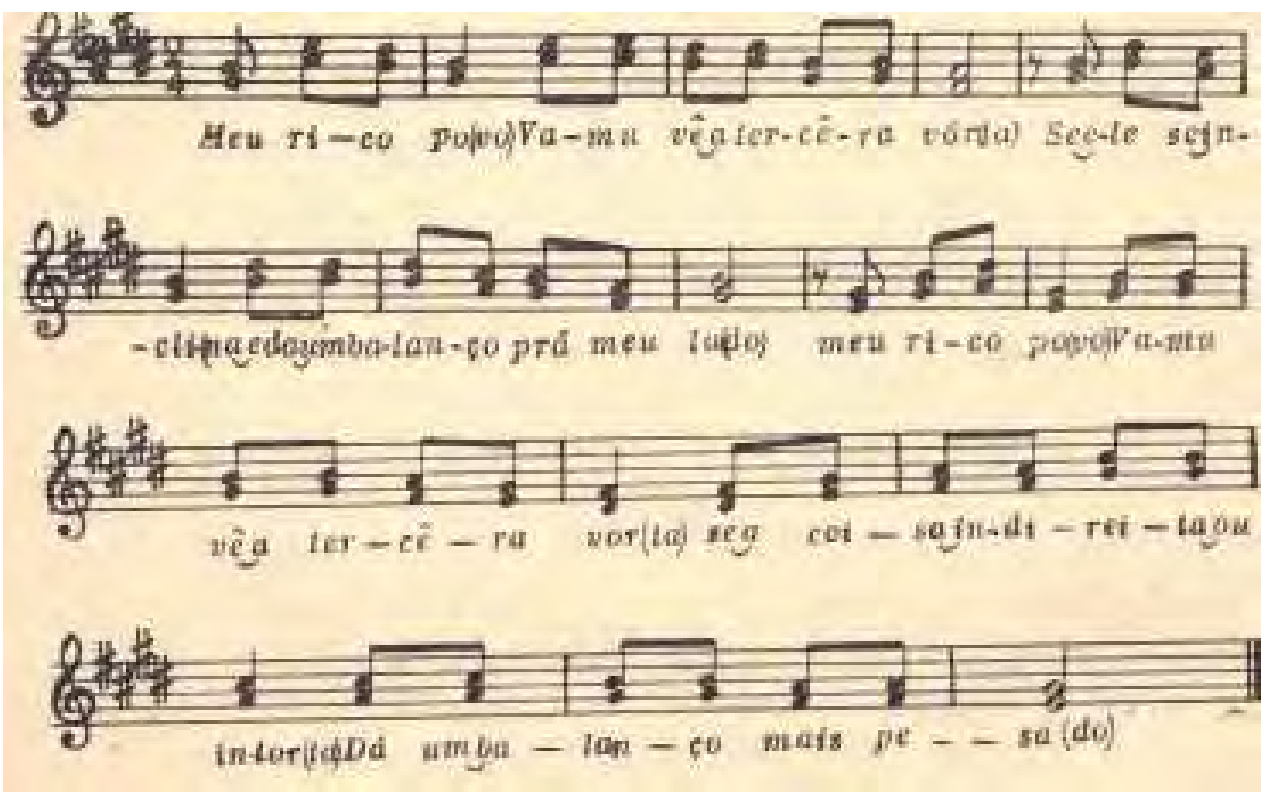

Fonte: MELODIA E RITMO NO FOLCLORE DE SÃO PAULO; Rossini Tavarez de Lima, Ed. Ricordi, São Paulo, 1954, pg. 31.

Figura 20 - Ritmo da viola de dez cordas da Toada de Baixão e Maião.

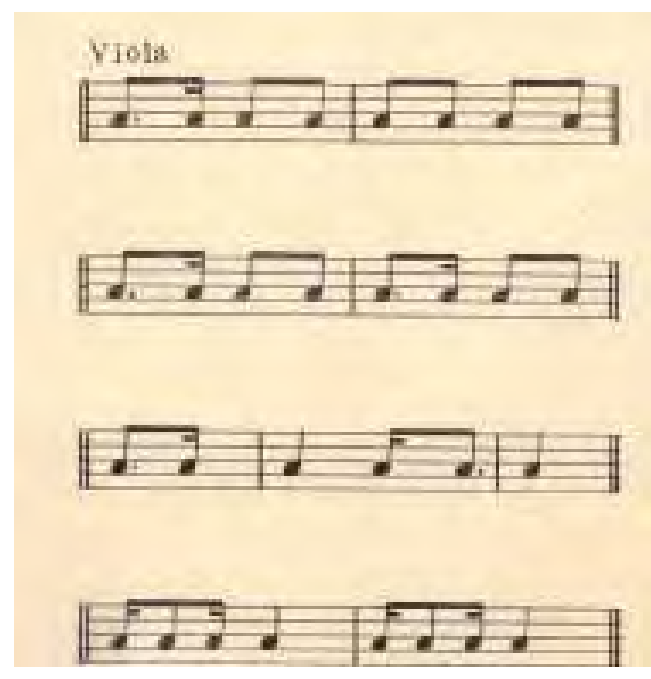

Fonte: MELODIA E RITMO NO FOLCLORE DE SÃO PAULO; Rossini Tavarez de Lima, Ed. Ricordi, São Paulo, 1954, pg. 32.

Duas características são apreensíveis das figuras acima em relação à Toada de Mignone: na primeira, a melodia de Meu rico Povo (fig. 19) tem um traço descendente comum às Toadas de Baixão e Maião presente na melodia do clarinete no Concertino; na segunda, o acompanhamento da viola da Toada de Baixão e Maião (fig. 20) se assemelha ao 
ritmo de acompanhamento da Toada de Mignone. Embora a maneira de escrita seja bem diferente, o que resulta sonoramente guarda semelhanças perceptíveis.

Figura 21 - Toada, compassos de 5 a 12, melodia do clarinete.

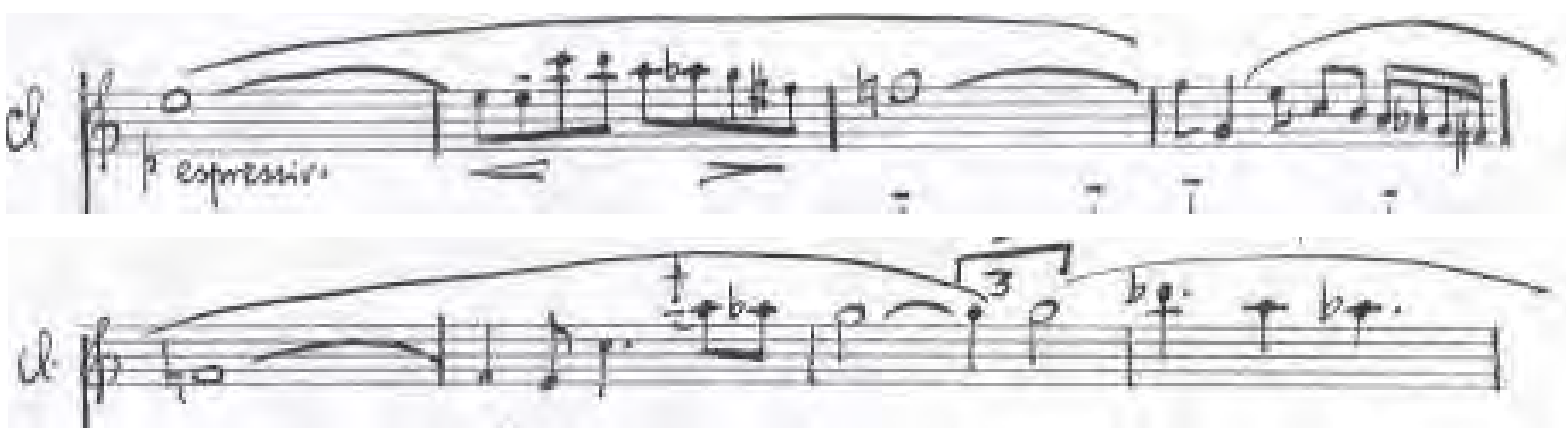

Fp3 (redução)

Figura 22 - Toada, compassos de 1 a 4, acompanhamento.

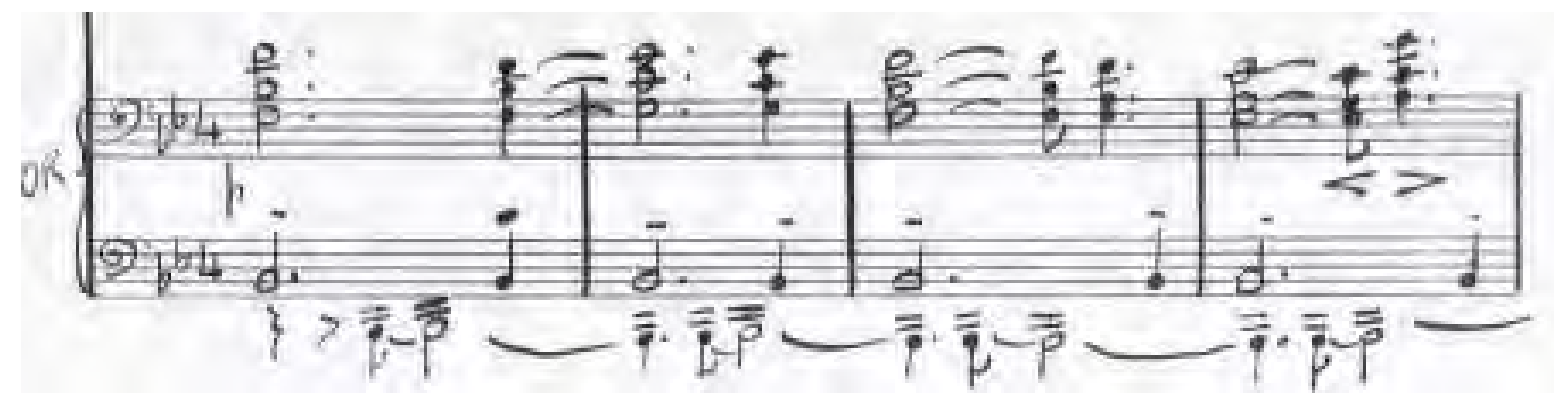

Fp3 (redução)

A harmonia da Toada é consideravelmente mais simples do que a da Fantasia, e as melodias são mais singelas e claras. A orquestra apenas pontua com variações pequenas, comentando como um violão de Seresta. É nos solos de clarinete, costurados pela flauta e pelo fagote em diálogo, que a Toada ganha seu maior interesse. As partes são as seguintes:

\section{A - Do início ao compasso 19}

Neste início, a pequena preparação da orquestra em quatro compassos põe em evidência o pedal constante no Sib (que vai durar até o compasso 20) e a exploração desse campo harmônico por meio do ciclo cadencial I-II-I-II-VII-I. A melodia do clarinete paira sobre o acompanhamento das cordas construído por meio do ritmo da figura 17. A presença de Láb e Mi natural não soa como os cromatismos do clarinete, mas como parte integrante da harmonia, isto é, amplia o campo harmônico de Sib. 


\section{B - Do compasso 20 ao 29}

A partir da entrada da flauta em diálogo com o clarinete no compasso 20, a orquestra inverte a utilização das figuras rítmicas: os materiais passam dos violinos e violas para violoncelos (com divisi) e contrabaixos e vice-versa. A nota pedal muda para Dó do compasso 21 ao 29, mas o campo harmônico utilizado permanece o de Sib expandido.

\section{C - Do compasso 30 até o fim}

Aqui o Sib retorna como nota pedal, ao mesmo tempo em que o fagote surge tomando o lugar da flauta no diálogo com o solista. A harmonia permanece estável no campo harmônico de Sib (com Mi natural e Láb), e a presença do acorde napolitano de $\mathrm{Gb}^{6+}$, nos compassos 37 e 39, como dominante faz a citação das estruturas harmônicas do primeiro movimento.

\section{Terceiro movimento - FINAL}

Dos três movimentos, o Final é o mais dançante. As variações de andamento são pontuais e a presença de ritmos brasileiros, aliada ao andamento solicitado pelo compositor, dão a ele o caráter festivo e vivaz, apesar da tonalidade menor. As estruturas harmônicas são simples, contando com cromatismos que caminham em tríades inteiras, e o campo harmônico é predominantemente o de Ré menor. A orquestra dialoga com o solista por meio de tuttis formalmente colocados na separação das partes e, quando o acompanha, utiliza-se de um procedimento próximo ao da Toada: ritmos ostinatos com variações pequenas.[H6] As partes são as seguintes:

\section{A - Do início até o compasso 36}

A utilização constante do ritmo - colcheia, pausa de semicolcheia, semicolcheia, pausa de colcheia, colcheia -, seguido de tercina de semínima, infere um caráter dançante e sincopado ao movimento. Apresentando algumas variações, esse ritmo é o fio condutor desse movimento. 
Figura 23 - Final: ritmo condutor

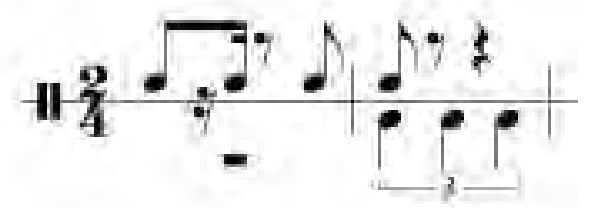

A harmonia dialoga com outros momentos importantes do Concertino. Logo no início do terceiro movimento (fig. 24), encontramos o paralelismo dos acordes de Dm, Eb, E e a resolução em Dm novamente. Procedimentos parecidos saparecem na Fantasia nos compassos 5, 6 e 7 (vide fig. 5) e 92, 93, 94, 97, 98, 99 (figs. 25 e 26). O mesmo acontece na Toada nos compassos 28 e 29.

Figura 24 - Final, compassos de 1 a 4

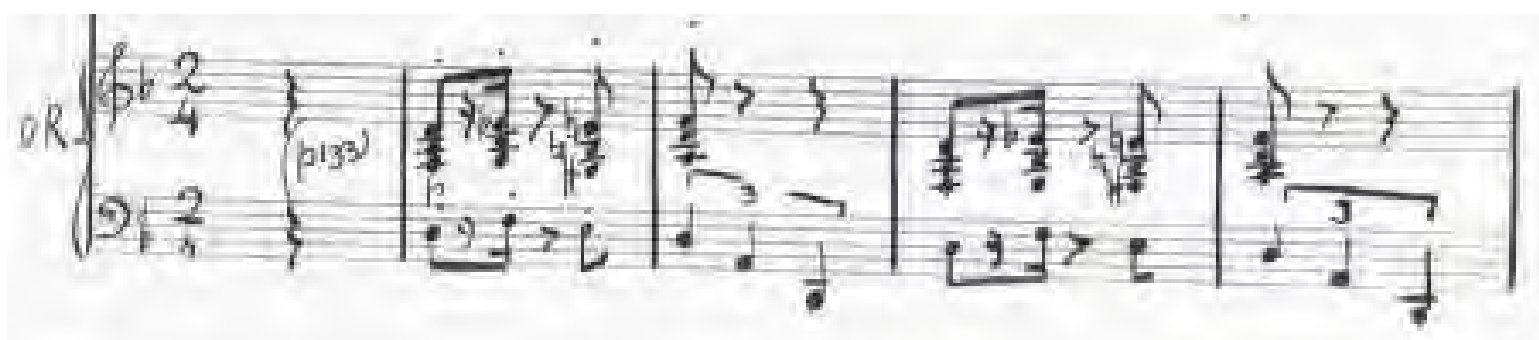

Fp3 (redução)

Figura 25 - Fantasia, compassos de 91 a 99

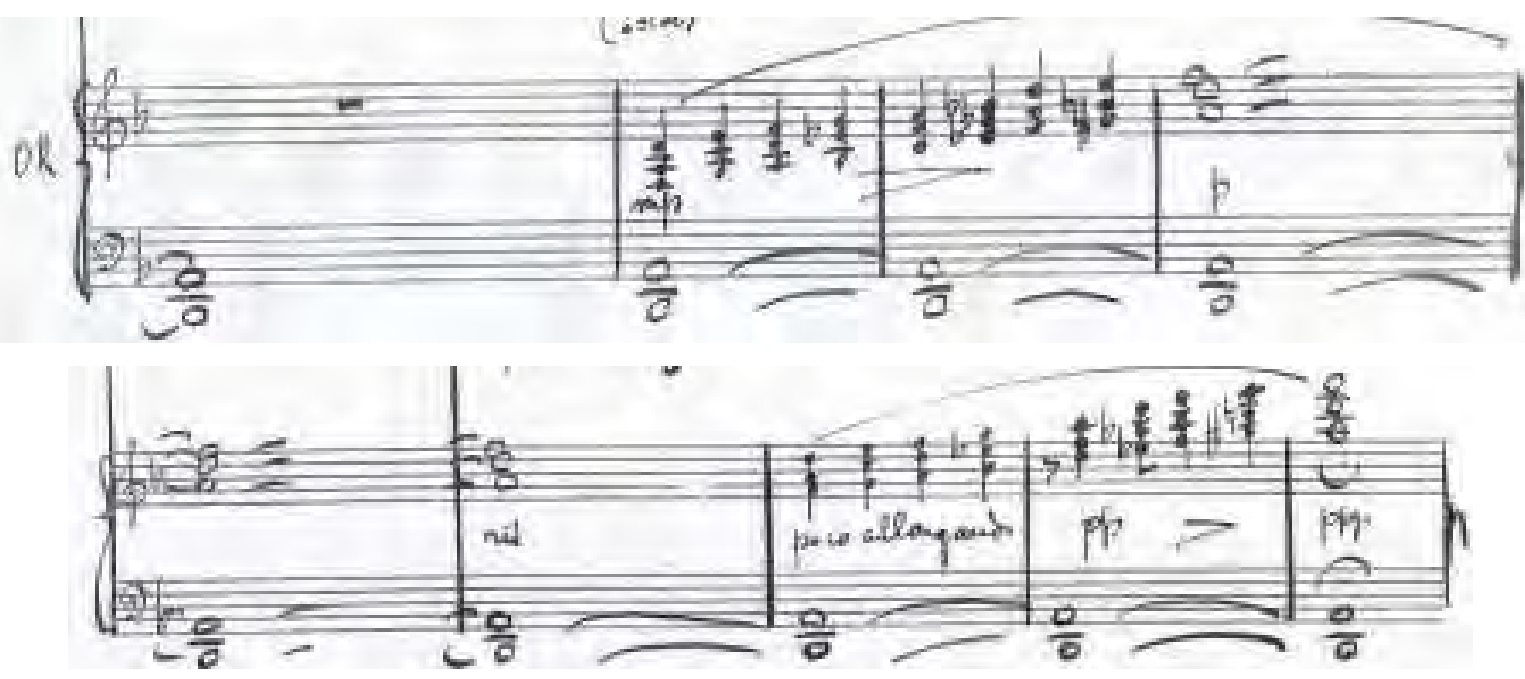

Fp3 (redução) 
Figura 26 - Toada, compassos 28 e 29

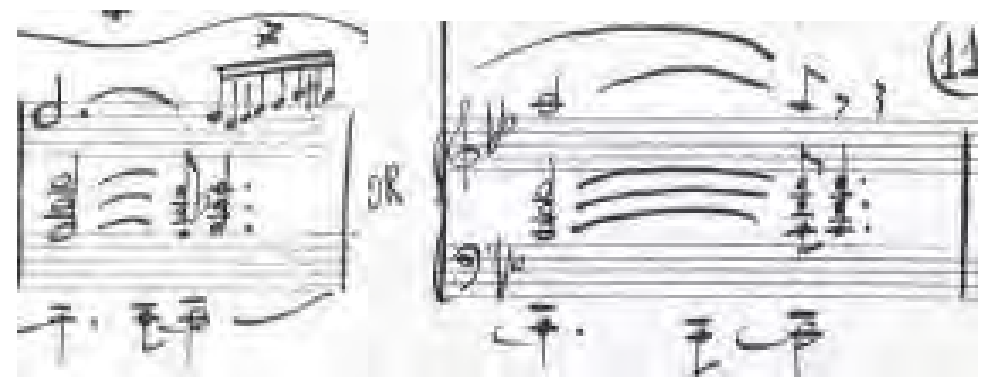

Fp3 (redução)

Considerar as claves de Sol para o pentagrama superior e de Fá, para o pentagrama inferior

O cromatismo de acordes inteiros em movimento contrário, oblíquo e paralelo à linha do baixo será percebido durante todo o terceiro movimento. Esse material amplia o campo harmônico dos trechos; apesar disso, a Fantasia e o Final permanecem quase que integralmente na tonalidade de Ré menor. No Final, as regiões próximas exploradas são as típicas de IV e $\mathrm{V}$ graus. No compasso 17 o acorde napolitano aparece novamente, corroborando a sonoridade harmônica pretendida no Concertino. Notamos a presença do acorde durante a obra, como mostram as figuras:

Figura 27 - Final, compassos de 15 a 17

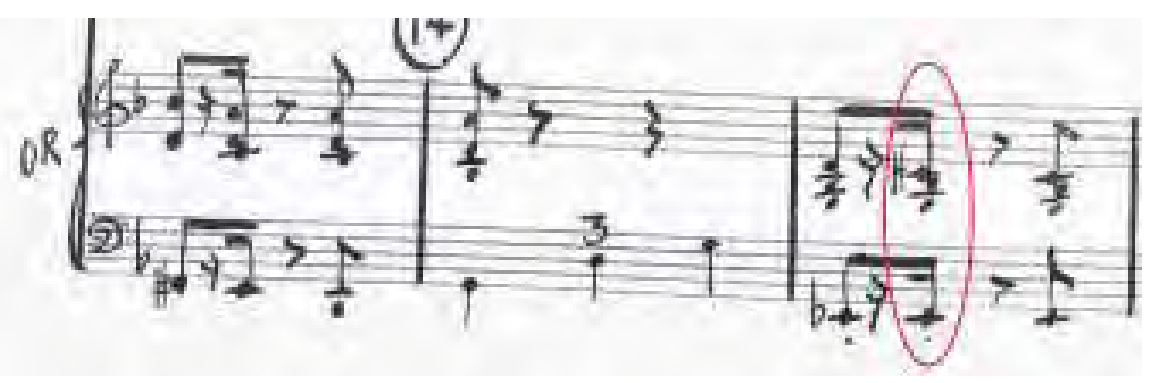

Fp3 (redução)

Figura 28 - Final, compassos 22 e 23

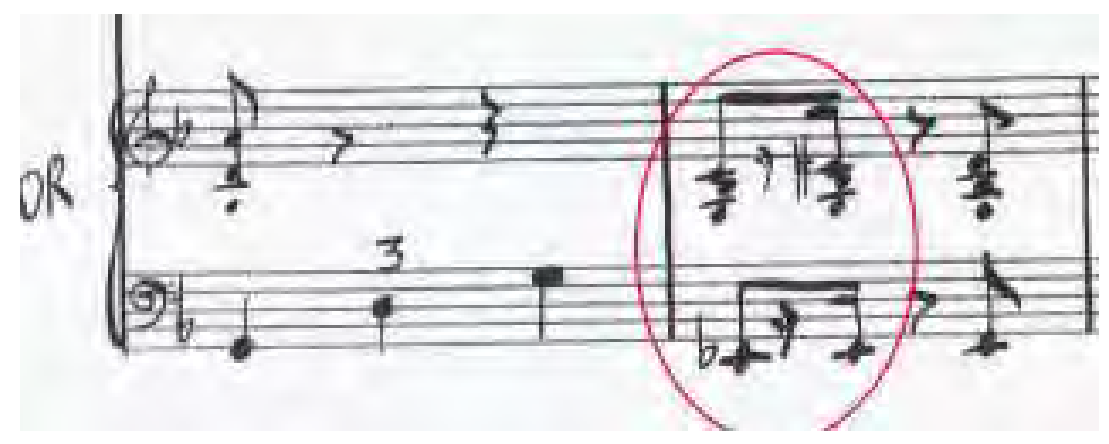

Fp3 (redução) 
Figura 29 - Final, compassos de 100 a 104

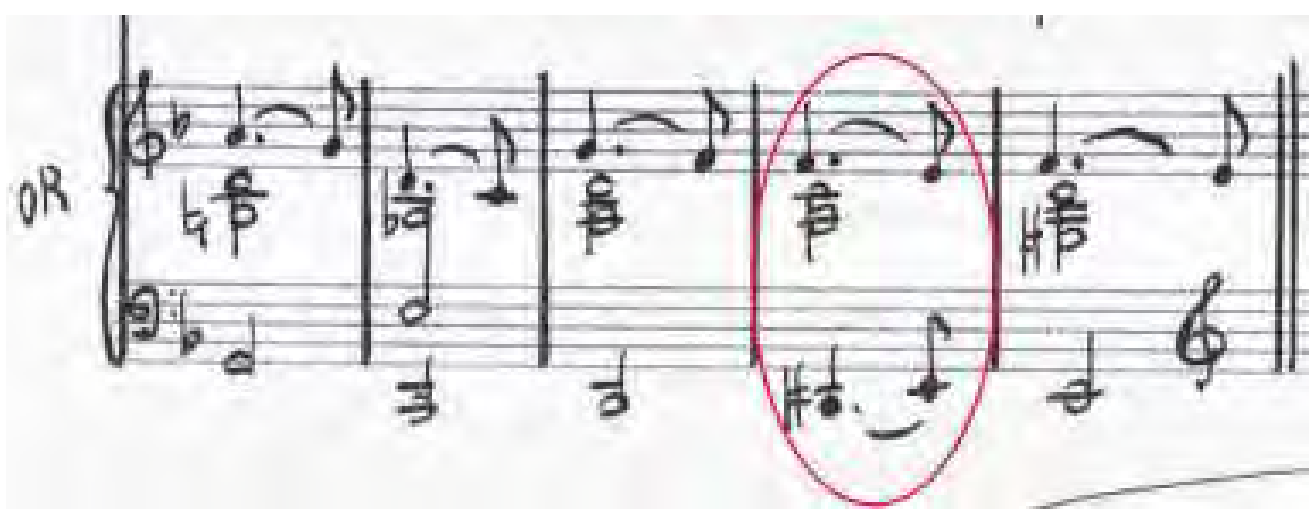

Fp3 (redução)

Figura 30 - Toada, compassos de 36 a 39

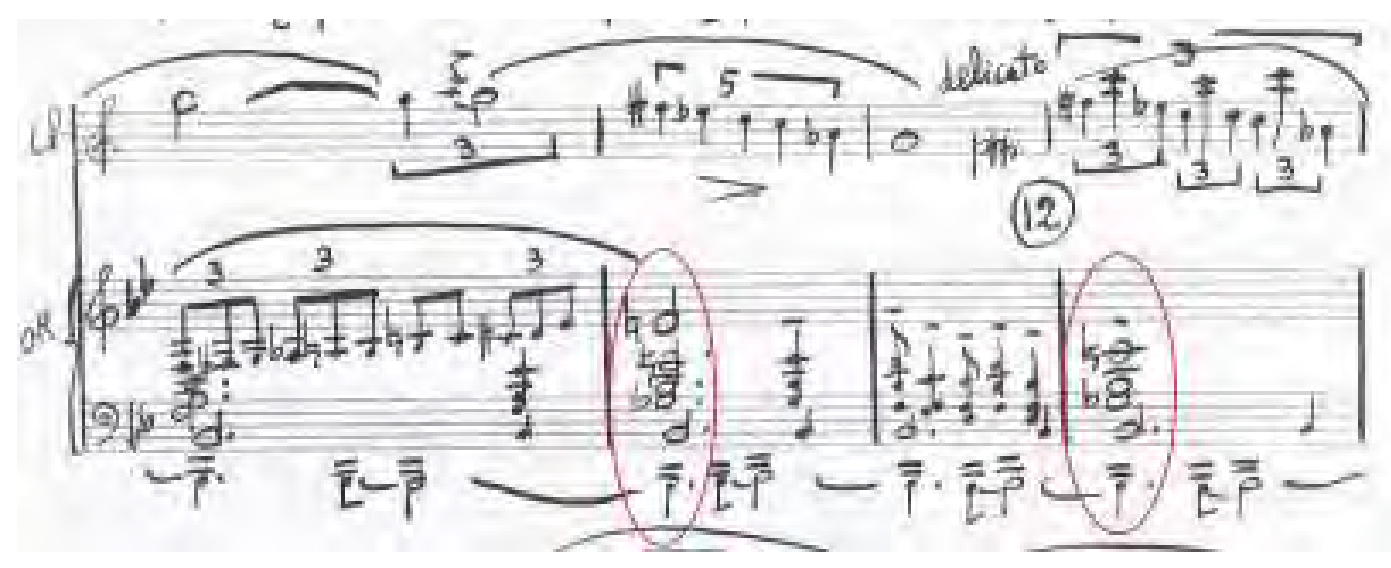

Fp3 (redução)

Figura 31 - Fantasia, compassos de 13 a 16

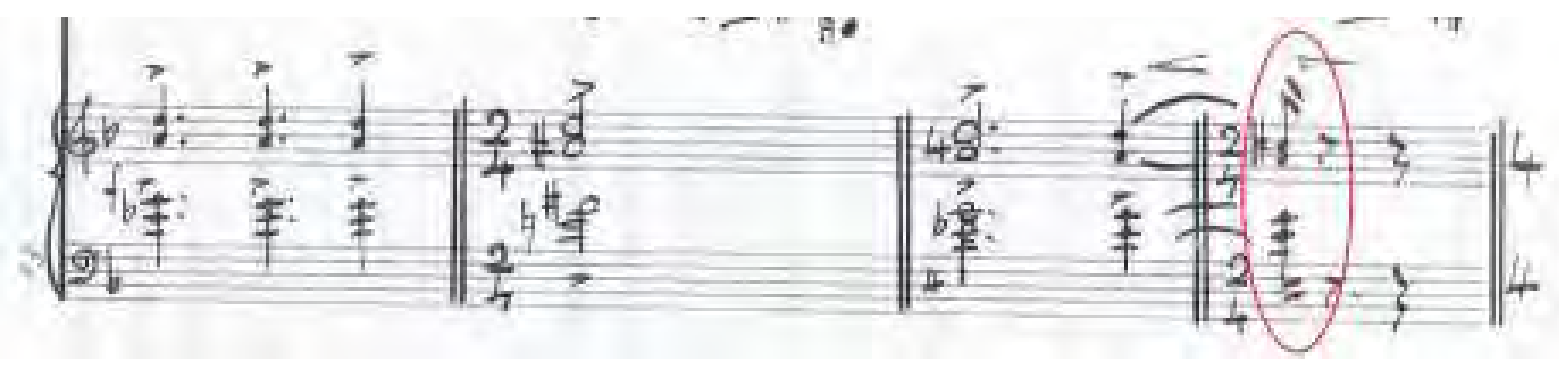

Fp3 (redução)

32 - Fantasia, compassos de 88 a 90

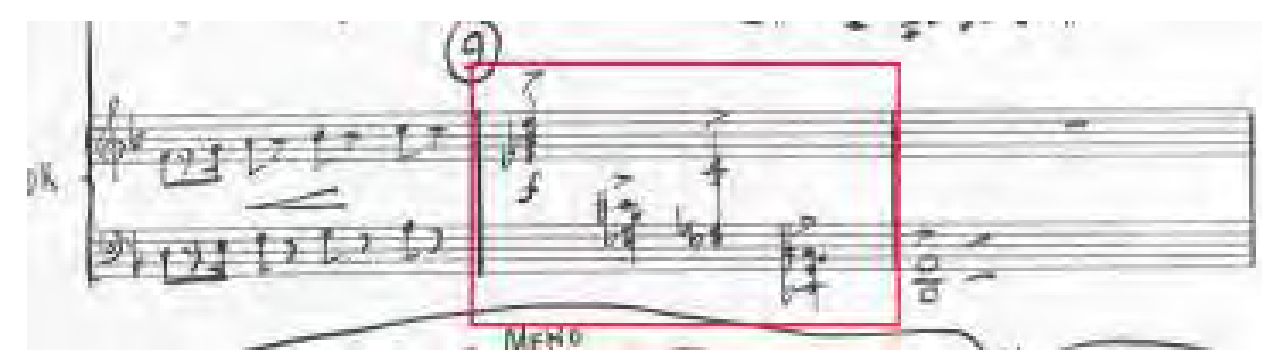

Fp3 (redução) 
Finalizando essa parte A e cumprindo o papel de preparação do tutti que virá na parte B, ressurgem as segundas paralelas que foram utilizadas no segundo compasso da Fantasia. Ainda será possível compreender essas paralelas do Final como oriundas do material cromático dos compassos 42 e 43 da Fantasia. A presença das terças também cromáticas, só que descendentes nos fagotes, corroboram essa expectativa, ajudando a alcançar o acorde dominante necessário para a chamada do tutti em $\mathbf{B} .^{16}$

Figura 33 - Final, compassos de 32 a 36

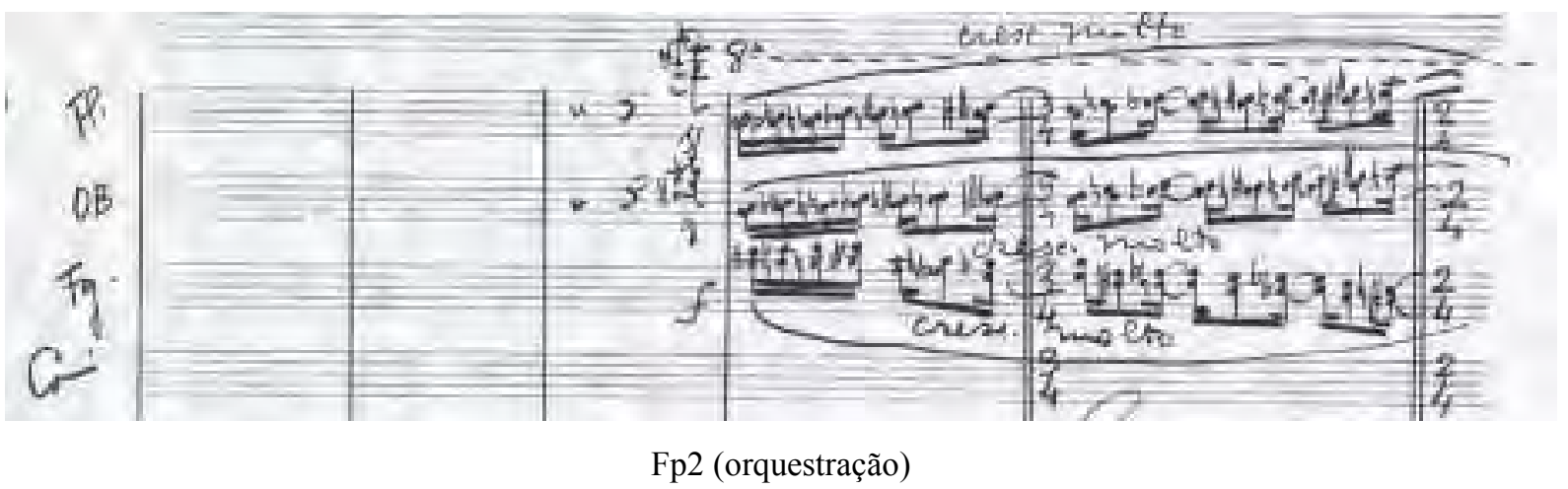

Considerar a clave de Sol para a flauta e o oboé, e a clave de Fá, para o fagote

Figura 34 - Final, compassos 42 e 43

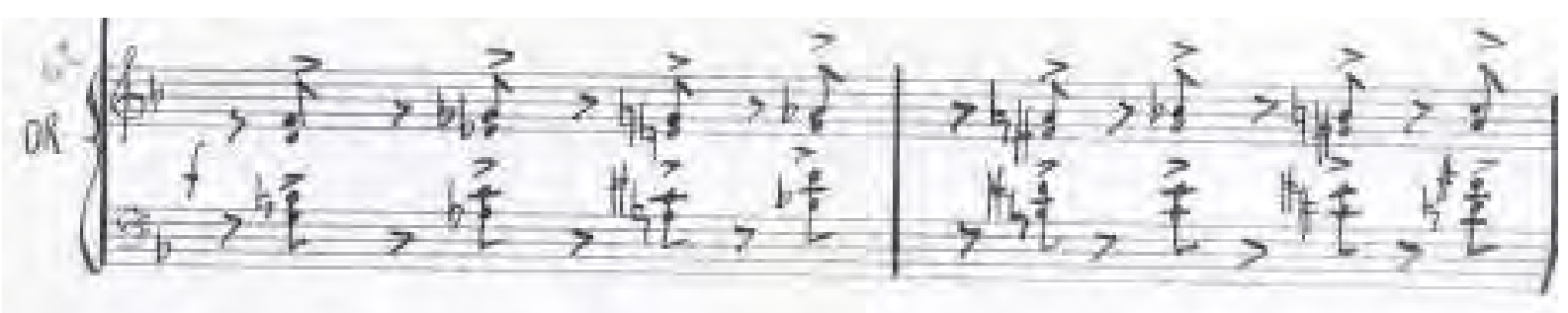

Fp3 (redução)

\section{B - Do compasso 37 ao 53}

O tutti orquestral que se inicia no compasso 37 utiliza o material melódico, rítmico e harmônico semelhante ao da parte $\mathbf{A}$, mostrando-se quase como uma reapresentação imediata da primeira parte com variações que não desconfiguram a identidade desses materiais. $\mathrm{O}$ clarinete comenta o tutti com arpejos e apogiaturas para, no compasso 45, assumir novamente a melodia.

\footnotetext{
${ }^{16}$ José Botelho conta que sugeriu a Mignone que tirasse as ligaduras das sincopas dessa frase para que ficassem melhor pronunciadas e adquirissem maior correspondência ao estilo brasileiro de execução dessa figuração rítmica. (N. A.)
} 


\section{C - Do compasso 54 ao 75}

O material harmônico permanece o mesmo, a não ser pela presença de nona aumentada nos compassos 56 e 64. É a primeira vez que dissonâncias dessa tipologia são usadas de maneira funcional por Mignone nessa obra. $\mathrm{O}$ ostinato rítmico assume uma característica um pouco mais rebuscada no acompanhamento da orquestra, mas a agógica não sofre alterações significativas.

Figura 35 - Final: ostinato rítmico

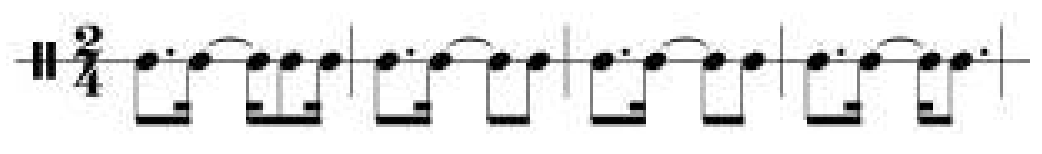

\section{D - Do compasso 76 ao 111}

Nesse ponto há uma queda de andamento e os materiais rítmicos (que foram invertidos em relação aos primeiros compassos do movimento, mas continuam os mesmos) são alargados, gerando certo lirismo. A presença harmônica da sequência de Dm, Eb, E e Dm deve ser notada, assim como o alargamento do retardo na melodia do clarinete; as estruturas harmônicas são mantidas, mas são aumentados os valores das notas.

Figura 36 - Final, compassos de 1 a 4

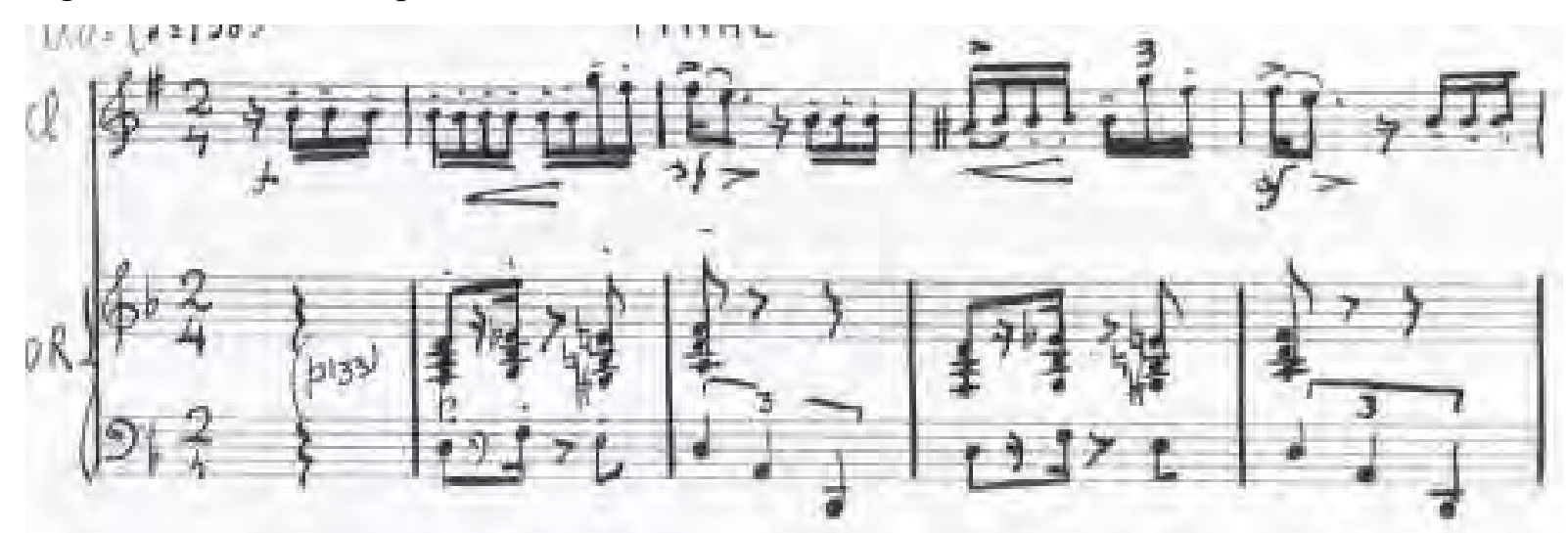

Fp3 (redução) 
Figura 37 - Final, compassos de 76 a 79

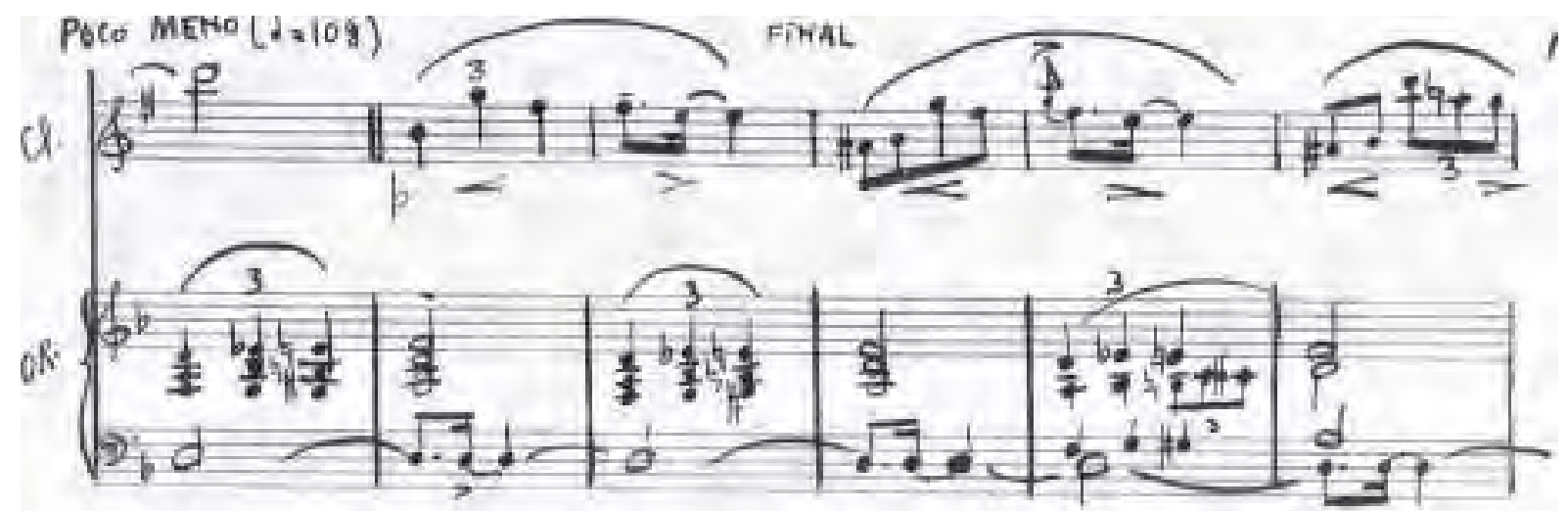

Fp3 (redução)

$\mathrm{O}$ aspecto de dança permanece importante, principalmente nas síncopas de cellos e contrabaixos. Há um animando no compasso 97 utilizado para retomar, no compasso 112, o caráter rítmico brilhante da primeira parte.

\section{E - Do compasso 112 ao 129}

O tema principal é alcançado novamente em tutti, muito semelhante ao da parte B. O material das segundas paralelas e cromáticas reaparece, preparando a chegada da Coda final 
Figura 38 - Final, compassos de 125 a 132

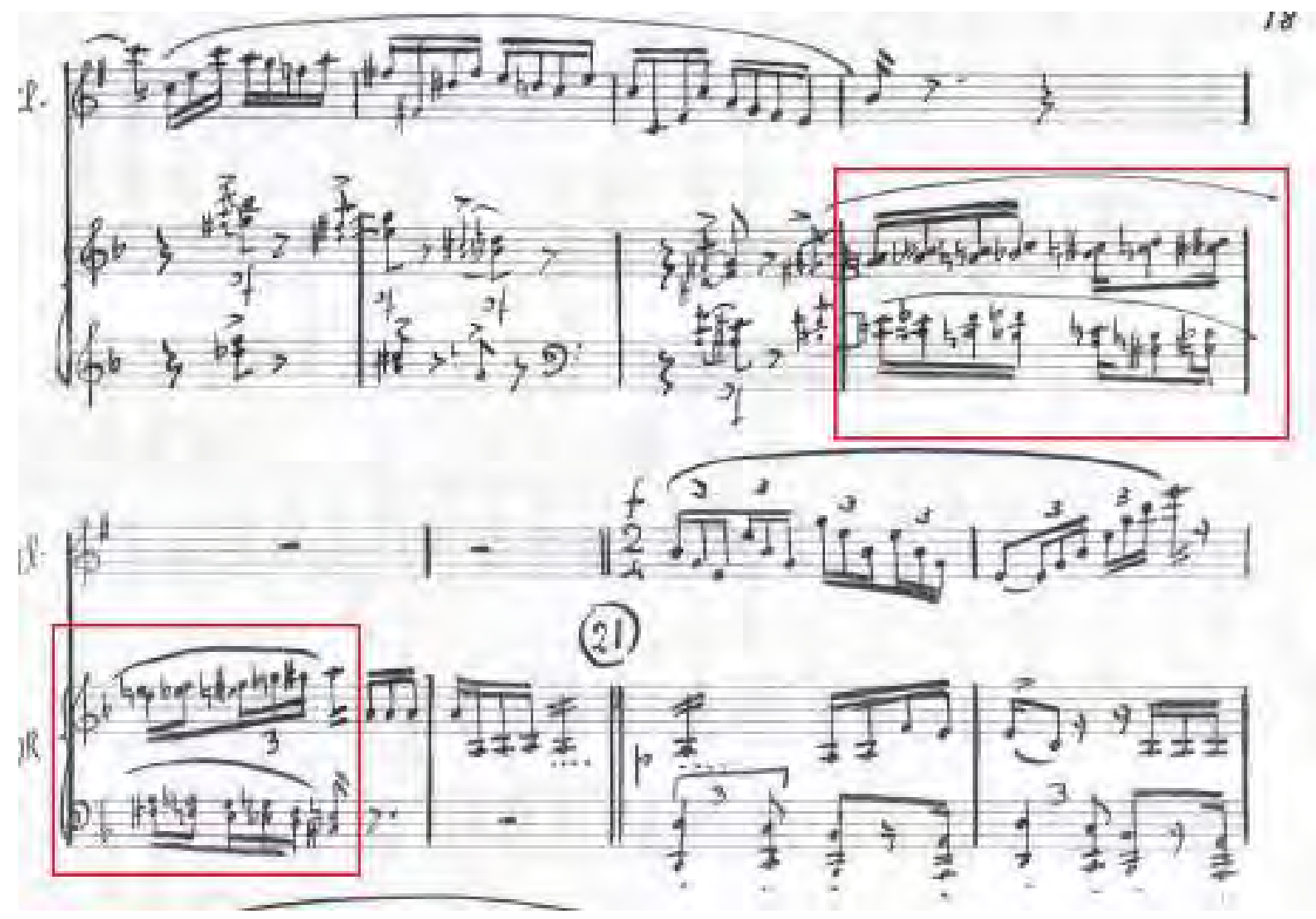

Fp3 (redução)

\section{F - Do compasso 130 até o fim}

A Coda se inicia em piano até o compasso 149, onde um $f f$ súbito e più vivo prepara a finalização da peça. Os materiais melódicos, rítmicos e harmônicos utilizados nesse movimento e em grande parte da obra reaparecem, confirmando as sonoridades que perpassaram o Concertino. 


\section{CAPÍTULO 3}

\section{Propostas para a Performance}

Cada ponto levantado por meio da observação atenta das fontes distintas será apresentado aqui de maneira a respeitar a ordem em que aparece na obra e a sequência dos movimentos. Em alguns casos, a simples comparação entre as fontes será suficiente para a reflexão; noutros, será necessária uma discussão mais profunda acerca do projeto do autor antes que qualquer decisão seja tomada. Para a comparação entre as fontes, utilizaremos figuras extraídas dos textos originais. No entanto, exemplos musicais não extraídos das fontes poderão ser utilizados para aclarar qualquer detalhe.

\section{$1^{0}$ movimento - FANTASIA}

1) Compasso 2 - quinta colcheia de Violinos 1

O primeiro violino apresenta a nota Fá (Fp2), quebrando a sequência de segundas maiores, enquanto as duas outras fontes primárias apresentam a nota Sol, conservando a sequência de segundas maiores. Nossa opção, portanto, seria corrigir a nota para Sol.

Figura 39 - Fantasia, compassos 1 e 2

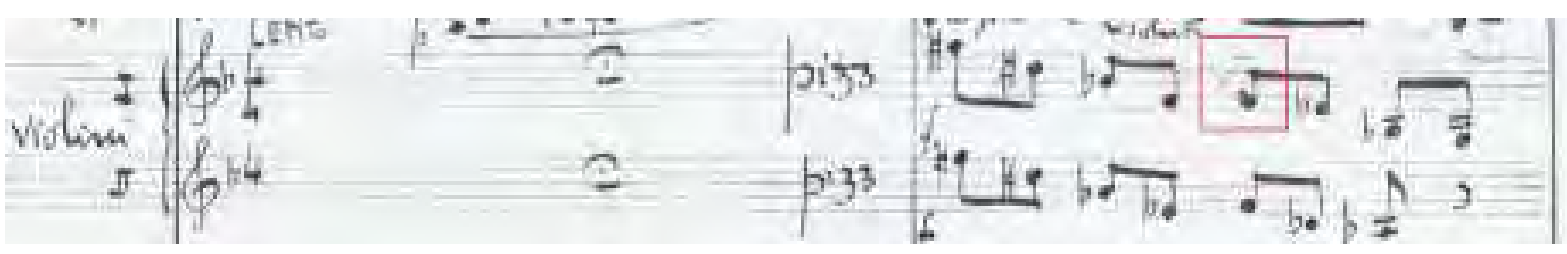

Fp2 (orquestração)

Figura 40 - Fantasia, compassos 1 e 2
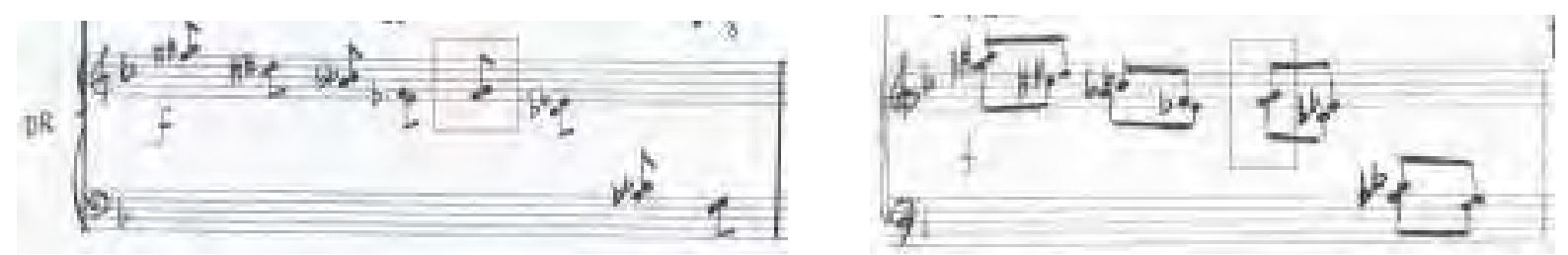

Fp3 (redução) e Fp1 (esboço) 
2) Compasso 5 - segunda nota do clarinete

Tanto o esboço (Fp1) quanto a partitura orquestral (Fp2) apresentam a nota Lá natural escrita (soando um tom abaixo, Sol). Já a redução pianística (Fp3) apresenta a nota Si natural escrita (soando Lá natural).

Figura 41 - Fantasia, compassos de 3 a 5

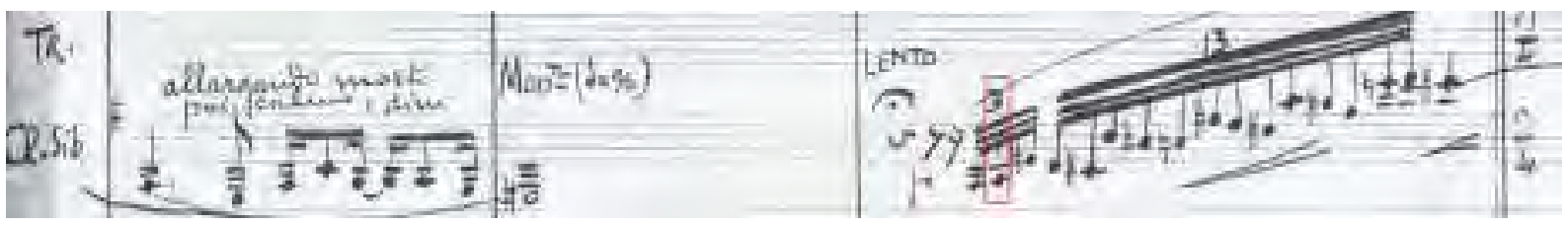

Fp2 (orquestração)

Figura 42 - Fantasia, compassos de 4 a 6

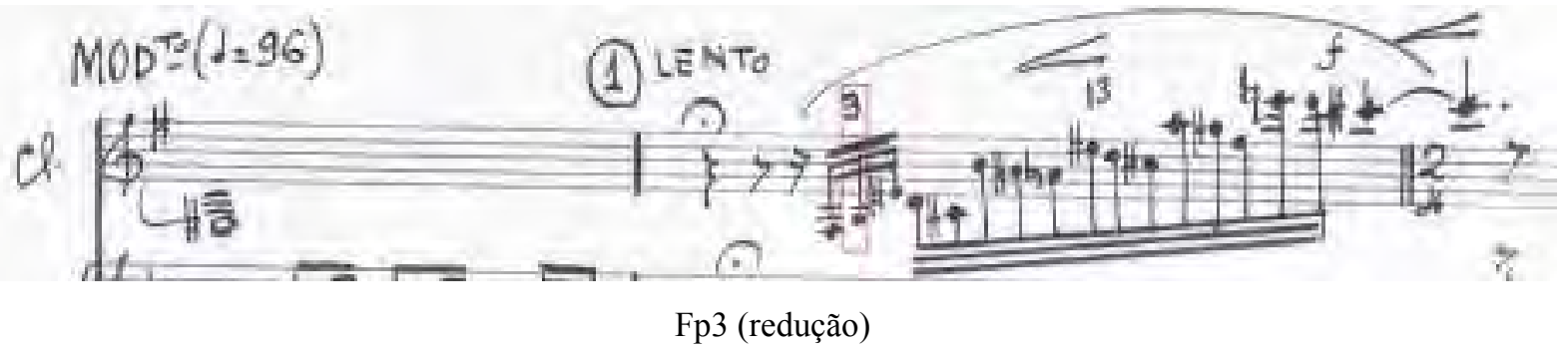

Figura 43 - Fantasia, compassos de 4 a 6

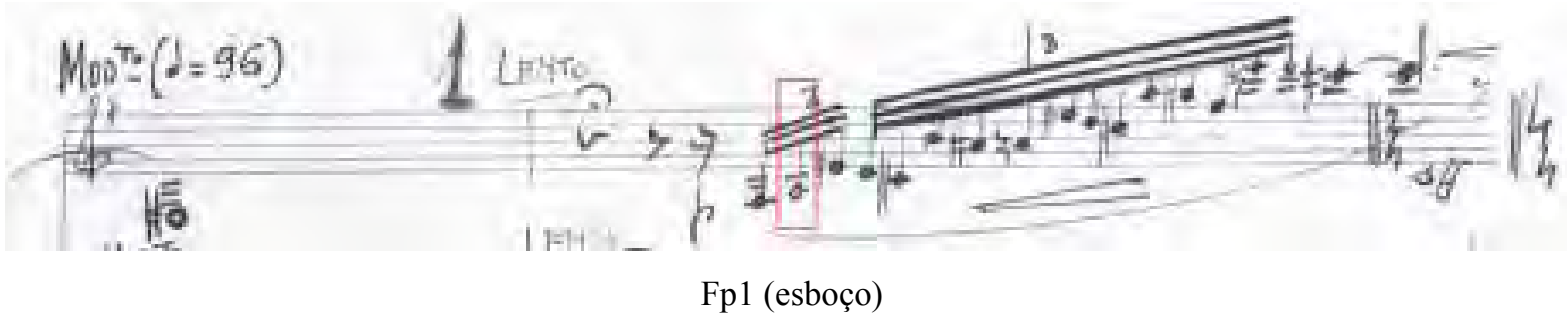

São dois os parâmetros utilizados para a resolução desse caso: a melodia e a harmonia. A harmonia está estável em Em7+/F, ou seja, a nota Sol está presente, corroborando a ideia das Fp2 e Fp1; contudo, melodicamente as dissonâncias do clarinete são alcançadas por meio de saltos ascendentes e as consonâncias estão nas resoluções descendentes. Isso cria a possibilidade de que nesse ponto da melodia caiba estilisticamente uma dissonância (a nota Lá sobre a harmonia descrita), como acontece da quinta para a sexta nota da frase, quando há um mesmo Lá oitava acima. Outros dois pontos são relevantes: a similaridade com a melodia 
inicial do clarinete no compasso 1 e a relevância da Fp3 na última revisão da obra por Mignone.

Figura 44 - Fantasia, compasso 1

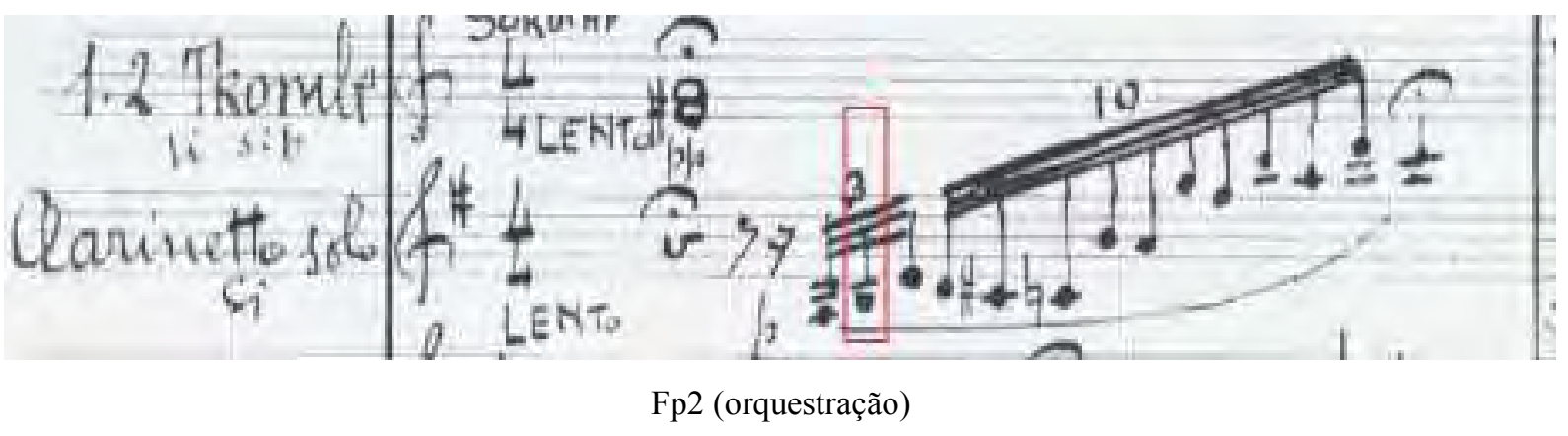

Entendemos que o parentesco das duas melodias será mais bem expresso se preservados os saltos de quarta do início de cada uma delas. Portanto, a opção pela nota Si escrita (soando Lá) na melodia do compasso 5 parece mais condizente com o projeto do autor.

3) Compasso 6 - notas das violas

Figura 45 - Fantasia, compassos de 5 a 7

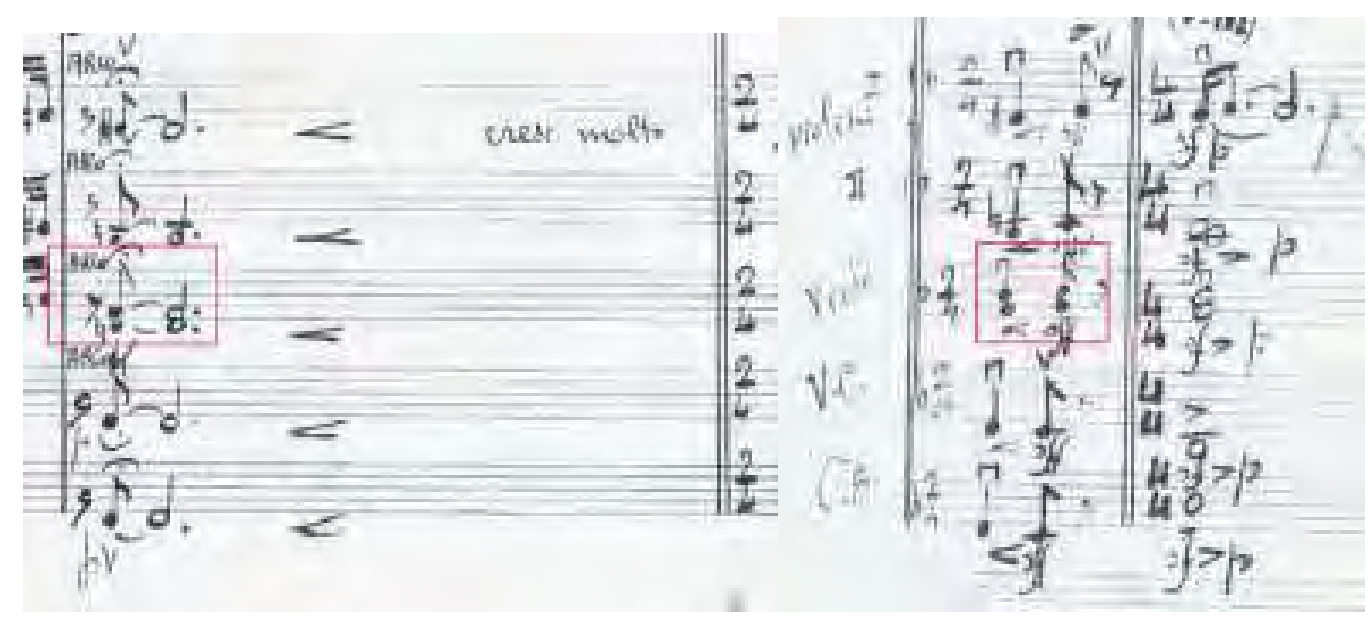

Fp2 (orquestração)

Excerto de cordas. Considerar as claves comuns respectivas a cada instrumento de baixo para cima: contrabaixo, violoncelo, viola, violino 2 e violino 1 .

Aqui existem dois importantes pontos de discussão: o primeiro é que as notas das violas são as únicas que se alteram na virada da página e essa alteração não tem força discursiva para ser relevante no trecho (se as notas tivessem permanecido inalteradas, a 
continuação da nota Mi na viola grave teria mais personalidade por manter a harmonia do compasso anterior); o segundo ponto é a arcada que Mignone escreve e que torna dúbia a agógica do gesto musical. Os dois pontos são mais bem compreendidos se comparados com as Fp3 e Fp1.

Figura 46 - Fantasia, compassos de 5 a 6

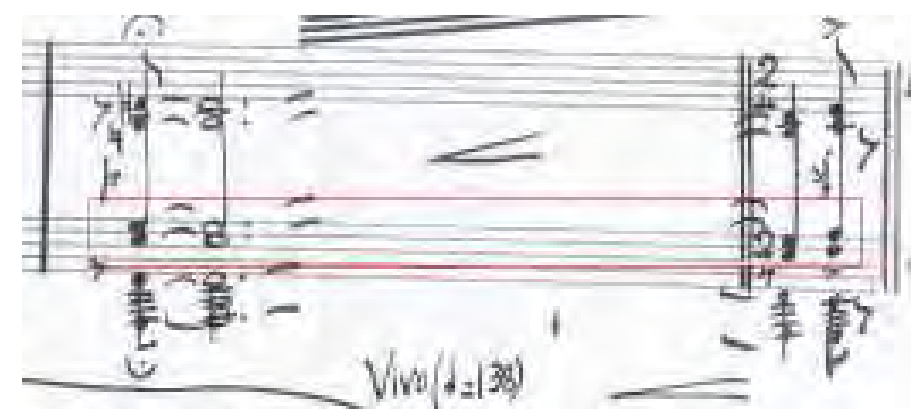

Fp3 (redução)

Considerar as claves de Fá e Sol da pauta de onze linhas

Figura 47 - Fantasia, compassos de 5 a 6

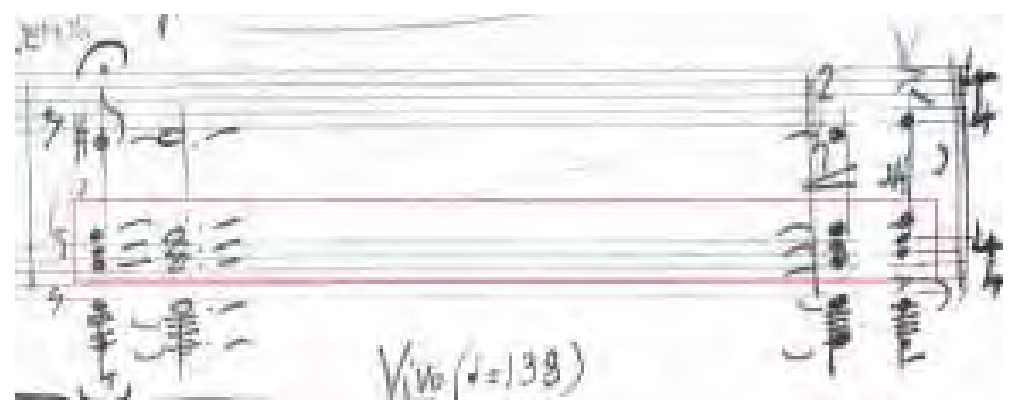

Fp1 (esboço)

Considerar as claves de Fá e Sol da pauta de onze linhas

$\mathrm{Na}$ questão da alteração das notas nas violas, é possível que Mignone não pretendesse uma mudança na harmonia do trecho. Podemos, portanto, assumir que, por distração, o autor tenha elevado em uma terça as notas das violas na virada da página, já que ele não repete a escrita das claves na próxima página. A opção acertada seria permanecer com as notas Mi e Sol nas violas no compasso 6 .

$\mathrm{Na}$ questão da arcada da versão orquestral, observamos que nas versões pianísticas o acorde vai ligado do compasso 5 ao 6 e, por consequência, sem rearticulação. $\mathrm{Na}$ versão orquestral a maneira que Mignone escolheu para escrever o trecho abre espaço para a interpretação de que seria necessário que o acorde fosse rearticulado no compasso 6. No 
entanto, o trecho também pode ser compreendido de modo a não ser necessária a rearticulação do acorde, aproximando assim a versão orquestral das versões pianísticas: se levarmos em conta o arco para cima no compasso 5 e o crescendo molto em seguida (portanto, na direção do talão), pode-se compreender que o arco para baixo no compasso 6 seria uma retomada de energia para a articulação do sff, e não uma rearticulação efetiva das notas. Em todo caso, nossa opção será aproximar a versão orquestral das versões pianísticas nesses compassos, corrigindo as notas das violas e esclarecendo a agógica, inserindo na partitura orquestral a ligadura presente no piano e ainda propondo uma nova arcada

Figura 48 - Fantasia, compassos de 5 a 7

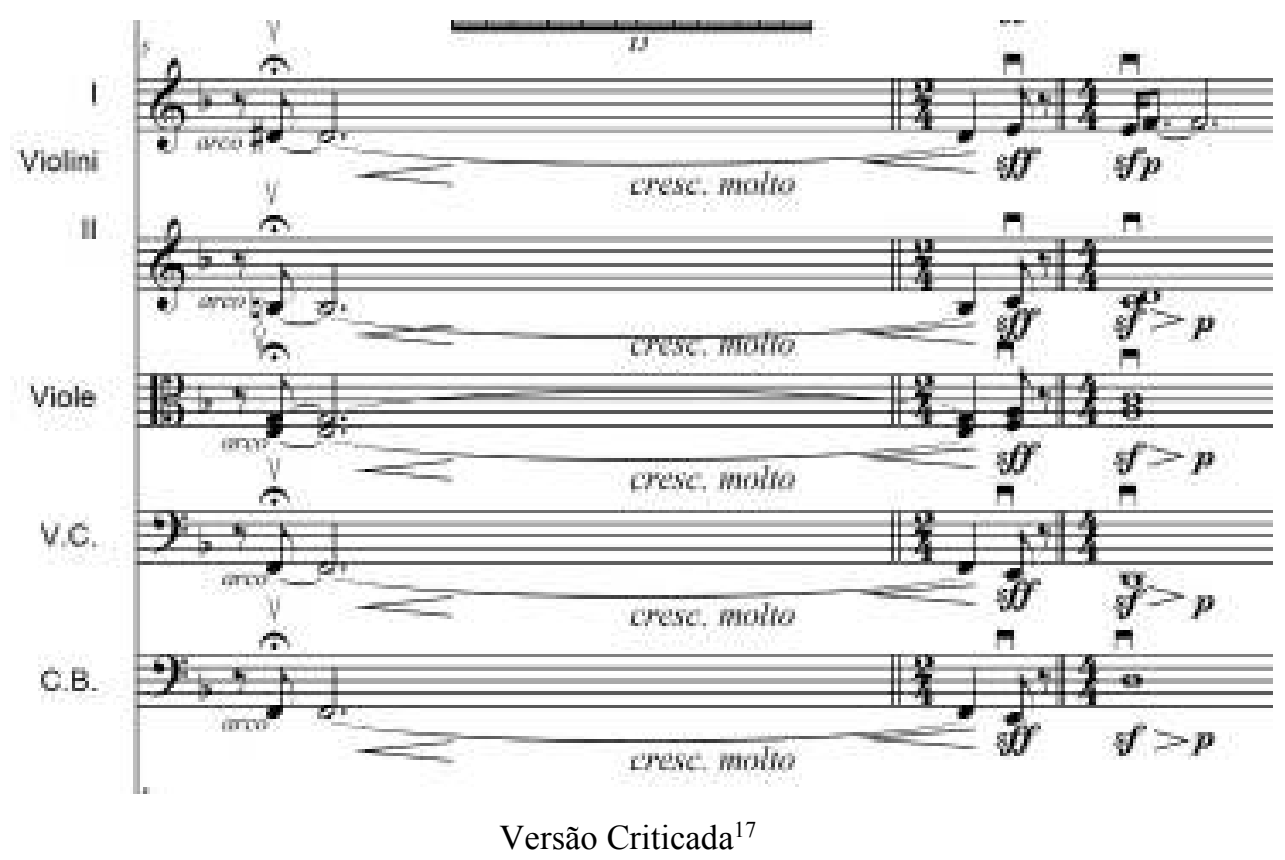

4) Compasso 9 - primeira nota do clarinete e do contrabaixo

Este é um ponto especial na nossa crítica, pois cada uma das fontes apresenta uma resolução harmônica diferente.

\footnotetext{
${ }^{17}$ Chamaremos de Versão Criticada trechos da partitura orquestral produzidos por nós no intuito de aclarar questões específicas que, de outra maneira, seriam de difícil compreensão para o leitor. (N.A)
} 
Figura 49 - Fantasia, compassos de 7 a 9

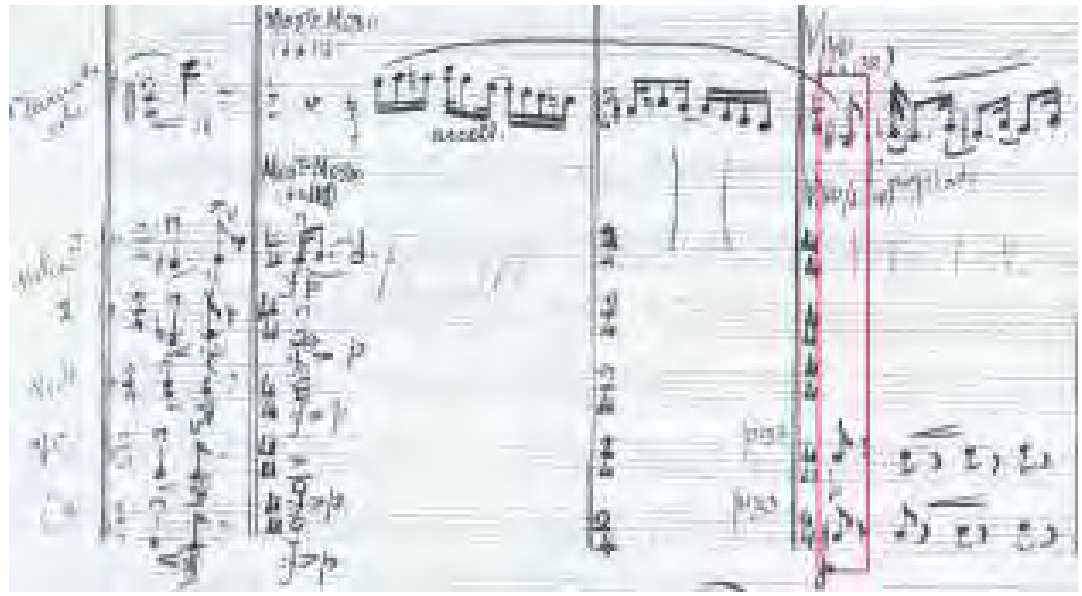

Fp2 (orquestração)

Figura 50 - Fantasia, compassos de 7 a 9

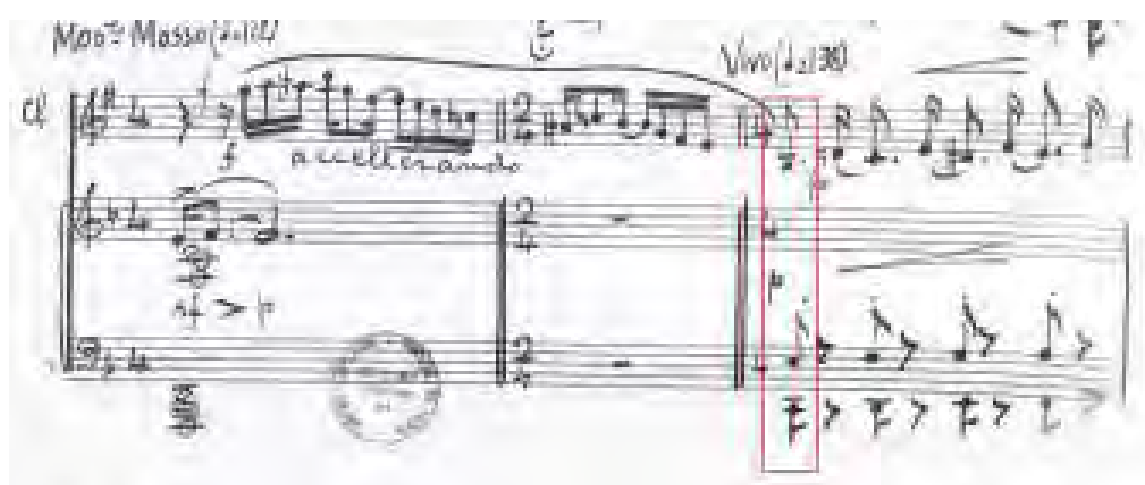

Fp3 (redução)

Figura 51 - Fantasia, compassos de 7 a 9

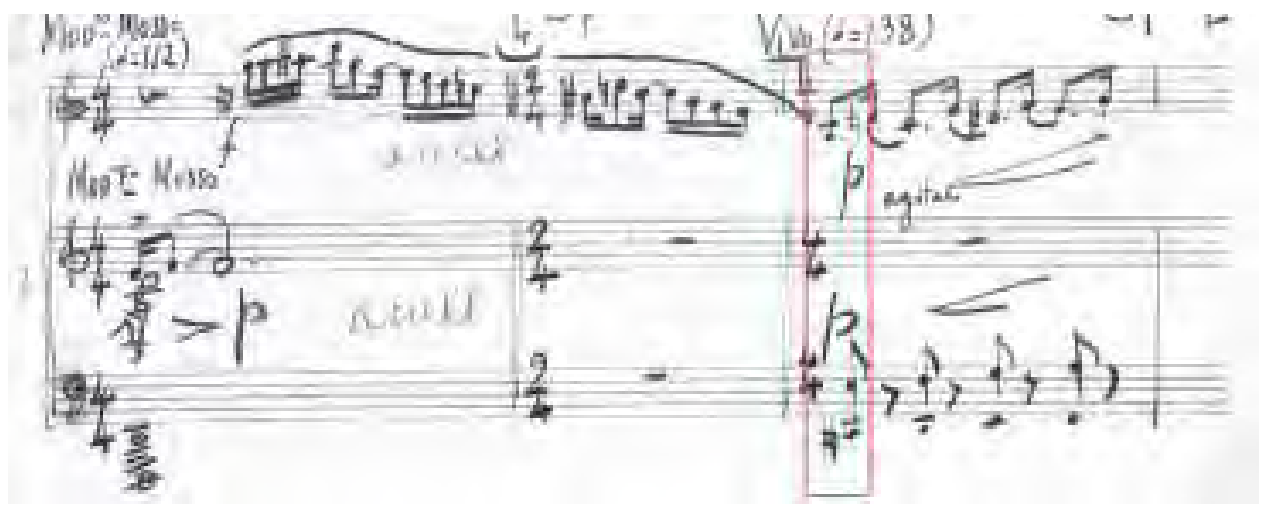

Fp1 (esboço) 
$\mathrm{Na}$ versão orquestral (Fp2) a harmonia está sobre o acorde de A\#dim/C\#, enquanto na redução (Fp3) encontramos Am/C e no esboço (Fp1), A/C\#. Dois aspectos principais devem ser levantados: a coerência melódica e a correspondência dos materiais temáticos.

$\mathrm{Na}$ versão orquestral a presença do $\mathrm{Si} \#$ faz com que o caráter ascendente da melodia fique prejudicado, visto que na sequência melódica encontra-se o Dó natural. Optamos, portanto, pelo Si natural para preservar a fluência melódica. Harmonicamente optamos pelo Dó natural na linha mais grave por conservar a sonoridade modal que o material composicional das décimas paralelas carrega em outras partes da obra. A resolução é em favor da redução pianística (Fp3).

5) Compasso 24 - harmonia no terceiro tempo

Outro ponto discutível é que, embora na partitura de orquestra a grafia de Mignone demonstre exatidão, o resultado sonoro do retardo da terça maior do acorde de F\# soa como erro, prejudicando a fluência do texto

Figura 52 - Fantasia, compassos de 21 a 24

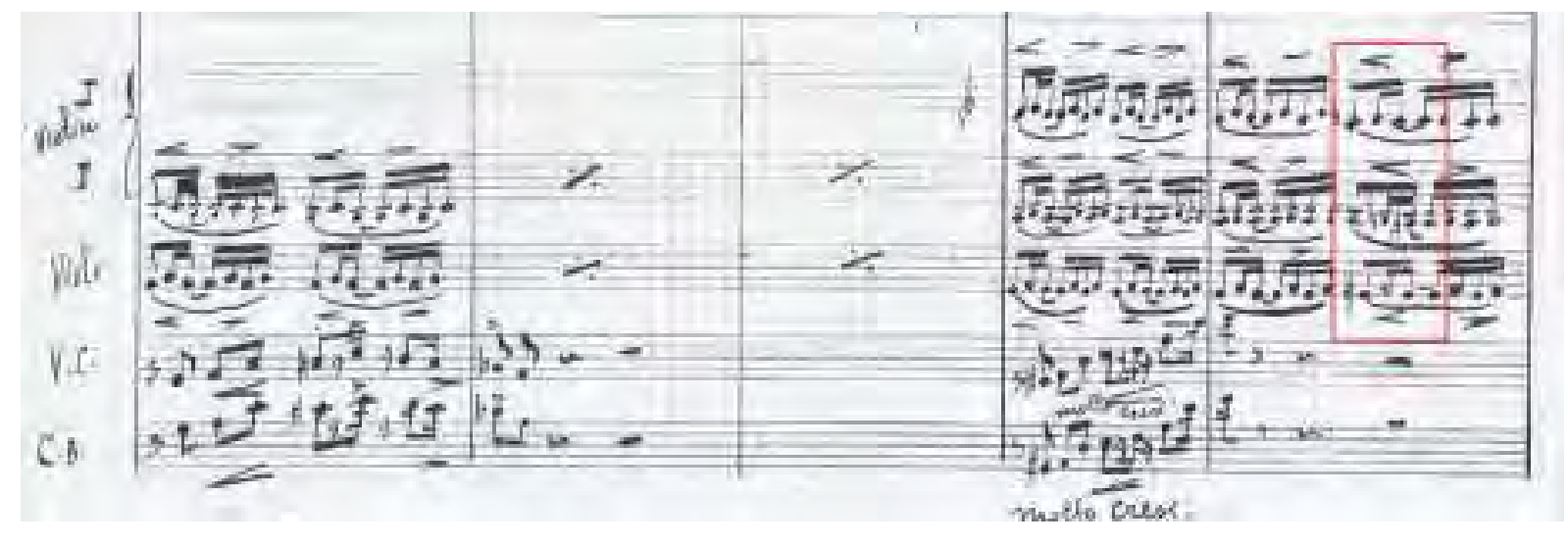

Fp2 (orquestração)

$\mathrm{Na}$ figura abaixo as versões pianísticas apresentam maior fluidez e não contam com o retardo. 
Figura 53 - Fantasia, compasso 24
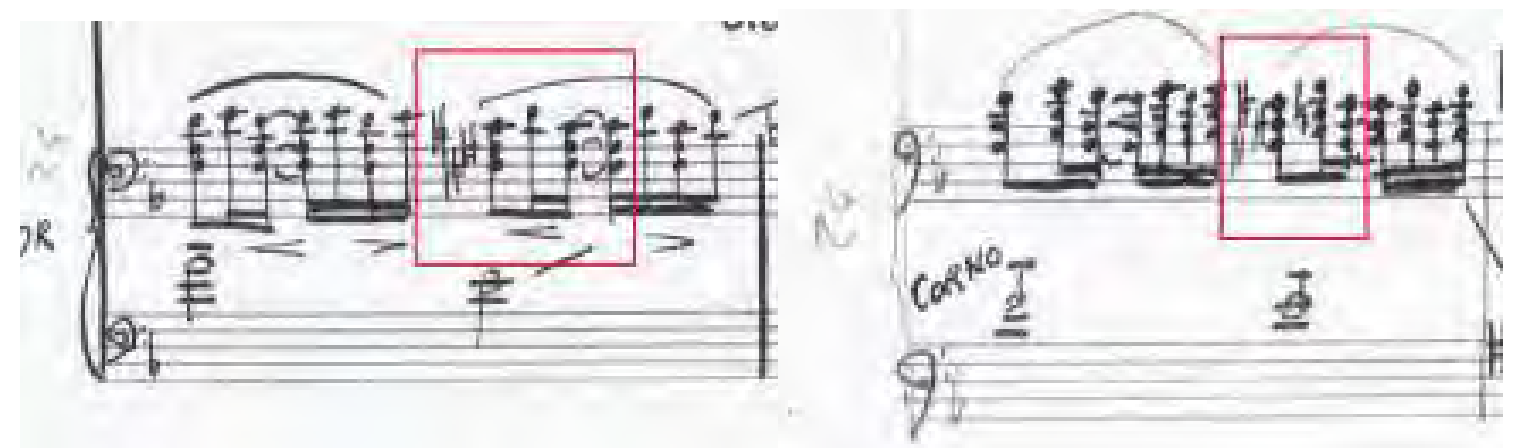

Fp3 (redução) e Fp1 (esboço)

Embora se possa admitir que a orquestração, principalmente pela alteração do meio de expressão, seja singular e reflita um pensamento novo sobre a obra, nossa opção será em favor das versões pianísticas. Apoiamo-nos na experiência da performance que demonstra a fragilidade do retardo em oposição à fluidez do não retardo.

6) Compasso 27 - nota das violas

A partitura orquestral e o esboço pianístico apresentam a nota Sol\#, enquanto a redução pianística apresenta Sol natural. Nesse caso, por se tratar de um trecho em que as relações tonais estão sendo exploradas, optaremos pelo Sol\#, já que dessa forma a atração entre as fundamentais harmônicas do trecho se torna mais explícita e o sol natural traria um caráter modal mais acentuado à passagem.

Figura 54 - Fantasia, compassos de 25 a 29

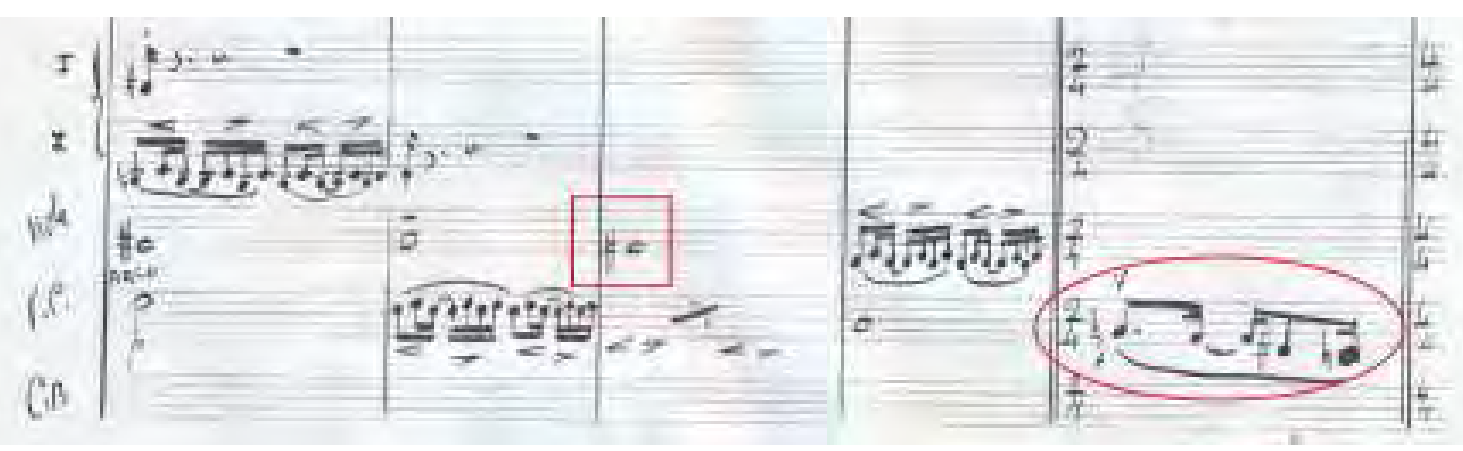

Fp2 (orquestração) 
Figura 55 - Fantasia, compassos de 27 a 29

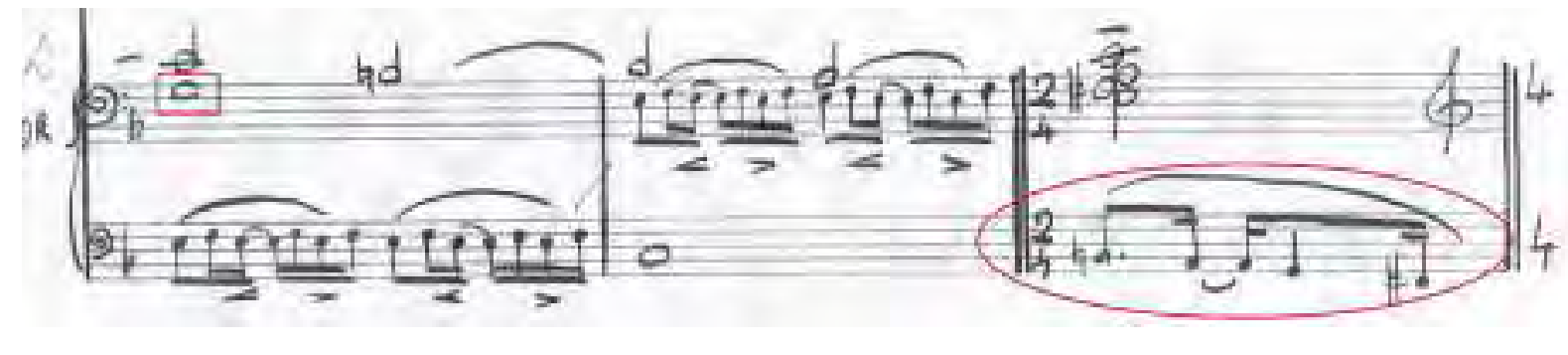

Fp3 (redução)

Figura 56 - Fantasia, compassos de 27 a 29

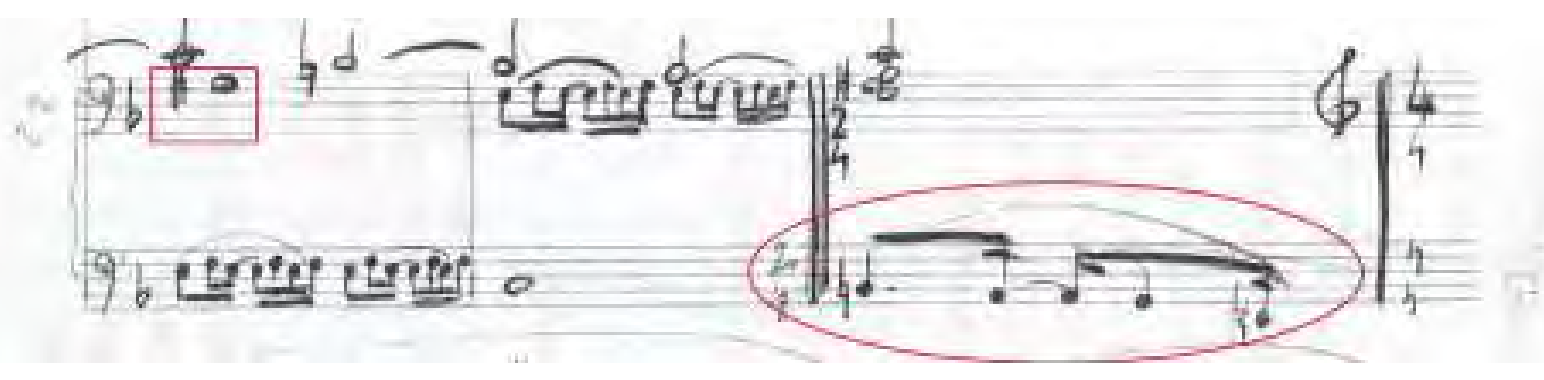

Fp1 (esboço)

Nos círculos das figuras acima podemos notar a diferença da escrita da frase sincopada. Na versão orquestral o Sol\# e o Fá não condizem com a harmonia do trecho $\left(\right.$ Bsus $\left.^{7(9 b)}\right)$. Nas versões pianísticas podemos perceber que há uma anotação de correção no esboço em favor do Fá\#, igualando a frase à redução pianística. Da mesma forma, por não se tratar de um trecho modal ou que se utiliza de sobreposição de acordes ou tonalidades, optaremos por aquele que apresenta a redução pianística (Fp3), ou seja, as notas Sol natural e Fá\#. Dessa forma colaboramos para que o caráter tonal do trecho seja respeitado. ${ }^{18}$

7) Compasso 40 - Mib e trillo no clarinete

No compasso 40, as três fontes estão iguais: todas apontam o Fá\# escrito (Mi natural soando) na linha do clarinete, respeitando a armadura de clave. Contudo, a inserção do Fá natural (Mib soando) no compasso anterior aponta o caminho modulatório que o trecho está tomando. Pode-se notar que o campo harmônico que está no acompanhamento das cordas

\footnotetext{
${ }^{18}$ Botelho sugeriu no compasso 29 da Fantasia que o compasso fosse de $4 / 4$ e que as fusas se tornassem semicolcheias, por serem muito rápidas. A frase dos violoncelos também se desdobraria. Mignone concordou, realizou dessa forma na estreia, mas não anotou na partitura. (N.A.)
} 
contém as notas Mib e Sib, configurando Sib Maior. As notas do clarinete completam a harmonia do acompanhamento, caminhando da sétima para a quinta nota dos acordes do compasso 39. Na sequência, o campo harmônico do acompanhamento permanece o mesmo, mas o Fá volta a ser sustenido (soando Mi natural) no clarinete, o qual mantém o mesmo desenho melódico. Poderíamos supor que o bequadro na nota Fá do compasso 39 não perderia sua validade para as notas Fá do compasso 40, apesar da barra de compasso. Nessa linha, dever-se-ia manter o Fá natural, respeitando o campo harmônico e o desenho melódico da frase que vem desde o compasso 38.

Figura 57 - Fantasia, compassos de 39 a 42

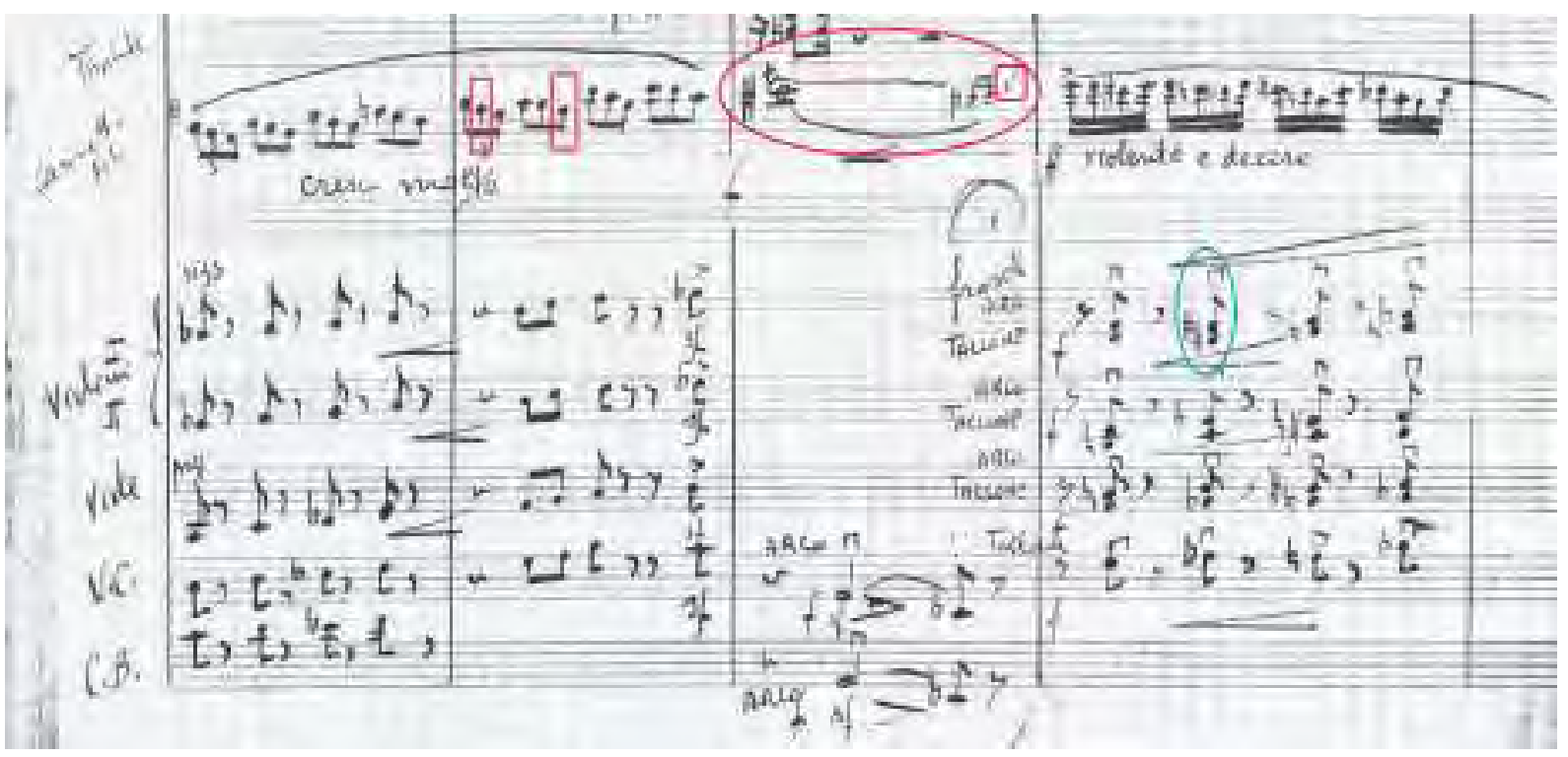

Fp2 (orquestração)

Considerar a clave de Sol para clarinete, violinos e violas, e a clave de Fá para violoncelos e contrabaixos.

Figura 58 - Fantasia, compassos de 39 a 42

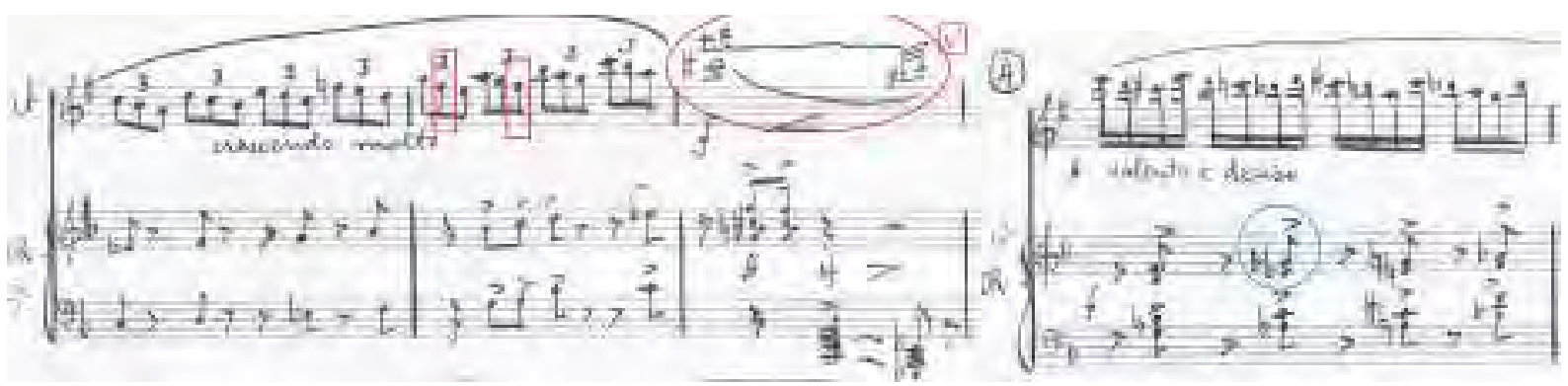

Fp3 (redução) 
Figura 59 - Fantasia, compassos de 39 a 42

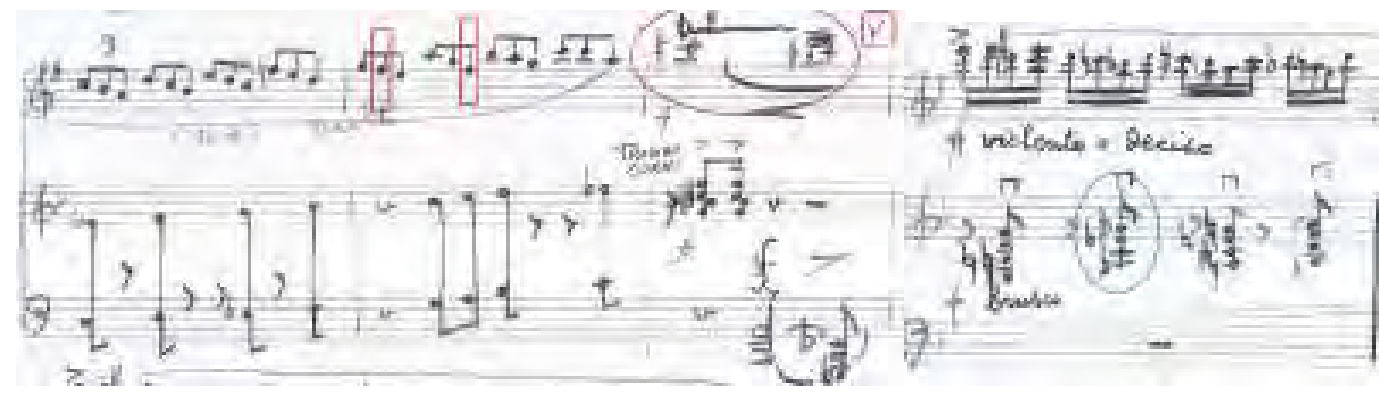

Fp1 (esboço)

No compasso 41 da versão orquestral, o clarinete executa o trillo com Ré natural escrito (Dó natural soando) como nota superior; já nas versões pianísticas ocorre a nota Ré\# escrita (soando Dó\#), corroborando a harmonia do compasso. Nesse caso, optamos pelas versões pianísticas que apresentam mais coerência harmônica. ${ }^{19}$

8) Compasso 44 - nota da segunda semicolcheia do terceiro tempo

Aqui sentimos a falta do bequadro no compasso 44, e tanto as versões pianísticas quanto a escrita da linha do violino 2 corroboram essa omissão. Além disso, na harmonia do terceiro tempo do compasso, que está configurada como Si dominante, o Lá natural como sétima nota do acorde seria opção mais apropriada do que o Láb. Optamos, então, pela inserção do bequadro.

Figura 60 - Fantasia, compasso 43 a 45

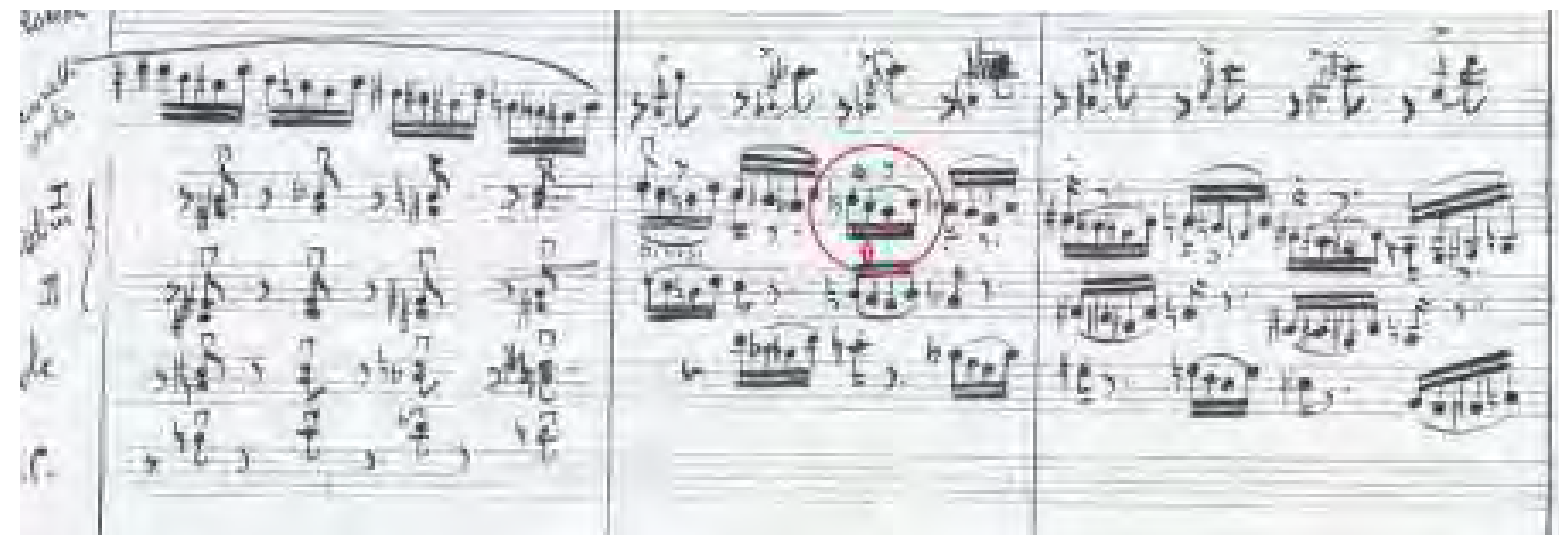

Fp2 (orquestração)

${ }^{19}$ É interessante notar a enarmonização que acontece na linha das cordas no compasso 42. Em Fpb e Fpc, o acorde de láb aparece com mib e solb, em Fp2, aparece com ré\# e fá\# para facilitar a leitura dos violinos. Isso demonstra o tipo de concessão que Mignone faz às estruturas harmônicas (N.A). 
9) Compasso 47 e 49 - frases do Clarinete

O compasso 47 se relaciona com o compasso 49 através do espelho retrógrado, mas existem algumas dessemelhanças na comparação.

Figura 61 - Fantasia, compassos de 46 a 49

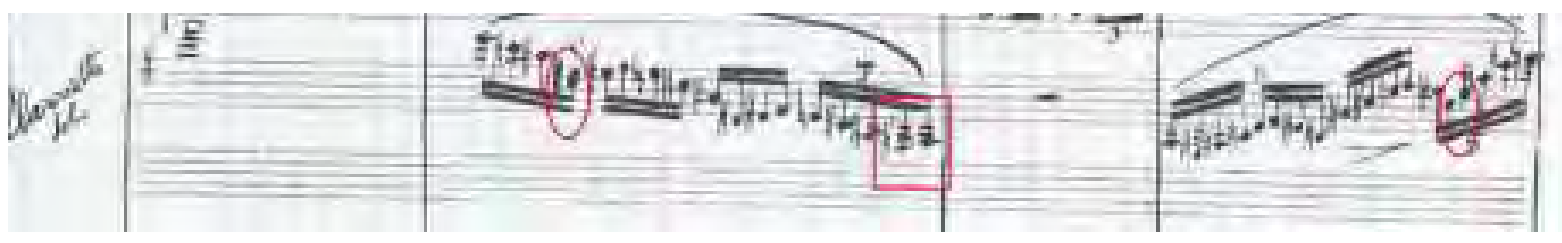

Fp2 (orquestração)

As notas circuladas perturbam o espelhamento das frases. Enquanto na primeira frase o que lemos é uma nota Ré\#, no mesmo lugar do espelho na segunda frase lemos as notas Mi\# e Dó\#. A presença da anotação de quintinas no quarto tempo da segunda frase denota a presença de erro, que a comparação com as outras fontes confirma.

Figura 62 - Fantasia, compassos de 46 a 49

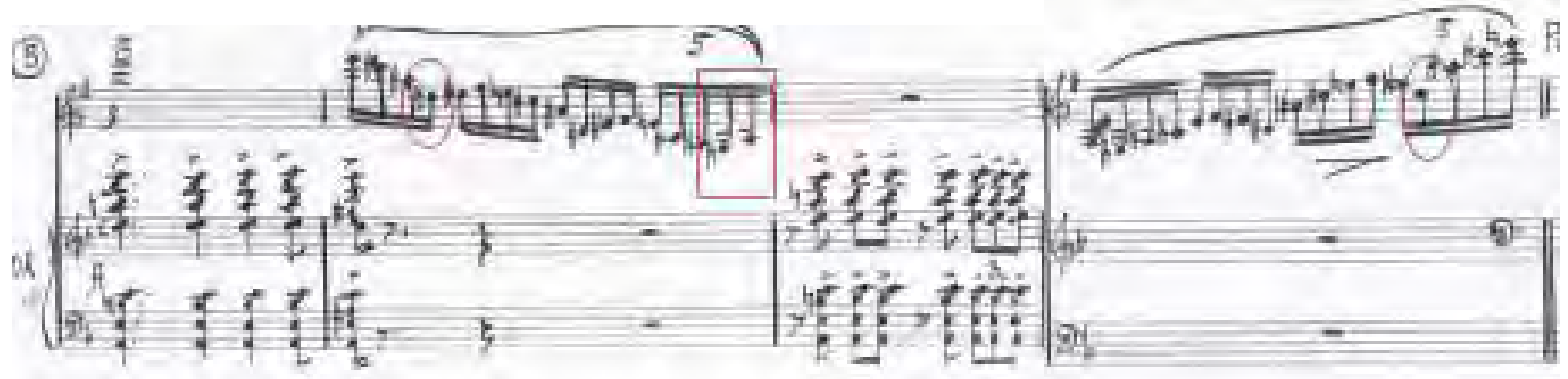

Fp3 (redução)

Figura 63 - Fantasia, compassos de 46 a 49

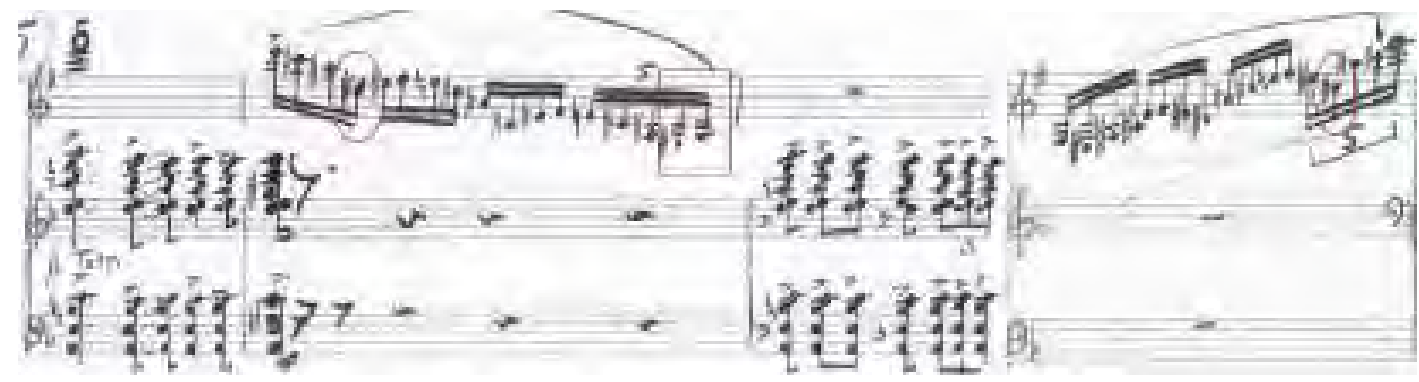

Fp1 (esboço) 
O que se resolve da comparação é a questão da quintina, mas o espelhamento continua equivocado. A opção seria a mudança de Dó\# para Ré\# na segunda frase. Porém, por se tratar de uma situação que não tem influência técnica na execução da obra (não existem instrumentos dobrando essas frases para que a qualquer diferença ocorra um choque melódico, por exemplo) e por compreendermos que também dos equívocos, conscientes ou não, surge o estilo do compositor, manteremos essa diferença no espelhamento, até porque há duas fontes a favor da diferença.

As notas que estão inseridas nos quadrados das figuras acima requerem um outro tipo de cuidado. As duas primeiras fontes cronológicas da obra (esboço e versão orquestral) trazem o espelhamento perfeito entre as duas últimas notas da primeira frase e as duas primeiras da segunda frase, Mi\# e Fá\#. A redução pianística traz esse espelhamento desfeito com a presença de Sol\# e Lá. Nesse caso, como há duas fontes a favor da igualdade, o esboço e a versão orquestral, nós a manteremos.

10) Compasso 51 - última nota das cordas

O caso da frase desse compasso é idêntico ao caso acima: apenas a redução pianística (Fp3) guarda diferença, apontando para a nota Fá na última colcheia. Faremos então a opção pela nota Ré da versão orquestral e do esboço.

Figura 64 - Fantasia, compassos de 50 a 54

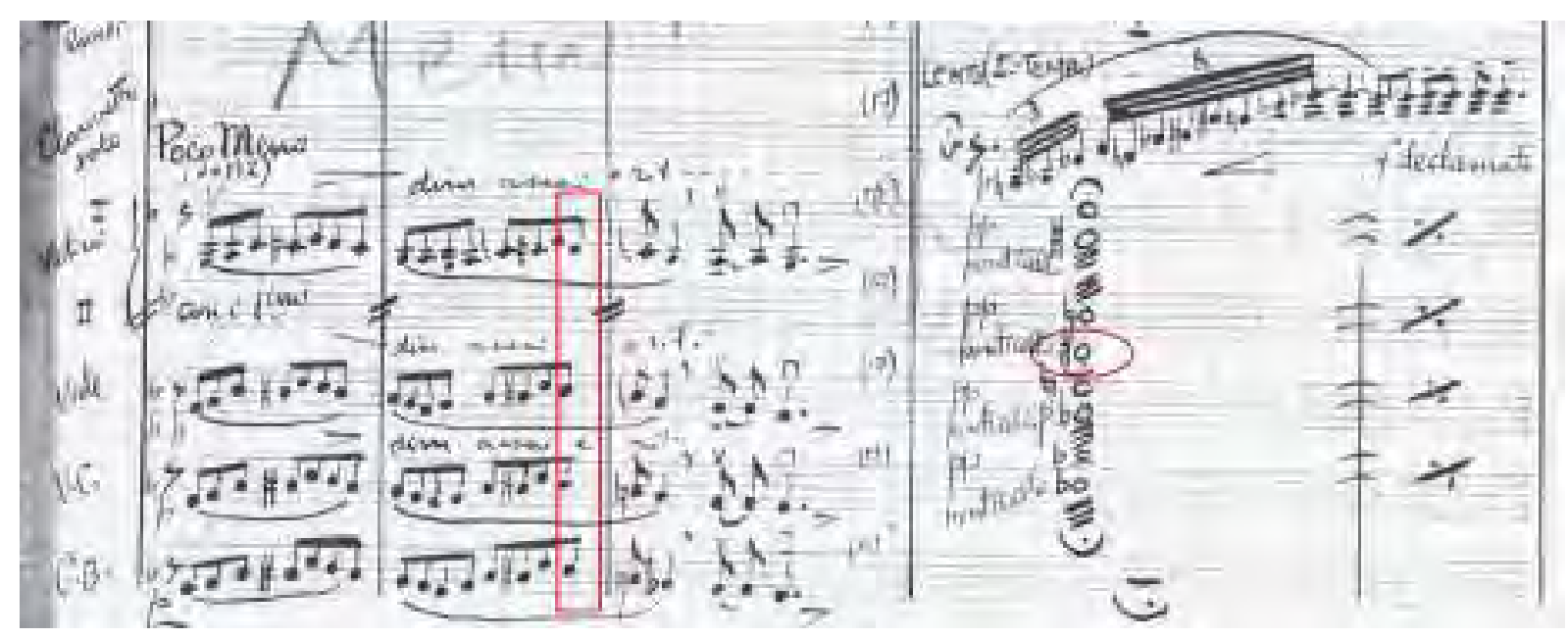

Fp2 (orquestração) 
Figura 65 - Fantasia, compassos de 50 a 54

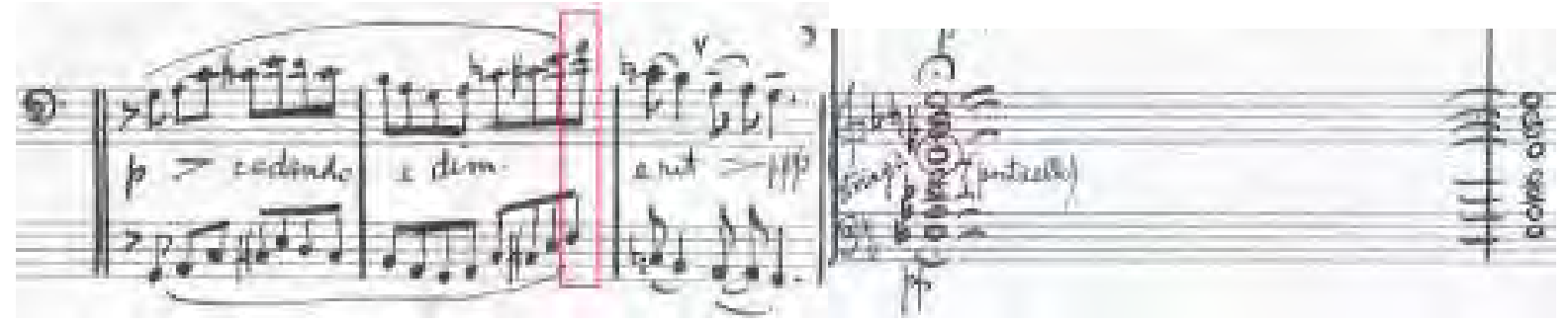

Fp3 (redução)

Figura 66 - Fantasia, compassos de 50 a 54

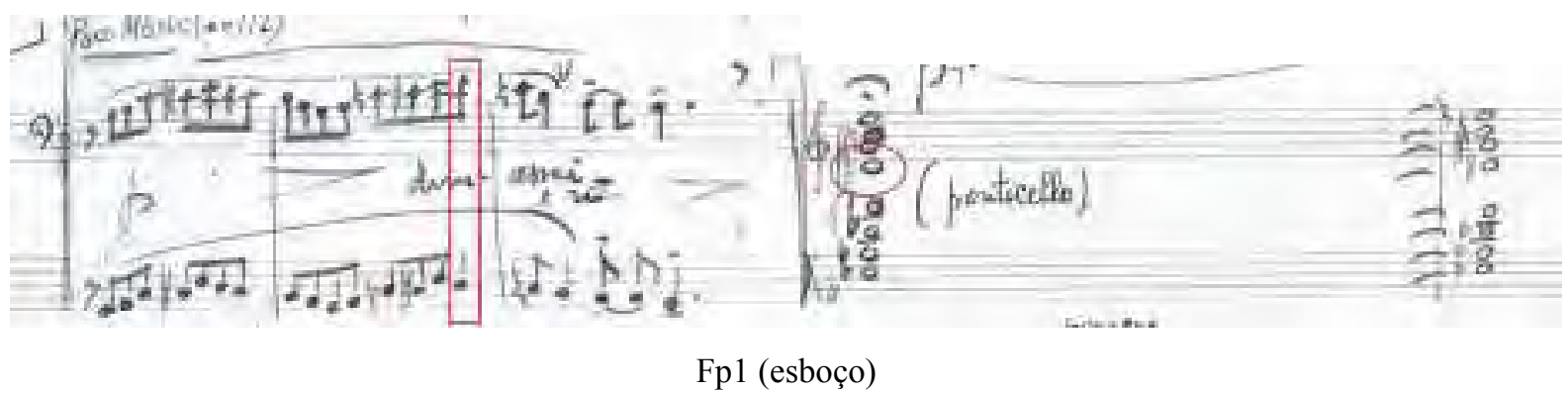

11) Compasso 53 - nota Ré dos segundos violinos

As notas circuladas nas figuras acima destacam a troca da nota Ré\# por Ré natural na redução pianística (Fp3). Nossa opção será pelo Ré\#, mantendo assim a harmonia que apoia a melodia do clarinete que tem Fá natural escrito (soando Ré\#).

12) Compasso 57 - terceira nota do clarinete

O mesmo acontece com o compasso 57, que traz a nota Si natural escrita (soando Lá natural) no clarinete na redução pianística e Si\# (soando Lá\#) no esboço e na versão orquestral. Nossa opção será pelo Si\# para integrá-lo à melodia cromática que parte dele. 
Figura 67 - Fantasia, compassos de 55 a 58

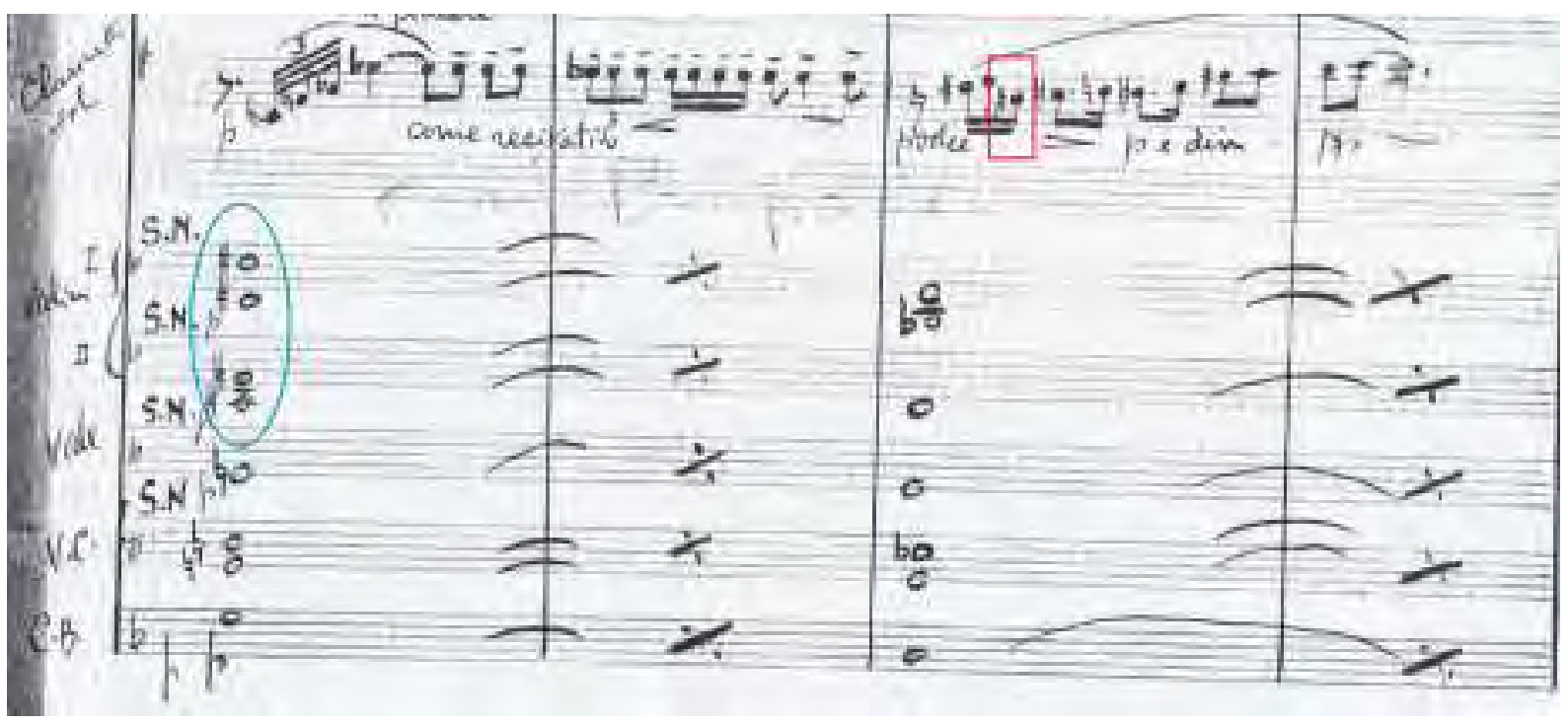

Fp2 (orquestração)

Figura 68 - Fantasia, compassos de 55 a 58

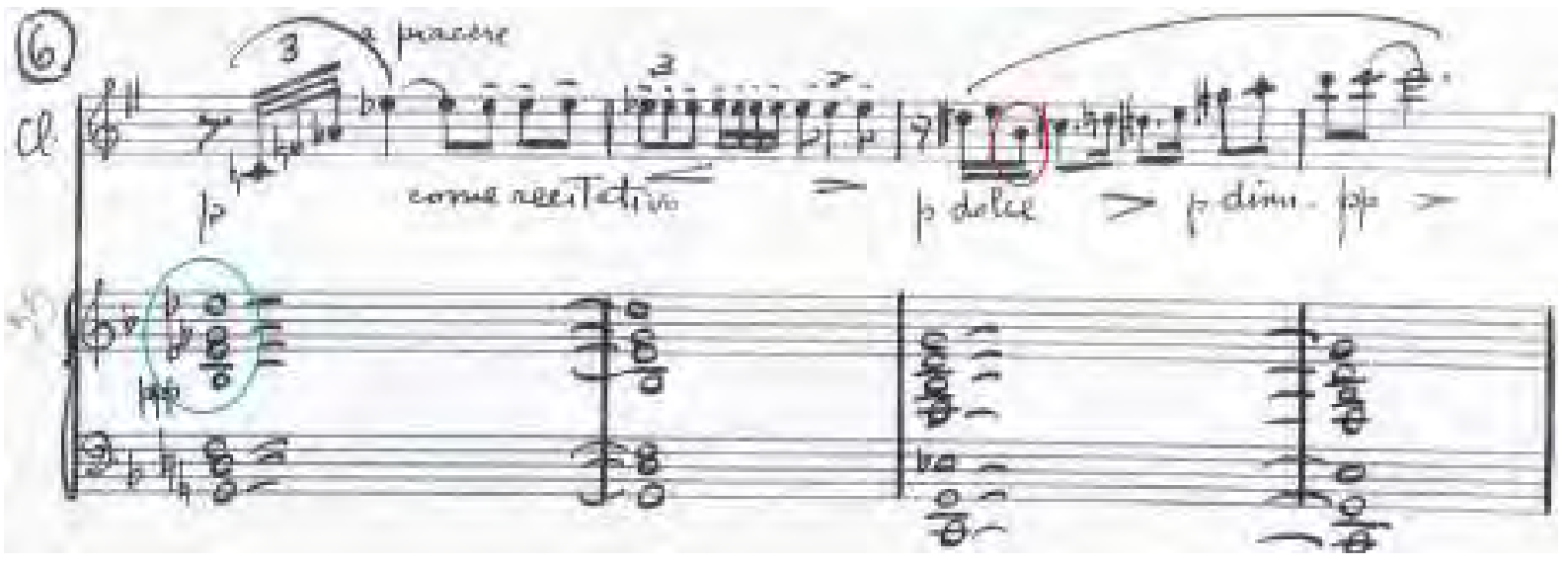

Fp2 (orquestração) 
Figura 69 - Fantasia, compassos de 55 a 58

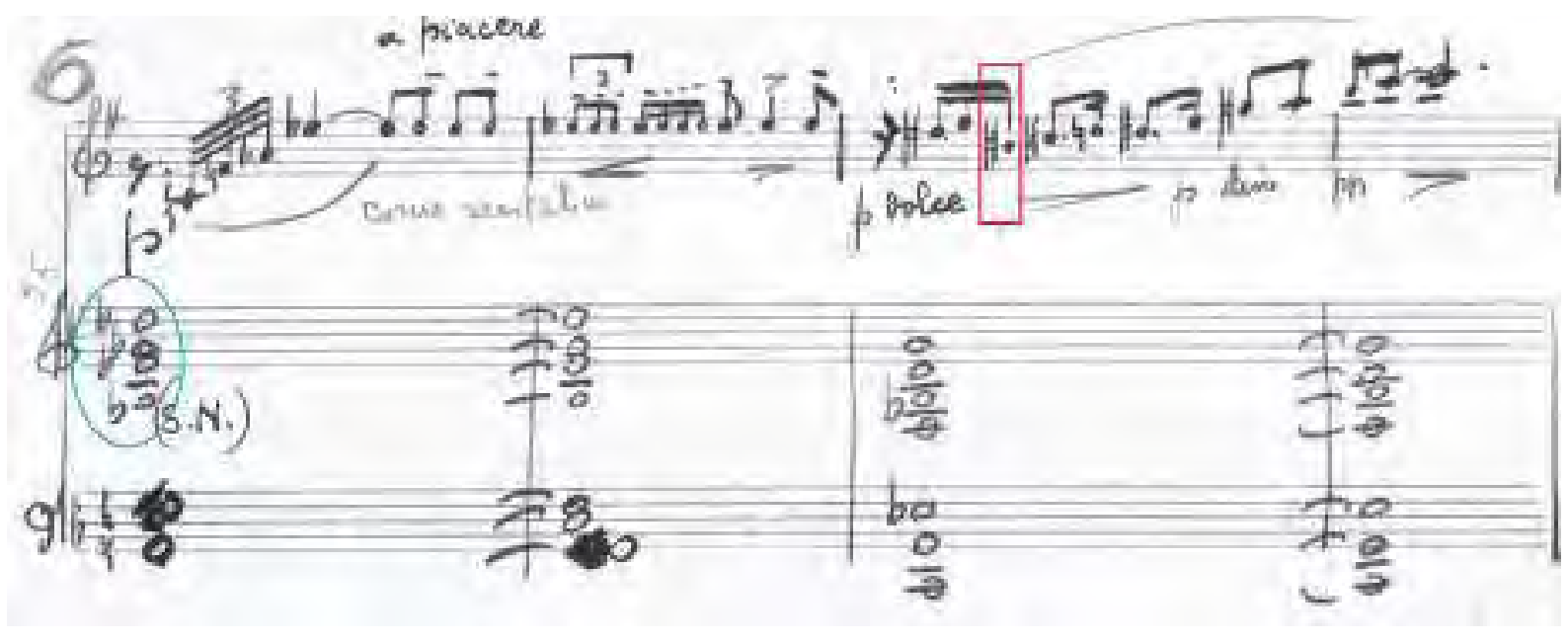

Fp2 (orquestração)

É interessante notar novamente a enarmonização na parte das cordas como traço da técnica de orquestração de Mignone (Ver Nota 19), talvez parte da influência da escola italiana. De certa forma, esse dado supõe que as versões pianísticas sejam mais fiéis ao pensamento harmônico do compositor do que a versão orquestral.

13) Compasso 65 - tessitura do clarinete

Um ponto especial na obra é a nota Mib grave escrita na partitura do clarinete. A tessitura moderna do instrumento solista não alcança esse Mib, pois vai apenas até Mi natural. A função harmônica dessa nota é importantíssima, visto que é a única quinta nota do acorde presente nesse ponto: o acorde é de $\mathrm{F} \mathrm{m}^{9}$ e a nota Mib aparece somente no clarinete (soando Dó\#), completando com os violoncelos o acorde das cordas. 
Figura 70 - Fantasia, compassos de 64 a 65

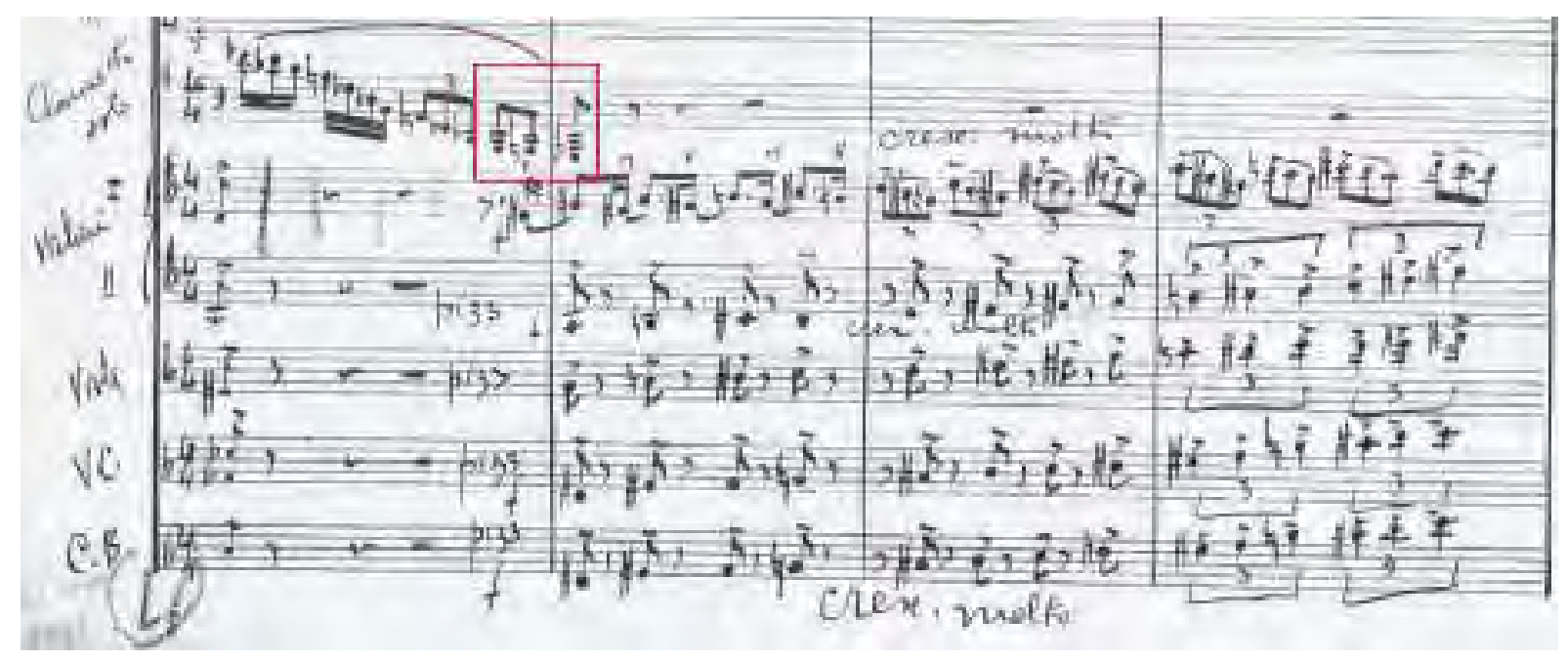

Fp2 (orquestração)

As fontes pianísticas apresentam esse mesmo texto musical. A solução que Botelho utilizou na estreia da obra e que foi aprovada pelo compositor foi a de elevar uma oitava as três últimas notas do clarinete. Dessa forma, o Dó\# completa a terça com os segundos violinos. Essa medida não é satisfatória na resolução da questão da tessitura e pouco preserva a natureza melódica da frase. Por se tratar de um arpejo descendente do acorde de $\operatorname{Solm}^{7(5 b)}$ escrito (soando $\mathrm{Fm}^{7(5 b)}$ ) a cada quatro notas e também por ser uma frase acéfala, uma opção é a de que a transposição de oitava aconteça nas cinco últimas notas do trecho.

Figura 71 - Fantasia, compassos de 64 a 65

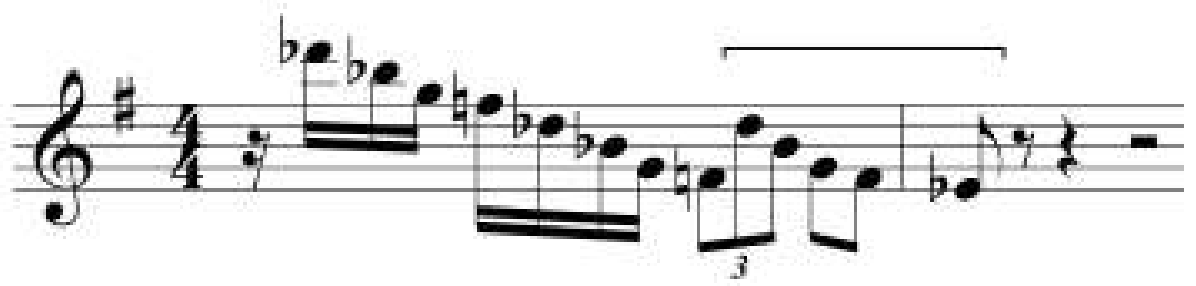

Versão Criticada 
O fato de Mignone não oferecer nenhuma alternativa ao trecho na redução pianística (Fp3) demonstra sua vontade acentuada de que a melodia seja executada com o Mib grave. Aliamos a isso o fato de haver a existência de um clarinete capaz de realizar essa nota, o Buffett Crampon CL20, do Sistema Boehm Completo ${ }^{20}$. Esse instrumento foi popular nos anos 1950 na Europa, principalmente entre os músicos de ópera, já que tinha tessitura suficiente para substituir os clarinetes em Lá, Sib e Dó ao mesmo tempo. Segundo o clarinetista Sérgio Antonio Burgani, "A escola de clarineta brasileira sofreu durante alguns anos forte influência da escola italiana, que na época utilizava uma clarineta em Sib contendo a nota Réb1, uma segunda menor abaixo da clarineta atual”. Burgani também relata sua experiência pessoal na utilização desse instrumento "de 1978 à 1987, fui integrante da Orquestra Sinfônica Municipal de São Paulo, na qual eu usava apenas esse modelo de clarineta para realizar toda transposição. Lá toquei ao lado do famoso clarinetista, italiano Leonardo Righi, que também usava apenas esse instrumento para todo o repertório”.

Por isso, entendemos a necessidade da indicação na partitura das possíveis resoluções do trecho para o clarinete moderno e a conservação do texto original em razão do clarinete de Righi. Essa medida preserva a intenção do compositor e conserva a referência ao instrumento utilizado no passado.

Contudo, há ainda uma outra alternativa, para a utilização do clarinete moderno, que interfere harmonicamente no trecho: a substituição da nota Mib (escrita) por Mi natural (escrito), modificando o acorde de Fá\# menor para o acorde de Ré Maior na primeira inversão. Com essa medida, a frase não sofreria alteração no seu desenho melódico, preservando sua natureza descendente. A alteração da harmonia não macula o estilo do compositor e tampouco perturba a sequência harmônica do trecho que segue.

\footnotetext{
20 Este instrumento é conhecido como Sistema Boehm Completo, possuindo 21 chaves e sete anéis. O sistema atualmente usado é o Sistema Boehm Simples com 18 chaves e seis anéis. (Burgani, S. A. 2013, FRANCISCO Mignone, Concertino Para Pequena Orquestra: Revisão, edição e execução, Artigo não publicado, IA UNESP $\mathrm{SP})$
} 
14) Compasso 76 - nota das violas

No momento da orquestração da obra, Mignone foi fiel ao esboço no que diz respeito às aberturas dos acordes de acompanhamento e ao posicionamento de oitava das melodias. Nesse compasso 76, embora a diferença sonora seja sutil, ocorre uma das poucas exceções nesse sentido. Por isso, optamos por sua exposição aqui.

Nas versões pianísticas a abertura do acorde do compasso 76 é fechada, ou seja, com todas as notas do acorde escritas sucessivamente. $\mathrm{Na}$ versão orquestral, podemos verificar a falta de uma nota Mi nas violas para que o acorde se iguale às versões pianísticas.

Figura 72 - Fantasia, compassos de 73 a 76

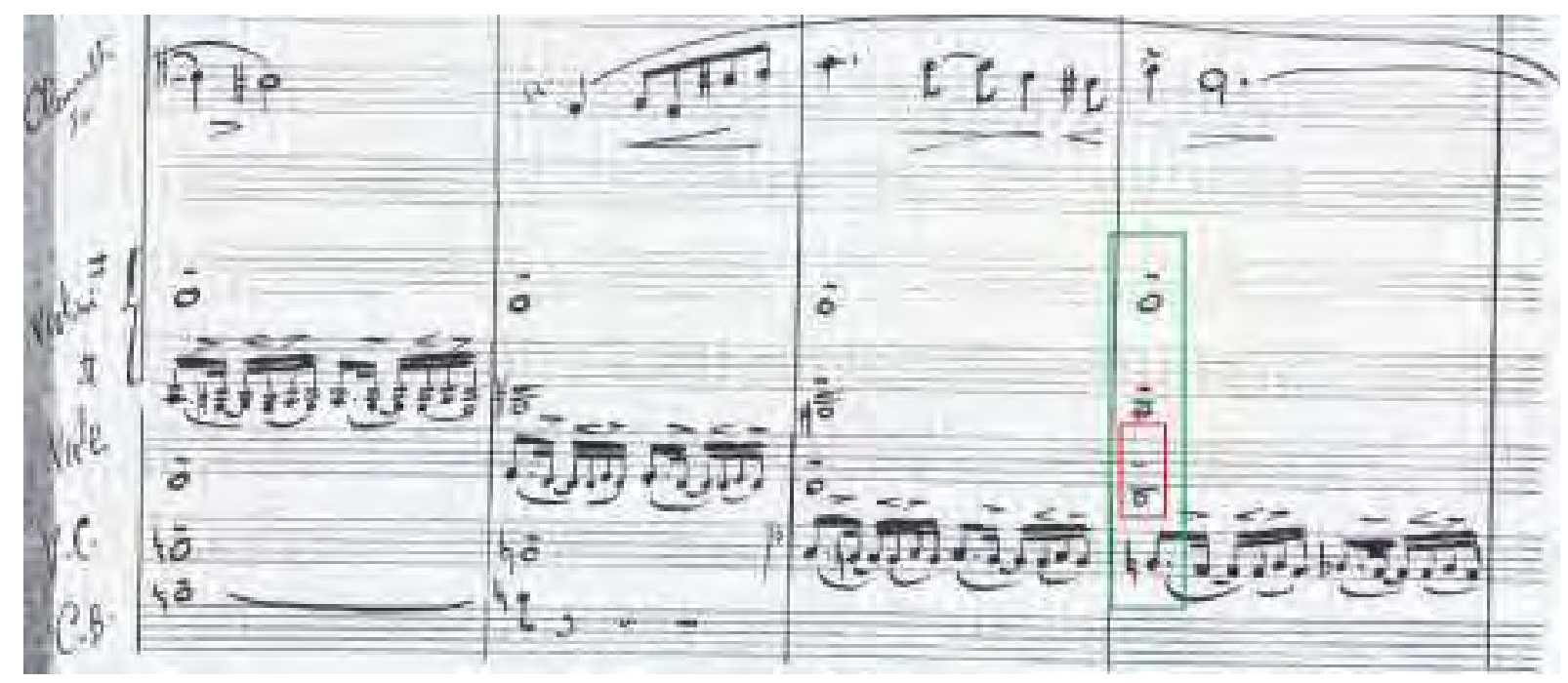

Fp2 (orquestração)

Figura 73 - Fantasia, compassos de 74 a 76

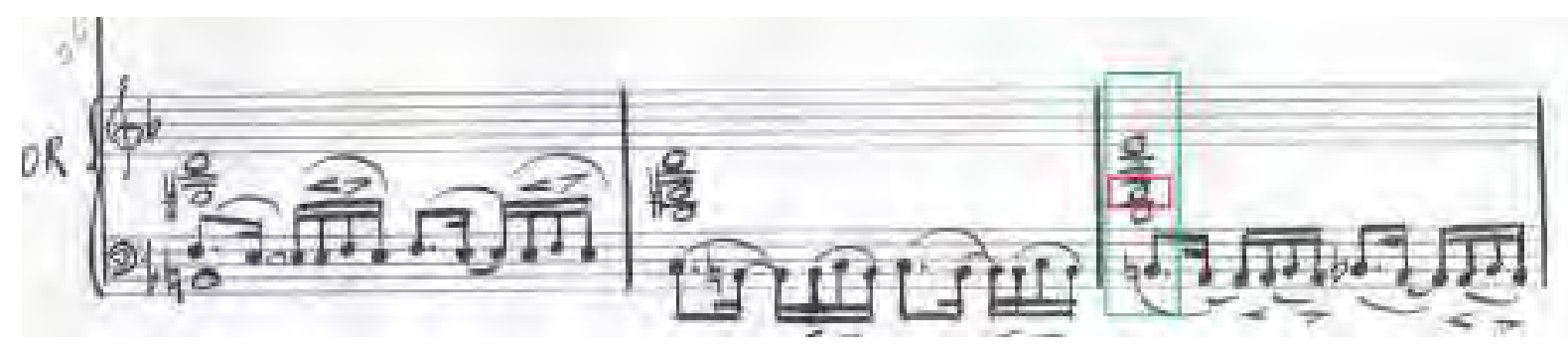

Fp3 (redução) 
Figura 74 - Fantasia, compassos de 74 a 76

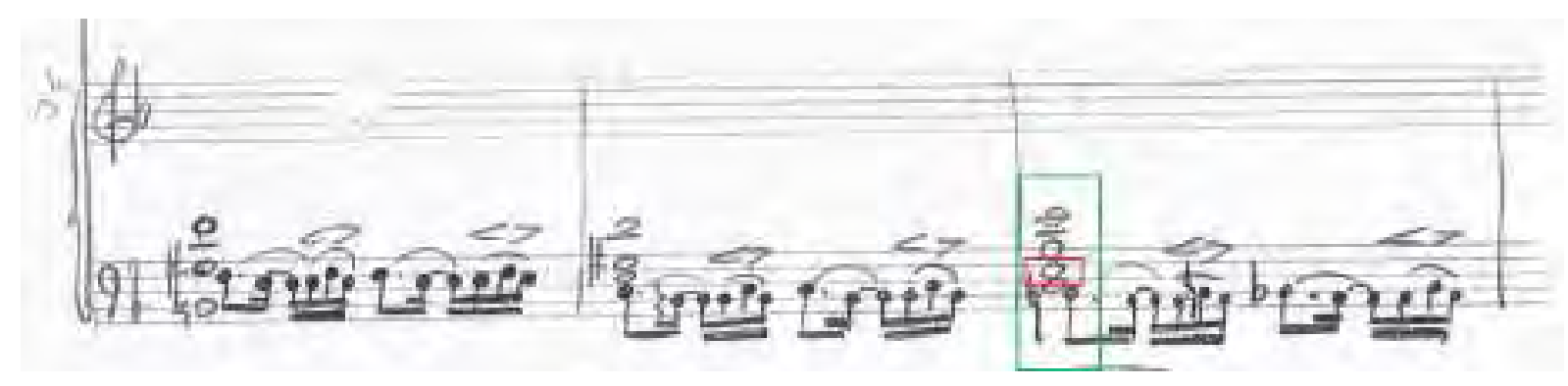

Fp1 (esboço)

Optar pela inclusão da nota Mi na versão orquestral (dividindo as violas, por exemplo) parece corroborar os preceitos de orquestração de Mignone. Dessa maneira, também a sonoridade do acorde fechado alcançada nas versões pianísticas seria reproduzido na versão orquestral.

15) Compasso 98 - ritmo do grupo

No penúltimo compasso do movimento existe uma diferença rítmica na versão orquestral, se comparada com as versões pianísticas. 
Figura 75 - Fantasia, compassos de 94 a 99

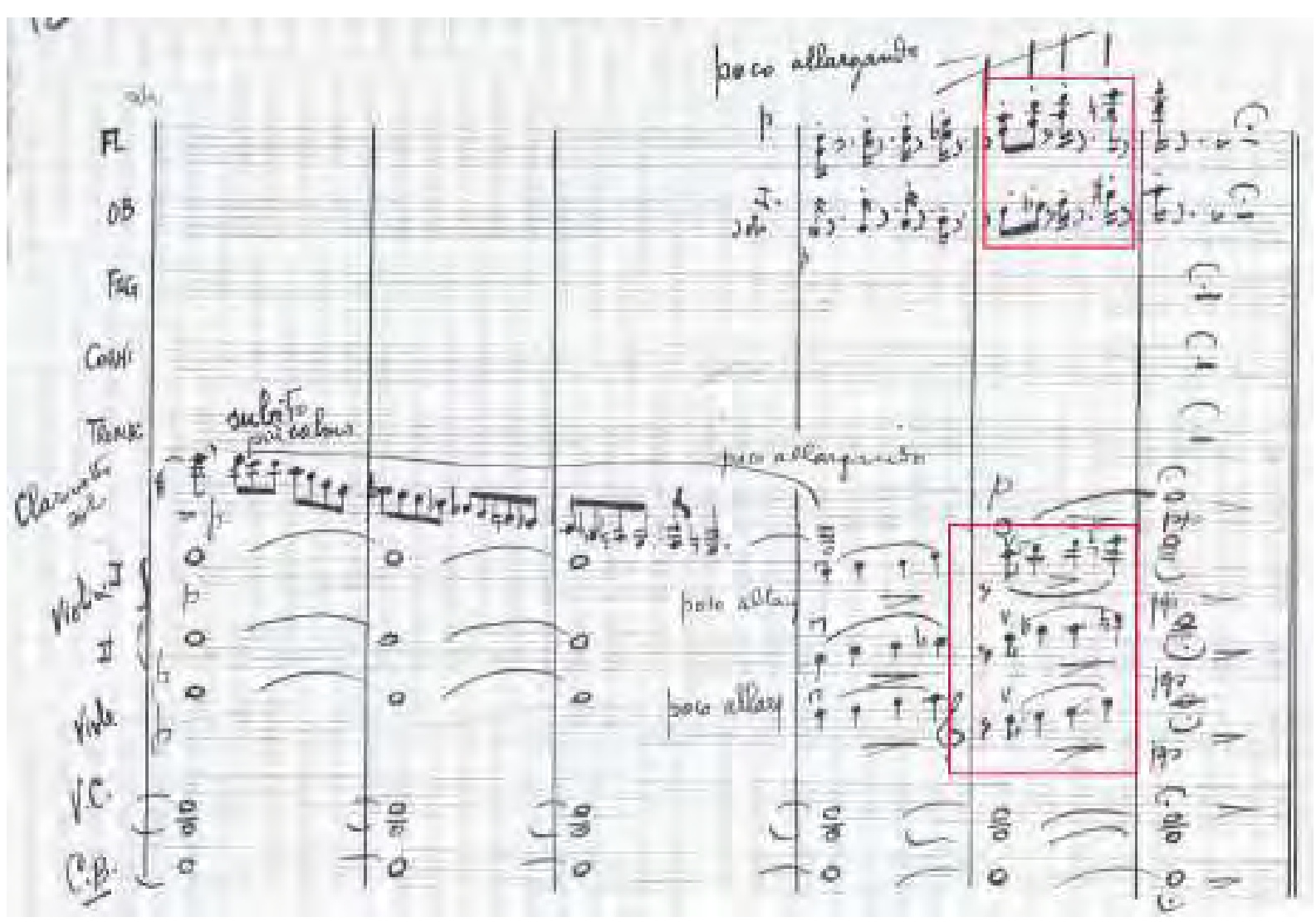

Fp2 (orquestração)

Figura 76 - Fantasia, compassos de 95 a 99

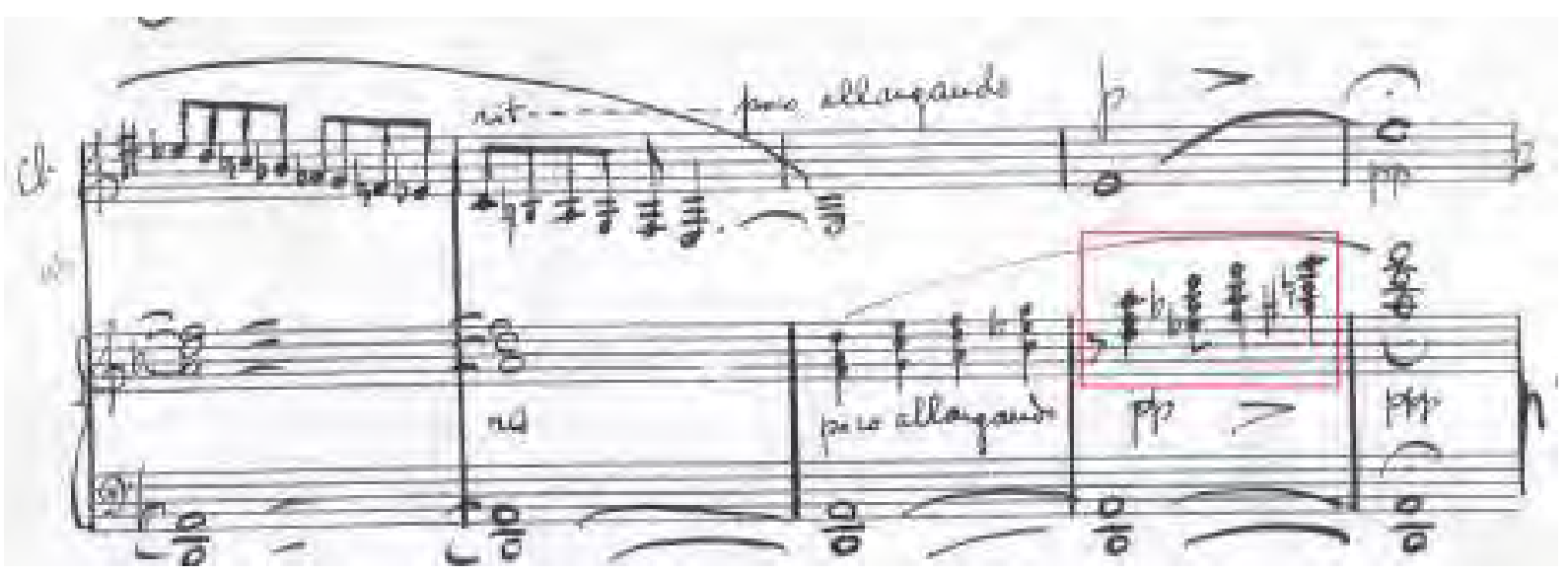

Fp3 (redução) 
Figura 76 - Fantasia, compassos de 95 a 99

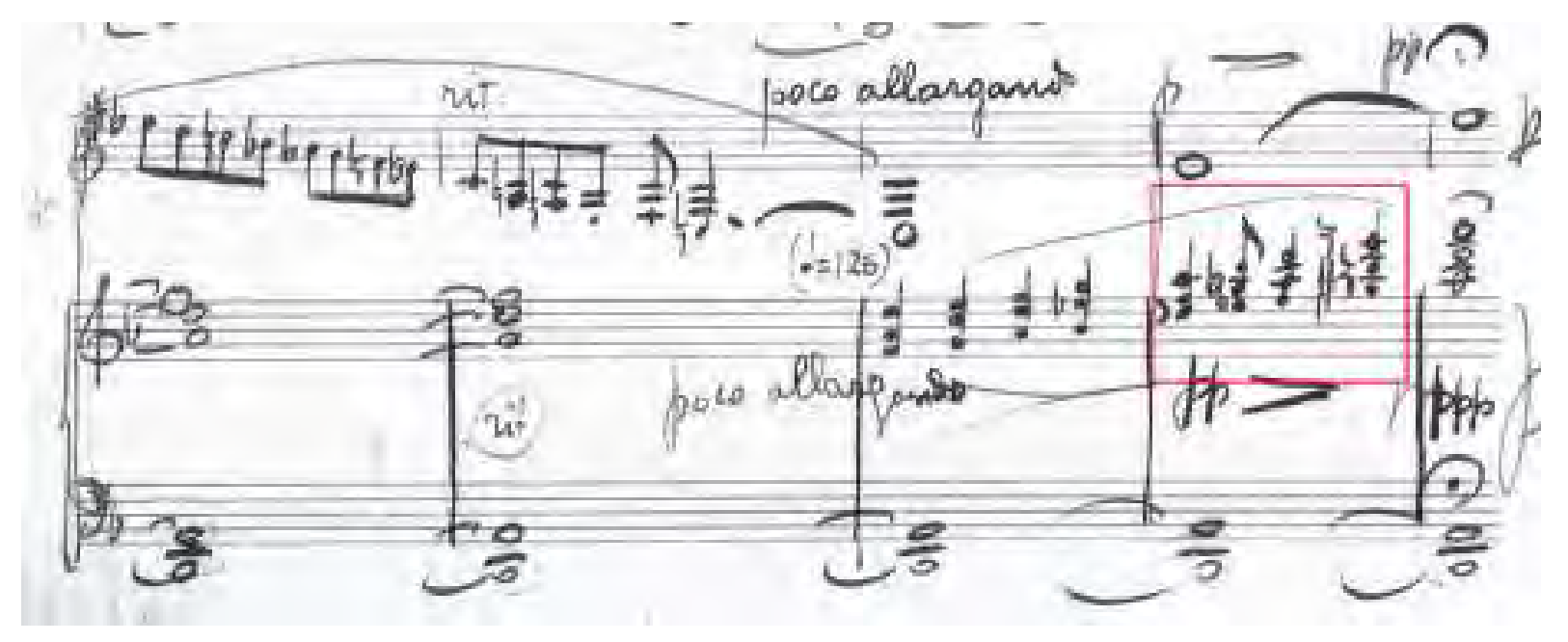

Fp1 (esboço)

A frase final, que é sincopada nas versões pianísticas, é mais simples na versão orquestral. Cronologicamente observaremos que Mignone mudou sua ideia original na transição do esboço para a versão orquestral e a retomou no momento da redução pianística. Mesmo assim, é importante considerar a questão da brasilidade da síncopa. José Botelho disse, em entrevista ${ }^{21}$, que naquela fase Mignone buscava incluir elementos brasileiros, rítmicos e melódios principalmente, em sua produção artística e que o Concertino seguia essa linha estética. Nesse sentido, a presença da síncopa como elemento característico brasileiro nesse penúltimo compasso corrobora o desejo estético mais amplo do autor. Nossa opção será dispor as duas versões do ritmo para o intérprete.

\section{$2^{\circ}$ movimento - TOADA}

1) Compasso 33 - sextina do clarinete

Há uma diferença na sextina da melodia do clarinete, que na versão orquestral foi escrita um tom acima das versões pianísticas.

\footnotetext{
${ }^{21}$ Entrevista exclusiva, cedida em julho de 2012 em sua casa no Rio de Janeiro. (N.A)
} 
Figura 78 - Toada, compassos de 30 a 35

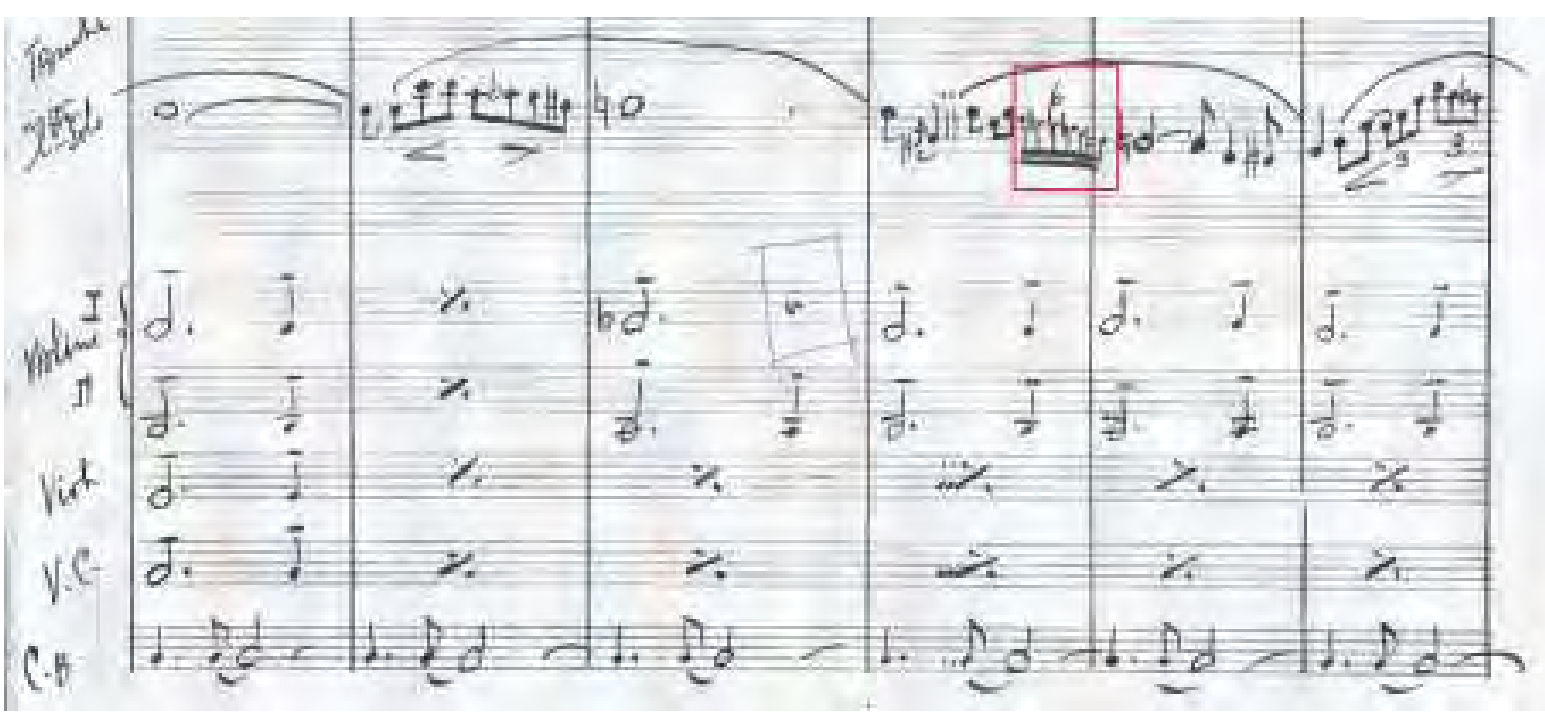

Fp2 (orquestração)

Figura 79 - Toada, compassos de 33 a 35

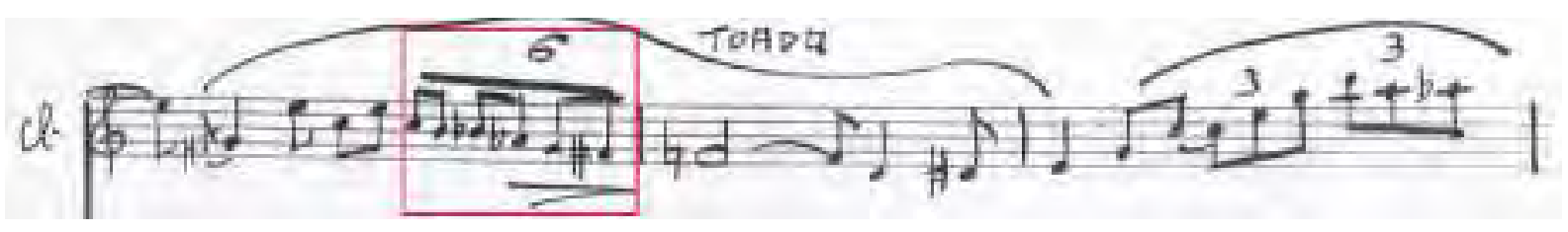

Fp3 (redução)

Figura 80 - Toada, compassos de 30 a 35

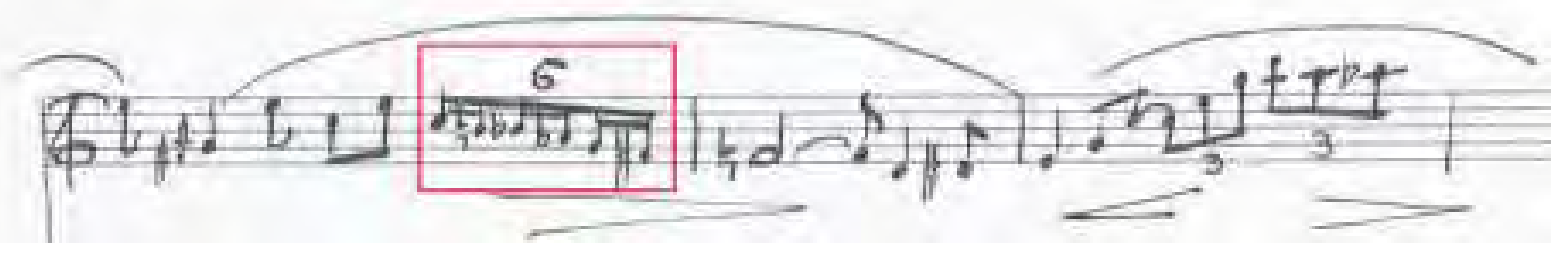

Fp1 (esboço)

Aqui a opção é em favor das versões pianísticas por se expressarem melhor dentro do contexto harmônico. 
2) Compasso 36 - melodia do fagote e ausência dos contrabaixos

A versão orquestral mostra a melodia do fagote com as notas Si natural e Si\#, perturbando o cromatismo da frase; as versões pianísticas apontam para a preservação do cromatismo por meio das notas Sib (respeitando a armadura de clave) e Si natural.

Figura 81 - Toada, compassos de 36 a 40

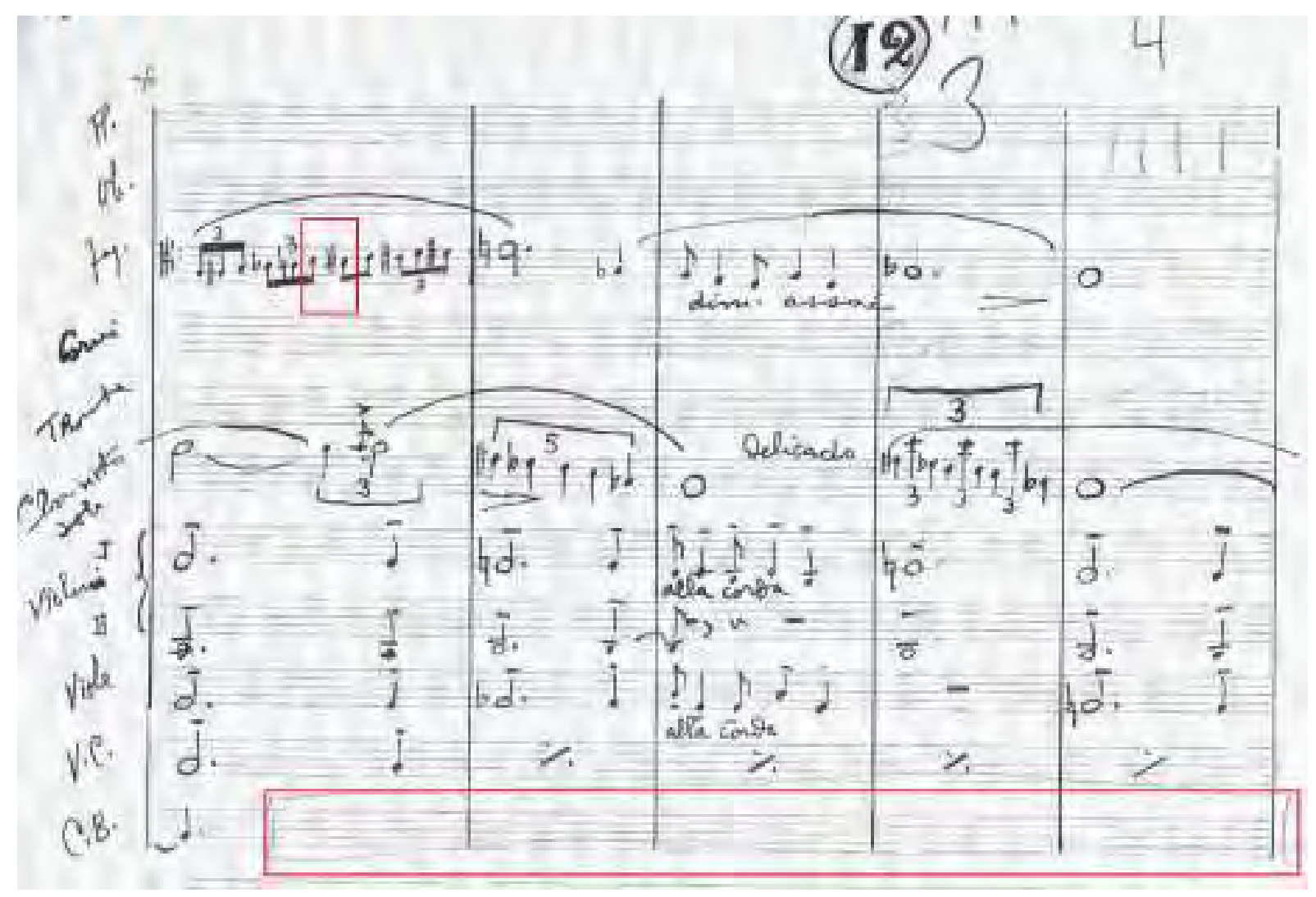

Fp2 (orquestração)

$\mathrm{Na}$ figura acima também se pode notar a ausência da linha dos contrabaixos do compasso 36 ao 40. E as versões pianísticas apontam para a presença da linha correspondente. 
Figura 82 - Toada, compassos de 36 a 39

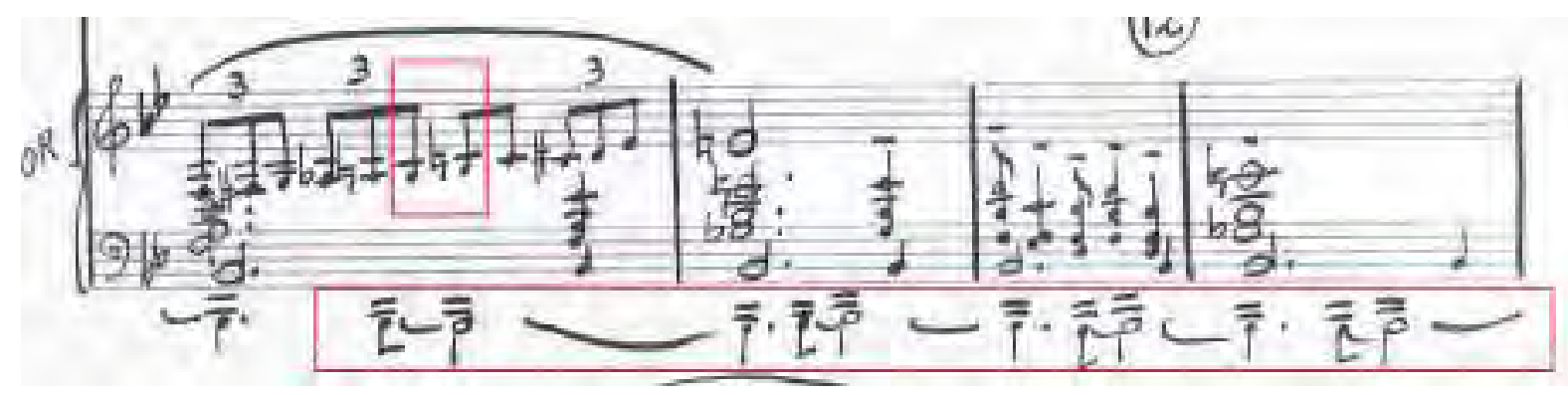

Fp3 (redução)

Figura 83 - Toada, compassos de 36 a 39

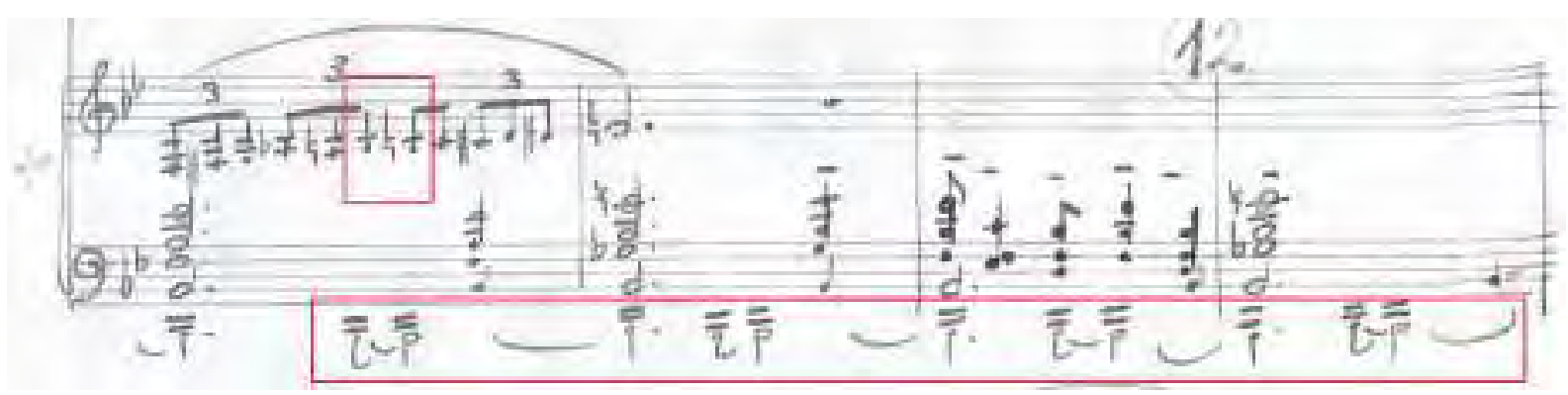

Fp1 (esboço)

Optamos pela manutenção da escala cromática e pela inserção da linha dos contrabaixos, levando em conta as versões pianísticas e a partitura de contrabaixos extraída pelo copista da versão orquestral.

Figura 84 - Toada, compassos de 33 a 40

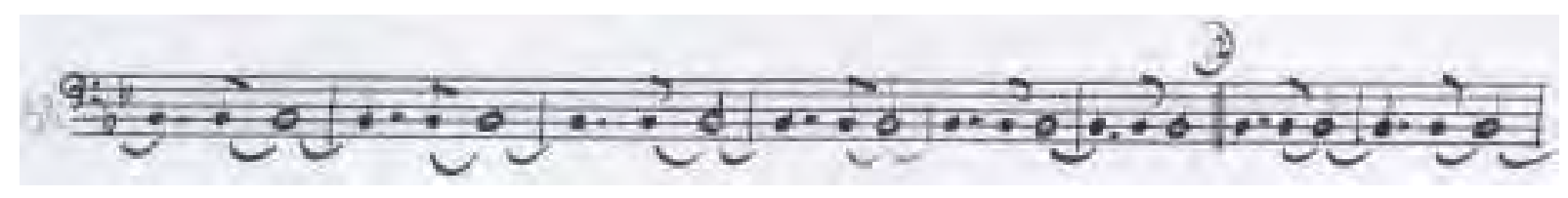

Fs1 (material do copista) 


\section{$3^{0}$ movimento - FINAL}

1) Compasso 19 - quinta semicolcheia do clarinete

Há uma correção a lápis, da nota Lá\# para a Sol\#, na versão orquestral. Contudo, as versões pianísticas mantêm a nota Lá\#. Nossa opção preserva a escrita original e ignora a correção a lápis, possivelmente feita para completar o arpejo de Mi Maior escrito (soando Ré Maior).

Figura 85 - Final, compassos de 14 a 19

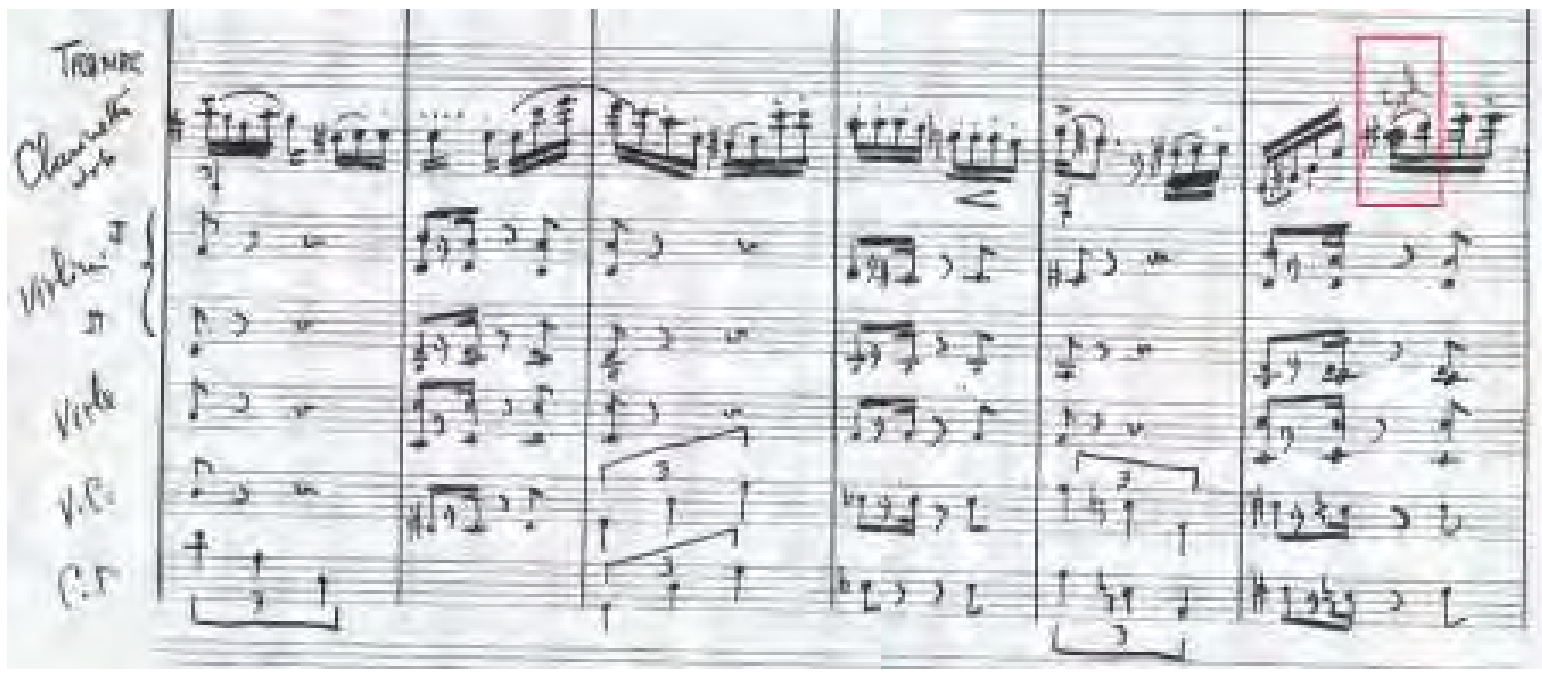

Fp2 (orquestração)

Figura 86 - Final, compassos de 15 a 19

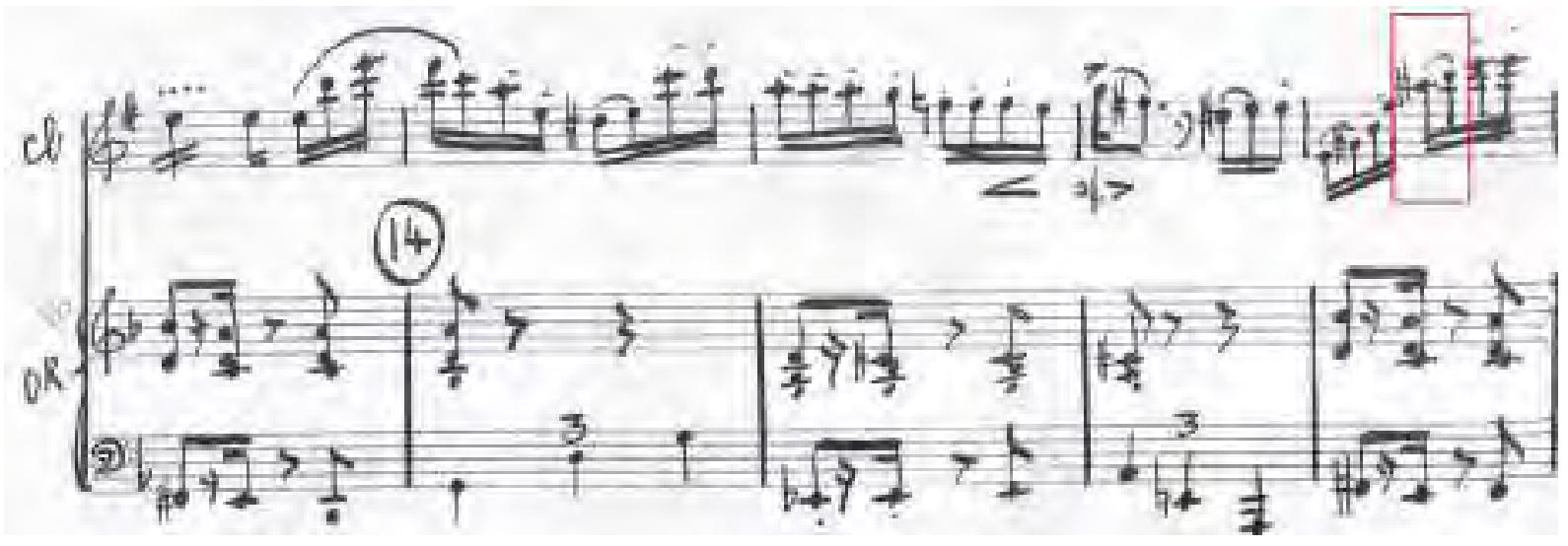

Fp3 (redução) 
Figura 87 - Final, compassos de 15 a 19

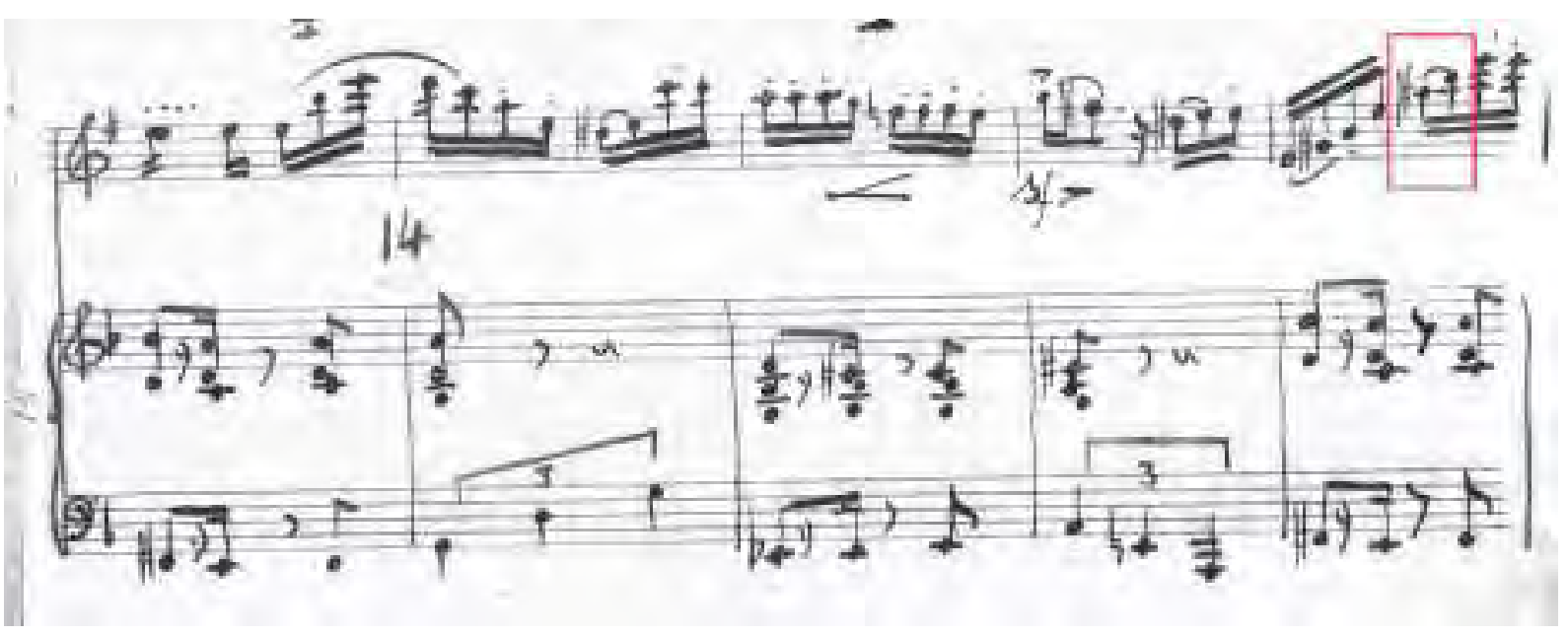

Fp1 (esboço)

Além disso, a quinta diminuta como apogiatura melódica aproxima a frase musical mais da música brasileira do que o arpejo da tríade o faria ${ }^{22}$. Isso se apoia ao que disse José Botelho sobre os compassos 35 e 36 desse movimento, quando relata que sugeriu a Mignone que fizesse as síncopas com a articulação staccato para que soassem mais brasileiras. Mignone aceitou; contudo, não há registro escrito dessa possibilidade em nenhuma das fontes.

Figura 88 - Final, compassos de 32 a 36

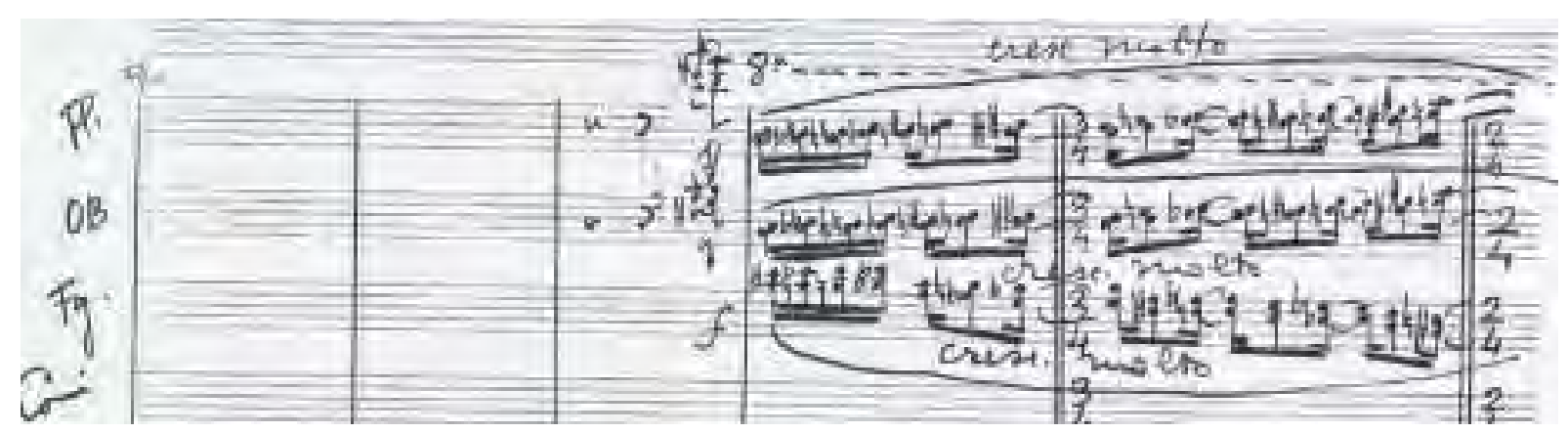

Fp2 (orquestração)

2) Compasso 59 - ritmo de violinos 2 e violas

Aqui há uma diferença na maneira como Mignone escreveu a orquestração. A utilização do sinal de repetição do compasso 59 confundiu a ideia original presente no esboço e na redução pianística.

${ }^{22}$ Ver Fantasia - 15) Comp. 98 - ritmo do grupo, como no compasso 35 e 36 sobre a brasilidade da sincopa que levou a execução ao staccato. 
Figura 89 - Final, compassos de 54 a 59

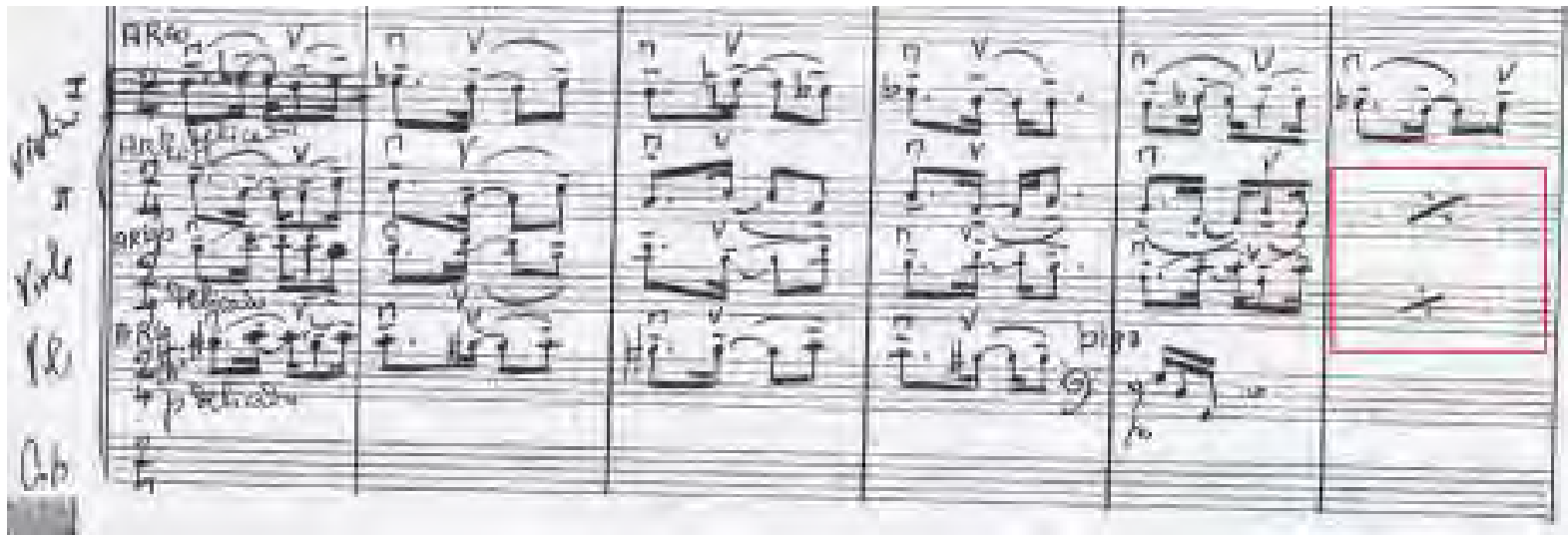

Fp2 (orquestração)

Figura 90 - Final, compassos de 56 a 59

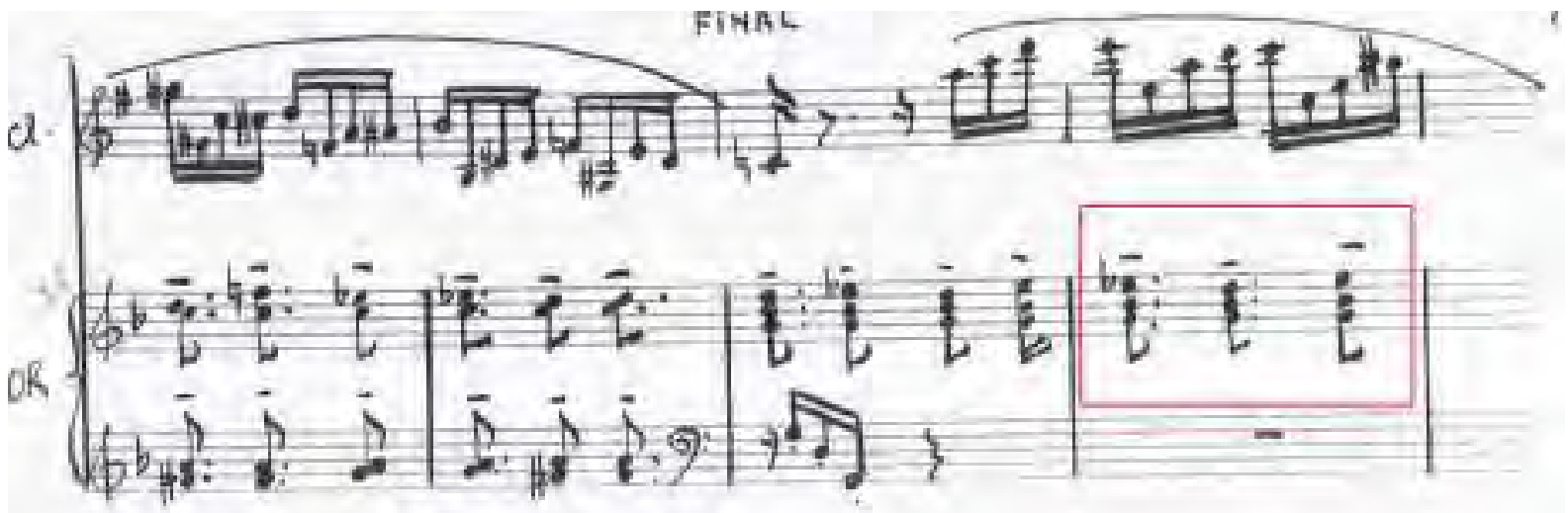

Fp3 (redução)

Figura 91 - Final, compassos de 5459

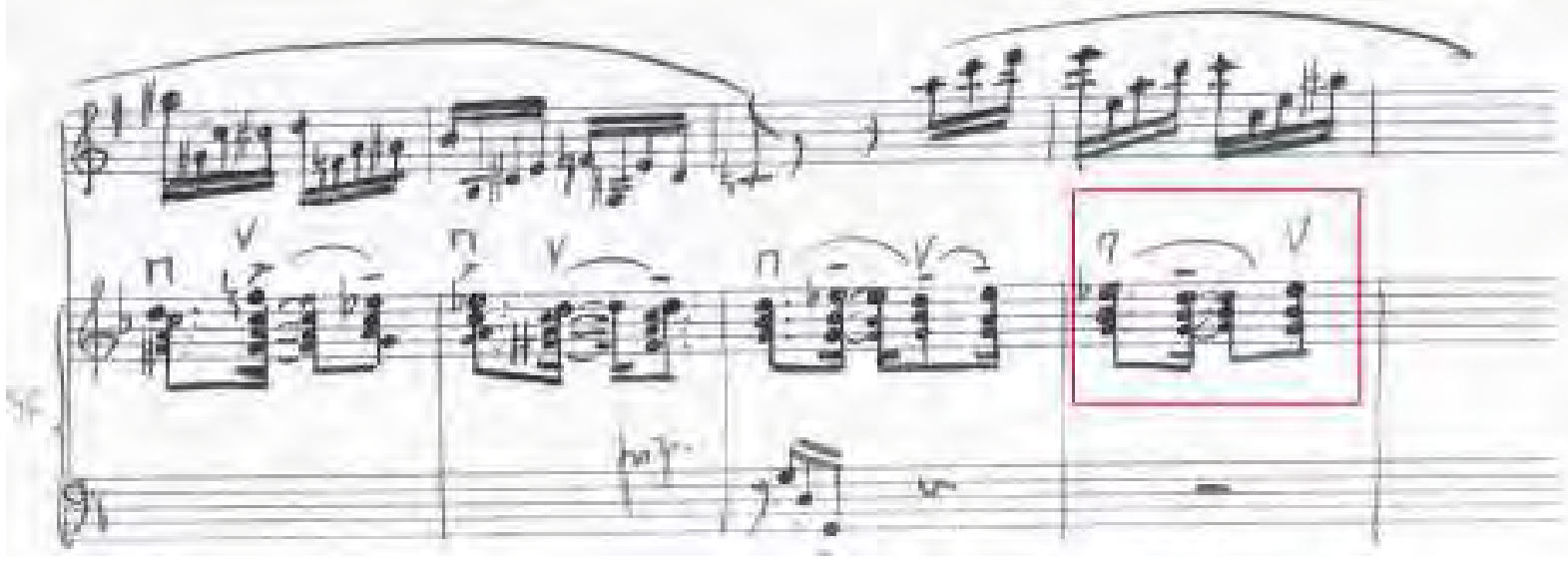

Fp2 (orquestração)

Nossa opção será pelas versões pianísticas. 
3) Compasso 62 - nota das violas

A nota Lá aparece no esboço pianístico e nas violas da versão orquestral, enquanto a redução pianística traz a nota Sol\#.

Figura 92 - Final, compassos de 60 a 65

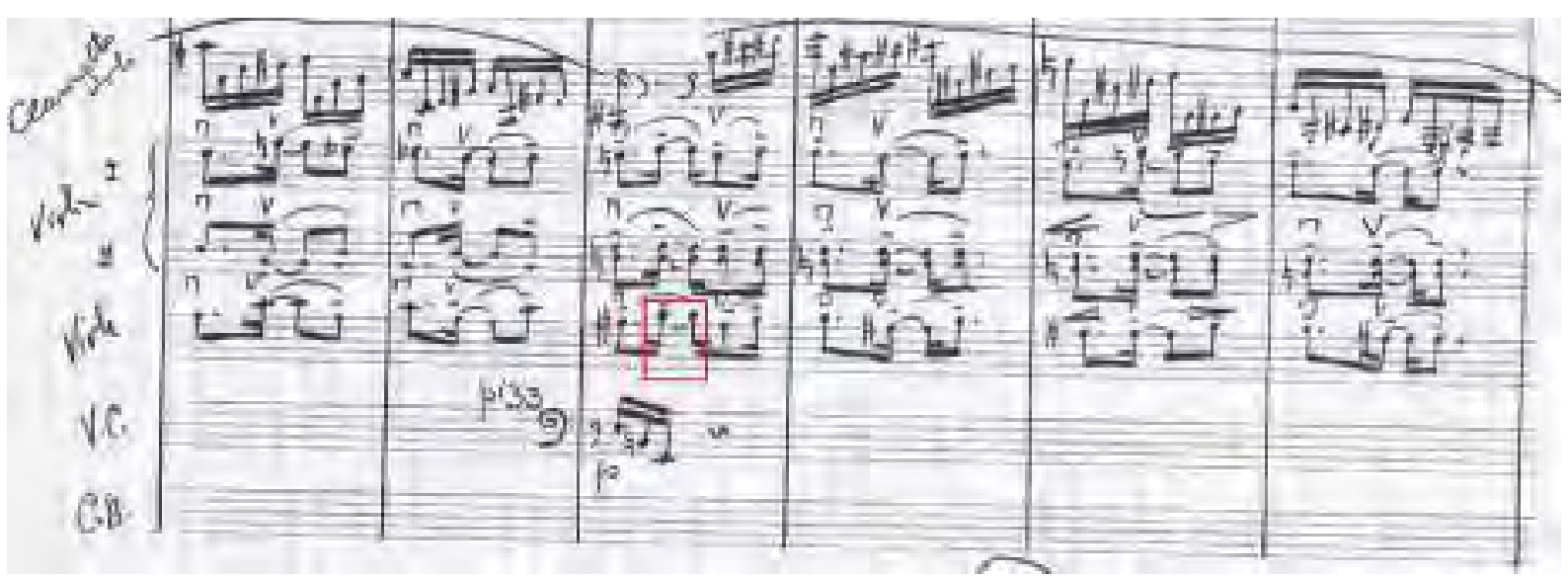

Fp2 (orquestração)

Figura 93 - Final, compassos de 60 a 64

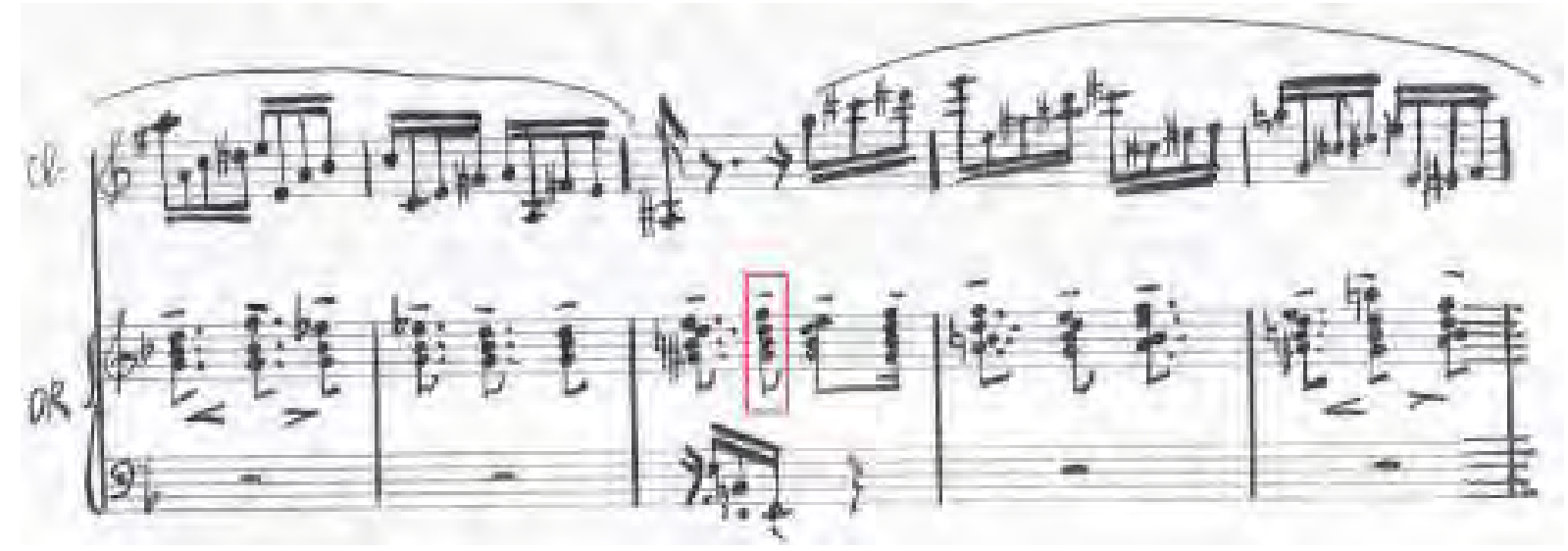

Fp3 (redução) 
Figura 94 - Final, compassos de 60 a 64

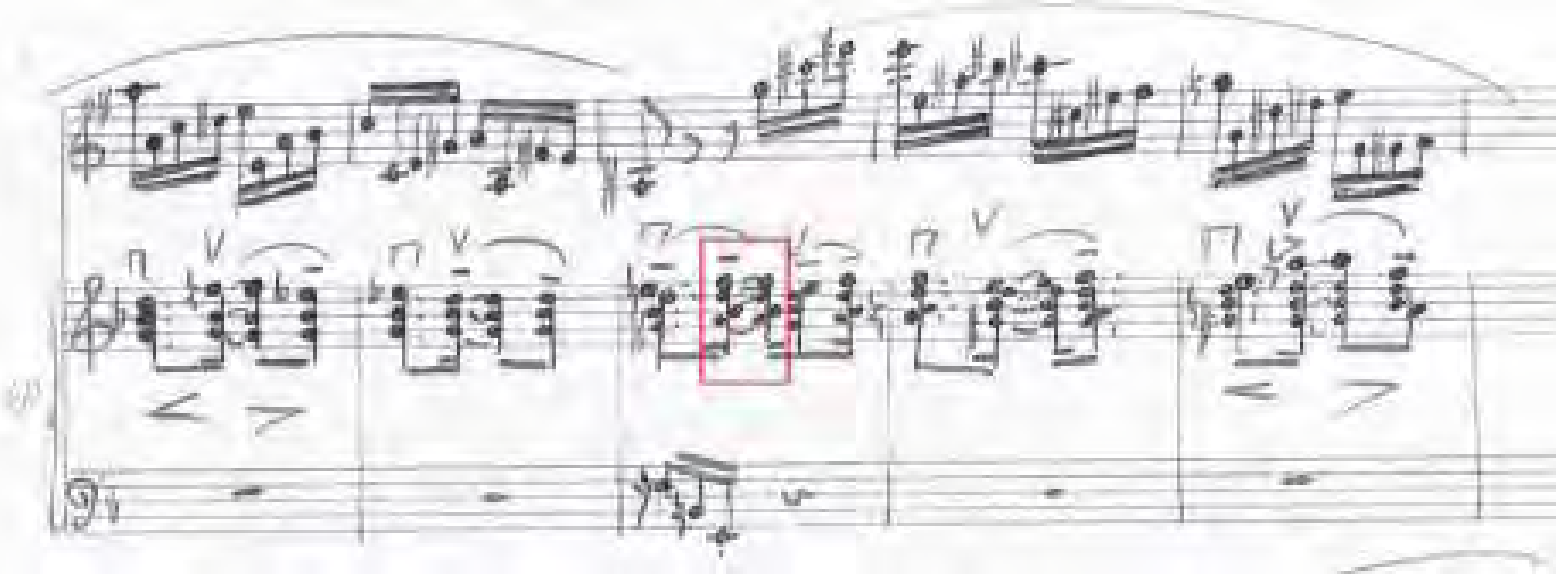

Fp1 (esboço)

Nossa opção é pela nota Lá por acompanhar em sexta a melodia superior, reforçando a mudança harmônica.

4) Compasso 69-Mib de trompa e clarinete

$\mathrm{Na}$ versão orquestral aparece escrita a nota Dó (soando Fá) para trompa e Fá\# (soando Mi natural) para clarinete. No entanto, as duas versões pianísticas registram claramente a passagem em Mib Maior, sendo, portanto, necessária a correção.

Figura 95 - Final, compassos de 66 a 74

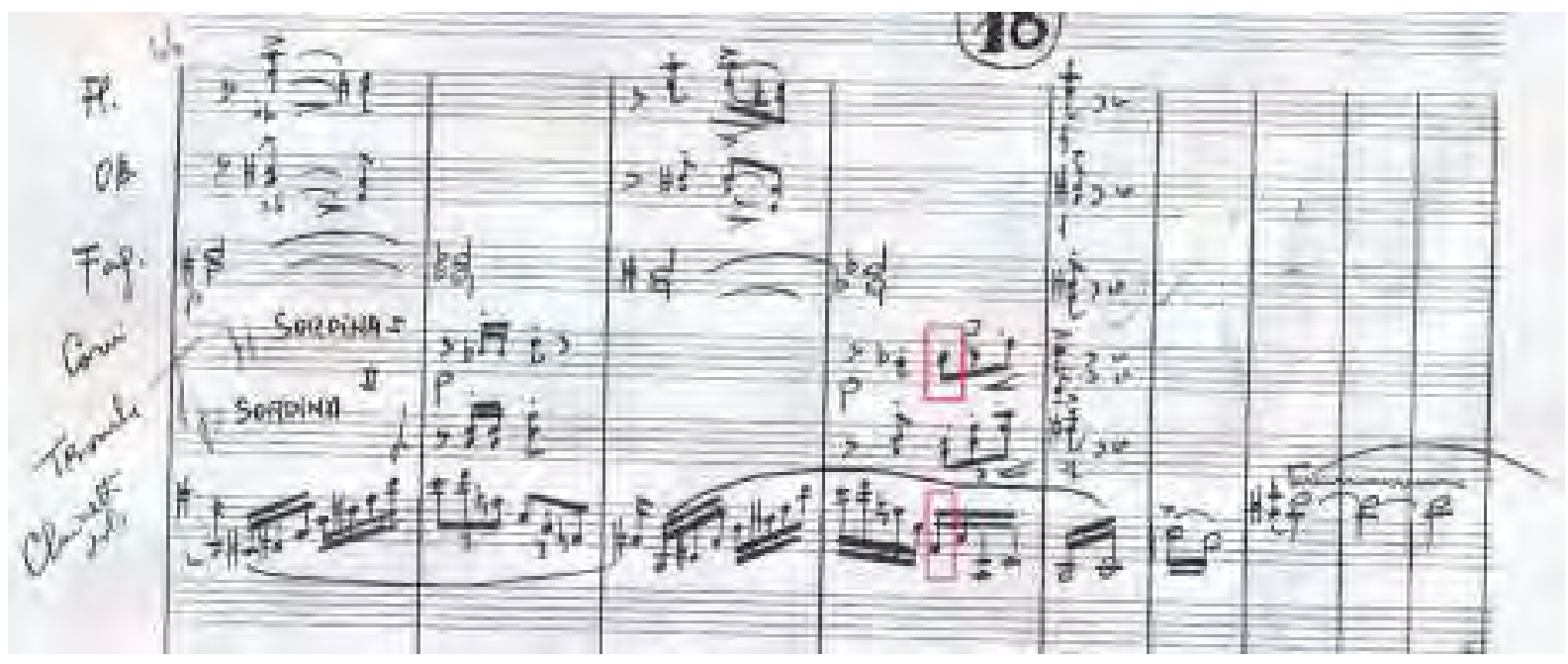

Fp2 (orquestração) 
Figura 96 - Final, compassos de 69 a 74

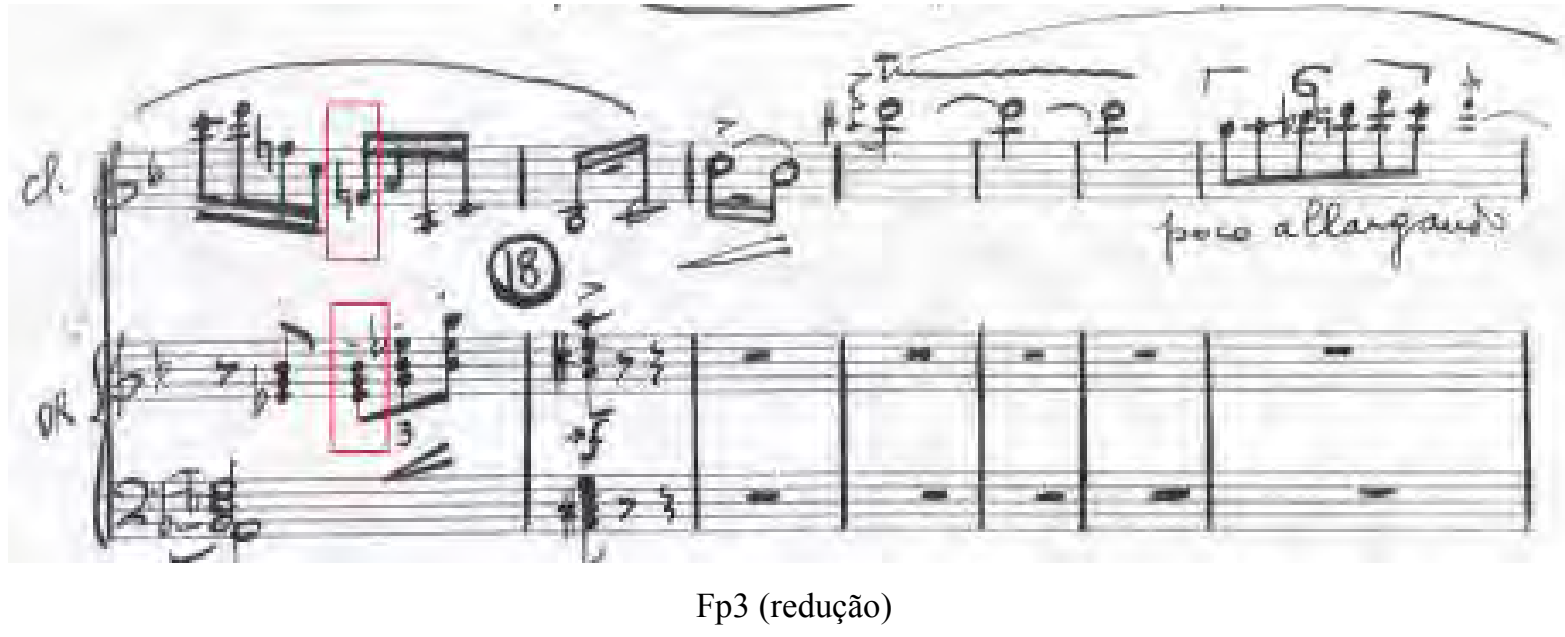

Figura 96 - Final, compassos de 69 a 74

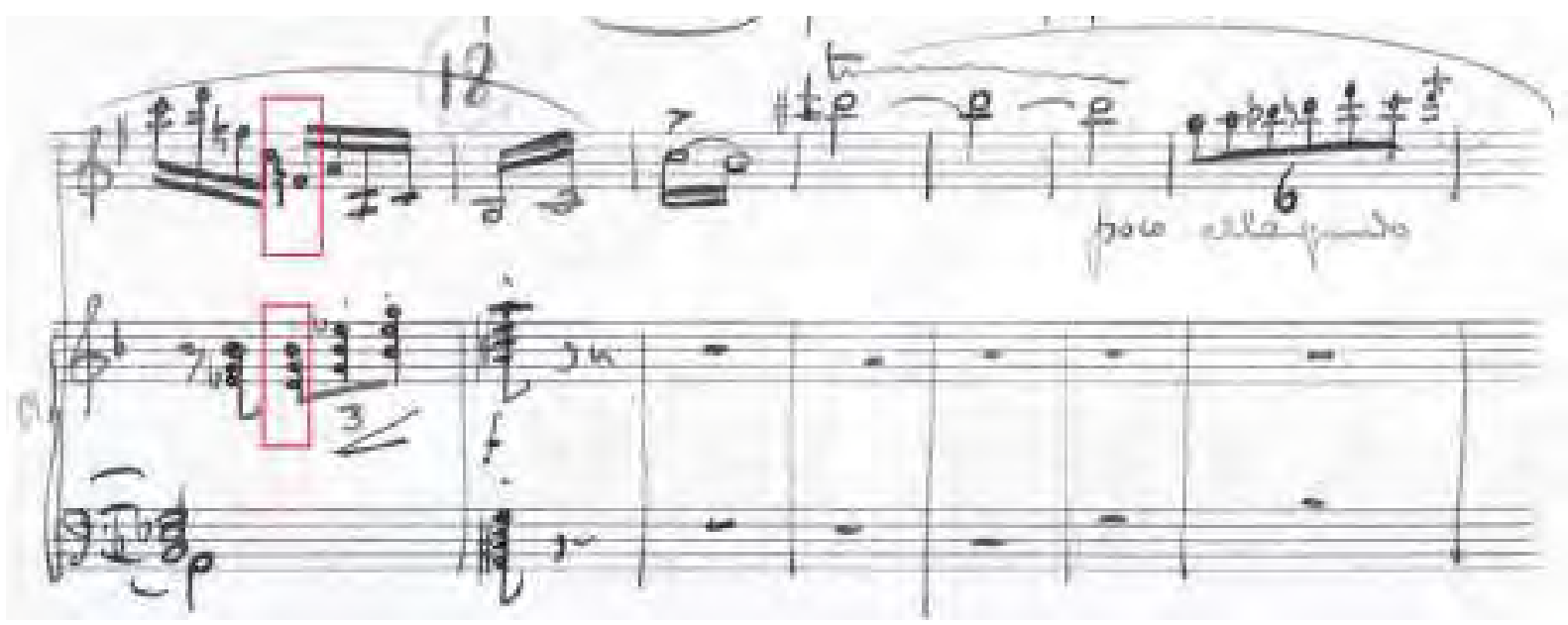

Fp1 (esboço)

5) Compassos 85 e 90 - nota das violas e ausência da frase de primeiros violinos

A nota das violas aparece como Lá\# apenas na versão orquestral, e a melodia faltante no compasso 90 de primeiros violinos aparece nas versões pianísticas. Optamos pela nota Lá natural nas violas por não estarmos em uma região de Si menor, e sim de Ré Maior, e pela presença de um acorde parecido dois compassos antes (83) escrito com Sib e respeitando a armadura de clave. A opção de acrescentar a melodia do compasso 90 aos violinos da versão orquestral é justificável pela presença da mesma melodia alguns compassos à frente (Fp2, comp. 94). 
Figura 97 - Final, compassos de 83 a 90

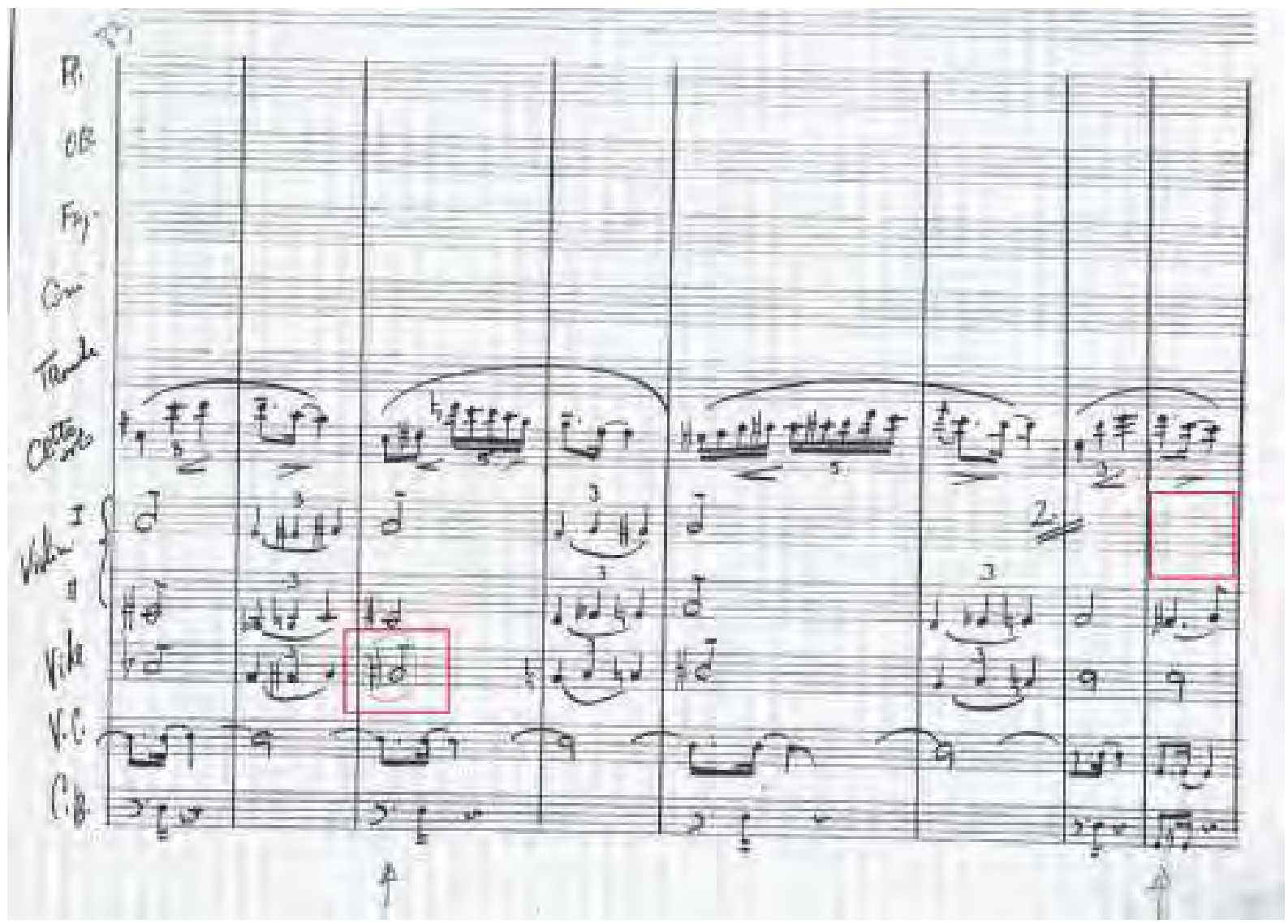

Fp2 (orquestração)

Figura 98 - Final, compassos de 82 a 93

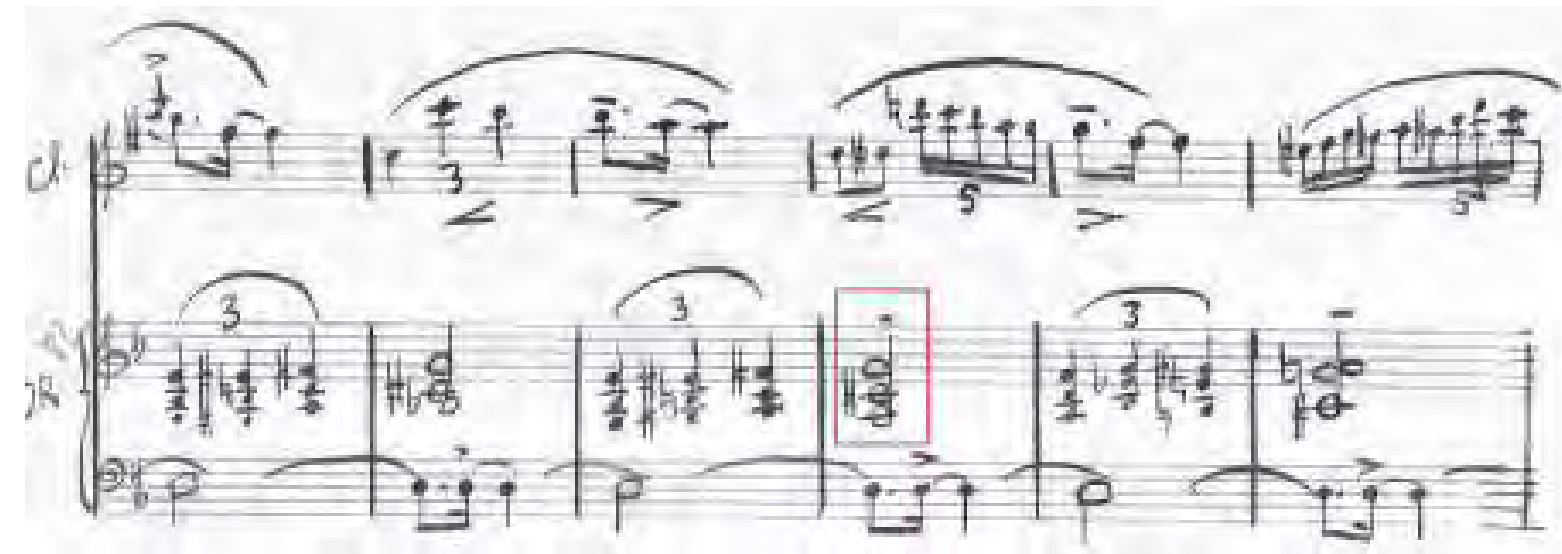




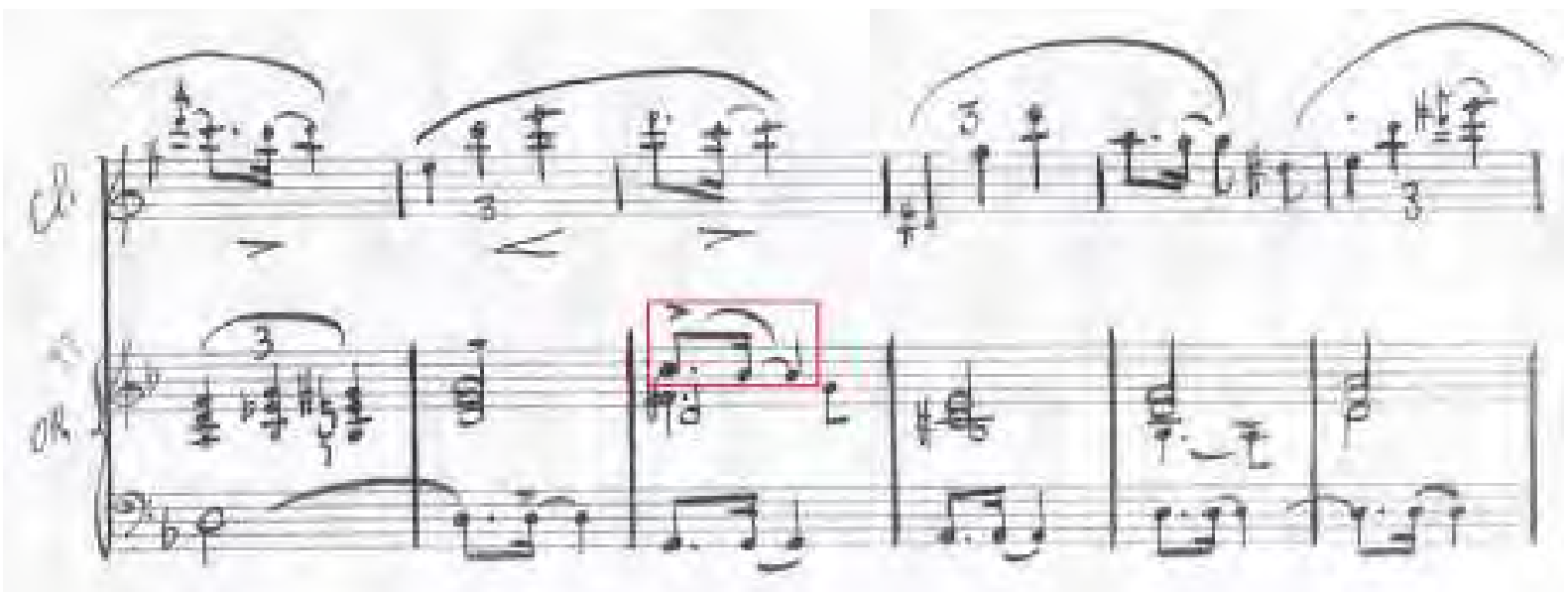

Fp3 (redução)

Figura 99 - Final, compassos de 82 a 93

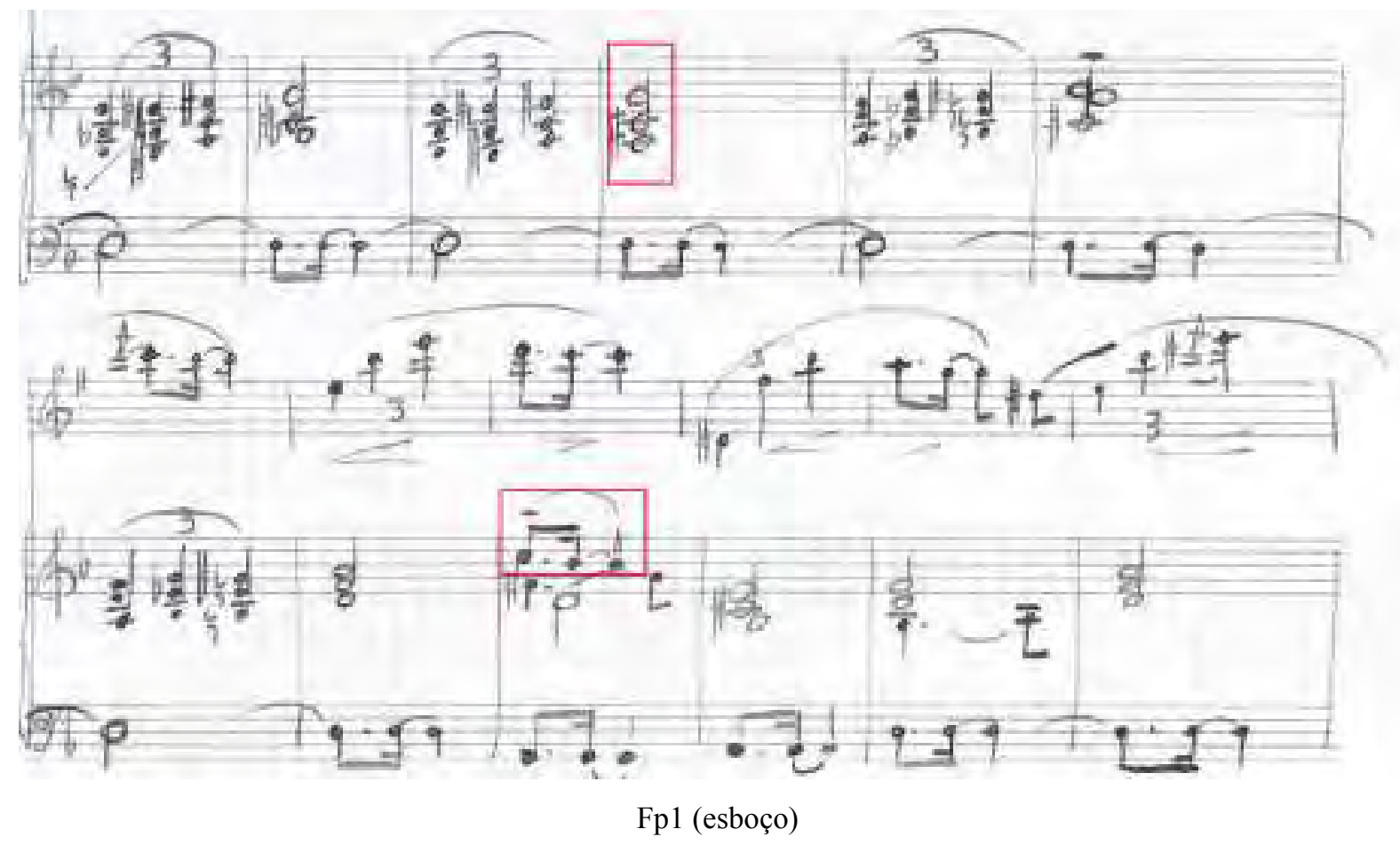

6) Compasso 105 - tessitura do clarinete

Da mesma forma como acontece no item 13 do primeiro movimento, a tessitura do clarinete moderno não é suficiente para a realização da melodia escrita que requer a nota Mib grave. A resolução desse ponto deve levar em conta alguns parâmetros: a harmonia do trecho que segue nos sopros e o desenho melódico da frase. A harmonia corrente no trecho é a de Do\#dim, e a fundamental do acorde está presente substancialmente apenas no clarinete 
(compassos de 105 a 108). A alteração da nota do clarinete, se feita no sentido de preservar a harmonia, deverá elevar em uma oitava o Ré\# escrito. Contudo, o desenho melódico da frase indica um movimento descendente em direção à nota longa; nesse sentido, uma alteração de nota, e não apenas de oitava, seria necessária. As notas possíveis dentro da harmonia em substituição ao Dó sustenido são: Mi natural, Sol natural, Si bemol (sons reais). A escolha da nota deve ser realizada pelo intérprete que executará a peça guiado pela sua escuta por não haver outros subsídios na partitura que justifiquem qualquer escolha. A tradição oral da obra aponta para a escolha do Si bemol.

Figura 100 - Final, compassos de 100 a 107

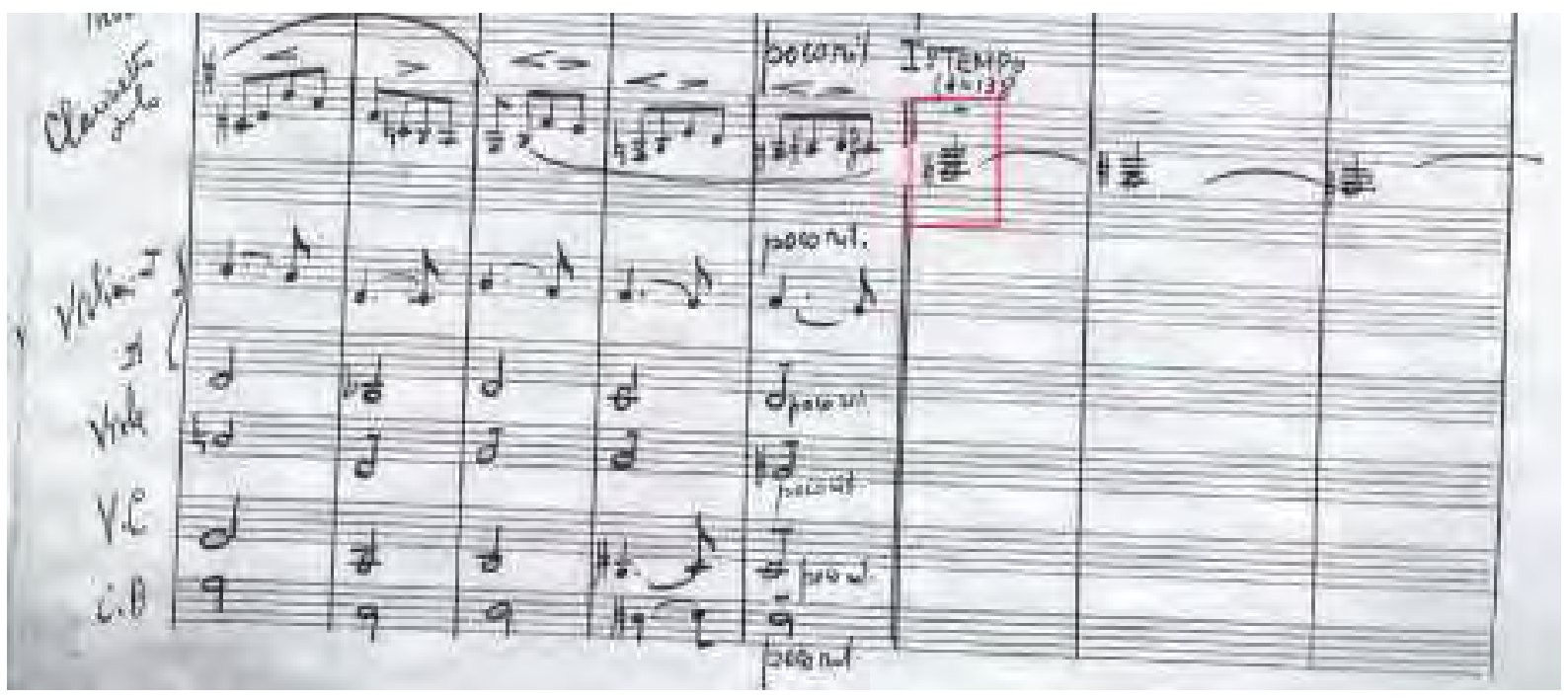

Fp2 (orquestração)

Figura 101 - Final, compassos de 100 a 107

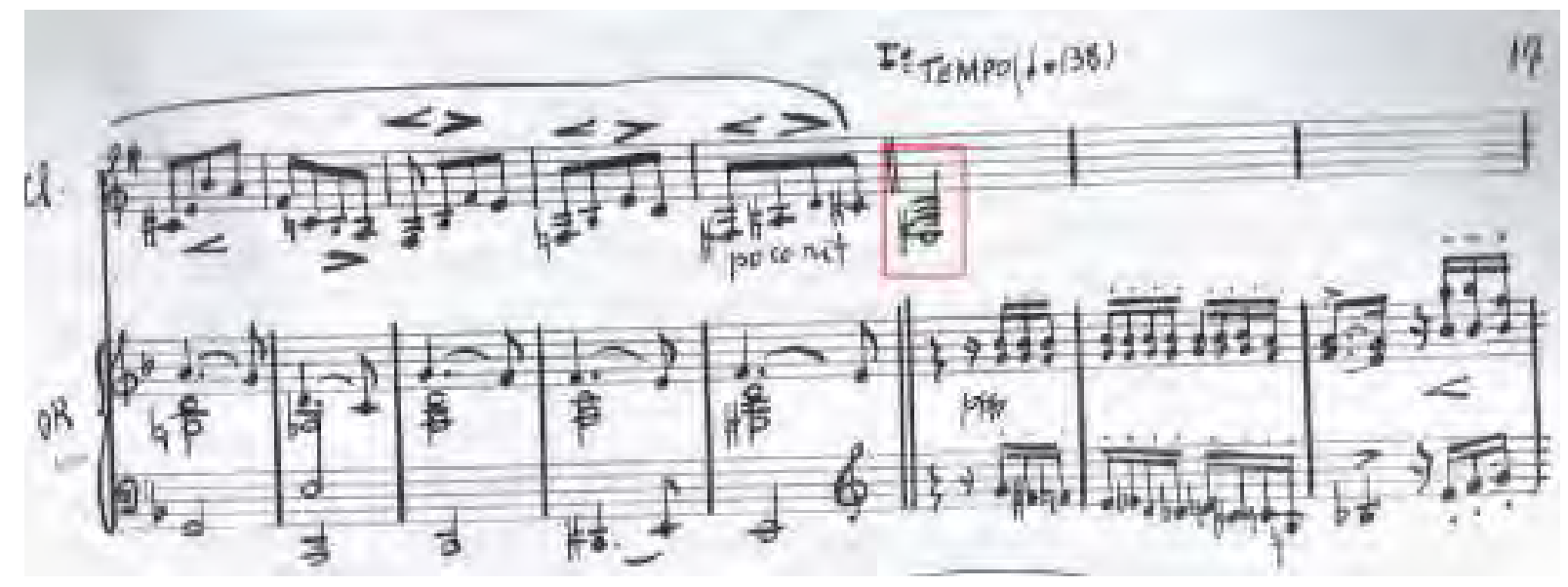

Fp3 (redução) 
Deve-se notar que a última nota do clarinete na Fp3 nessa frase não se estende pelos outros compassos, como nas outras versões.

Figura 103 - Final, compassos de 100 a 107

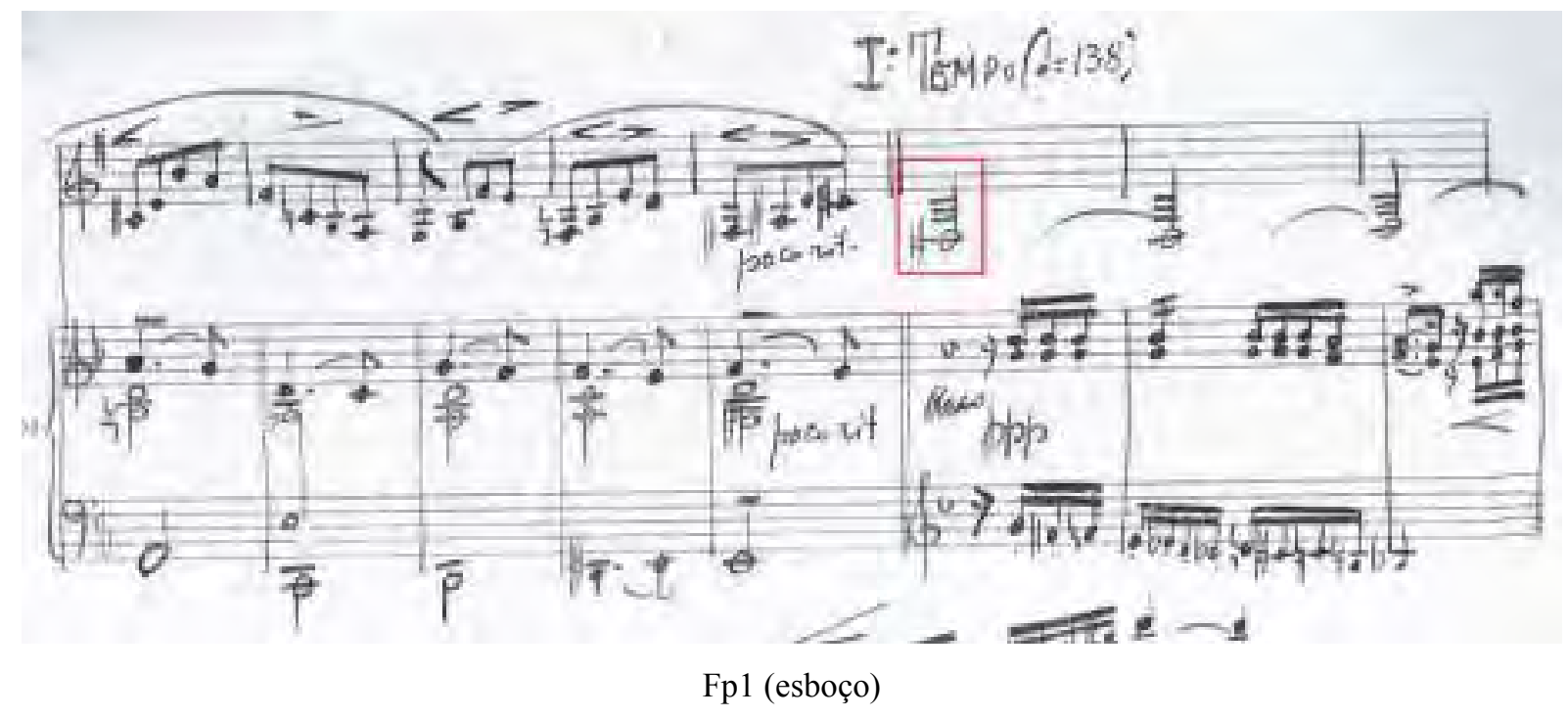

7) Compasso 120 - nota de contrabaixo

Aqui a questão é a da inversão dos acordes: na versão orquestral o acorde de Ré menor está em posição fundamental, e nas versões pianísticas o mesmo acorde está em primeira inversão (nota Fá no baixo). Essa diferença se justifica em cada uma das versões em razão da natureza de cada fonte: nas versões pianísticas a quantidade de notas a ser executadas pela mão esquerda do pianista impossibilita a presença do Ré como nota mais grave, enquanto na versão orquestral não existe razão técnica para que a nota Ré não seja a mais grave do acorde. Contudo, pode-se notar que a subida na escala da nota Mi do compasso 119 até a nota Do\# do compasso 124 poderia demonstrar uma intenção composicional que se resolveria em favor da nota Fá no compasso 120 (de acordo com as versões pianísticas). Apesar disso, nossa escolha se fará em favor do texto musical apresentado na versão orquestral e será justificada pela primazia dessa versão já comentada no início deste capítulo. 
Figura 104 - Final, compassos de 115 a 120

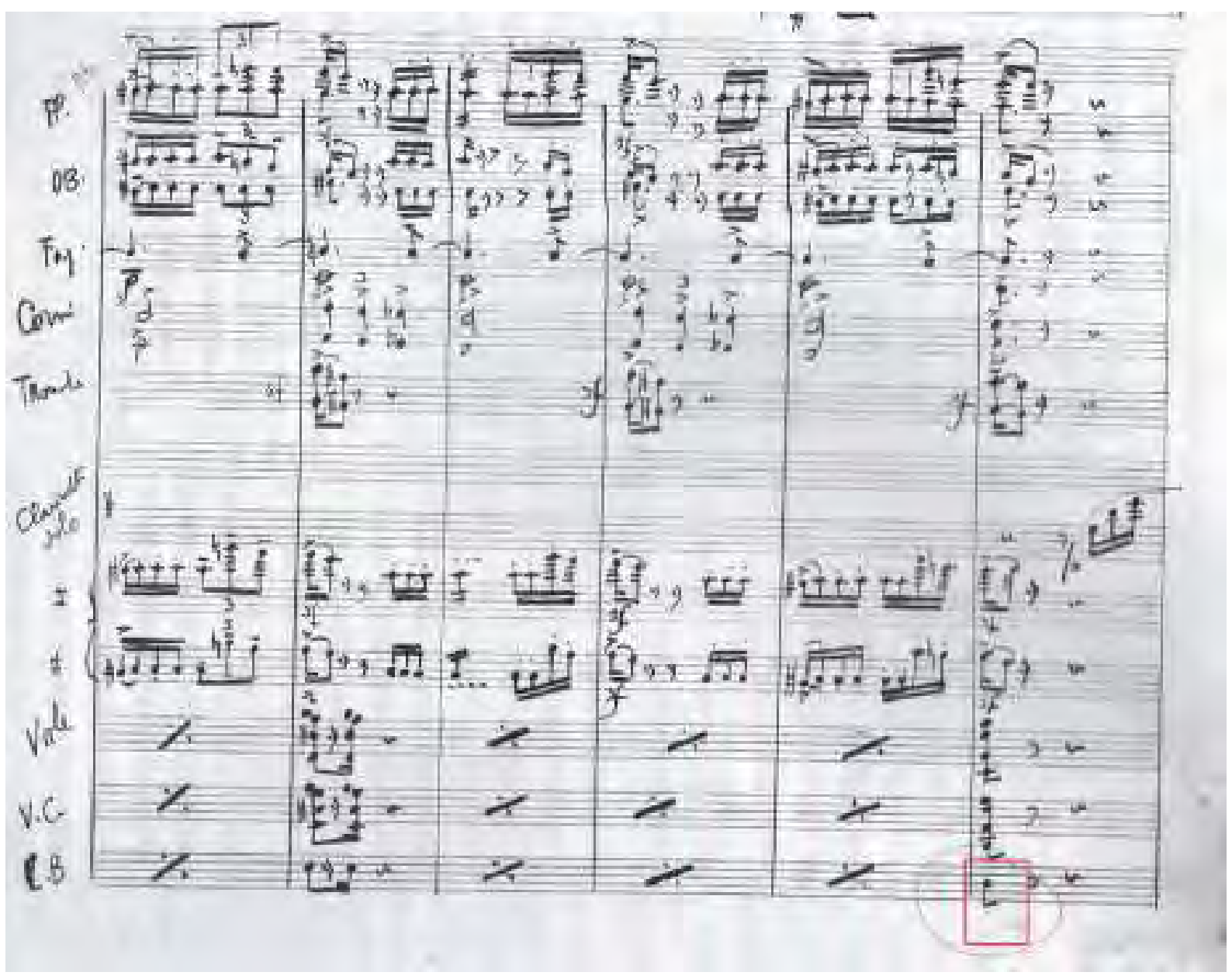

Fp2 (orquestração)

Figura 105 - Final, compassos de 119 a 124

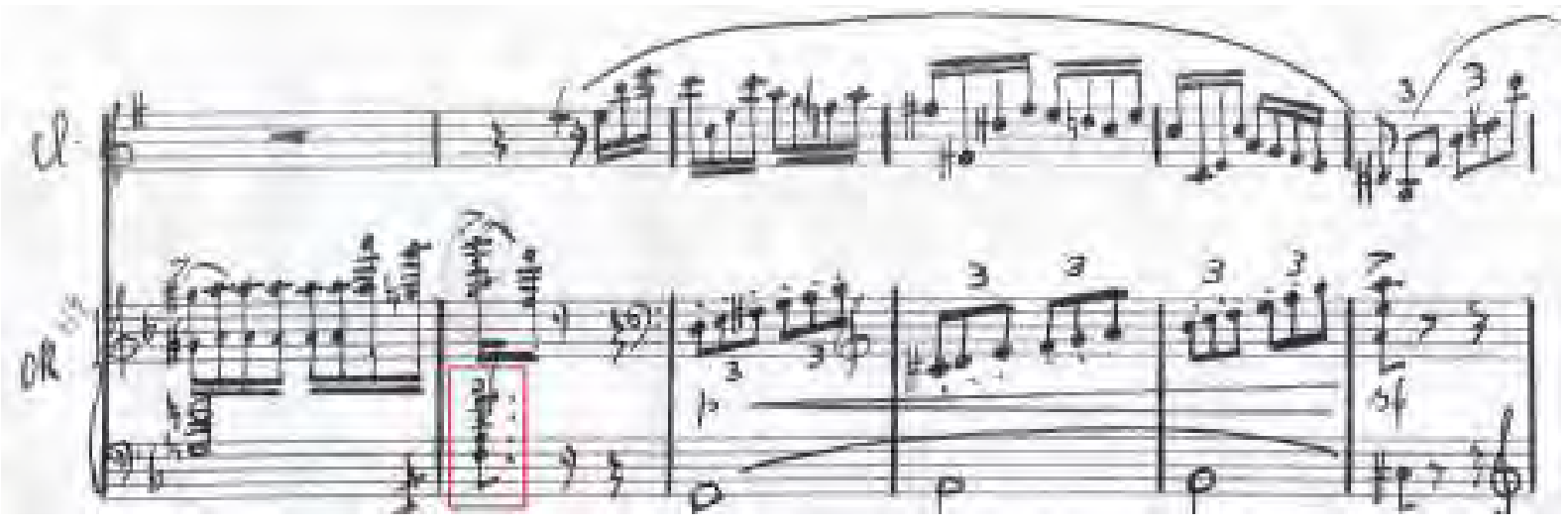

Fp3 (redução) 
Figura 106 - Final, compassos de 119 a 124

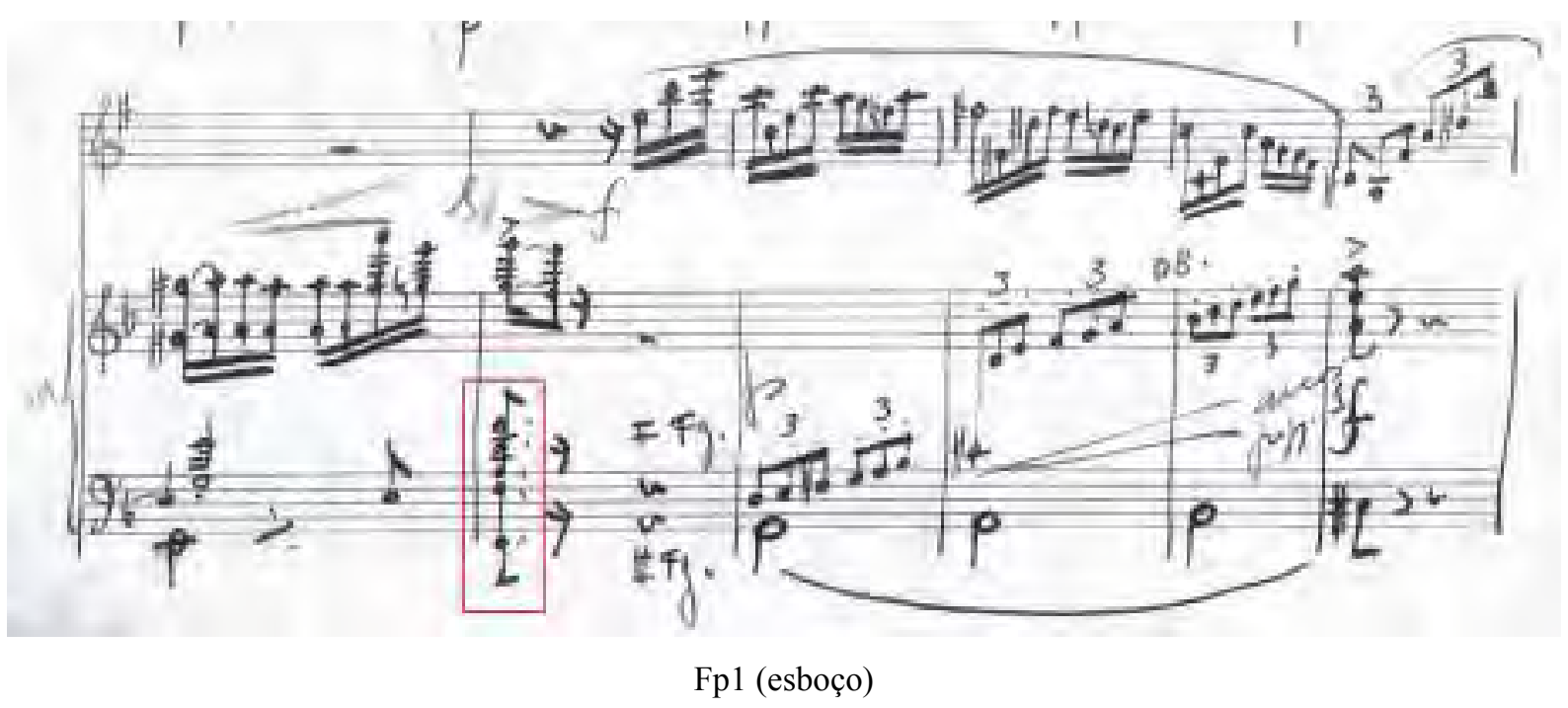

8) Compassos de 131 a 148 - Ossia de clarinete

Essa Ossia nasceu por intervenção de José Botelho por ocasião da estreia da peça. Mignone entregou o esboço do Concertino a Botelho num encontro entre os dois no qual o compositor apresentou a obra ao solista, tocando alguns trechos e mostrando suas intensões. Botelho levou o esboço para casa para estudar a obra e num segundo encontro entre eles comentou sobre a dificuldade de executar a proposta do esboço para esses compassos do último movimento e pediu a Mignone que fizesse alterações. Mignone prontamente reescreveu o texto musical da maneira como aparece na versão orquestral. Na estreia da peça, Botelho utilizou a segunda versão do trecho como na partitura orquestral. Contudo, ao realizar a redução pianística, Mignone manteve a primeira versão da linha do clarinete, demonstrando sua vontade de que essa primeira versão fosse a oficial, apesar da partitura orquestral. Como acontece nesse tipo de situação, optamos por oferecer as duas versões do trecho, ampliando assim a gama de solistas que poderão realizar a peça. 
Figura 107 - Final, compassos de 131 a 149
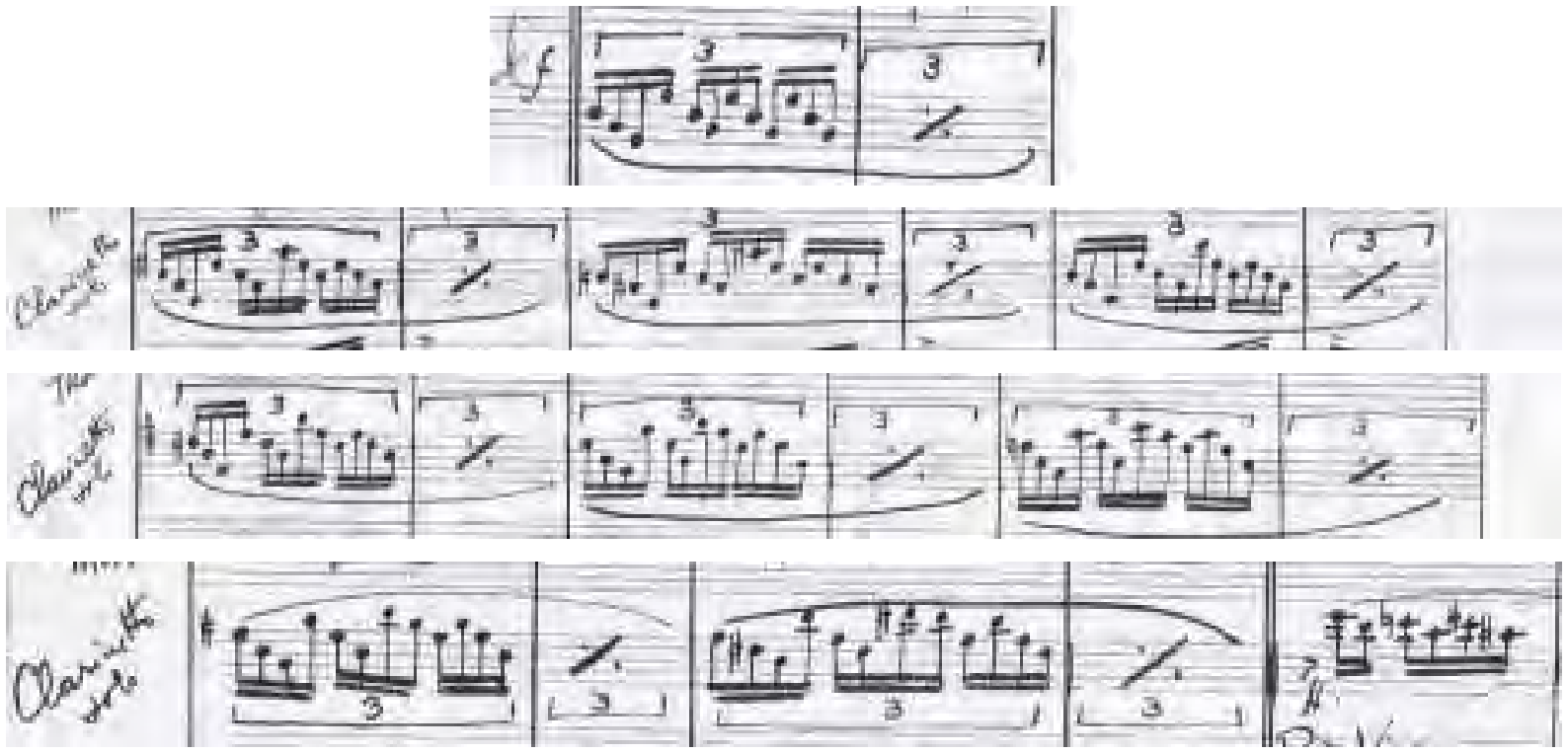

Fp2 (orquestração)

Figura 108 - Final, compassos de 131 a 148

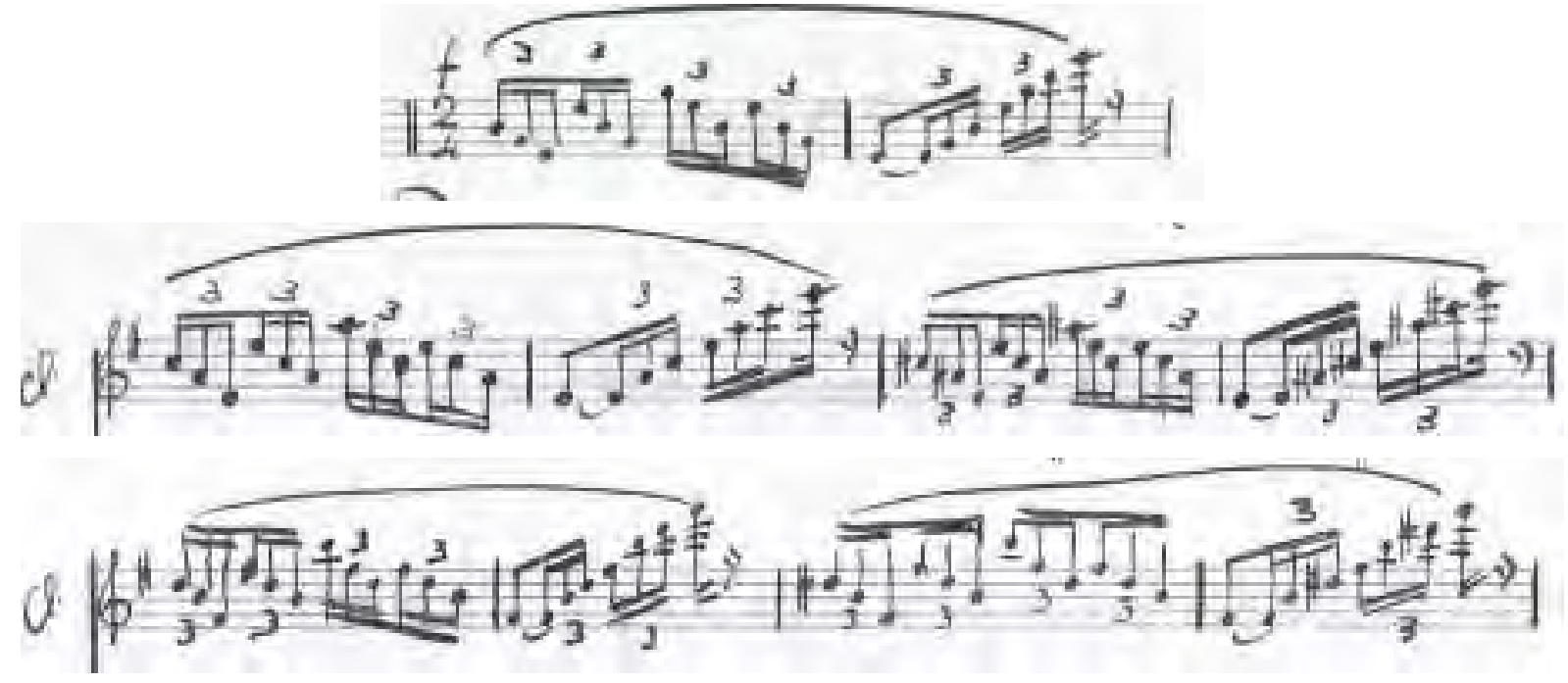

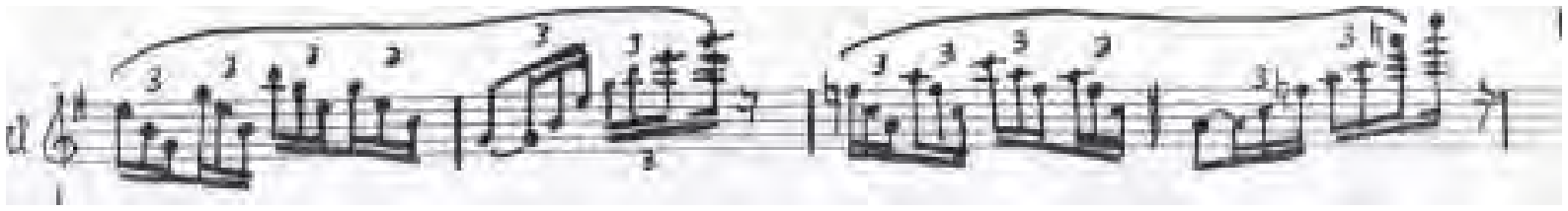

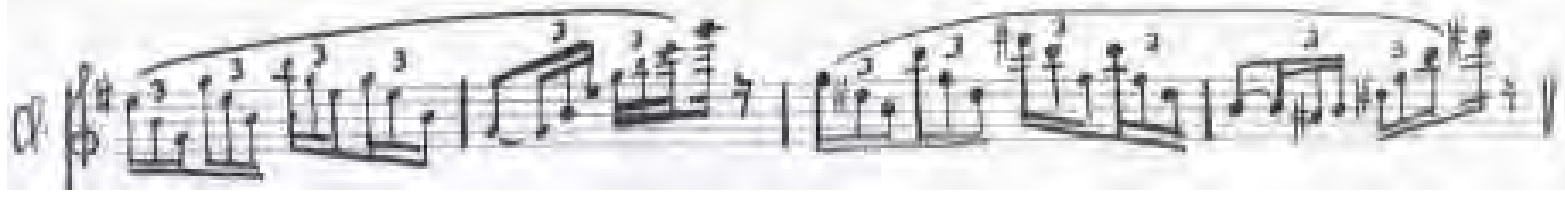
Fp3 (redução) 
Figura 109 - Final, compassos de 131 a 148

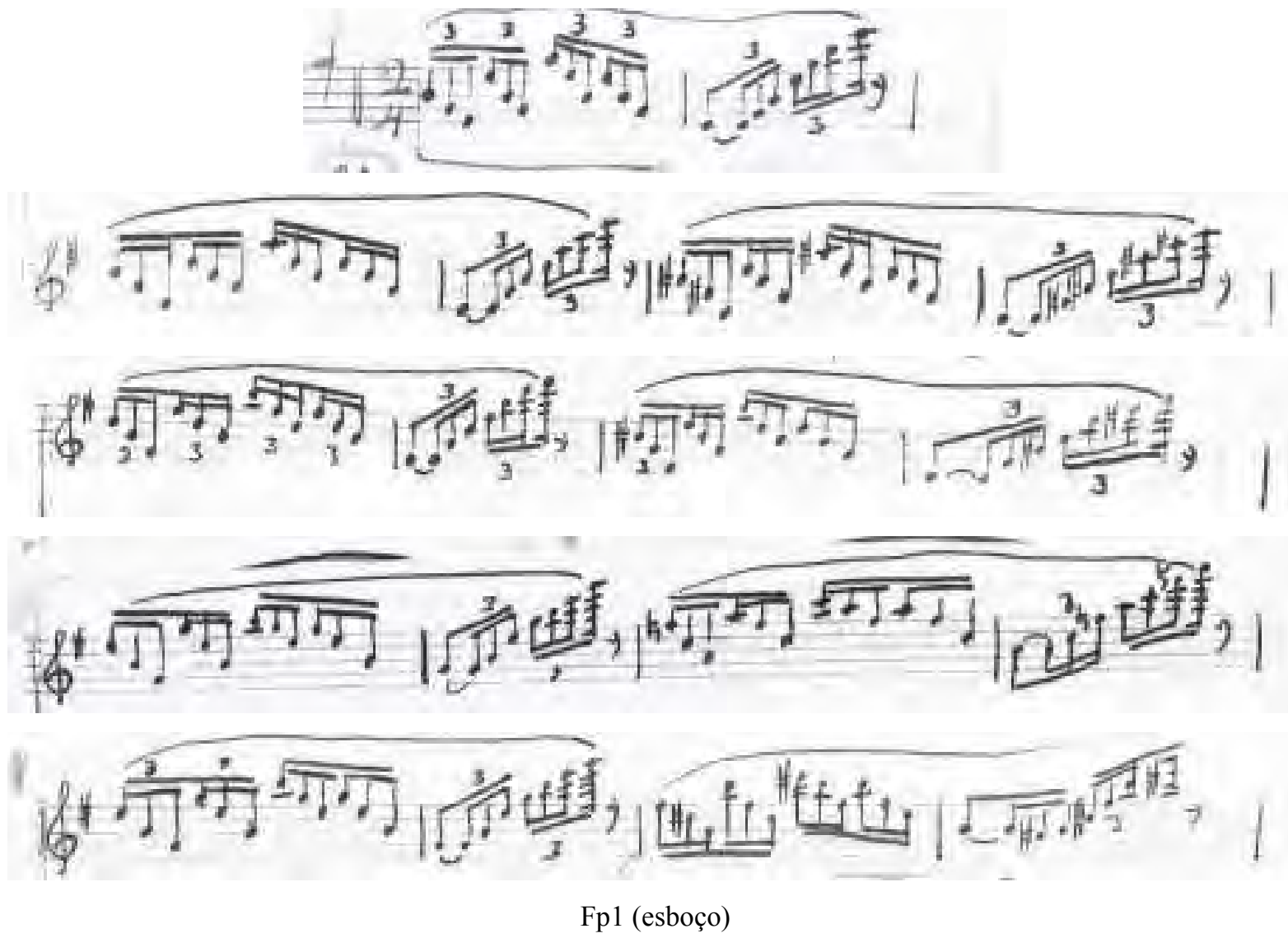

9) Compassos 148 - ausência das notas de violino 1 no final do compasso

Aqui as versões pianísticas apresentam a anacruse da frase que vem dos compassos anteriores, mas a versão orquestral não. A inserção na versão orquestral dessas três notas Lá valorizaria a pausa de colcheia no Più Vivo da sequência. Do ponto de vista da agógica, a inserção das notas é um recurso de grande valor, já que a obra se encaminha para o fim e não existem impedimentos técnicos para essa inserção. O corte súbito da frase valoriza a entrada do trecho que representa a Coda do movimento. Nossa opção será pela inserção. 
Figura 110 - Final, compassos de 145 a 149

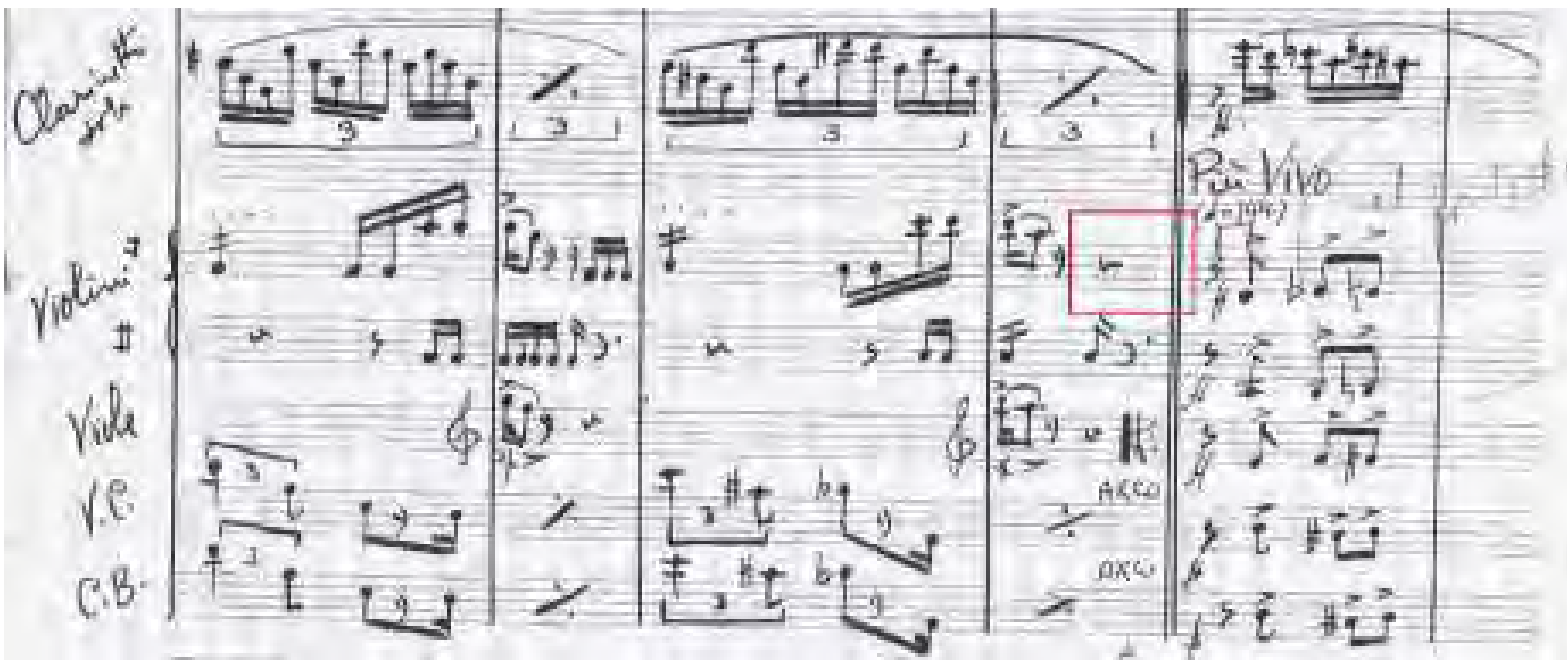

Fp2 (orquestração)

Figura 111 - Final, compassos de 145 a 148

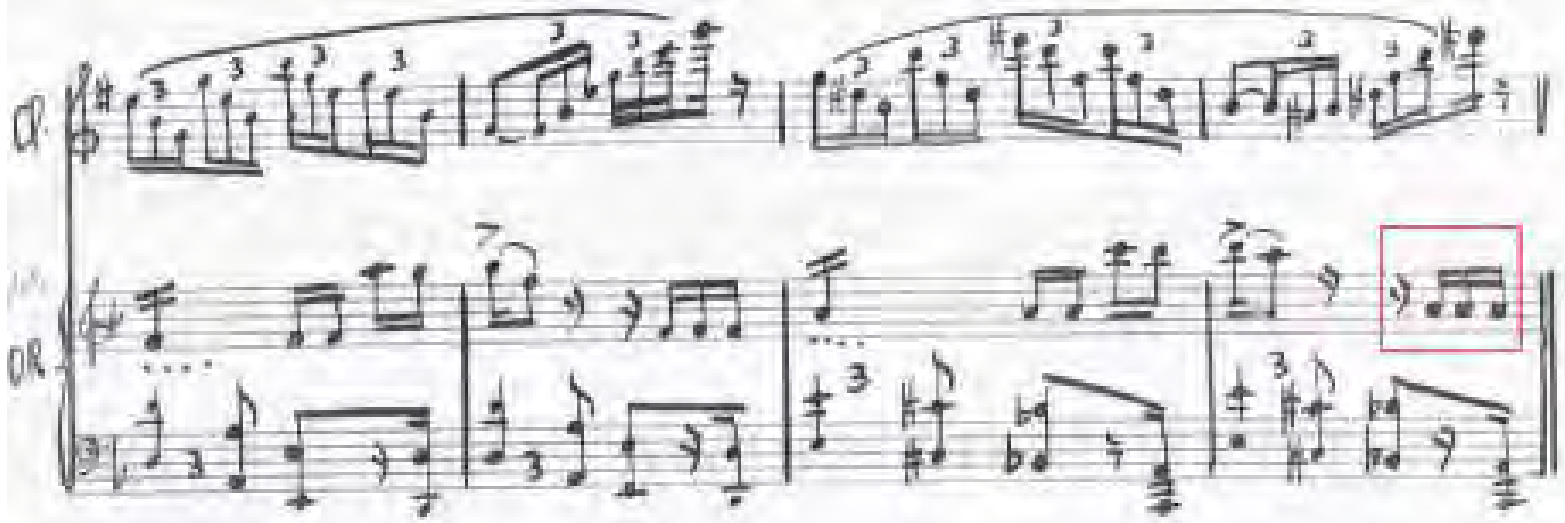

Fp3 (redução)

Figura 112 - Final, compassos de 145 a 148

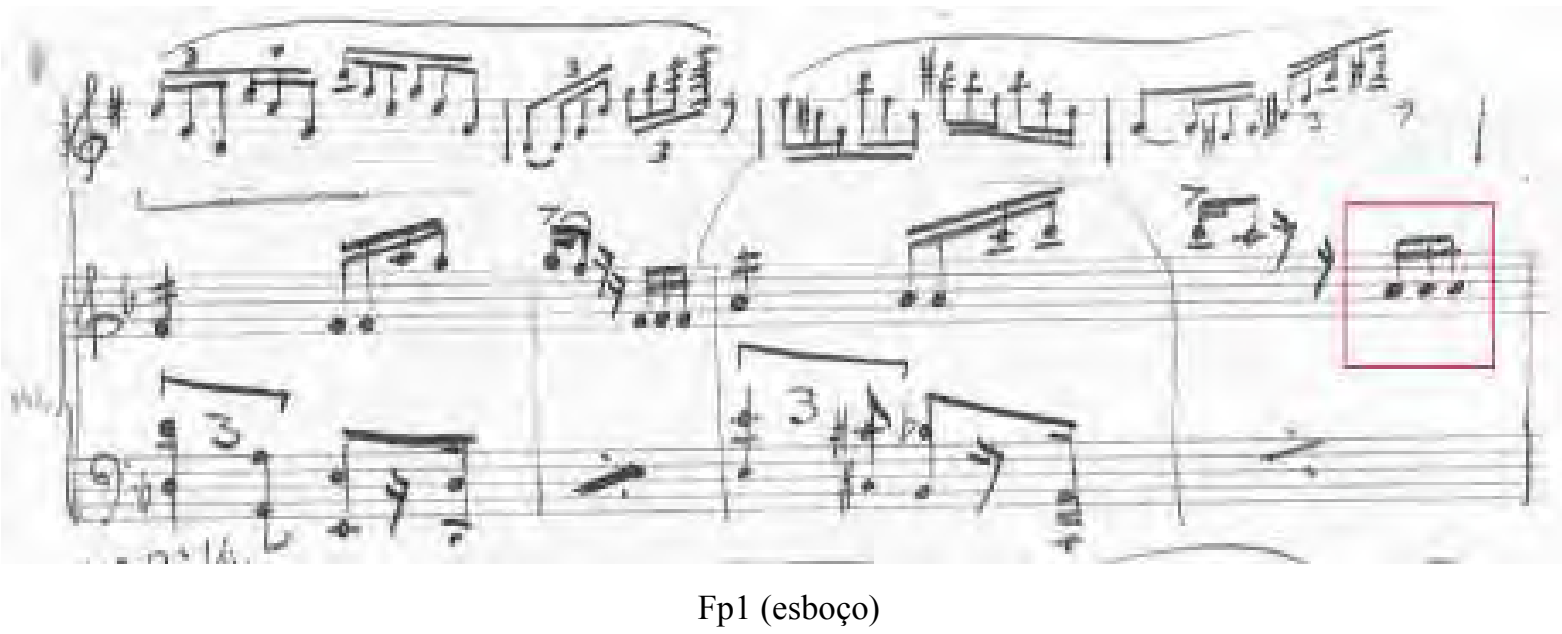


10) Compasso 161 - inserção por tradição oral de colcheia como anacruse do compasso 162.

Assim como no caso da Ossia na melodia do clarinete (item 8 desse movimento), Botelho sugeriu a Mignone que colocasse uma anacruse na linha do clarinete antes do último compasso da peça. Mignone aceitou. Embora não tenha incorporado essa nota na redução pianística, a sugestão de Botelho faz parte da tradição oral da peça e raramente não é executada. Para nós, a sugestão de Botelho enriquece a obra e deverá ser incluída como possibilidade de execução.

Figura 113 - Final, compassos de 156 a 162

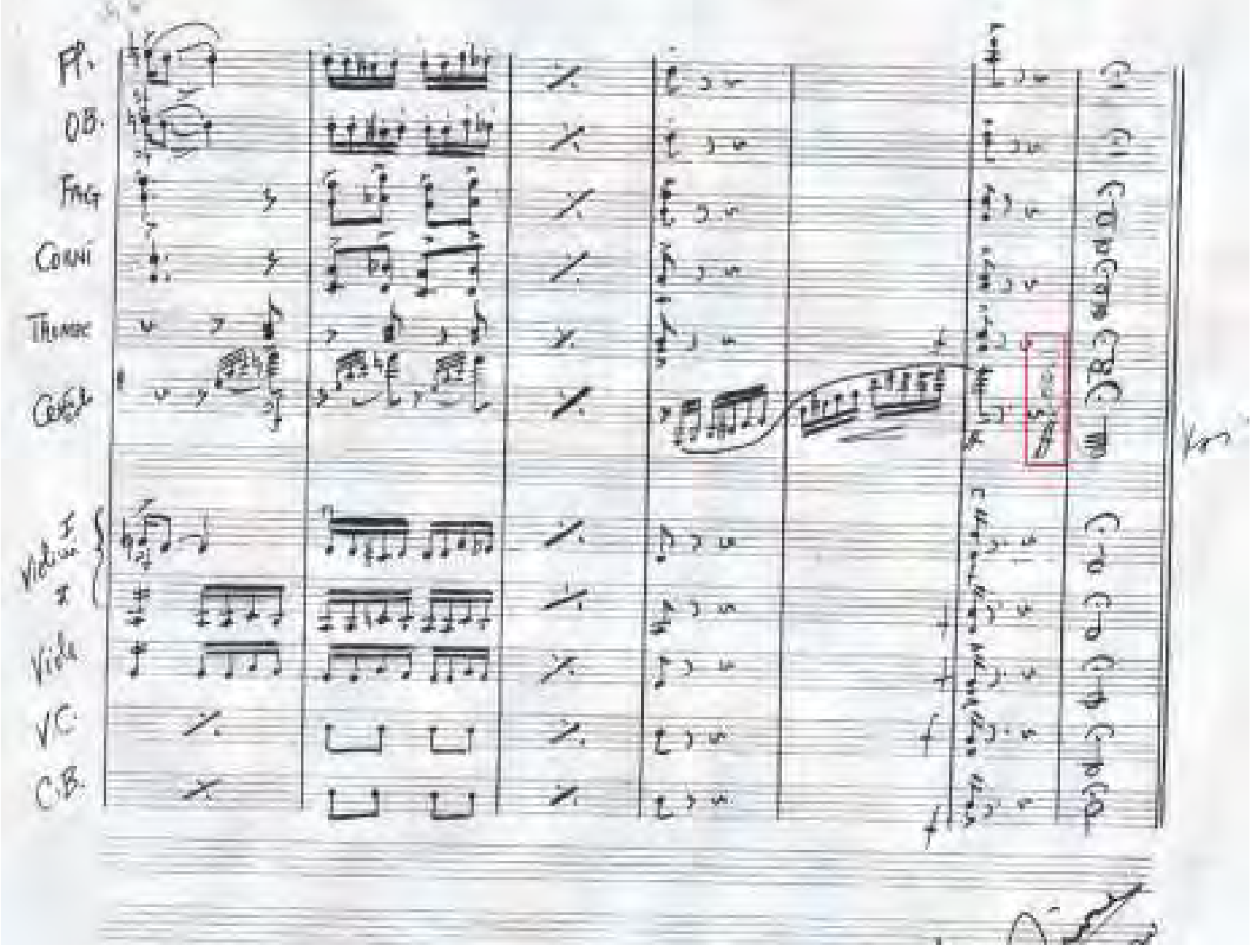

Fp2 (orquestração) 
Figura 114 - Final, compassos de 155 a 162

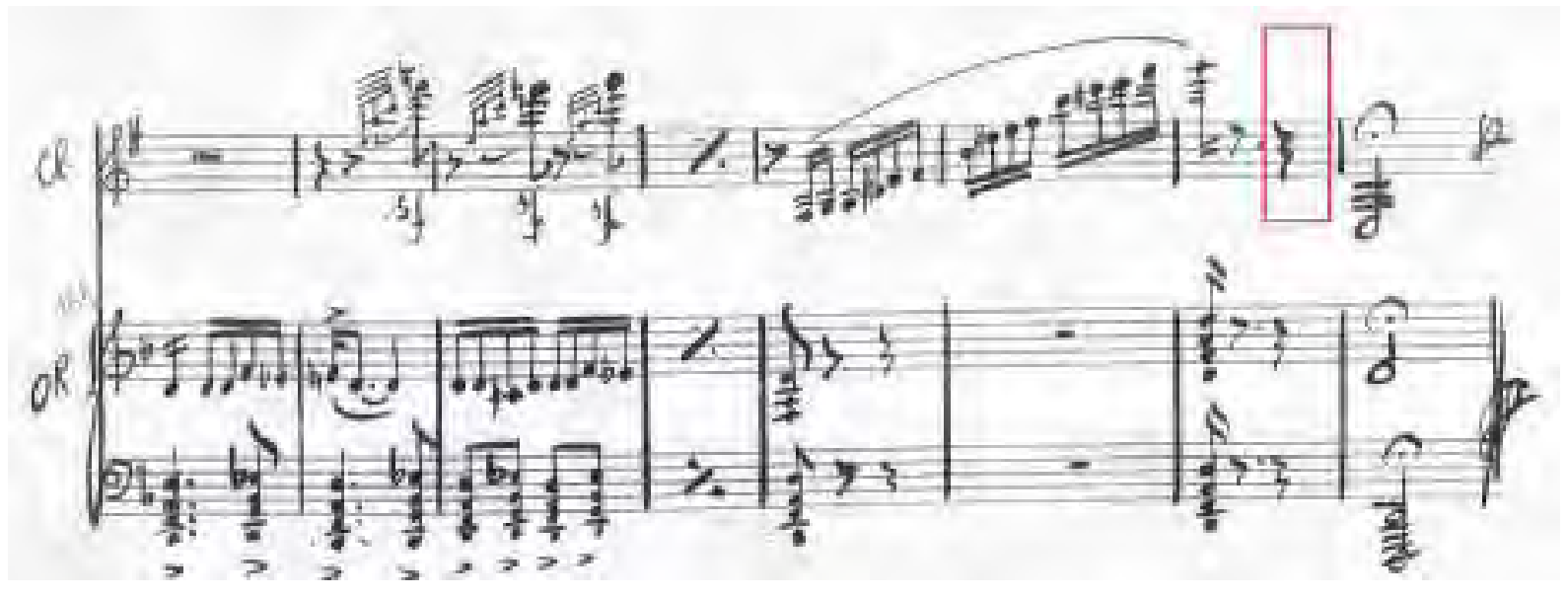

Fp3 (redução)

Figura 115 - Final, compassos de 155 a 162

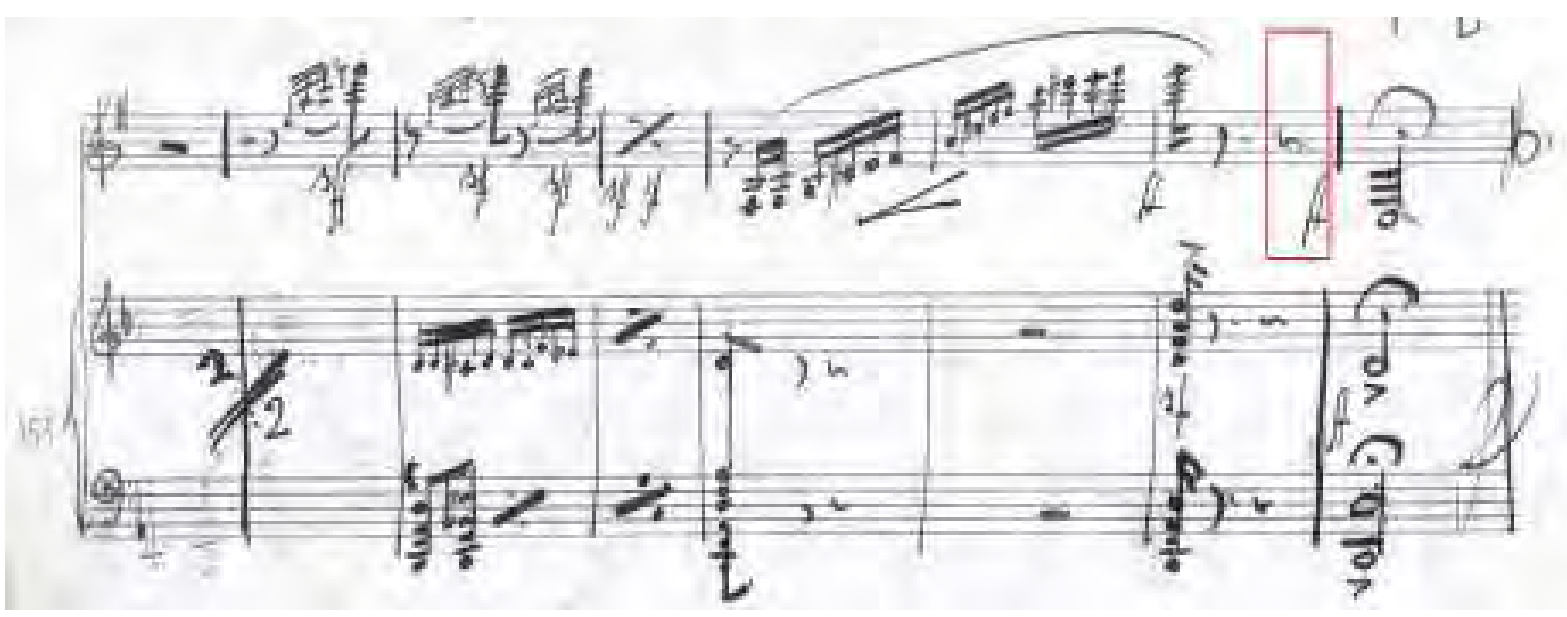

Fp1 (esboço)

A reunião dos pontos discutidos neste capítulo auxiliará o intérprete da obra no momento da performance e garantirá que as decisões tomadas não turvem as intenções do autor. Mesmo sendo vontade do intérprete ir contra o pensamento do autor em determinados momentos, essa decisão não será feita sem que haja uma reflexão profunda sobre o texto musical.

Não obstante, outras resoluções para os trechos aqui apresentados poderão existir, enriquecendo ainda mais a discussão e valorizando da mesma forma a obra. Nosso projeto visa ampliar e aprofundar essa discussão, e não encerrá-la. Acreditamos que esse é um caminho bom, ainda que existiam outros igualmente bons a serem tomados. 


\section{CONSIDERAÇÕES FINAIS}

A imersão na obra e na biografia de Francisco Mignone, que resultou na escrita desse trabalho, fez vislumbrar para nós paradigmas que merecem algumas palavras.

A começar pela questão da crítica artística, e de como esta influencia o artista e por vezes determina rumos na sua carreira. Nesse ponto será importante distinguir uma crítica "séria" e uma crítica por "modismo", por assim dizer. O caso de Mignone é realmente especial, Mignone foi "vítima" dessas duas modalidades da crítica. Talvez pelo fato de seu maior crítico ser um homem cuja obsessão por seus ideais tenha parido gerações e gerações de seguidores catequizados. A crítica séria e sincera de Mario de Andrade sobre Mignone na busca pelo seu Nacionalismo, tornou-se leviana na repetição gratuita e destorcid dos catequisados simpatizantes desse movimento. Se Mario diz: "Eu, faz muito tempo que venho sendo discretíssimo a respeito de Francisco Mignone. Embora sempre respeitoso desse compositor, pela cultura que reconheço nele e pela sinceridade com que o imagino, suas obras, quando não me desagradavam francamente, no geral me deixavam muito frio"; Bruno Kiefer muitos anos depois diz: "Num segundo grupo, caberiam as canções com versos em idiomas estrangeiros [...]. Certo, um compositor pode usar um texto estrangeiro [...]. Quando ouvimos, por exemplo, A tu Puerta Cantando [...] sentimo-nos transportados à Espanha [...]. Isso, no entanto, nada tem a ver com criação artística [...]. A nosso ver, levando em conta uma ou outra exceção, tais canções poderiam ser omitidas do catálogo do compositor, sem prejuízo[...]".

Arnaldo Contier desenvolve esse tema com clareza e imparcialidade, em seu artigo Chico Bororó Mignone, diz: "Em geral, essa interpretação positivista sobre a obra de Francisco Mignone fundamenta-se nas críticas de Mario de Andrade, publicadas nos periódicos de 1921 a 1945. Na realidade, esses textos de Mário, escritos em momentos históricos cronologicamente determinados, foram lidos, parafraseados, citados parcial ou integralmente pelos historiadores dos anos 70, 80 e 90 como fontes documentais".

Tanto a crítica de Mario de Andrade quanto a de Bruno Kiefer exerceram influência na figura "pública" do compositor e em sua estética artística de maneiras diferentes. A fase esteticamente livre da obra de Mignone teve início numa data próxima à morte de Mario de Andrade (1945), quando as críticas do amigo cessaram o pensamento do compositor se viu livre e, embora não tenha conseguido se libertar completamente do crivo do catecismo de Mário, Mignone pode trilhar seu próprio caminho. A crítica de Bruno Kiefer perpetuou a 
imagem de um compositor incompleto e menor em relação a outros de seu tempo, e faz parte de um livro referencial na música brasileira, não apenas pelo trabalho do autor do texto, que é considerável, mas sim e com maior relevância pelo conteúdo abordado, Mignone.

Outro ponto que se revelou crucial no desenrolar dessa pesquisa é a relação da crítica musical e da edição crítica. Na busca por não incorrer no mesmo erro de Kiefer intentamos reunir a maior quantidade de argumentos possível para uma discussão imparcial de cada um dos pontos criticados na partitura. O levantamento desses pontos foi norteado por critérios estilísticos e técnicos internos e inerentes à obra, na tentativa de diminuir ao máximo a intervenção no texto musical.

Por fim, apesar de considerarmos o trabalho aqui apresentado como um passo grande no sentido da facilitação da difusão e valorização da obra de Mignone e da música brasileira erudita - em especial do Concertino - fez-se claro para nós que a não publicação da edição crítica da partitura em si, resultará no estancamento dessa empreitada. Consideramos essa publicação prioritária e elegemos este o próximo passo para o sobrevir de nossa pesquisa. 


\section{BIBLIOGRAFIA}

BARBEITAS, Flavio. Circularidade Cultural e Nacionalismo nas 12 Valsas para Violão de Francisco Mignone. Rio de Janeiro: UFRJ, Escola de Música, 1993. Dissertação de Mestrado.

BOTELHO, José C. Entrevista exclusiva cedida em 2012 no Rio de Janeiro.

CHARTIER, Roger. A aventura do livro - do leitor ao navegador. São Paulo: UNESP, 1998.

FEDER, Georg. Filologia Musicale: Introduzione alla critica del testo, all'ermeneutica e alle tecniche d'edizione. Traduzione di Giovanni di Stefano. Revisione: Lorenzo Bianconi. Bologna: Società Editrice Il Molino, 1992.

FIGUEIREDO, Carlos Alberto. As edições de obras sacras de José Maurício Nunes Garcia. Rio de Janeiro: Anppom - Décimo Quinto Congresso, 2005.

FIGUEIREDO, Carlos Alberto. Editar José Maurício Nunes Garcia. Rio de Janeiro: UNIRIO, 2000. Tese de Doutorado.

GRIER, James. The critical editing of music: history, method, and practice. Cambridge University Press, Cambridge, 1996.

INGARDEN, Roman. The work of music and the problem of its identify. Berkeley, Los Angeles: University of California Press, 1986.

LOUREIRO, Maurício Alves. The Clarinet in the Brazilian Choro with an Analysis of the Chôro para Clarinete e Orquestra (chôro for clarinet and orchestra) by Camargo Guarnieri. EUA: University of Iowa, 1991. Tese de Doutorado em Música (DMA).

MARIZ, Vasco. Francisco Mignone: o homem e a obra. Rio de Janeiro: Funarte: Editora da Universidade do Estado do Rio de Janeiro, 1997.

MEDEIROS, Elione A. de. Uma Abordagem Técnica e Interpretativa das 16 Valsas para Fagote Solo de Francisco Mignone. Rio de Janeiro: UFRJ, Escola de Música, 1995. Dissertação de Mestrado.

NATTIEZ, Jeans-Jacques. Music and Discourse: Toward a Semiology of Music. New Jersey: Princeton University Press, 1990.

SILVEIRA, José Silva, Rodrigues da. Concertino para Clarineta e Orquestra de Francisco Mignone: reflexões interpretativas. Universidade Federal da Bahia. Programa de PósGraduação em Música - Doutorado em Música - Execução Musical. Salvador. 2005. 
STRAVINSKY, Igor. Poética Musical em 6 Lições. Rio de Janeiro: Jorge Zahar Ed., 1996. Tradução, Luiz Paulo Horta.

VERHAALEN, Marion. Camargo Guarnieri: expressões de uma vida. São Paulo: Universidade de São Paulo, 2001.

\section{PARTITURAS}

MIGNONE, Francisco. Concertino para Clarineta e Orquestra. Edição orquestral de José Silva Rodrigues da Silveira. Rio de Janeiro: 2004.

MIGNONE, Francisco. Concertino para Clarineta e Orquestra. Partitura manuscrita. Rio de Janeiro: 1957.

MIGNONE, Francisco. Concertino para Clarineta e Orquestra. Partitura para piano de José Silva Rodrigues da Silveira. Rio de Janeiro: 2004.

MIGNONE, Francisco. Concertino para Clarineta e Orquestra. Partitura manuscrita para piano (esboço). Rio de Janeiro: 1957.

MIGNONE, Francisco. Concertino para Clarineta e Orquestra. Partitura manuscrita para piano (redução). Rio de Janeiro: 1957. 
ANEXOS 
MANUSCRITO AUTÓGRAFO DA VERSÃO ORQUESTRAL PERTENCENTE À BIBLIOTECA NACIONAL DO RIO DE JANEIRO 
MANUSCRITO AUTÓGRAFO DA REDUÇÃO PIANÍSTICA PERTENCENTE À BIBLIOTECA NACIONAL DO RIO DE JANEIRO 
MANUSCRITO AUTÓGRAFO DO ESBOÇO DA OBRA PERTENCENTE À BIBLIOTECA NACIONAL DO RIO DE JANEIRO 
EDIÇÃO CRITICADA DA PARTITURA ORQUESTRAL 
PRANCISCO MIGNONE,

Concertino

para clarinete sib com orquestra

1) Fantasia

2) Toada

3) Final

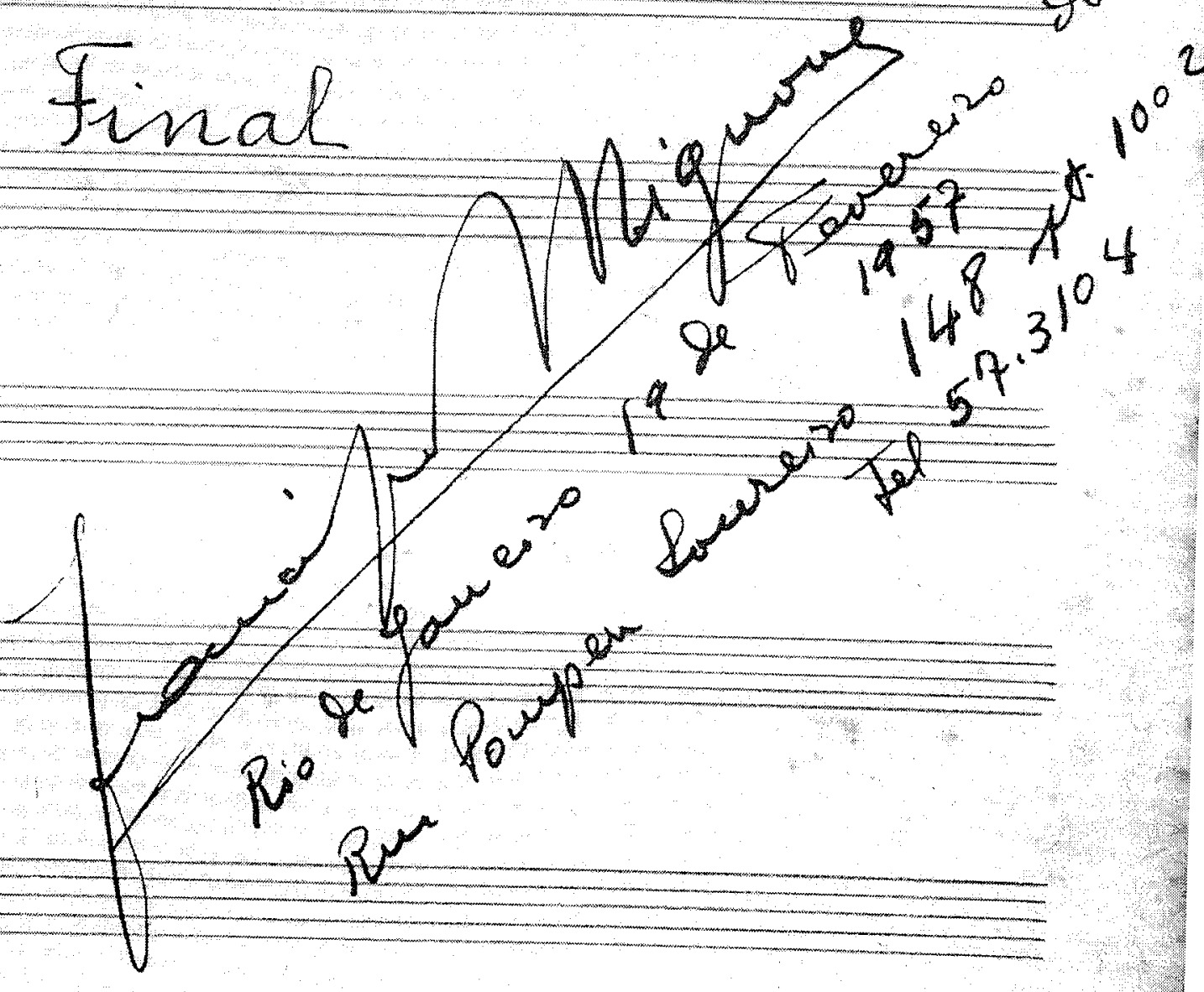


CONCERTINO

LENTO para clarineta e orquestra

Francisco Mignone

1.) FANTASiA

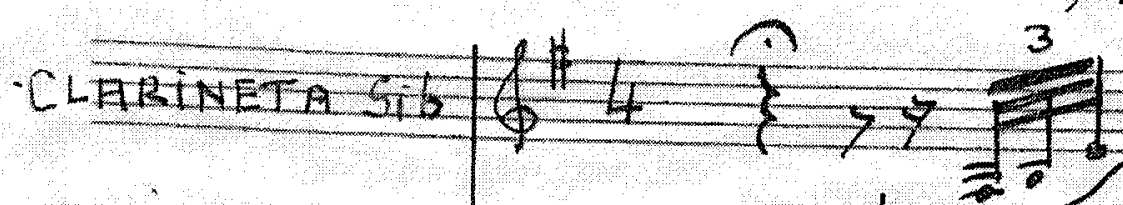

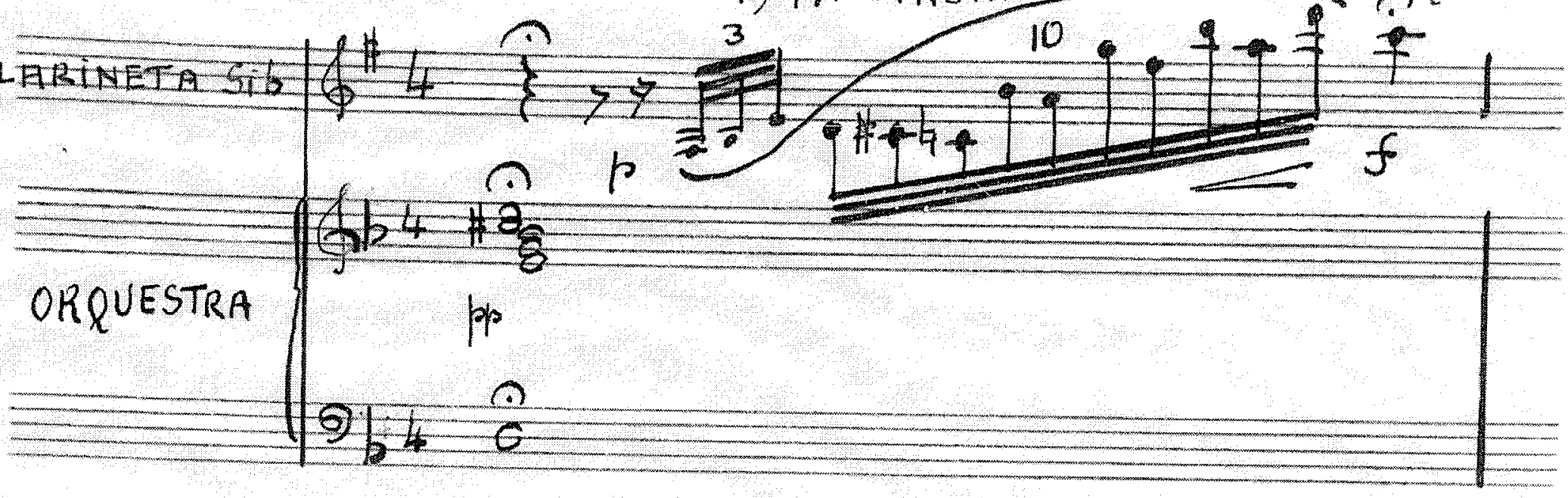

Vivo $(d=120)$

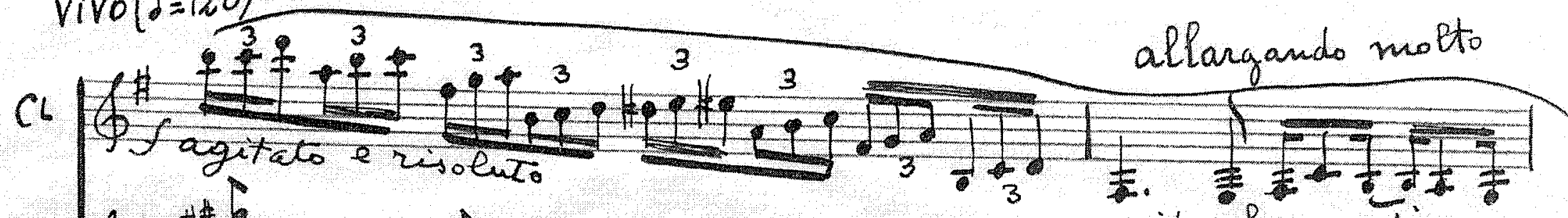

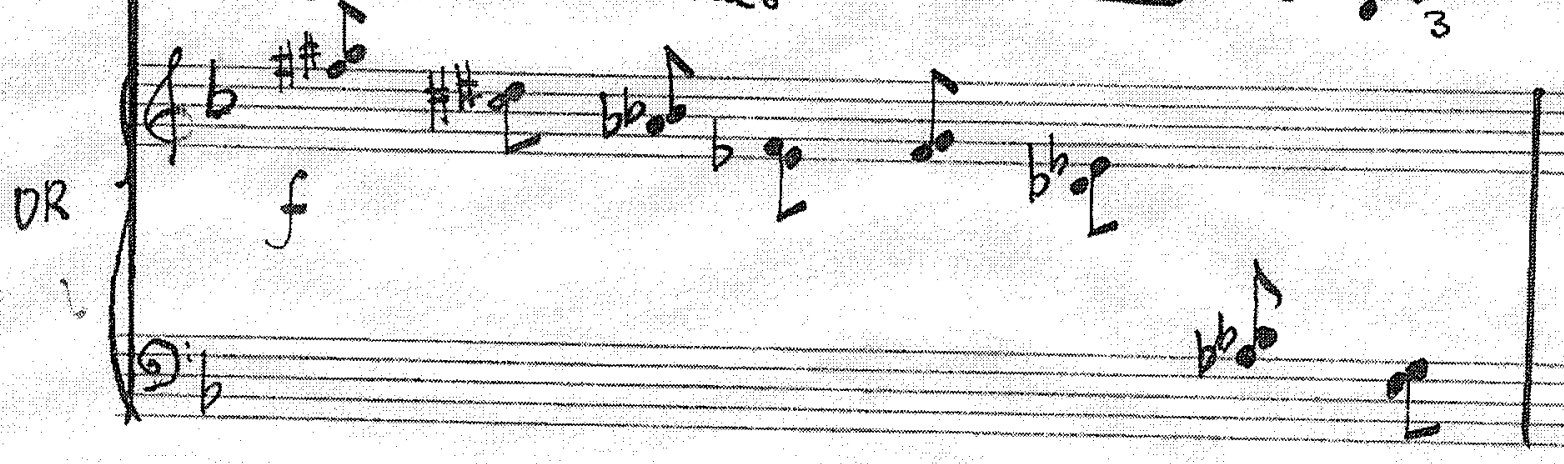

pin calmo e dima 1957) 


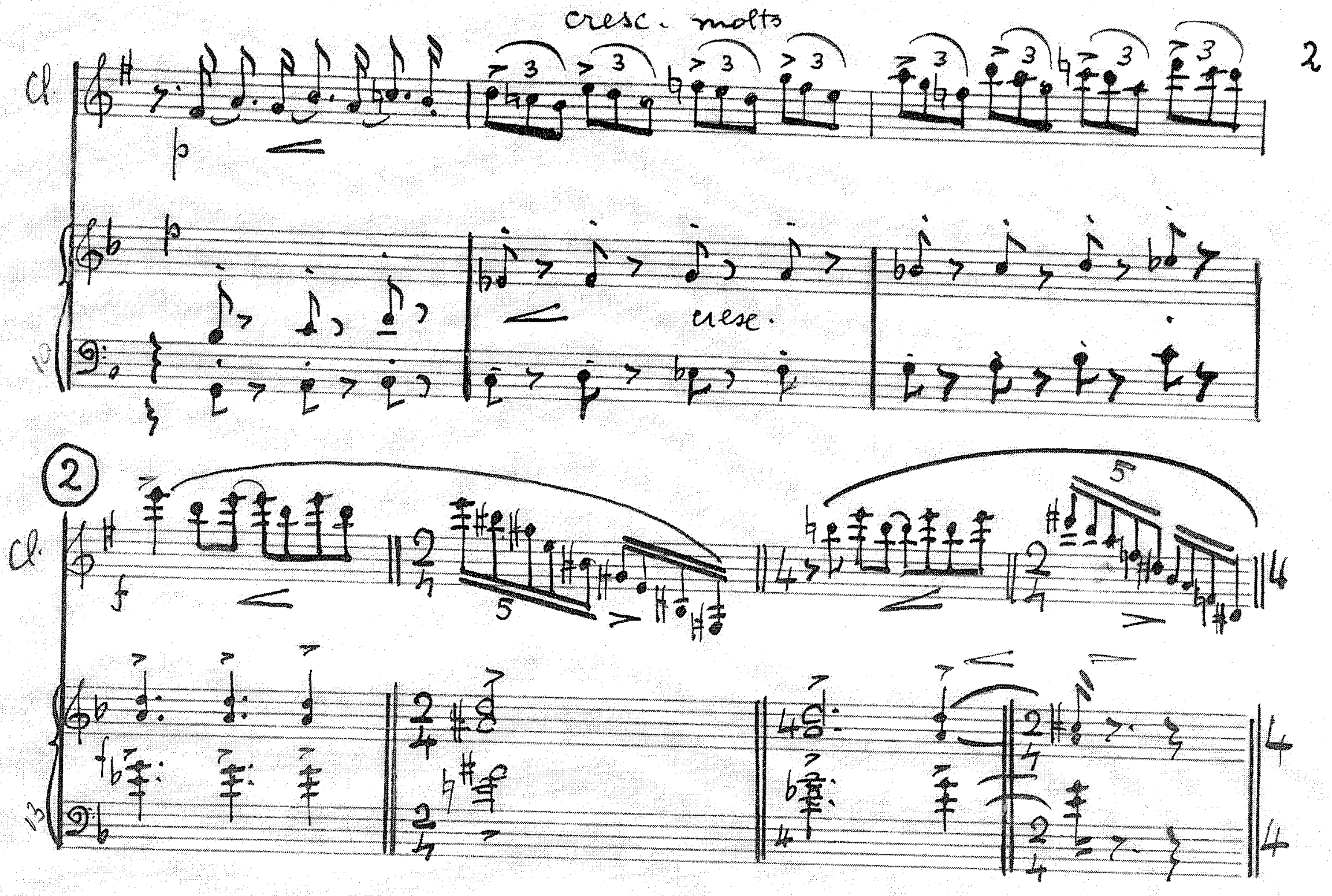

POCOMEHO $(d=120)$

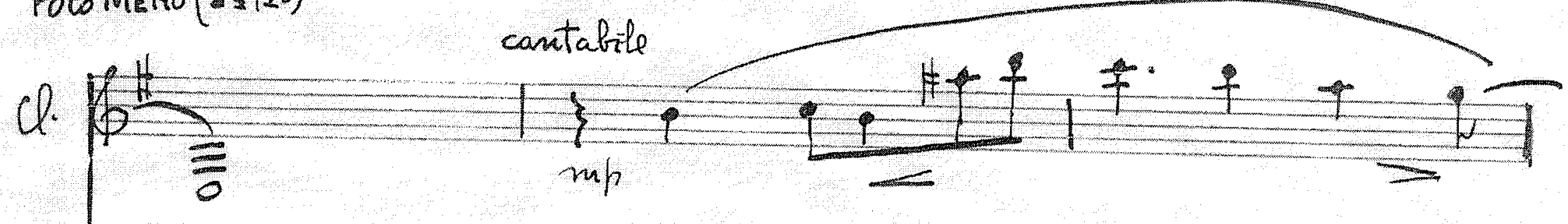

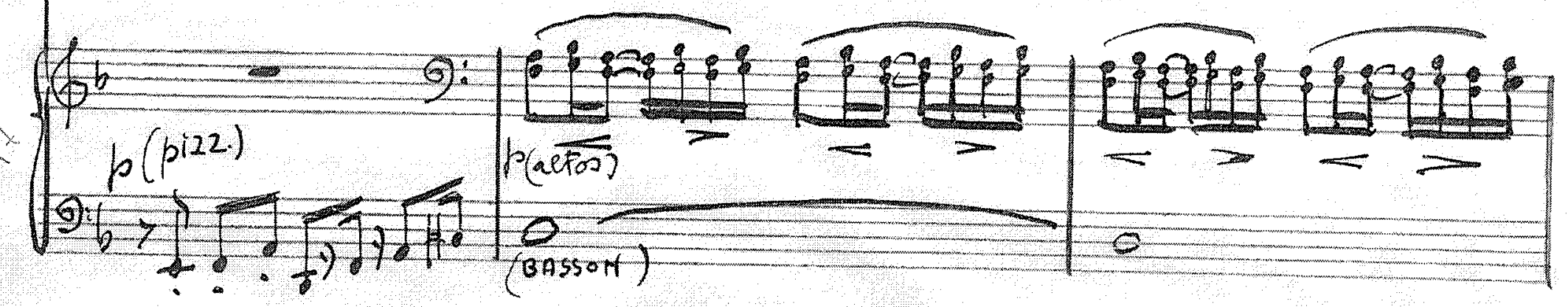

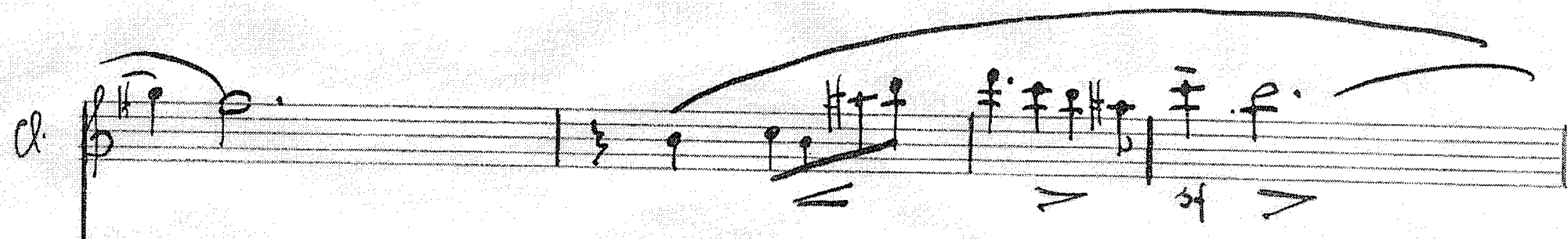

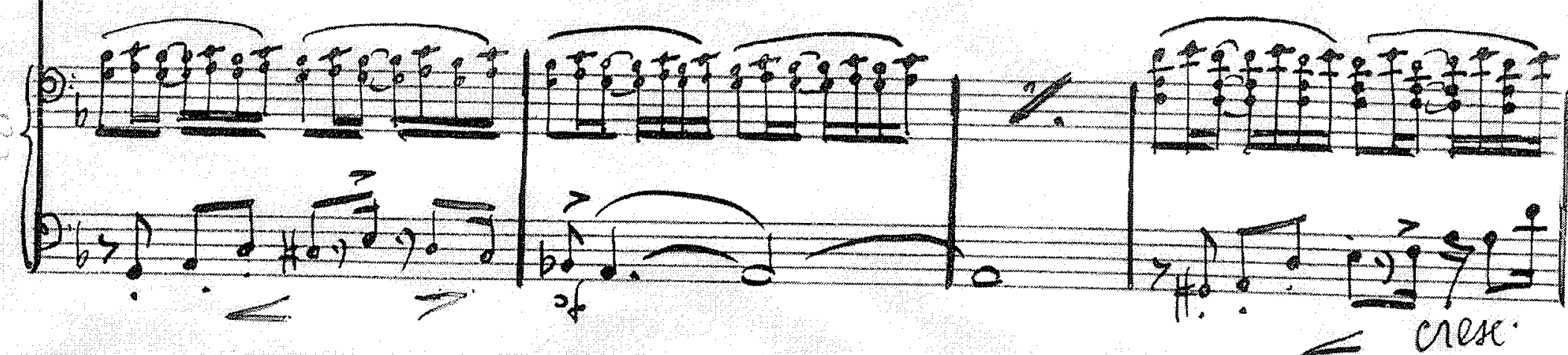




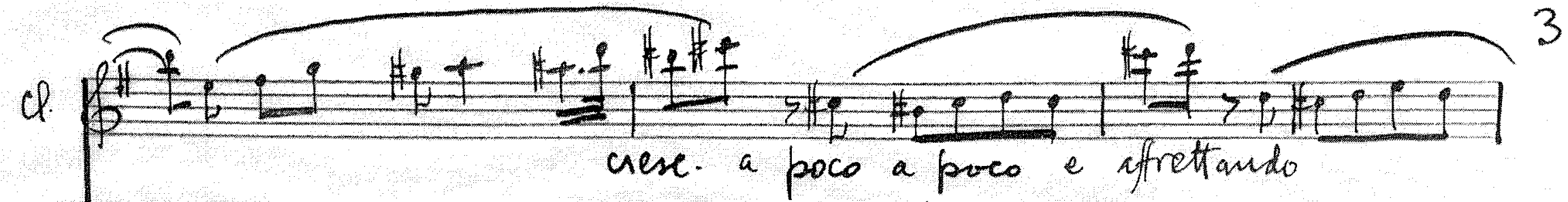

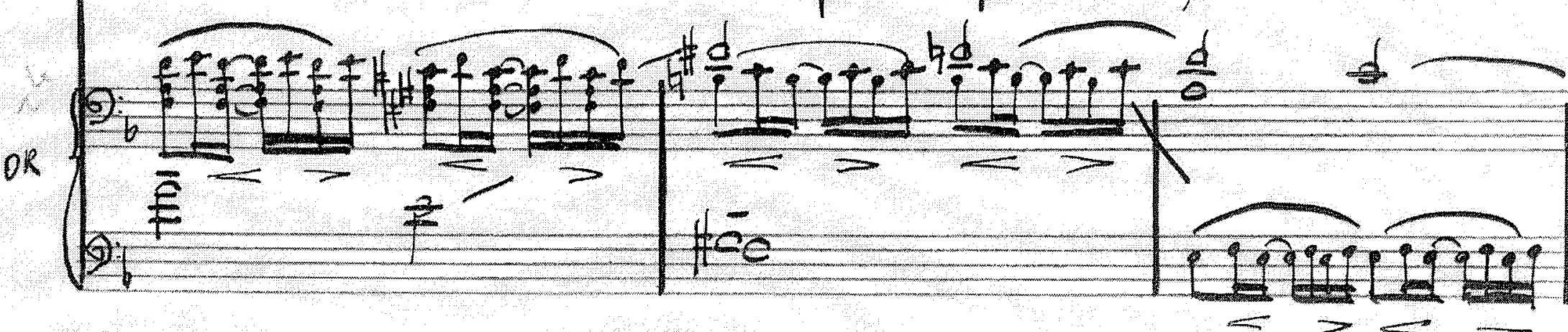

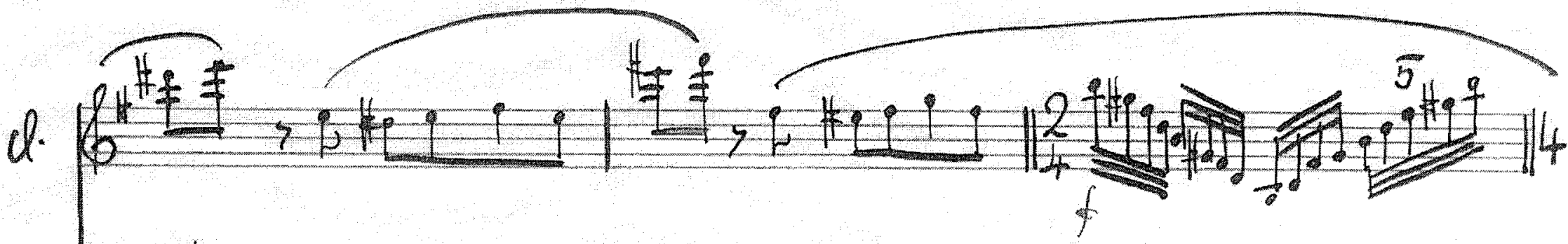

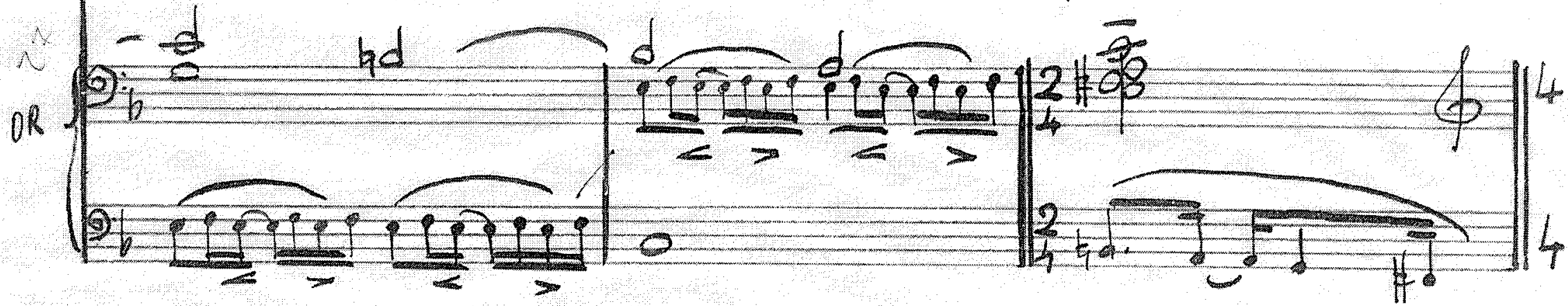

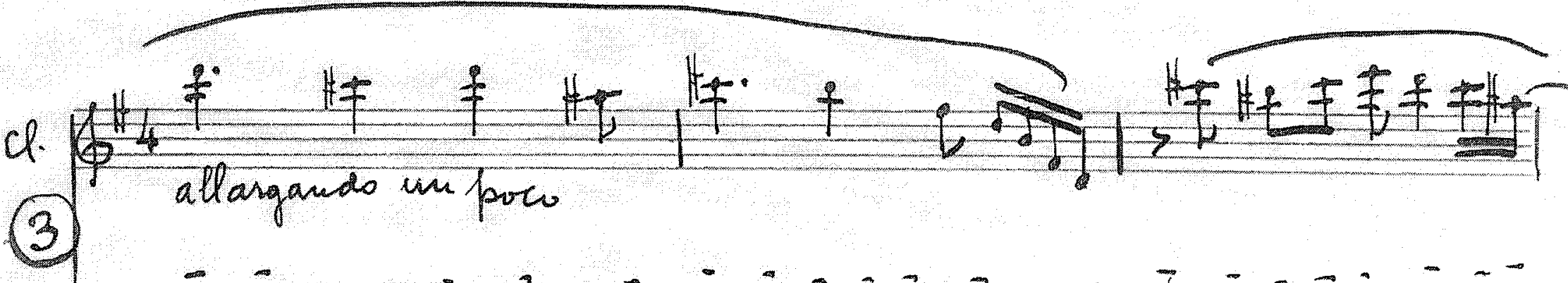

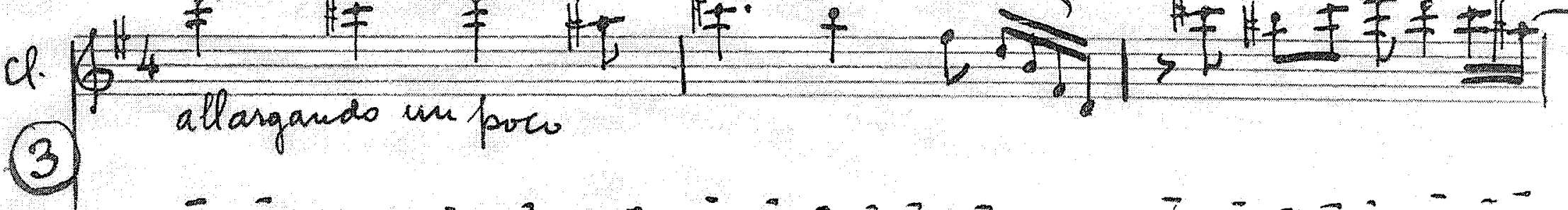

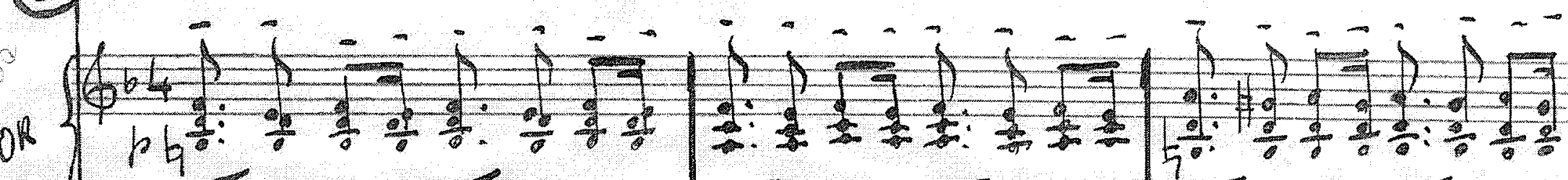

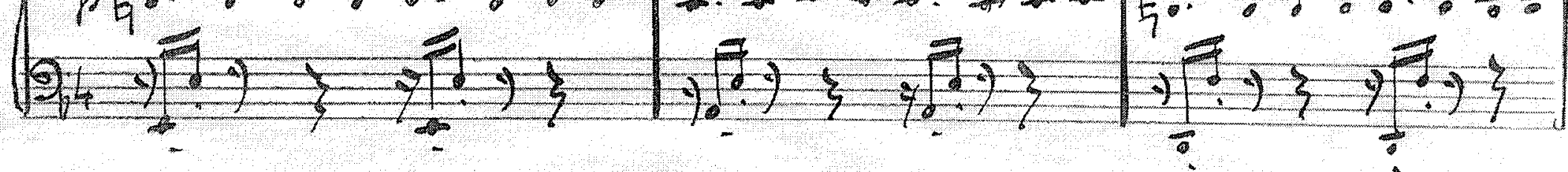

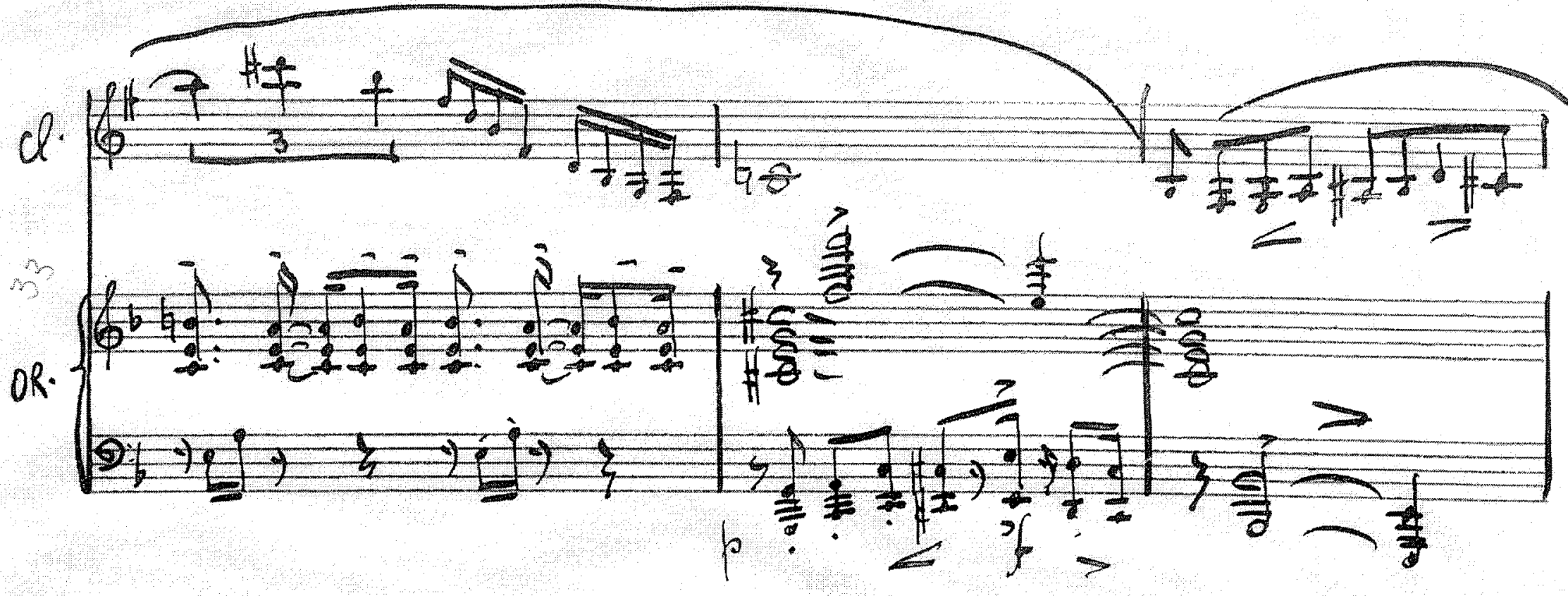




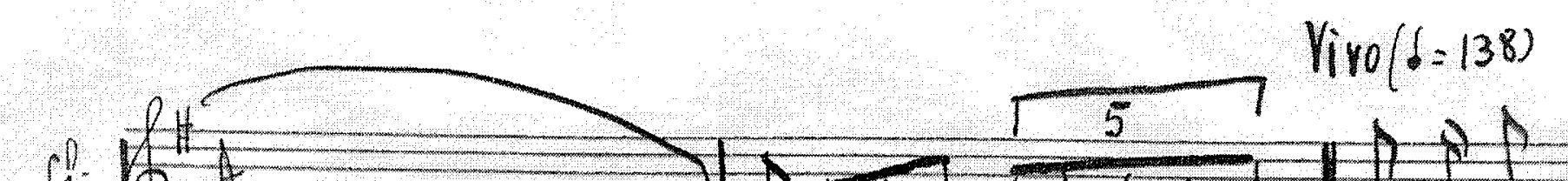

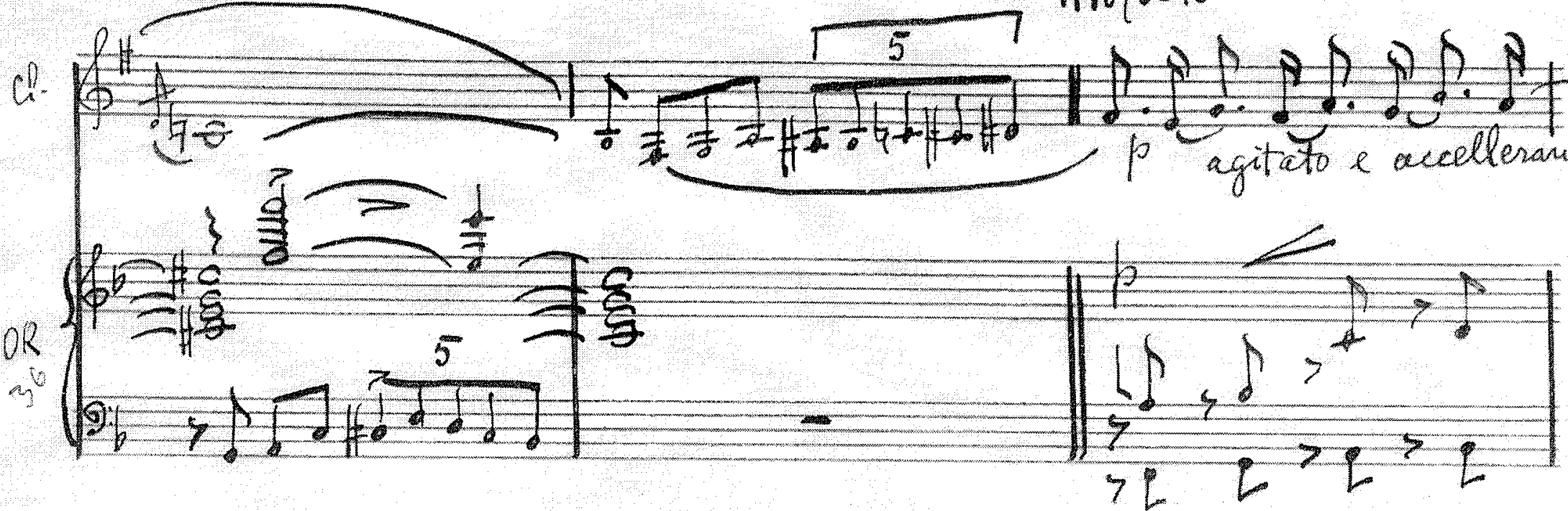

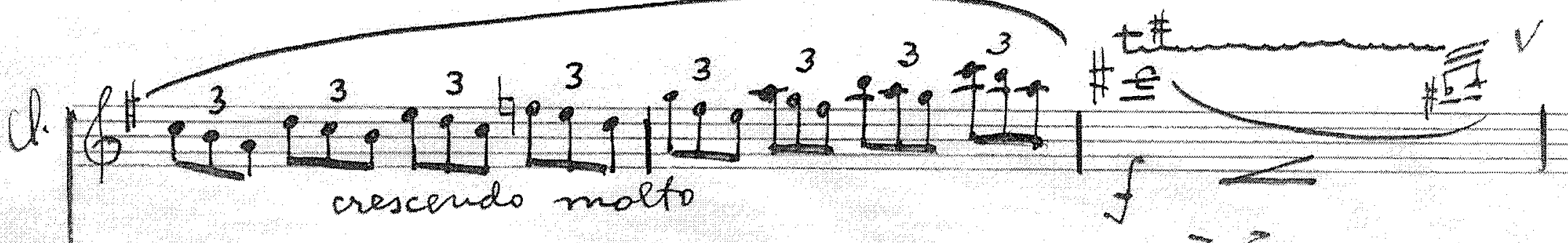

सी

(1)

(4)

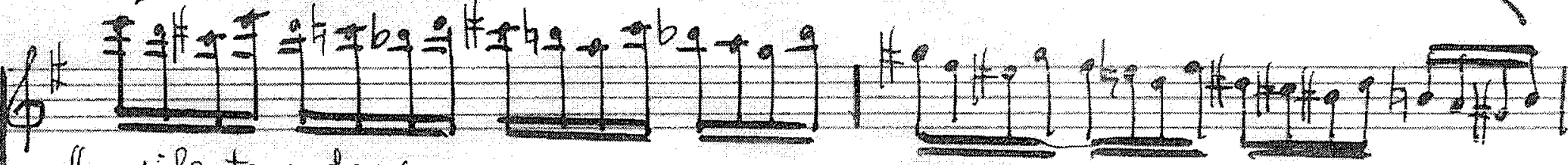
If violeuto e deciso

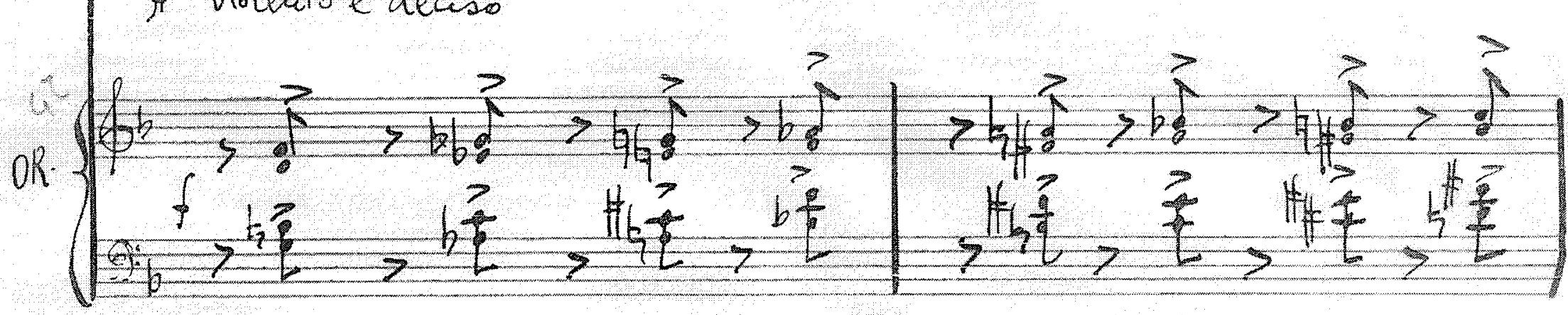

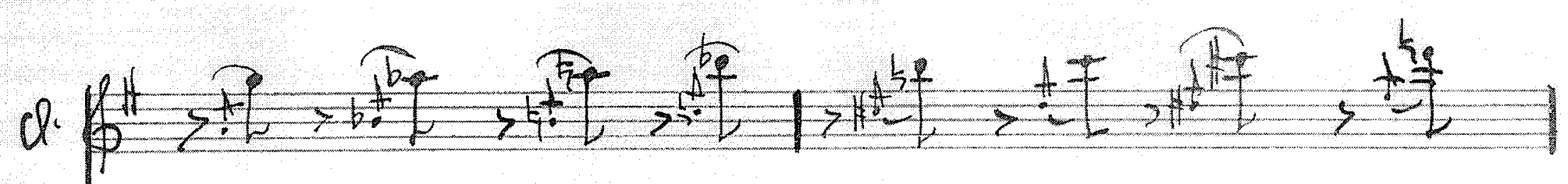

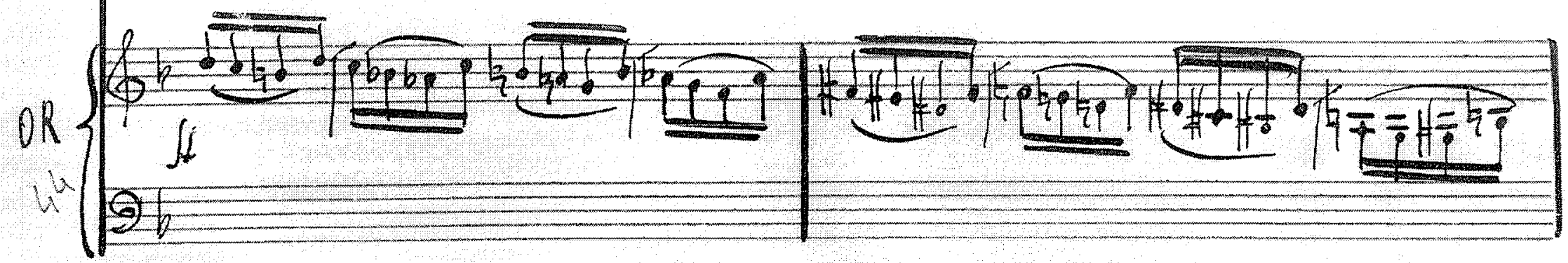



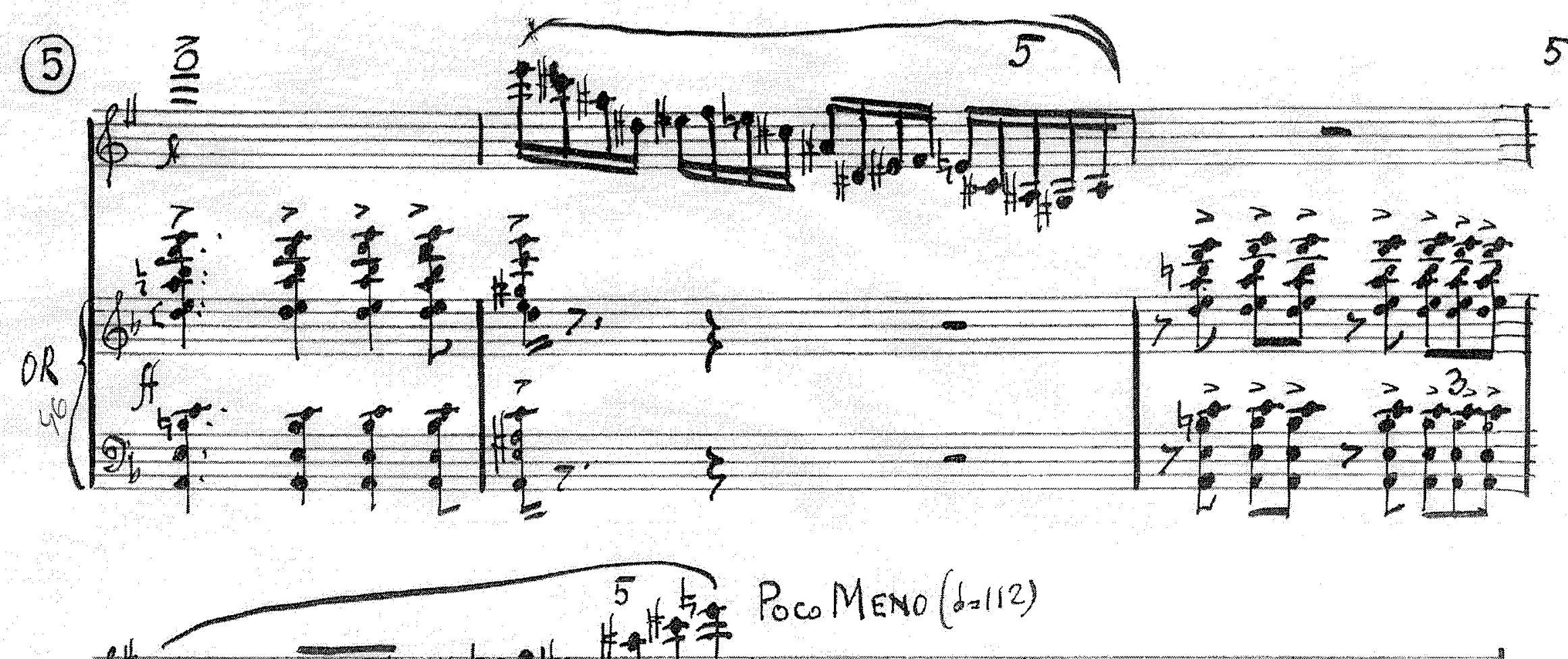

a.

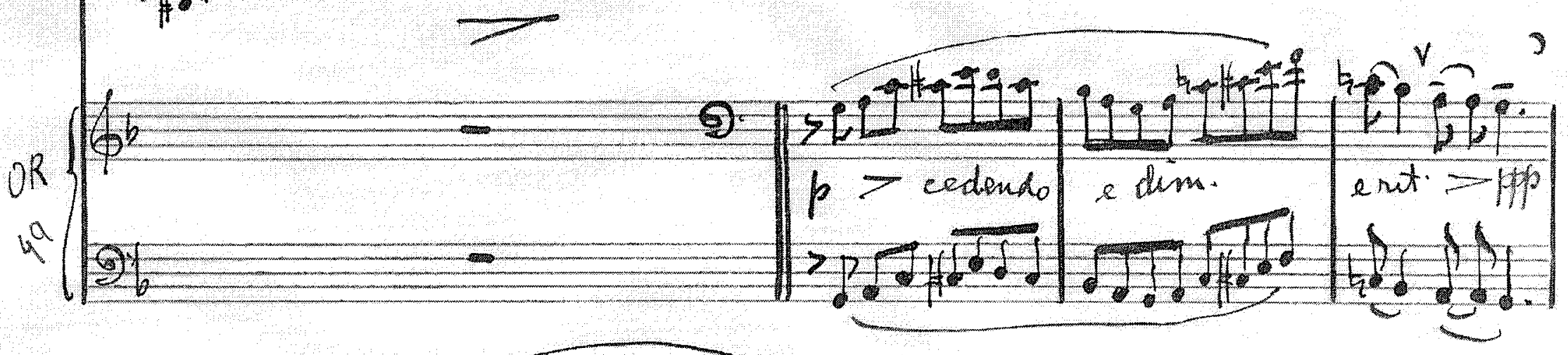

LENTO (IVTEMPO)

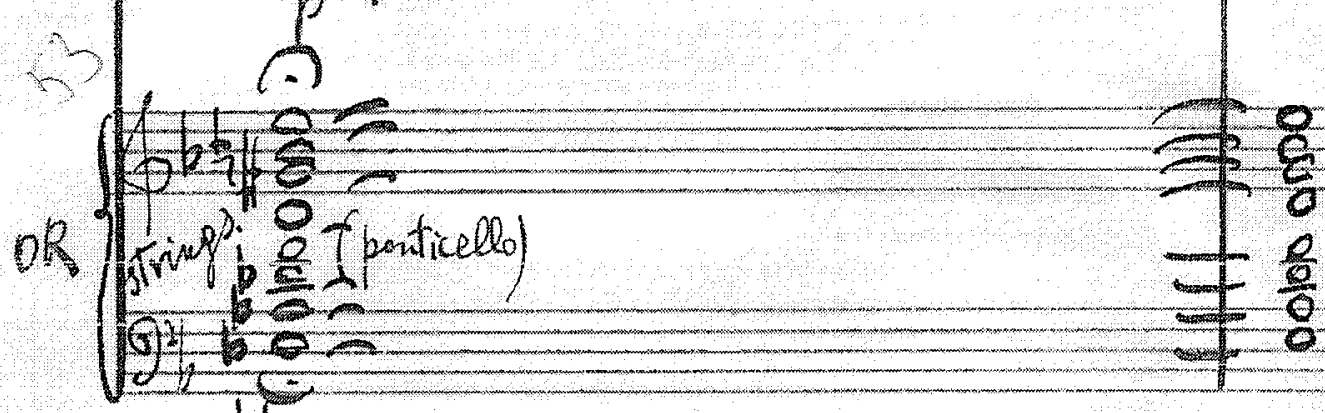

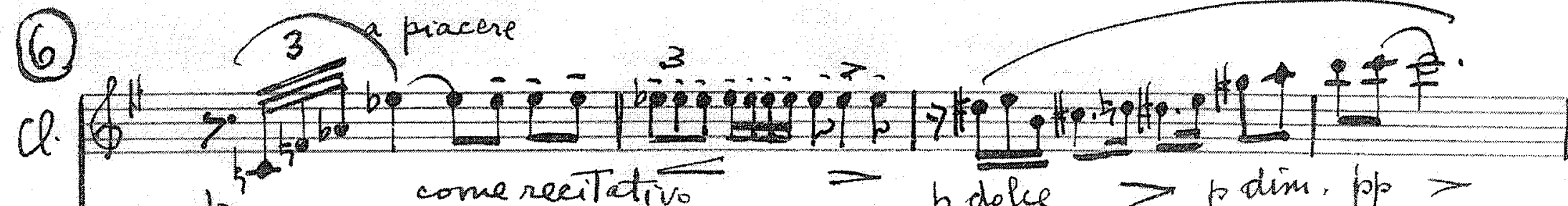
$p^{p^{-}}$comerecitativo $\Rightarrow p$ dolee $\Rightarrow p$ dim $p p>$

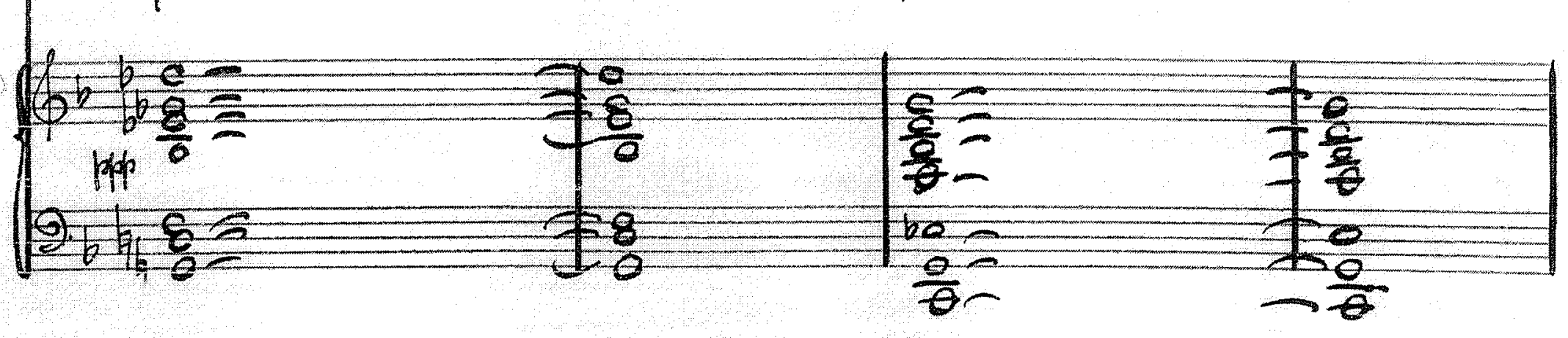



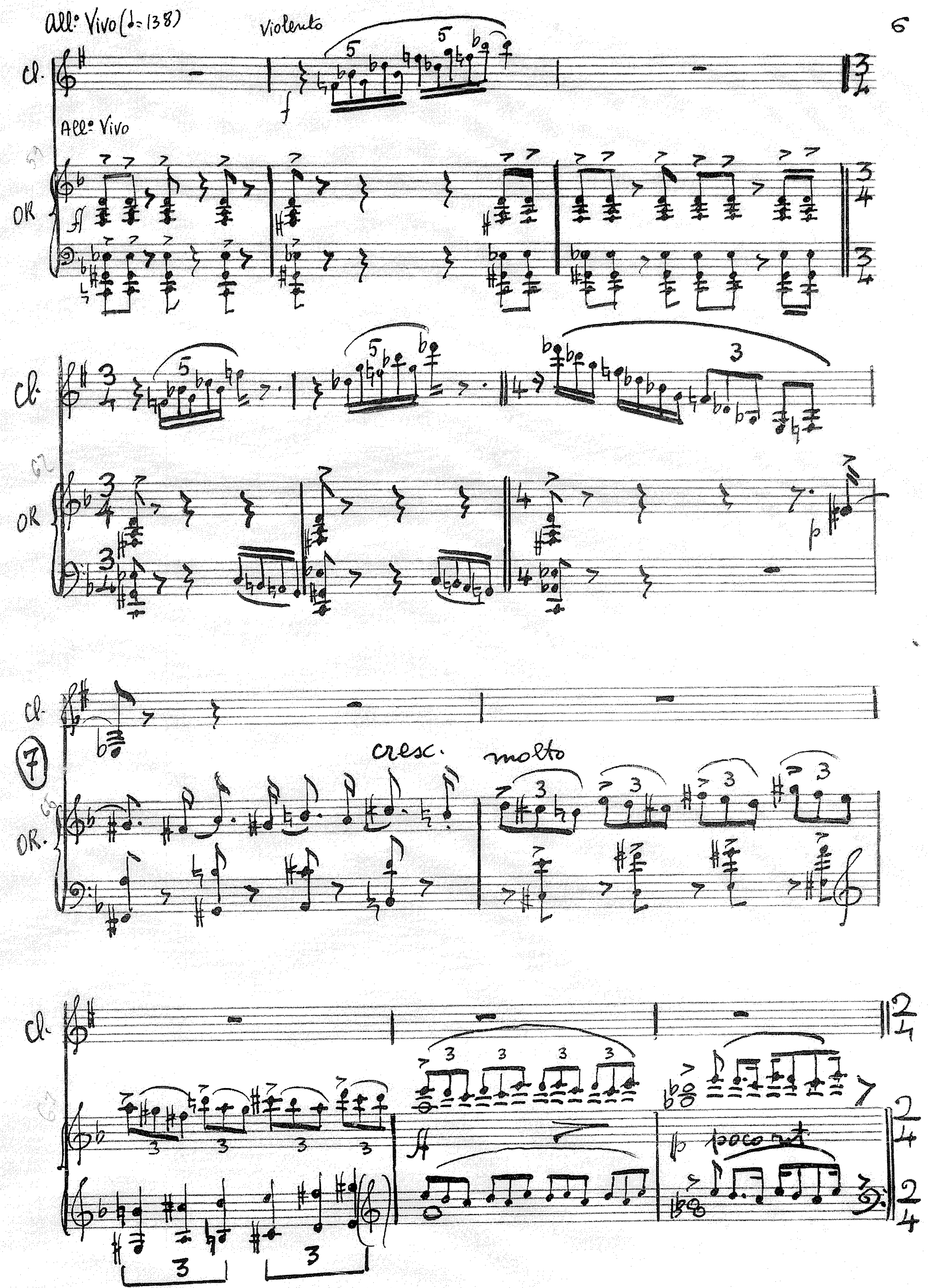
PǘCahmo(do120) (8) MoDT. cantafile

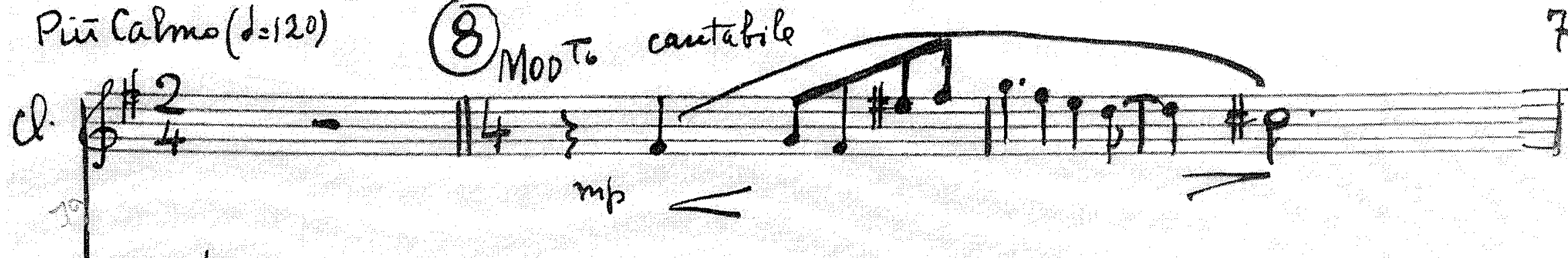

OR

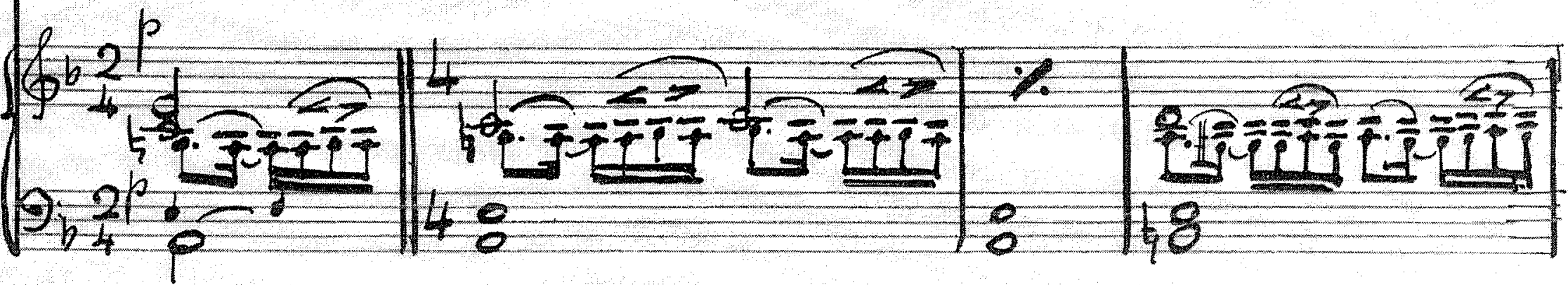

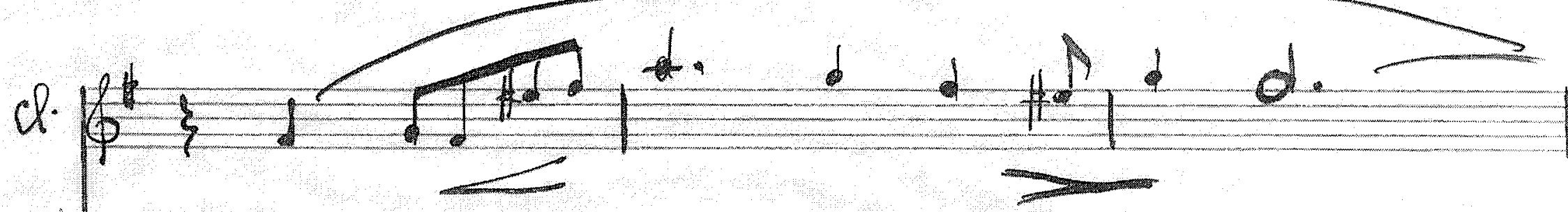

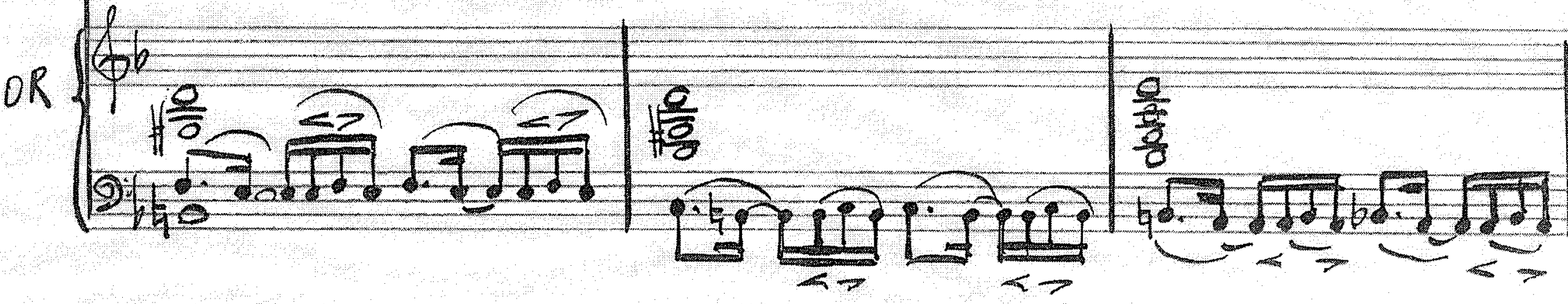

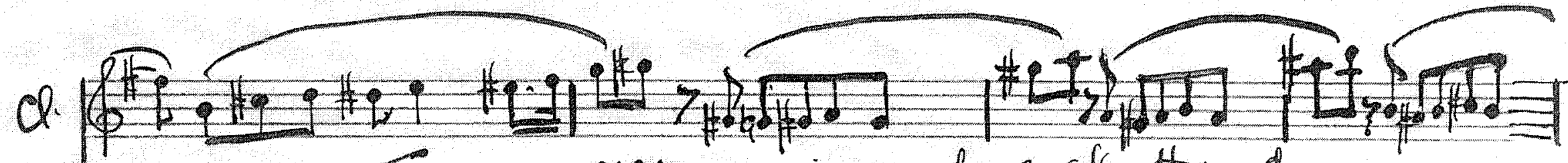
$\Longrightarrow$ crese animando \& affrettando

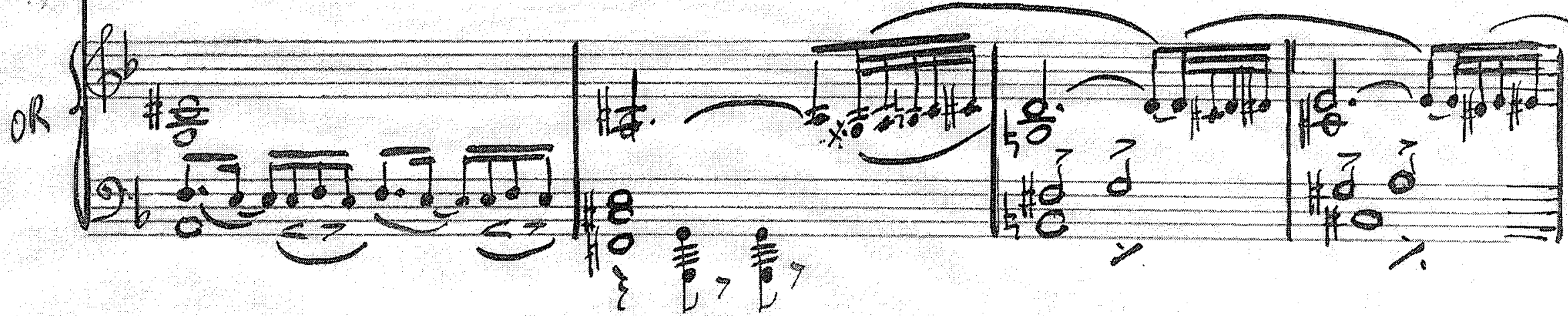

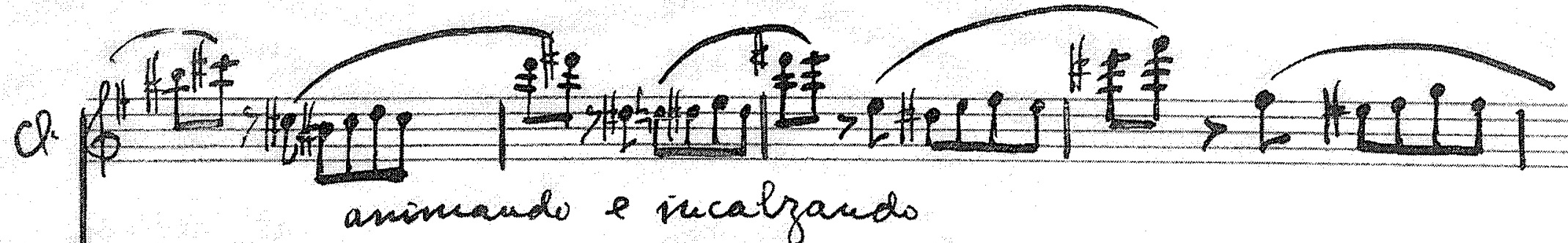

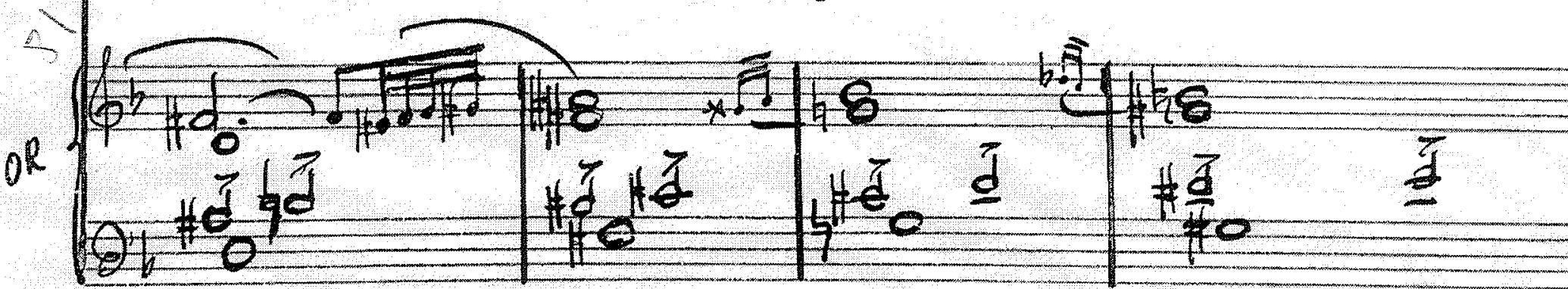


ASSAI Vivo

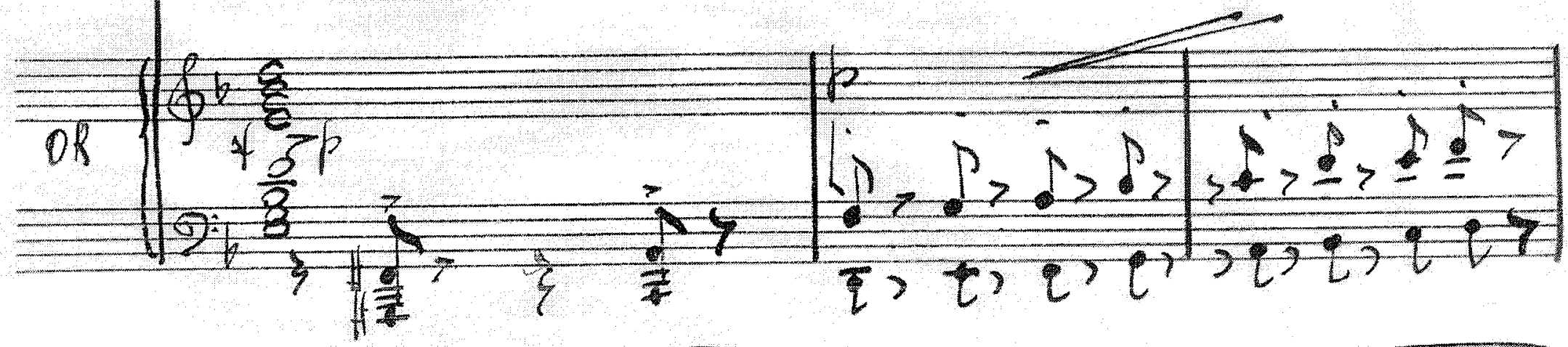

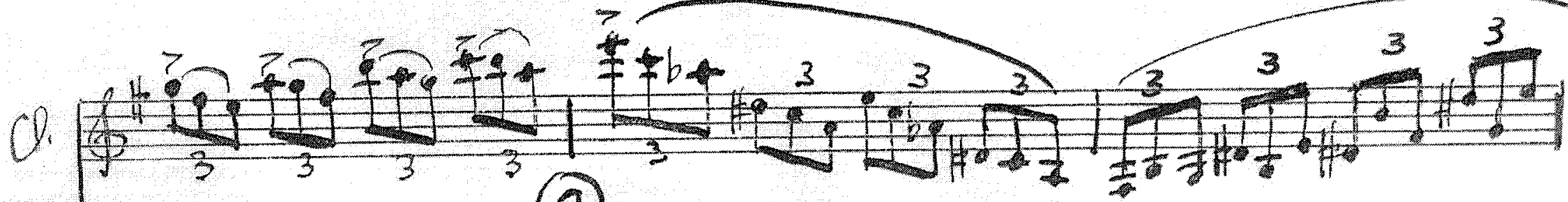

(9)

OR
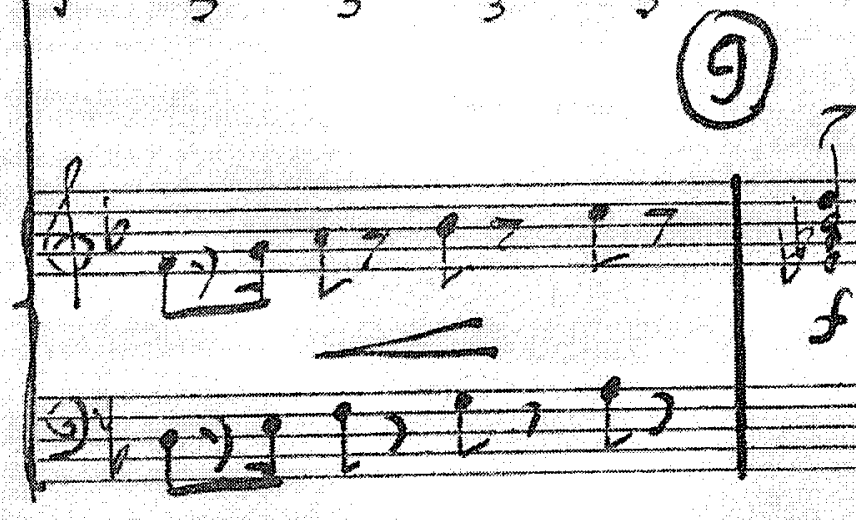

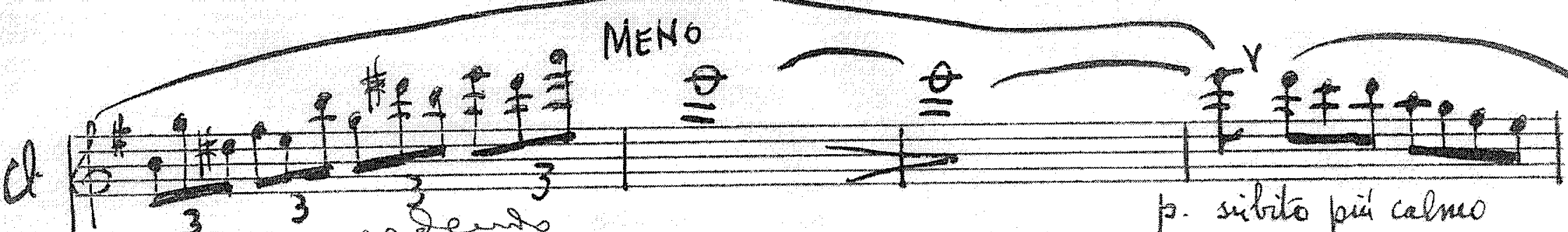

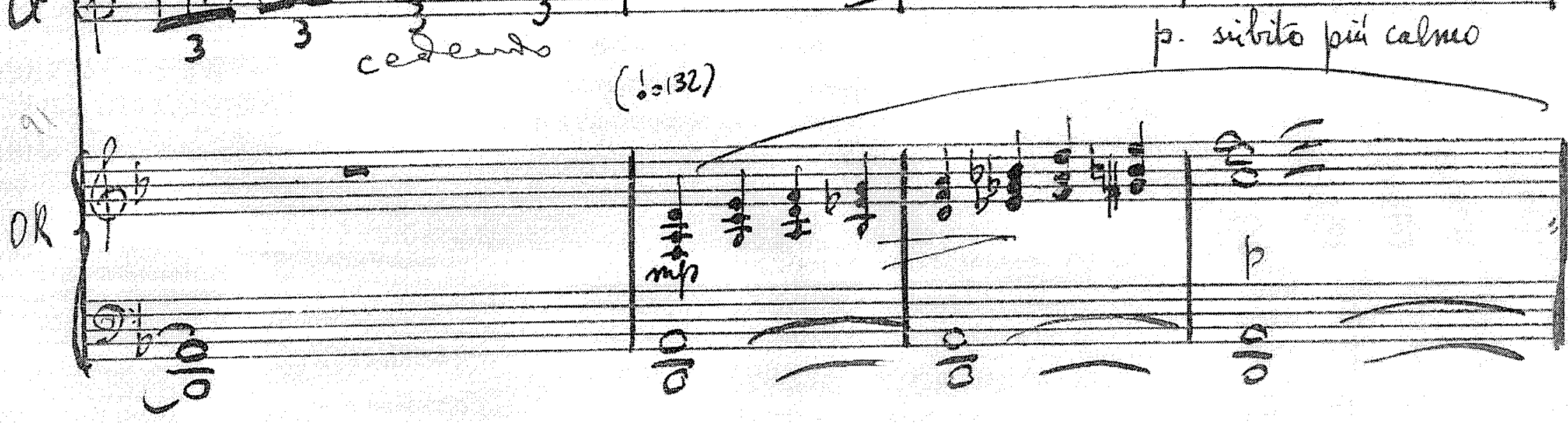

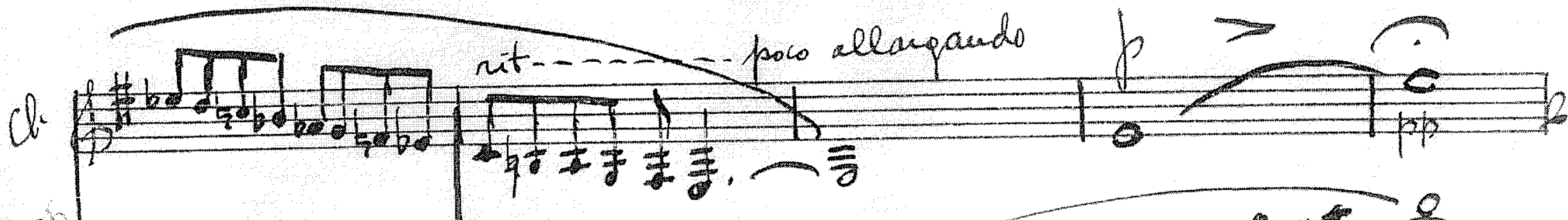

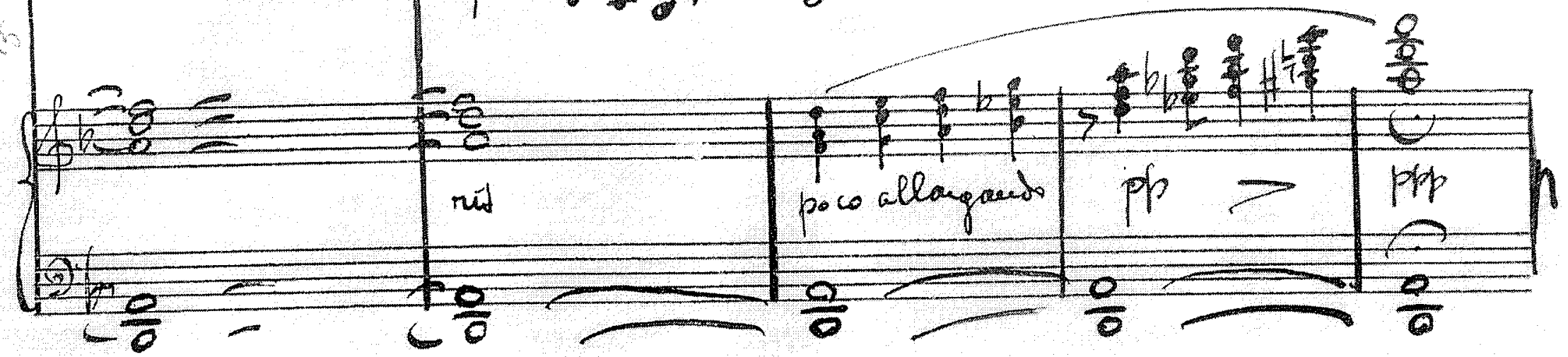


AND - NON TROPPO

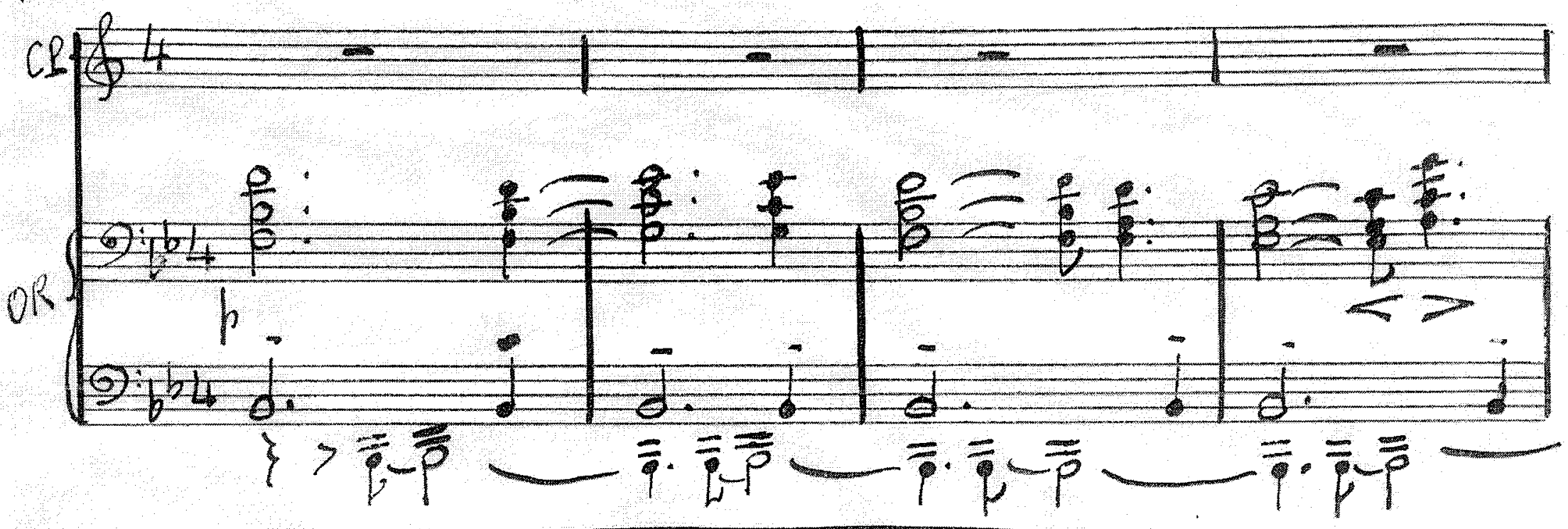

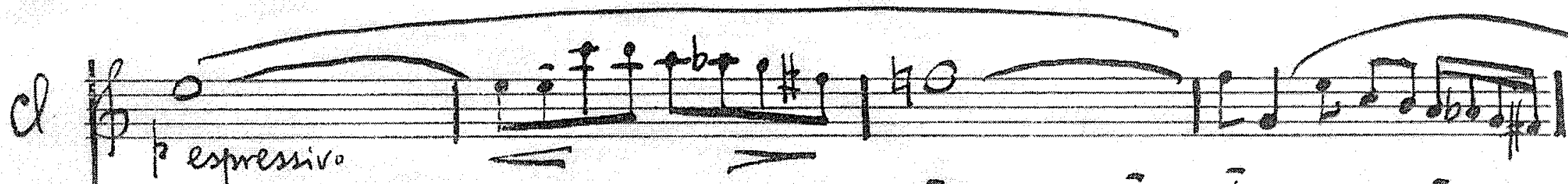

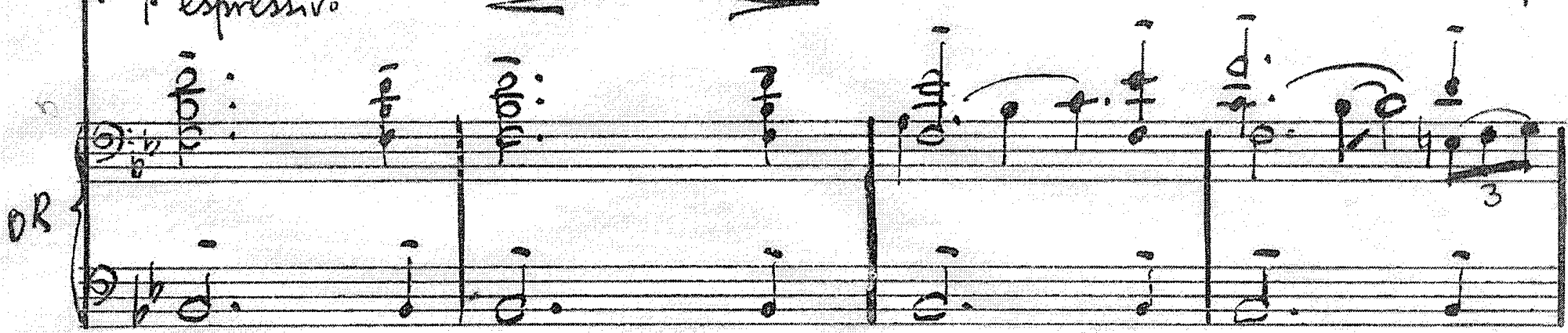

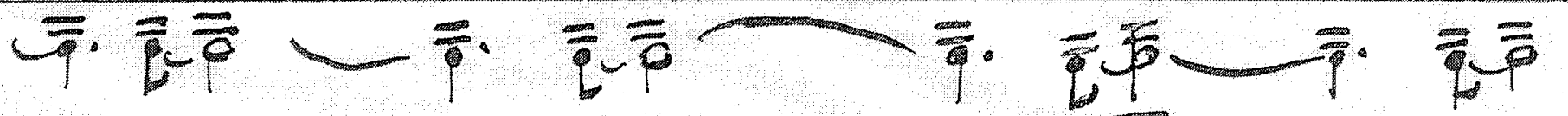

Q.

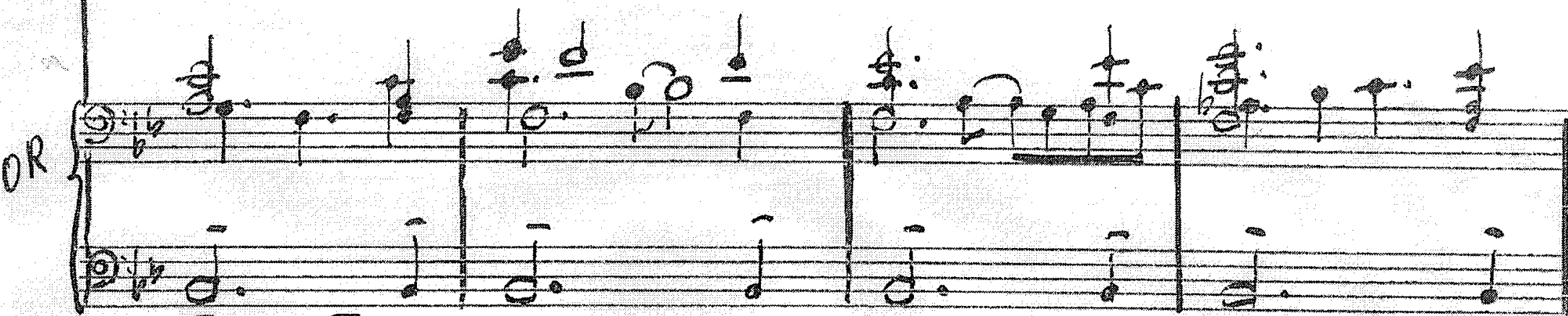

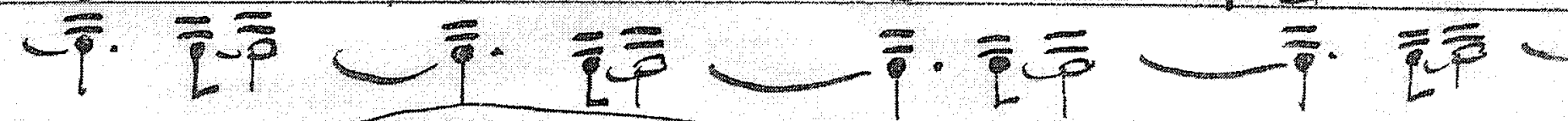

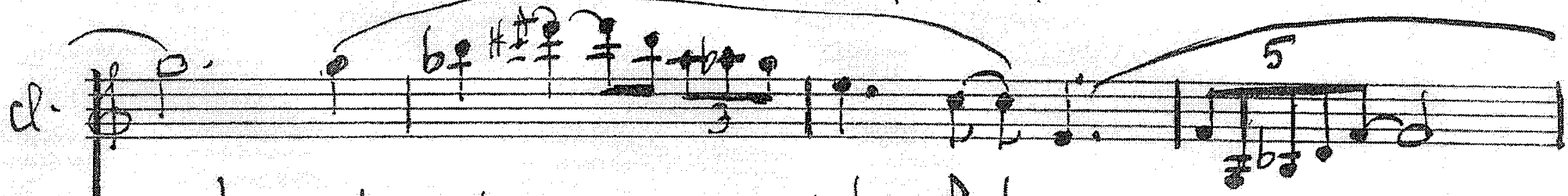

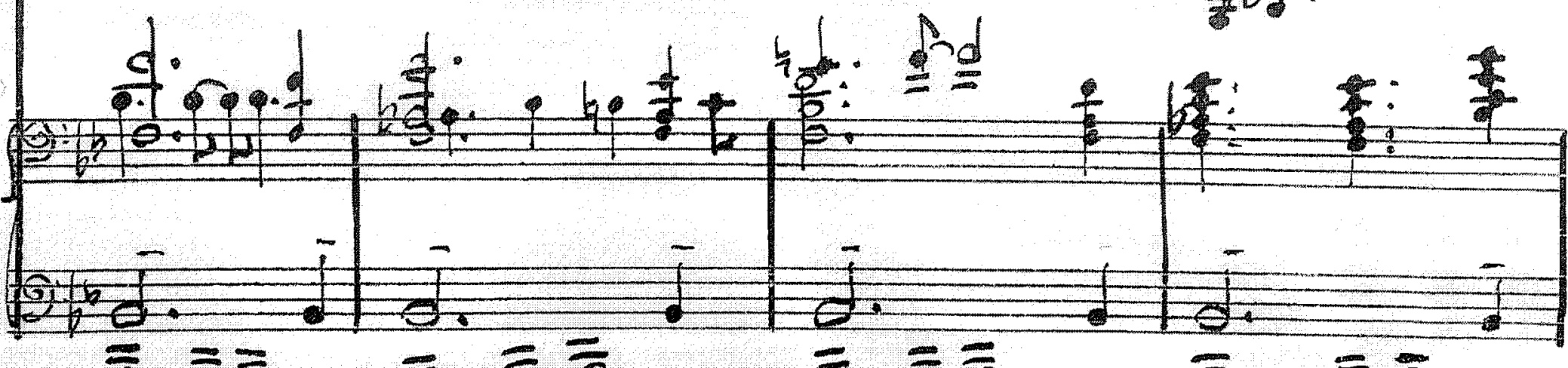

or

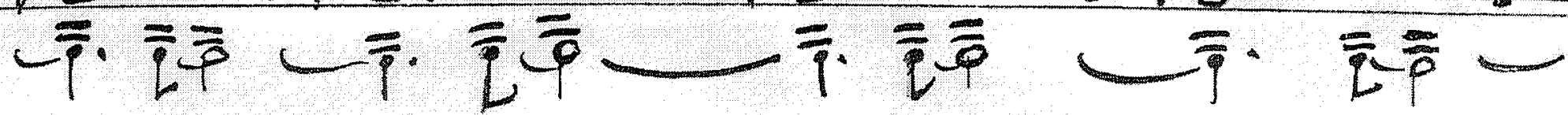




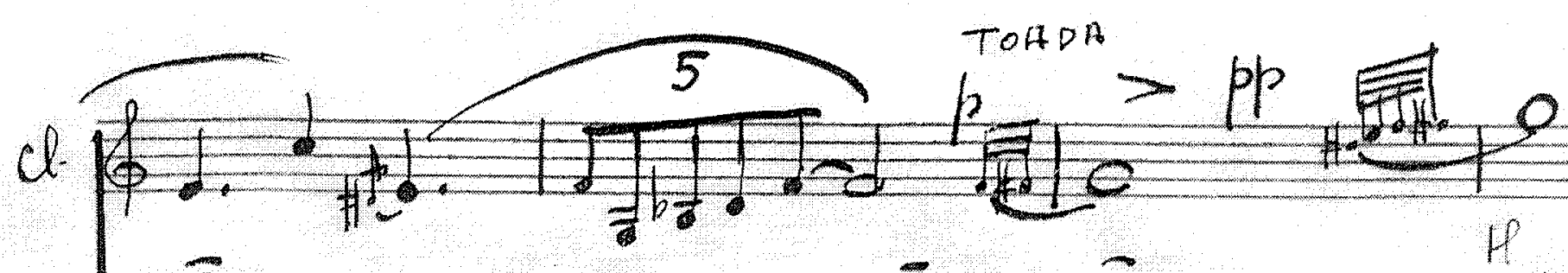

OR

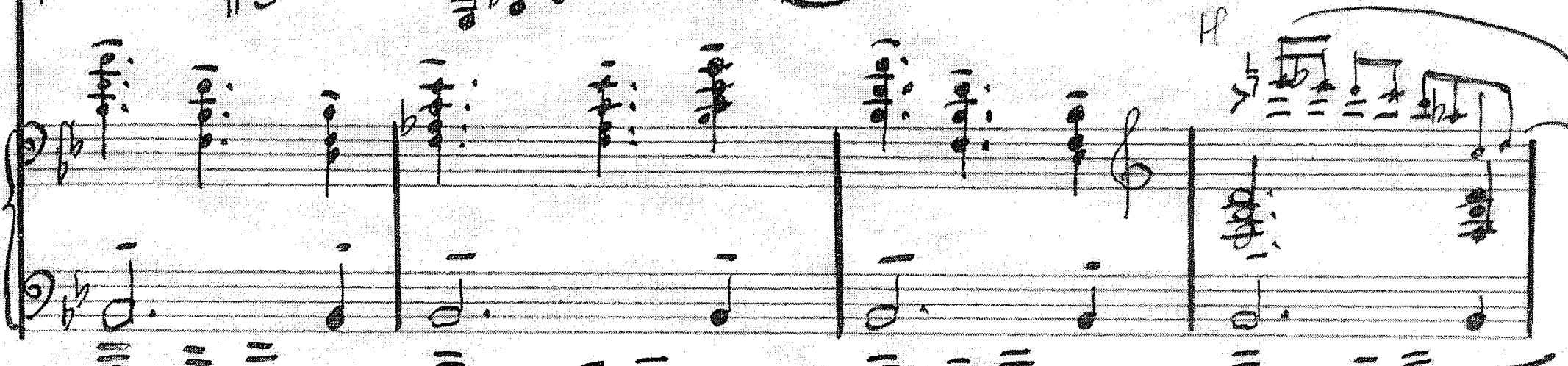

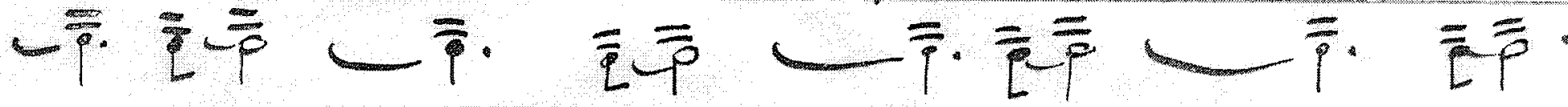

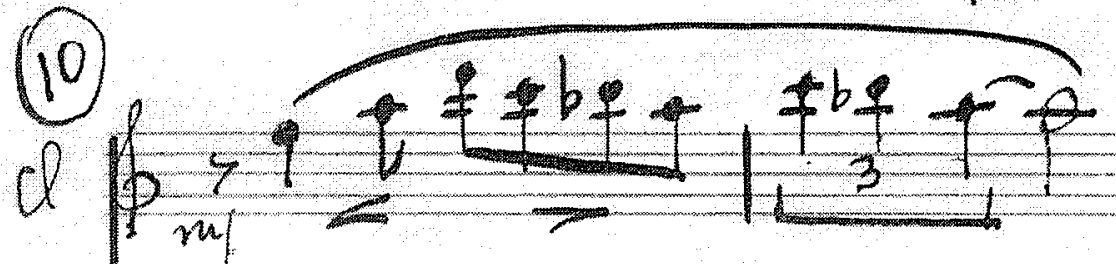

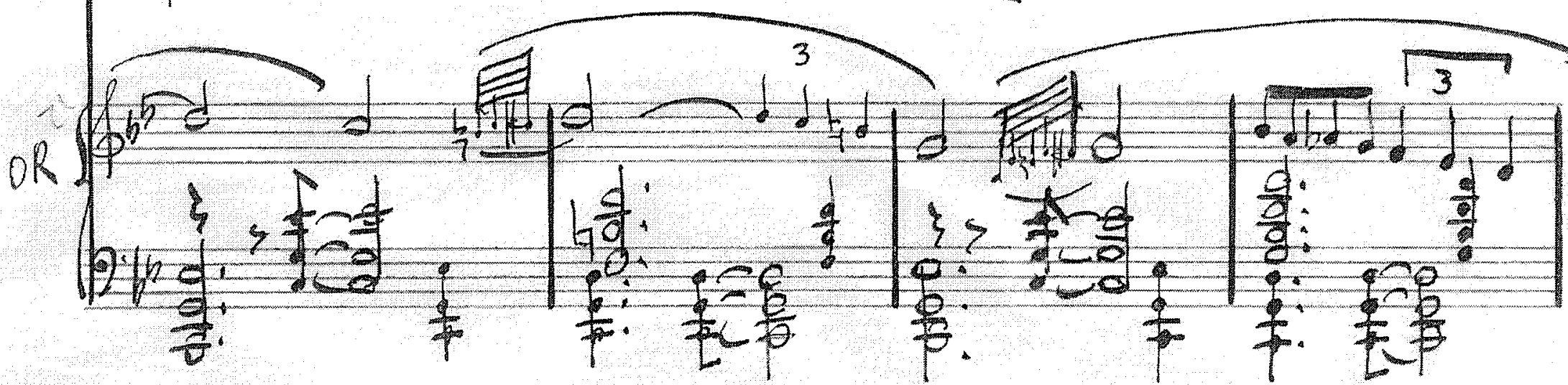

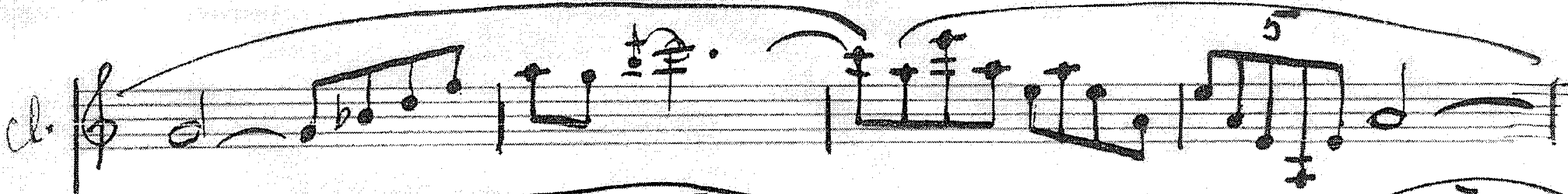

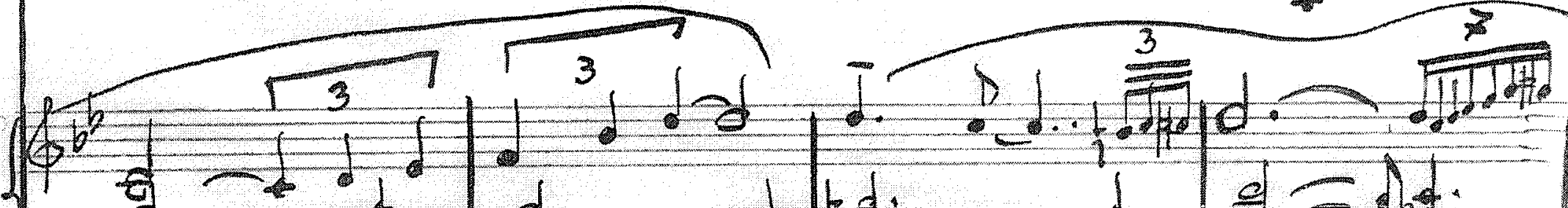

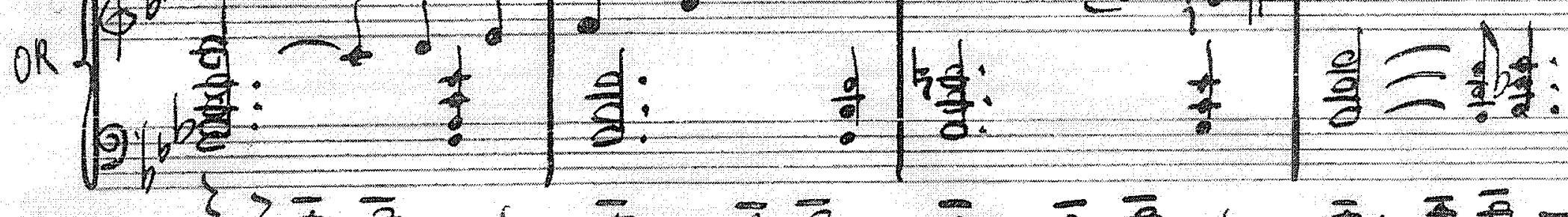

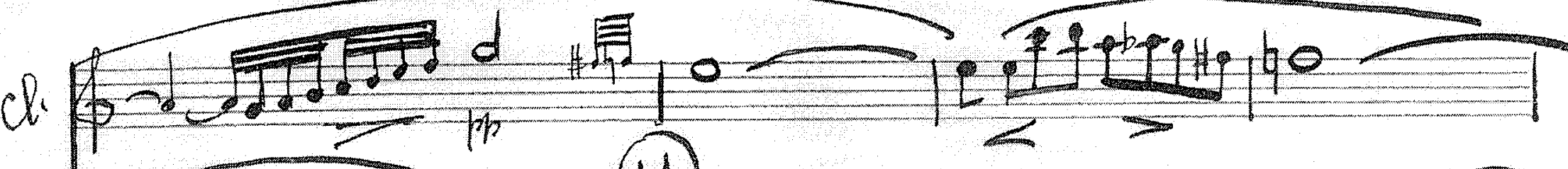

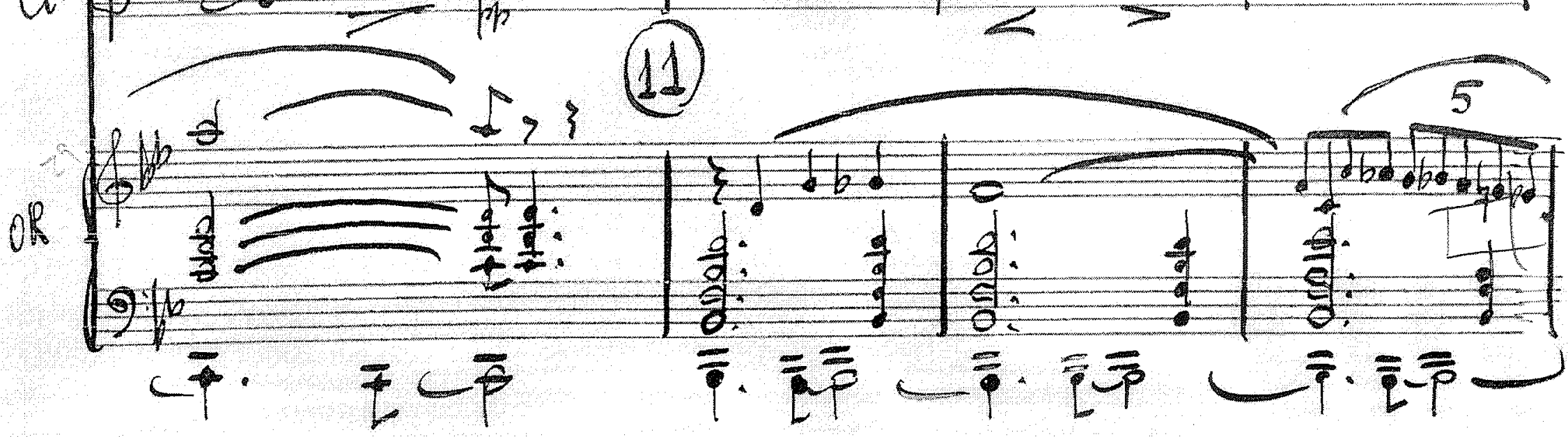



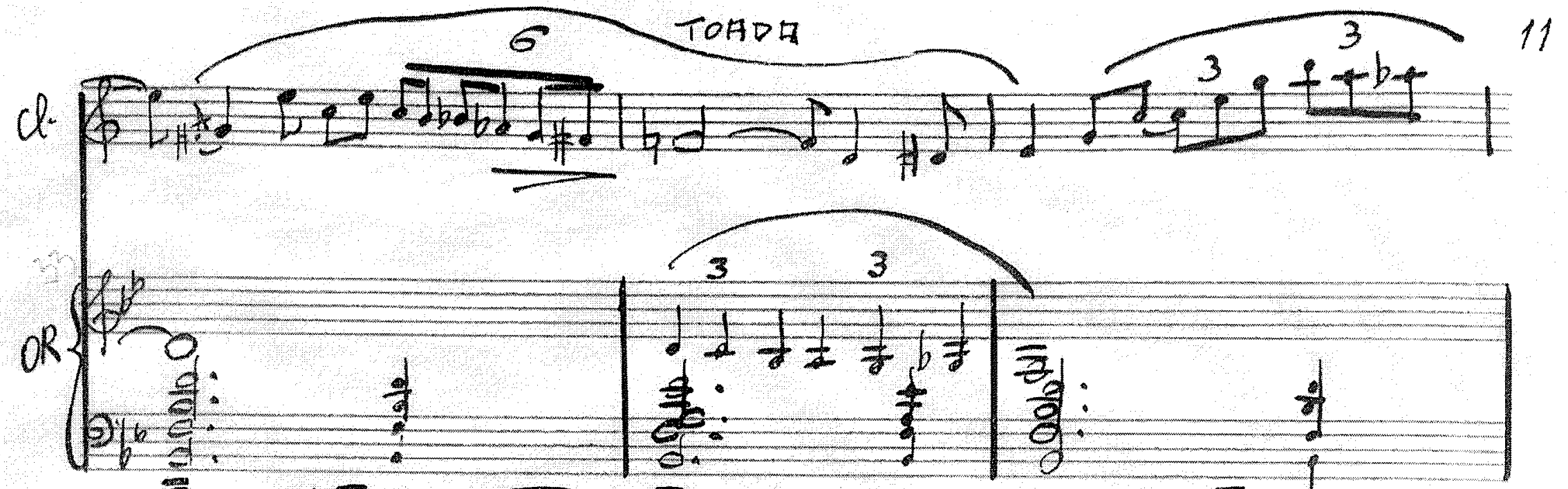

$\checkmark \overline{\bar{q}} \overline{\bar{p}} \longrightarrow \overline{\bar{p}} \overline{\bar{q}} \overline{\bar{p}} \longrightarrow \overline{\bar{p}} \cdot \overline{\bar{q}}-\overline{\bar{p}}$

(4)

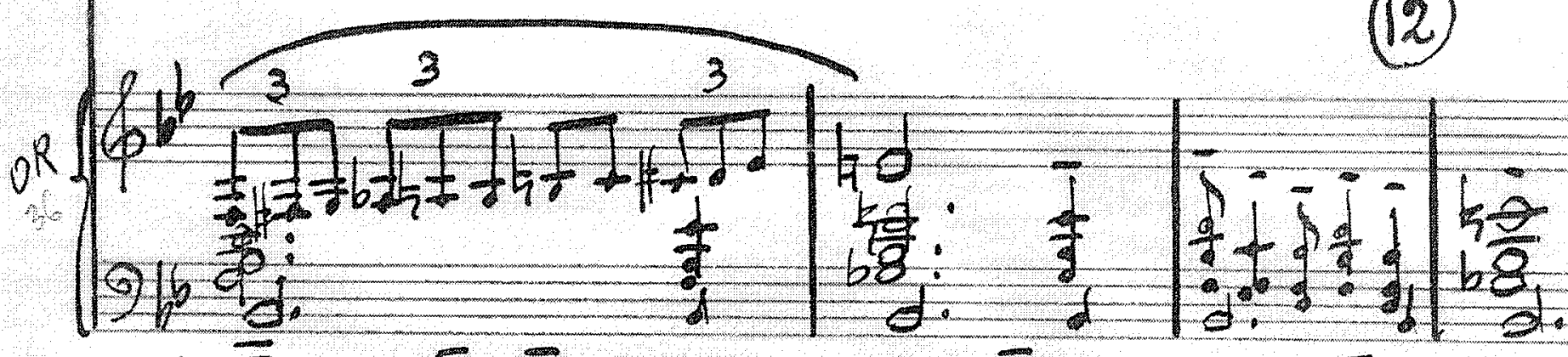

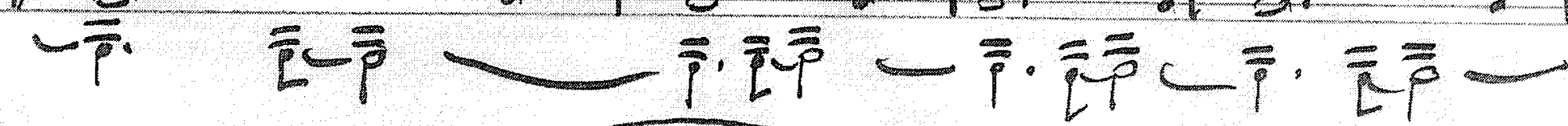

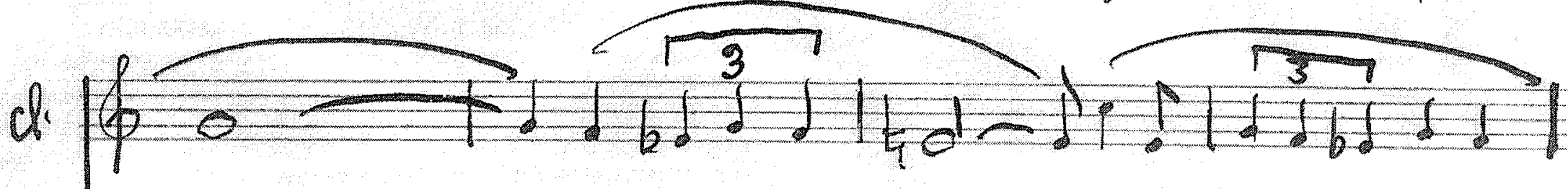

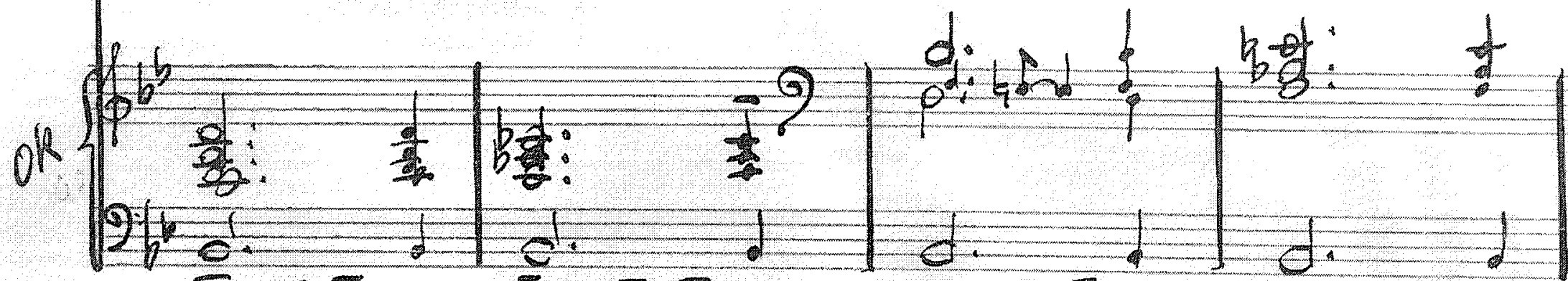

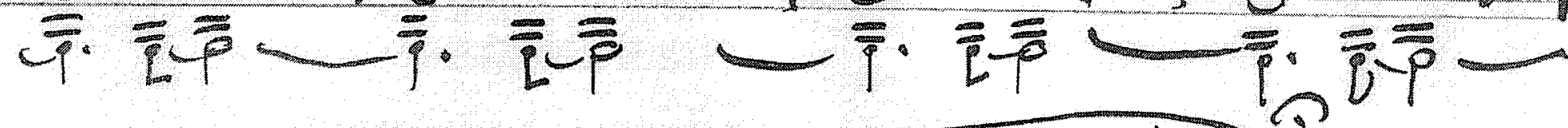

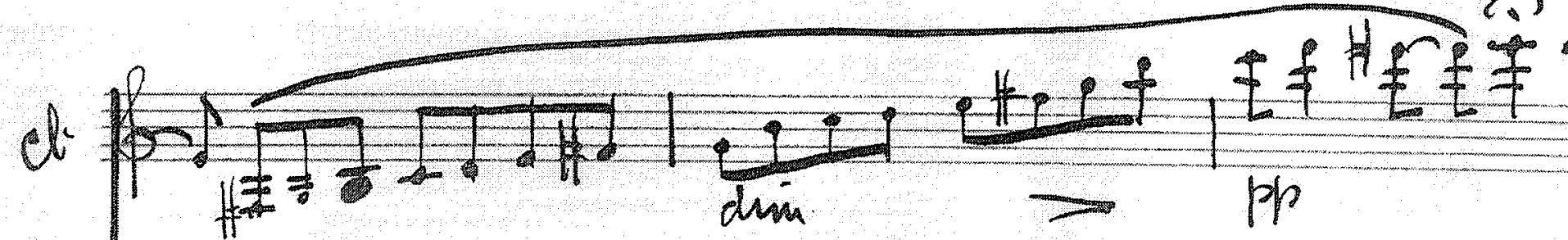

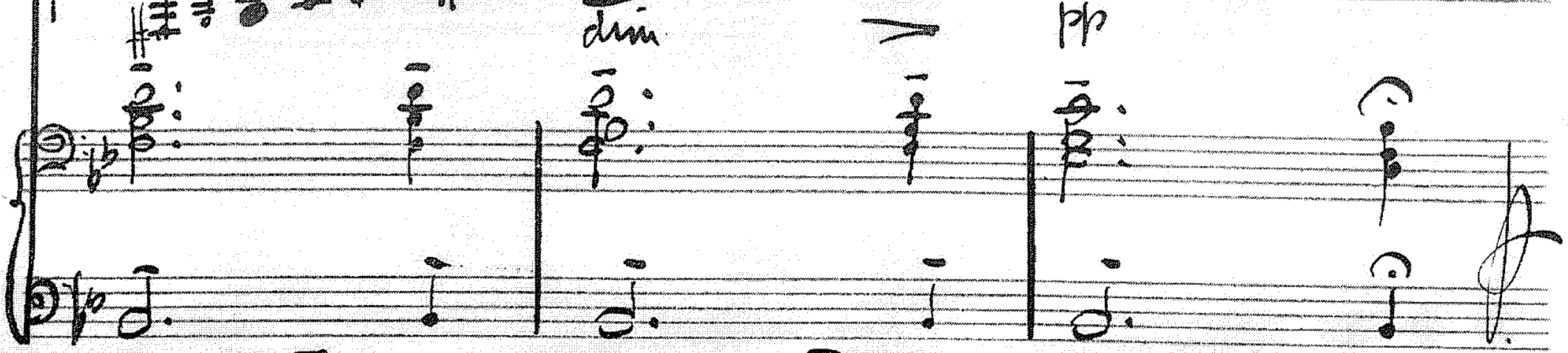

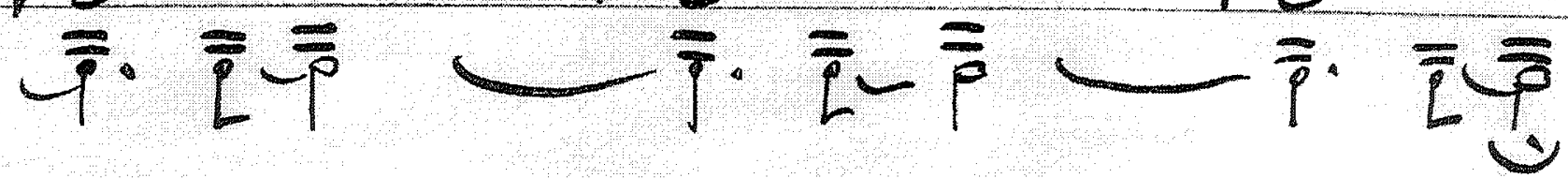


$Q W=(d=138) \quad$ FINAL

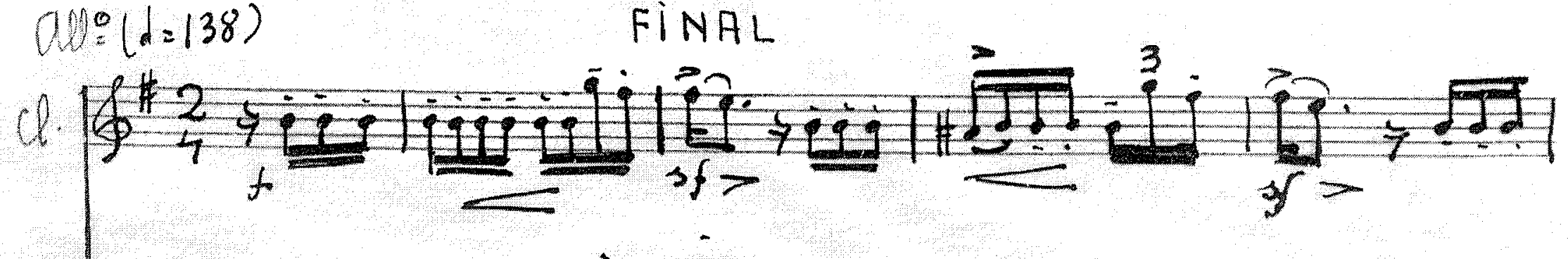

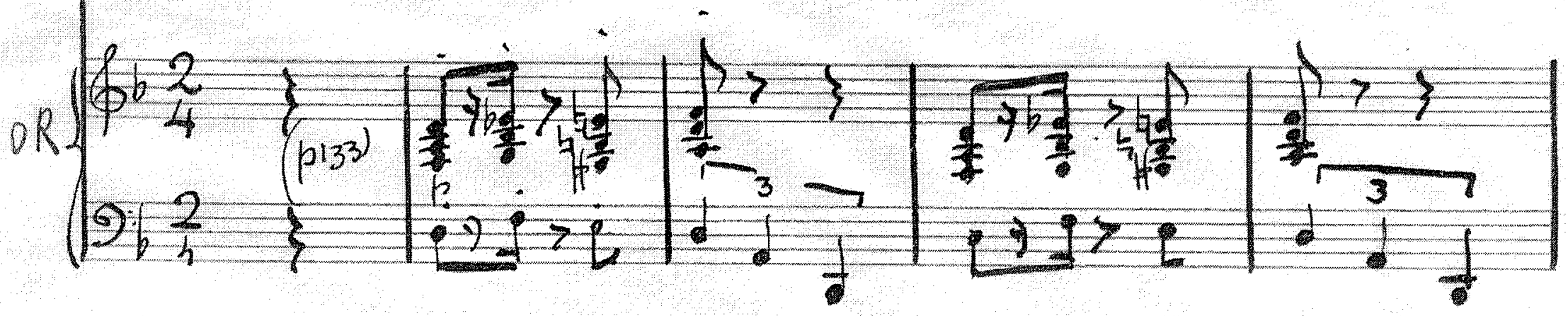

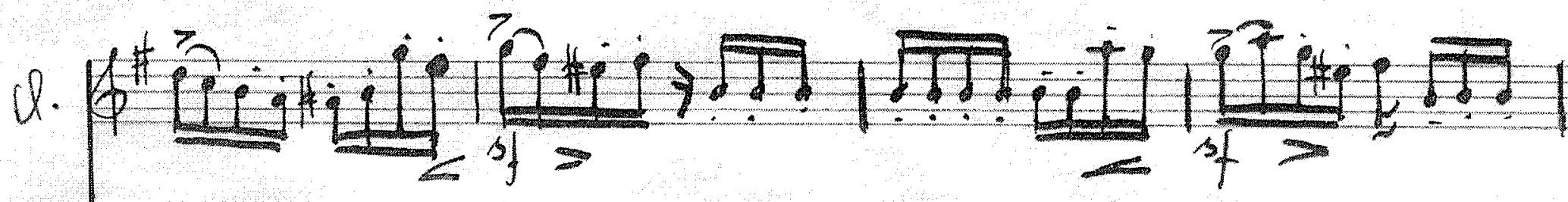

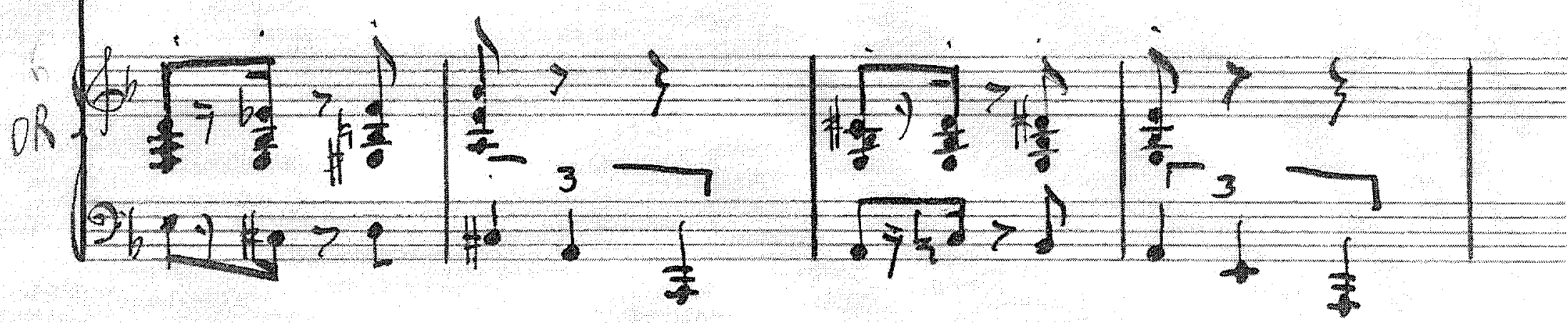

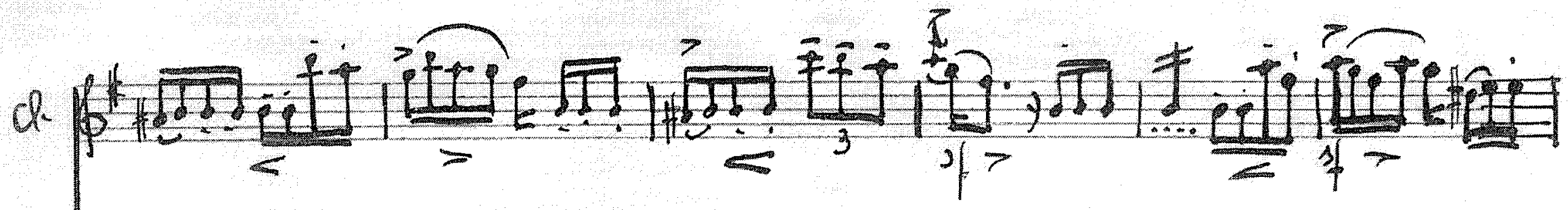

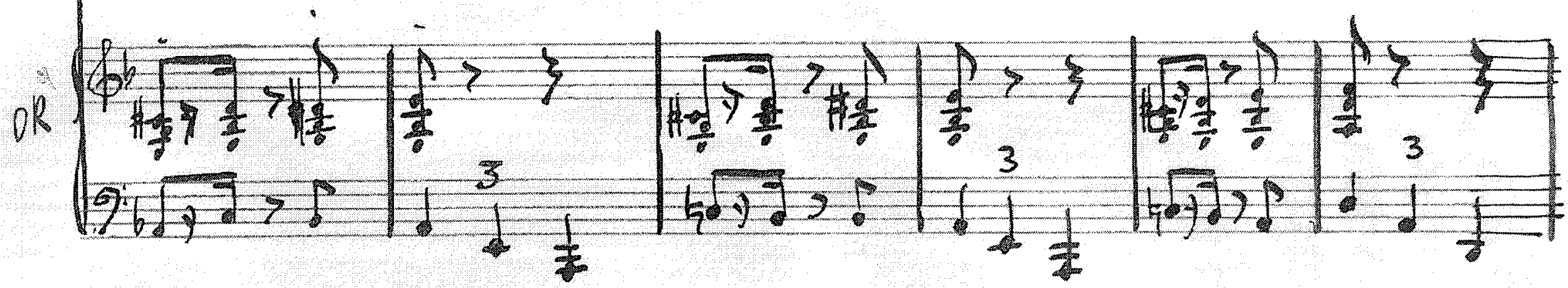

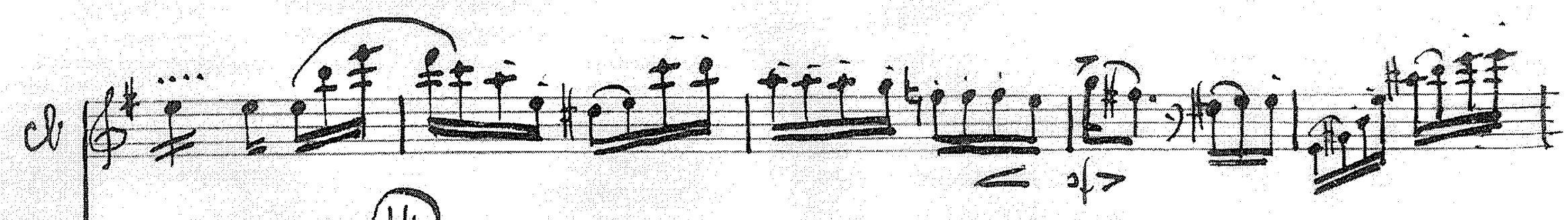

(14)

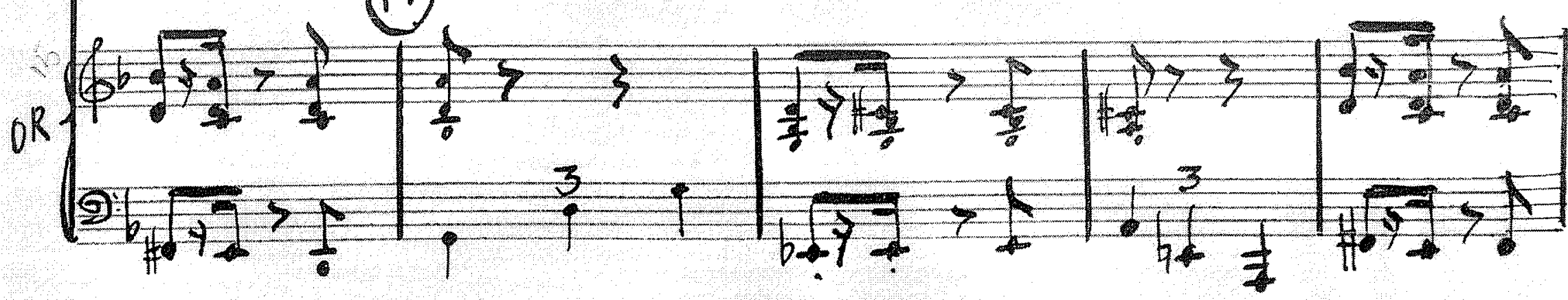




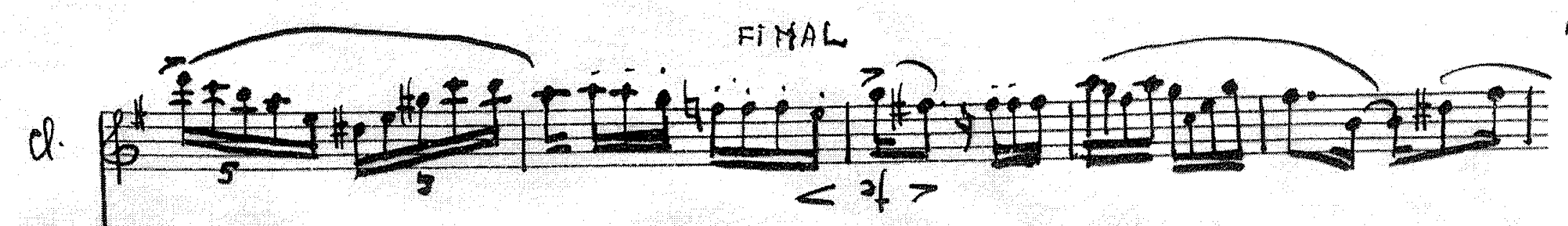

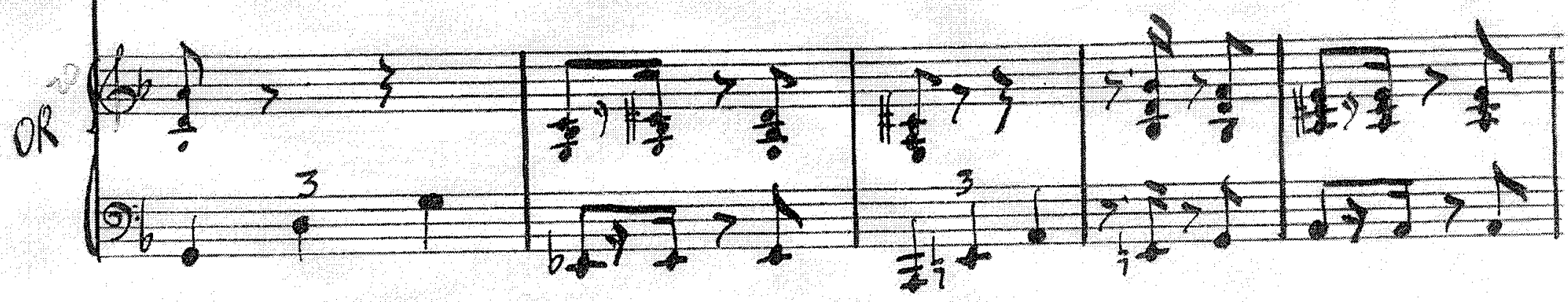

d.

of

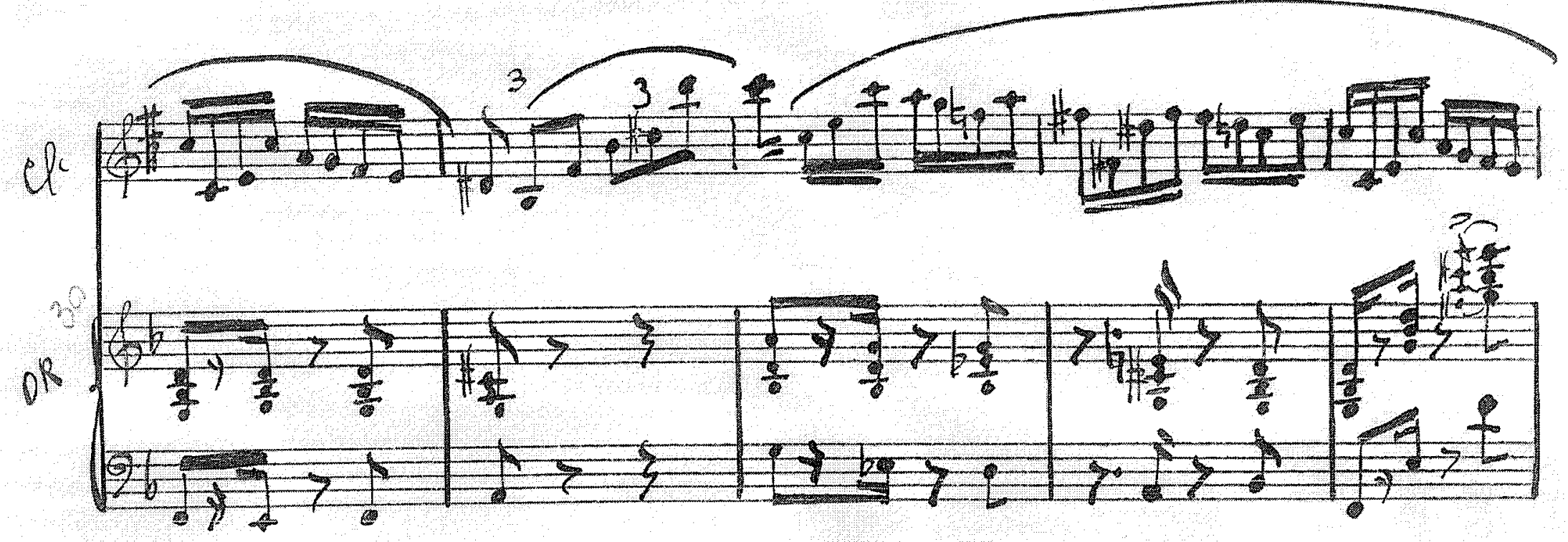

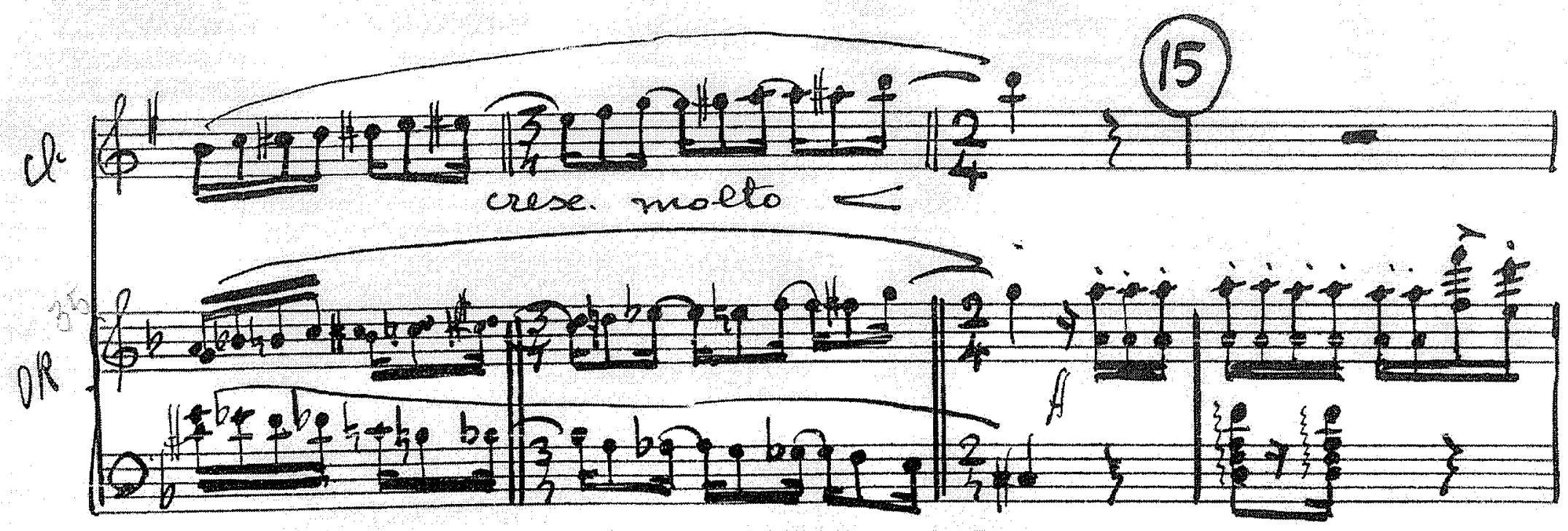



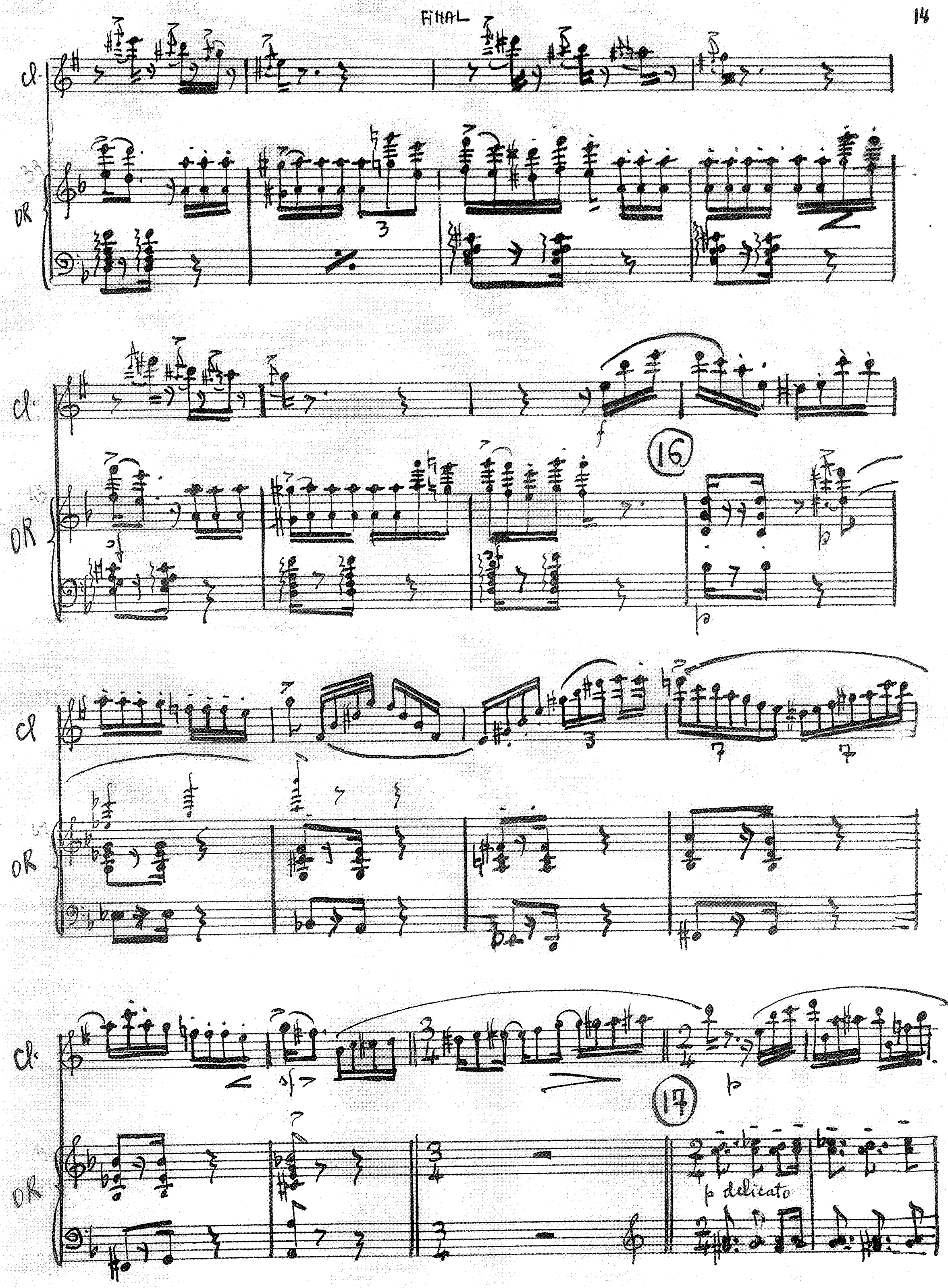
FINAL

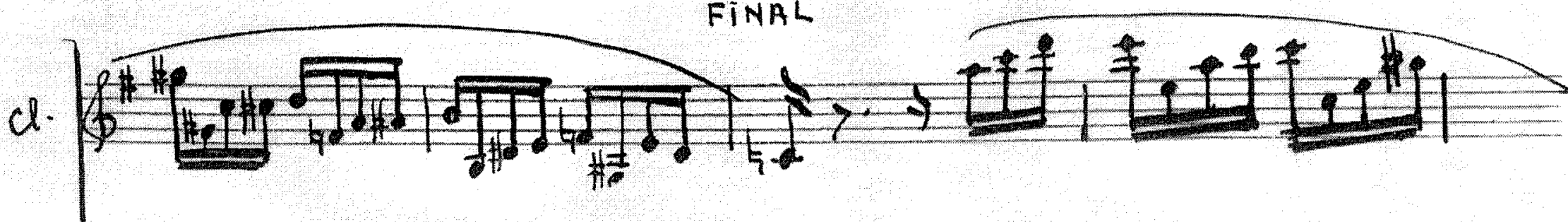
OR

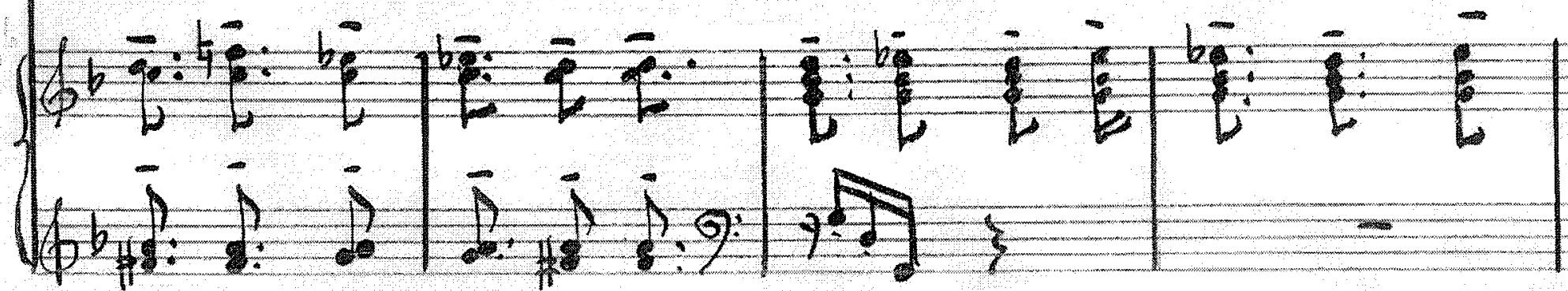

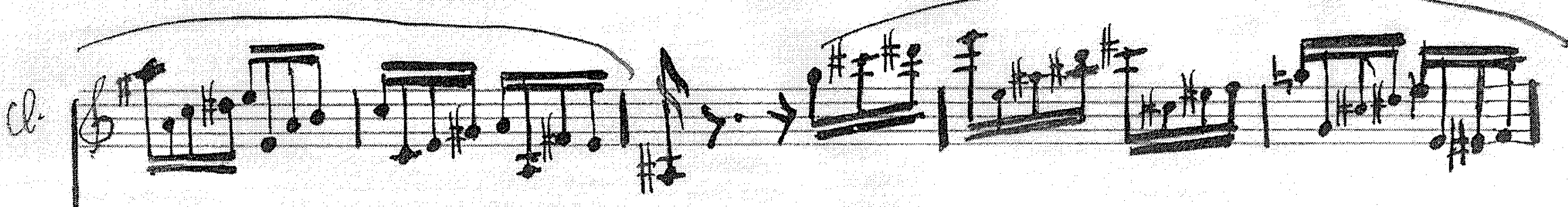

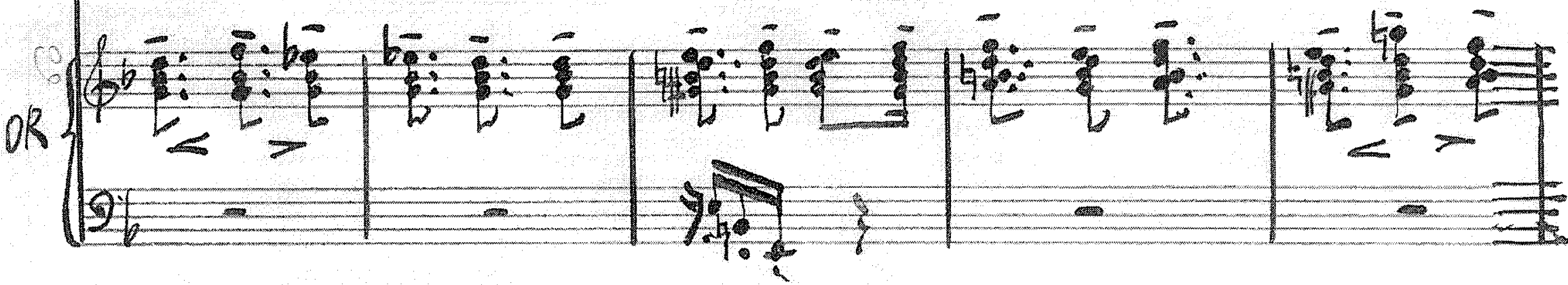

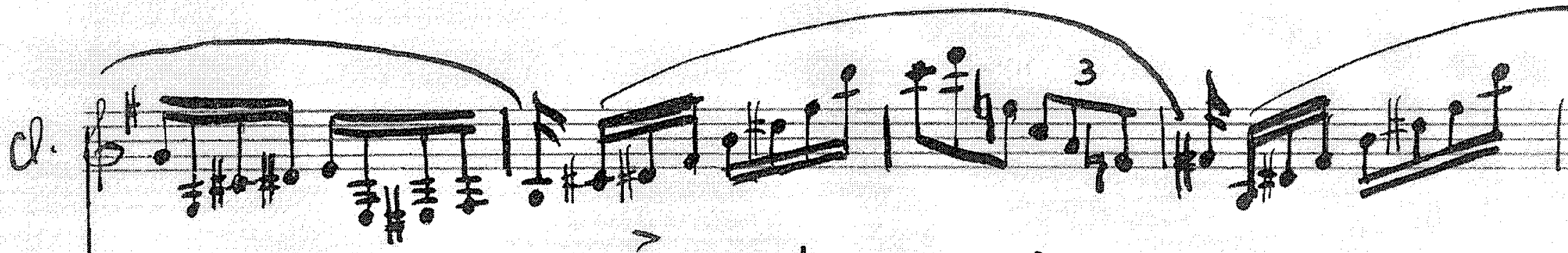

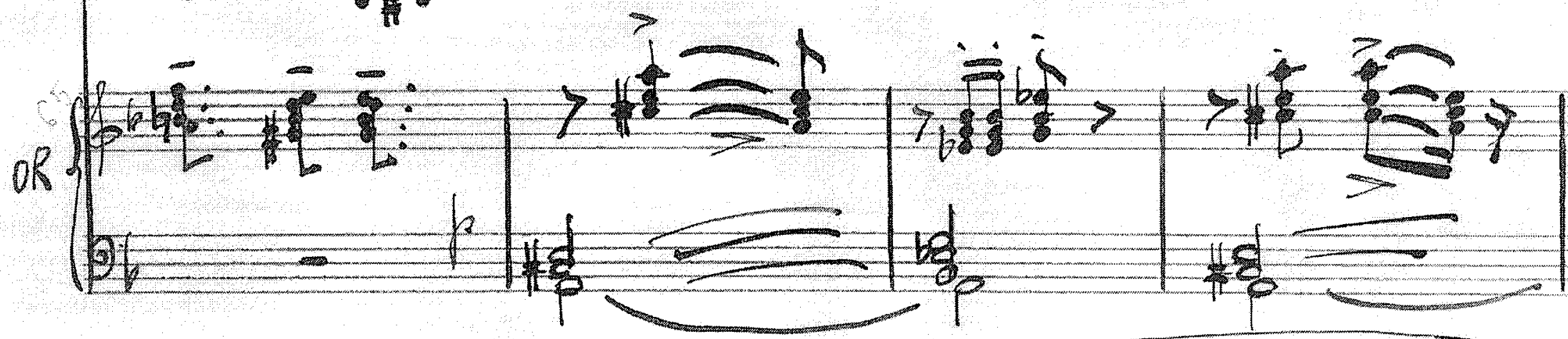

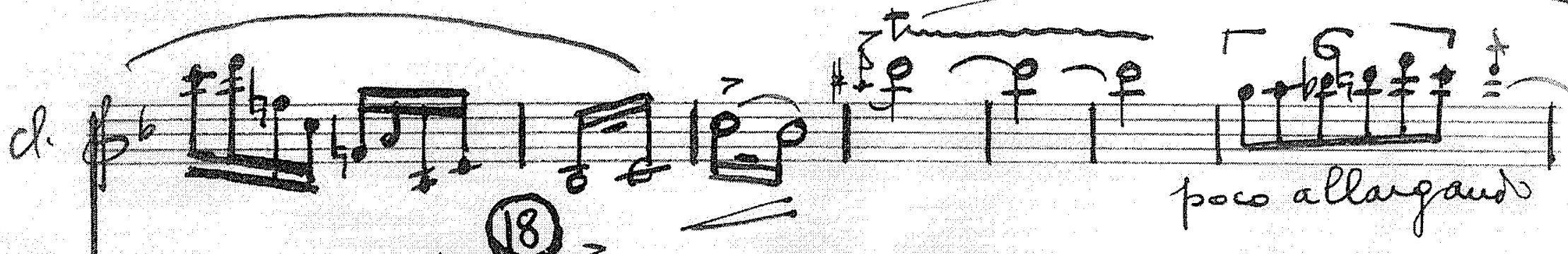

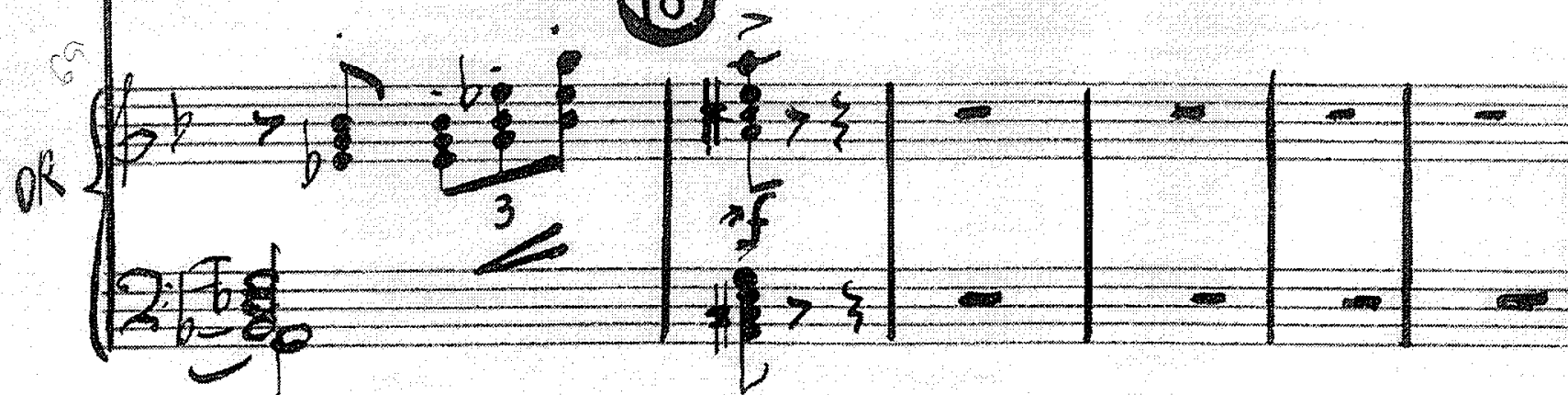


POCO MENO (dz108)

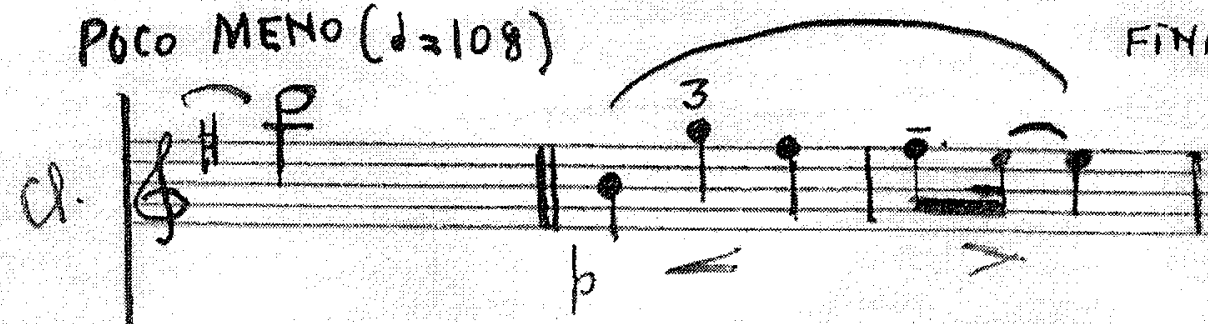

INAL

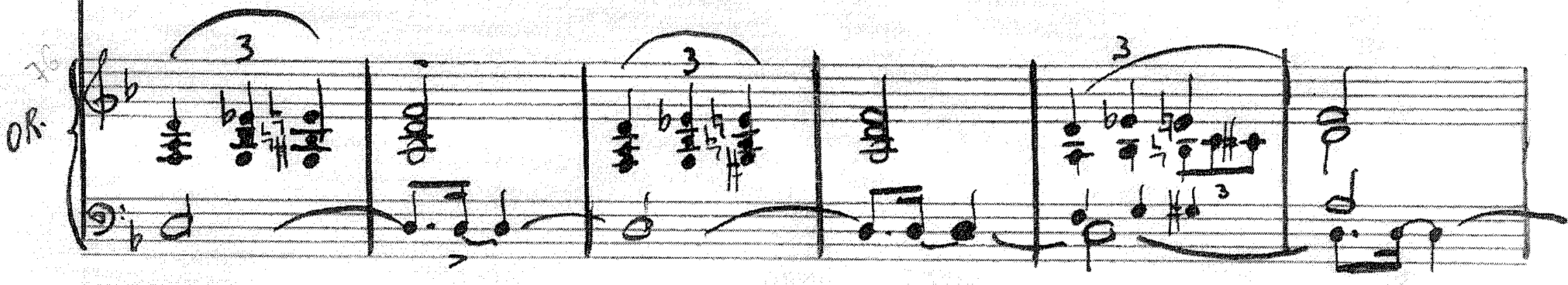

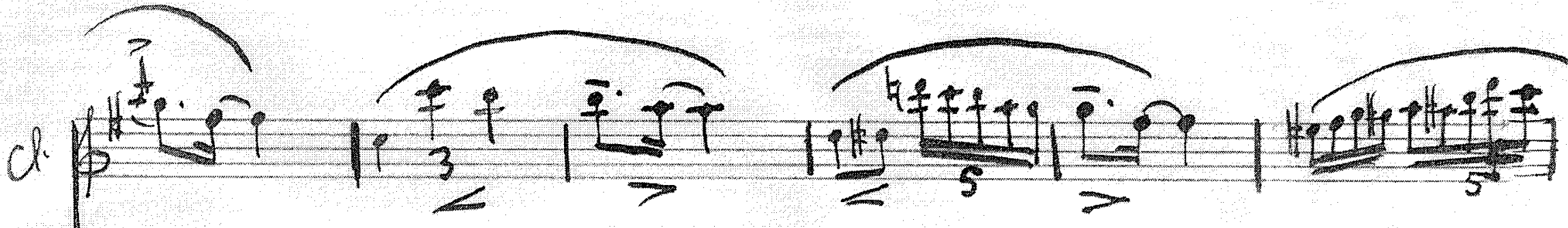

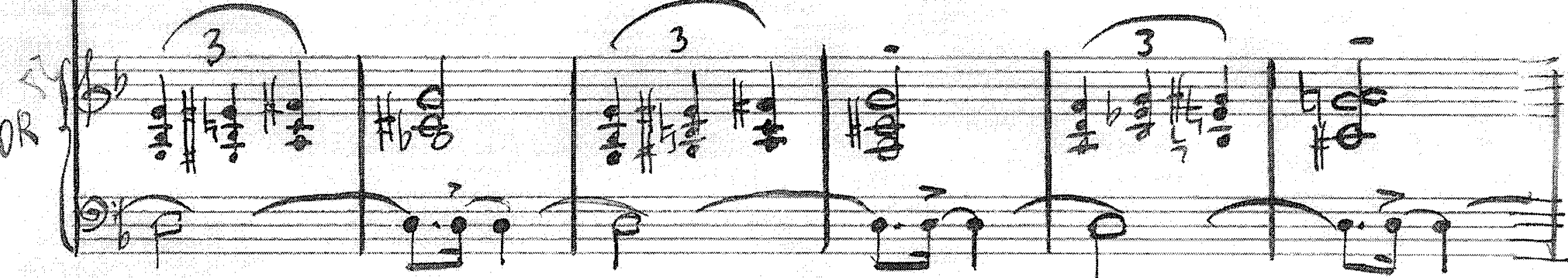

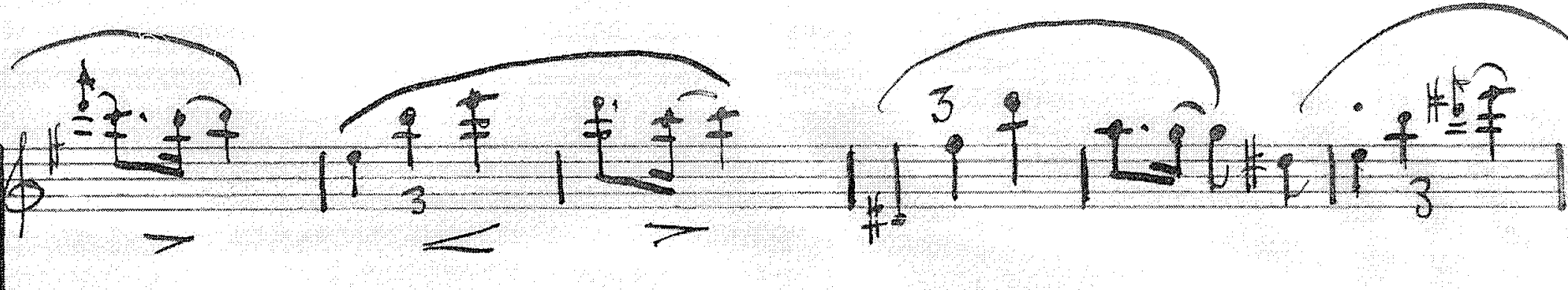

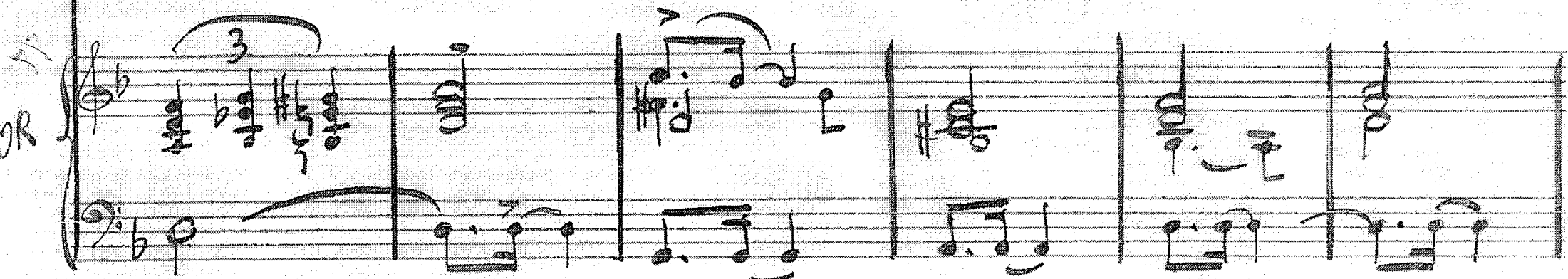

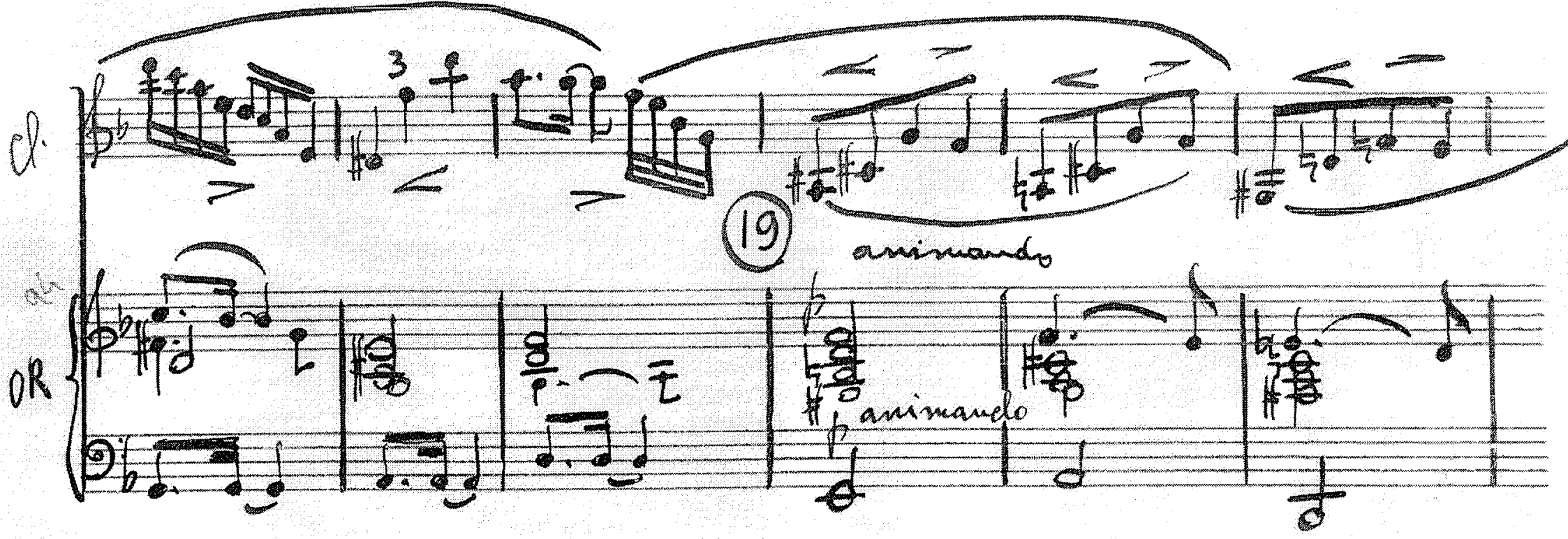


Q.

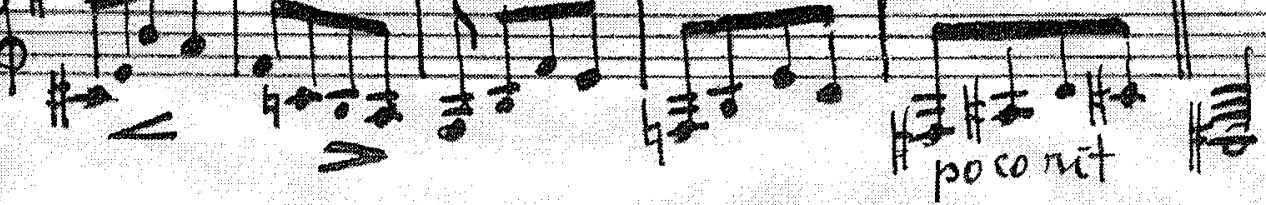

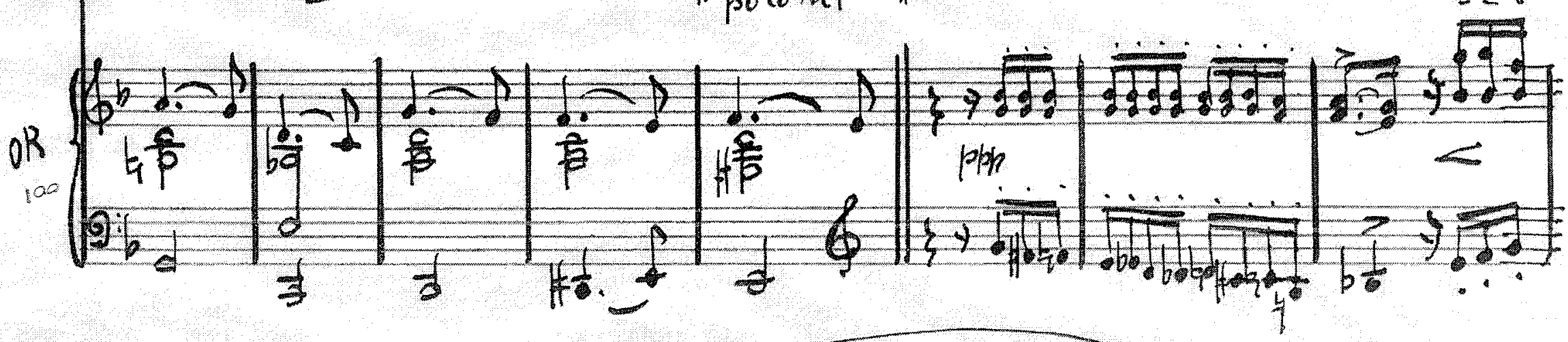

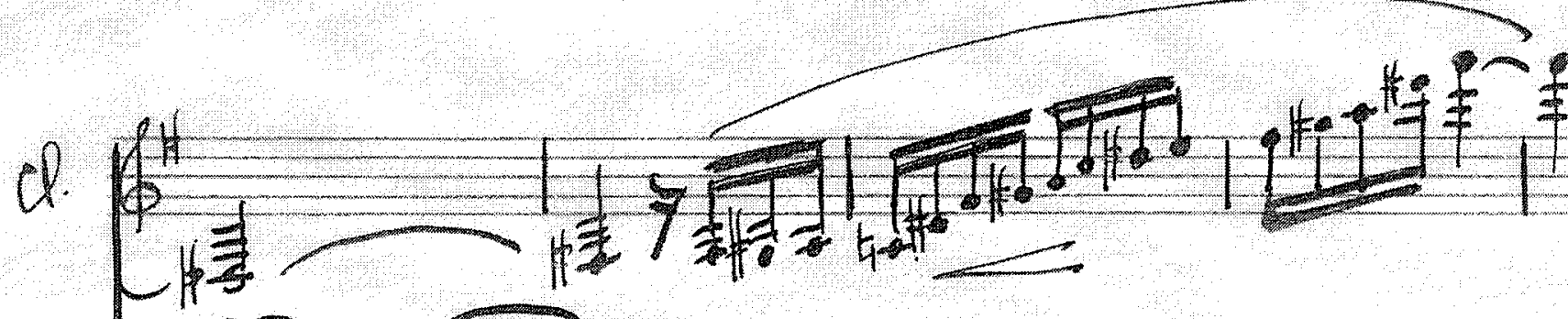

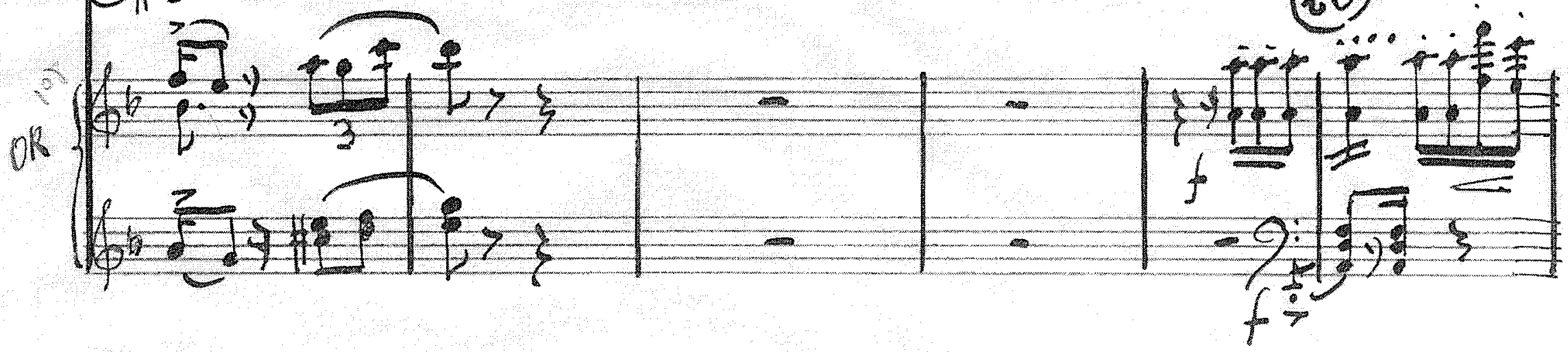

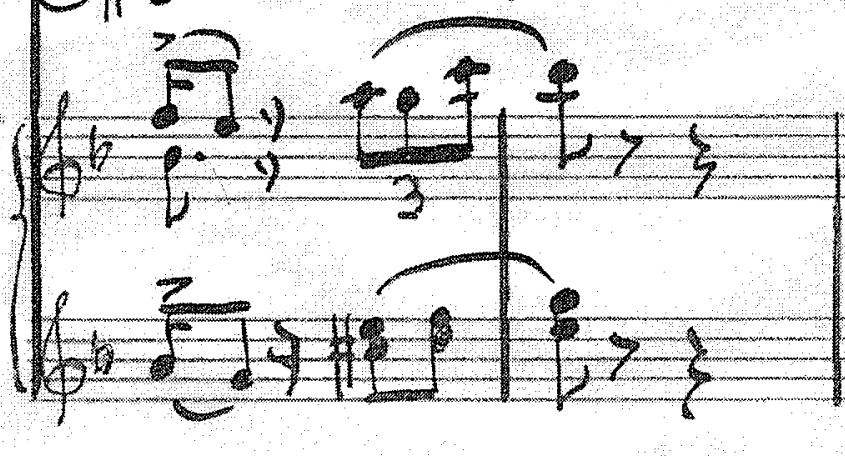

(20)

₹

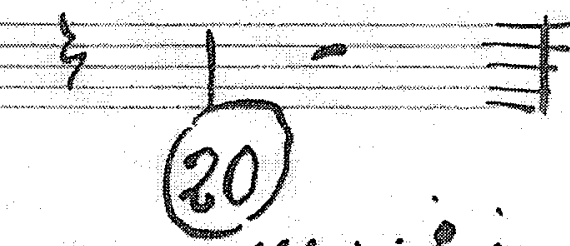

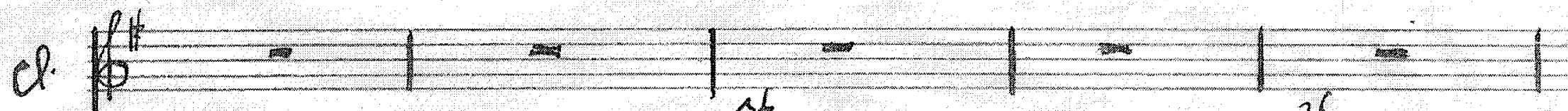

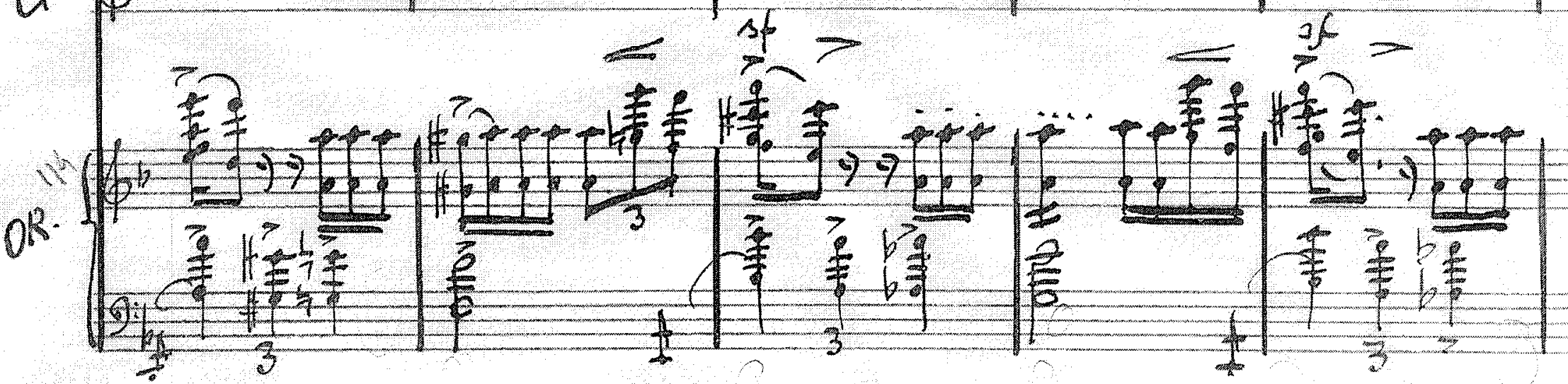
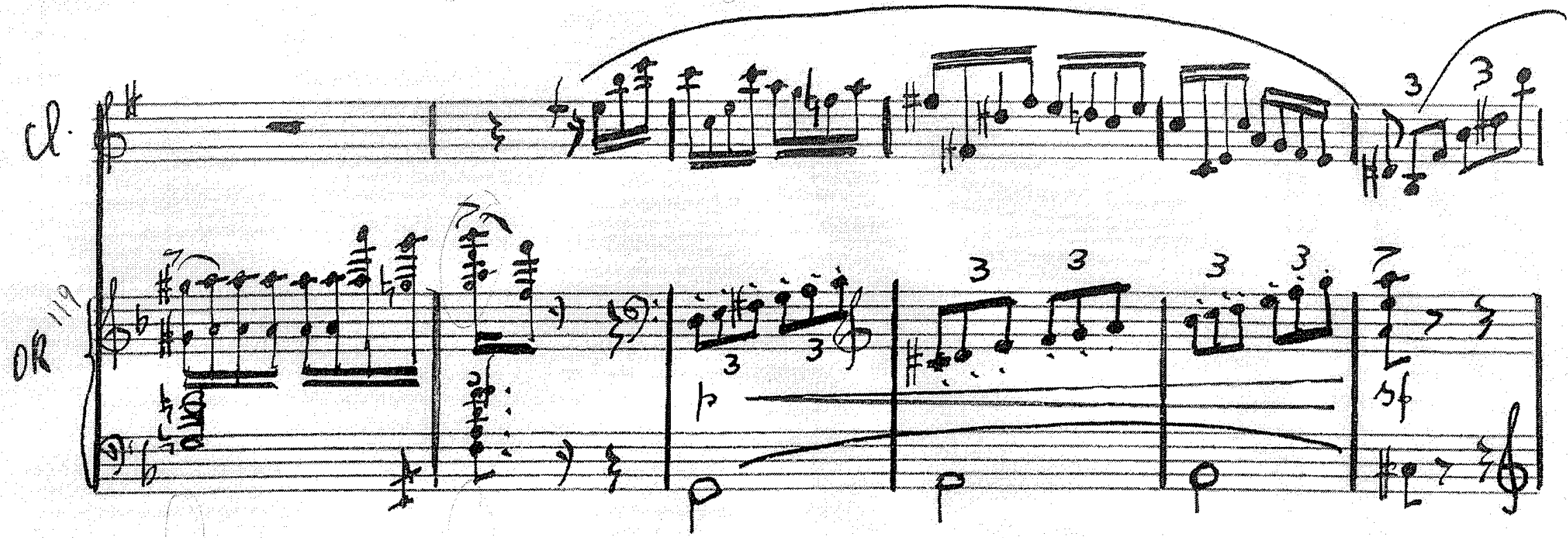
Cl.

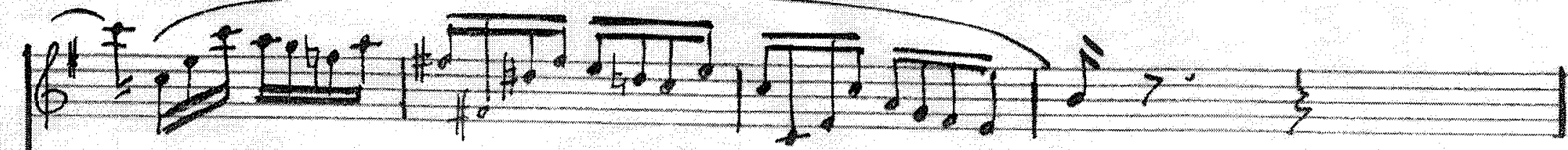

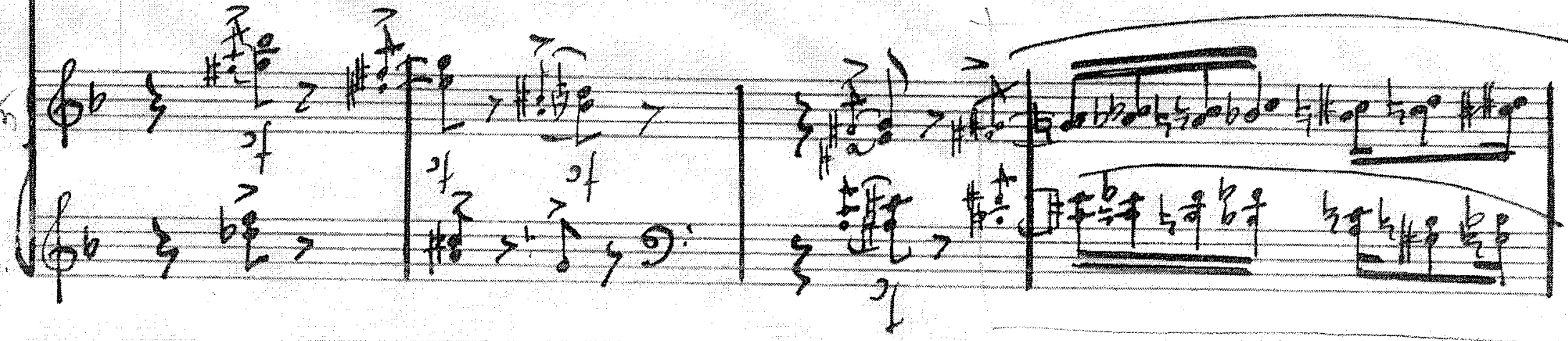

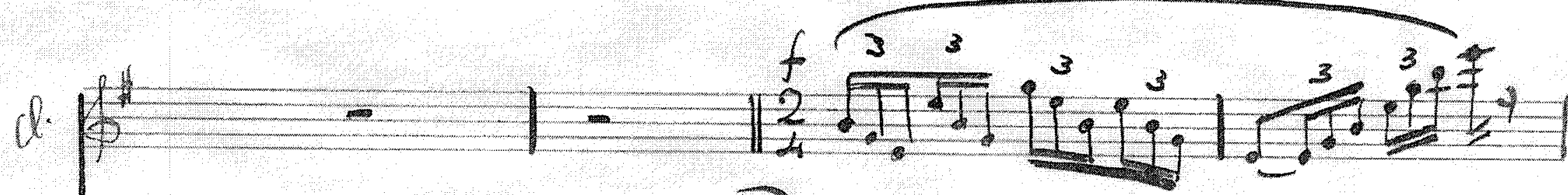

(21)

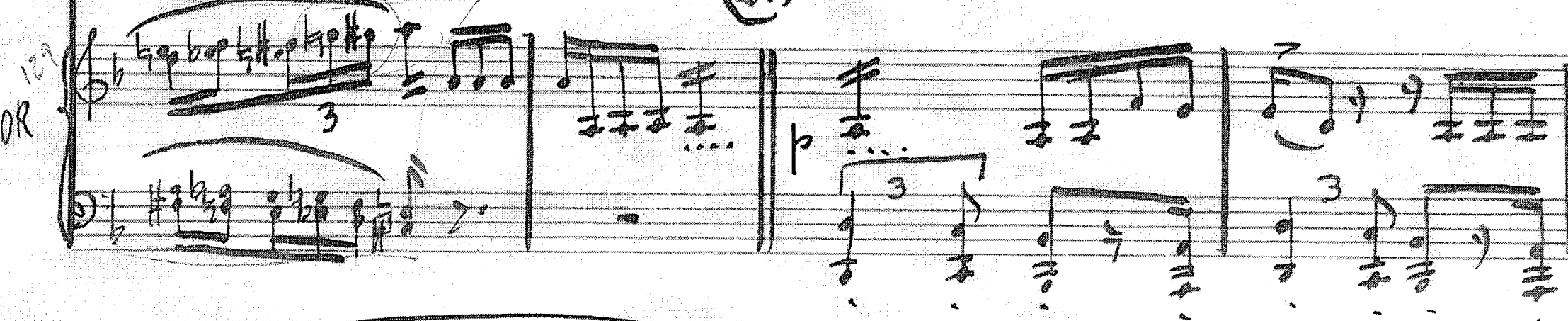

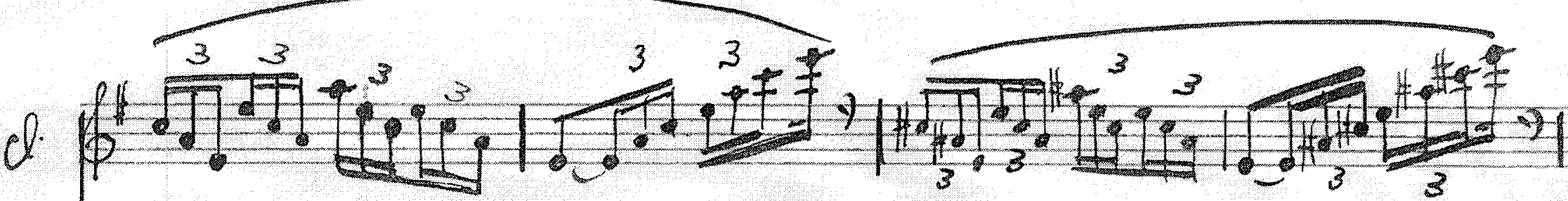

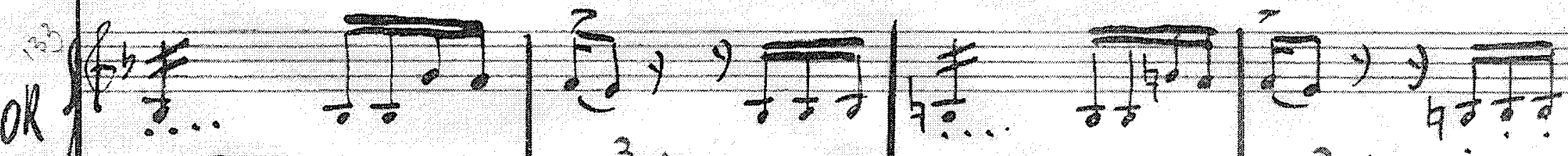

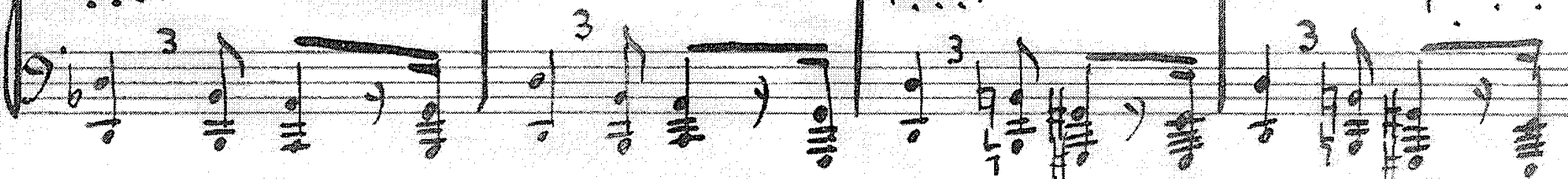

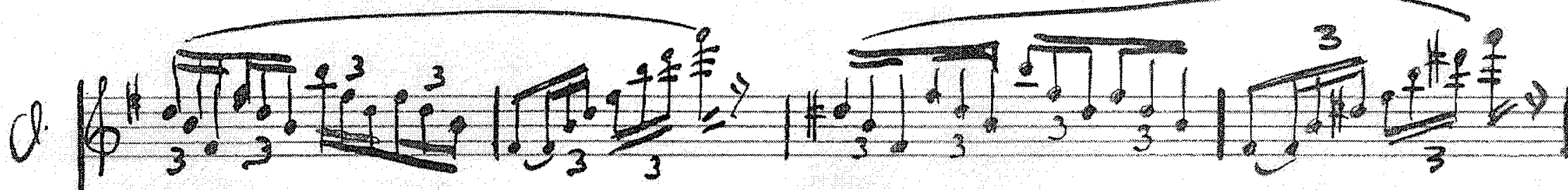

or

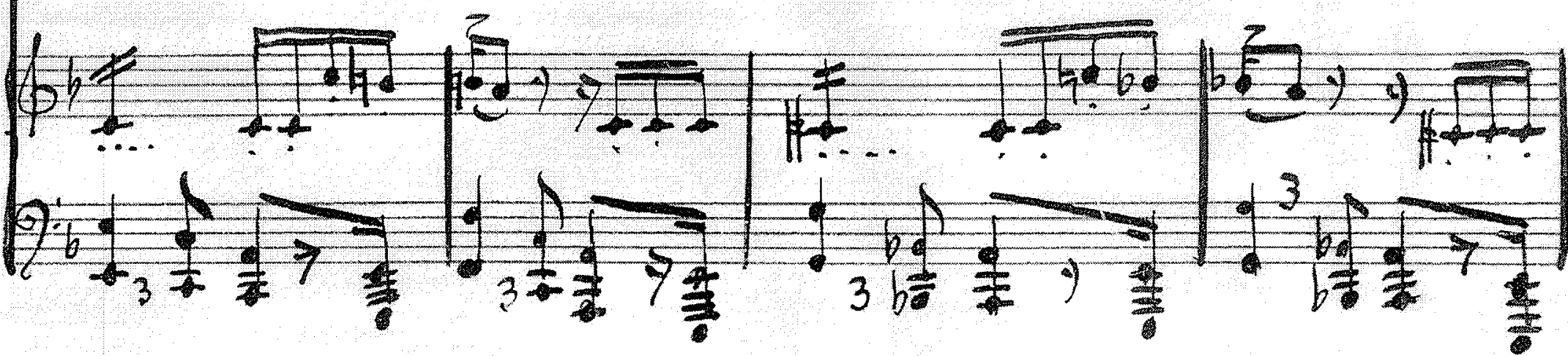



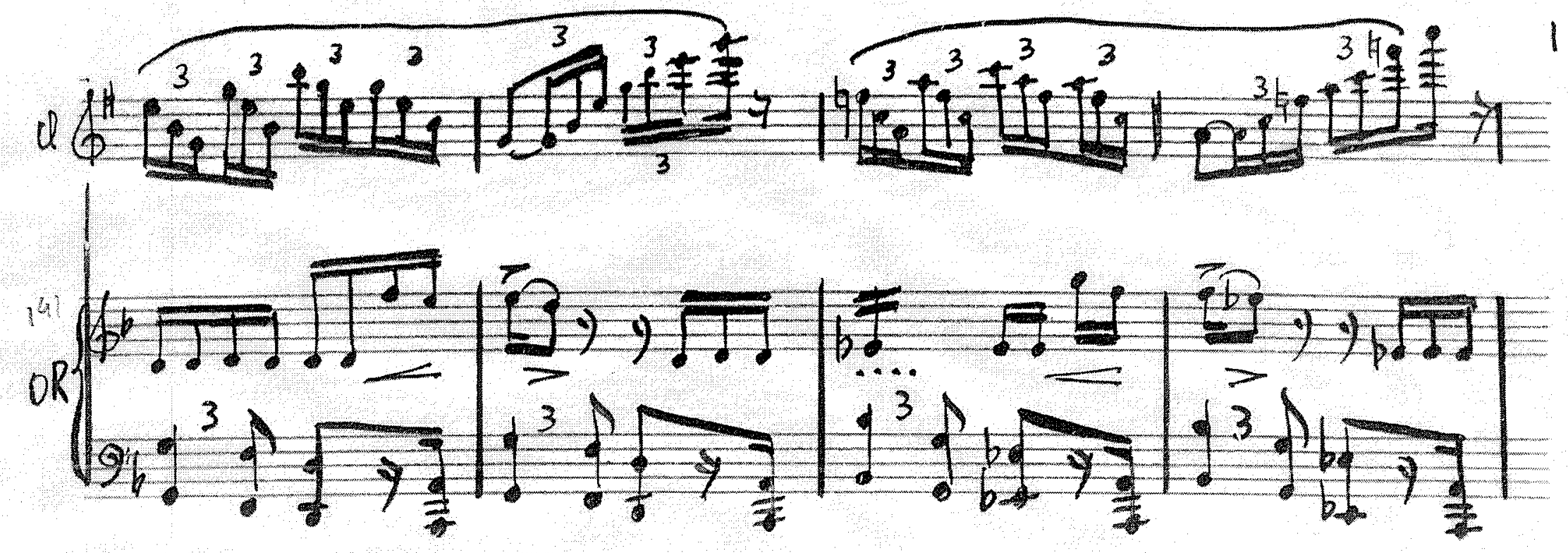
Q.

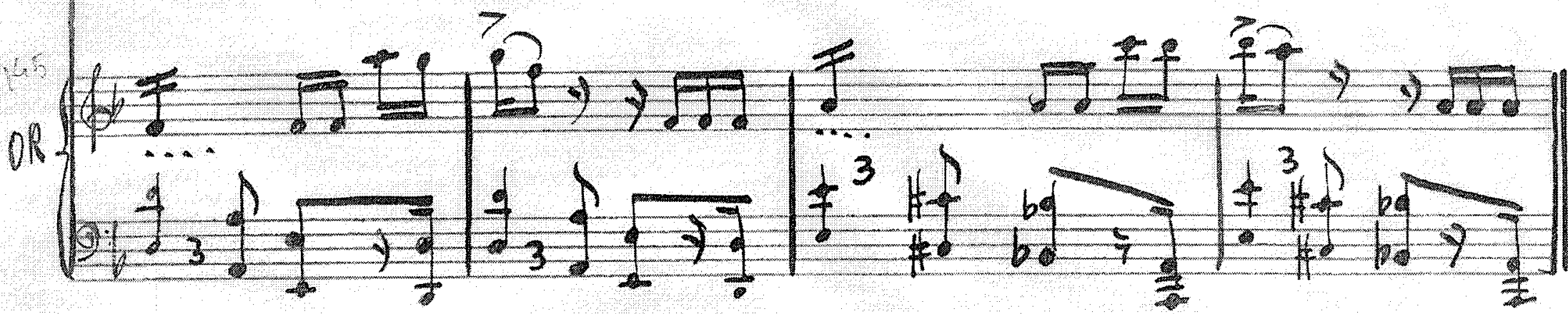
Riv Vivo(b) OR

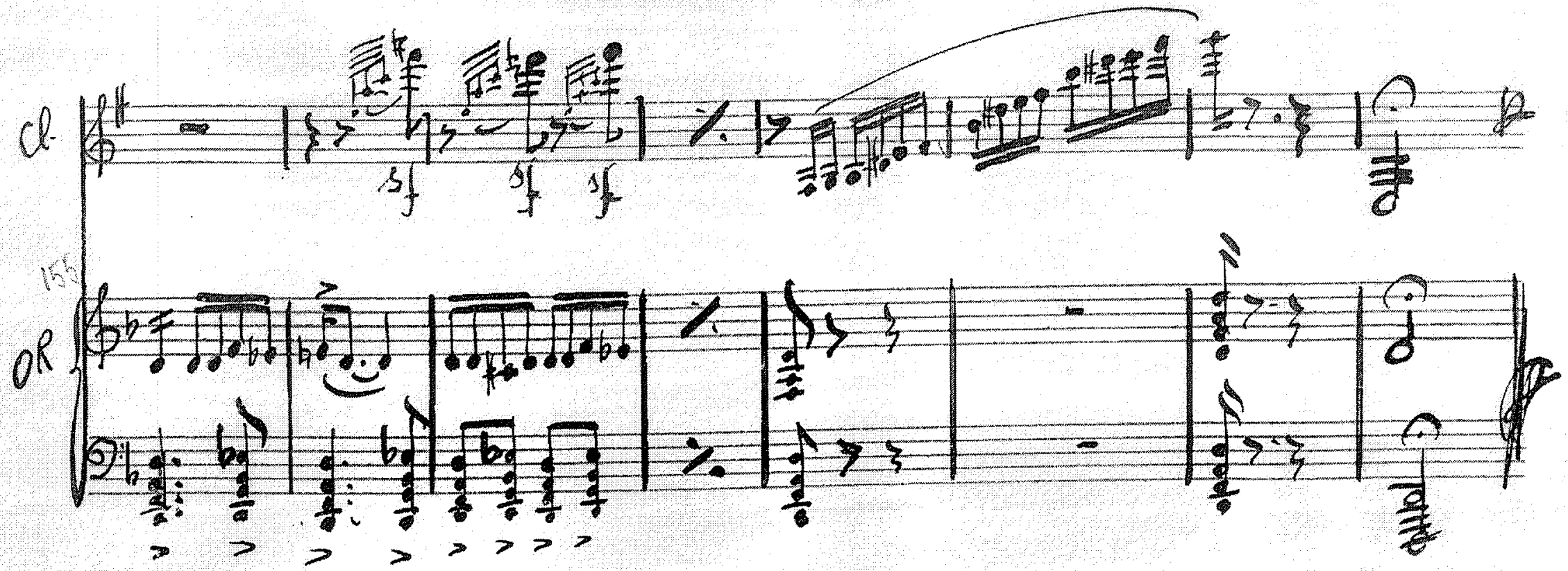




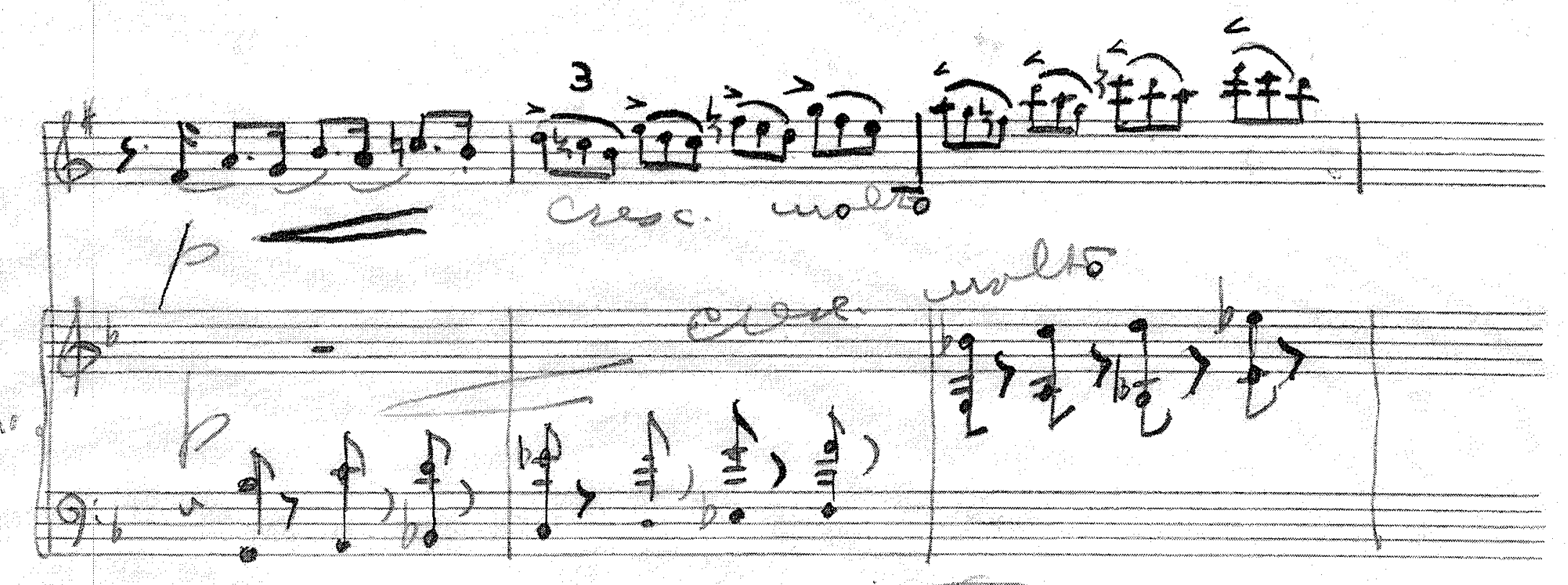

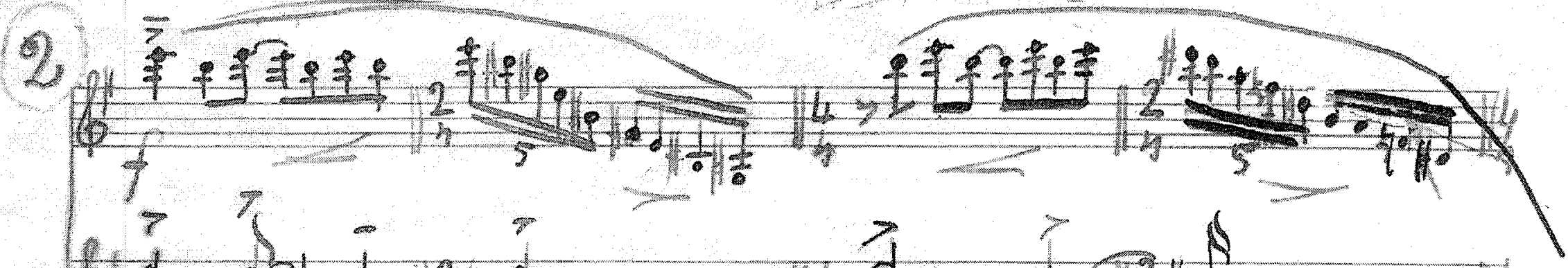

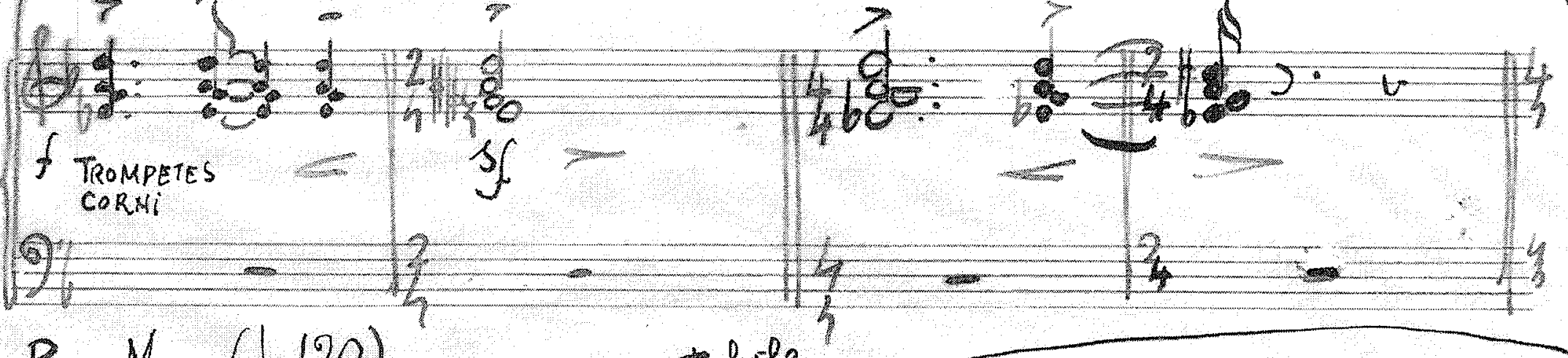

Poco Meno $(6=120) \quad$ coutabitle

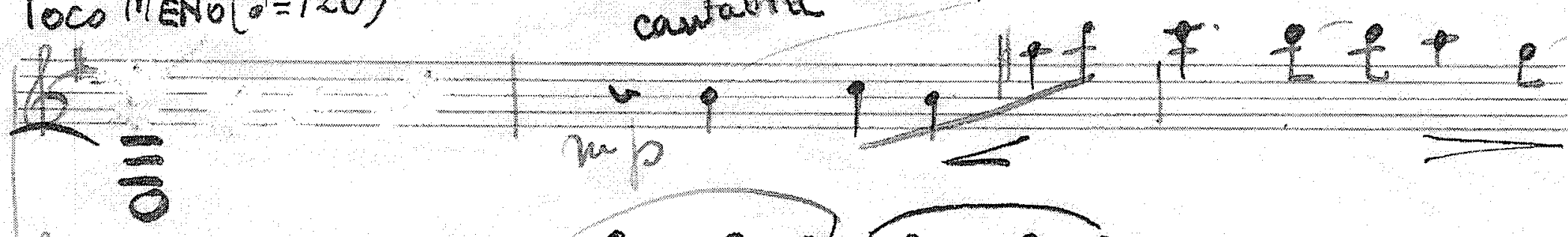

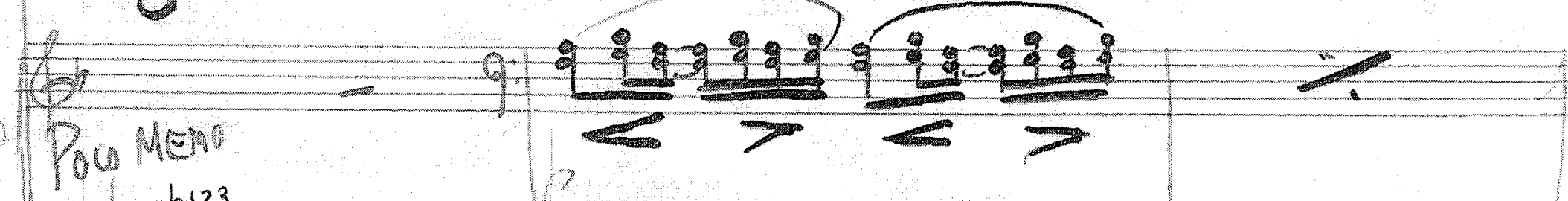

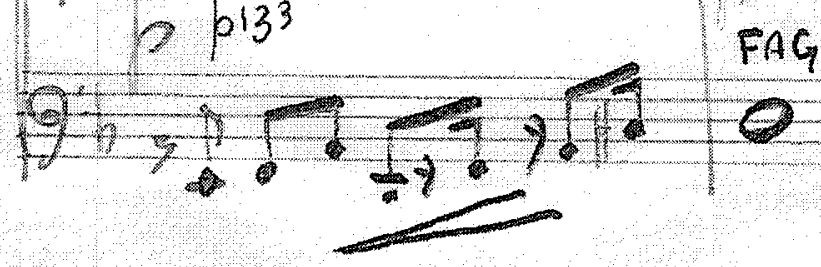

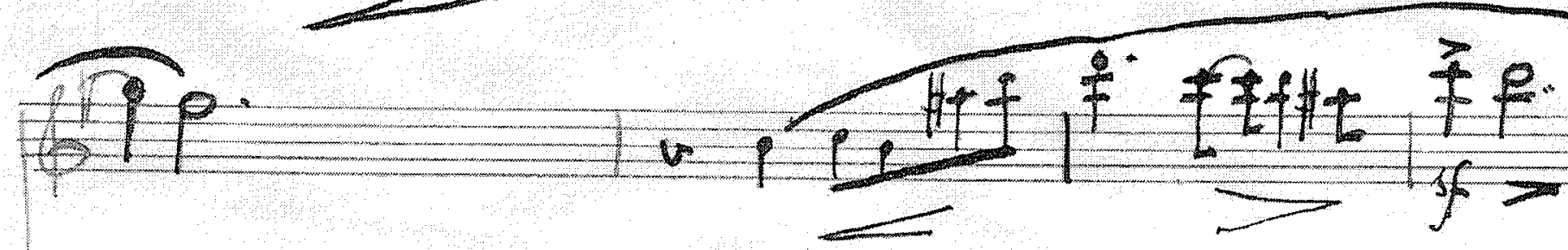

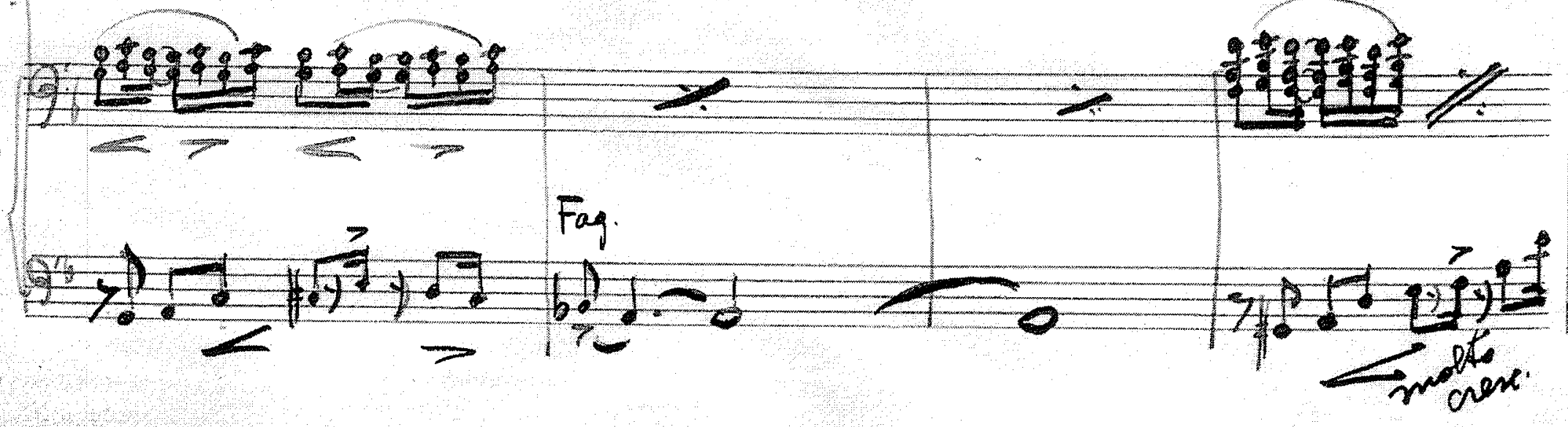




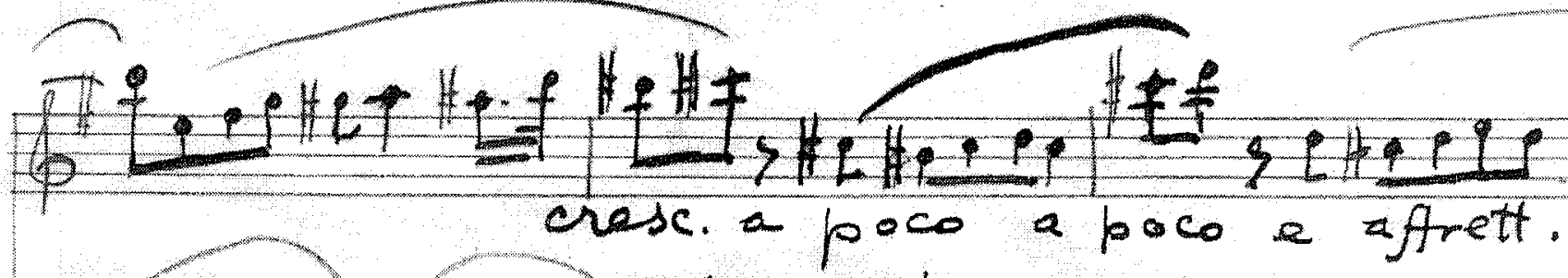

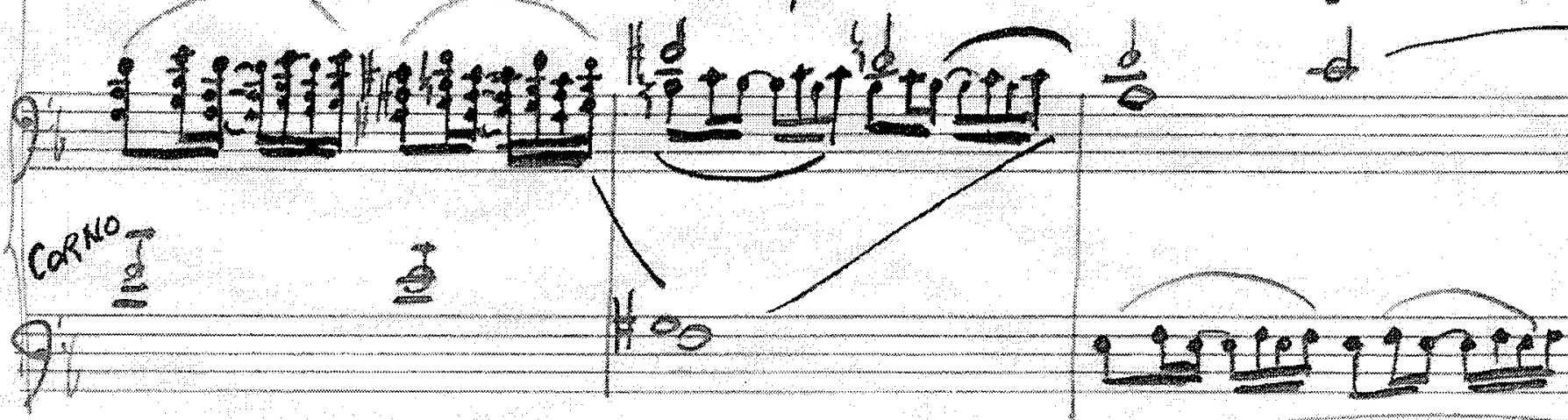

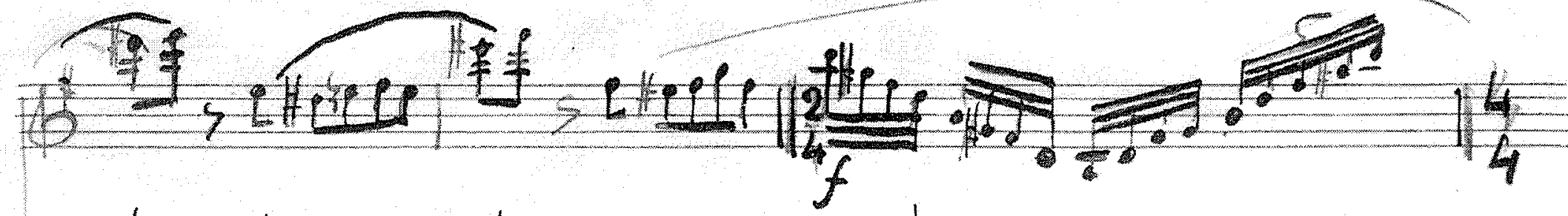

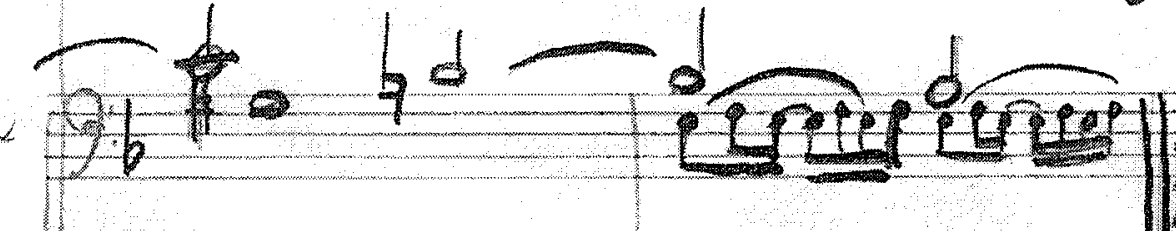

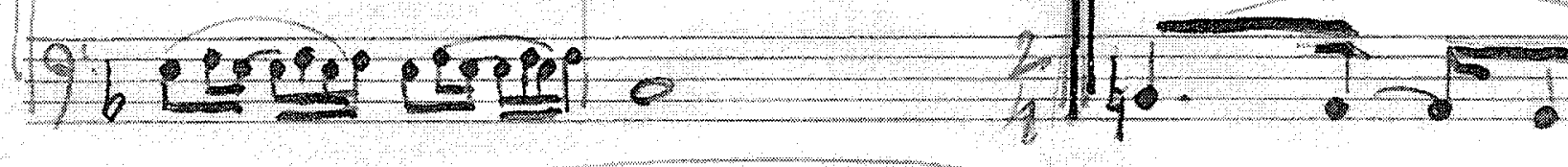

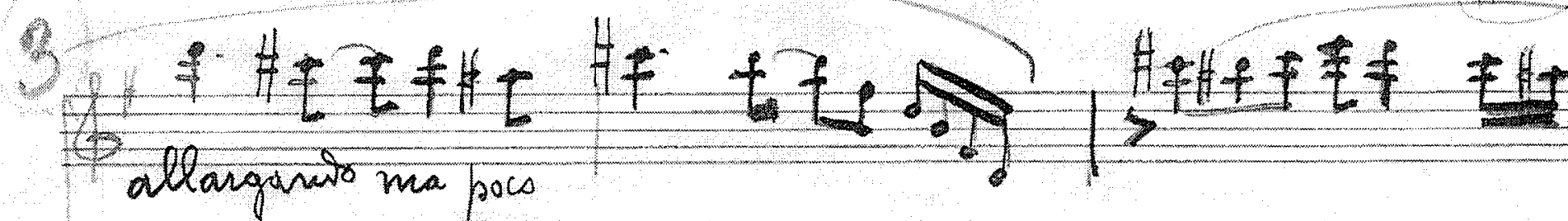
7.

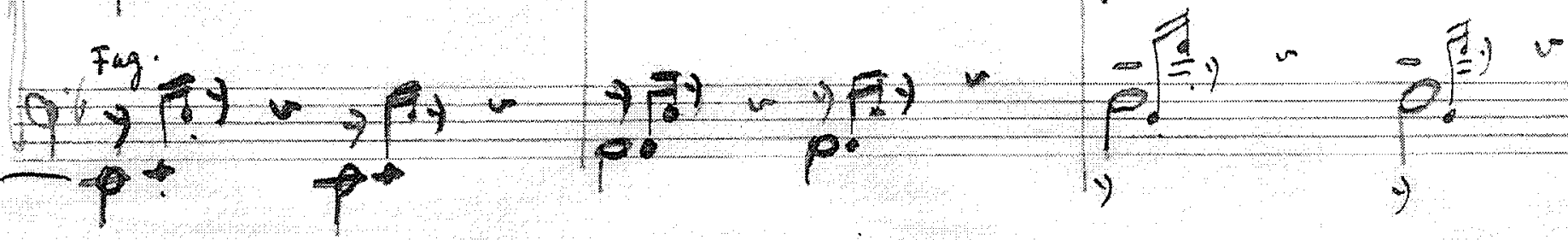

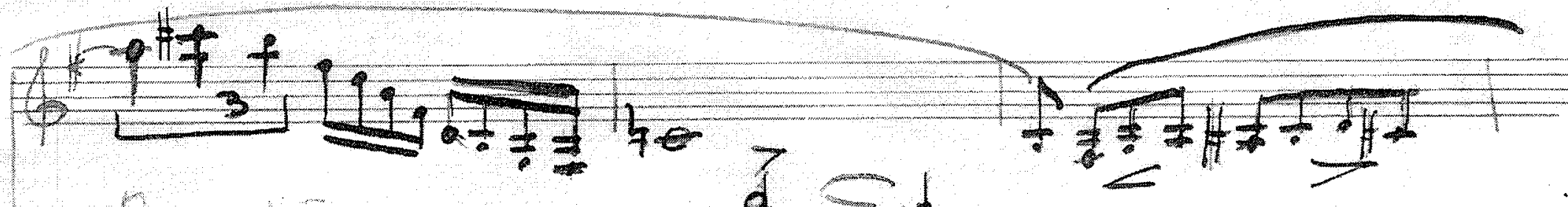

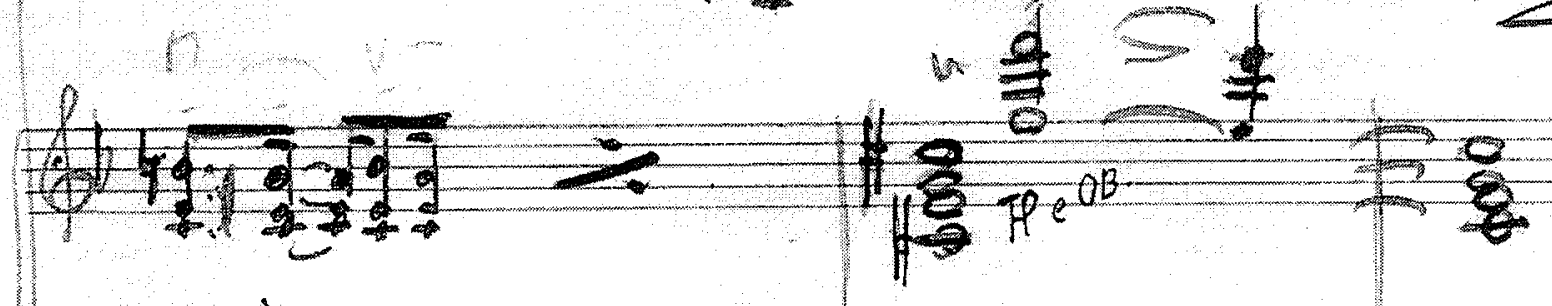

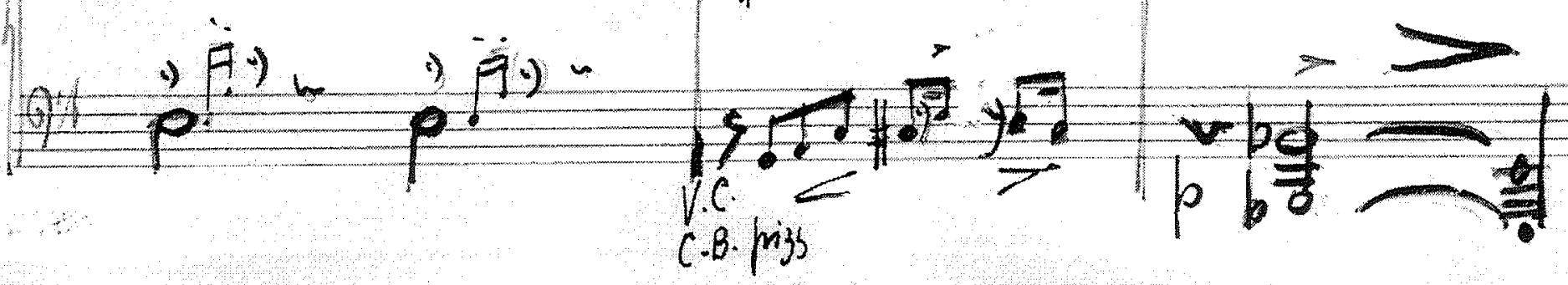




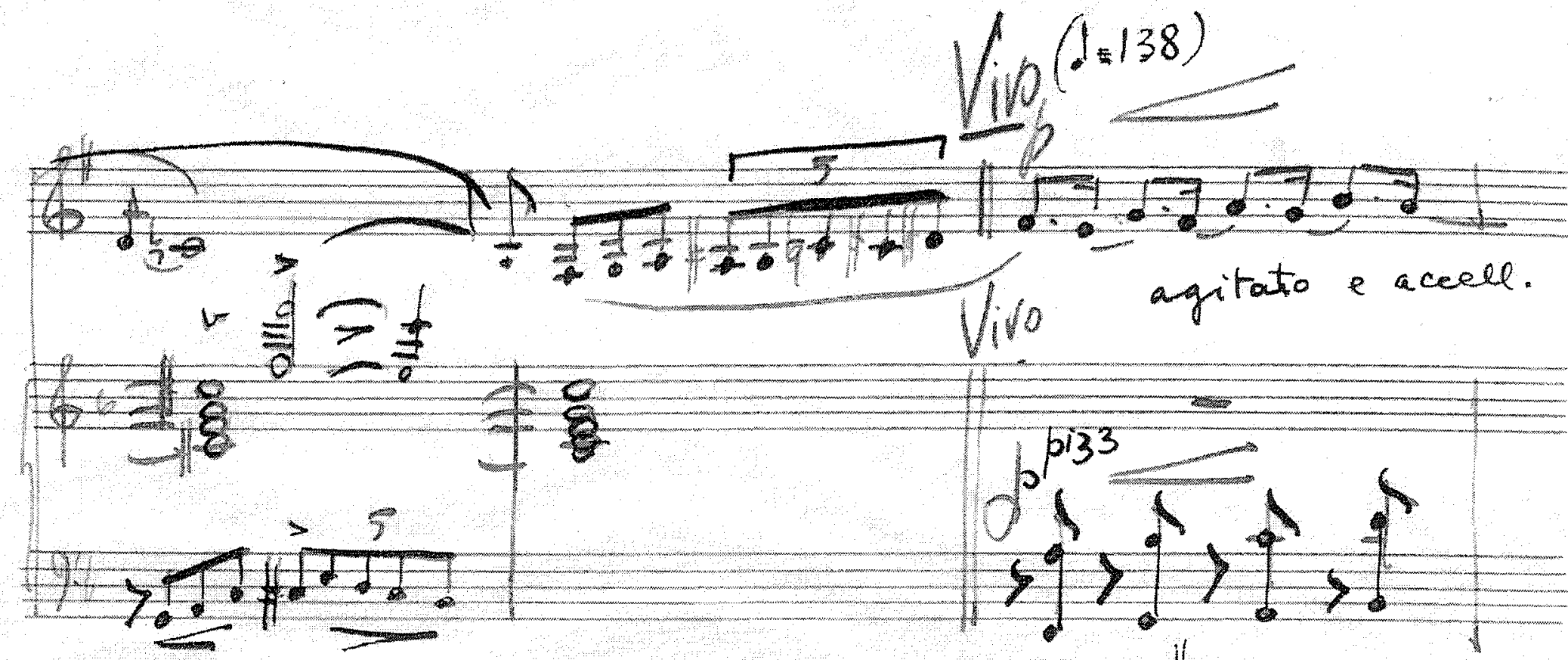

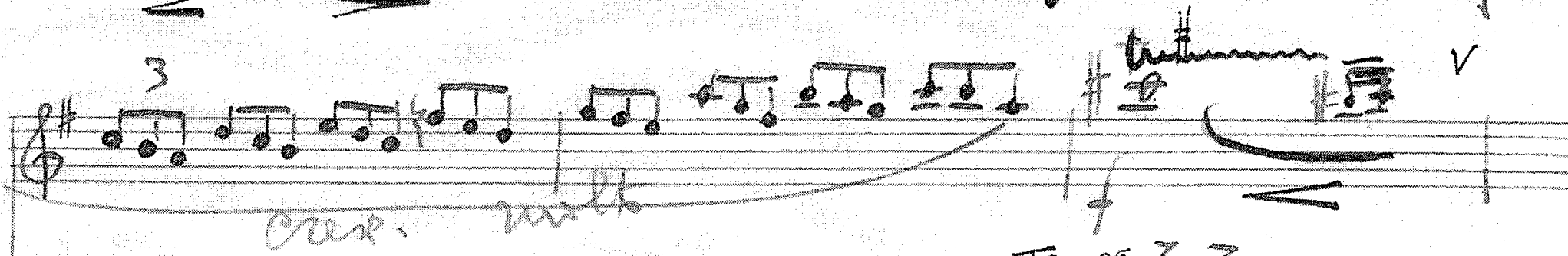

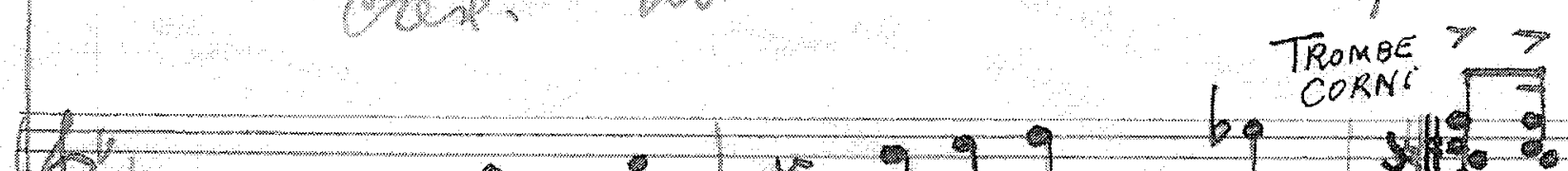

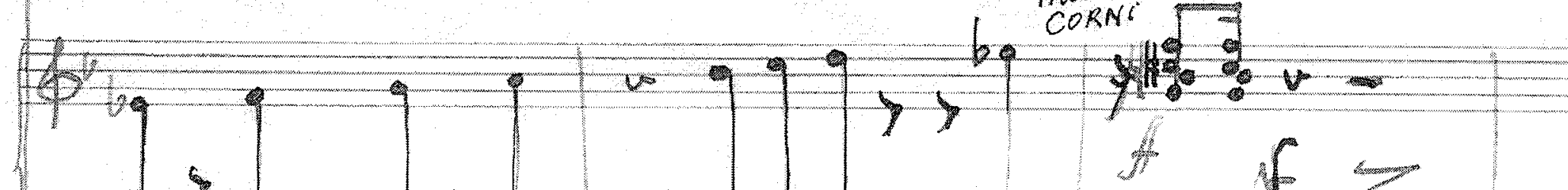

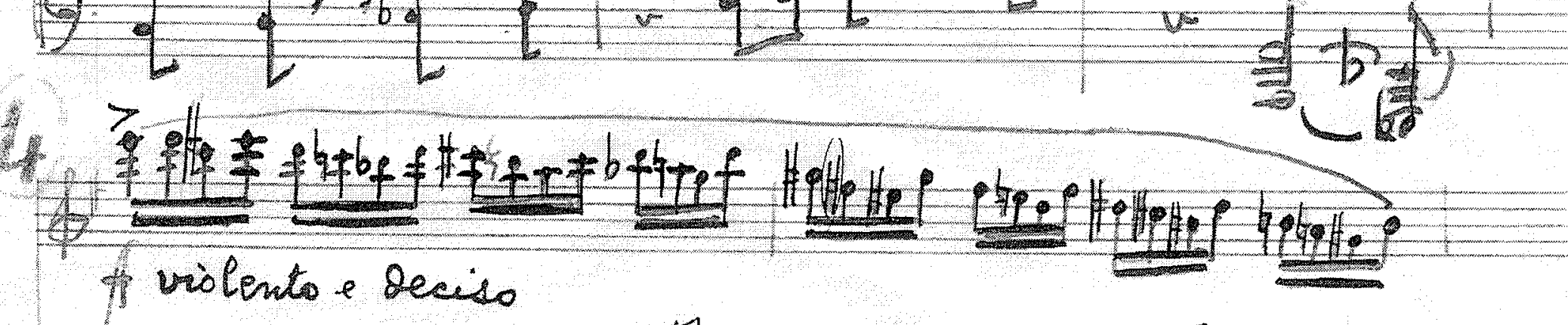

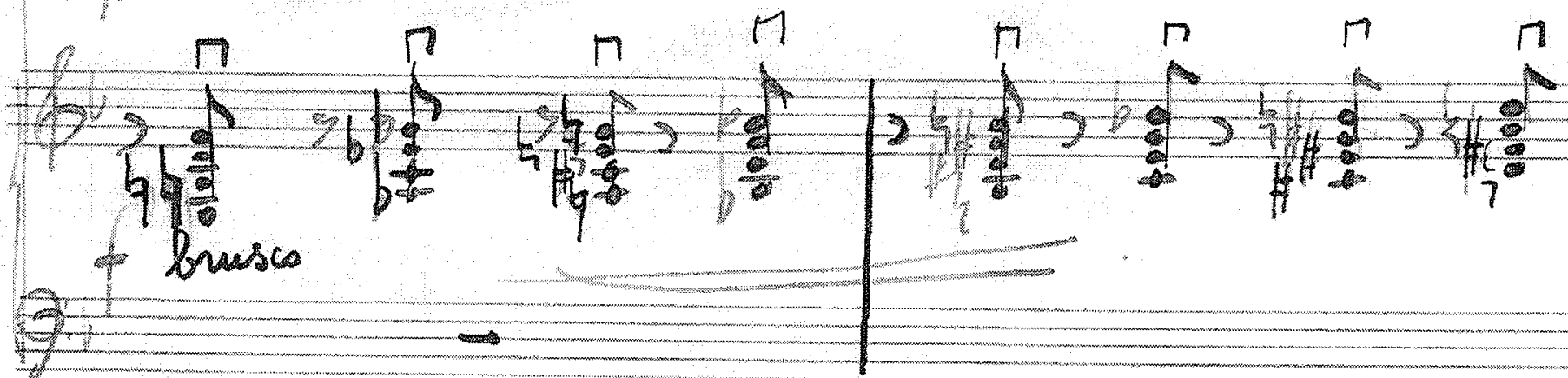

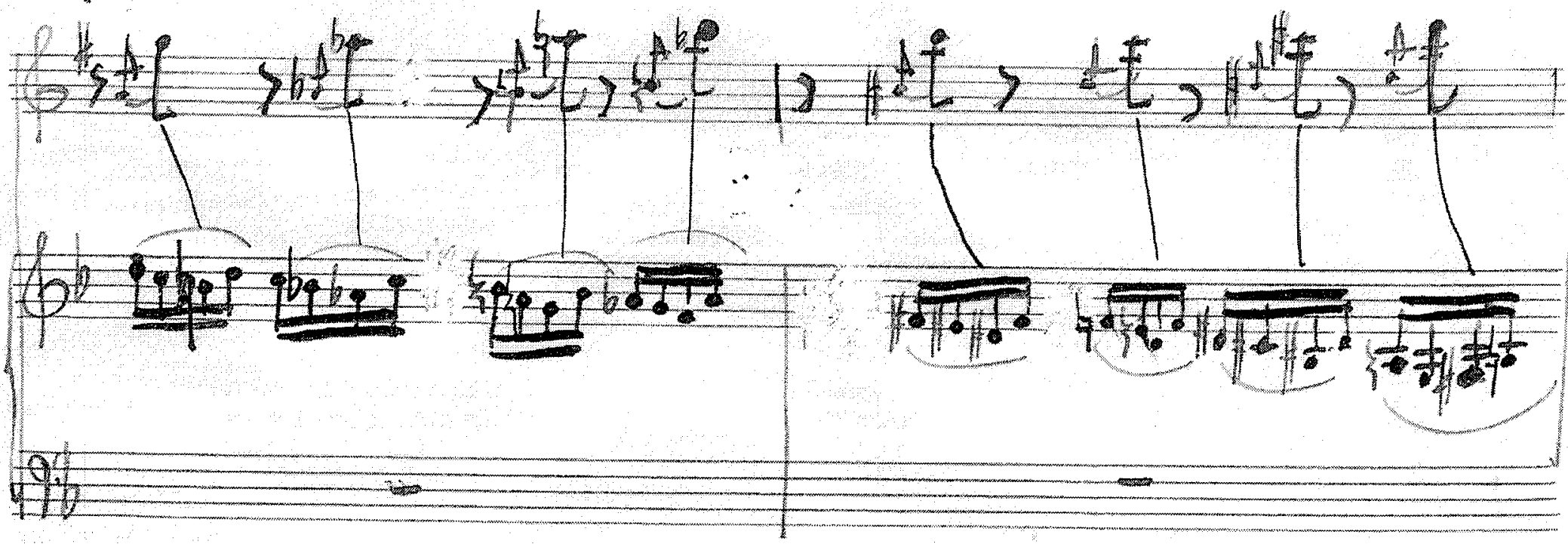




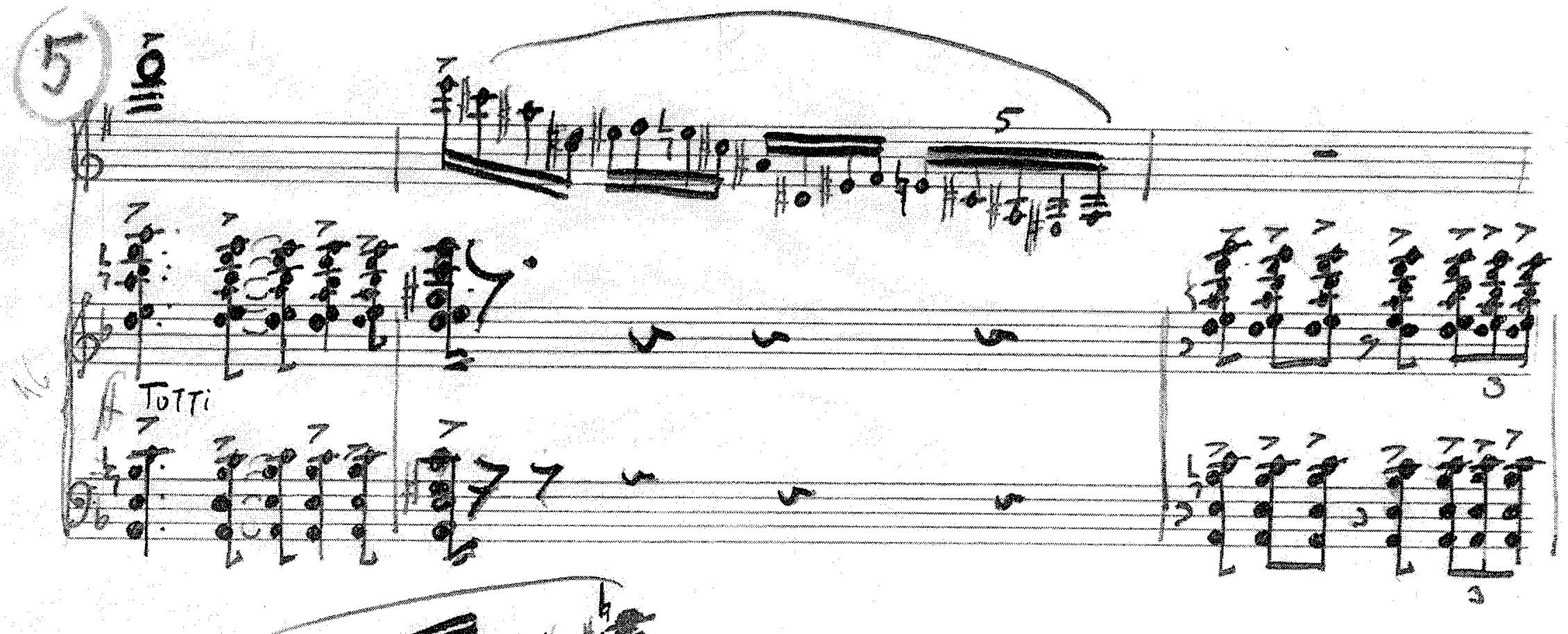

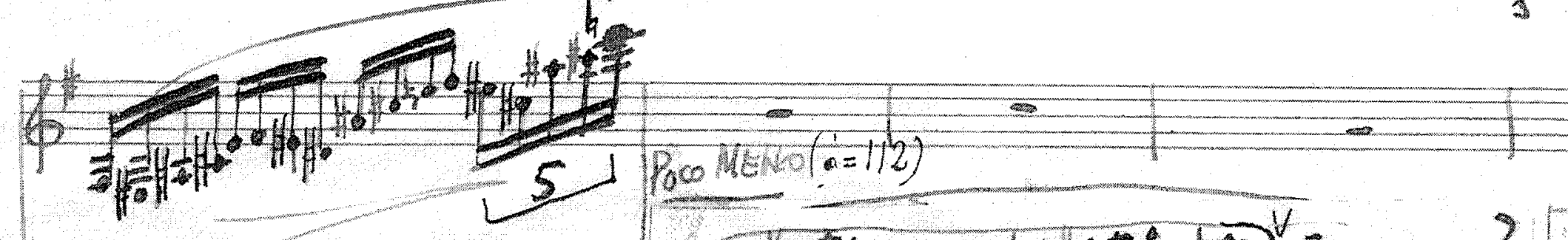

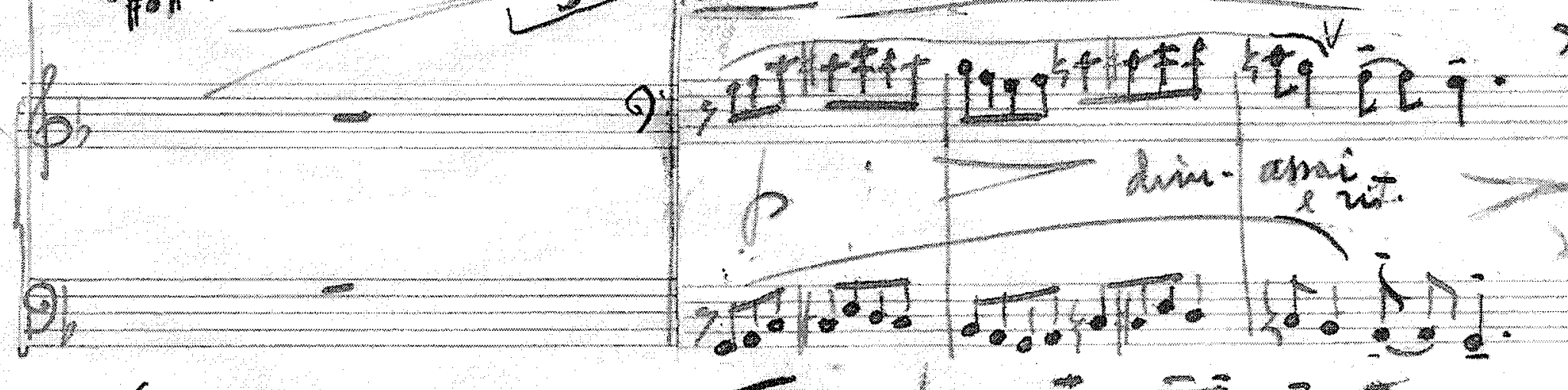

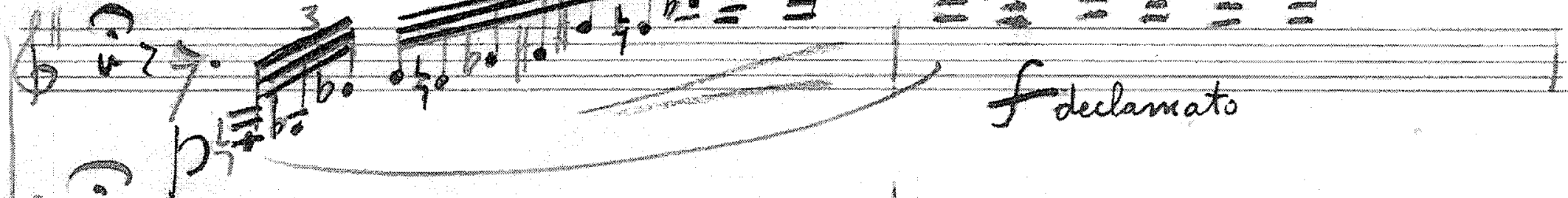

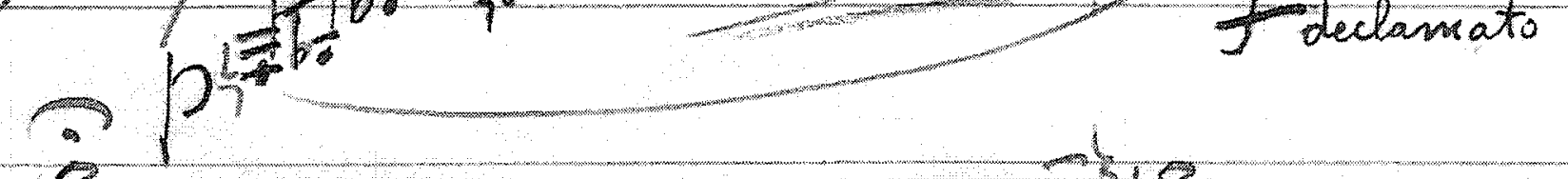

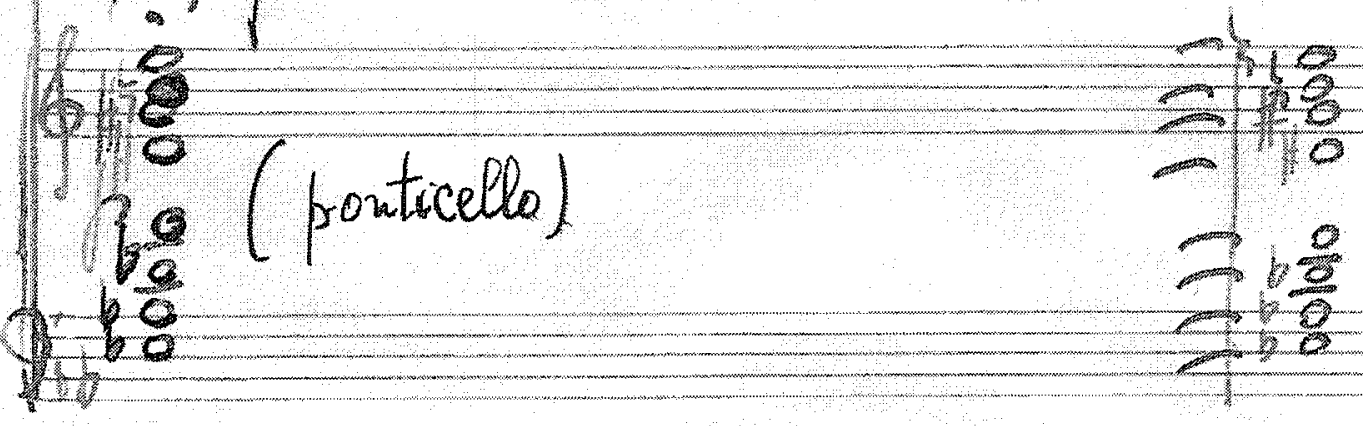

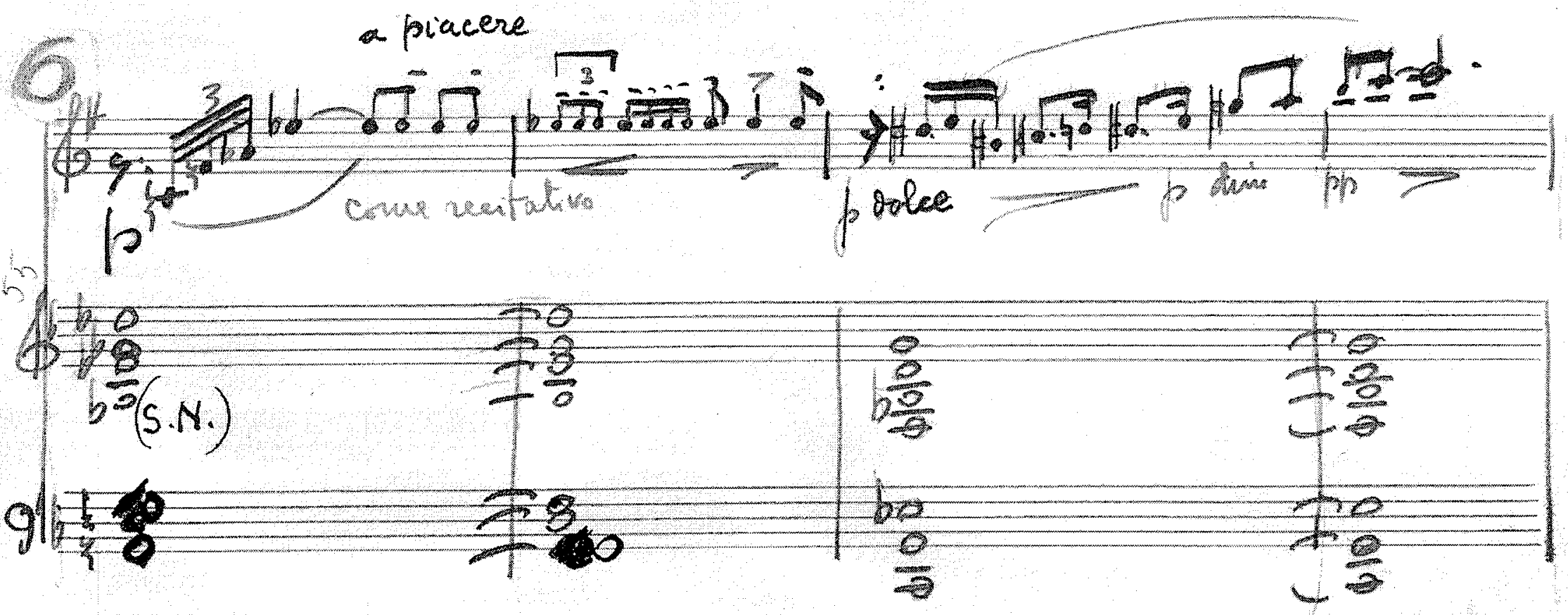




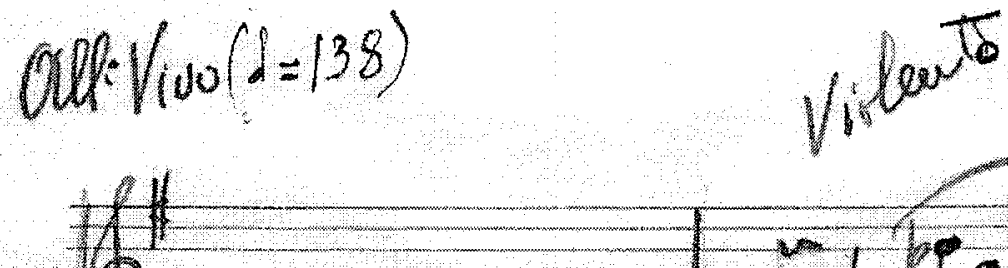

A

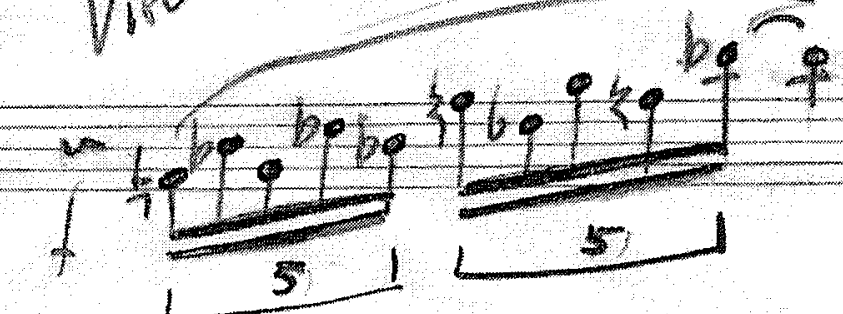

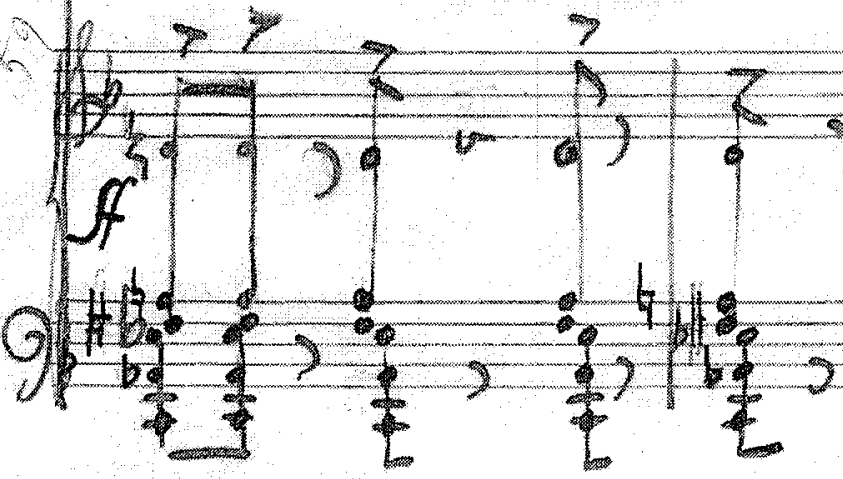

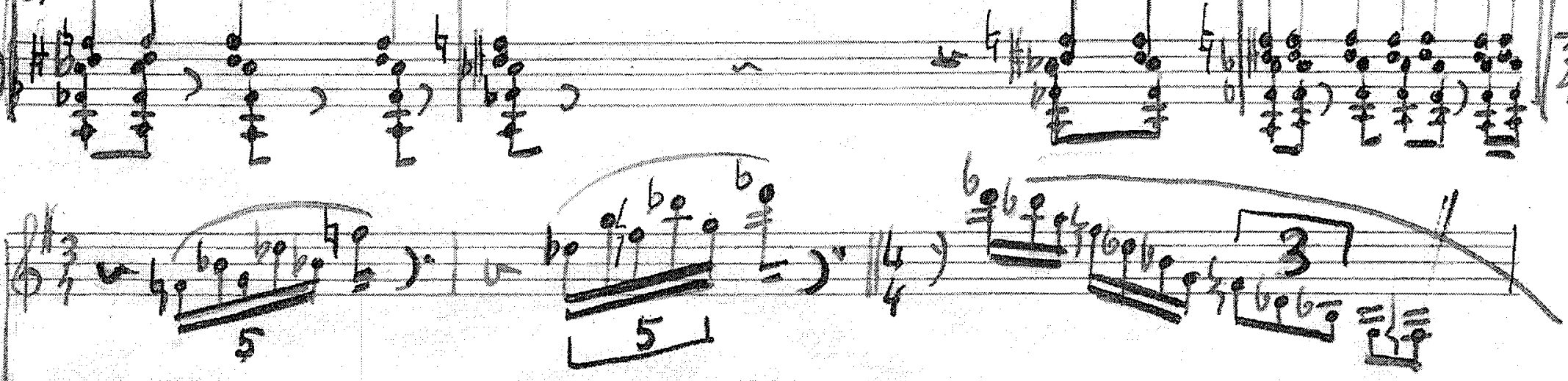

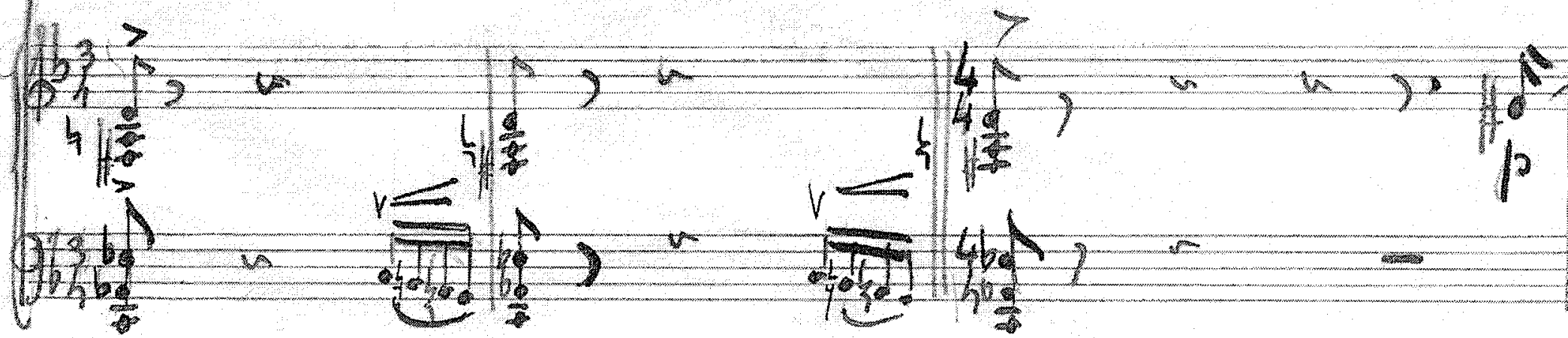

के

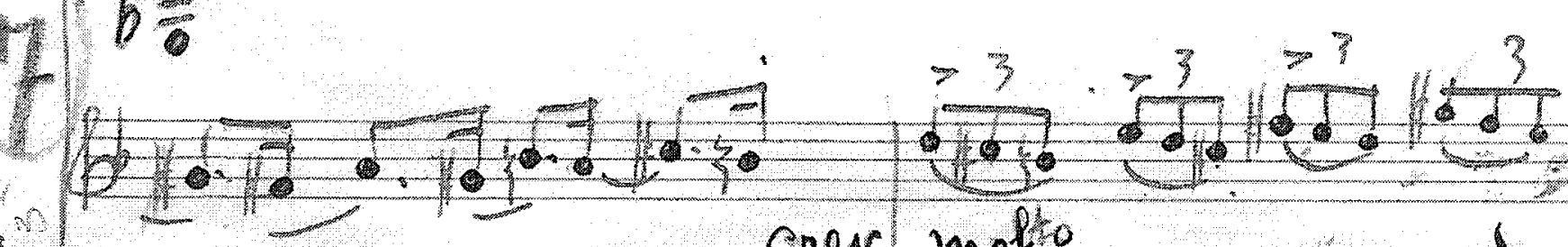

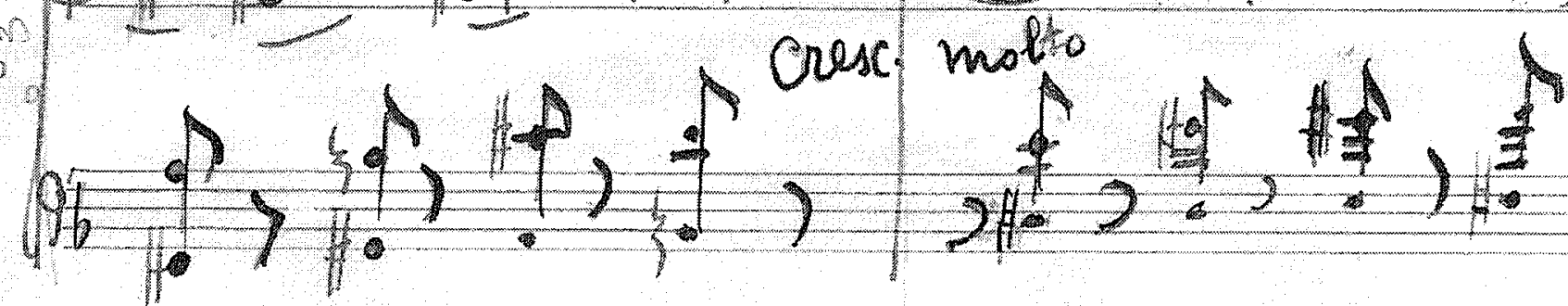

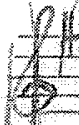

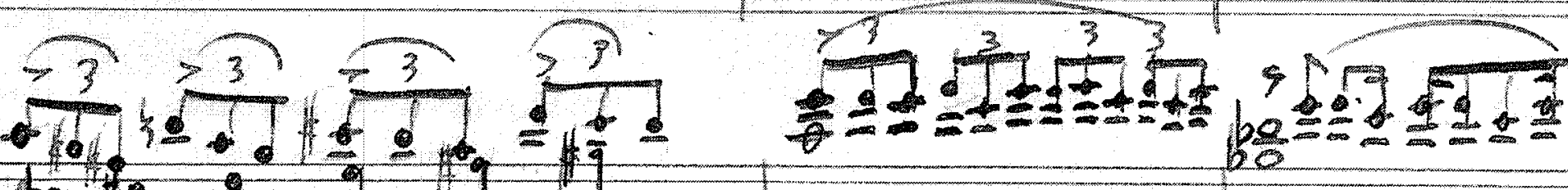

(4)

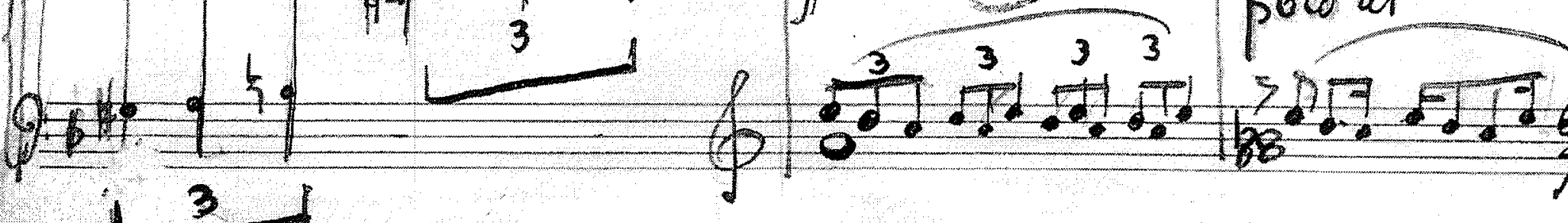




\section{(8)}

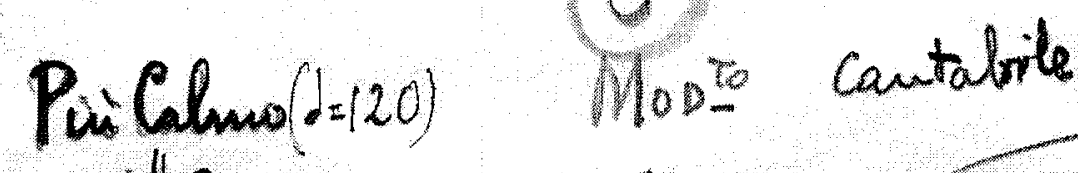

19

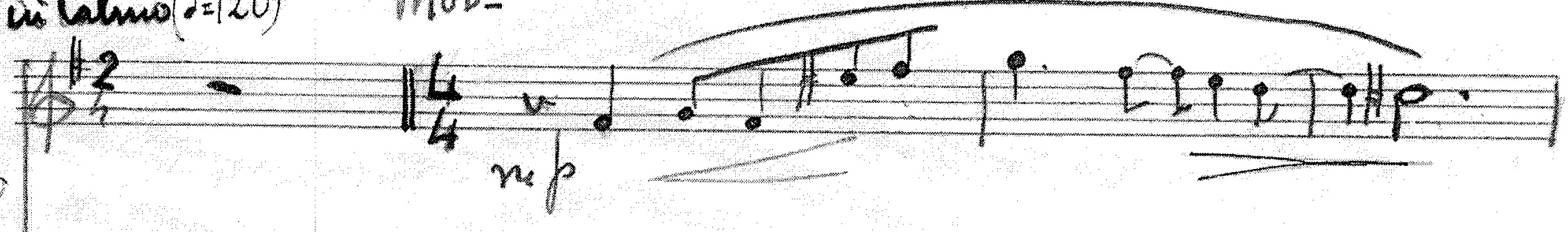

ती

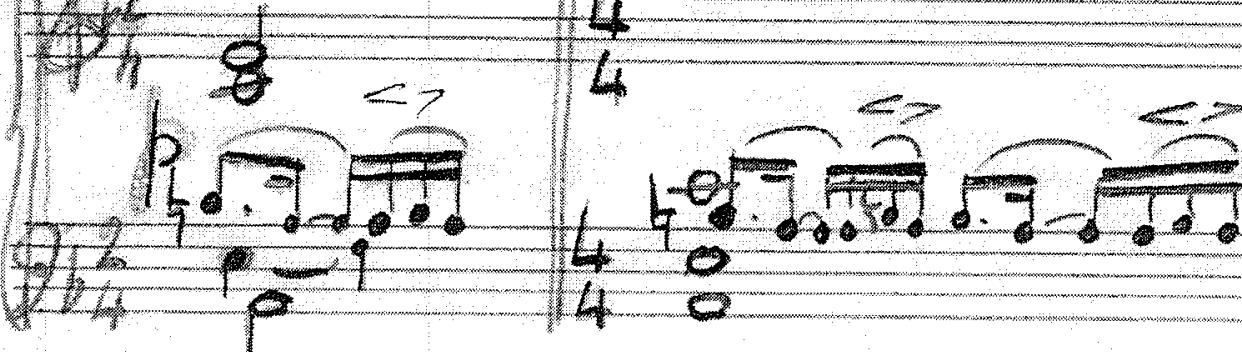

$\int_{4}^{4}$

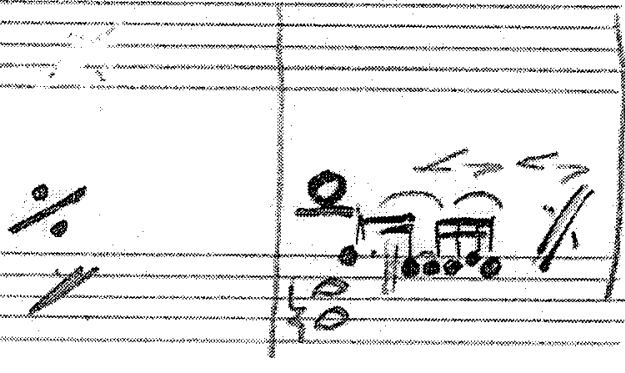

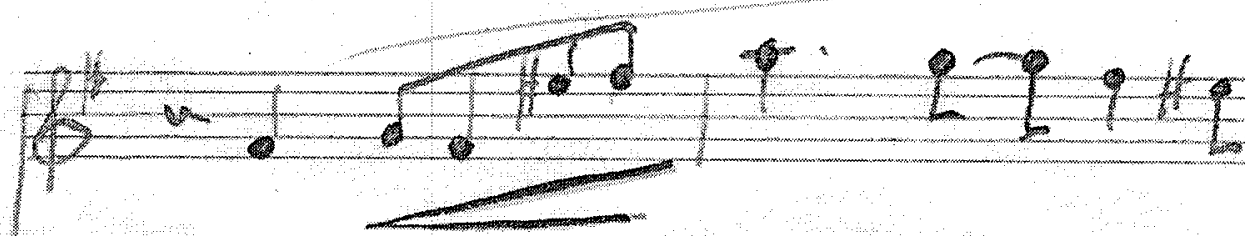

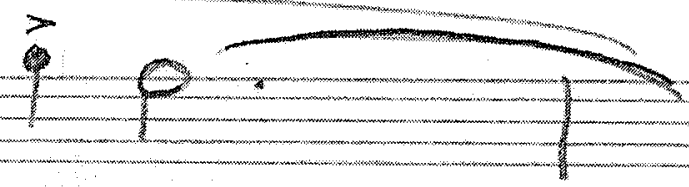

$\frac{4}{12}$

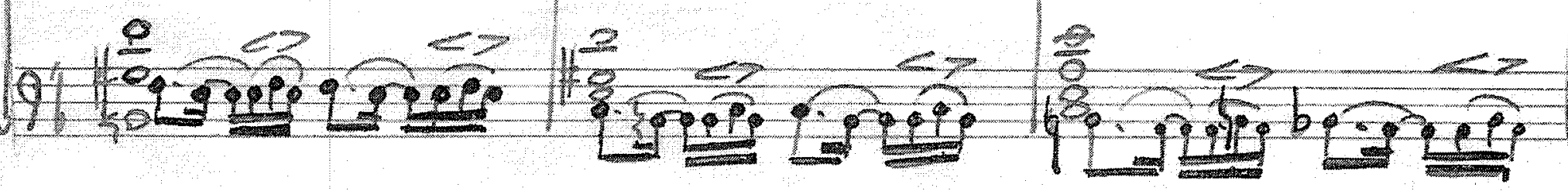

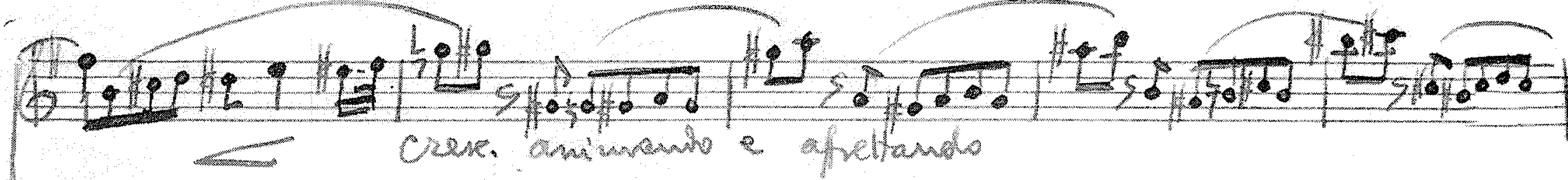

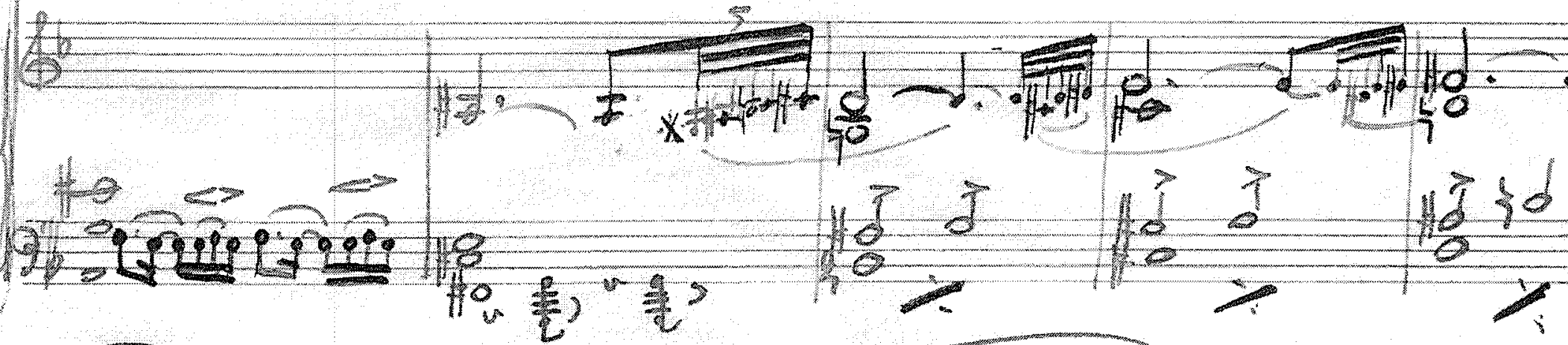

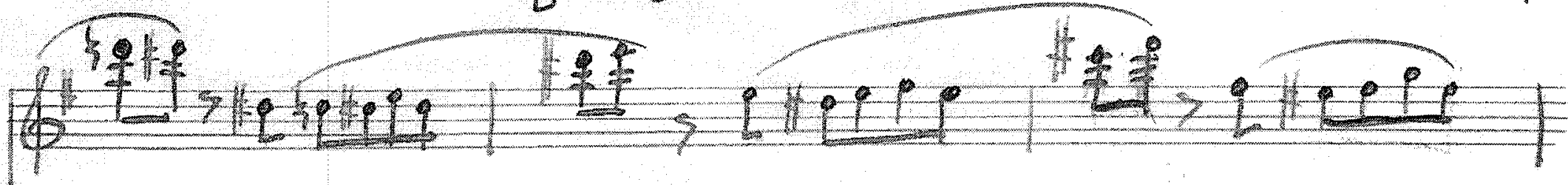

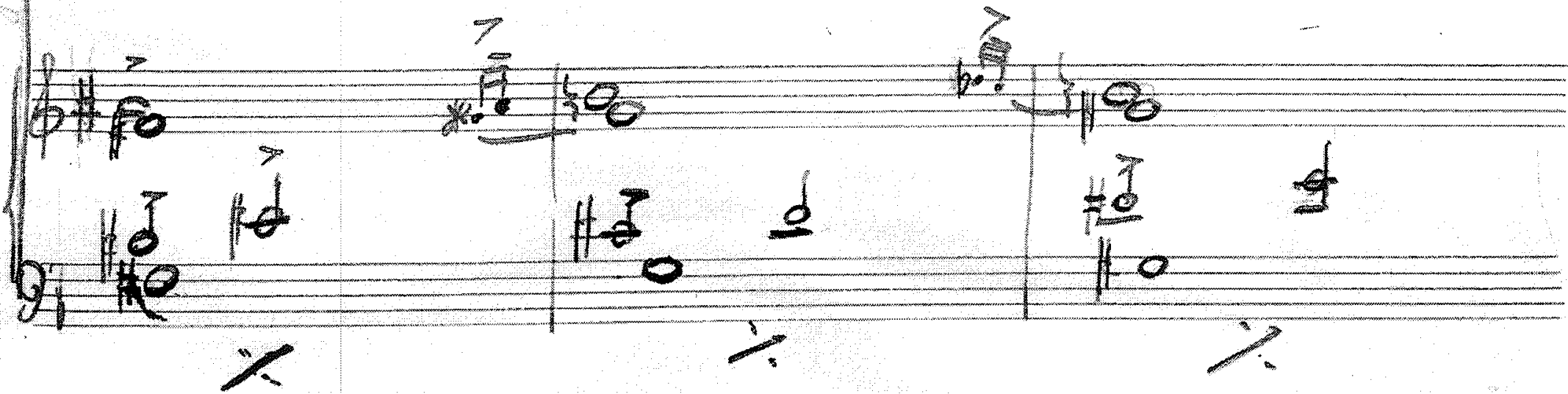




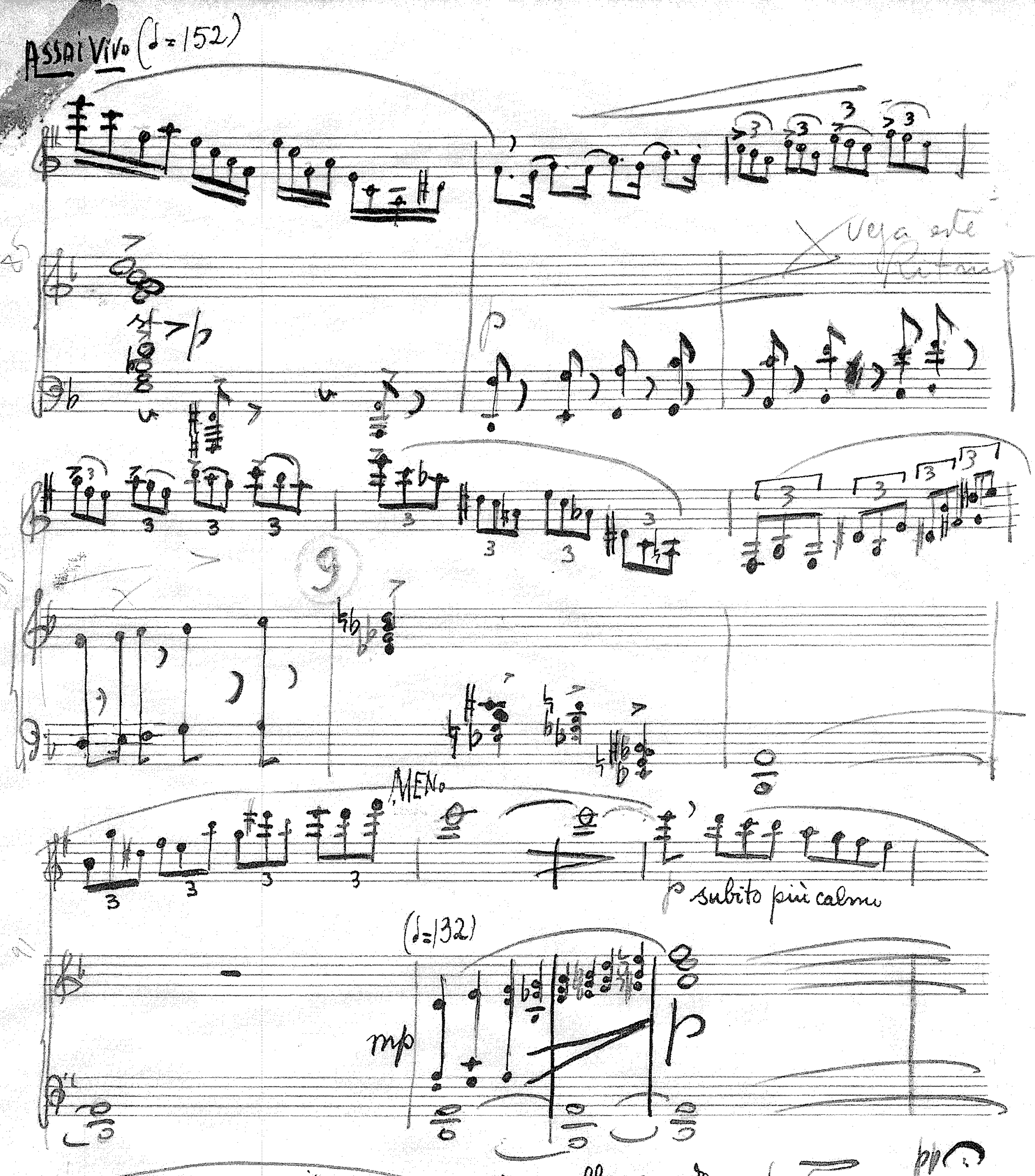

4

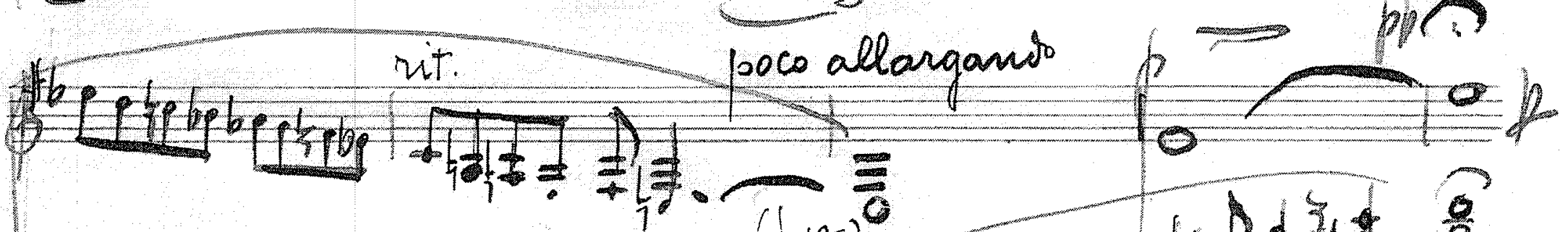

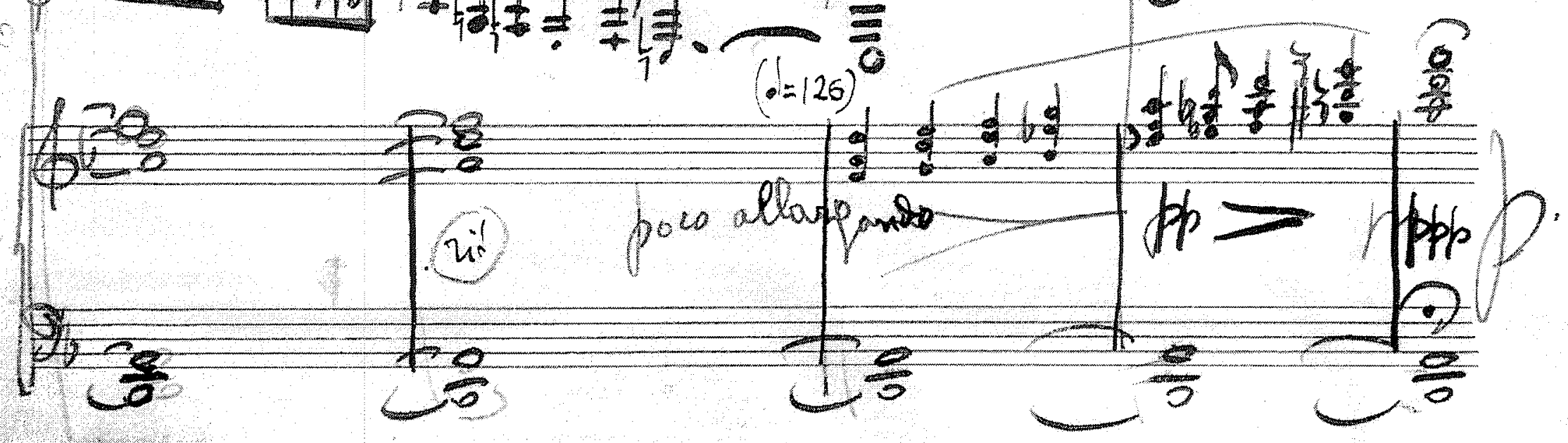


AND ${ }^{N-}$ MA NON TROPPO
$\log _{4}$
$(\alpha=108)$
MON ma wo tropho

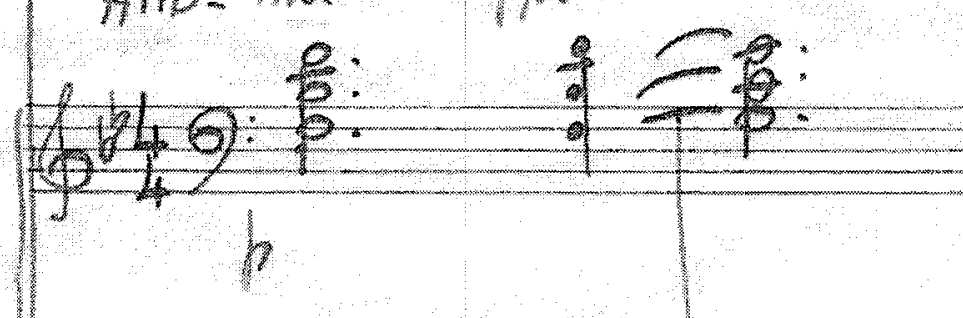

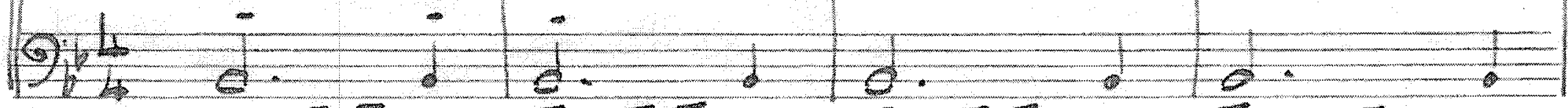

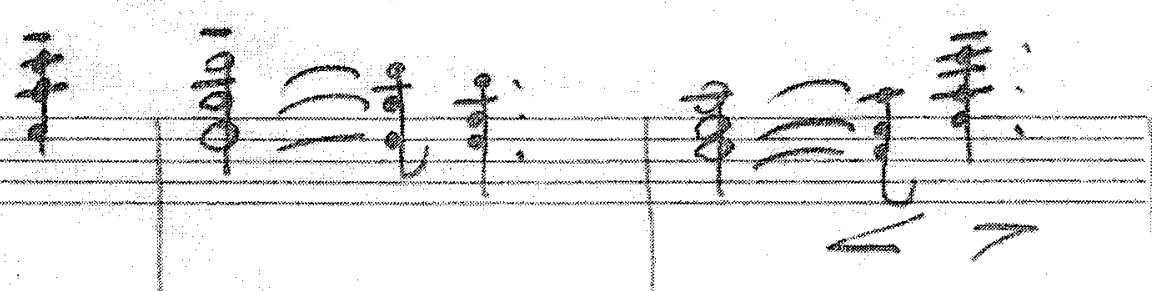

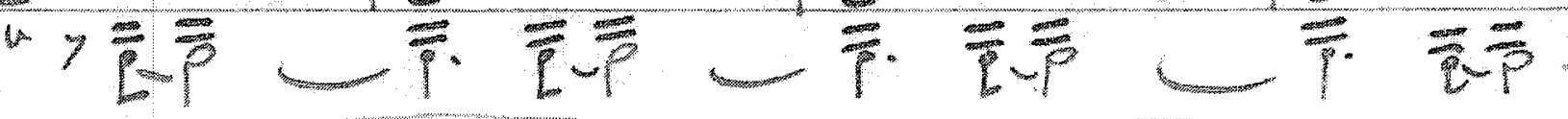

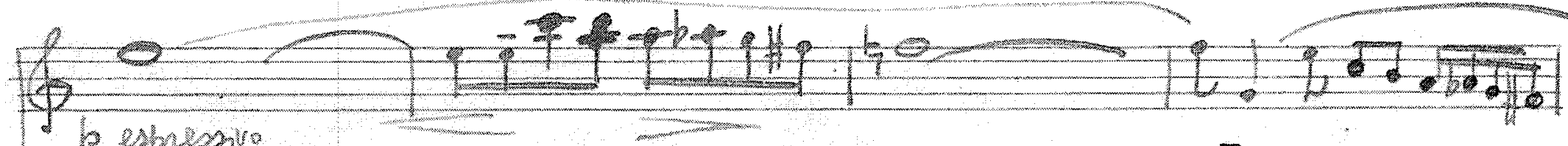

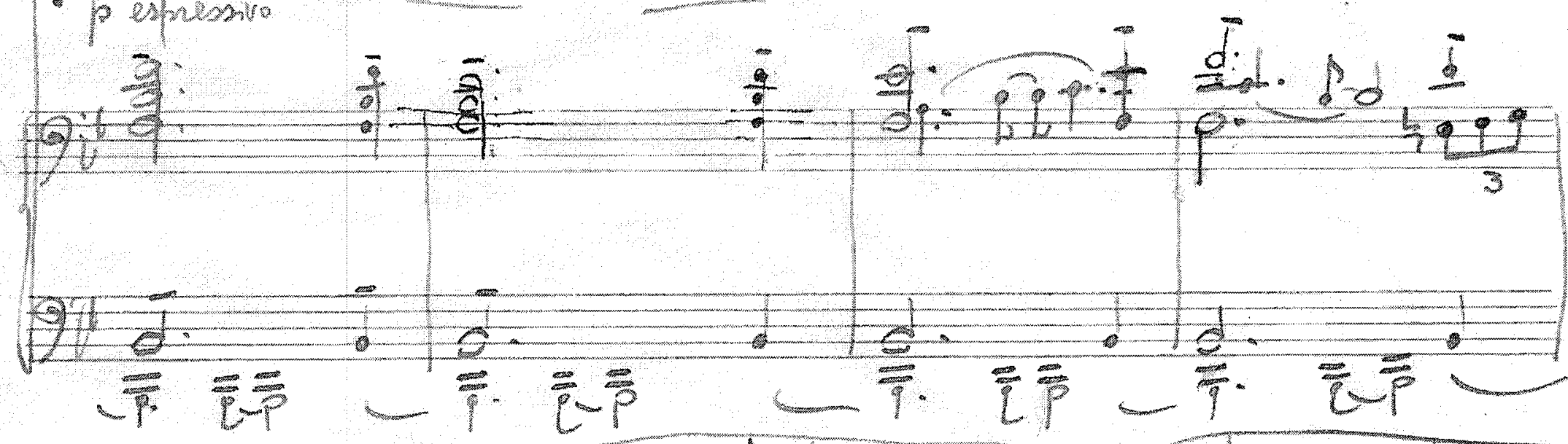

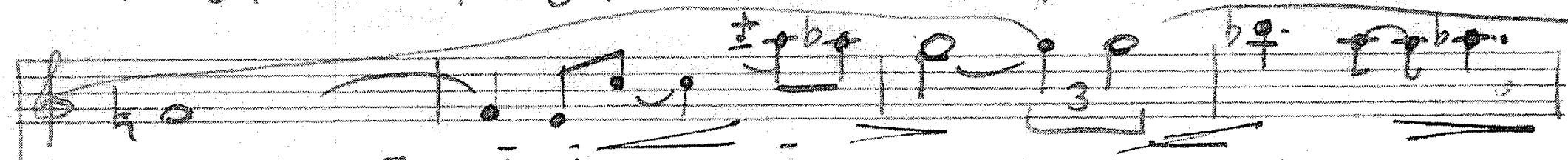

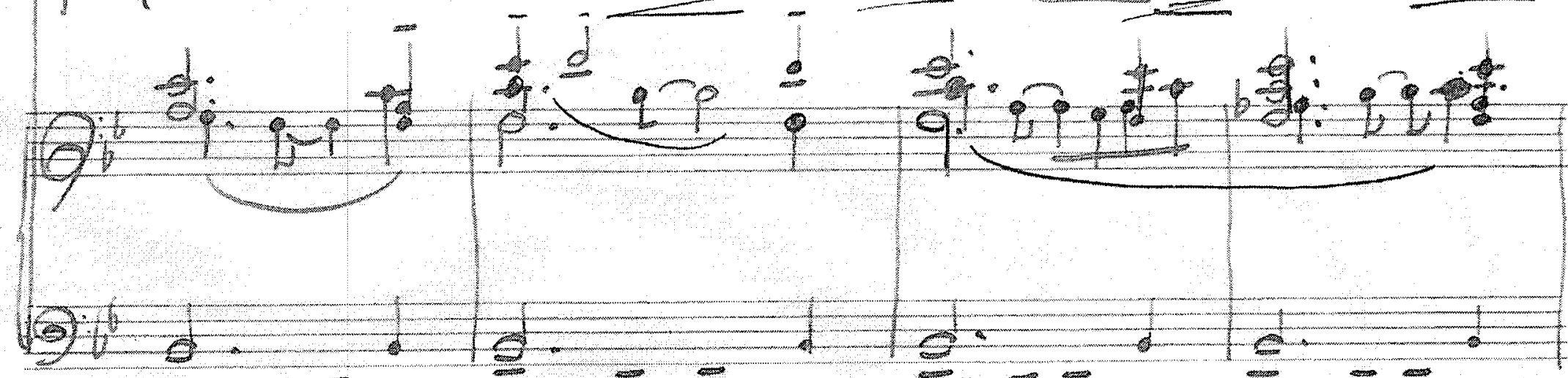

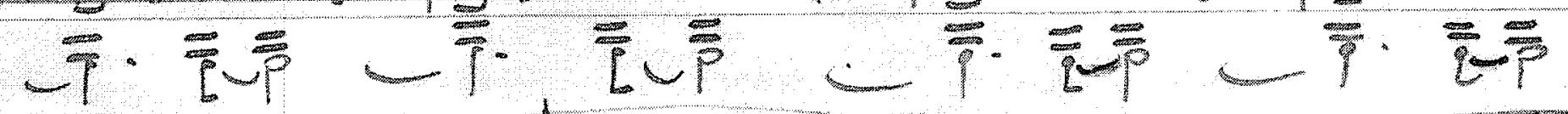

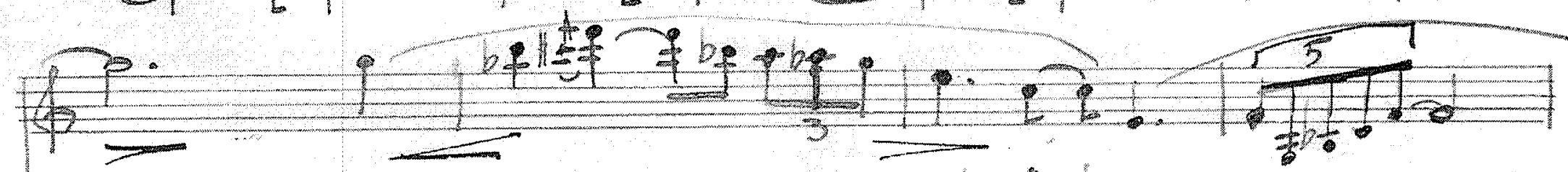

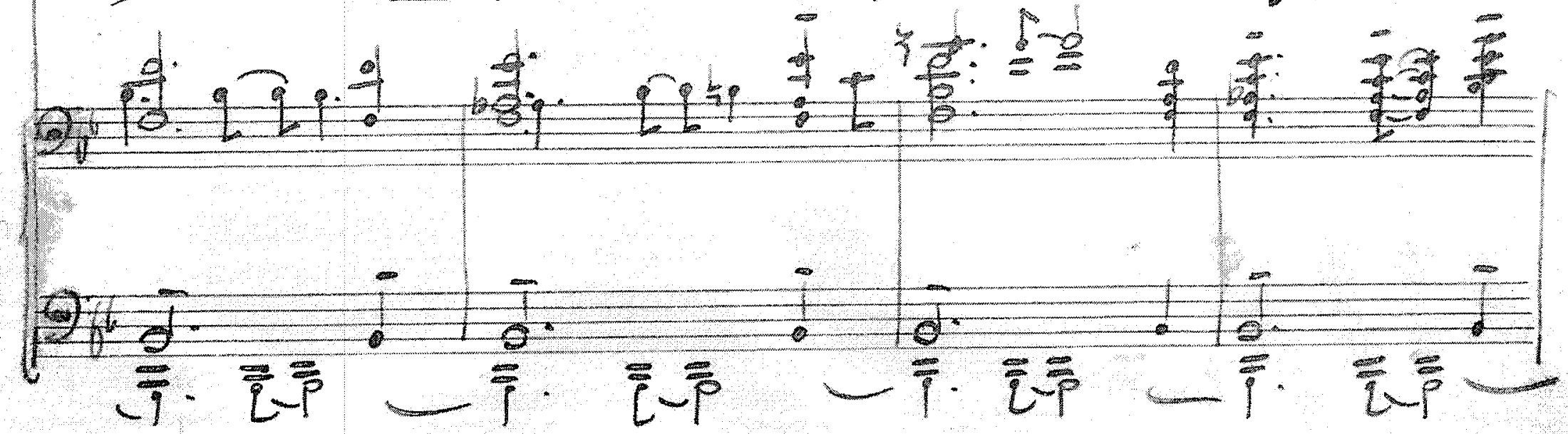




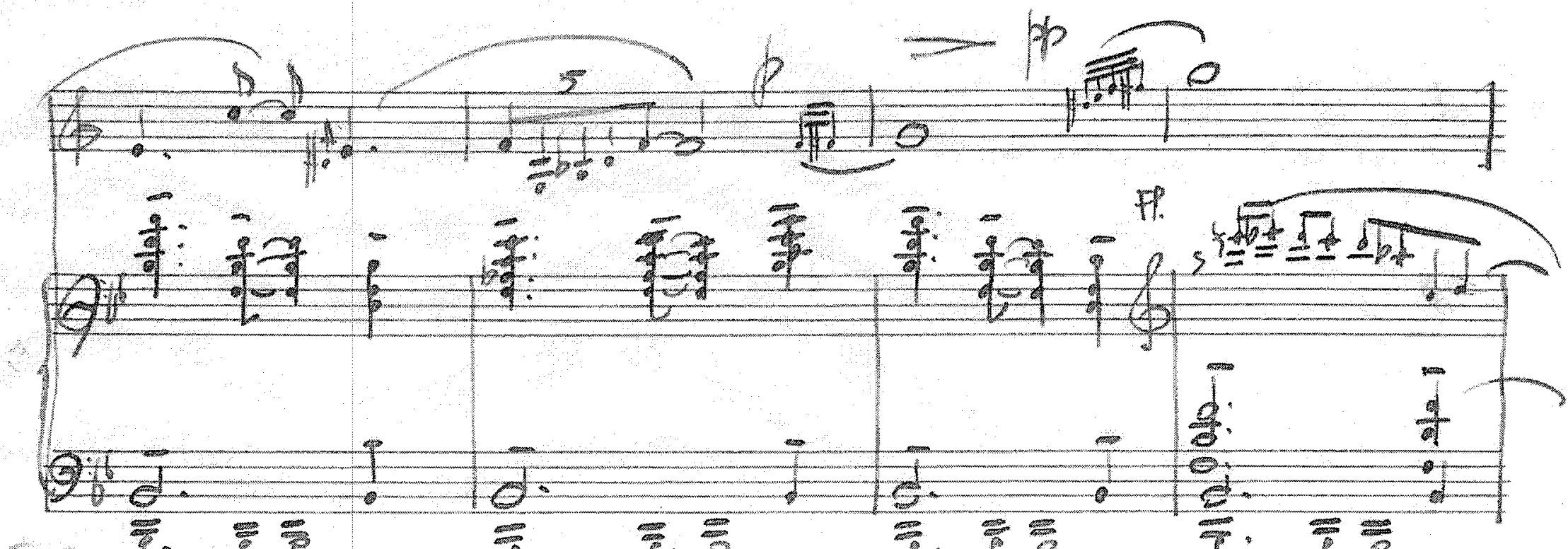

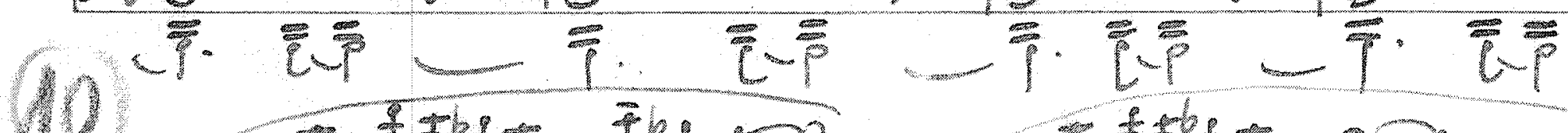

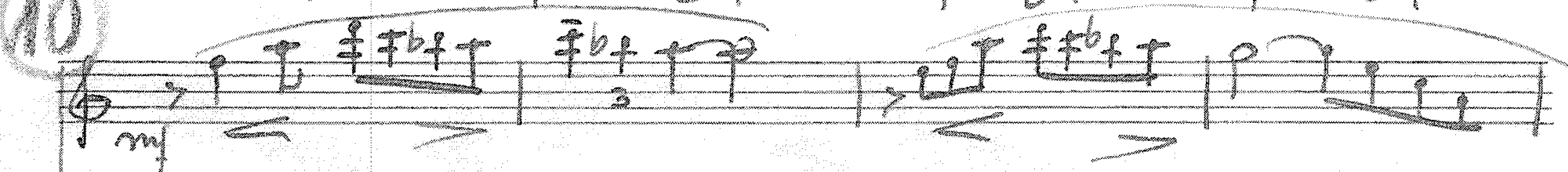

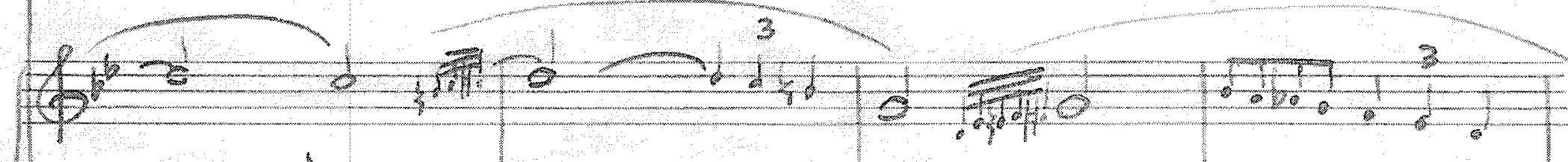

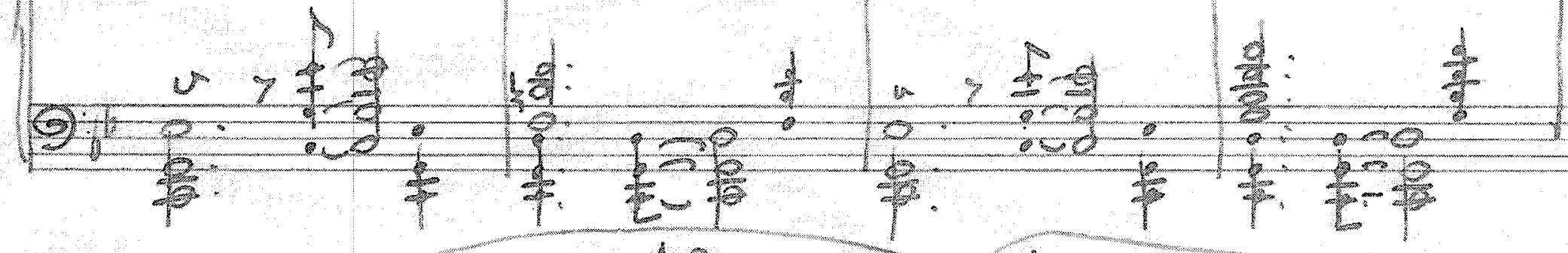

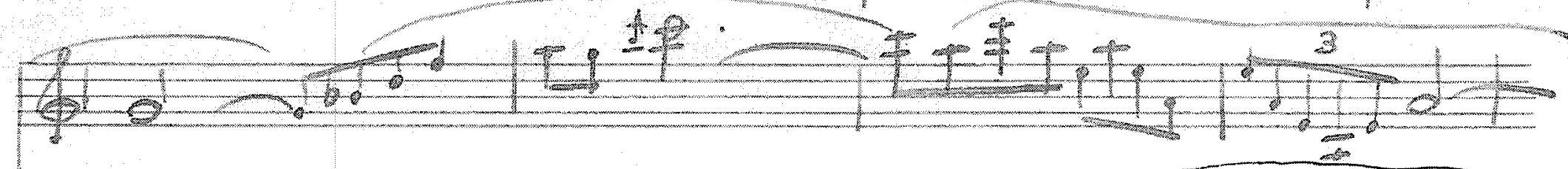

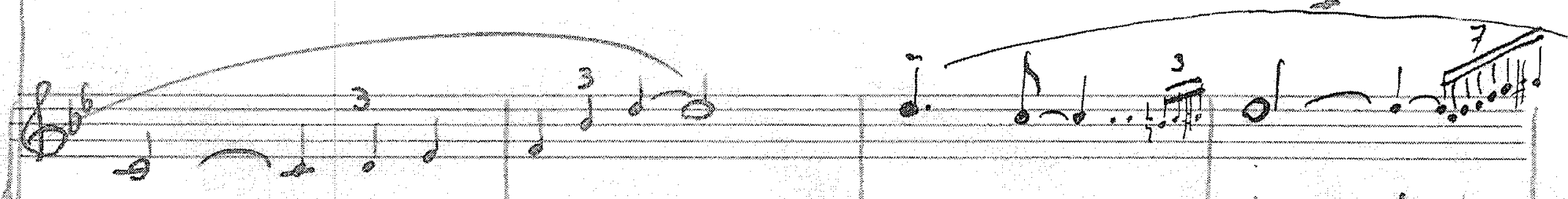

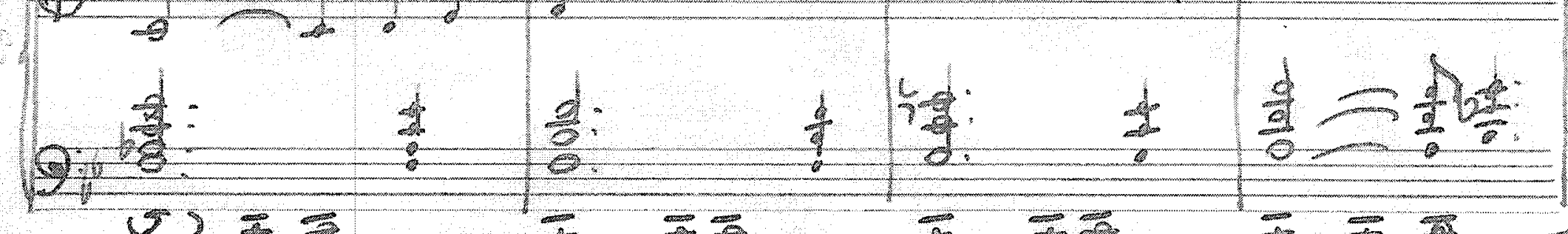

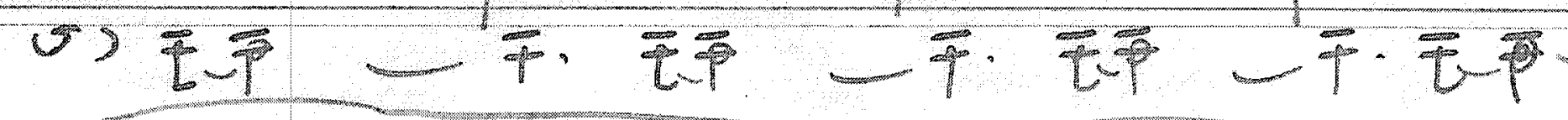
. - .

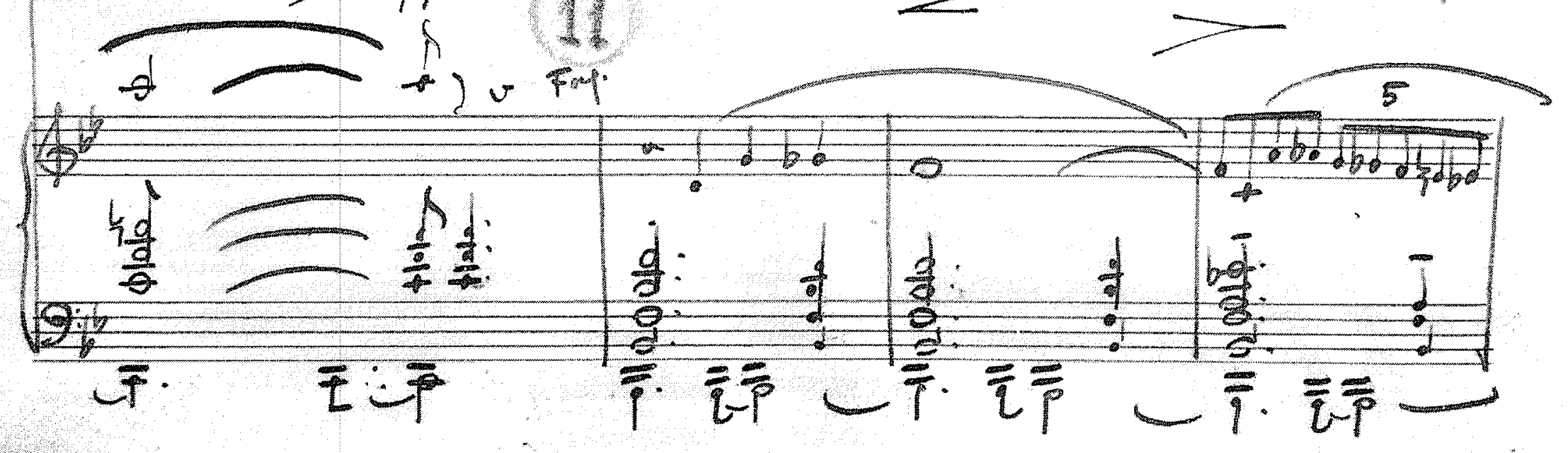




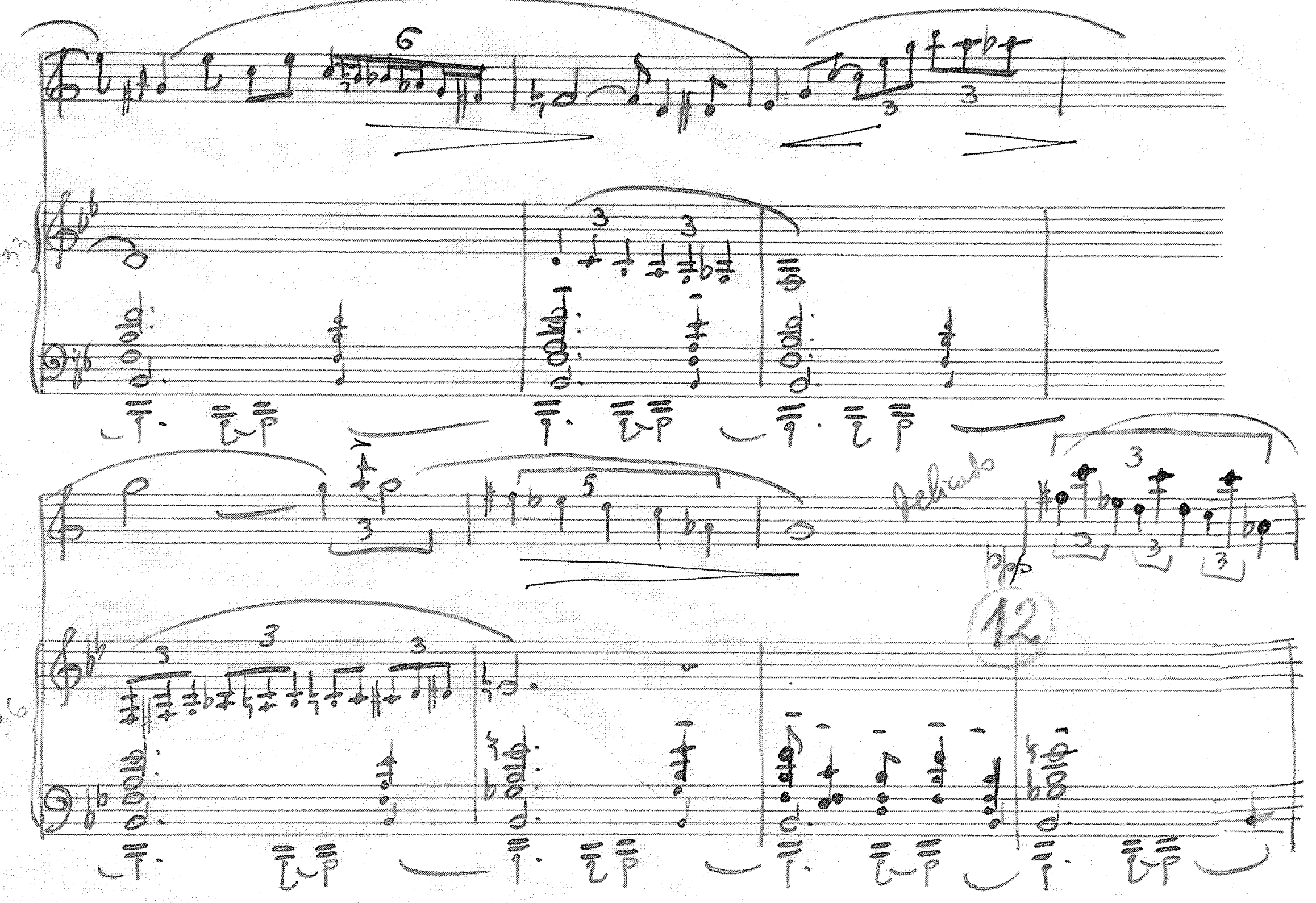

2

$e^{2}$

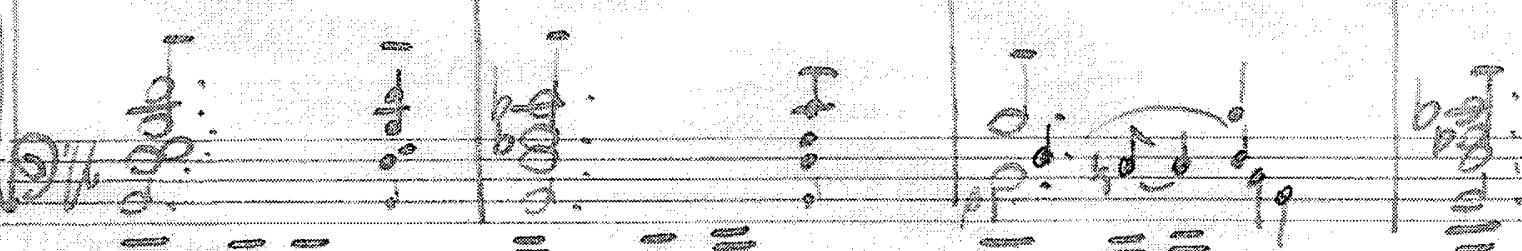

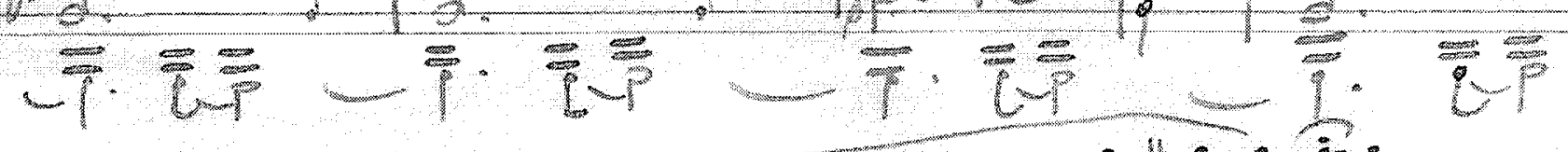

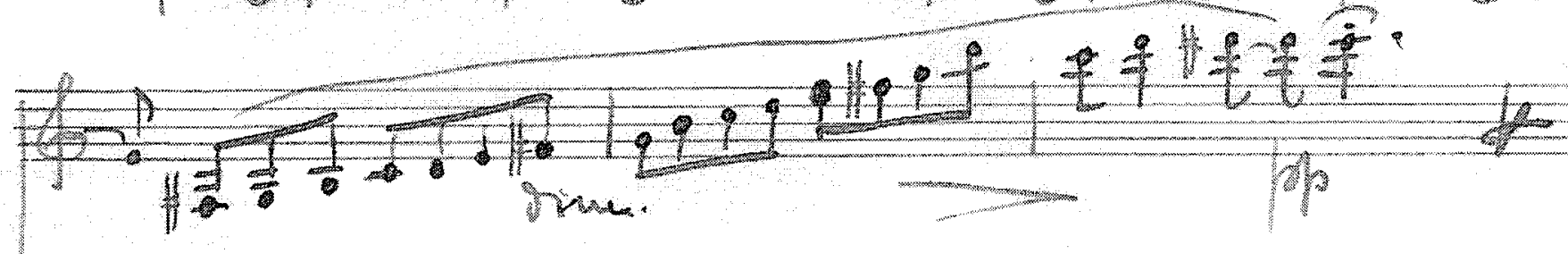
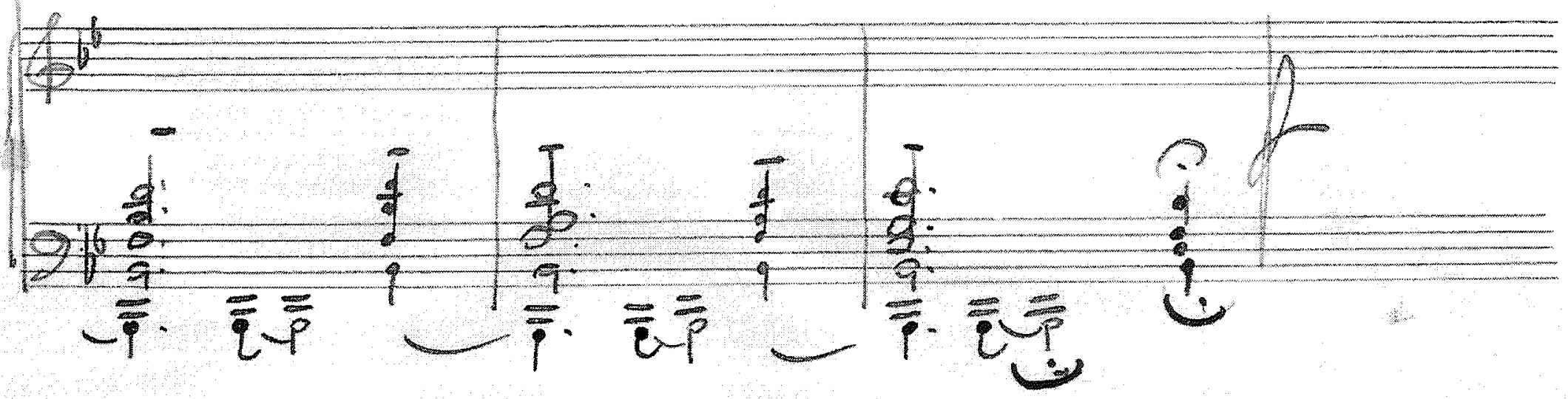
Final

all: $(6=138)$

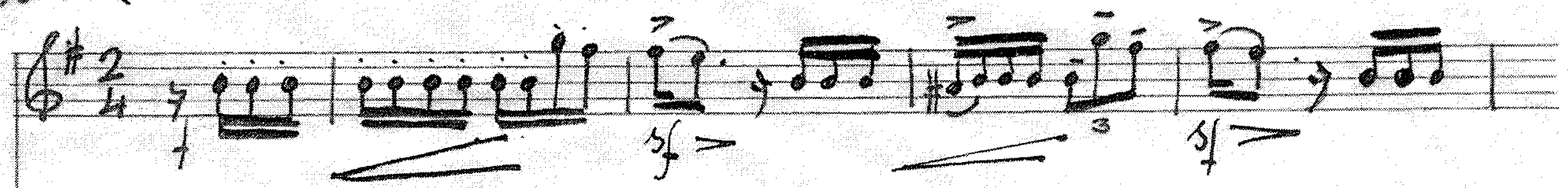

6,2

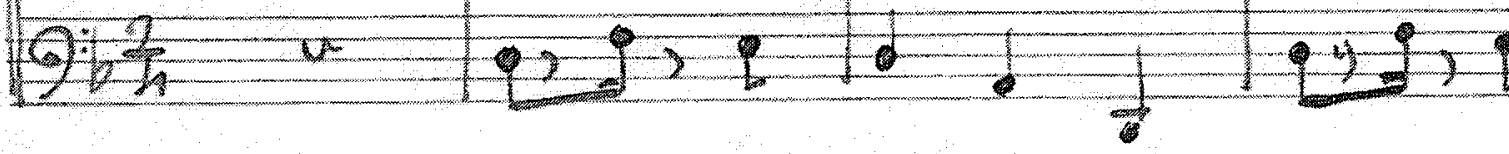

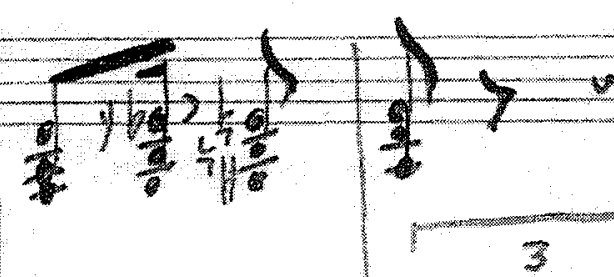

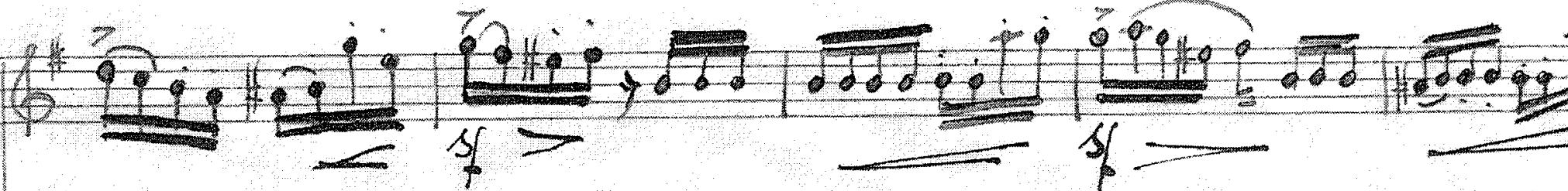

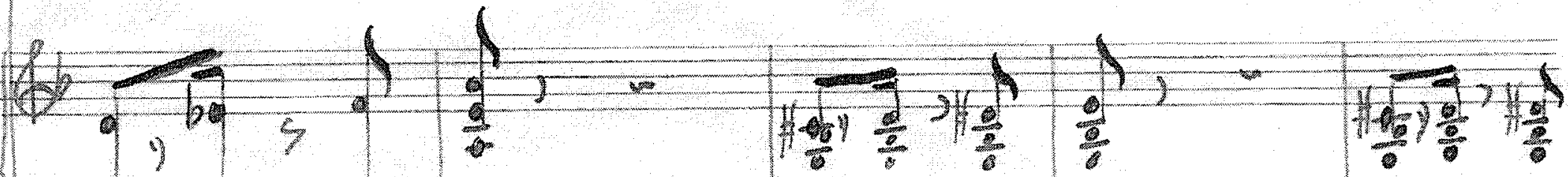

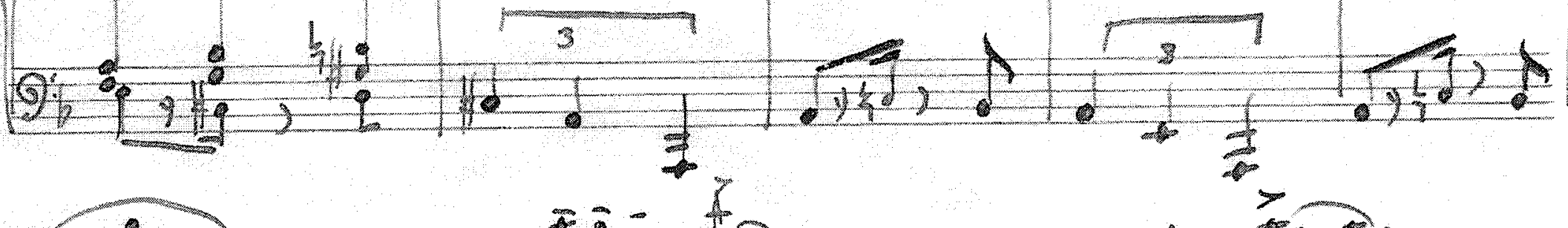

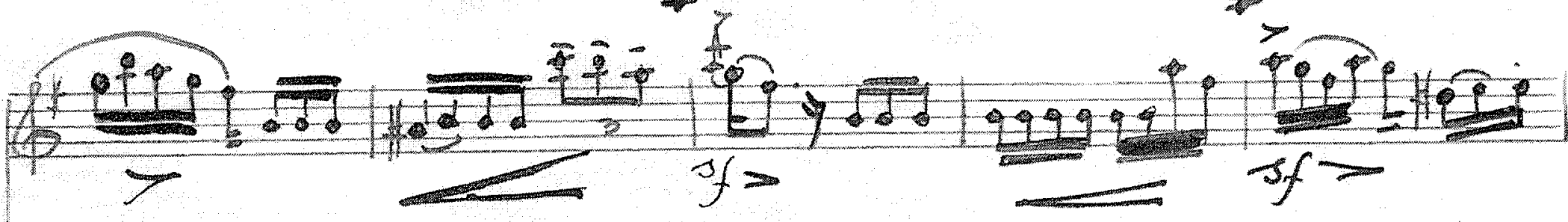

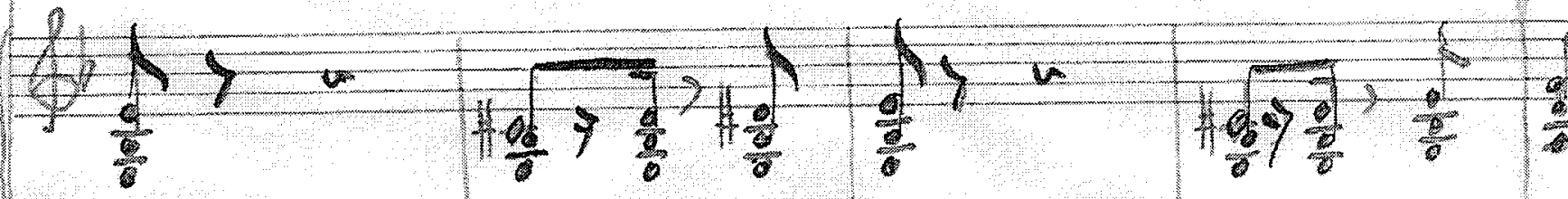

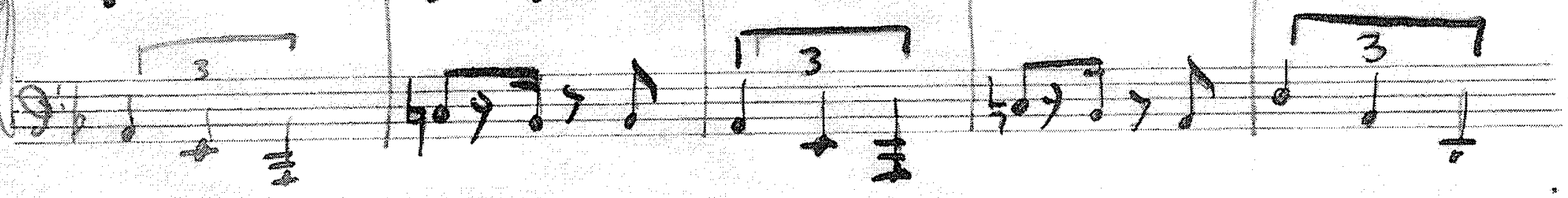

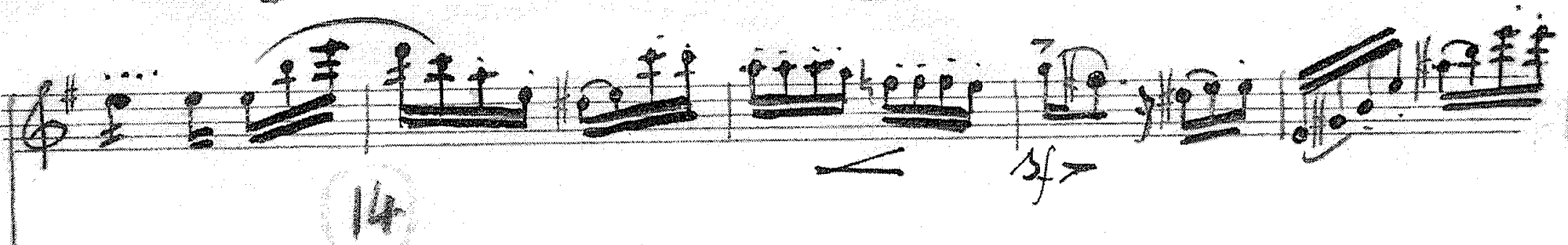

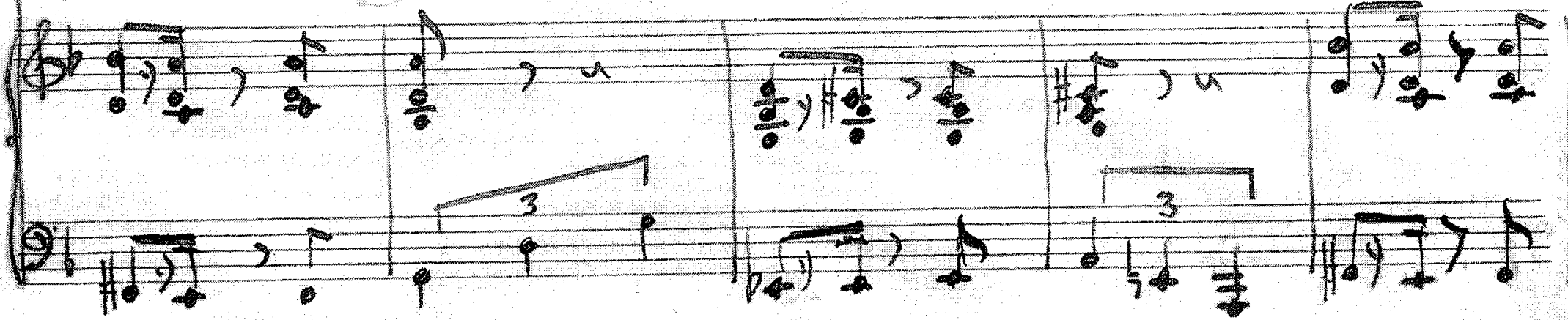




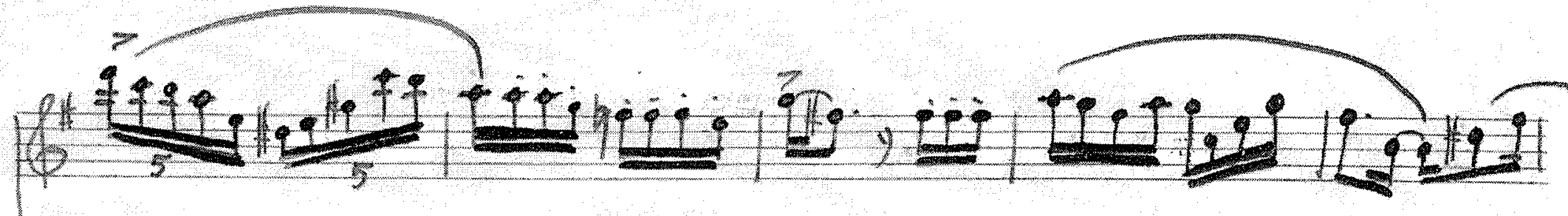

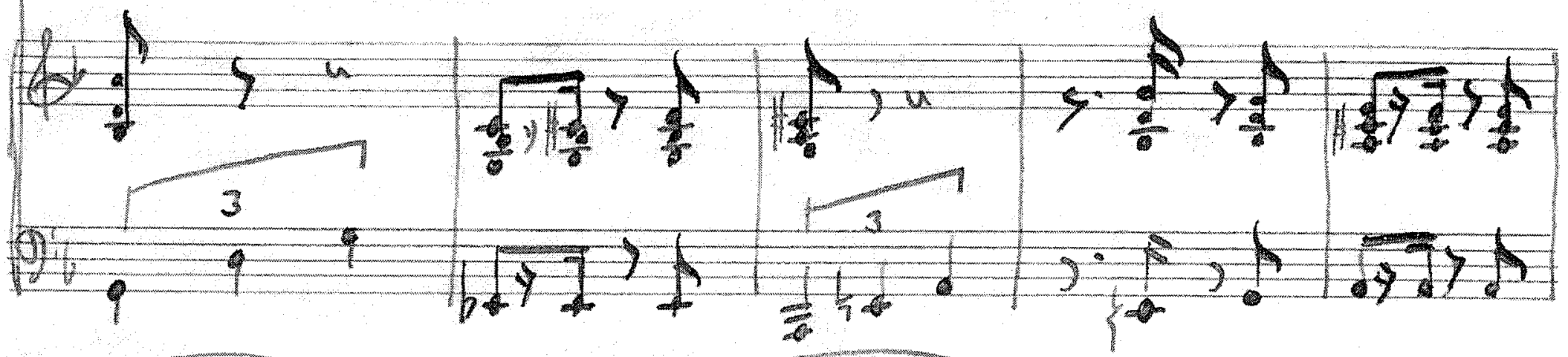

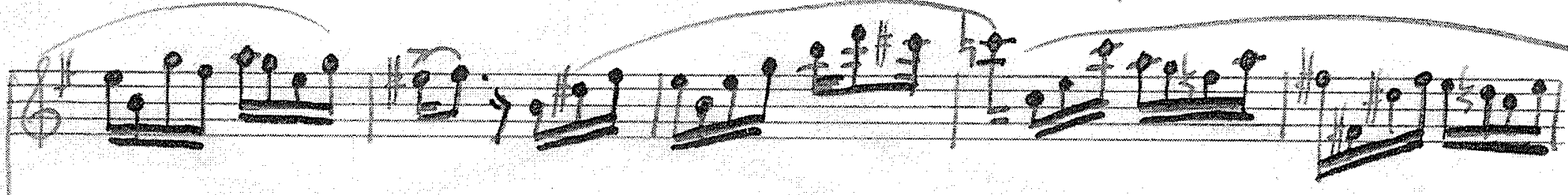

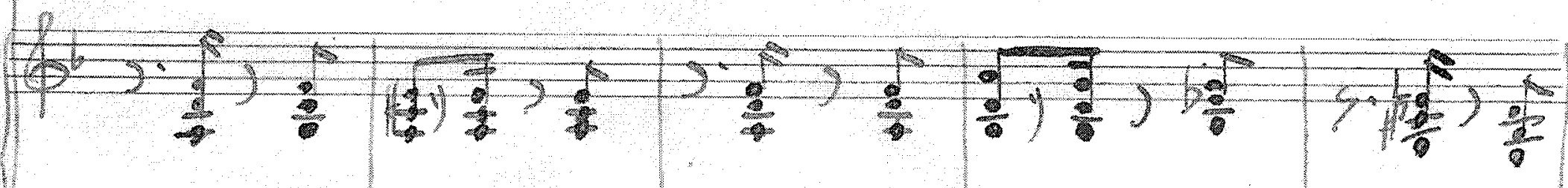

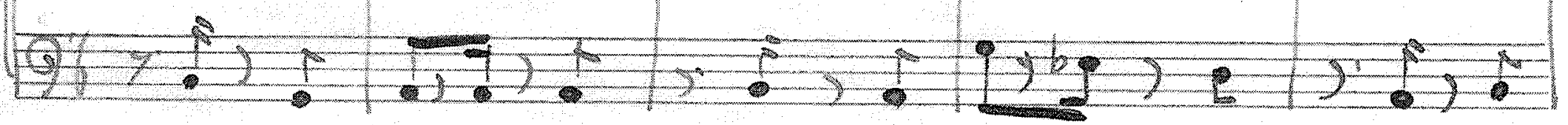

1+10

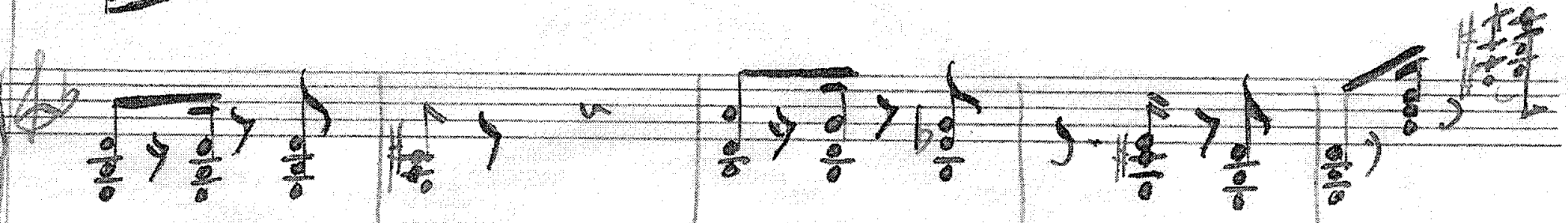

91.

40

$+3$

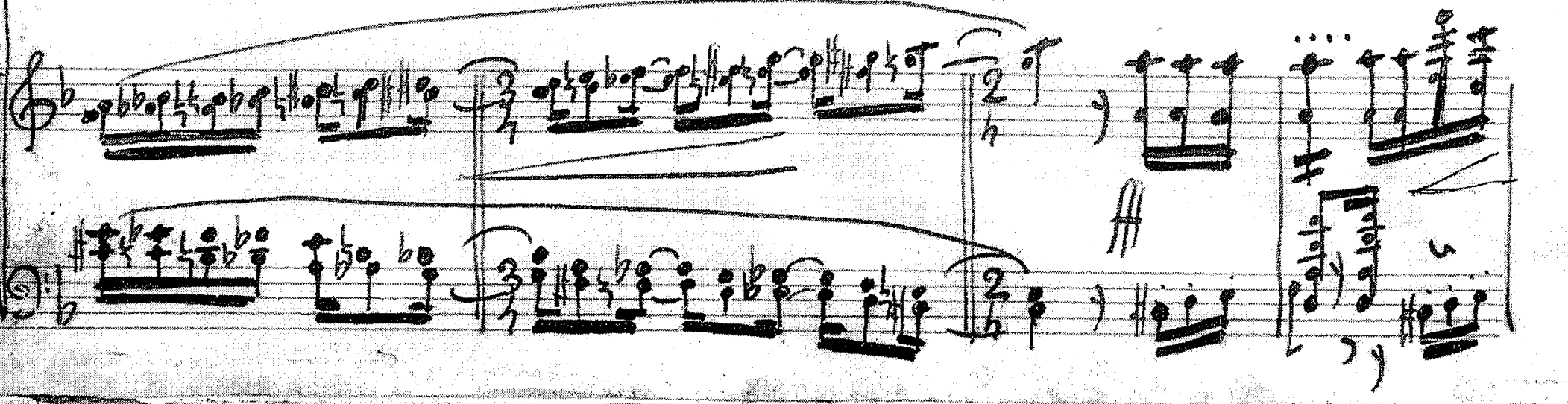



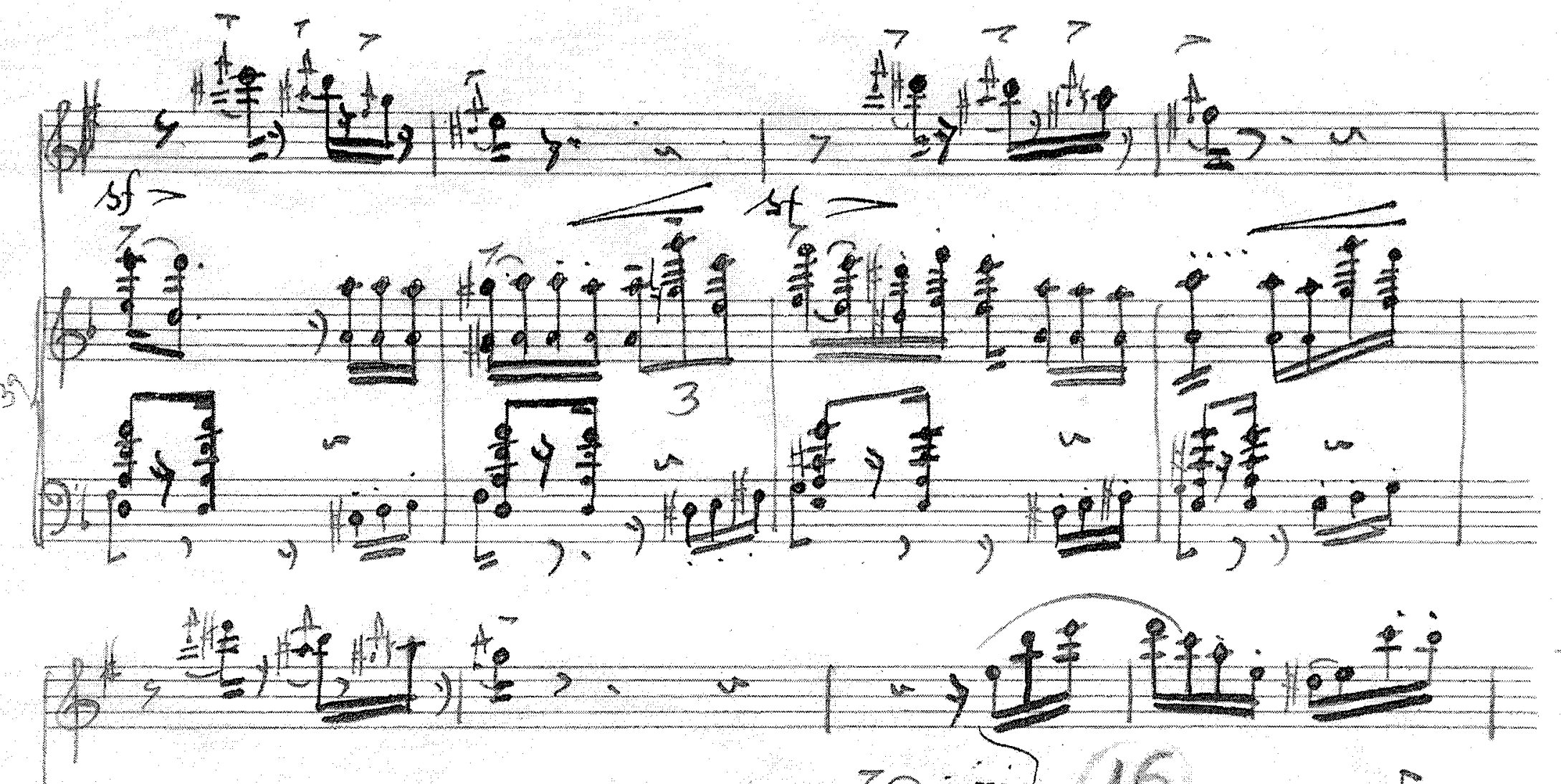

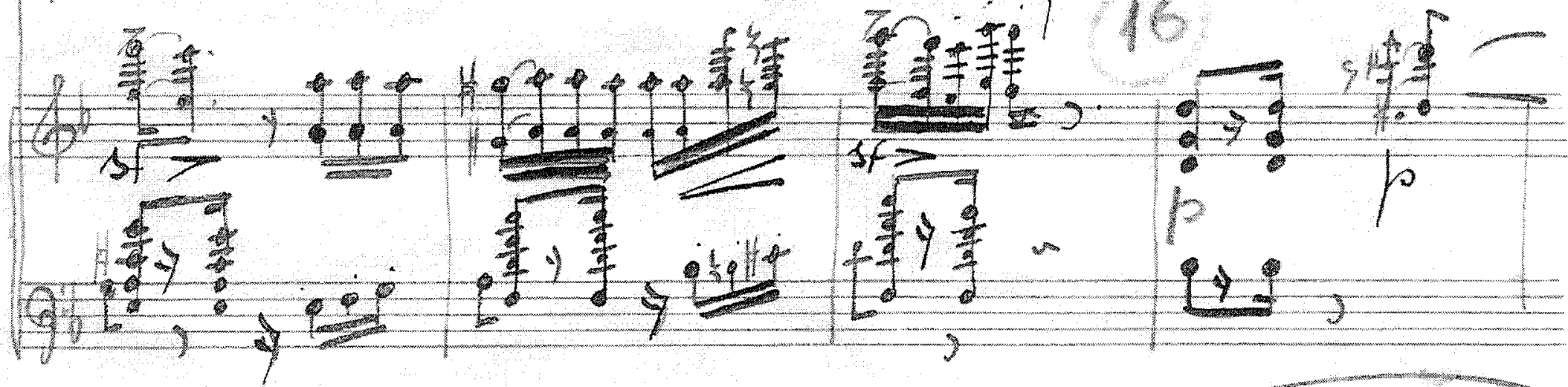

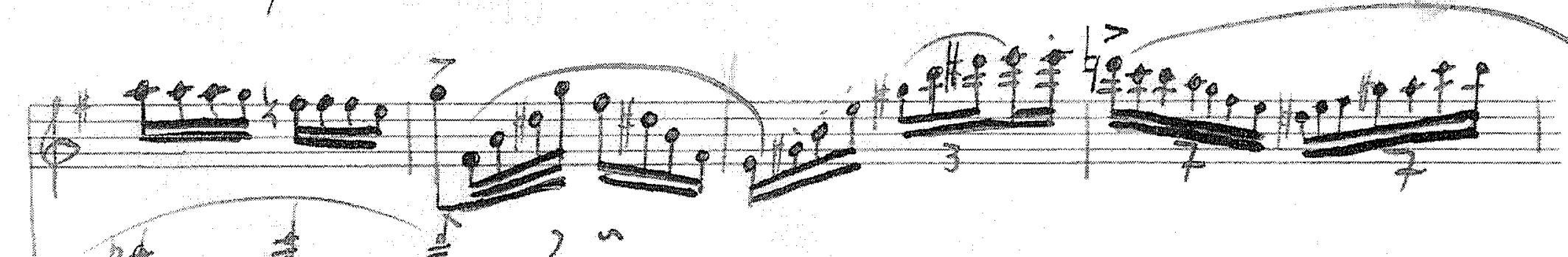

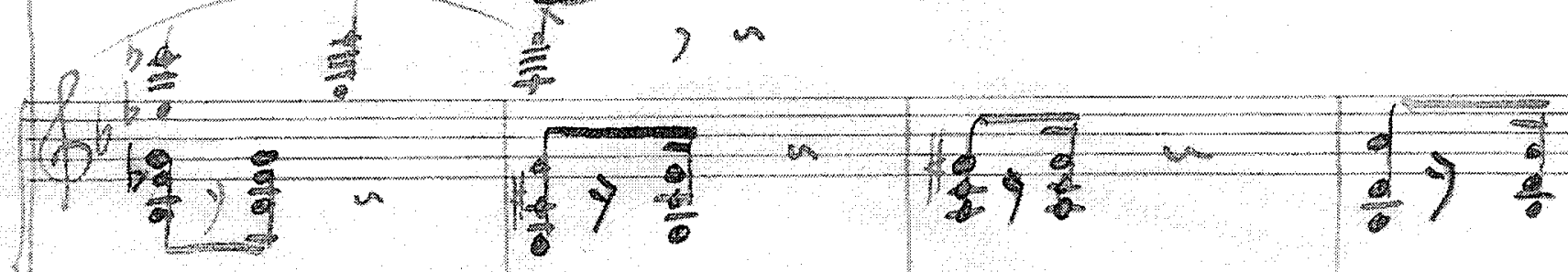

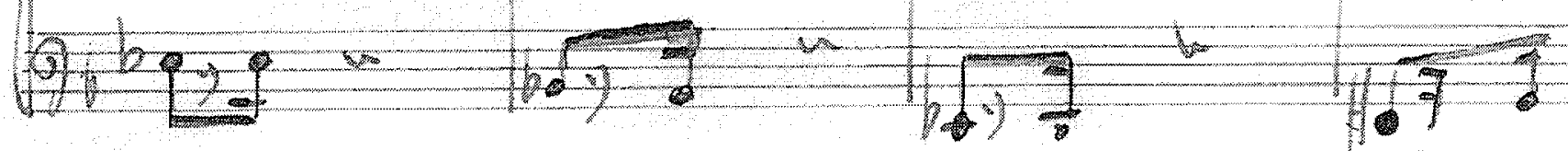

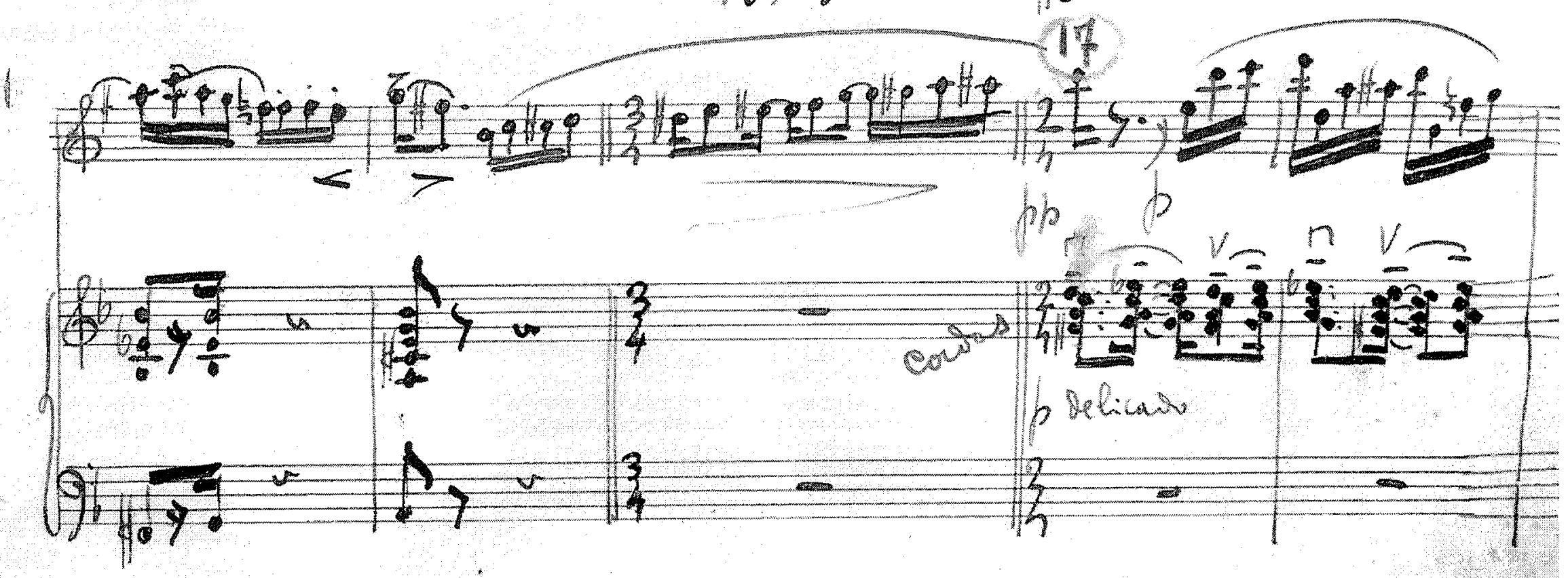




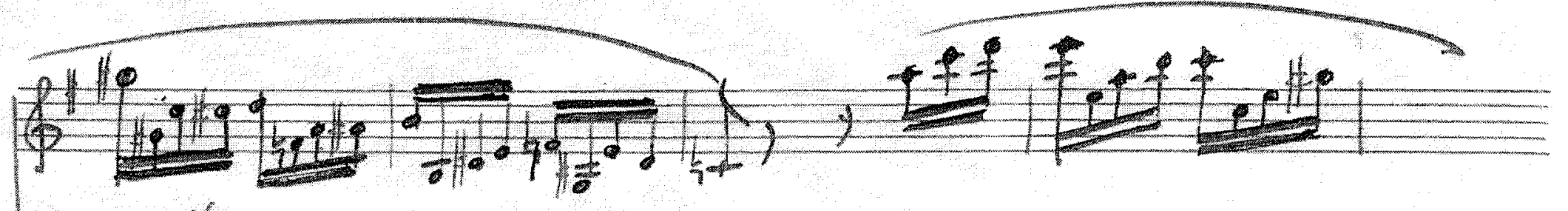

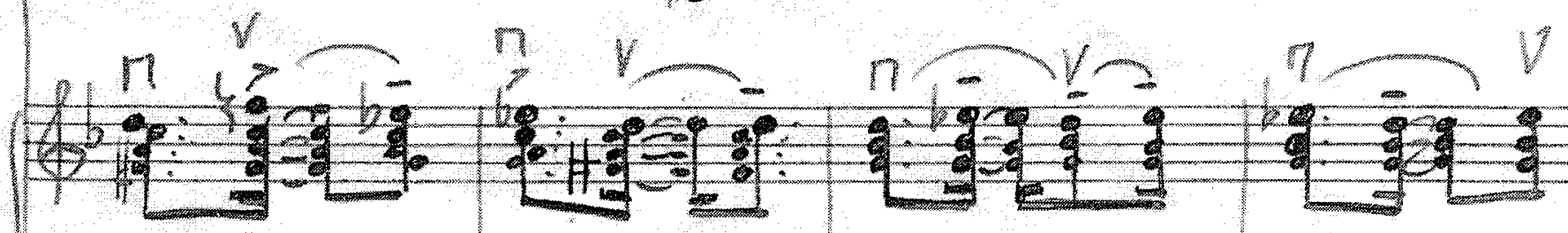
a for $\div$

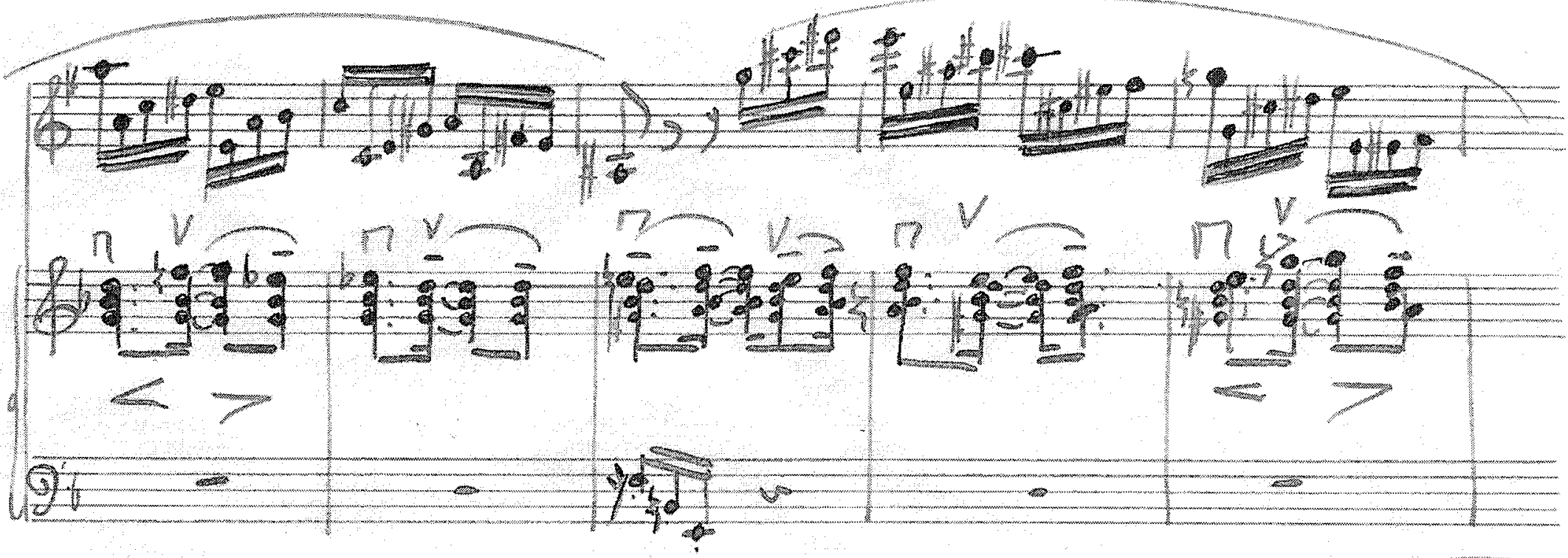

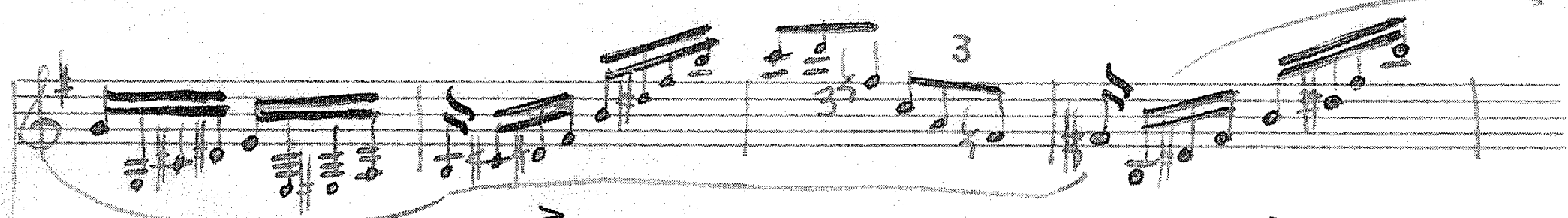

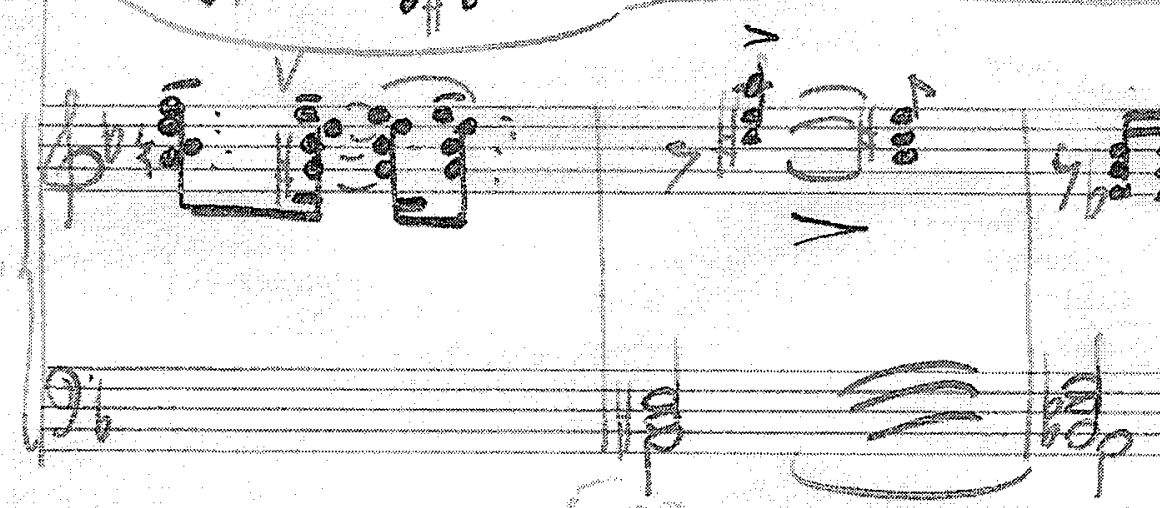

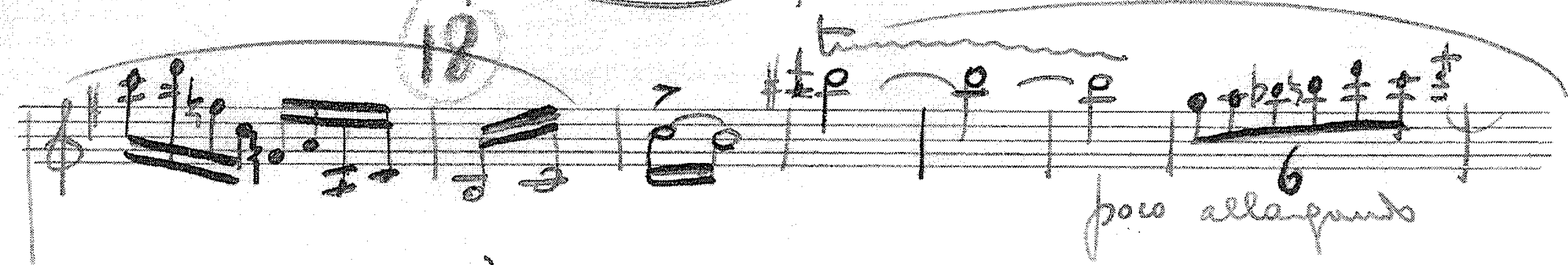

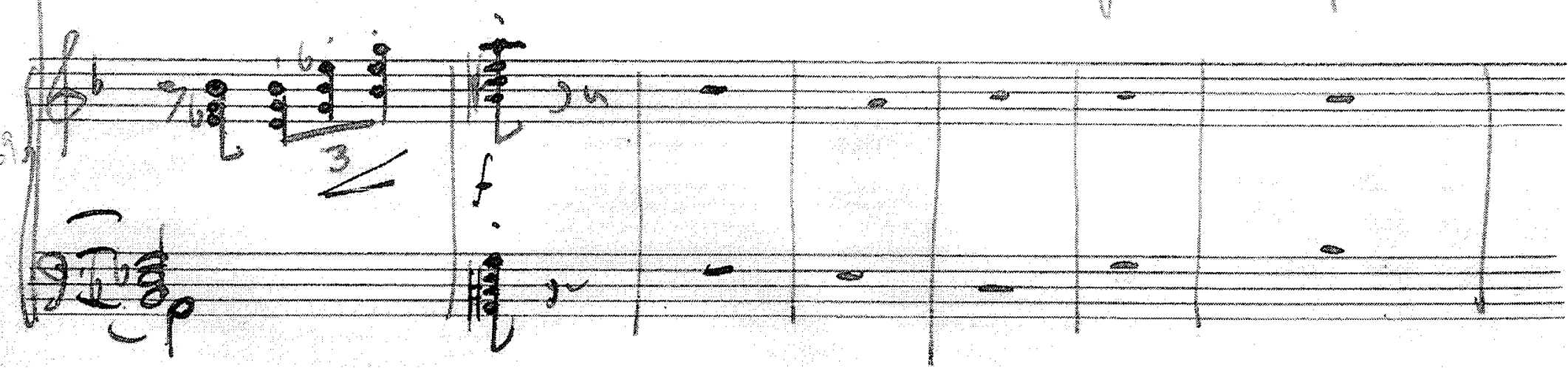


Poce Menoro $(f=108)$
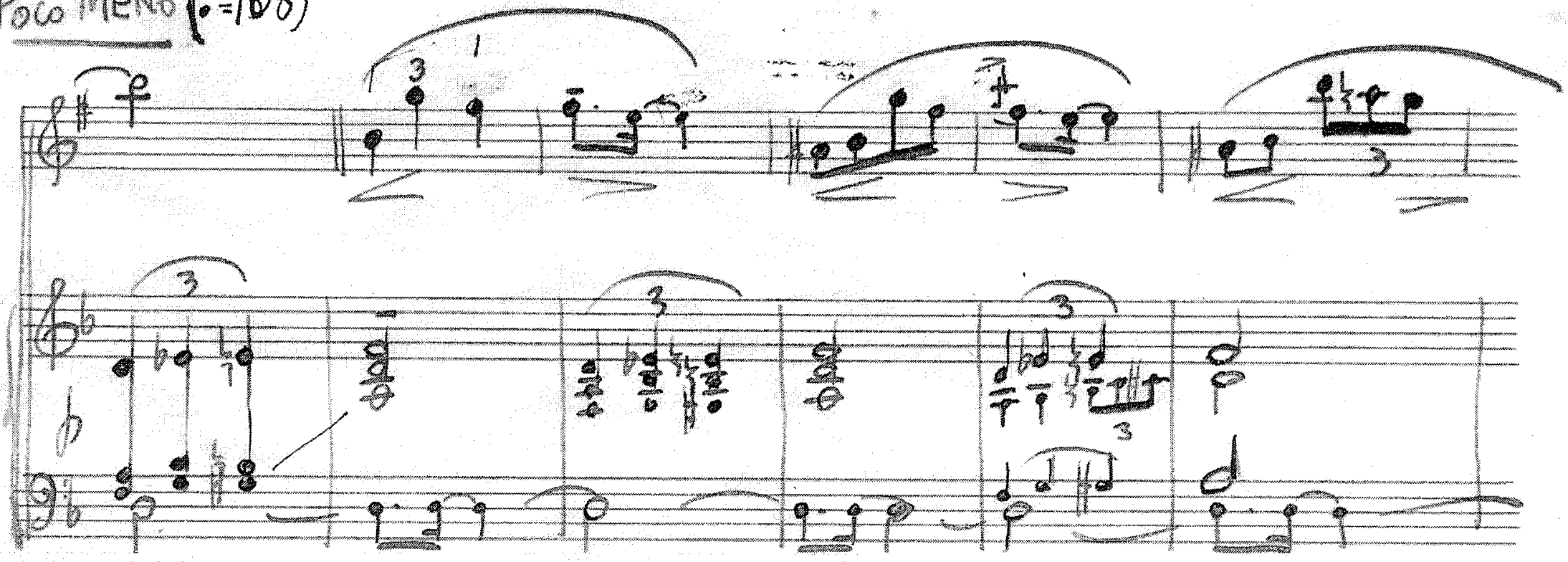

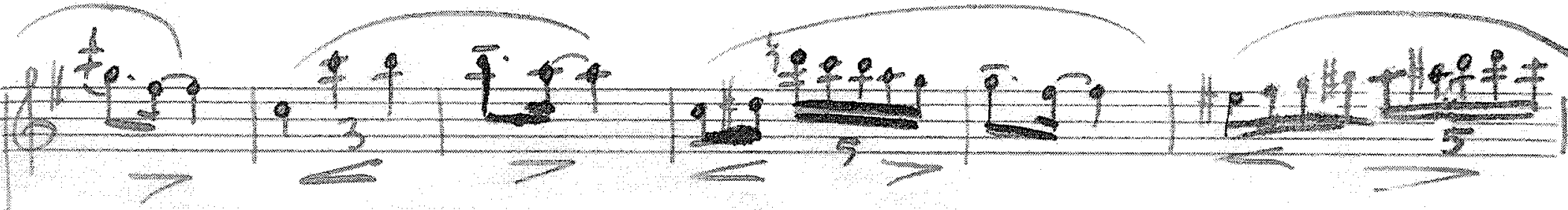

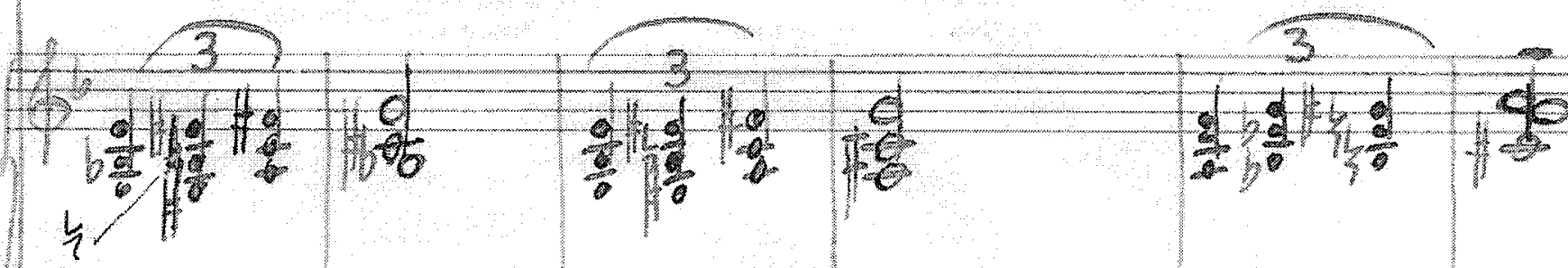

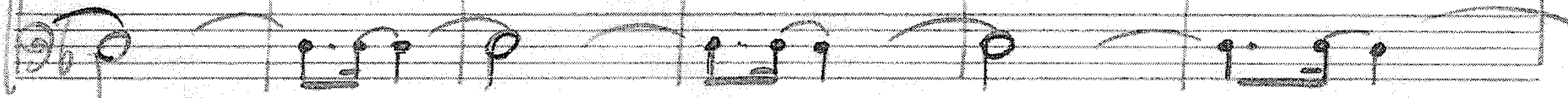

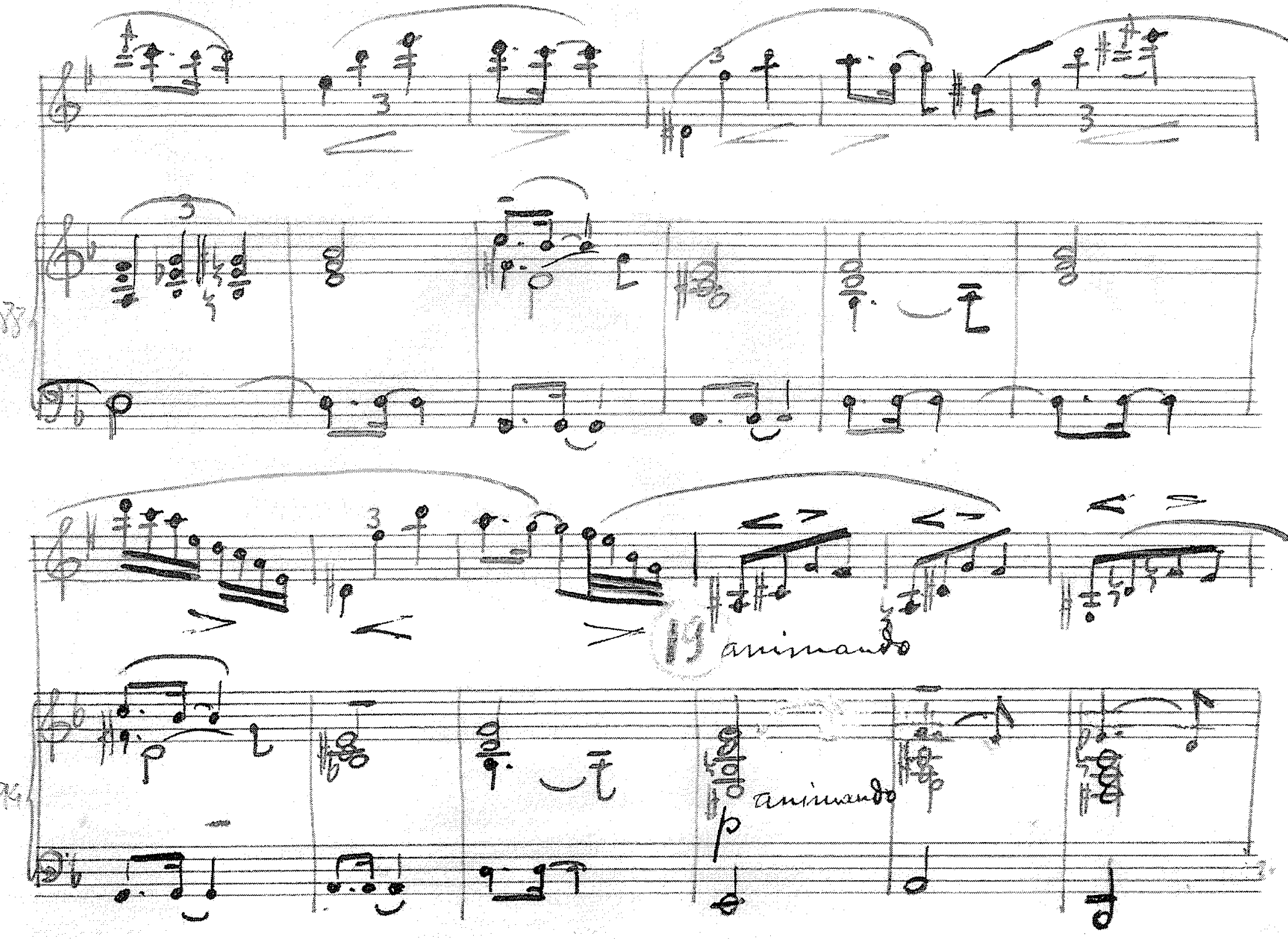




$$
\text { I: TEMPO (E) } 138 \text {; }
$$

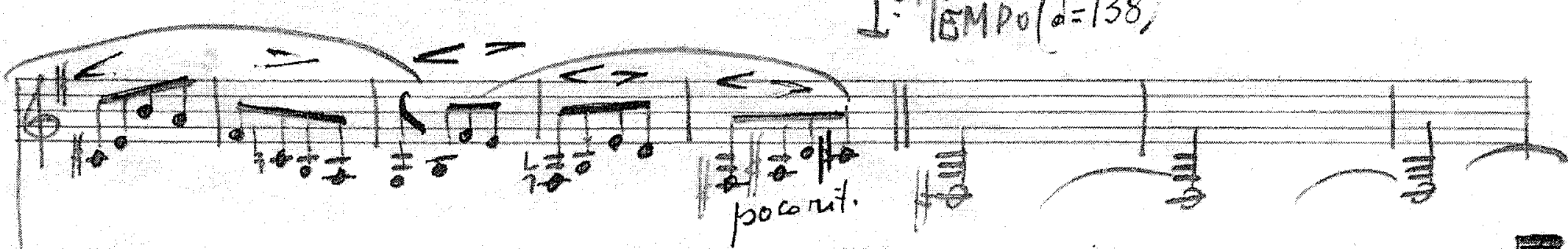

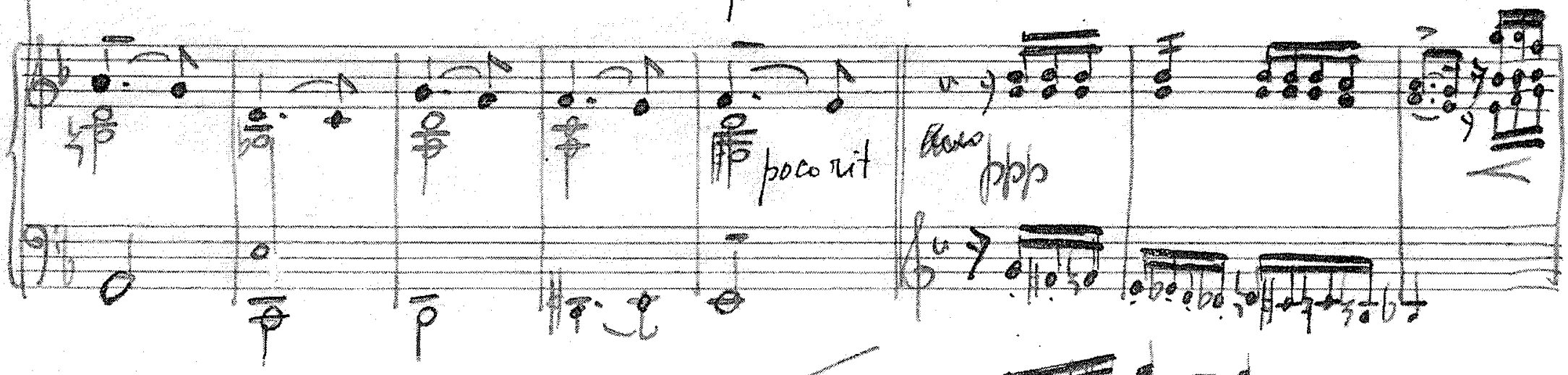

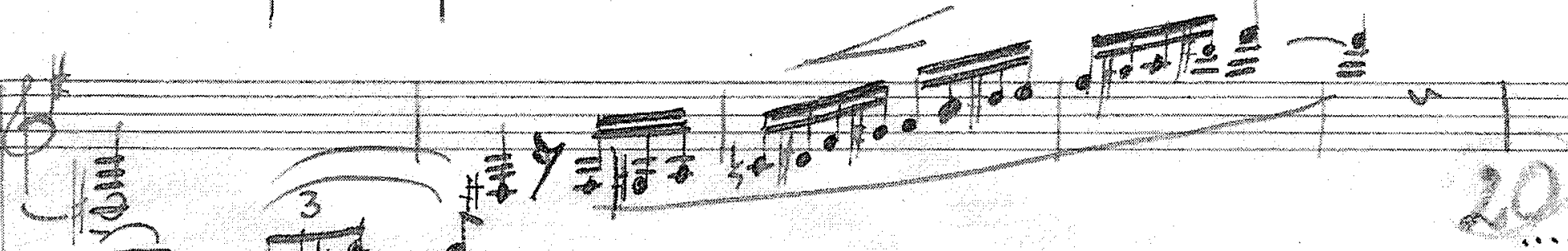

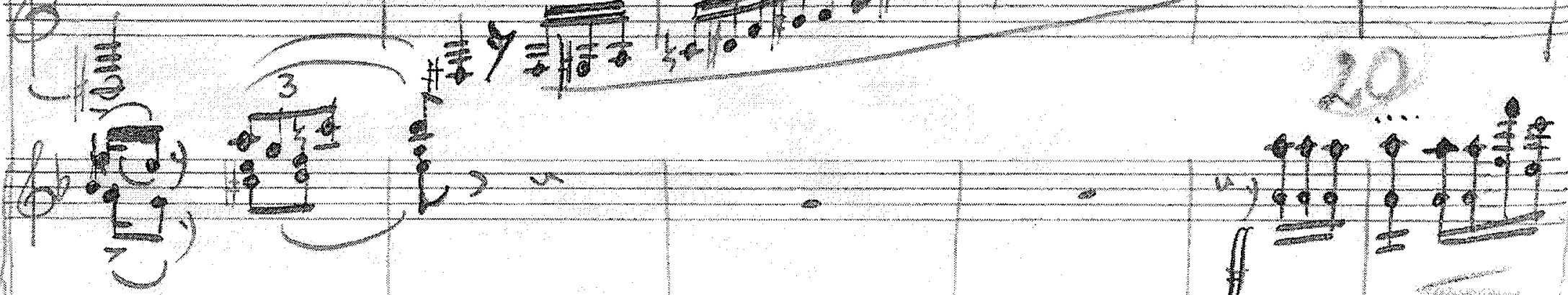

(3)

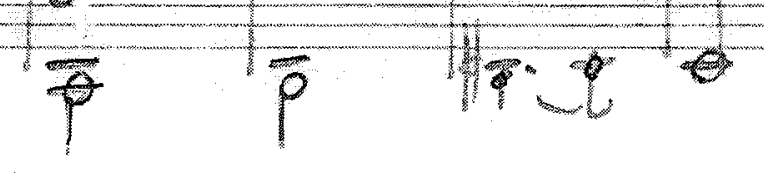

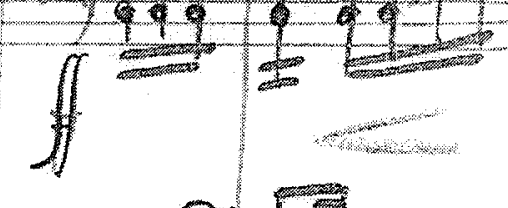

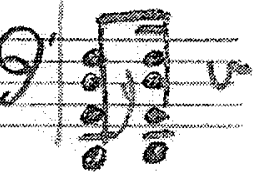

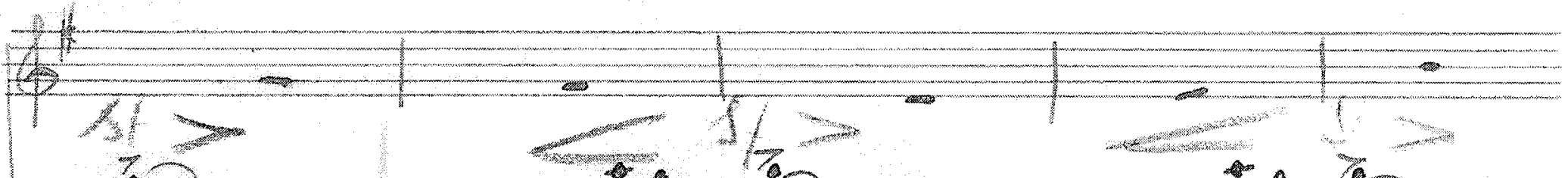

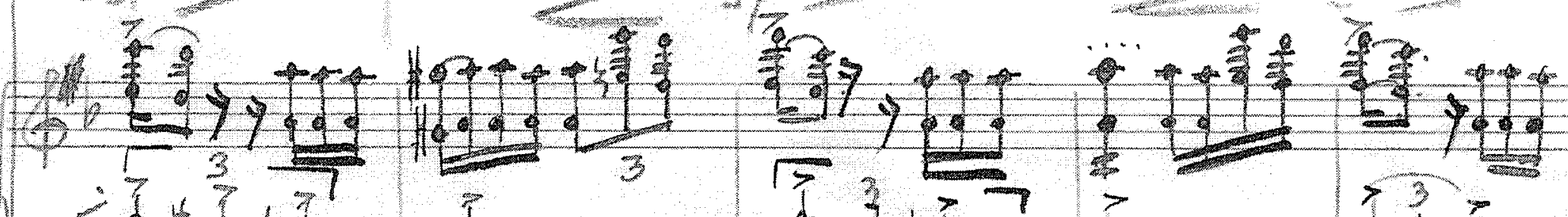

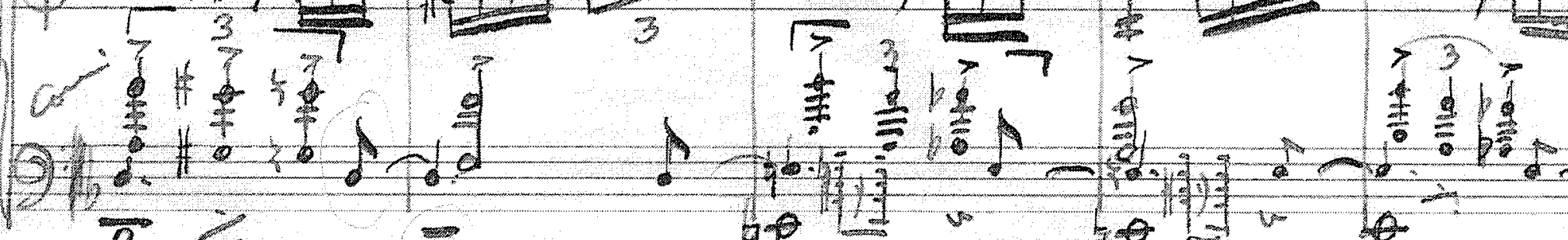

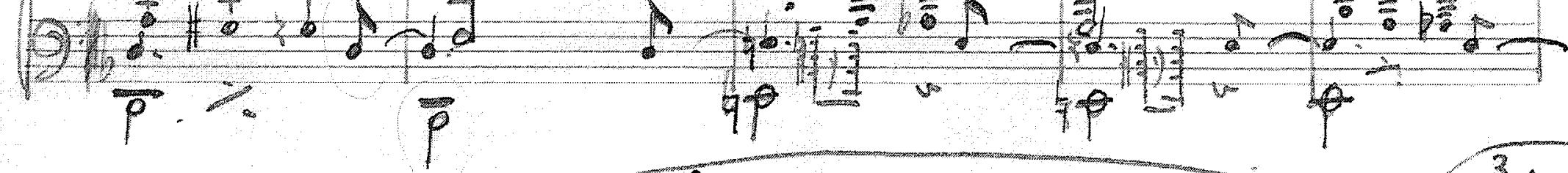
-

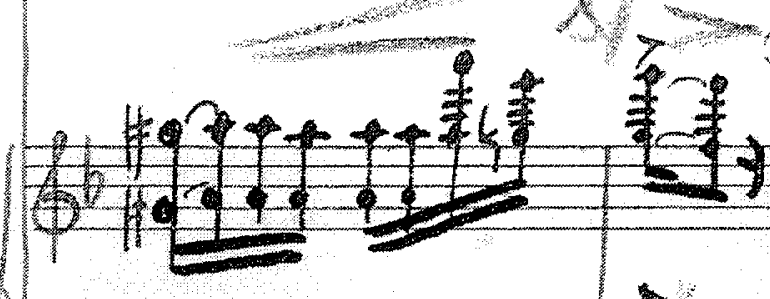

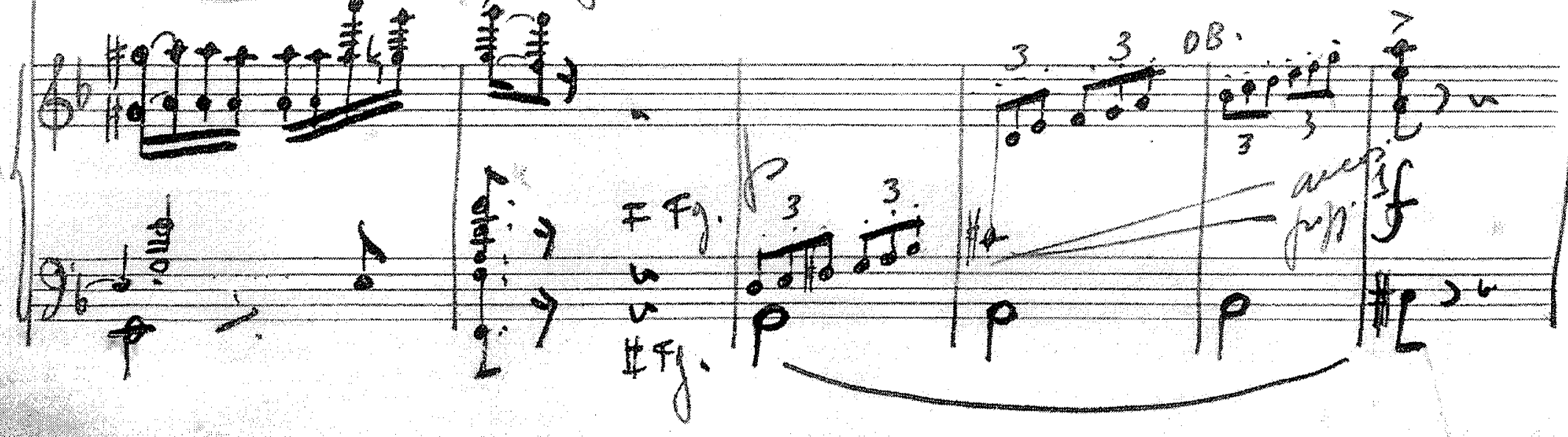




\section{保}

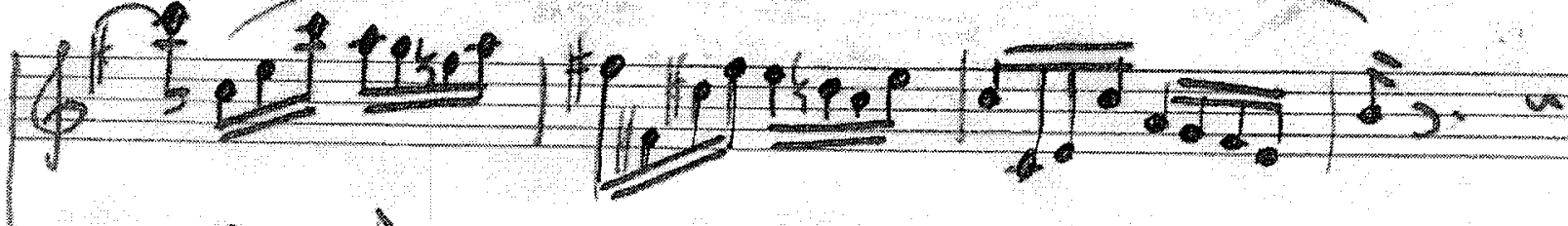

का in

19: 69

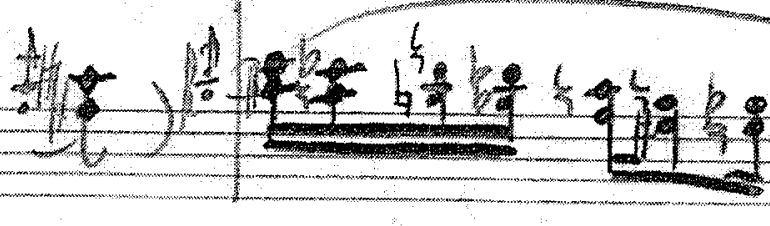

若

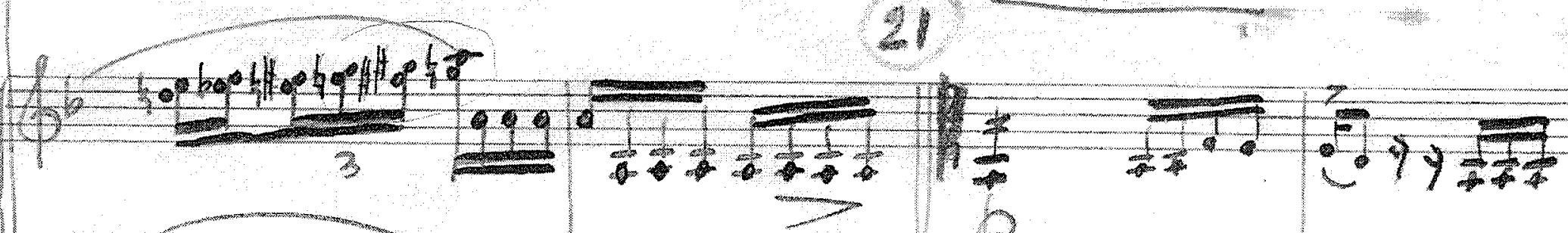

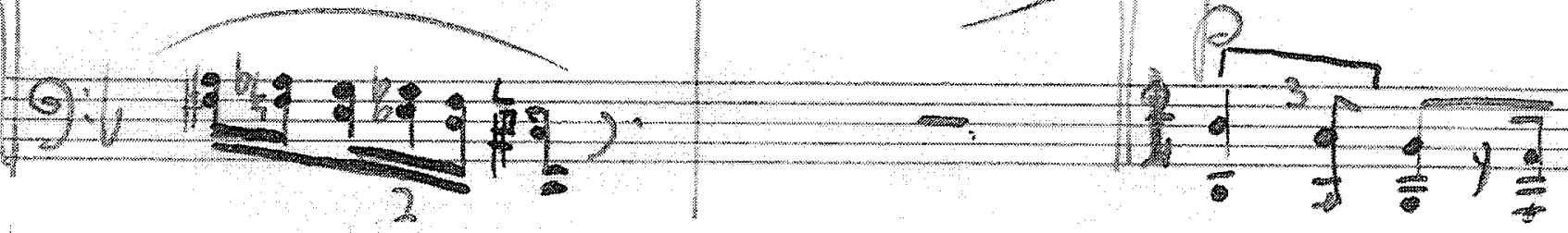

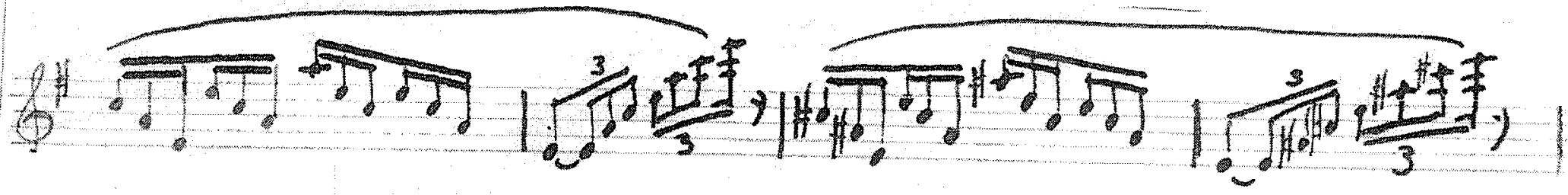

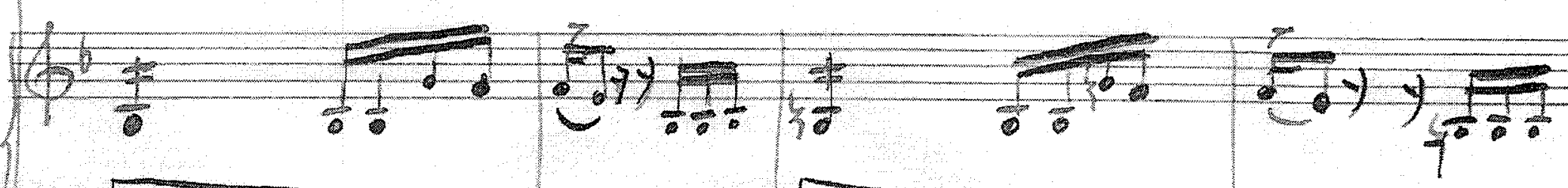

एक

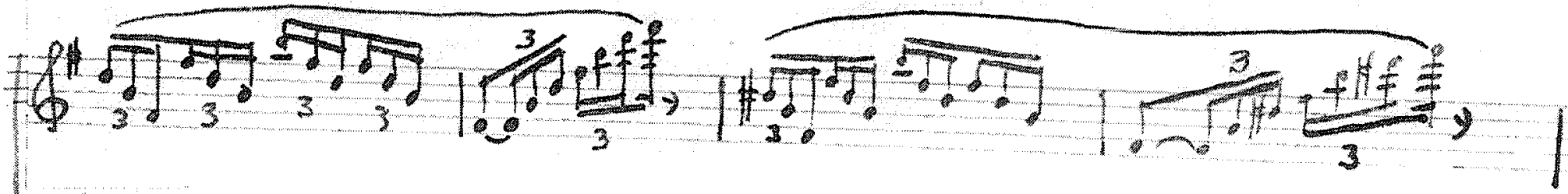

46.

(20) 


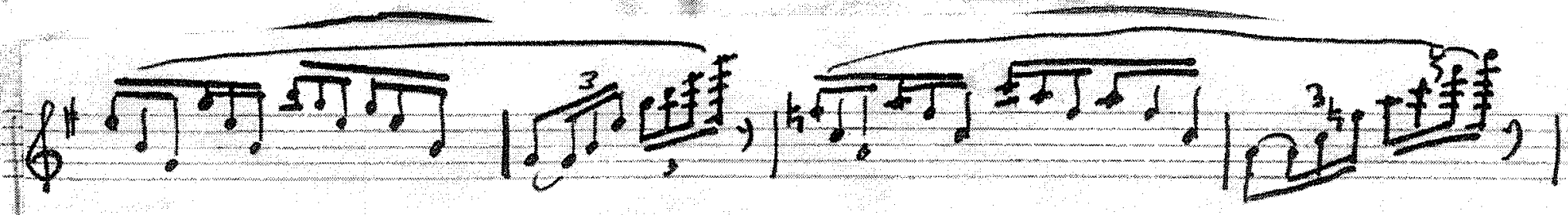
胎。

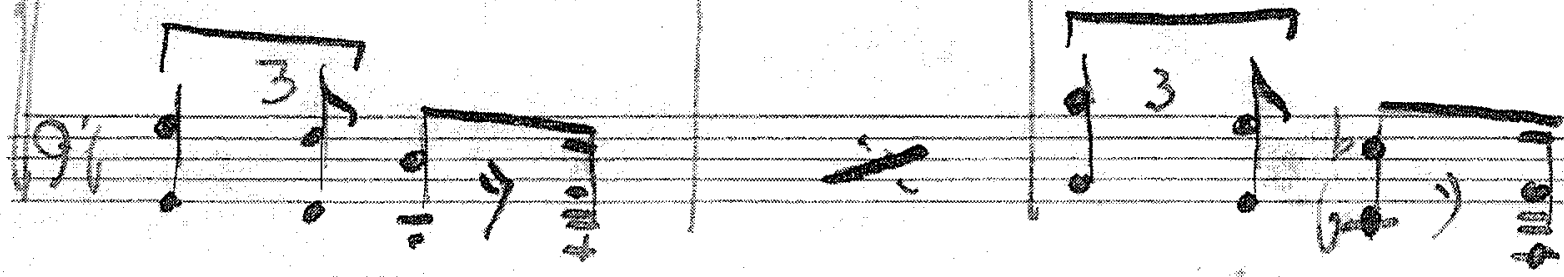

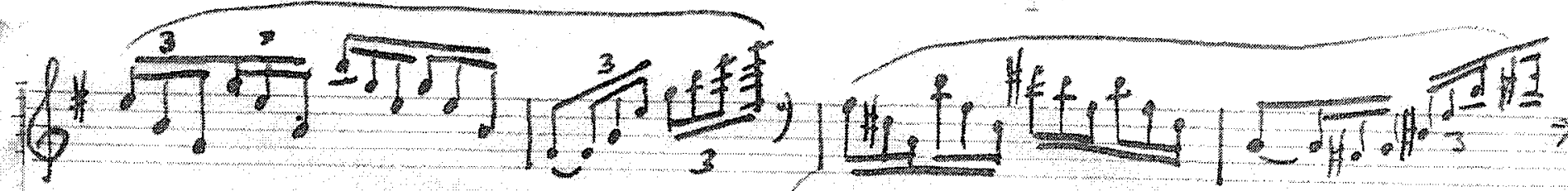

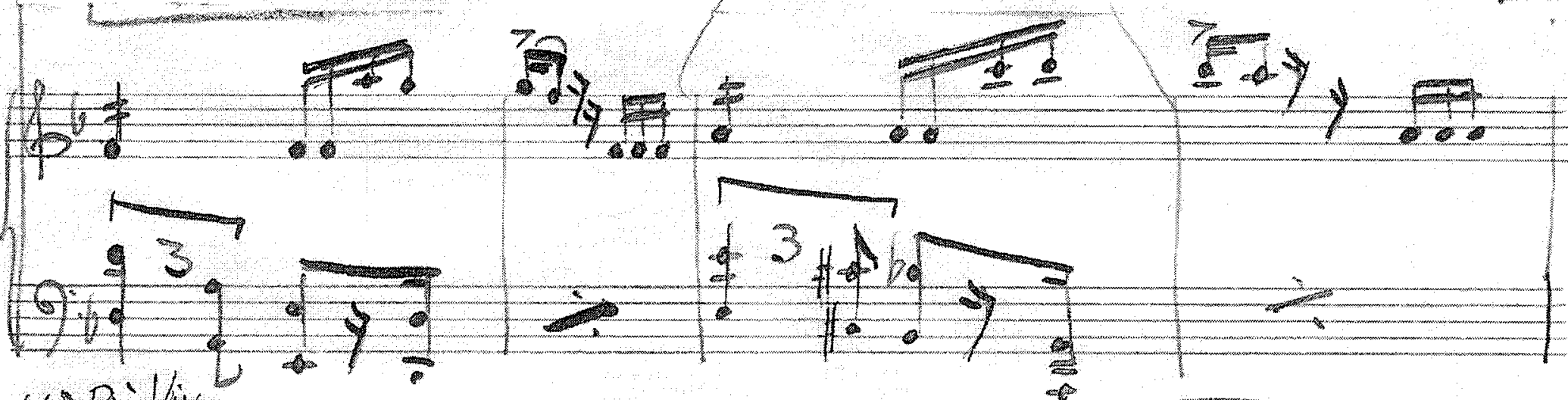

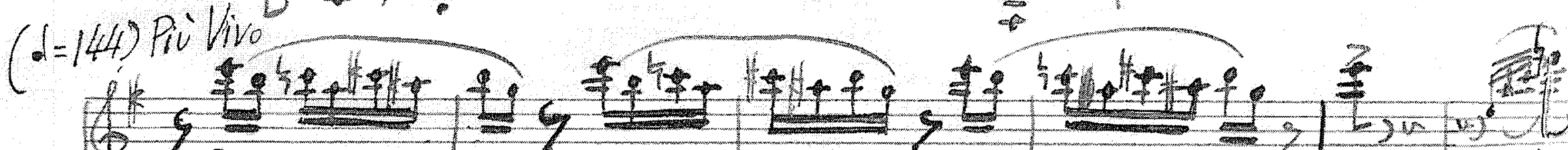

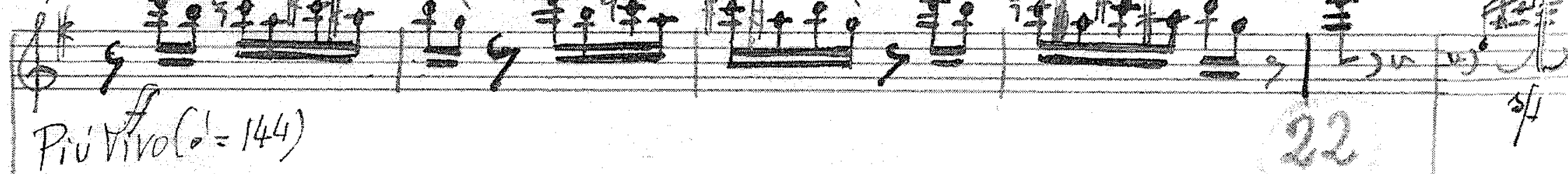

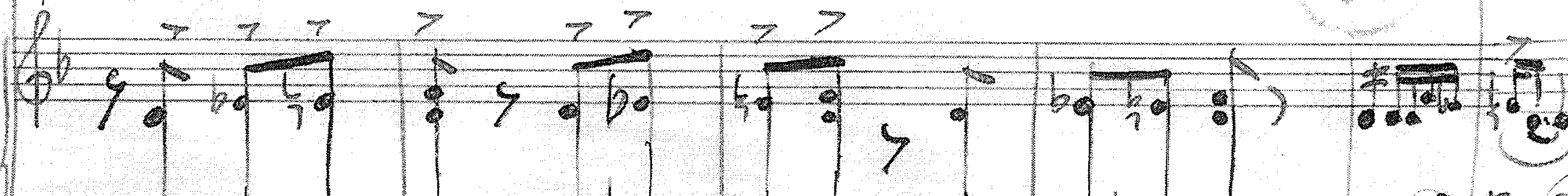

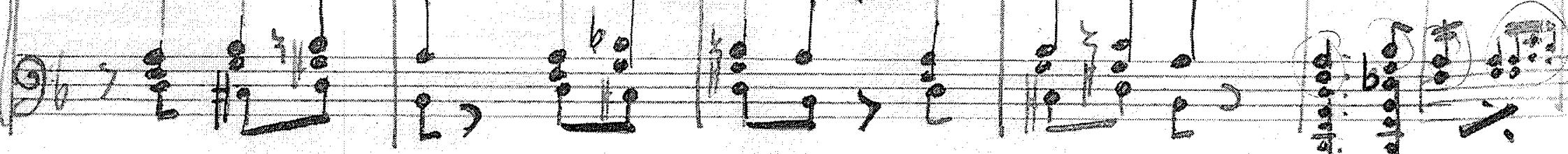

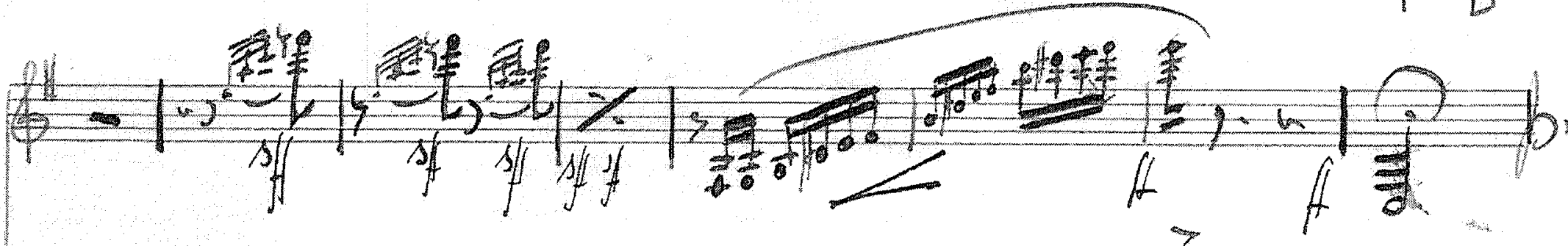

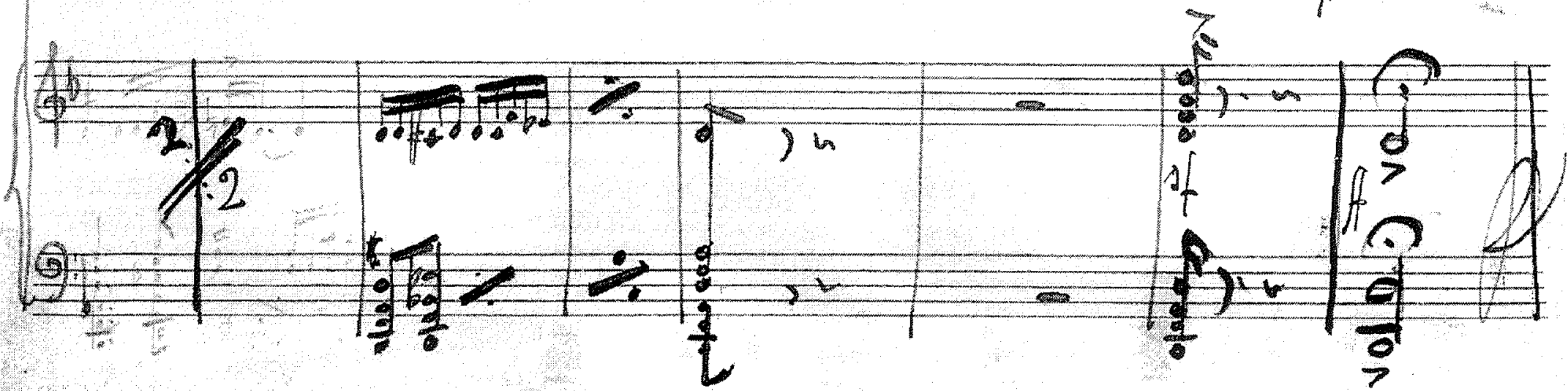



CONCER TINO para clanincete sibe rquestra 1.) Fantasia
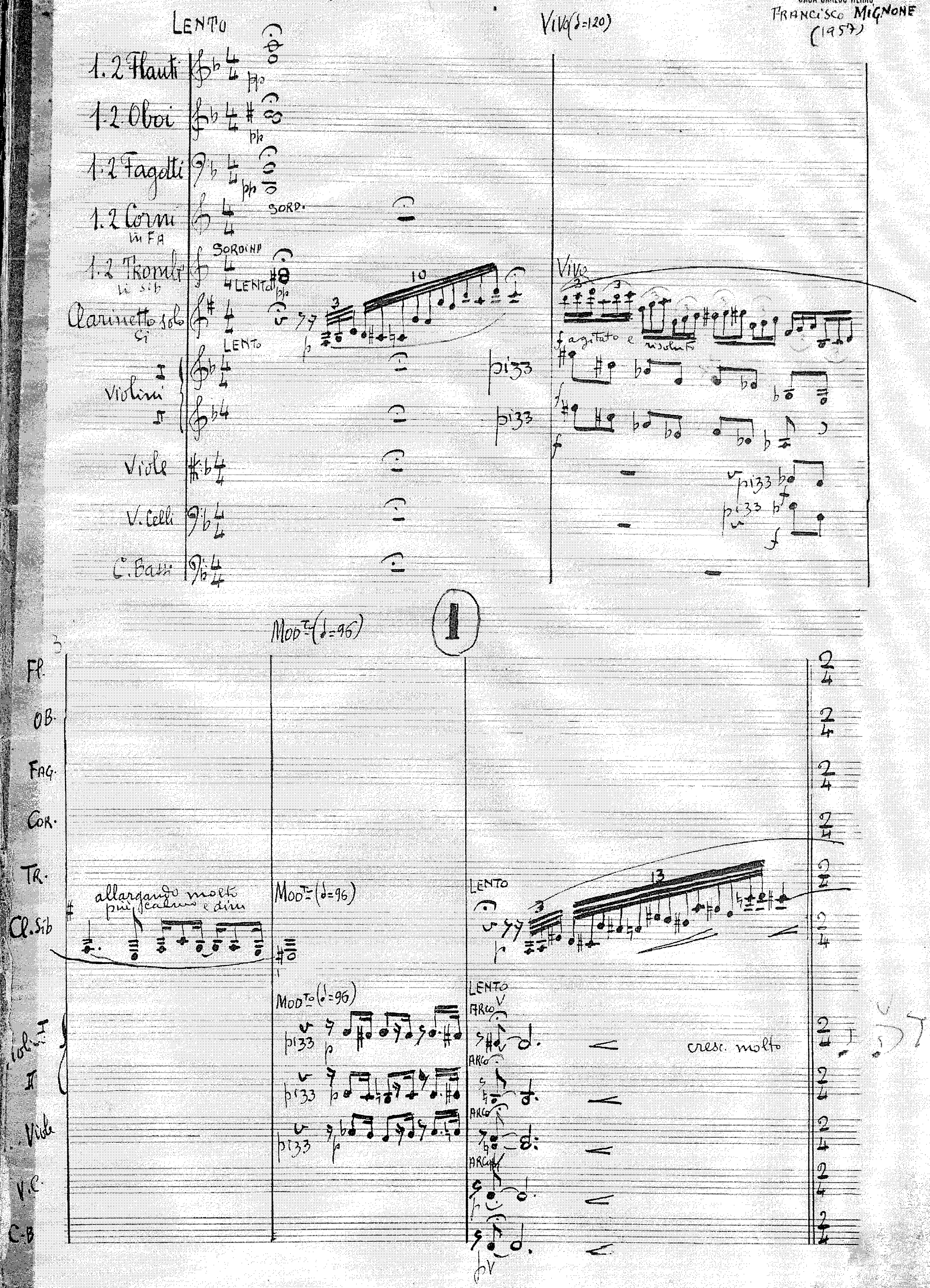
7

Nitos: Mosio

$(b=112$ )

Vives $s=138)$

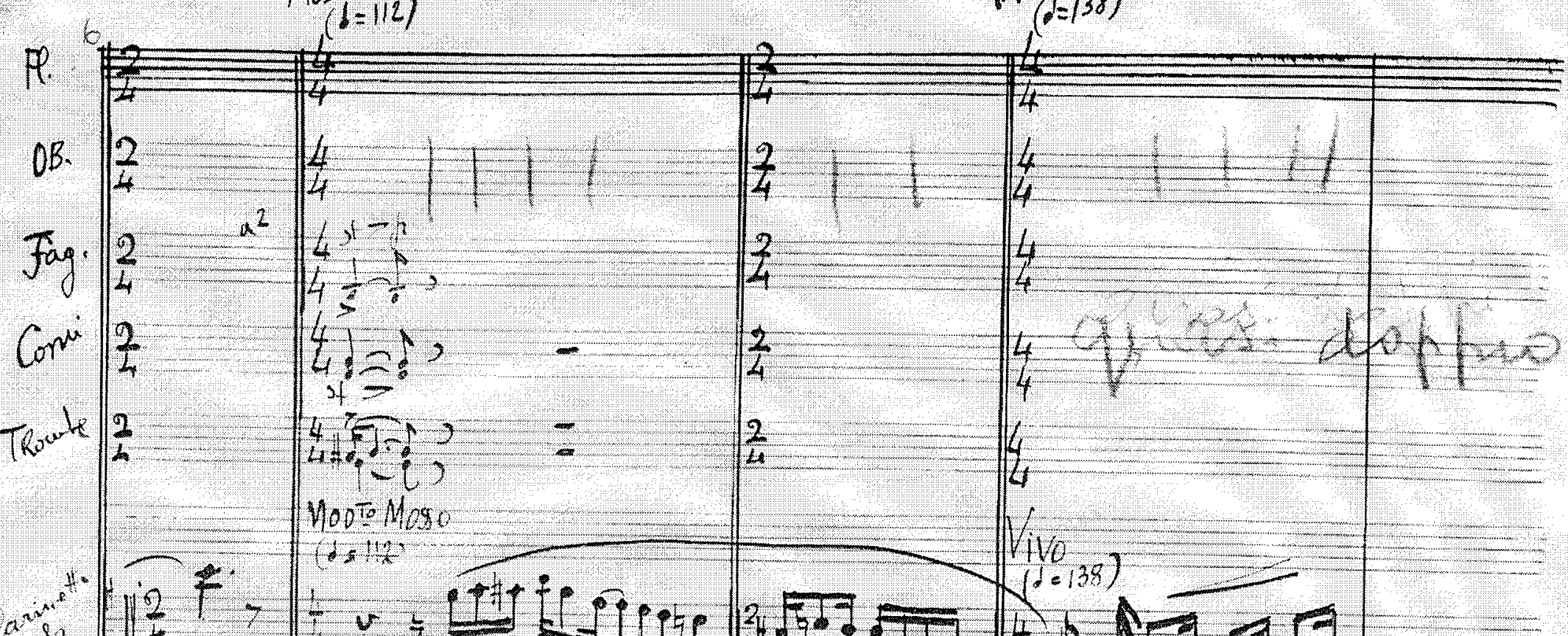

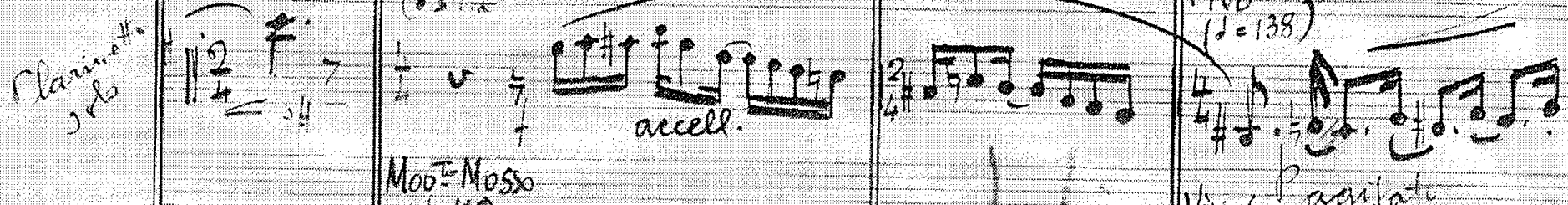

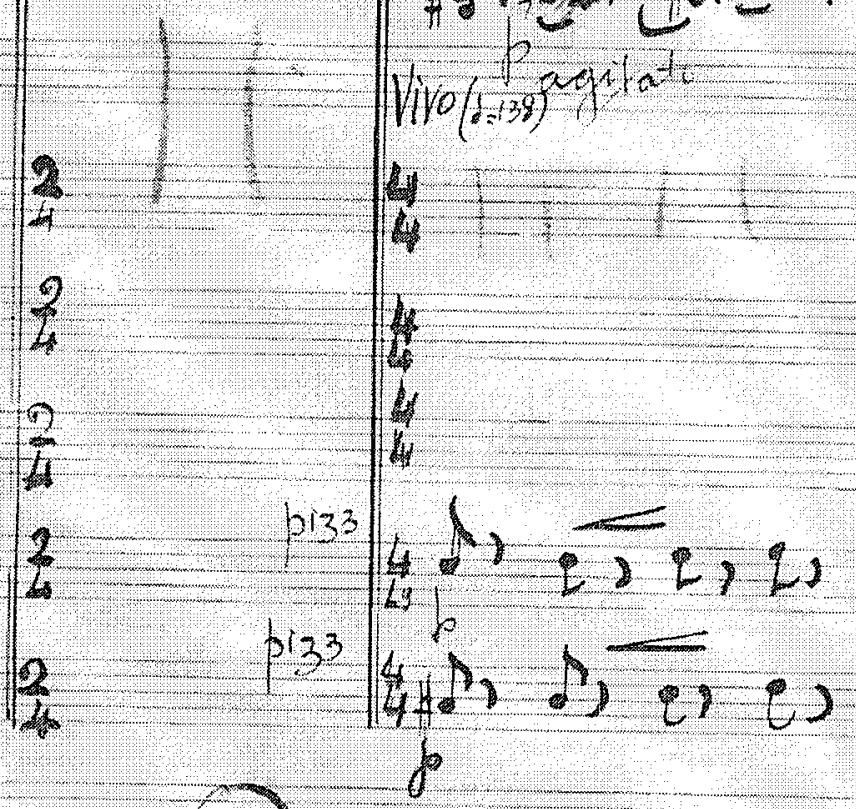

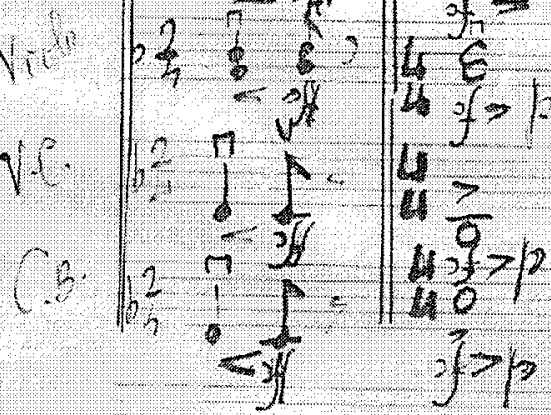

(2)

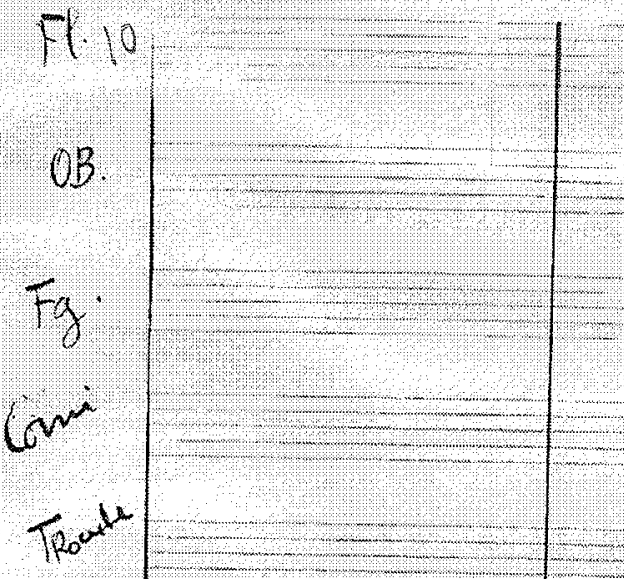

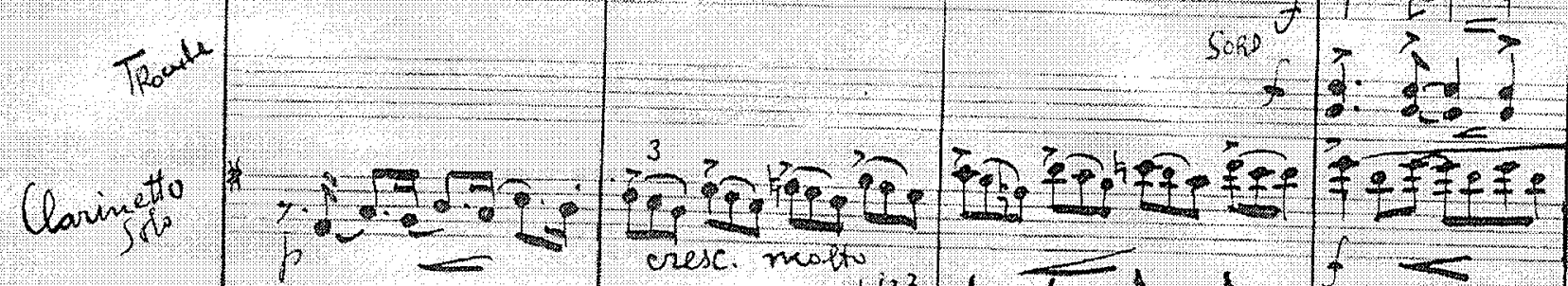

if.

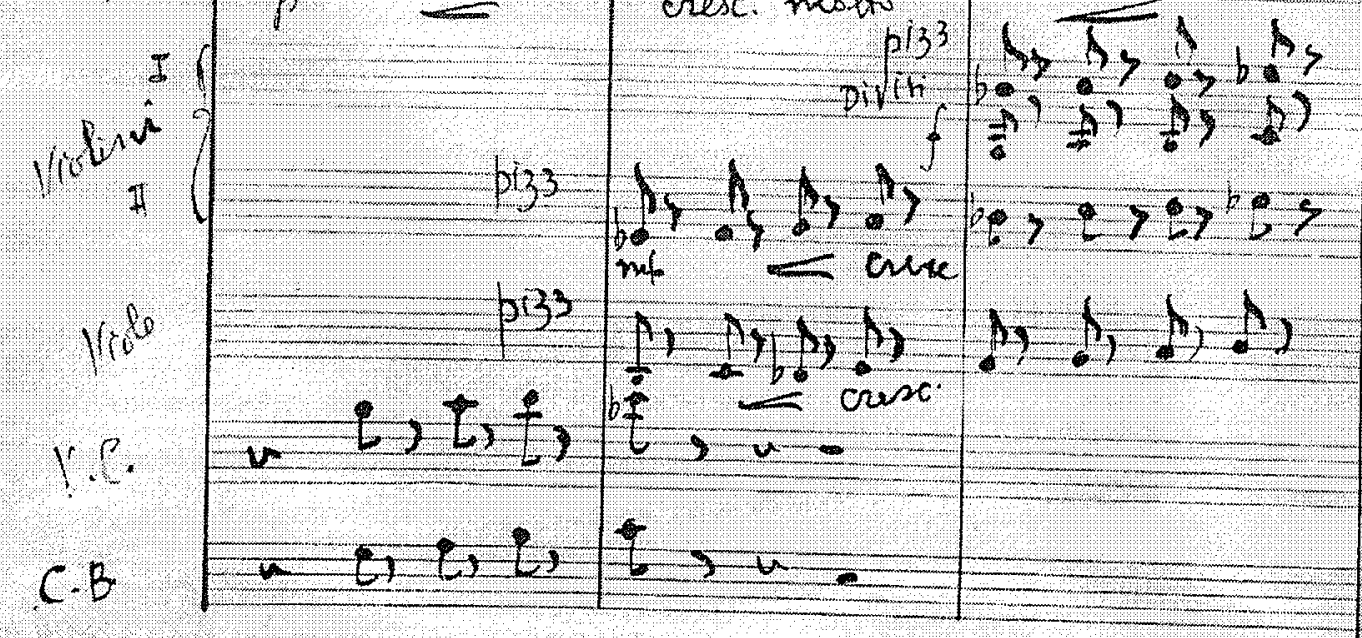

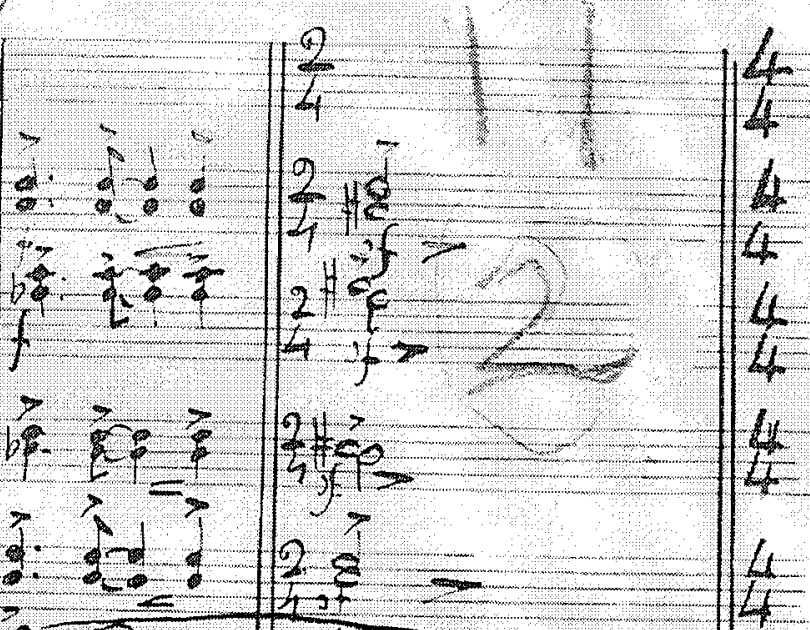

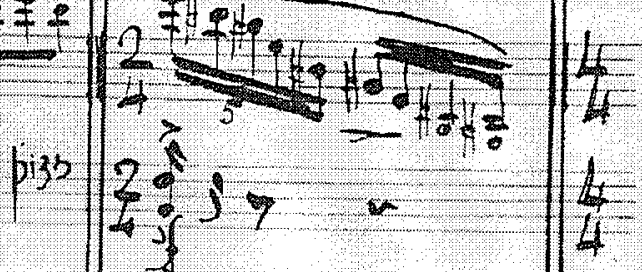

$\frac{2}{2} i^{2}+7 \quad n$

2 
$4+1$

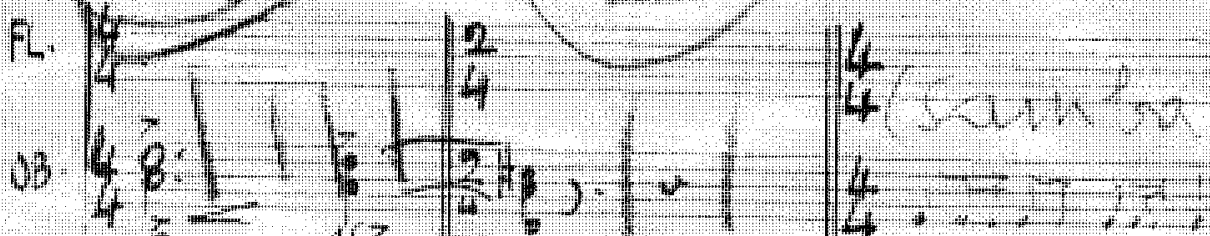

$\frac{\operatorname{con} l a}{\cos (\operatorname{lon})}$

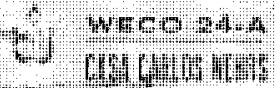

$+\frac{1}{4}$

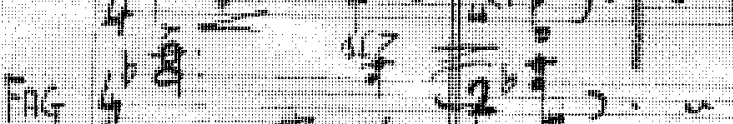

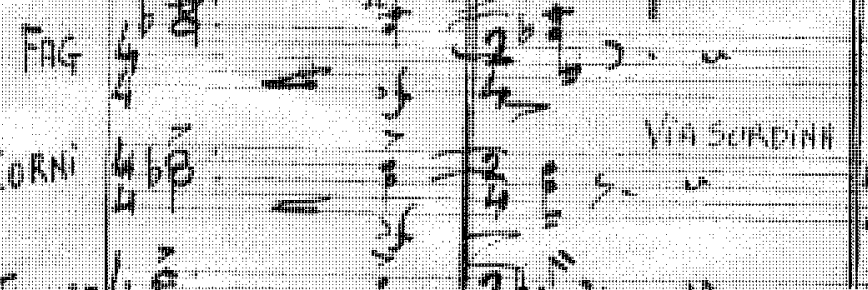

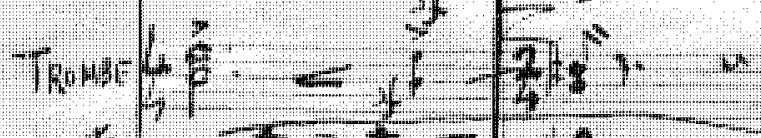

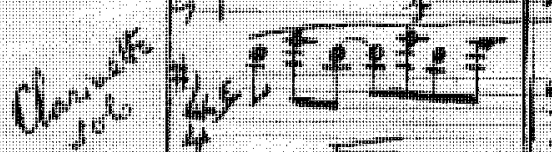

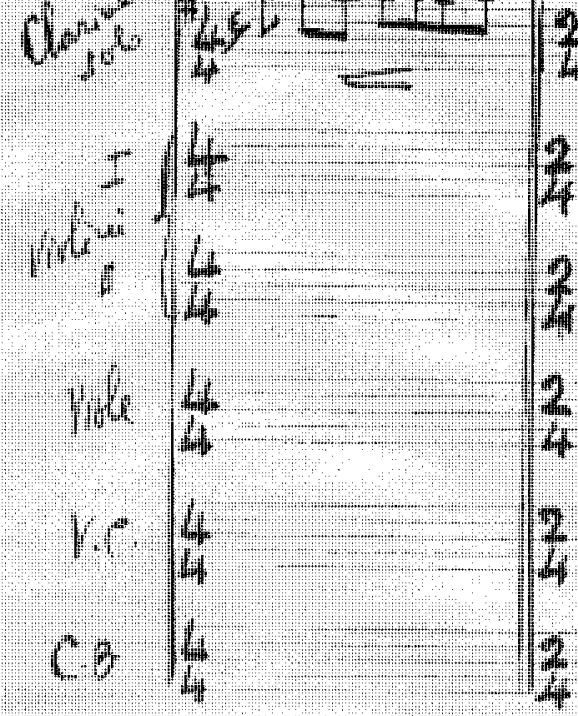

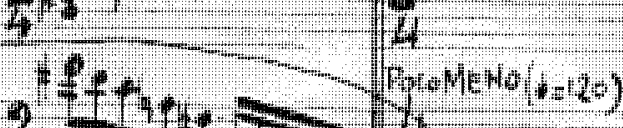

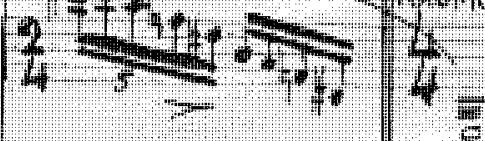

$\frac{2}{4}$

2.

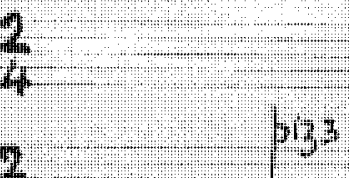

$2 \quad b i 3$,

2
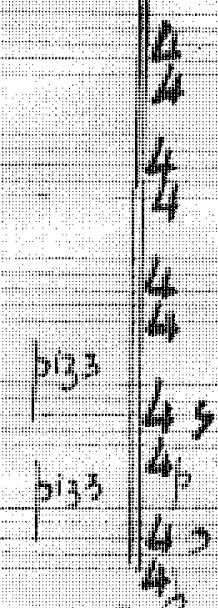

9

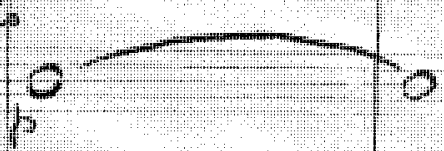

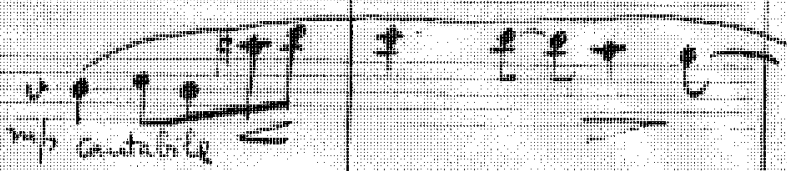

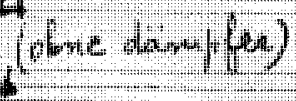
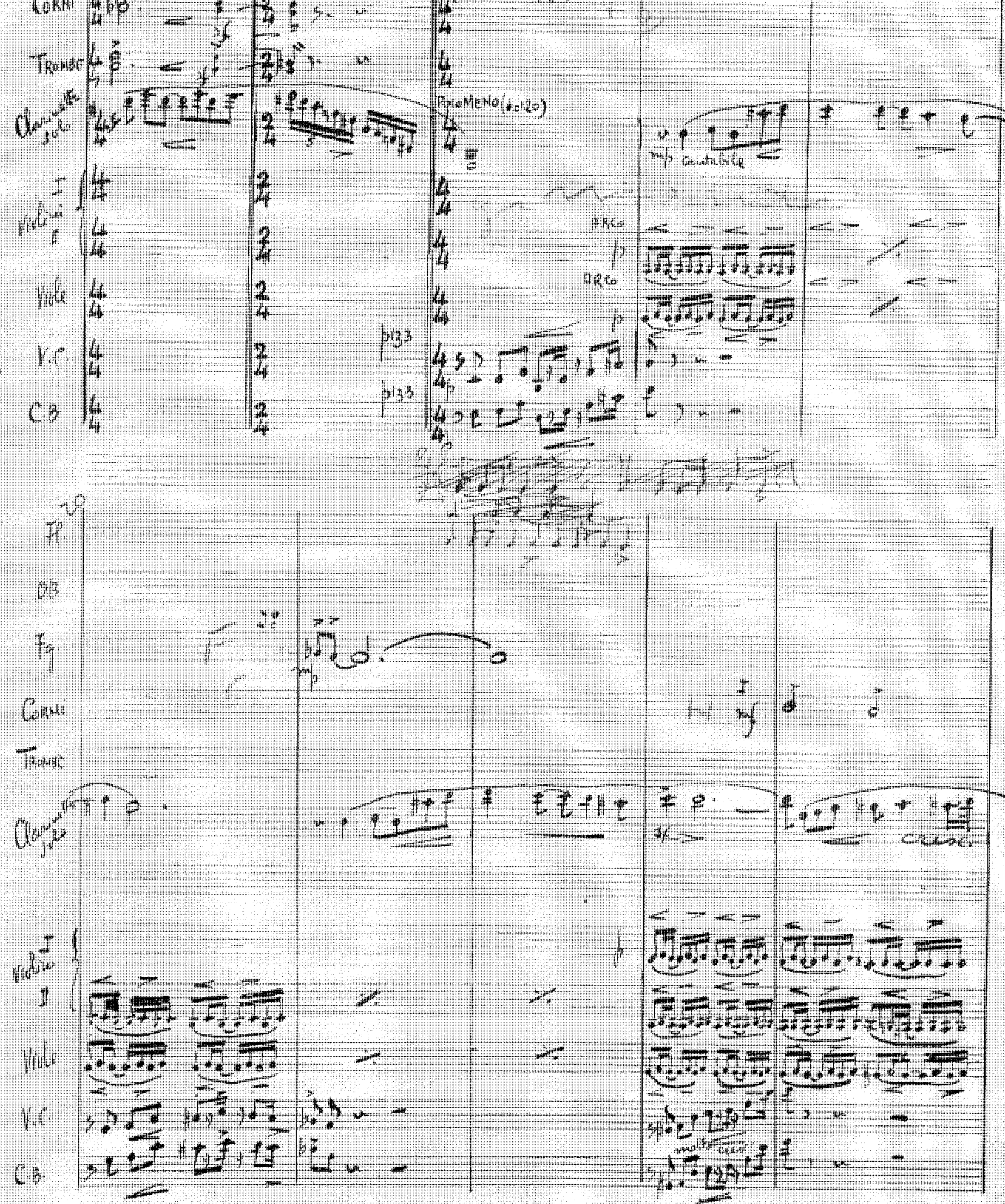

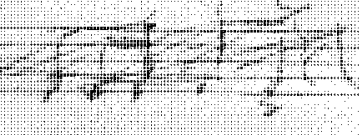


1)

Pf:

$O B$

Fing:

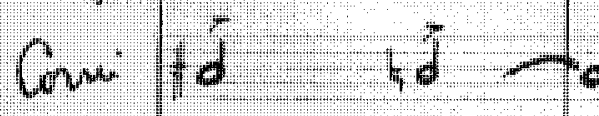

Tiso

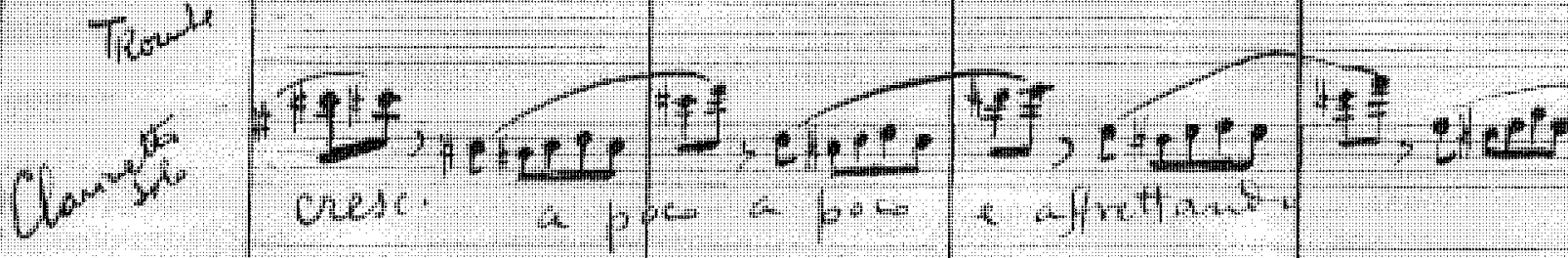

$92 \frac{14}{43}$

stiting
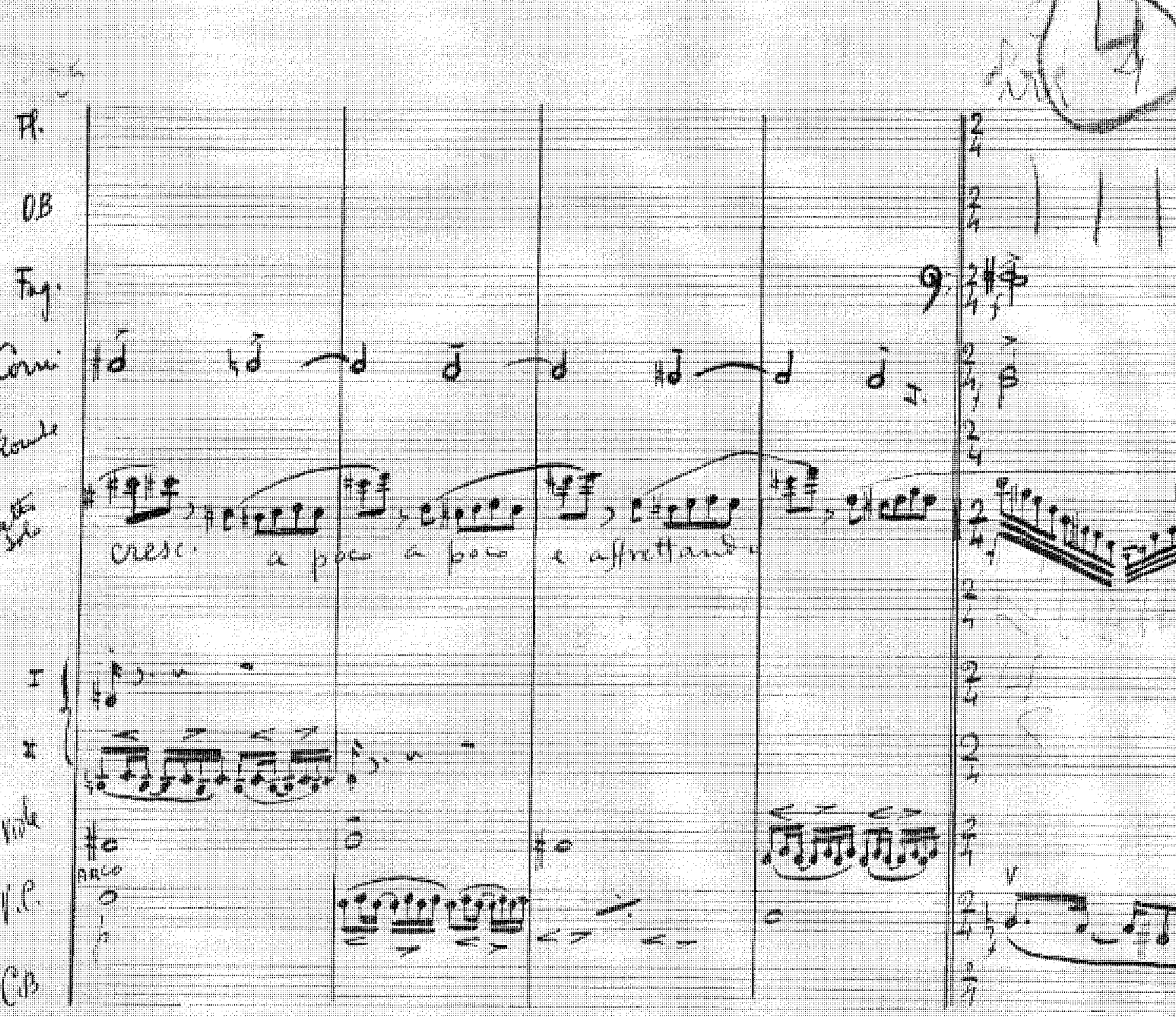

(3)

$x+4$

Nit.

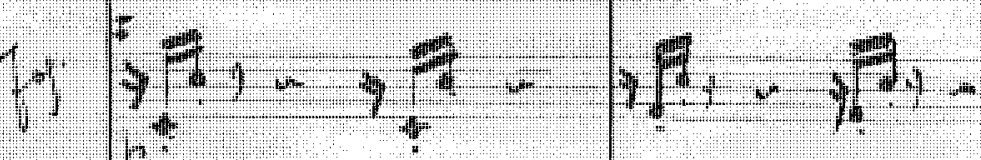

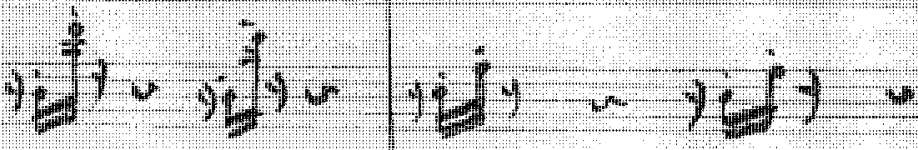

covi

$\pi^{3 n}$

$+i^{2}$ th $^{2}$

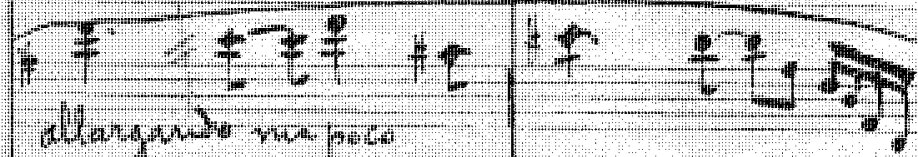

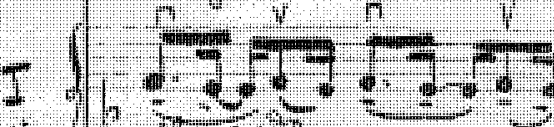

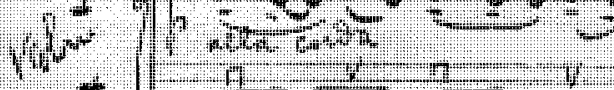

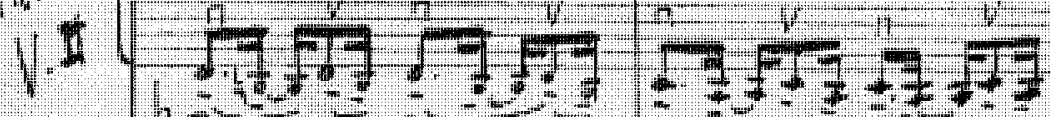

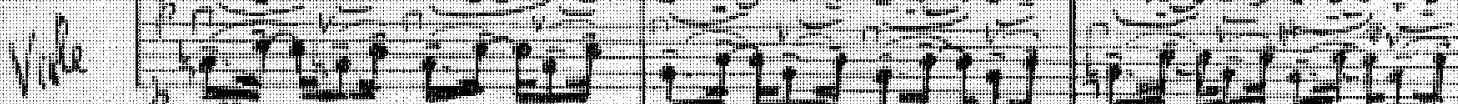

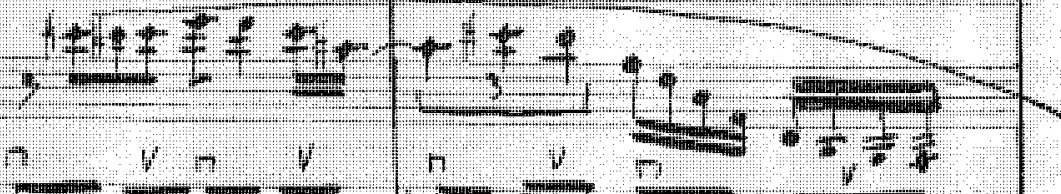

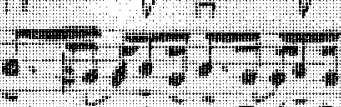

$\left|\begin{array}{l}2+\sqrt{2}-5 \cdot 7 \\ \frac{4}{7}\end{array}\right|$

if
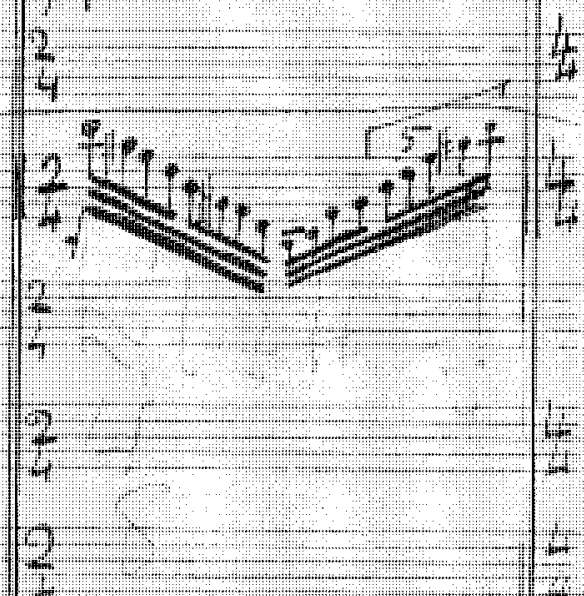

गुำ.
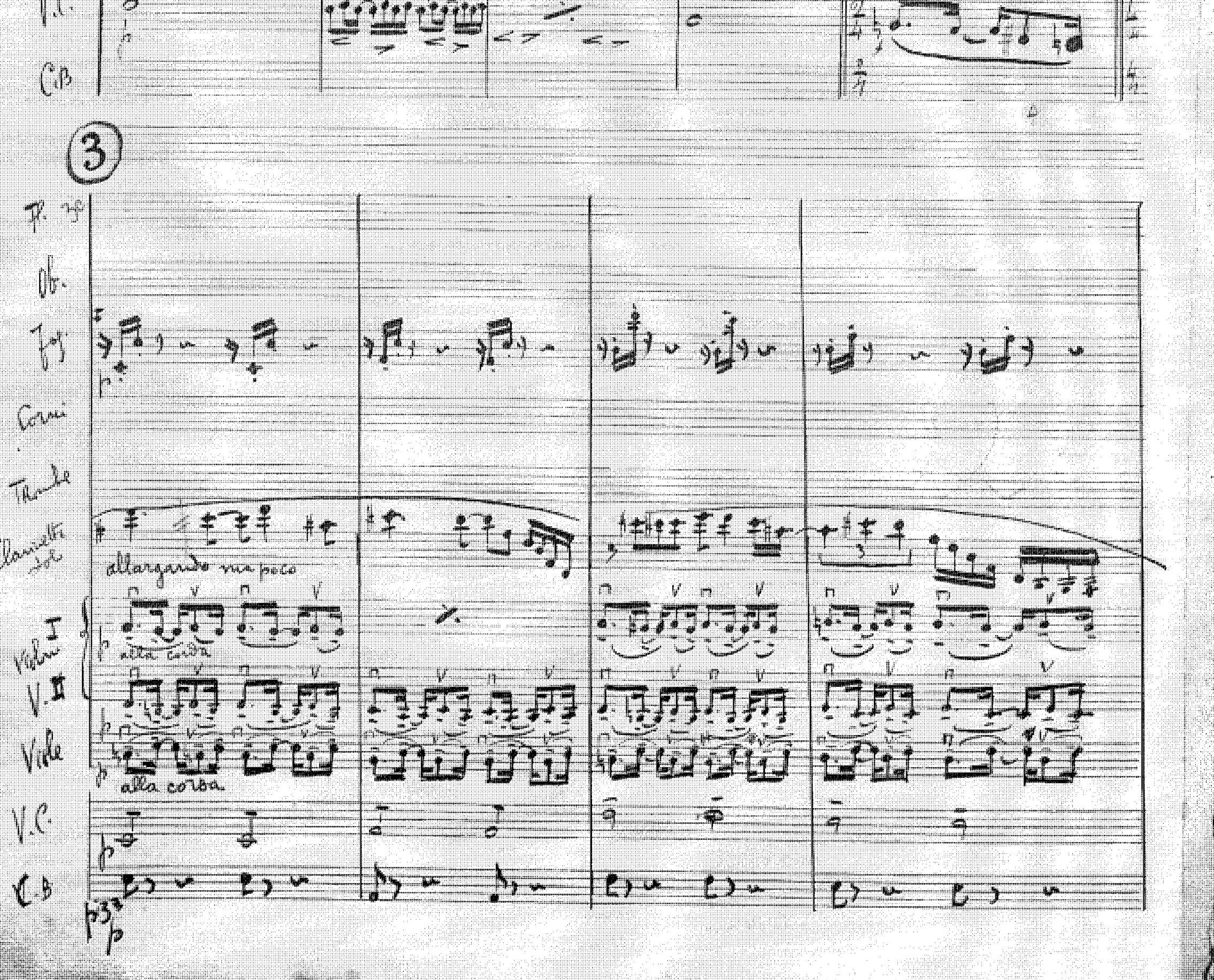
$4^{4}$

I.

1

Fin:

Qunin

$T_{1 w w^{\mathrm{E}}}$

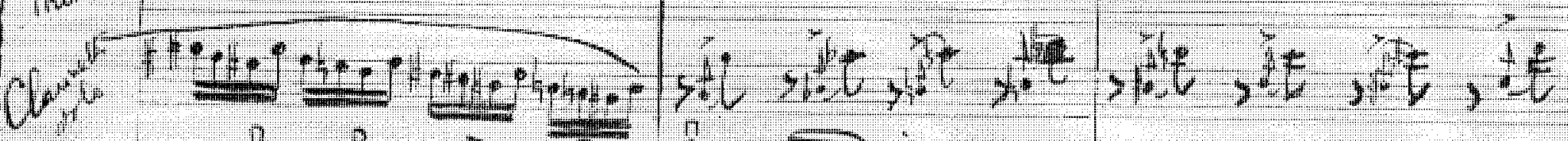

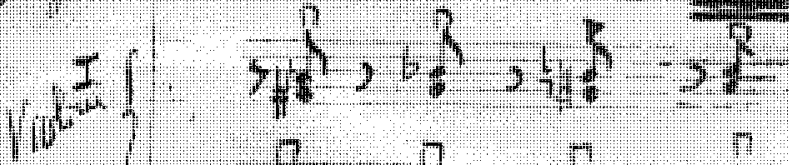

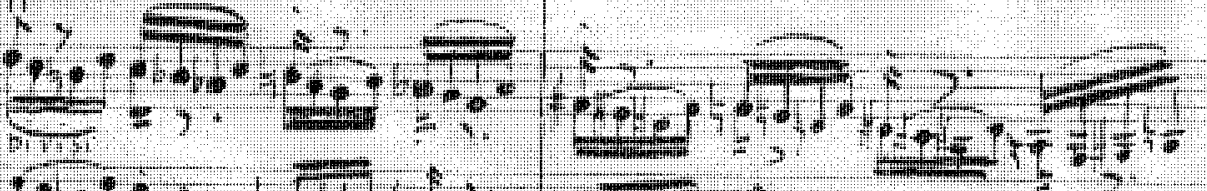

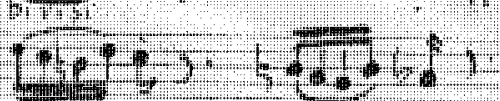

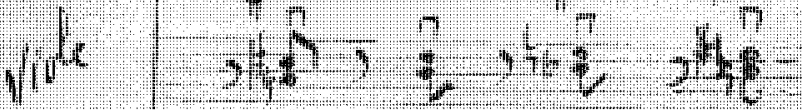

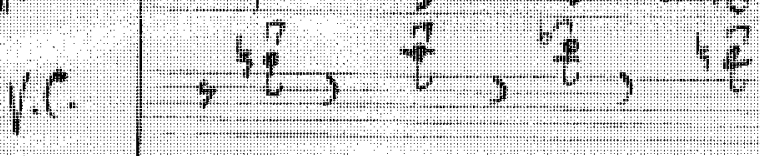

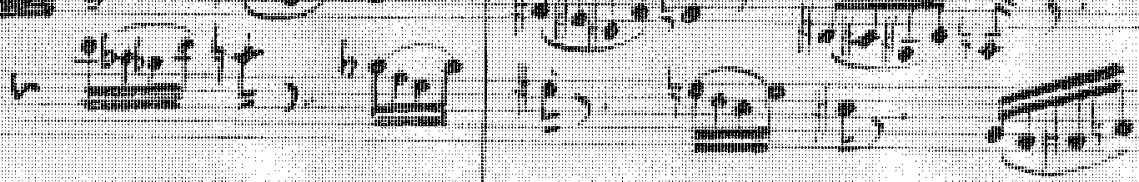

(a)

$(B)$

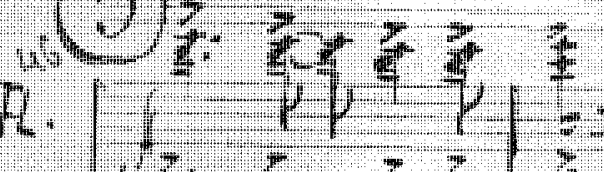

013

$46: \quad 3+3 z^{2}$

$-3^{4}=$

- thatiming

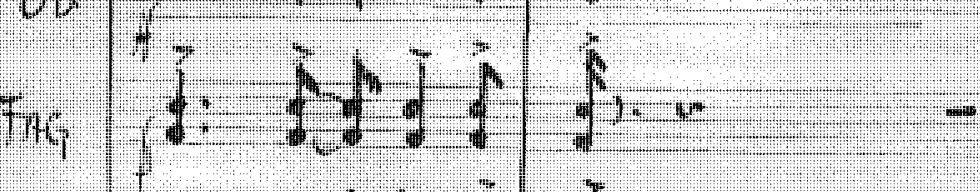

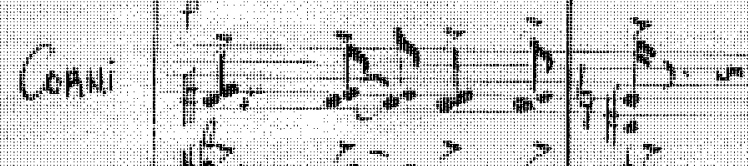

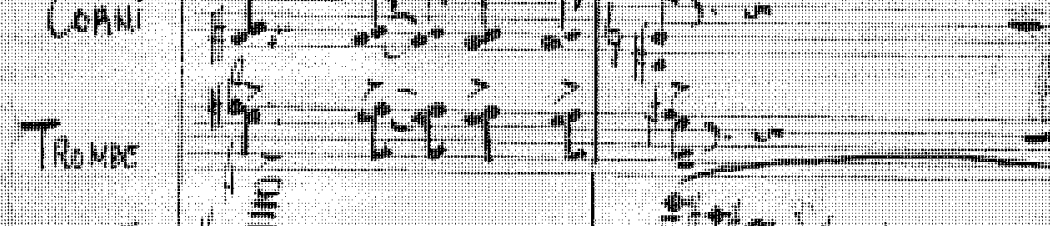

( 11

$p^{2} y^{2}$

C.s

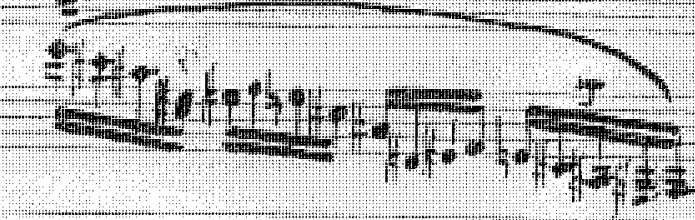


8

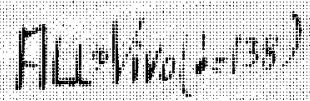

then

of

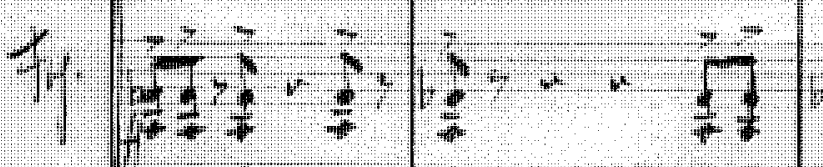

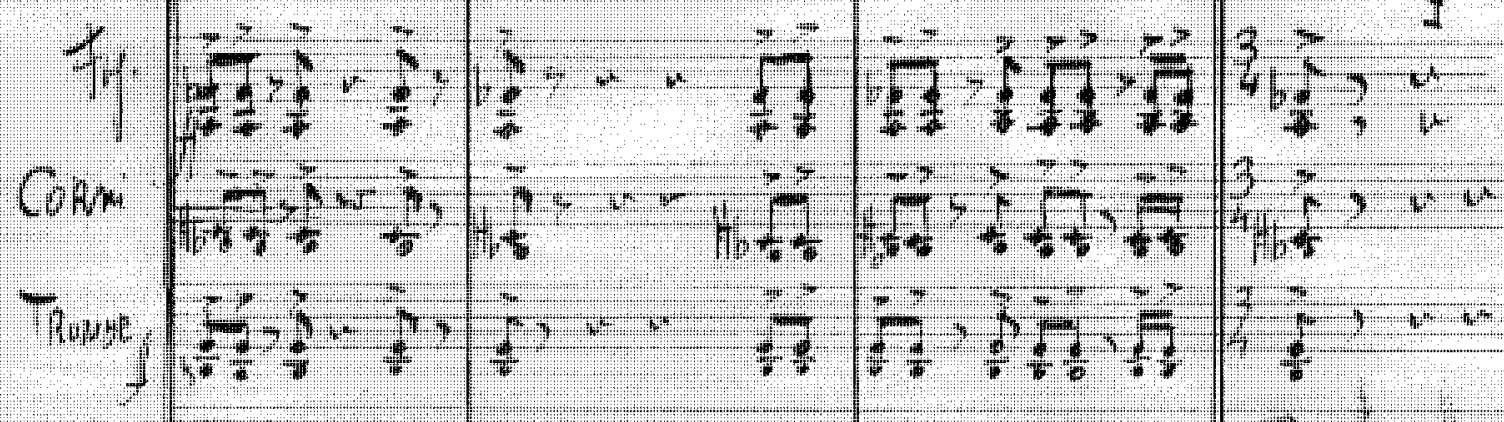

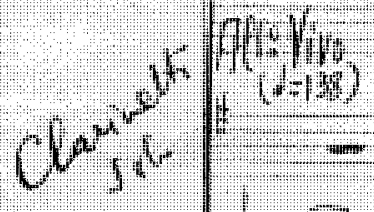

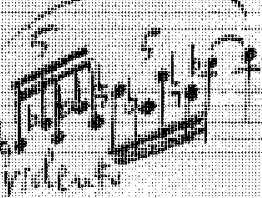

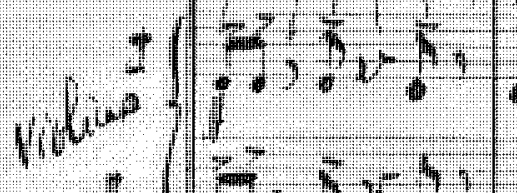

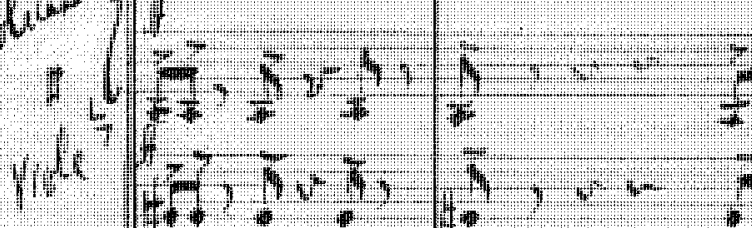

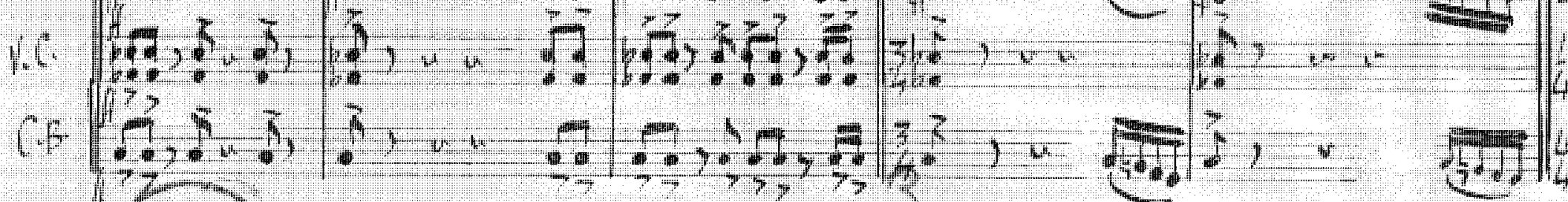

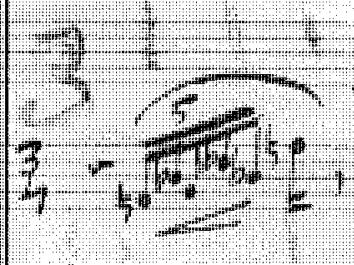

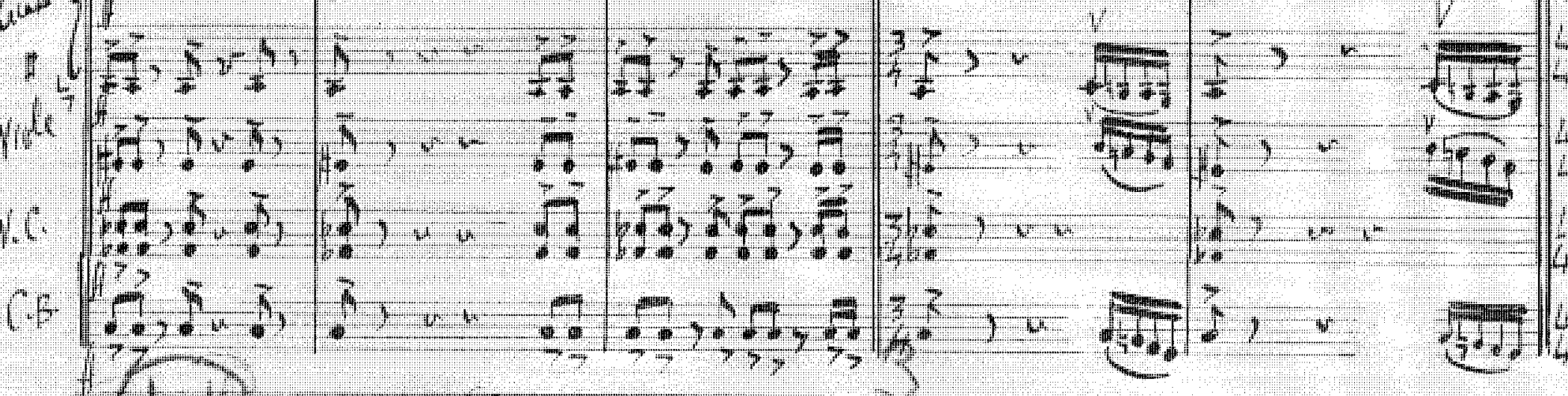

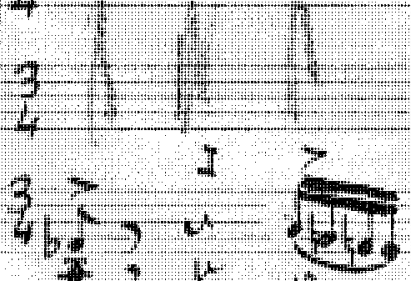

$\frac{-}{3+5}$

14

tis

7

$\rightarrow, c^{2}$

tis

$\div$

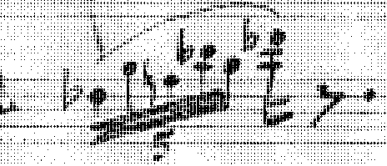

$\rightarrow 3=$

$\sqrt{1+5}$

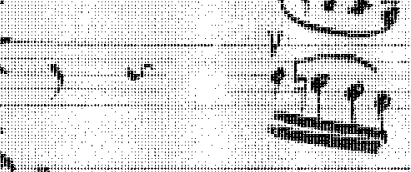

1..

\section{$\mathbb{P}^{2}$ I.ex $(7$

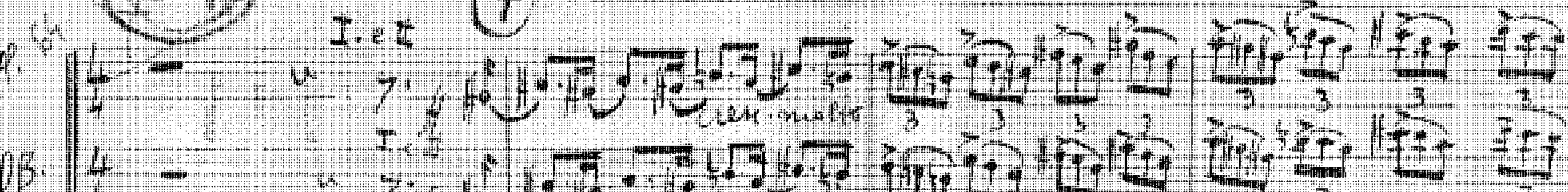

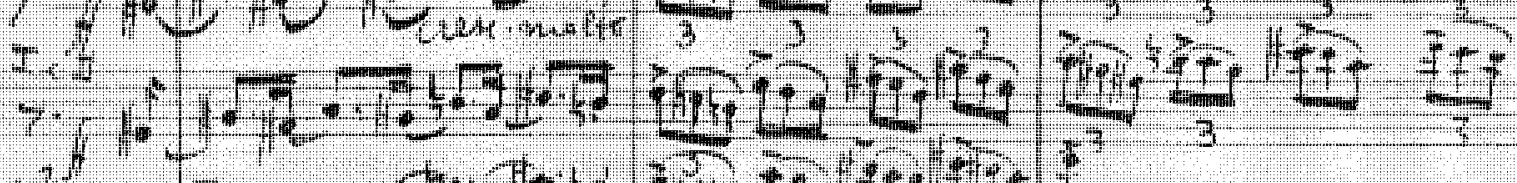

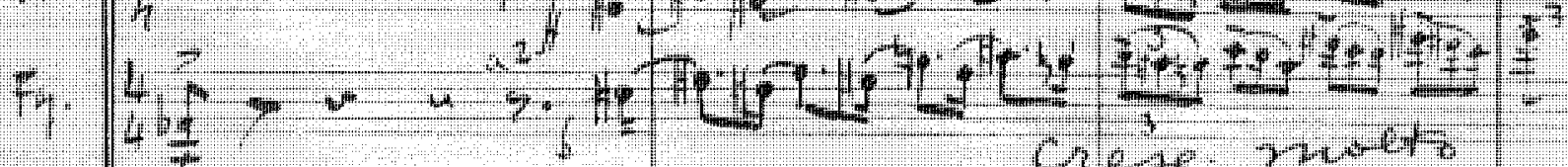

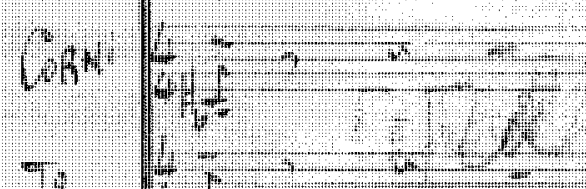

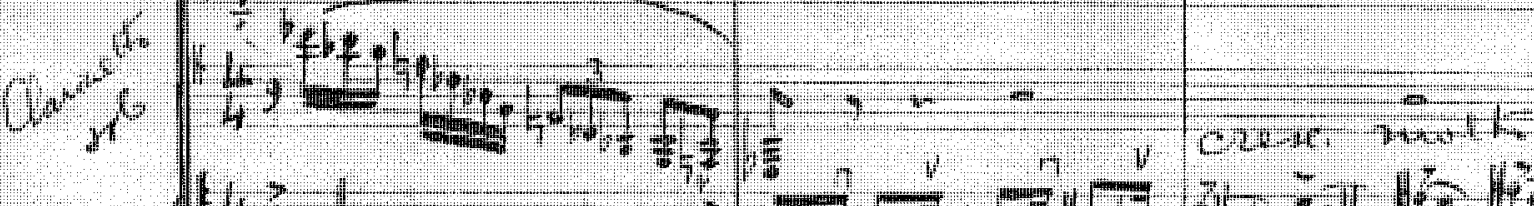

corent

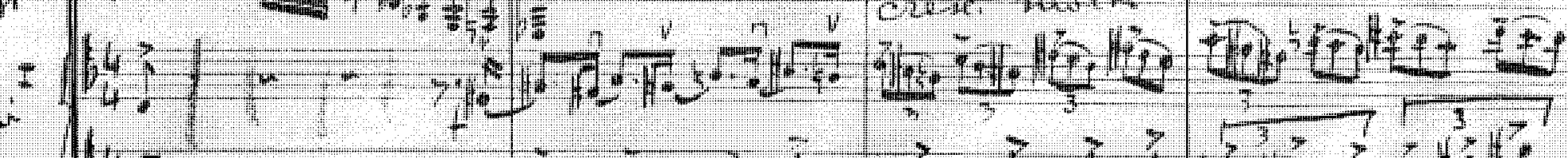
whon

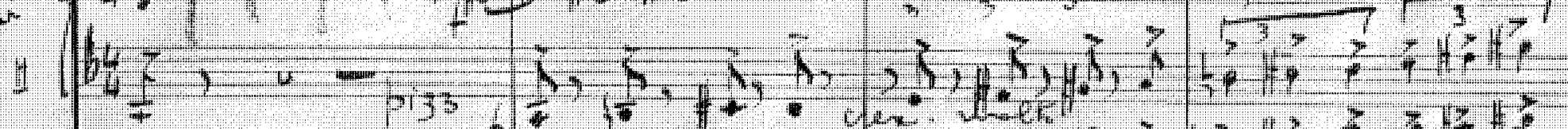

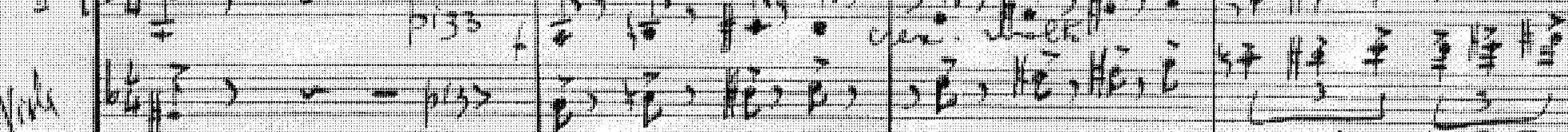

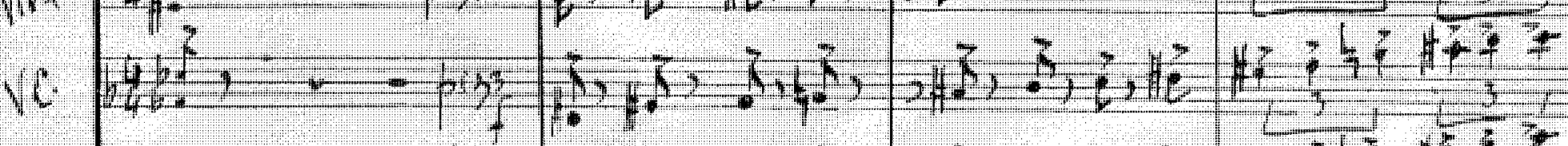

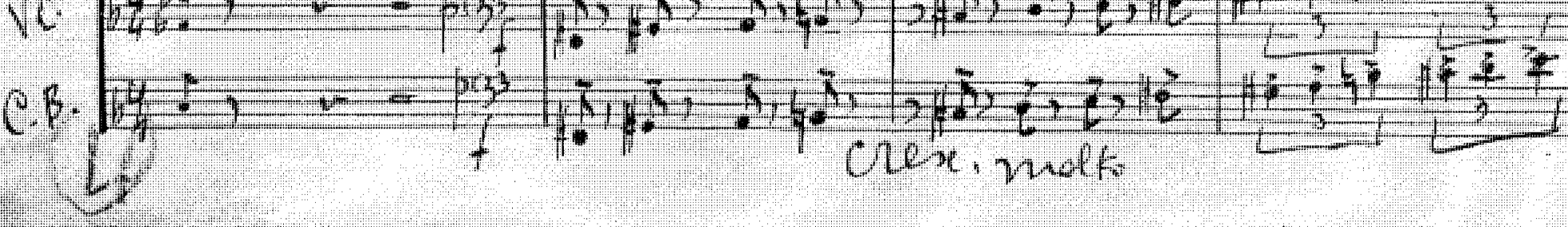
clex, molk 
Asspi $\sqrt{116}(6-152)$

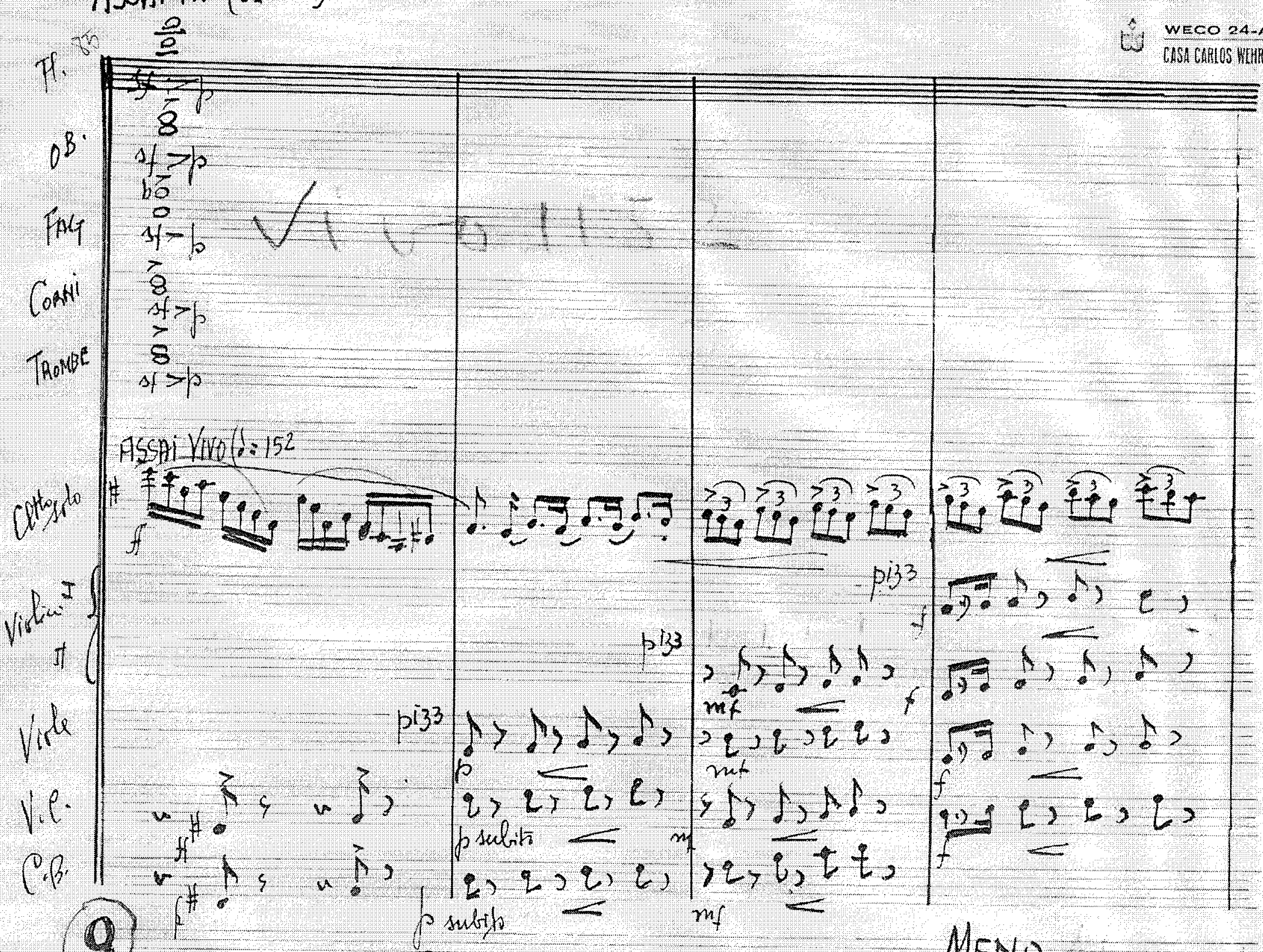

(9)
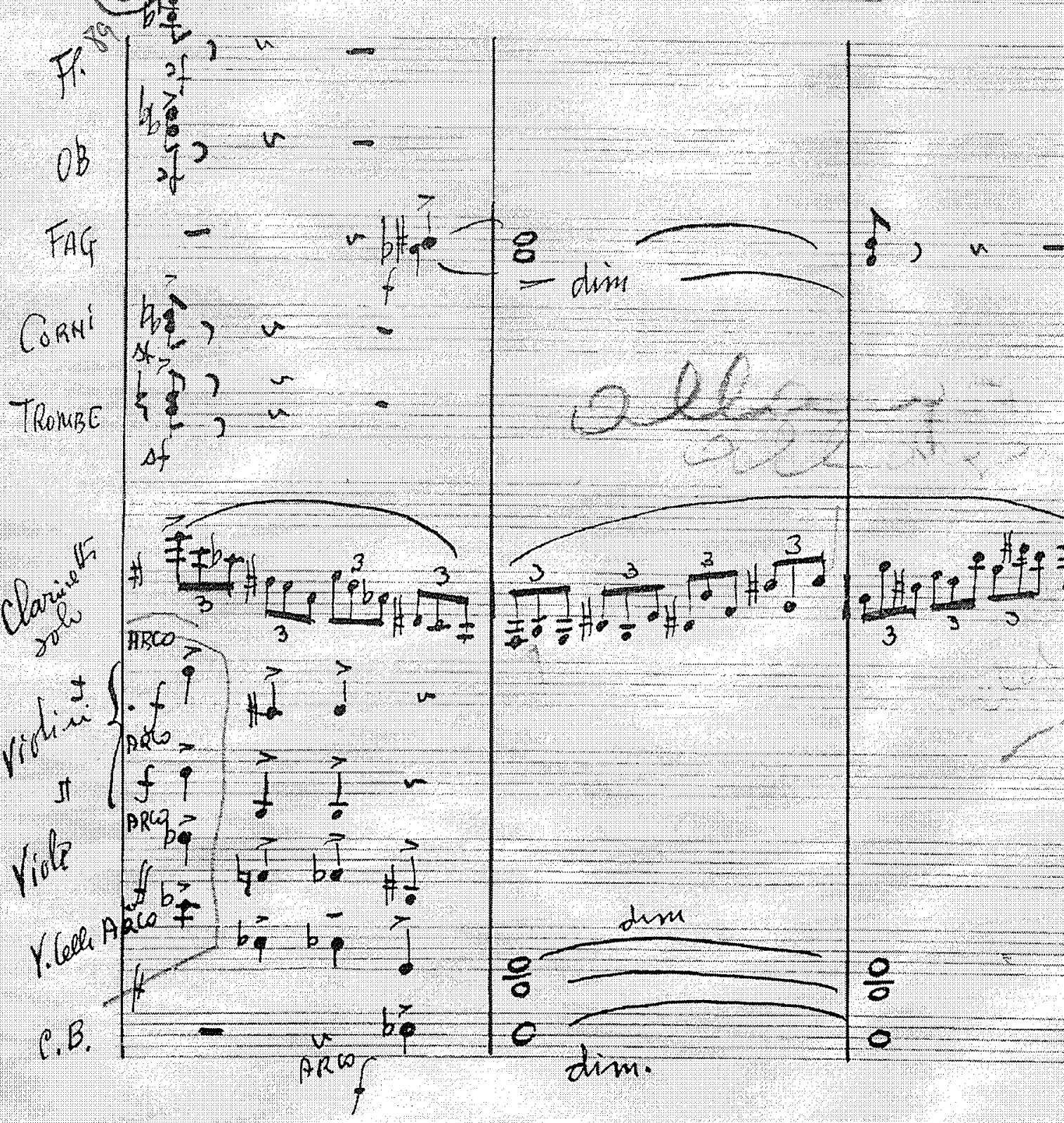

MENO

$(d=132)$

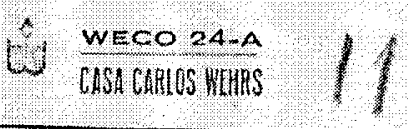




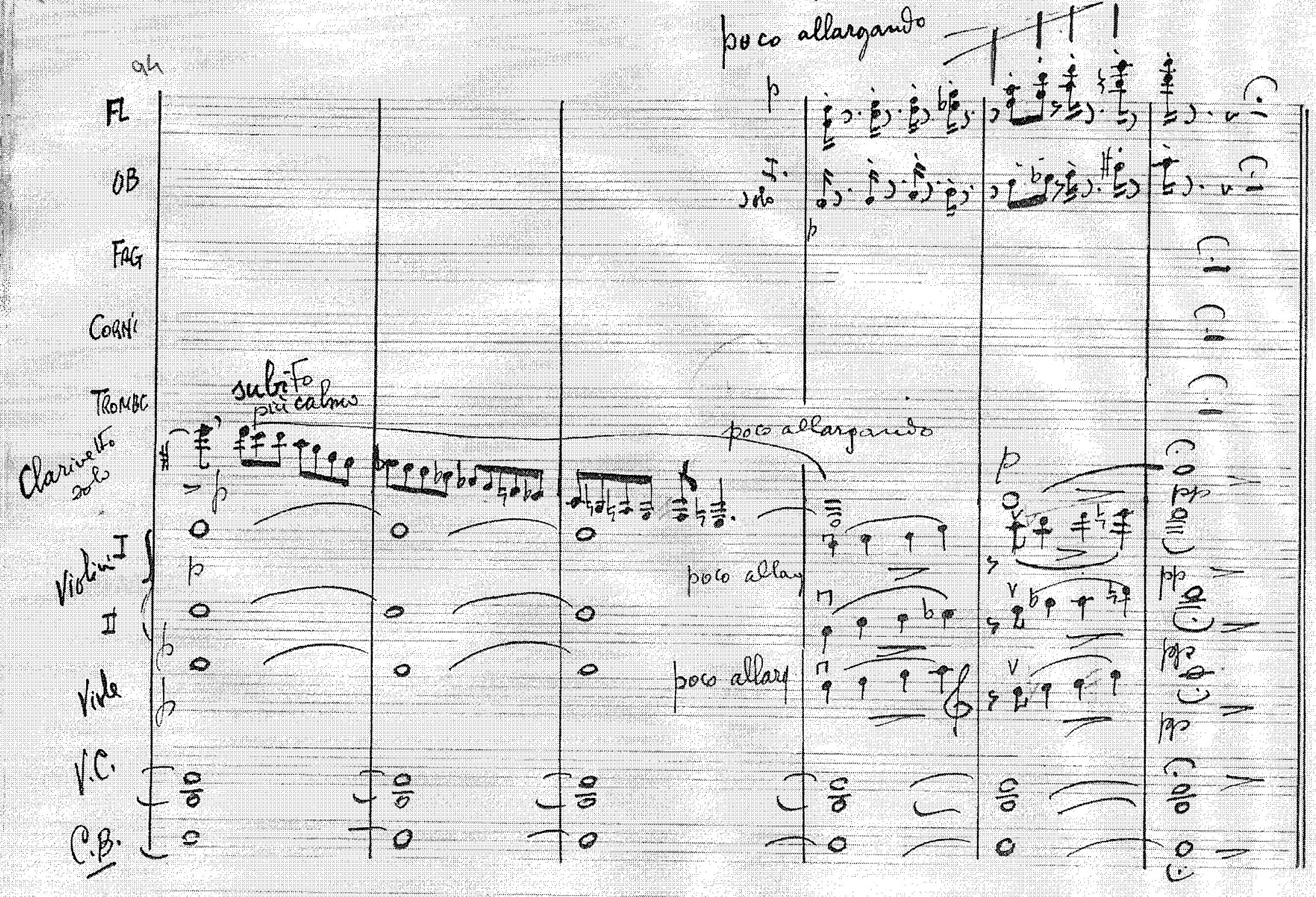




\section{TOADA}

AND TE MA HON TRoPPO

F 14 (d)

(B. $6^{b}+$

foy 9164

Cor $\oint_{4} 4$

1Fivi 6.6

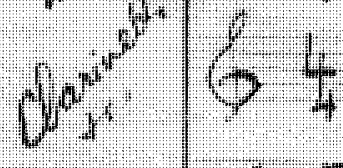

AND' Nist TRetoro(t-10s)

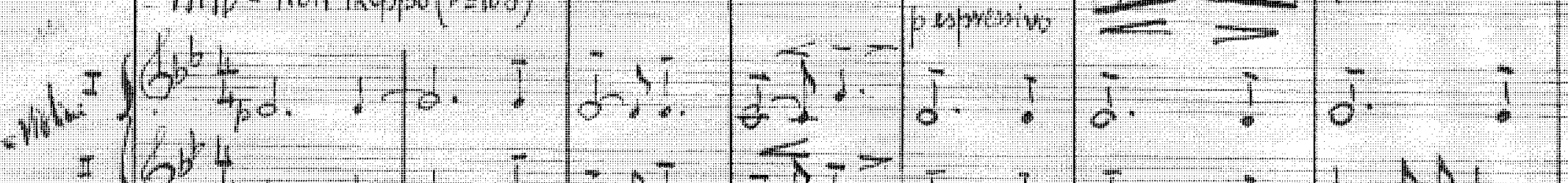

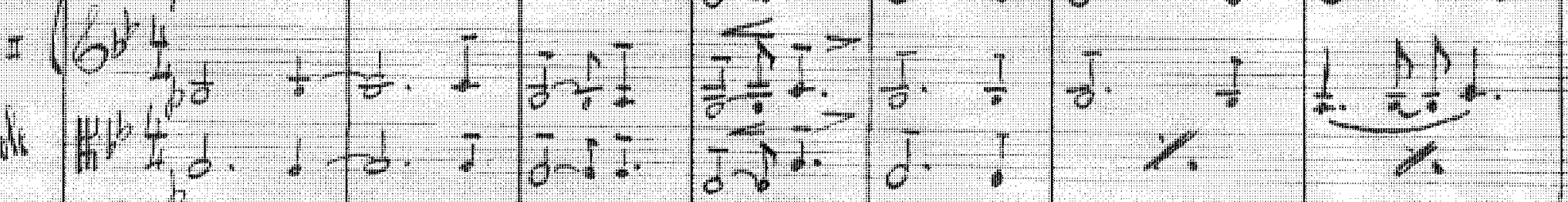

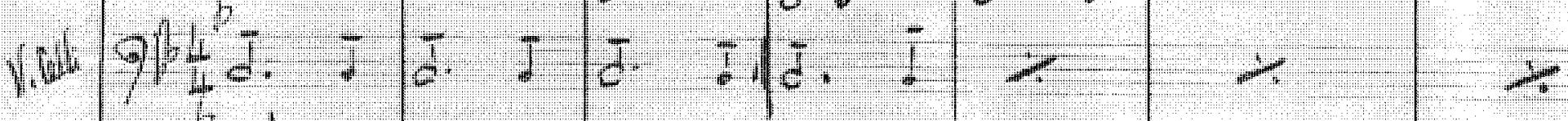

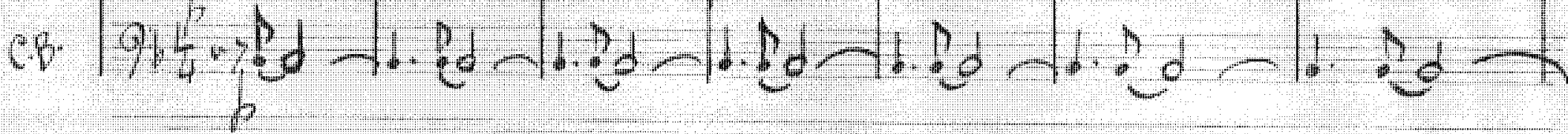

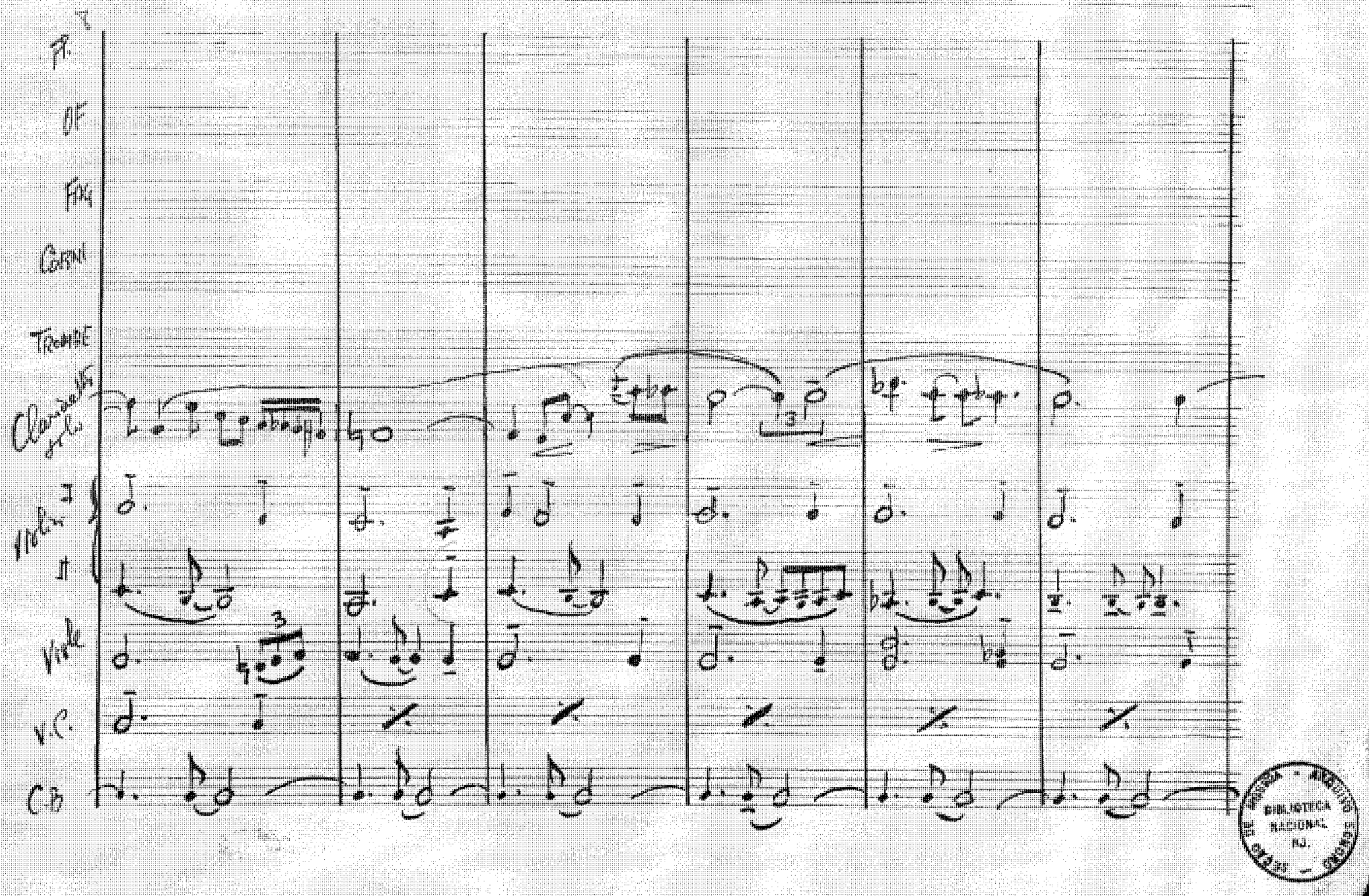


Pl.

Pú

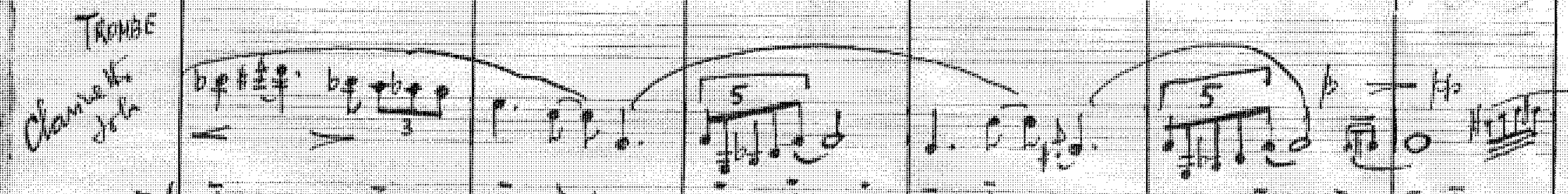

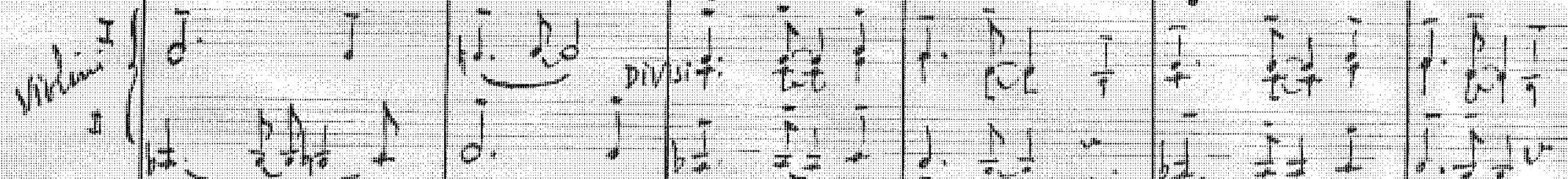
vith be

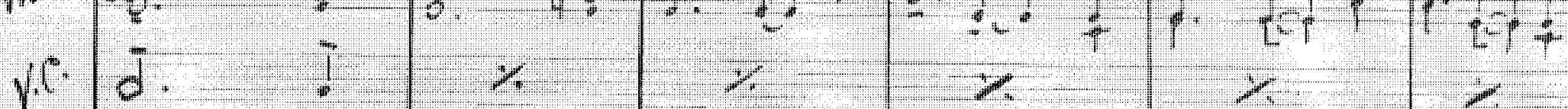

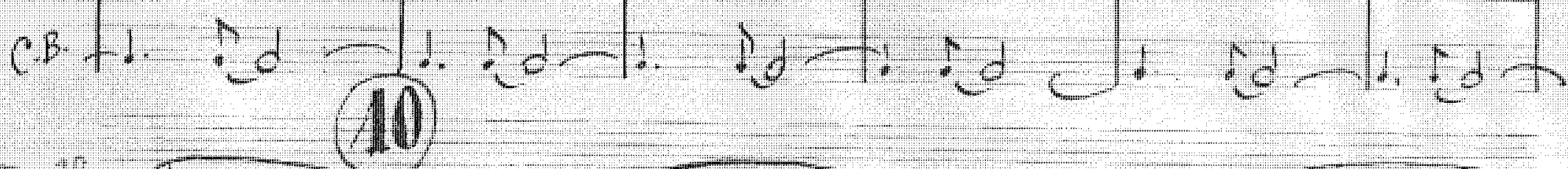

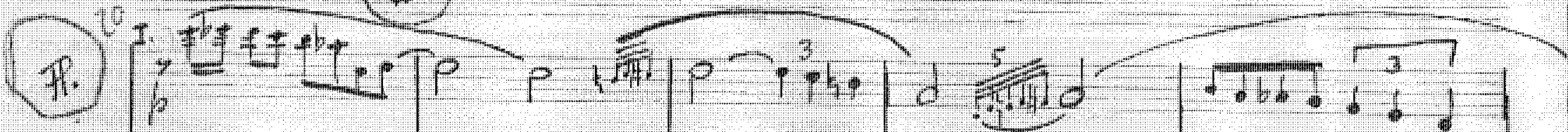
$O B$

Pig

Cow

$100^{2}$

.

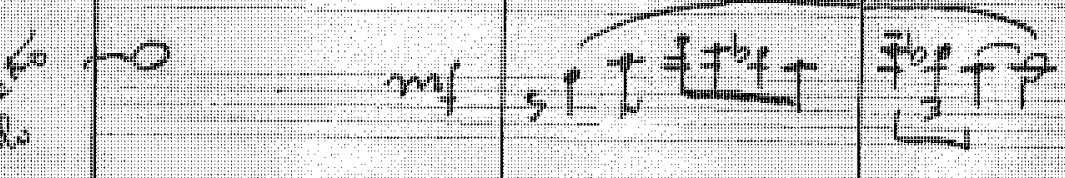

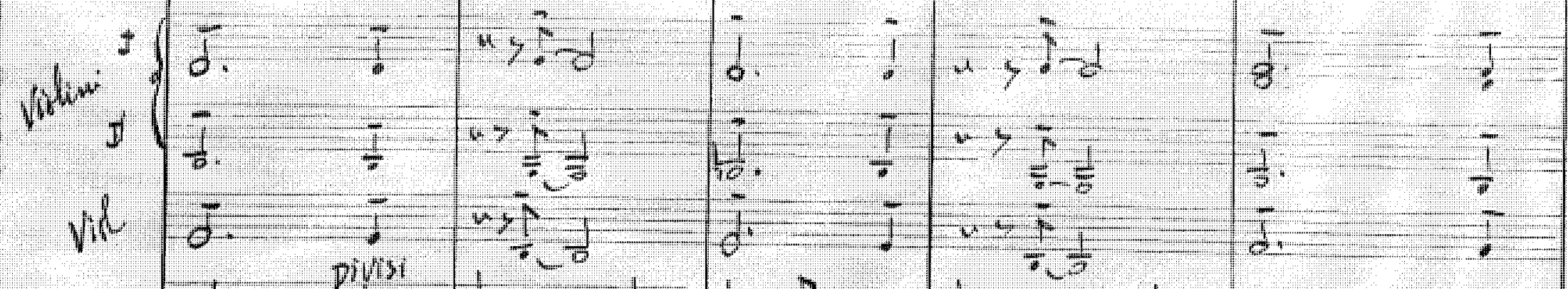

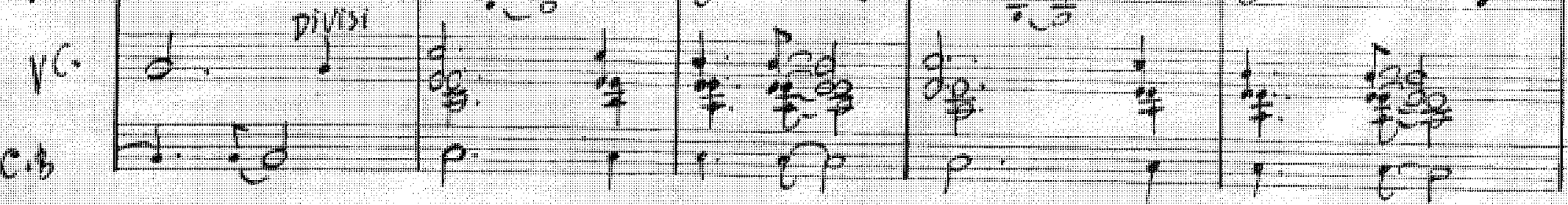




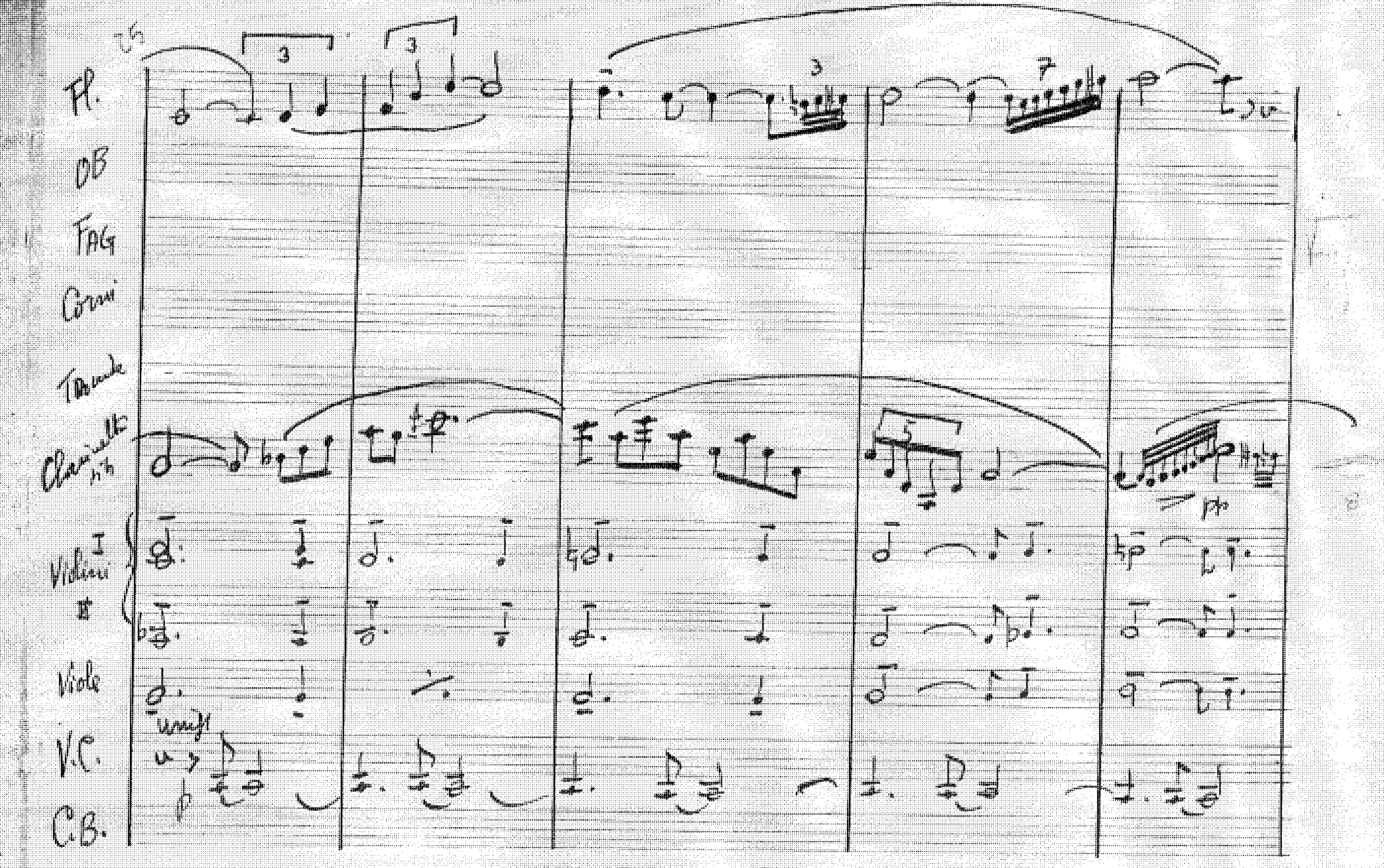

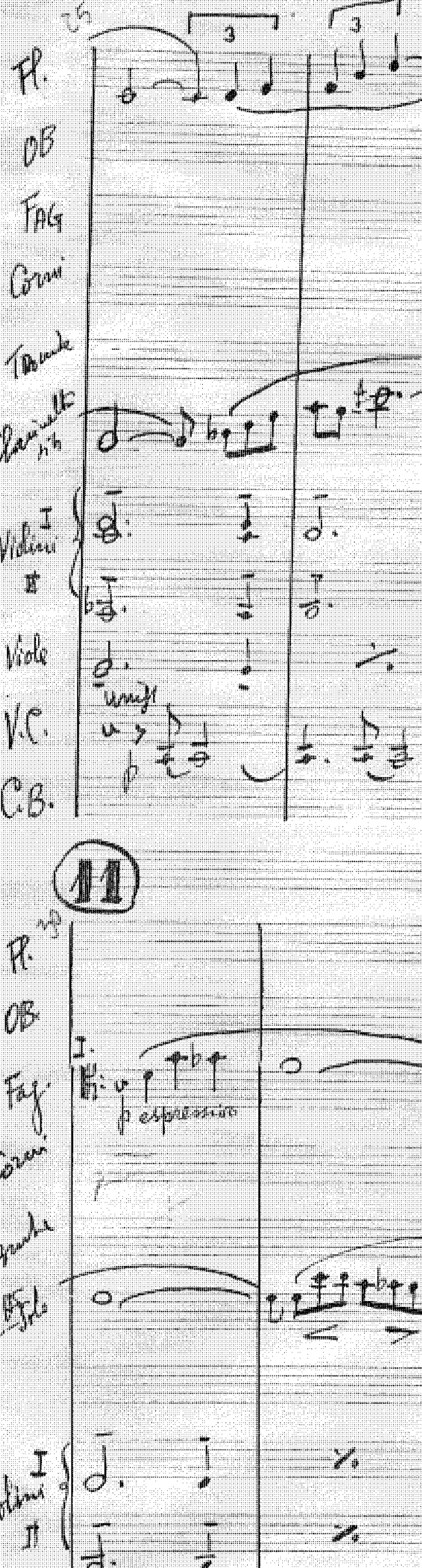

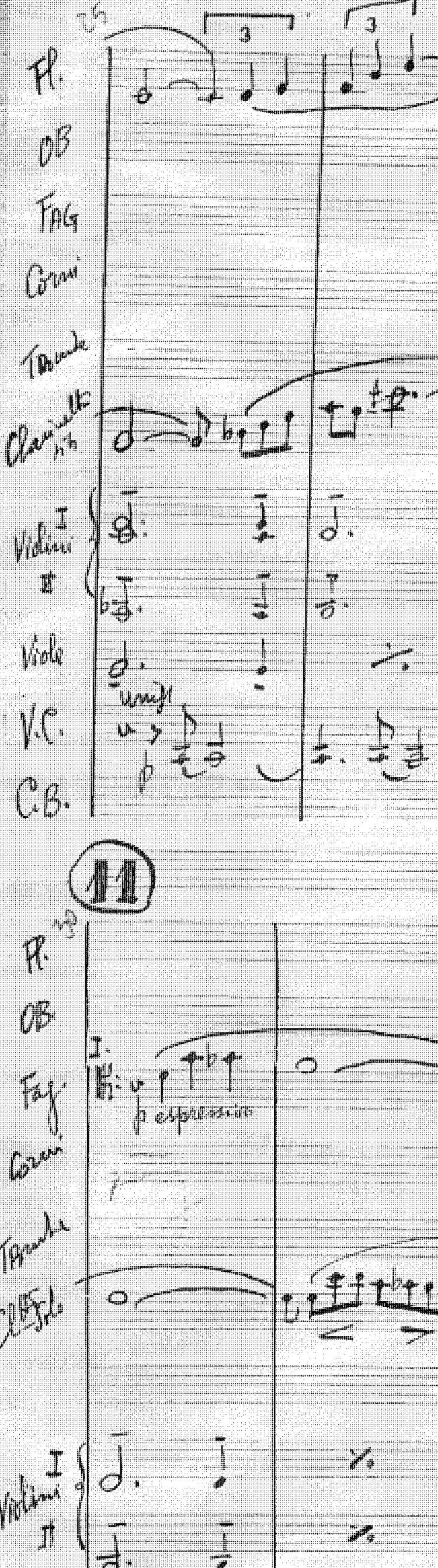

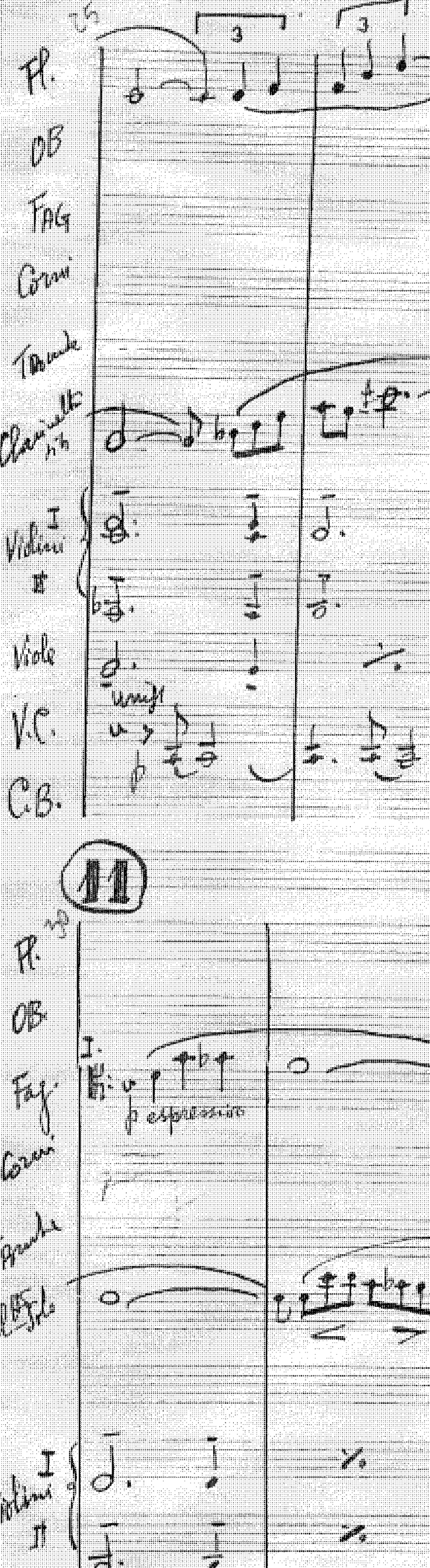

(5)

(19)

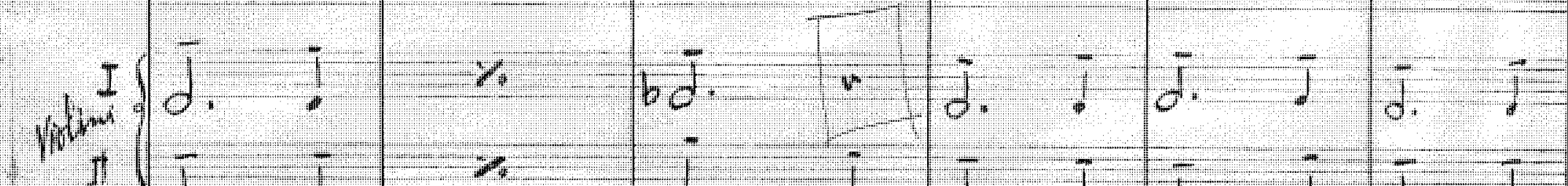

\begin{tabular}{l|l|l|l} 
& 3 & $=1$ & $=$
\end{tabular}

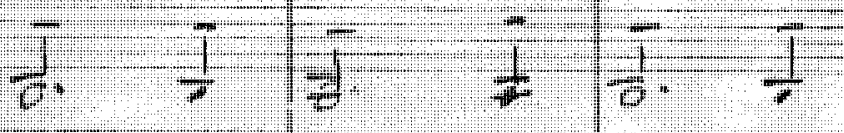

ic

j.

!

$\approx$

$x \quad>-1$

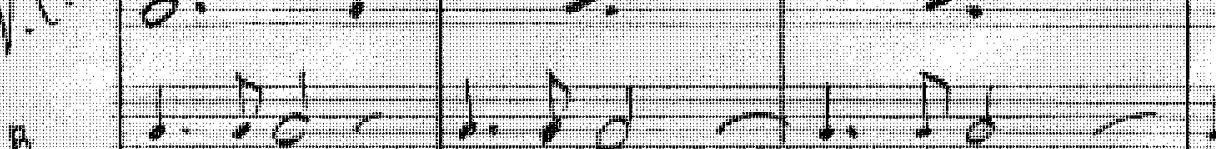
$\div \quad x-2$

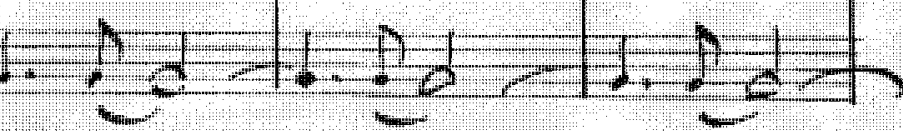


16

\section{(12)}

A: $|=|-1+3$

do.

H.

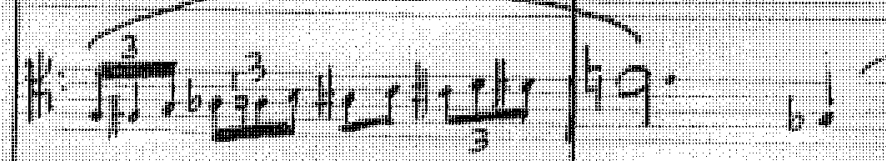

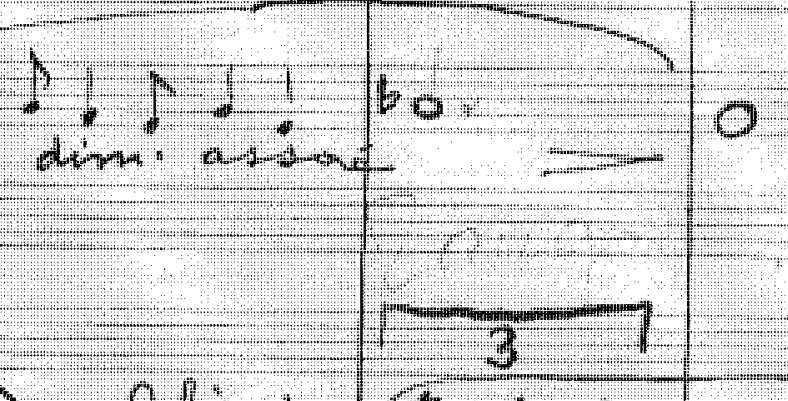

$\cos ^{2}$

$p=1, i$

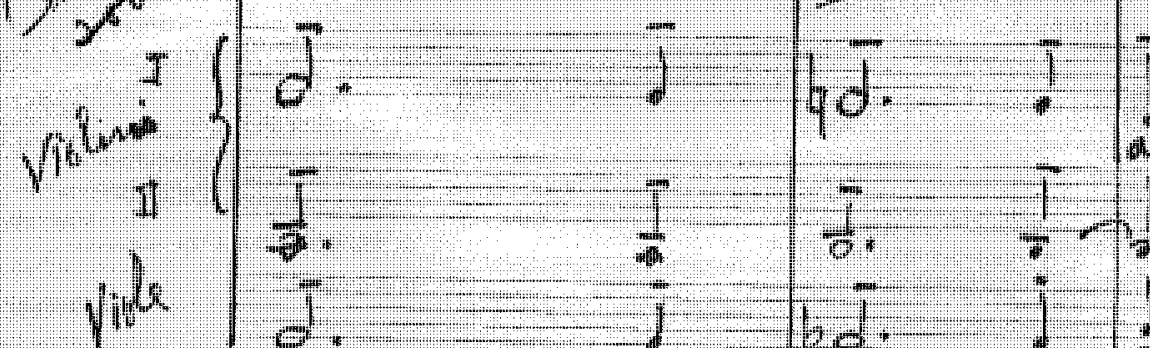

vi. $\dot{d}$.

C.B. I.

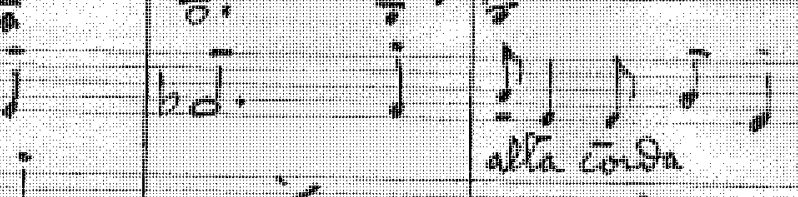

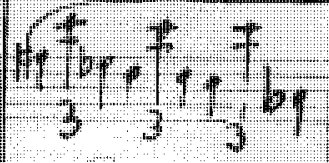

0

alk caroa $=70$

$\overline{5}$

0
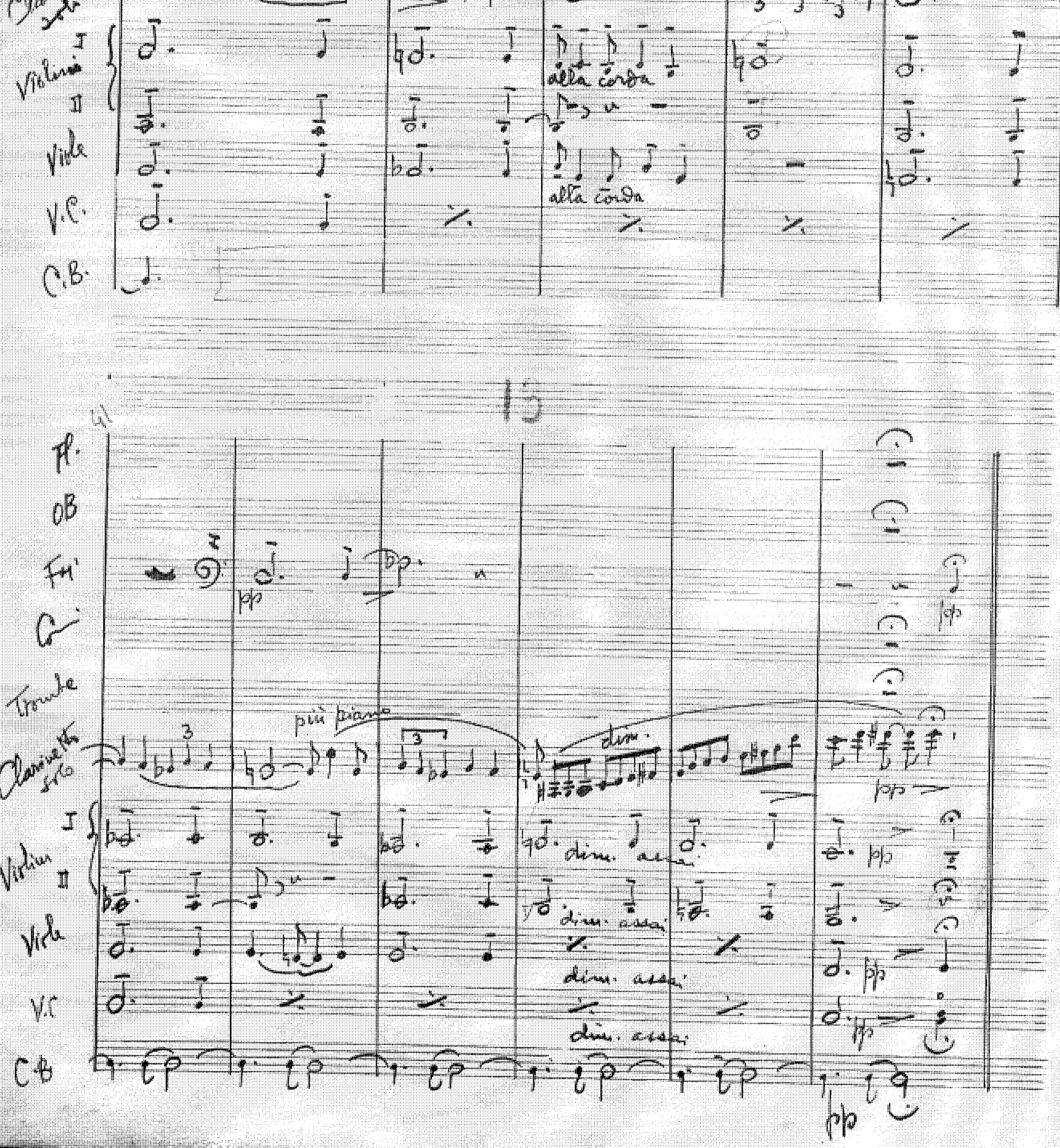


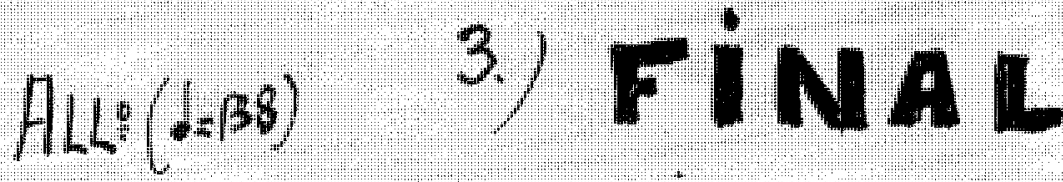

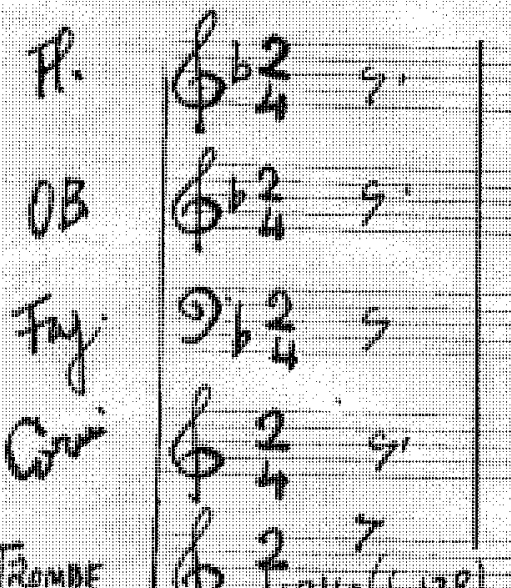

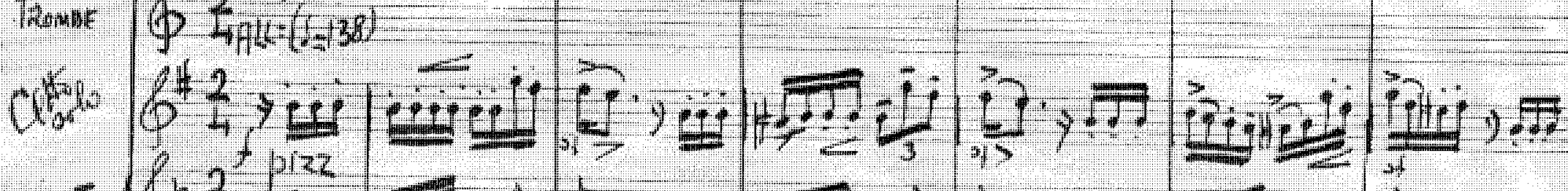

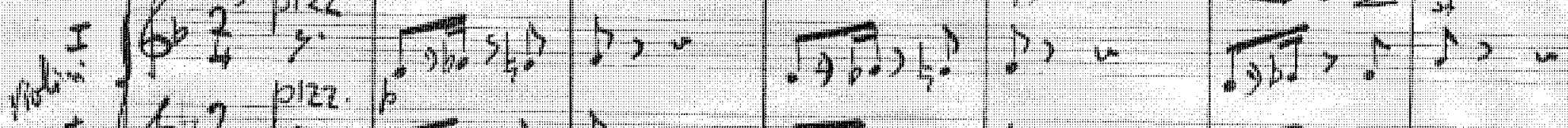

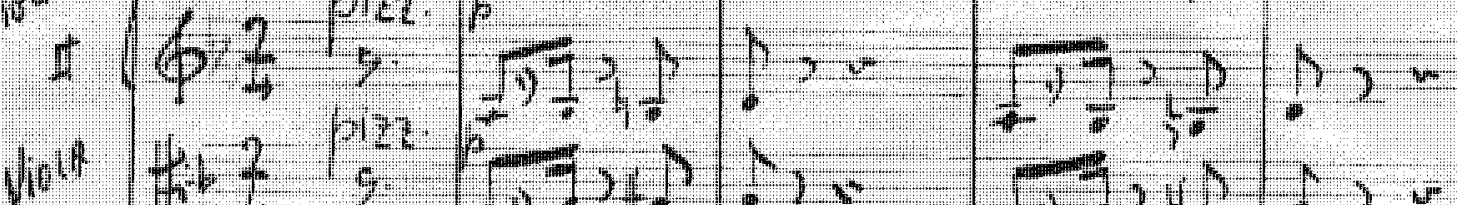

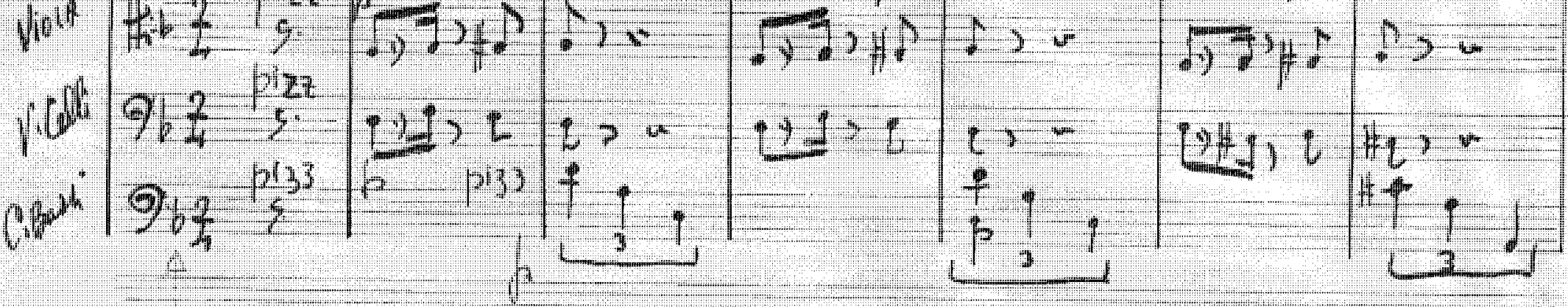

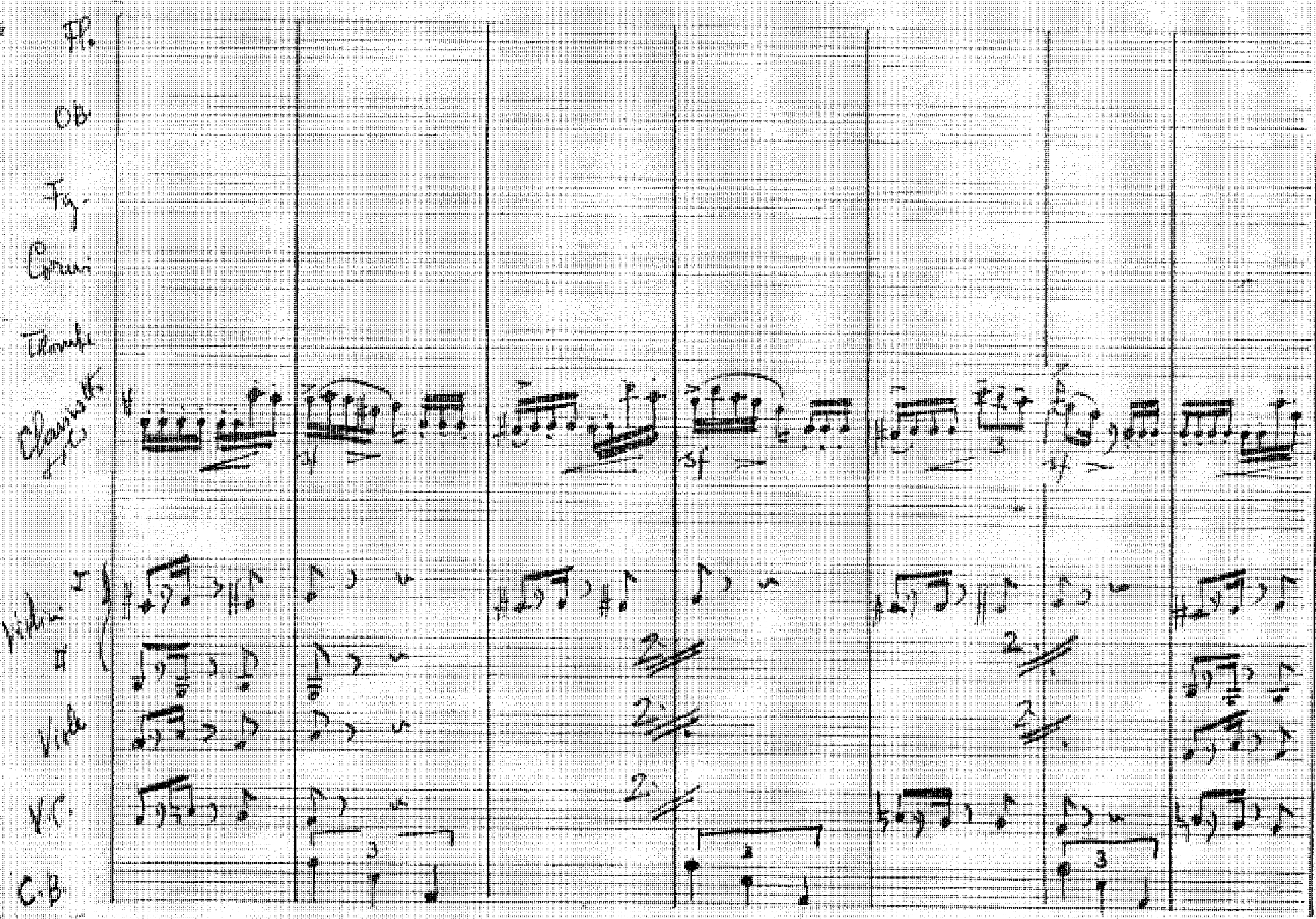




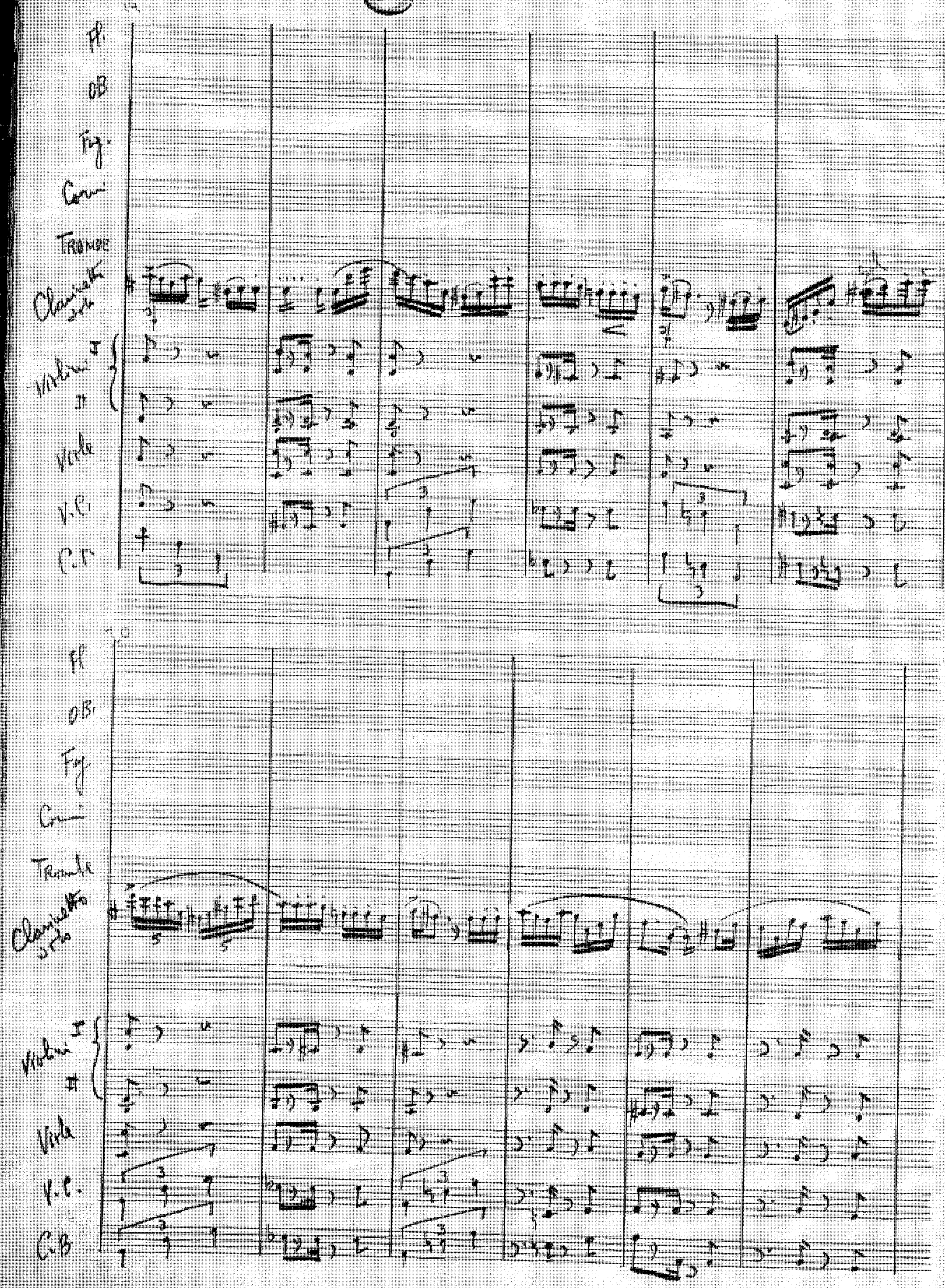


p.

dr

Corsi

Thouse

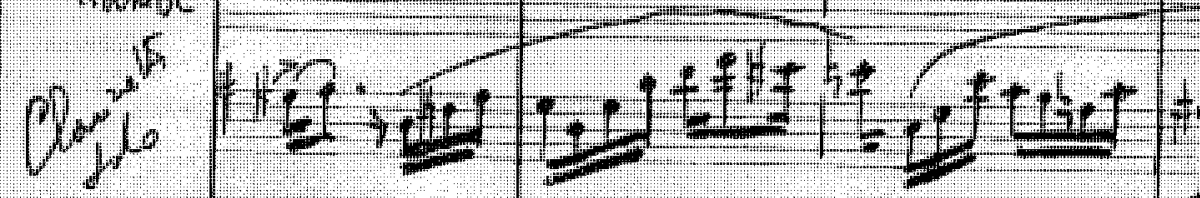

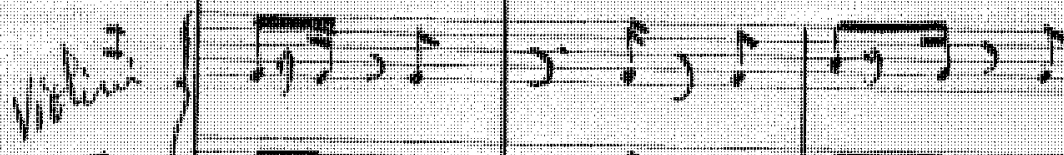

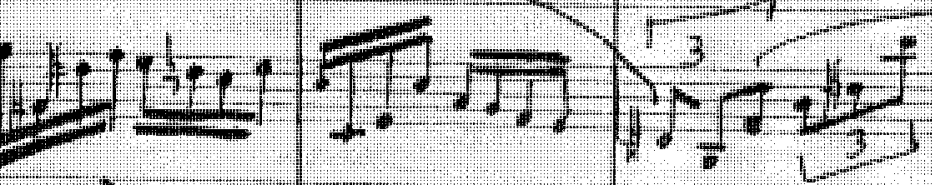

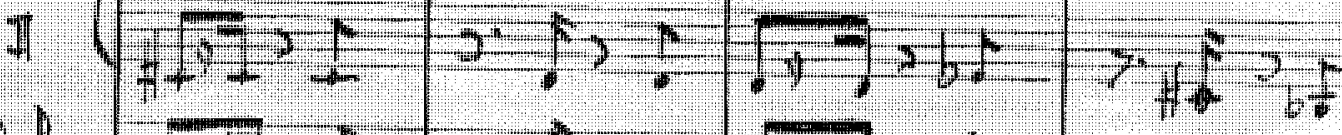

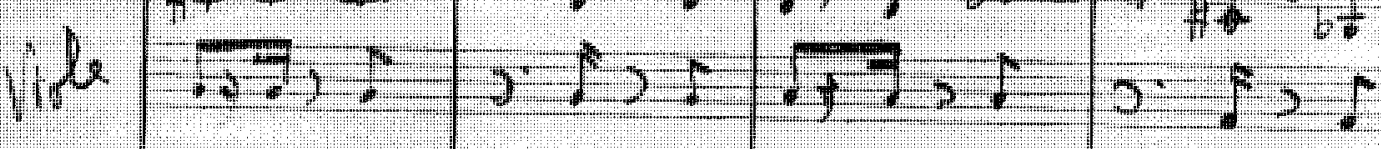

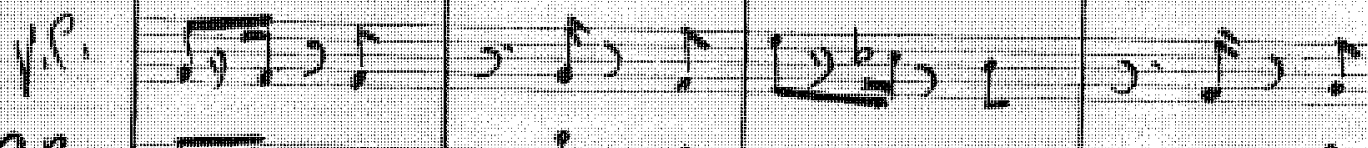

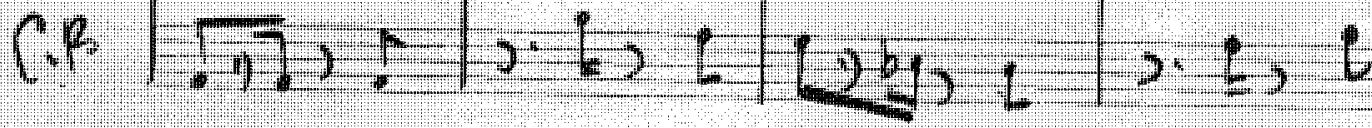

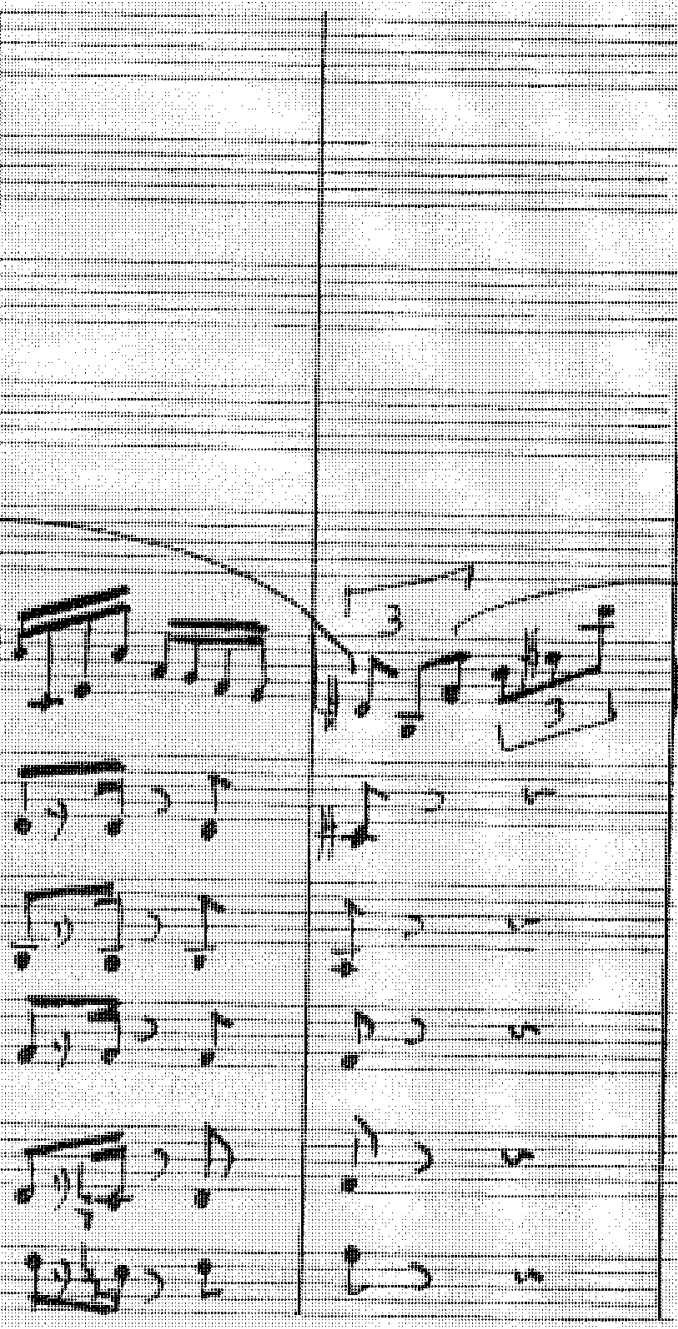

4t: $8^{\circ}$

wex nut to

fo

Thante

$a^{+}$

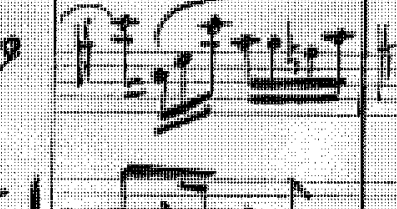

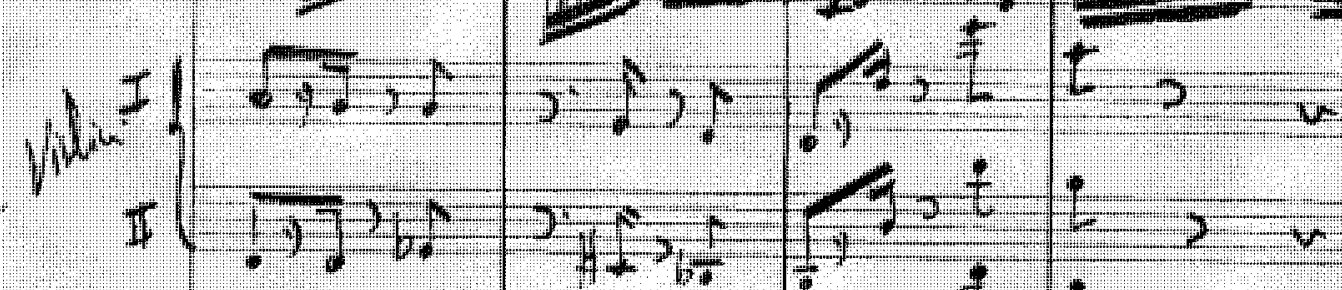

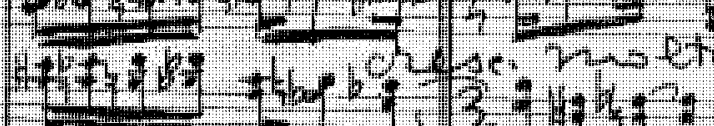

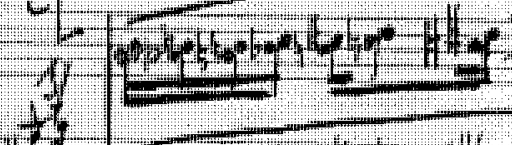

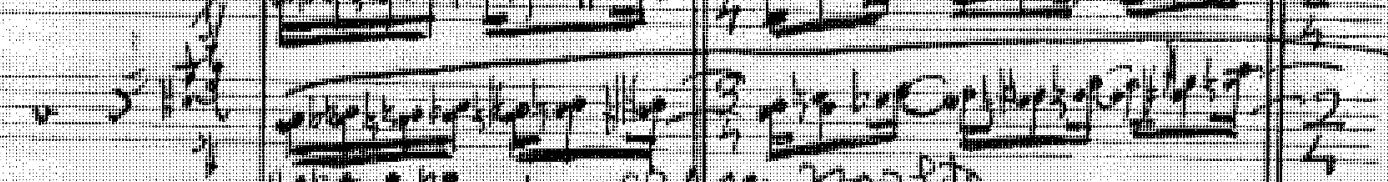

f

cise

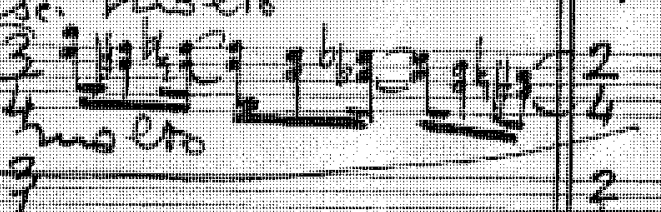

2

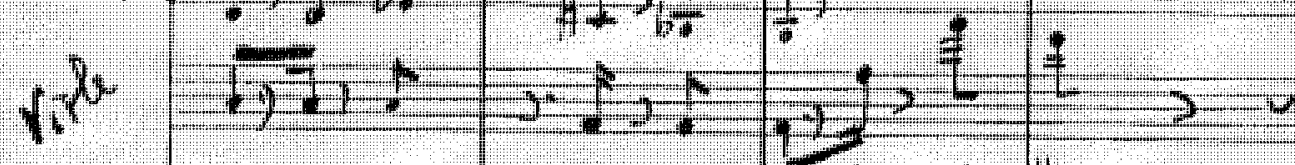

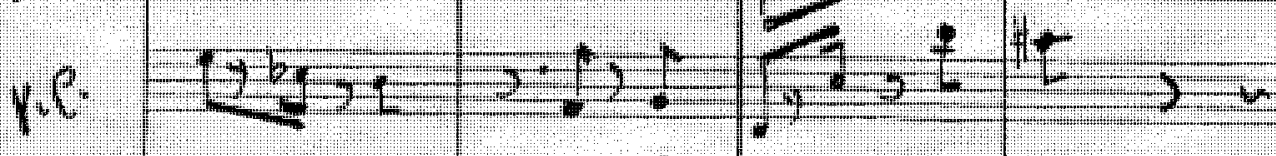

C.

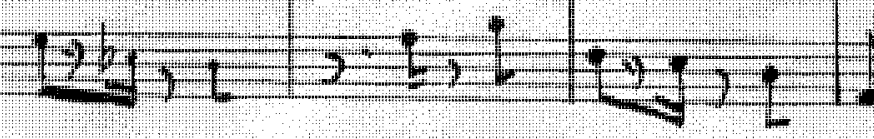

$\int_{\frac{3}{4}+2}^{\frac{3}{4}}$

$\frac{2}{4}$ 
$20{ }^{3.57}$ (15)

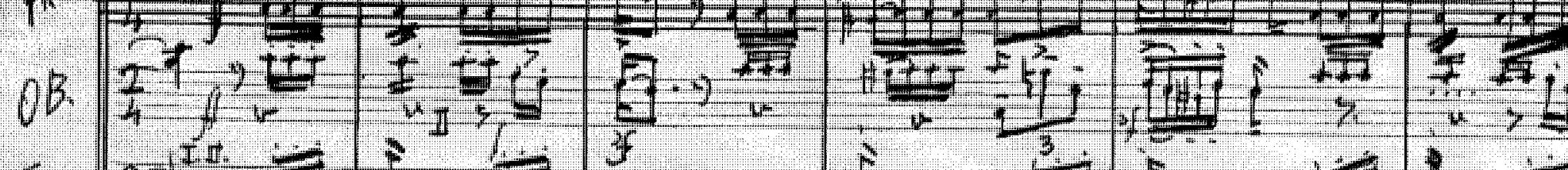
F a avi $\frac{2}{4}, x=0$

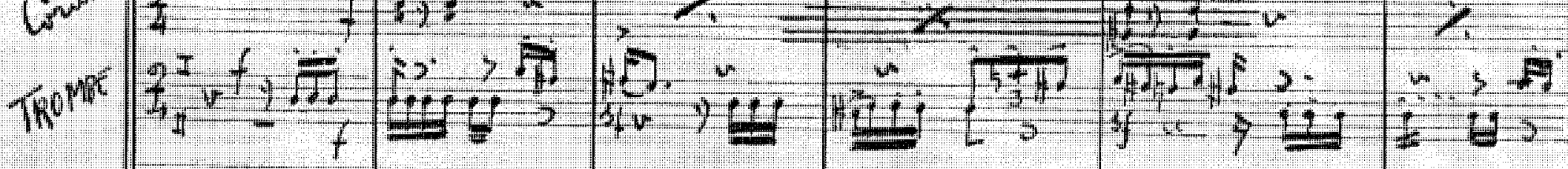

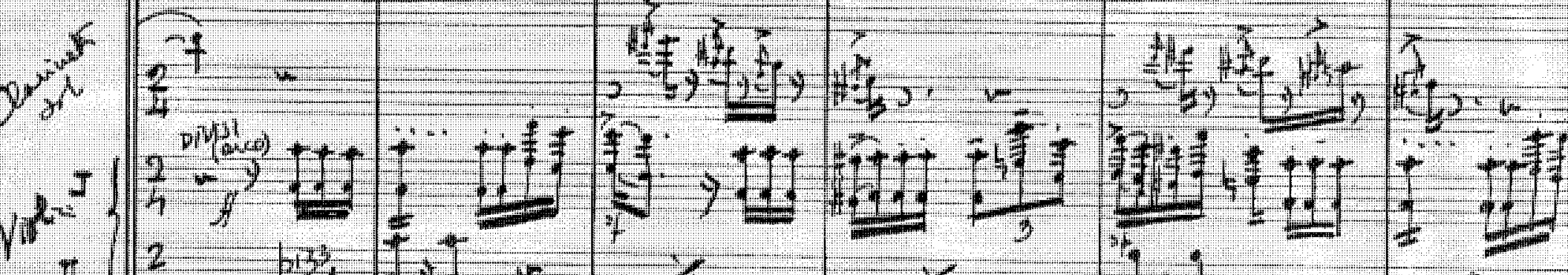

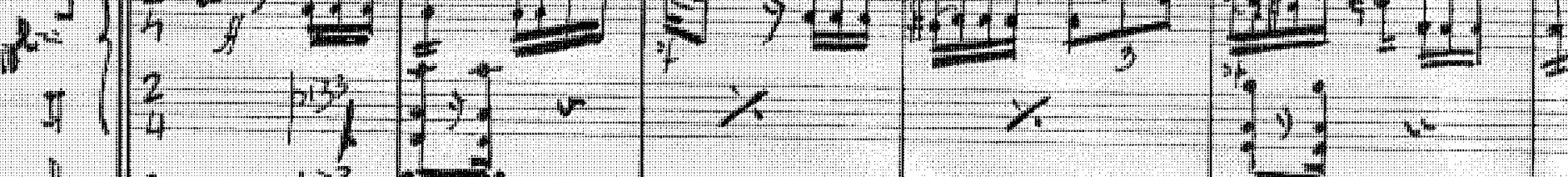
vite $\frac{2}{4} p_{3}^{3}$ 光.

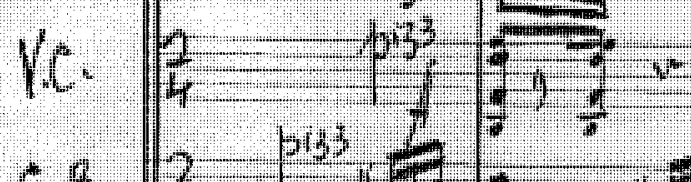

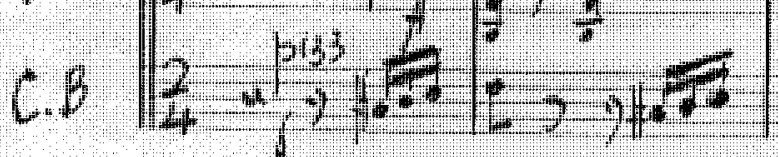

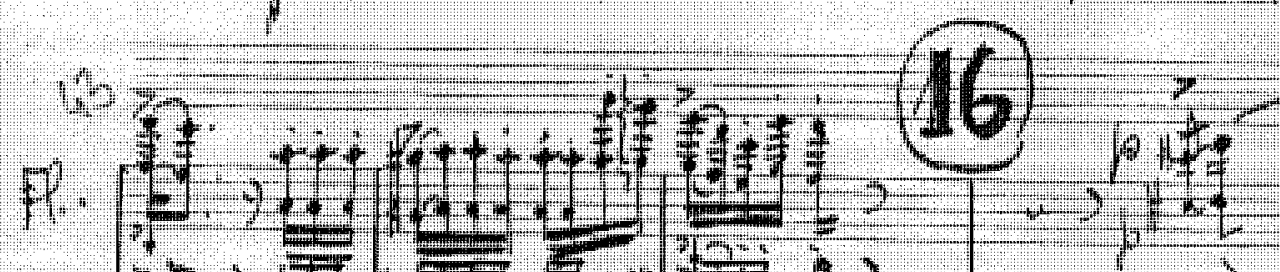

OB 5 (5)

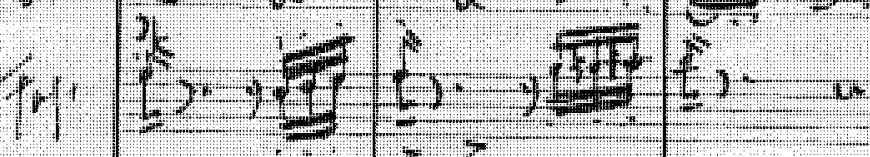

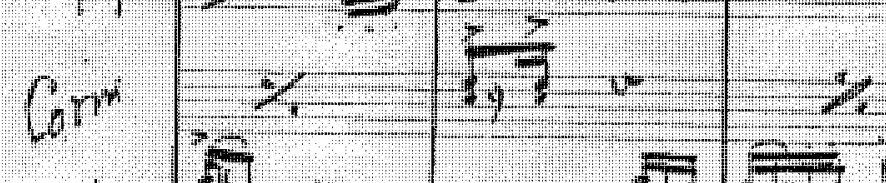

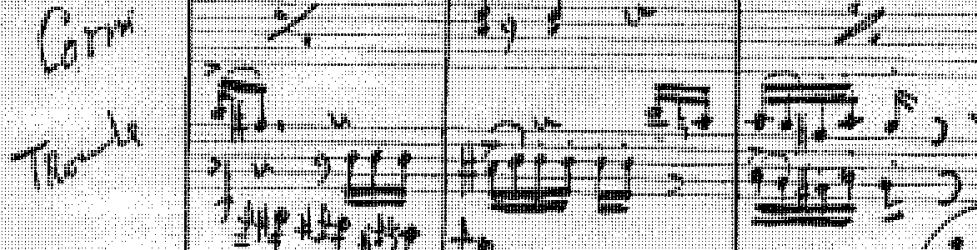

Q $w^{3}$ $1+2+2+1+2+$

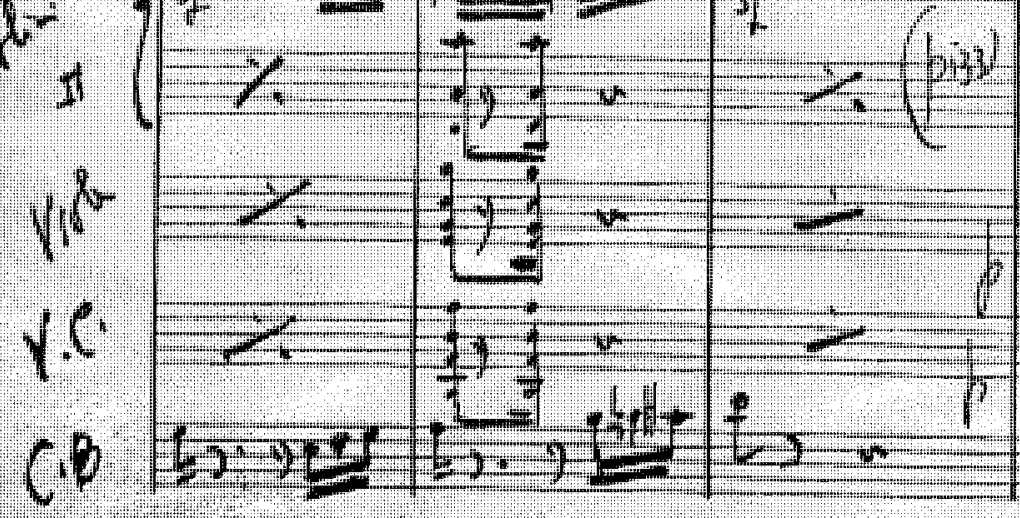

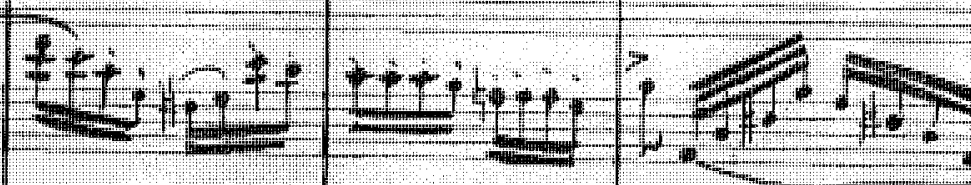
at 15 i2: 2 然| $x$ : 


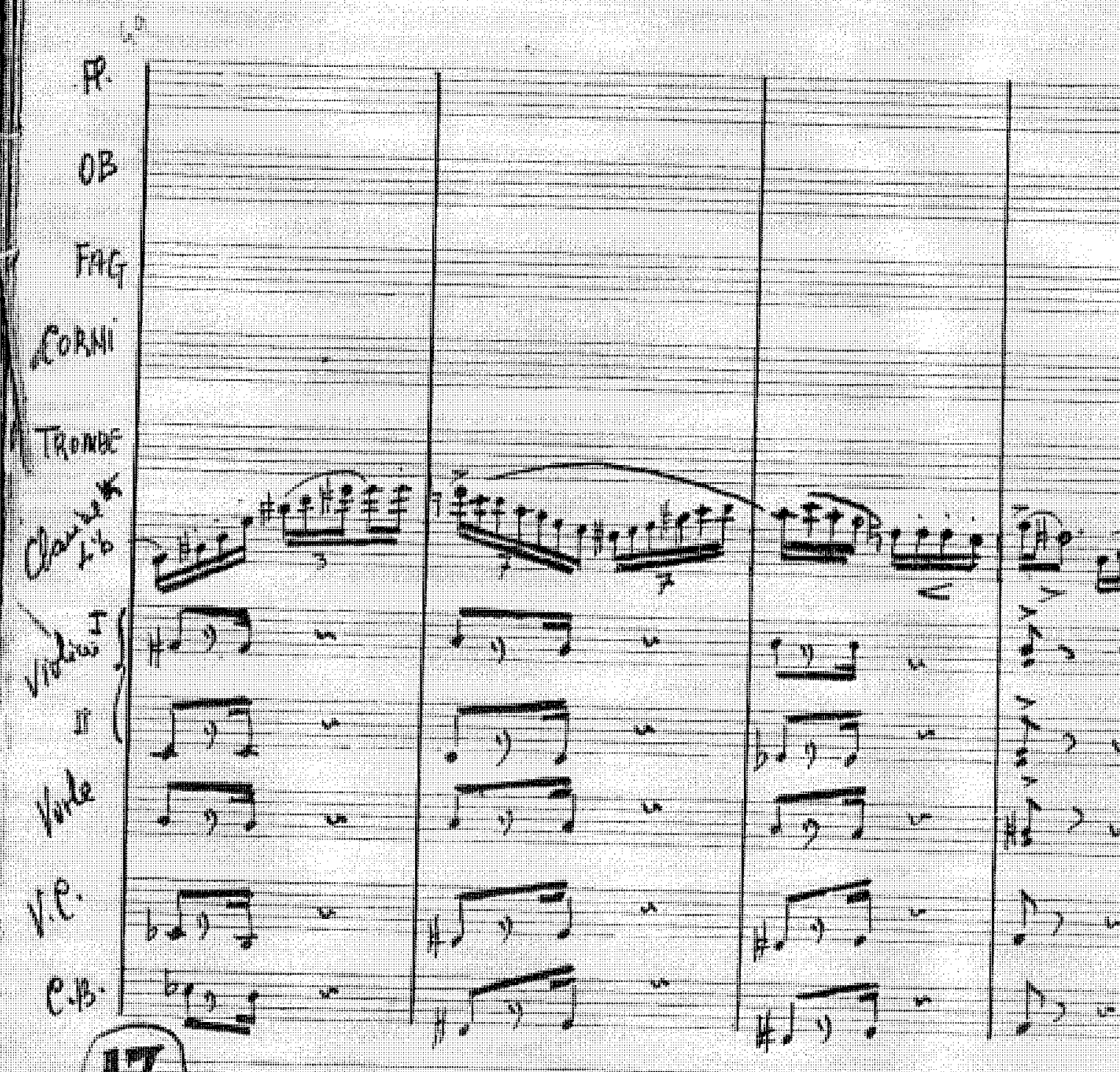

(17)

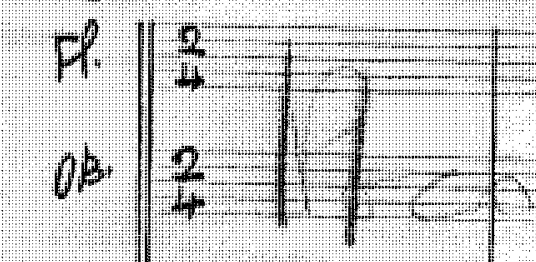

Fand $\frac{2}{2}$

$\left.1 \omega^{m}\right)^{7} \frac{2}{4}$

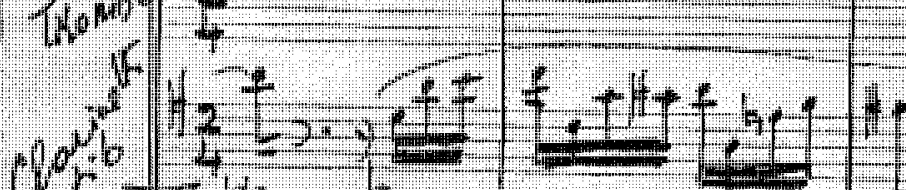

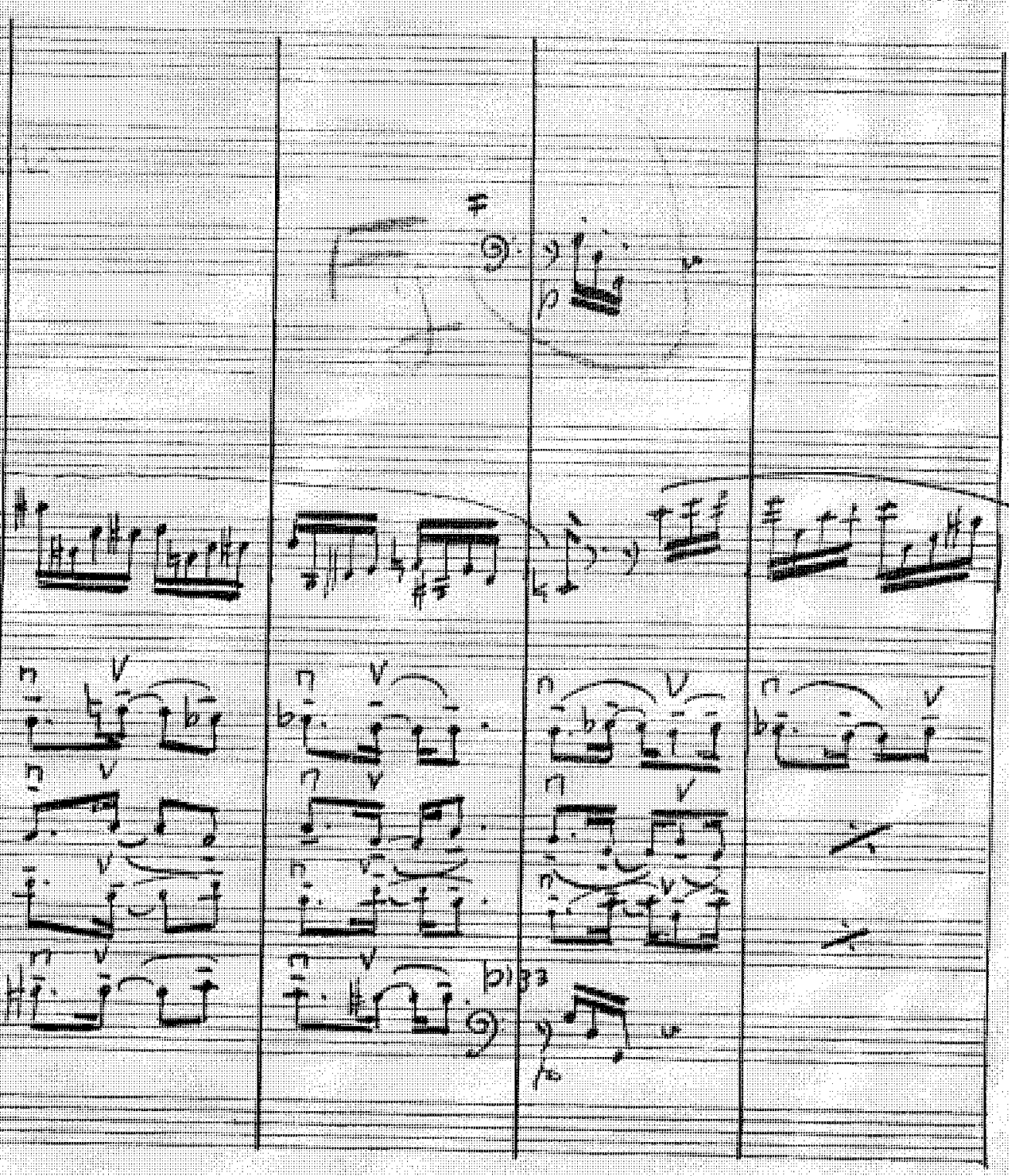



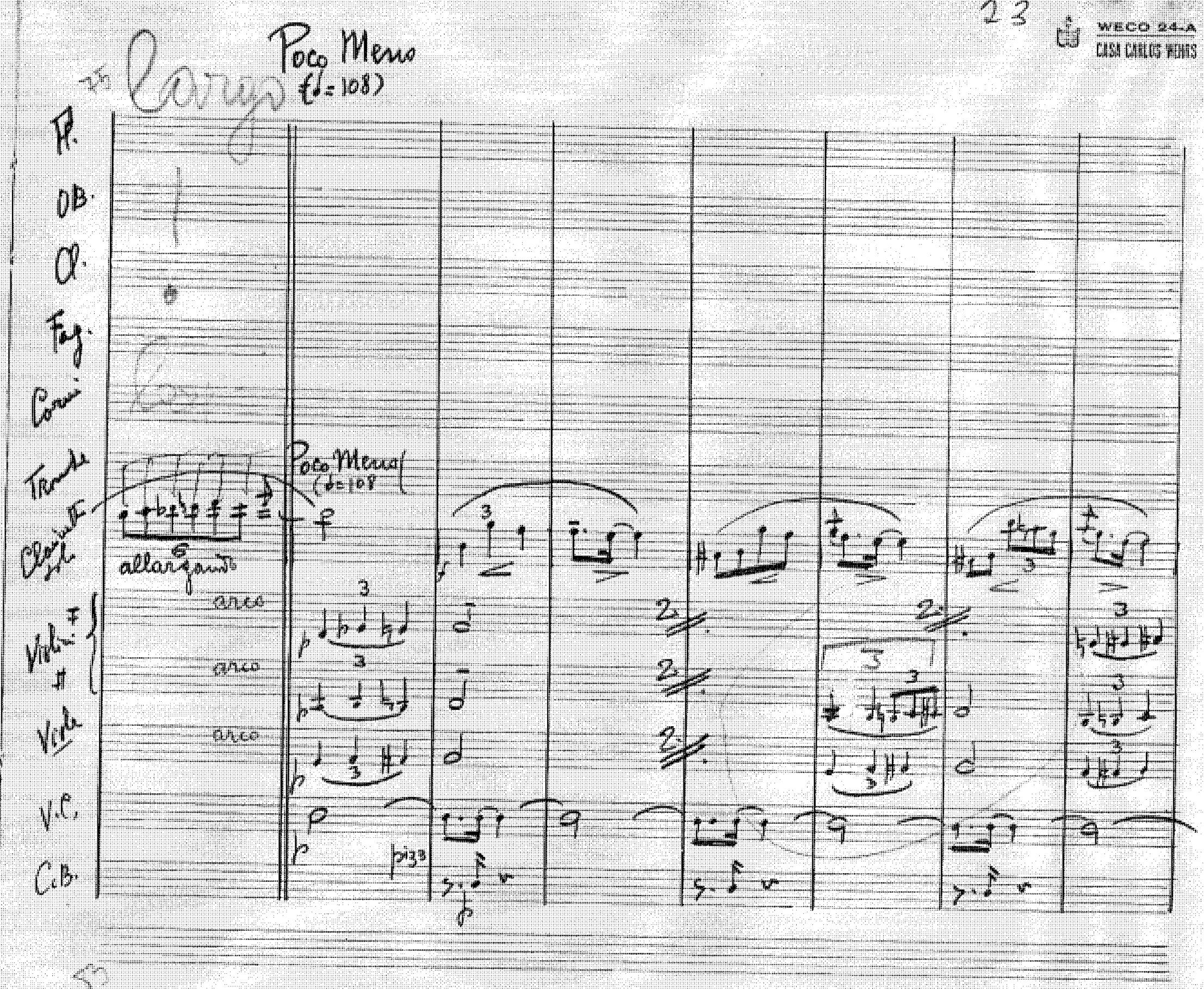

H.

Ut

Fit:

(y)

10

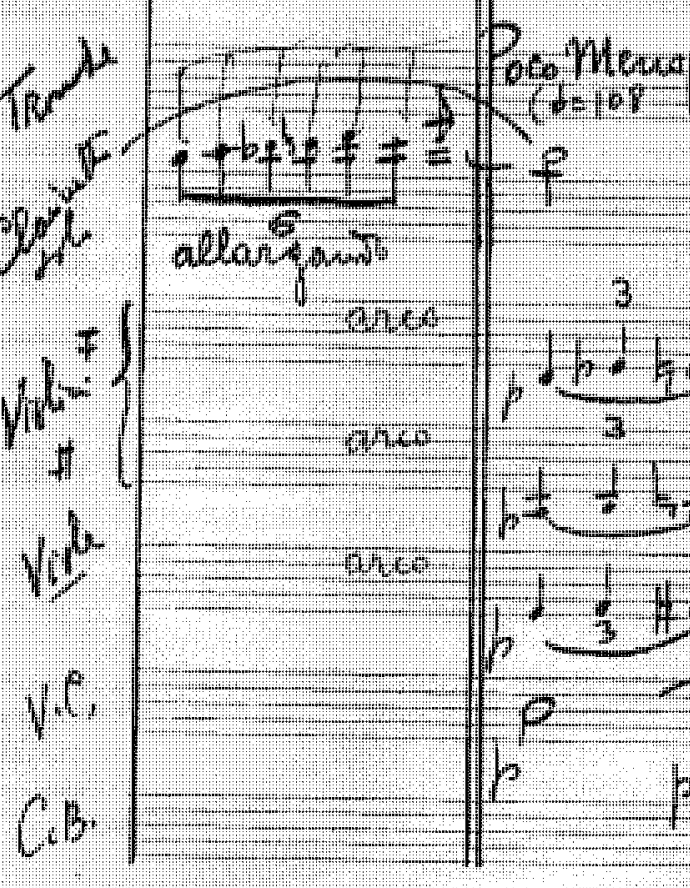

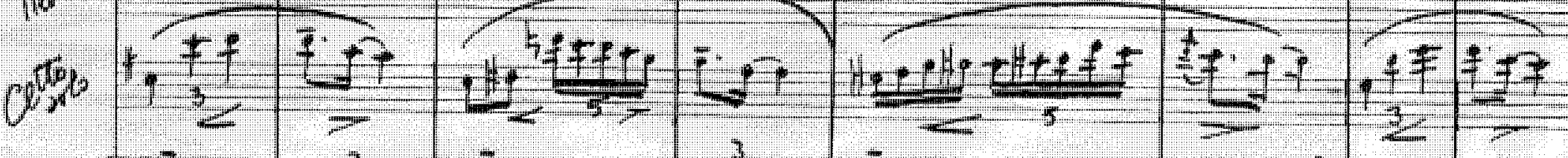

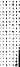

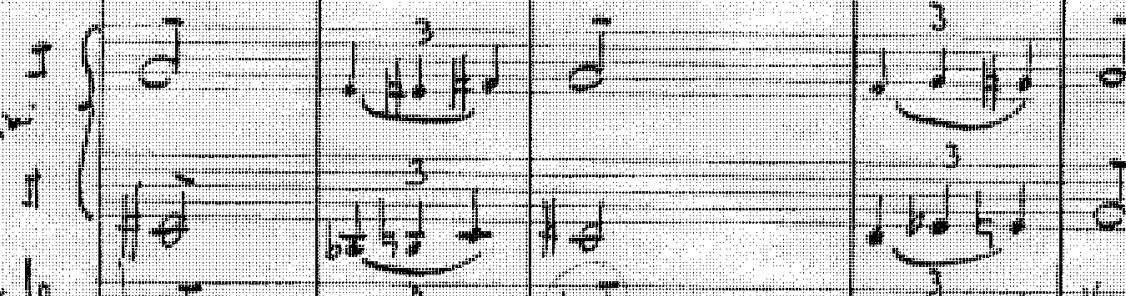

(iv)

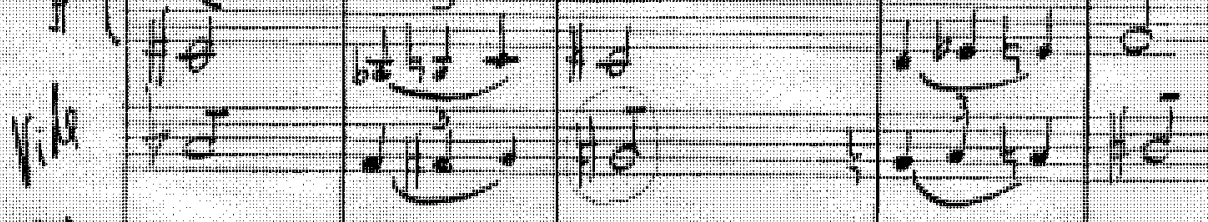

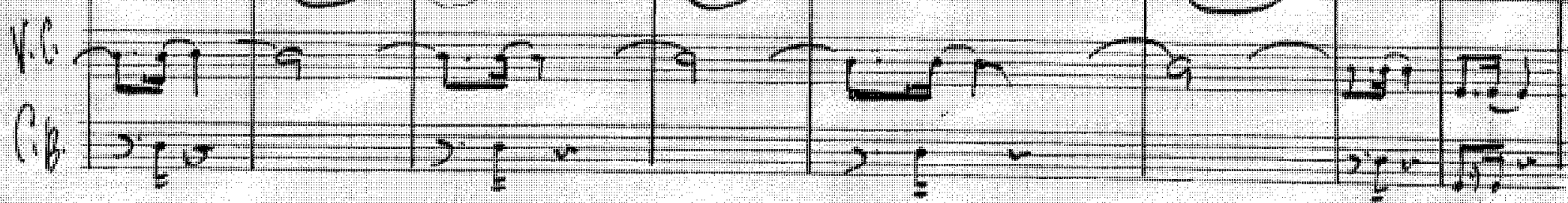




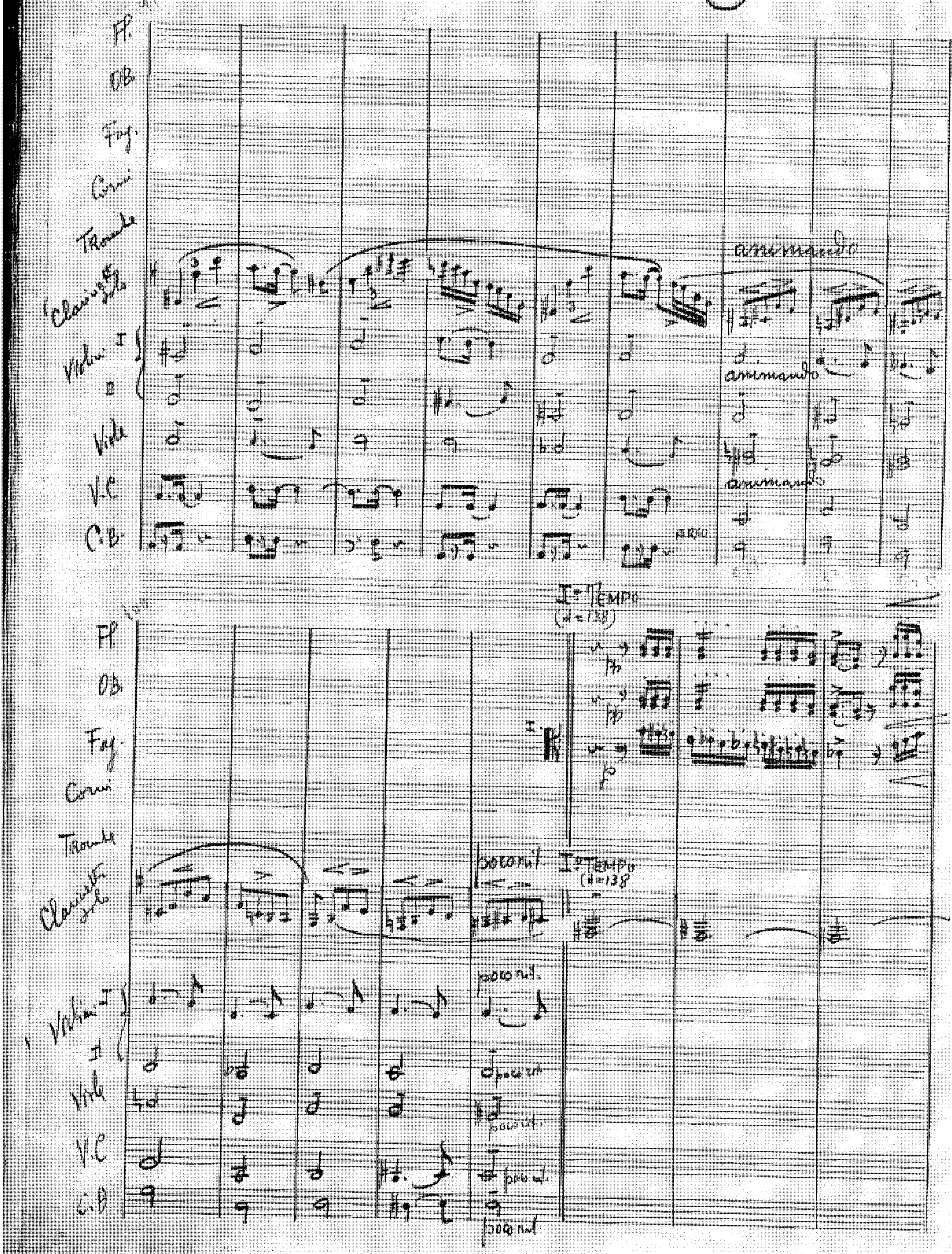




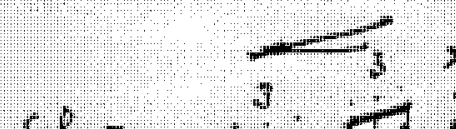

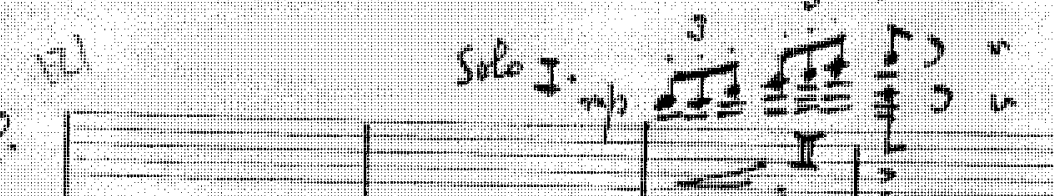

$f f_{1}, t+5, \quad$ of

\section{F.
WB}

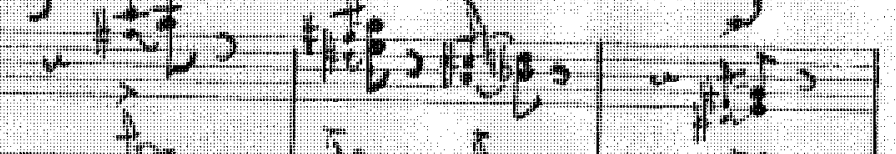

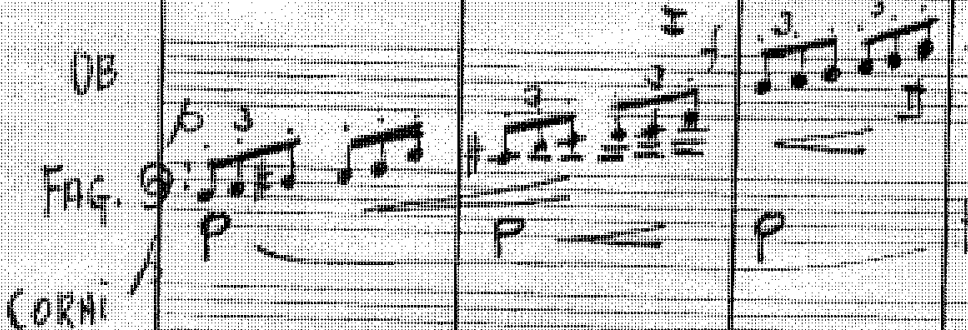

conti

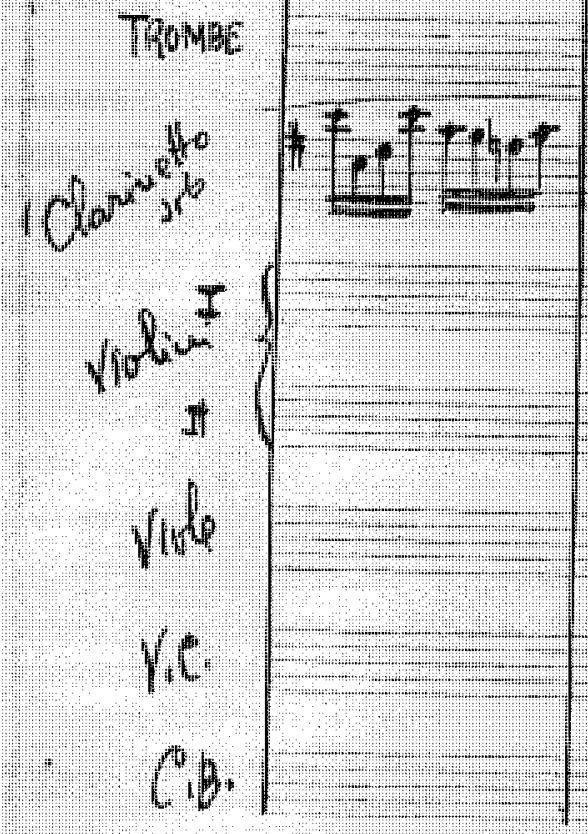

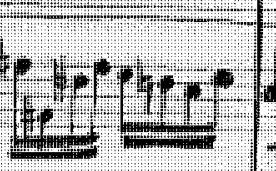

एक कर

$\sqrt{p}+5$

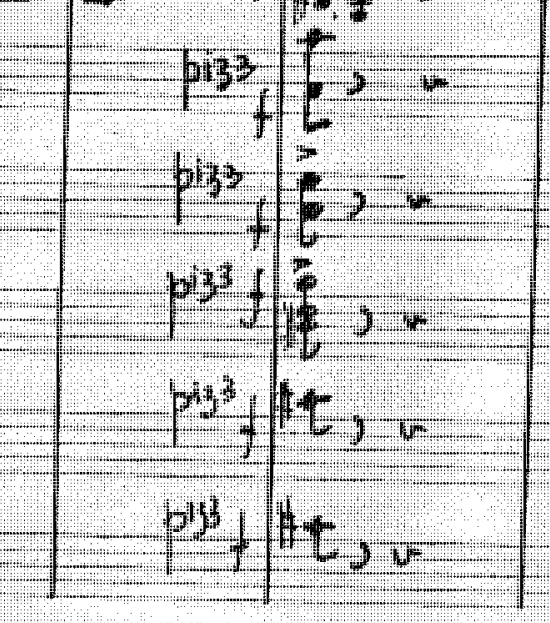

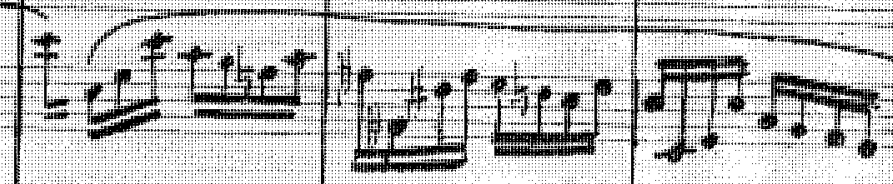

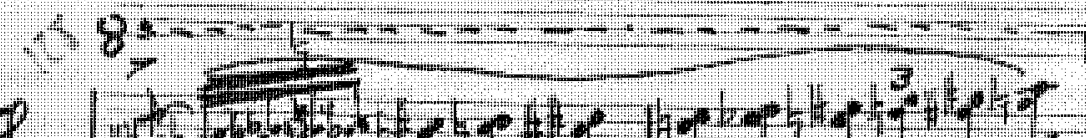

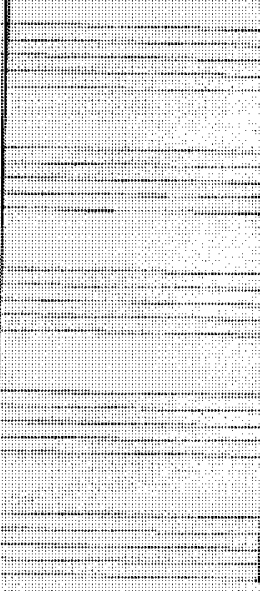

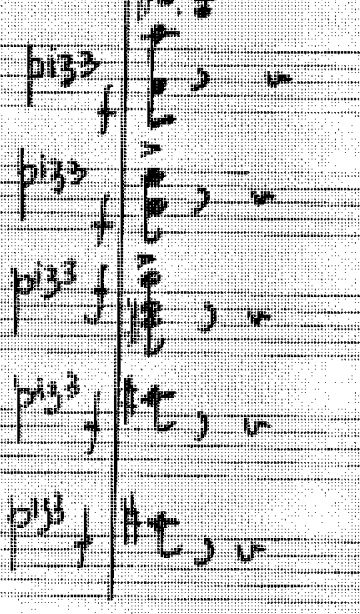

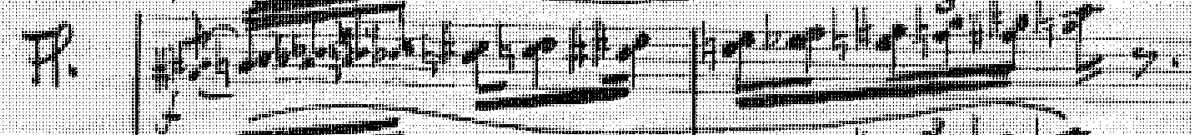

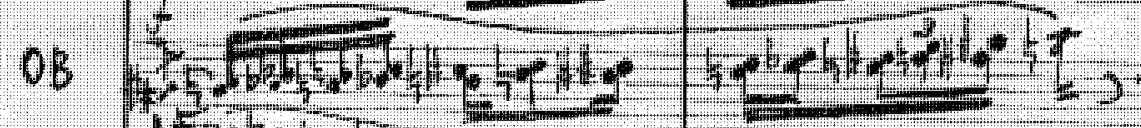

Fag

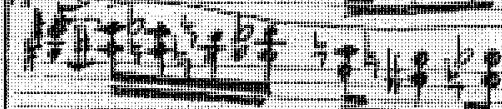

$(n+1)$

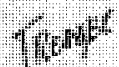

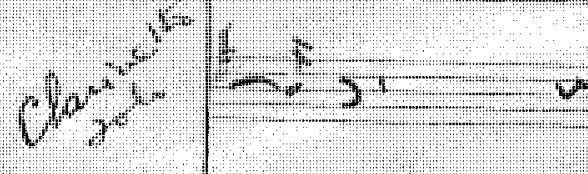

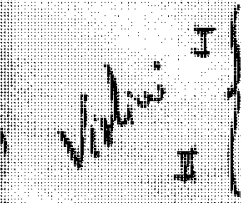

$\sqrt{10}$

yc.

C.B

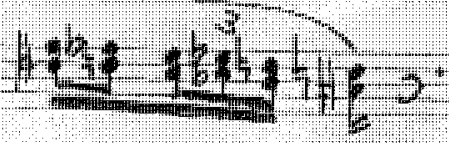




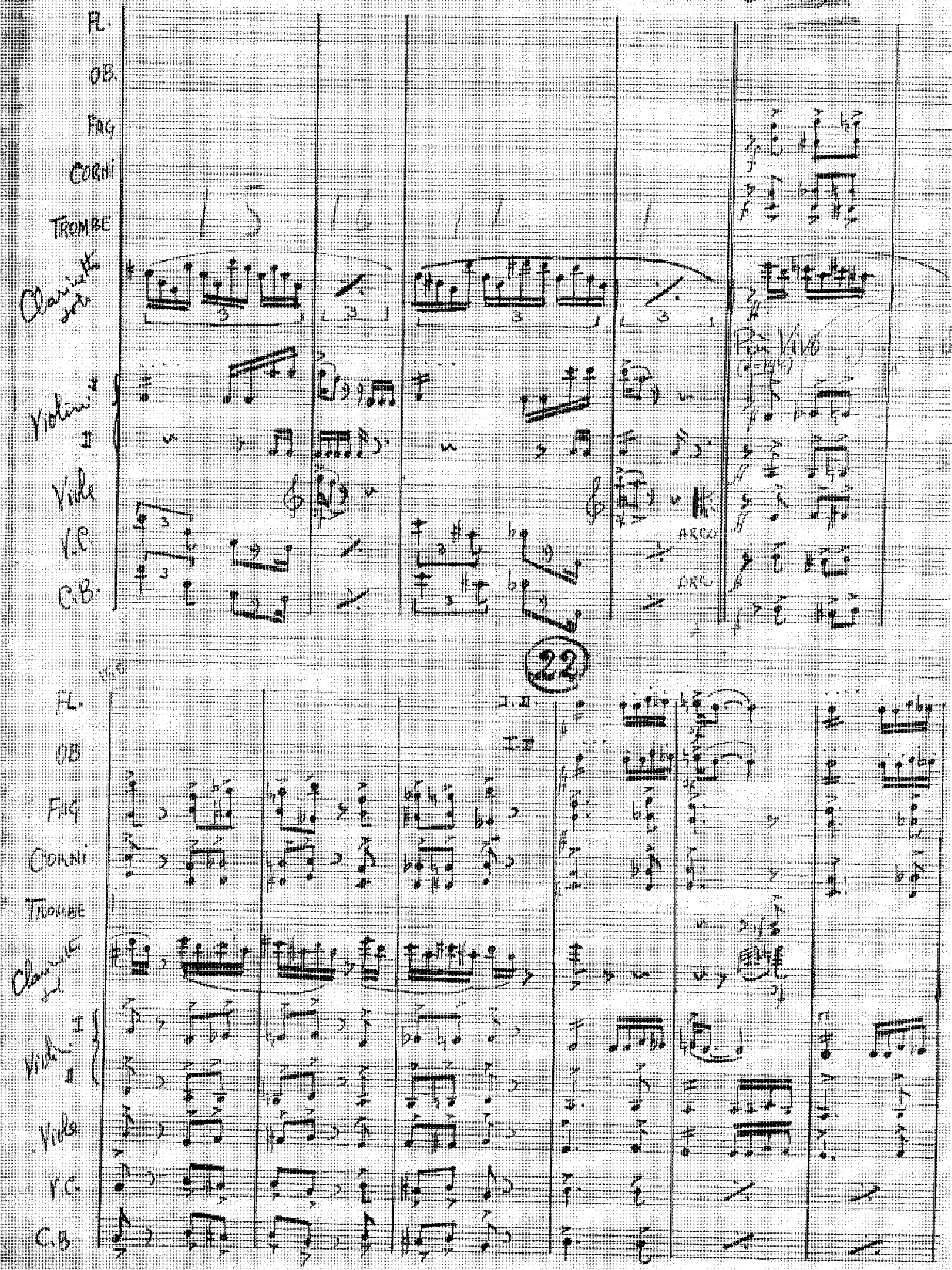




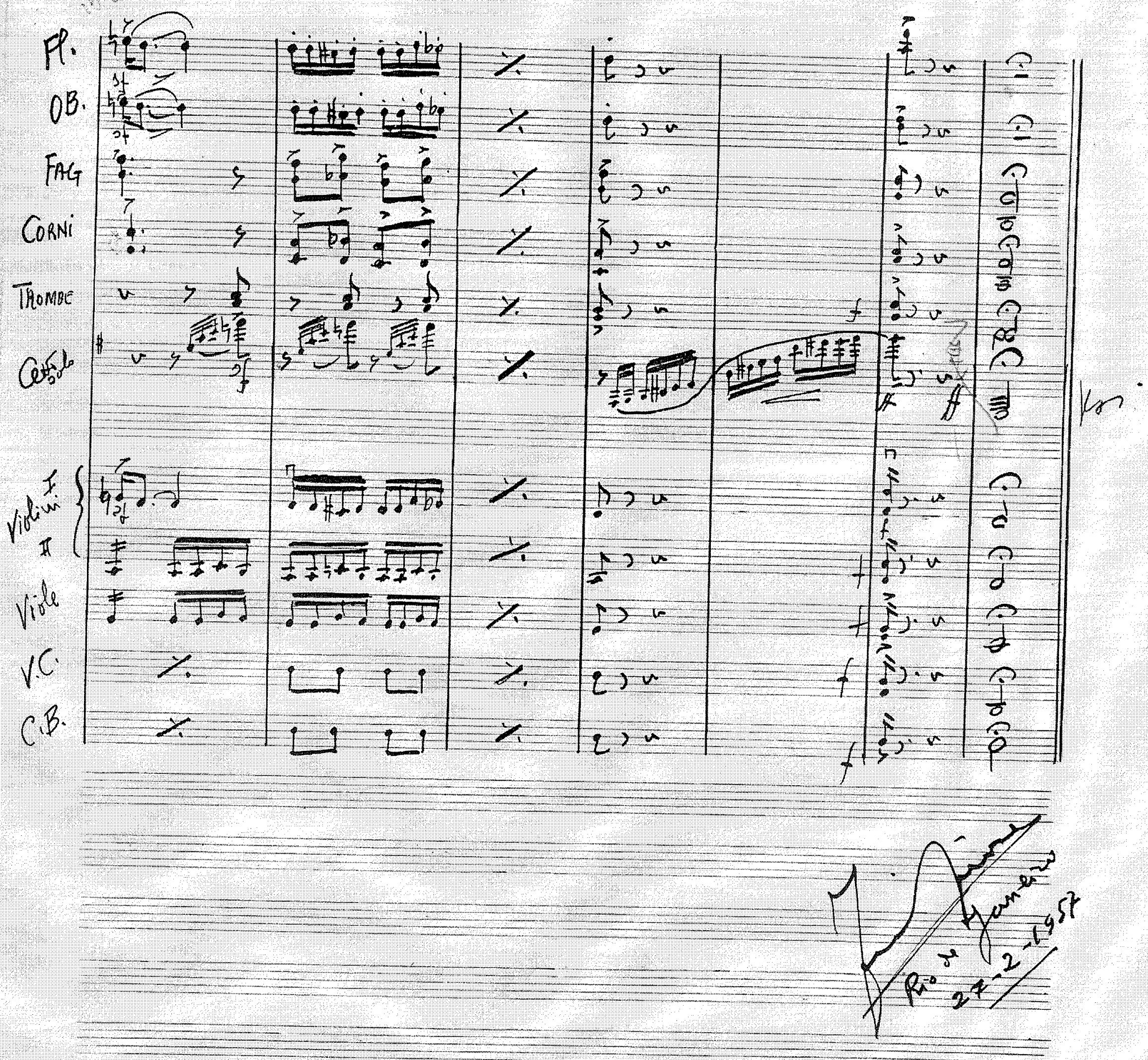




\section{CONCERTINO}

para clarinete sib e orquestra (1957)

Francisco Mignone (1897-1986)

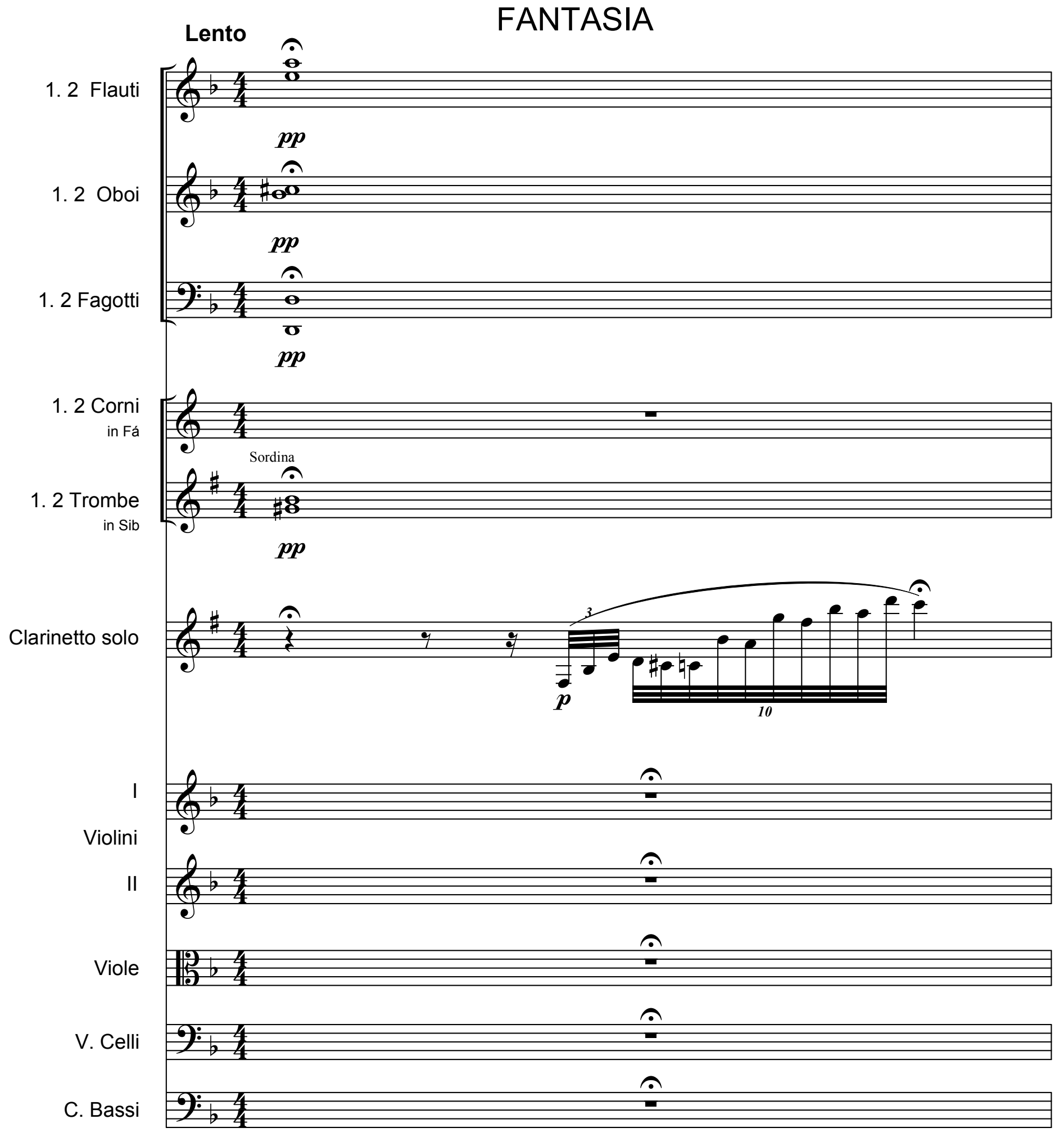




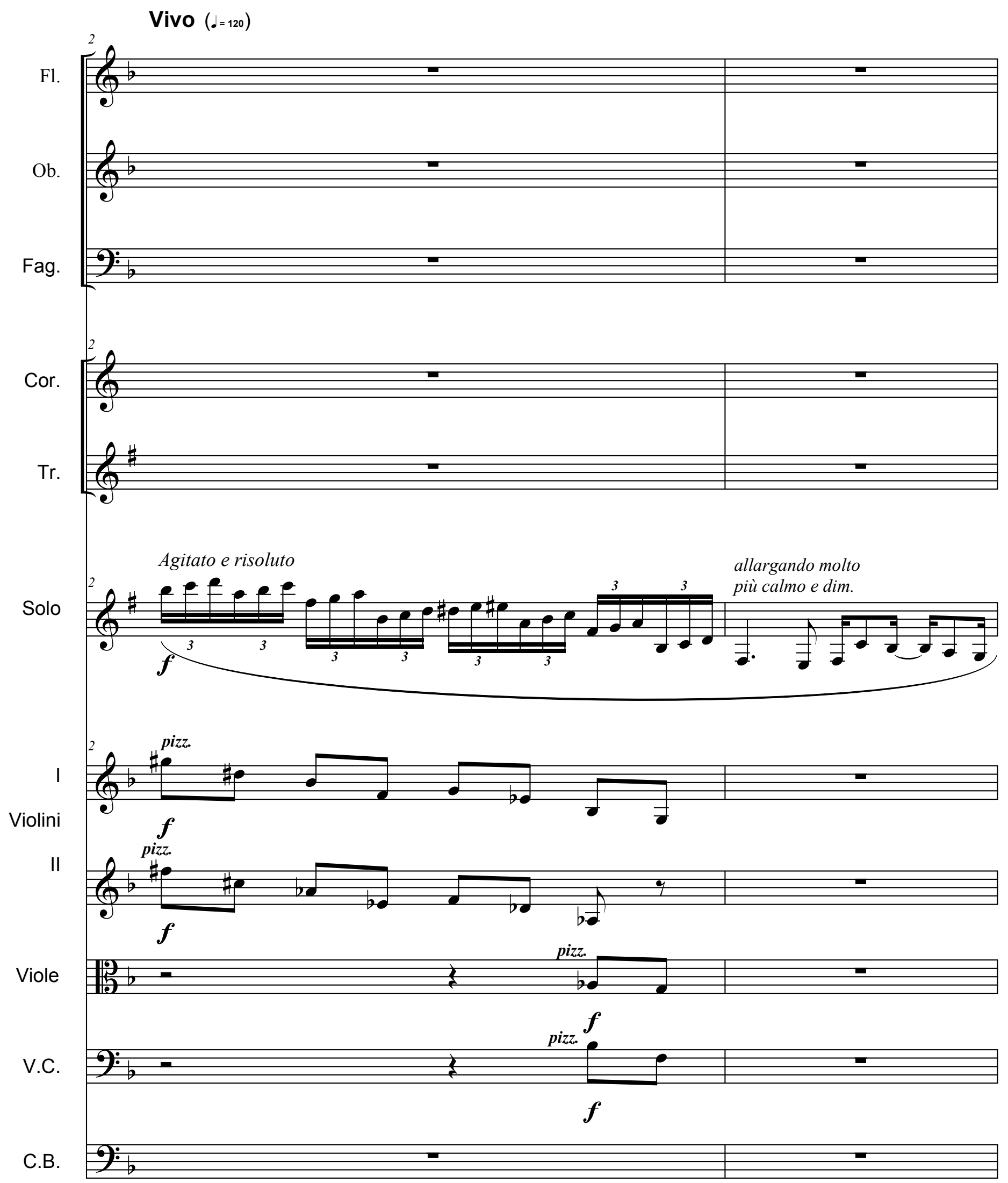


(1)

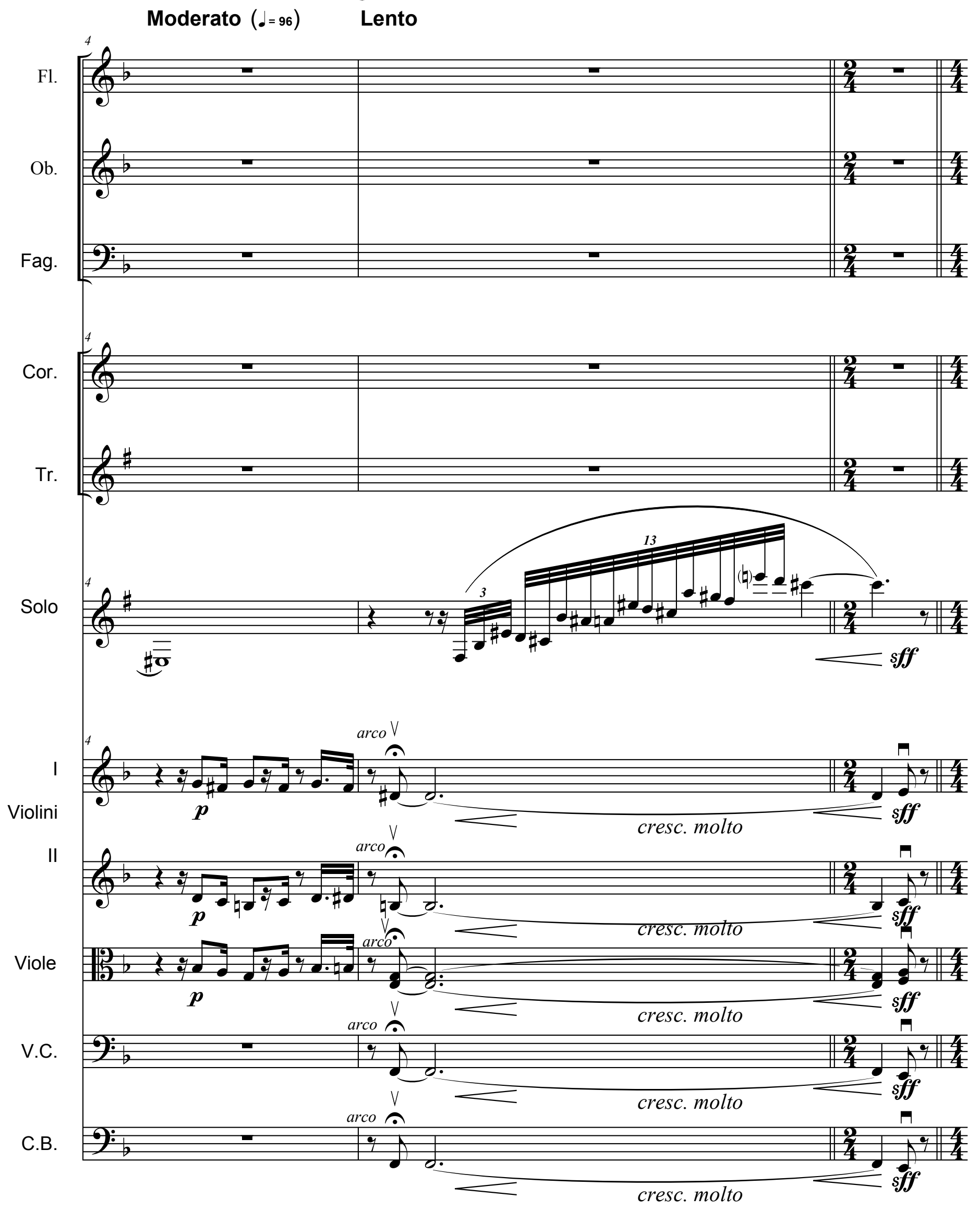




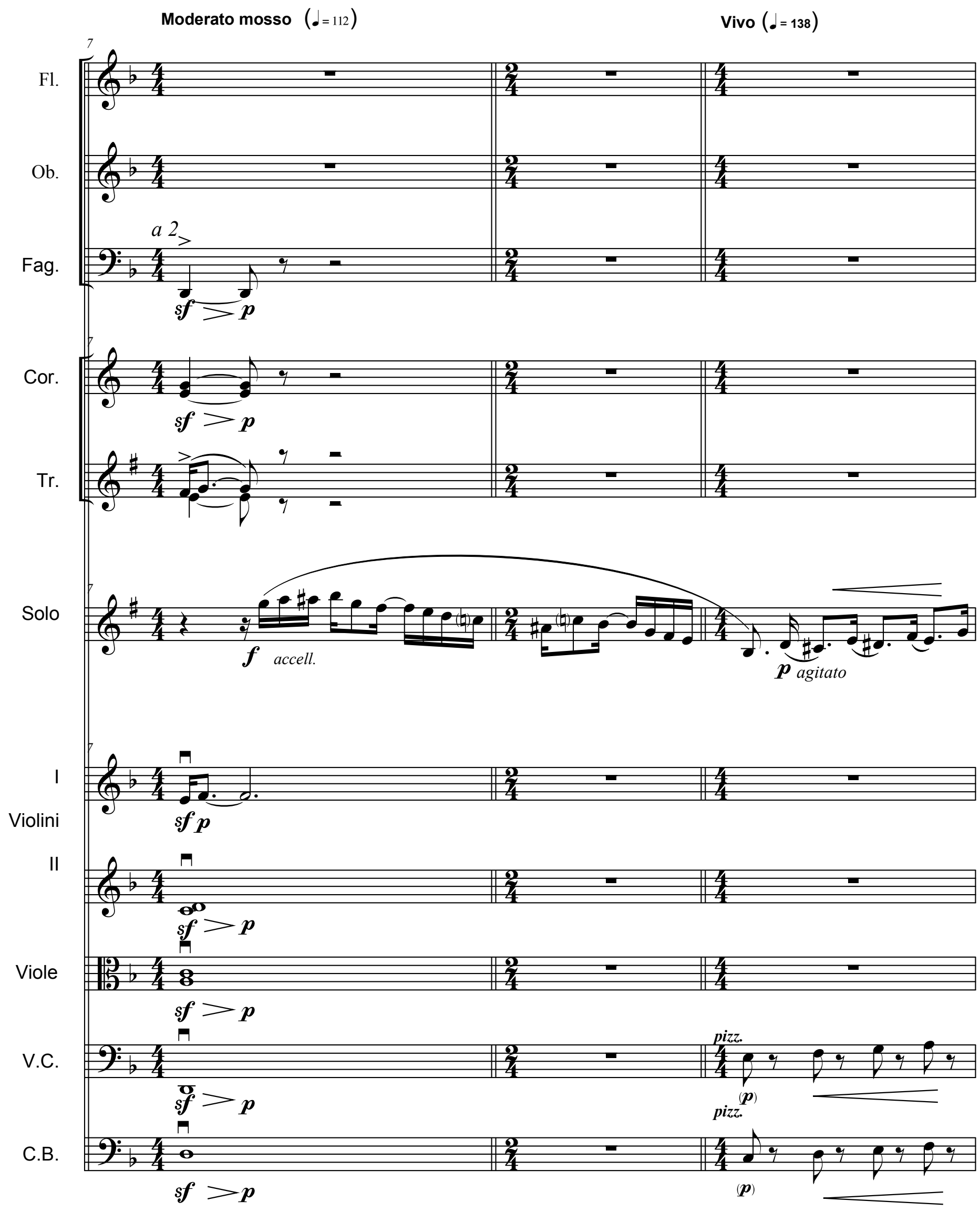


(2)

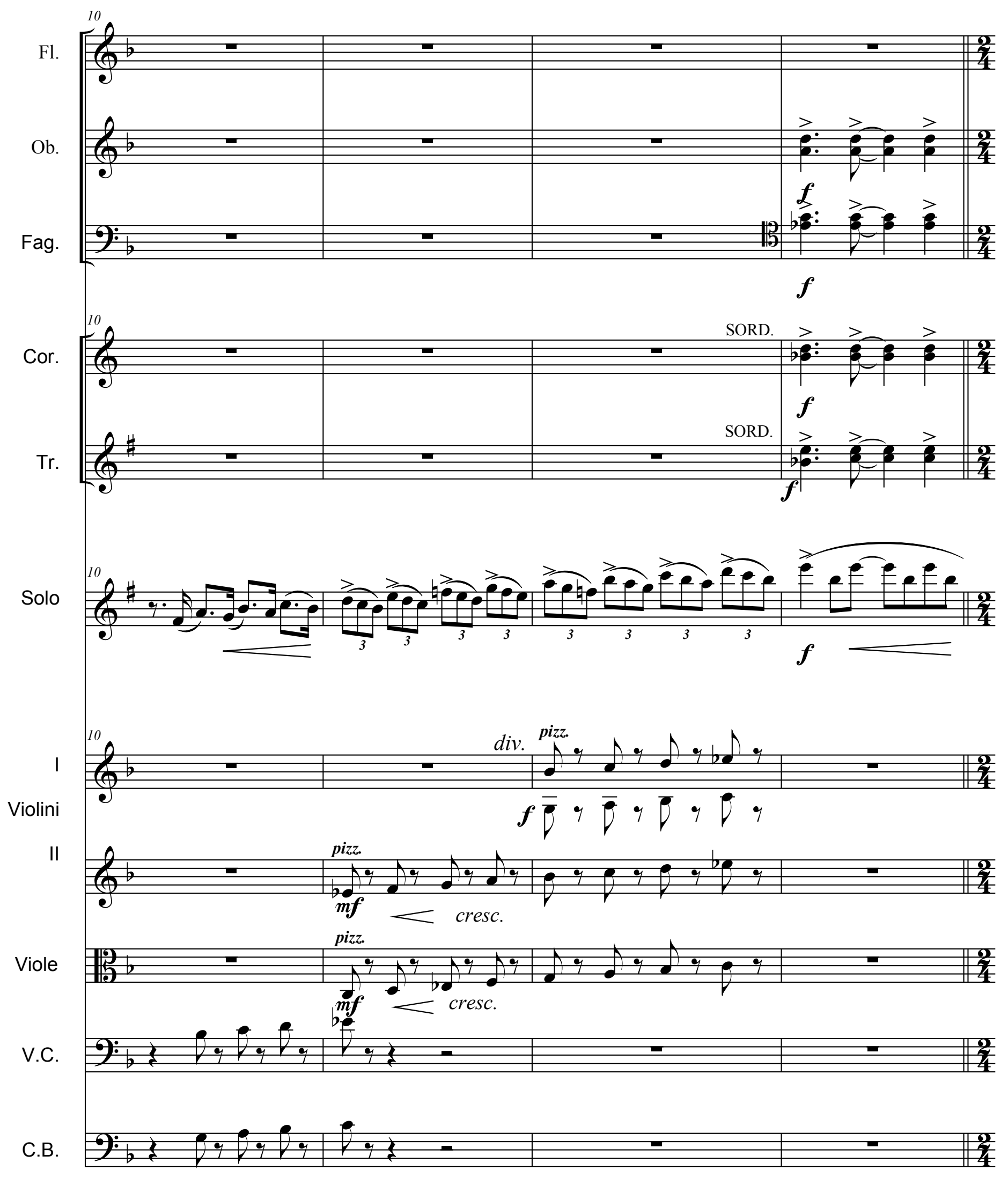



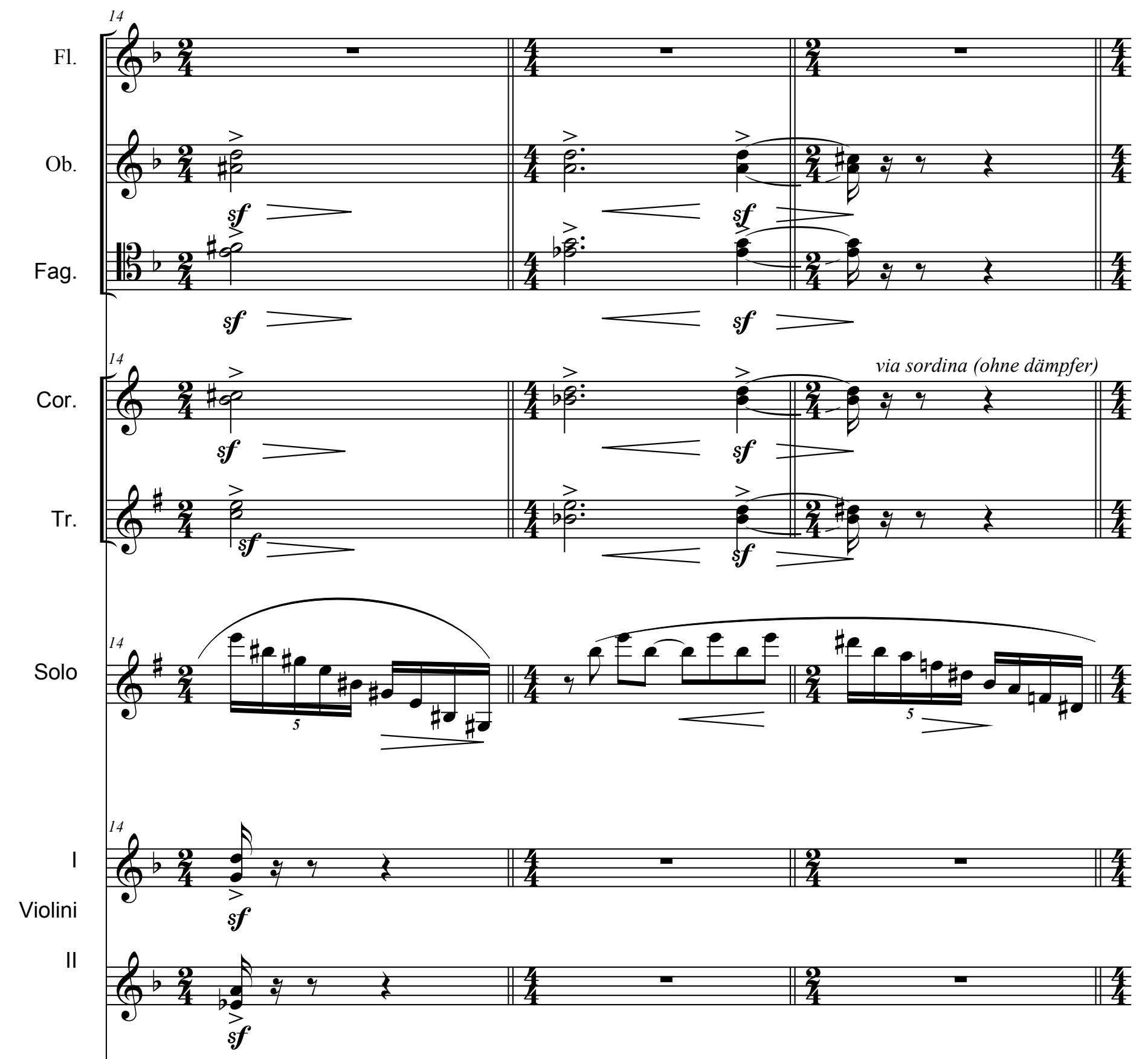

Viole

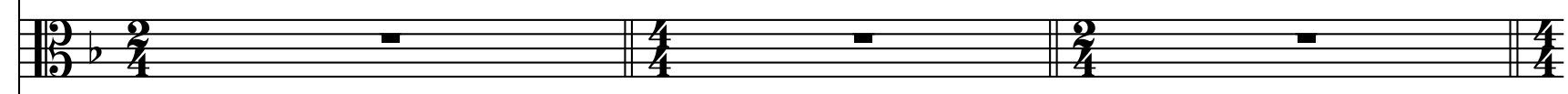

v.c. 2

с.в. $20 \mathrm{CO}$ 


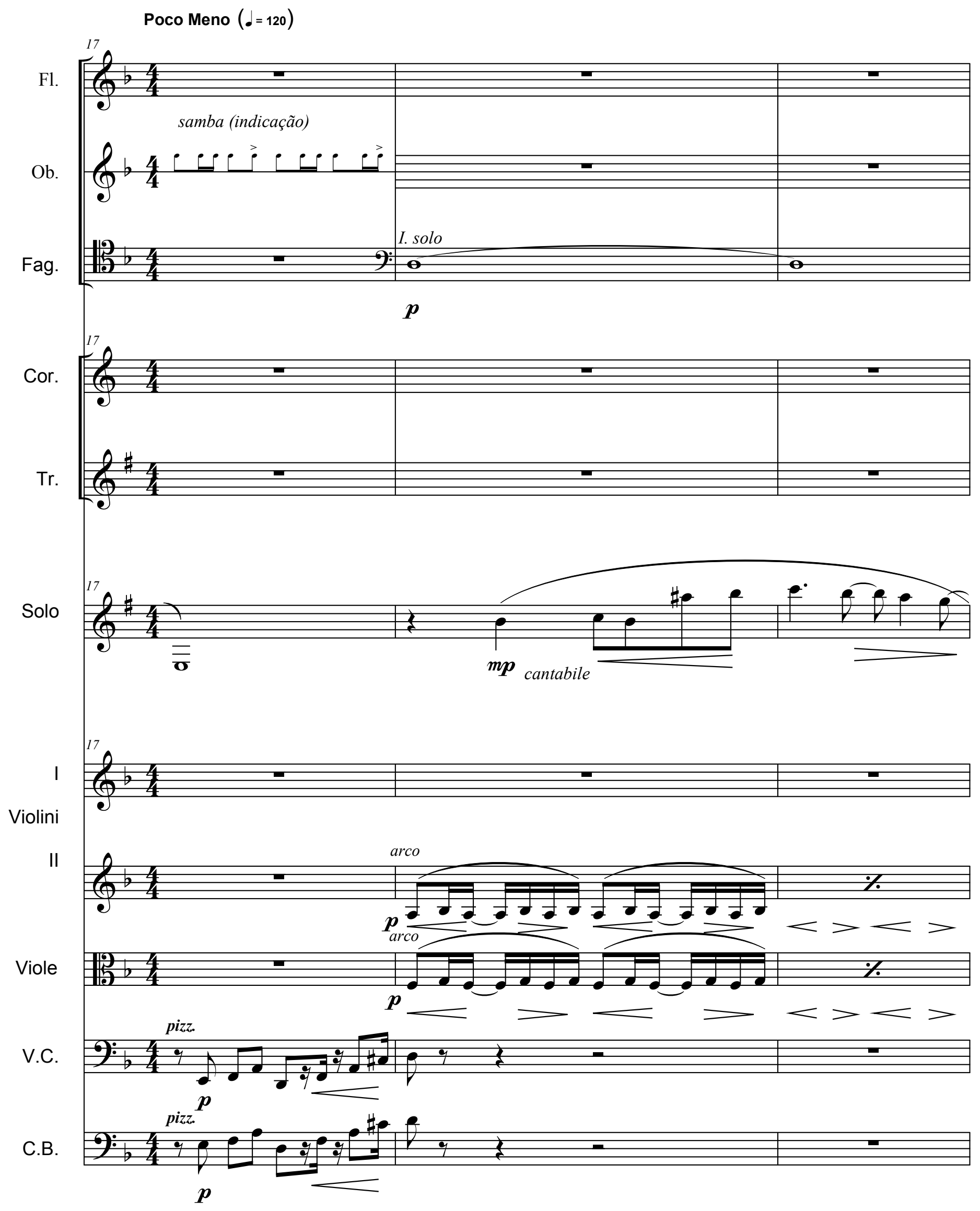



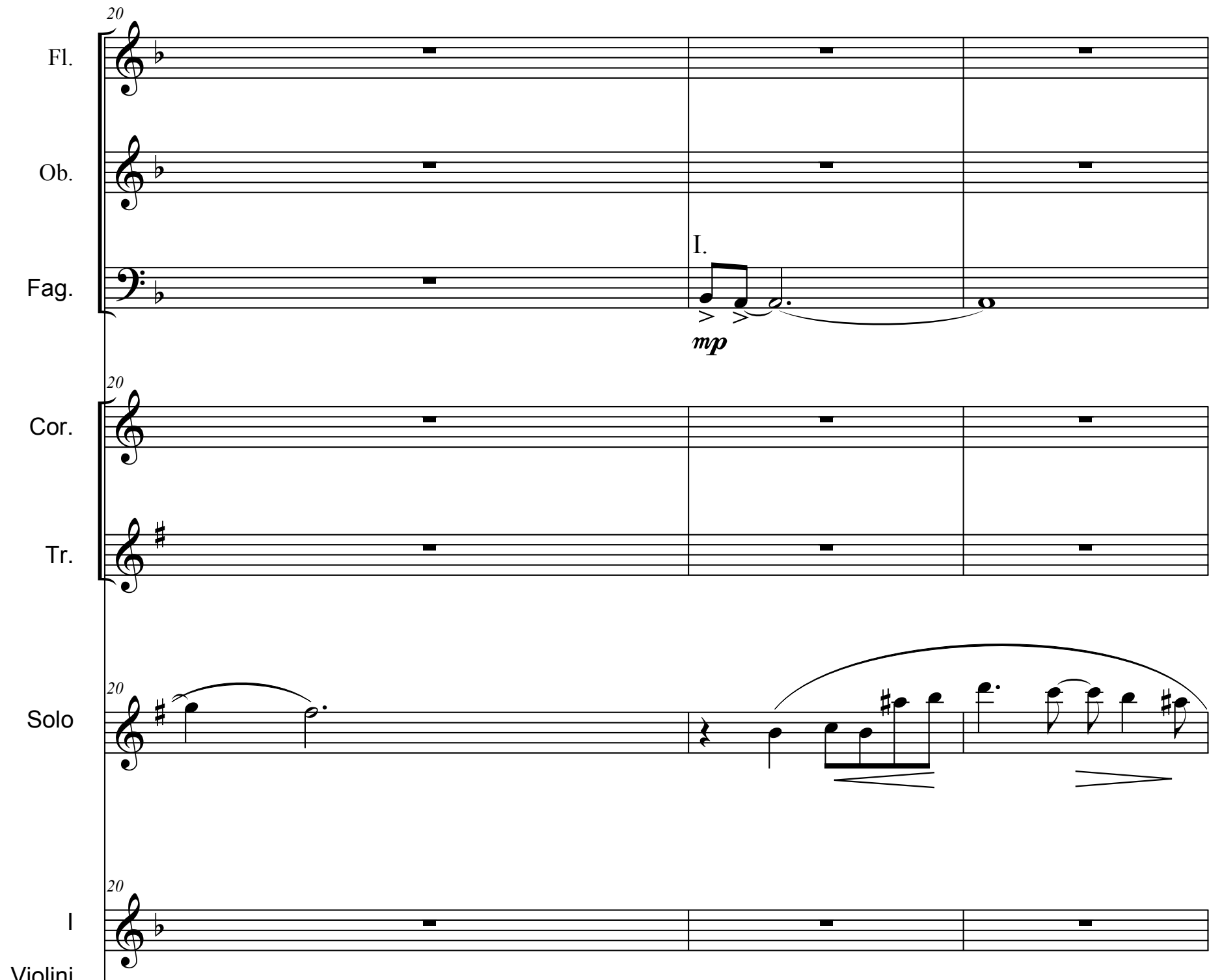

Violini

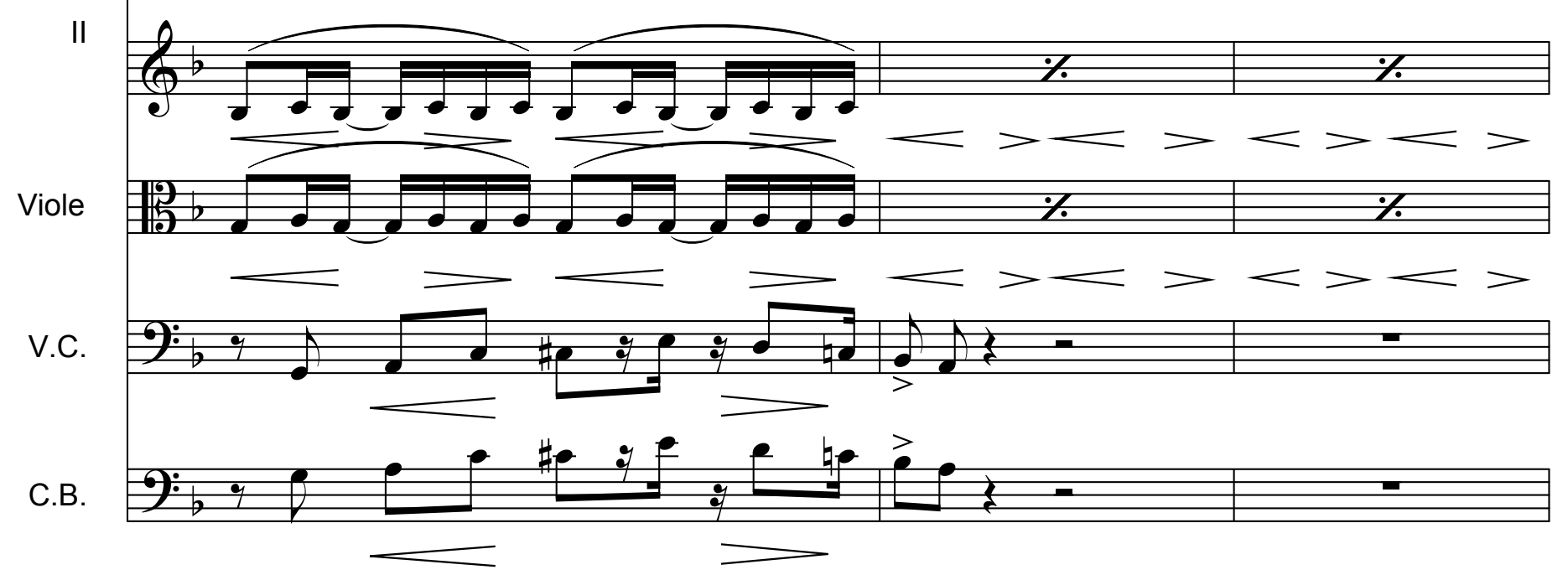




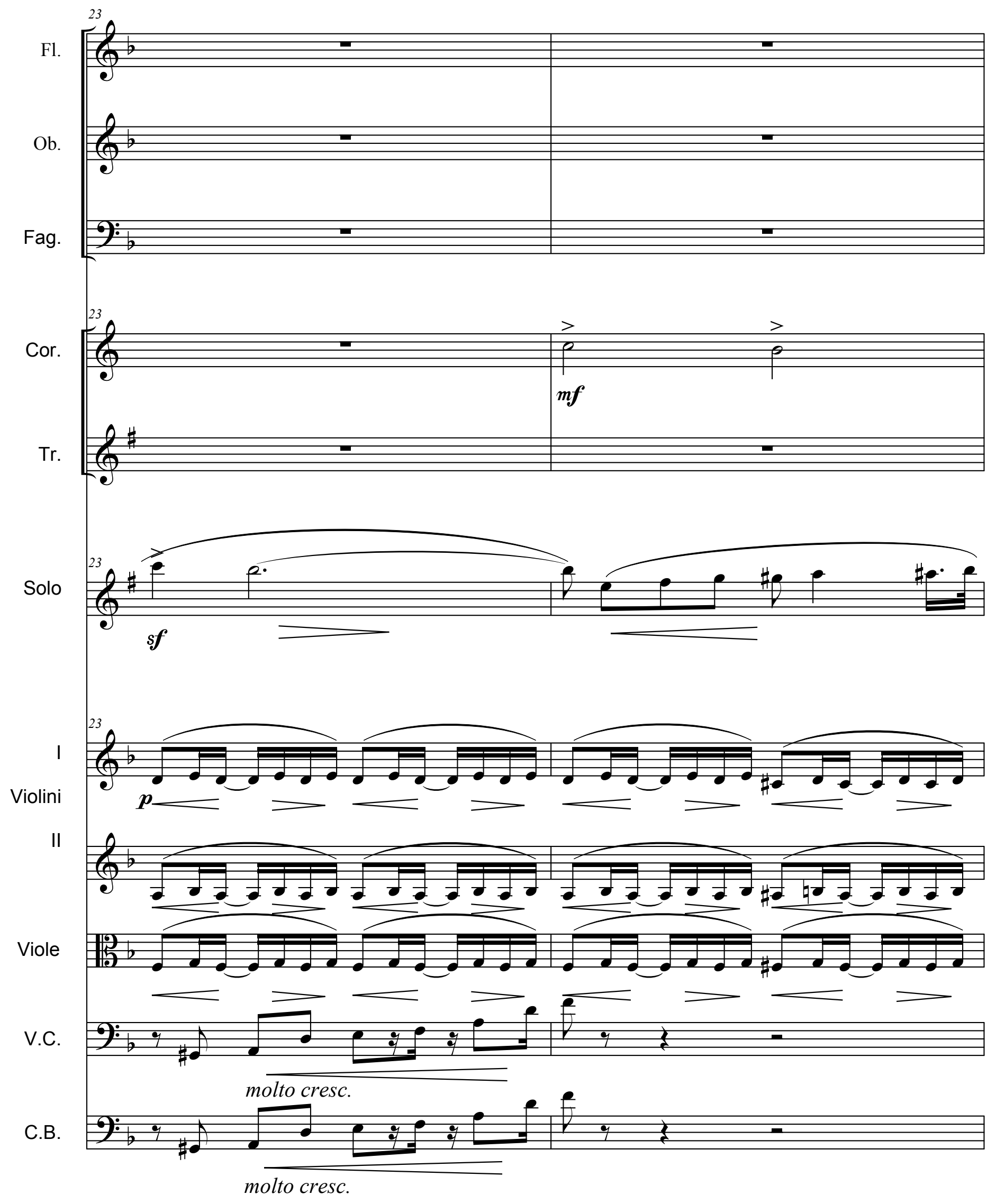




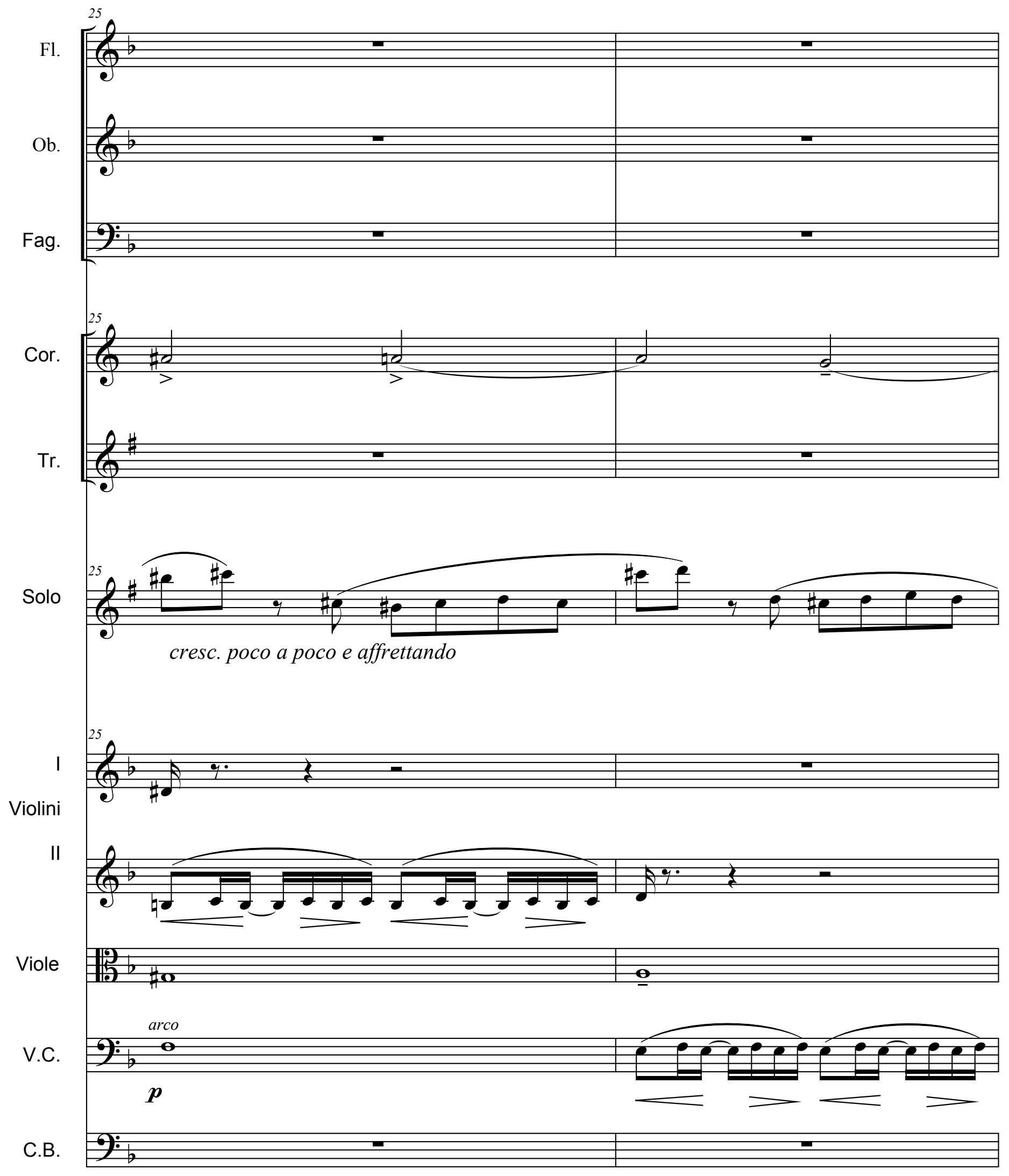




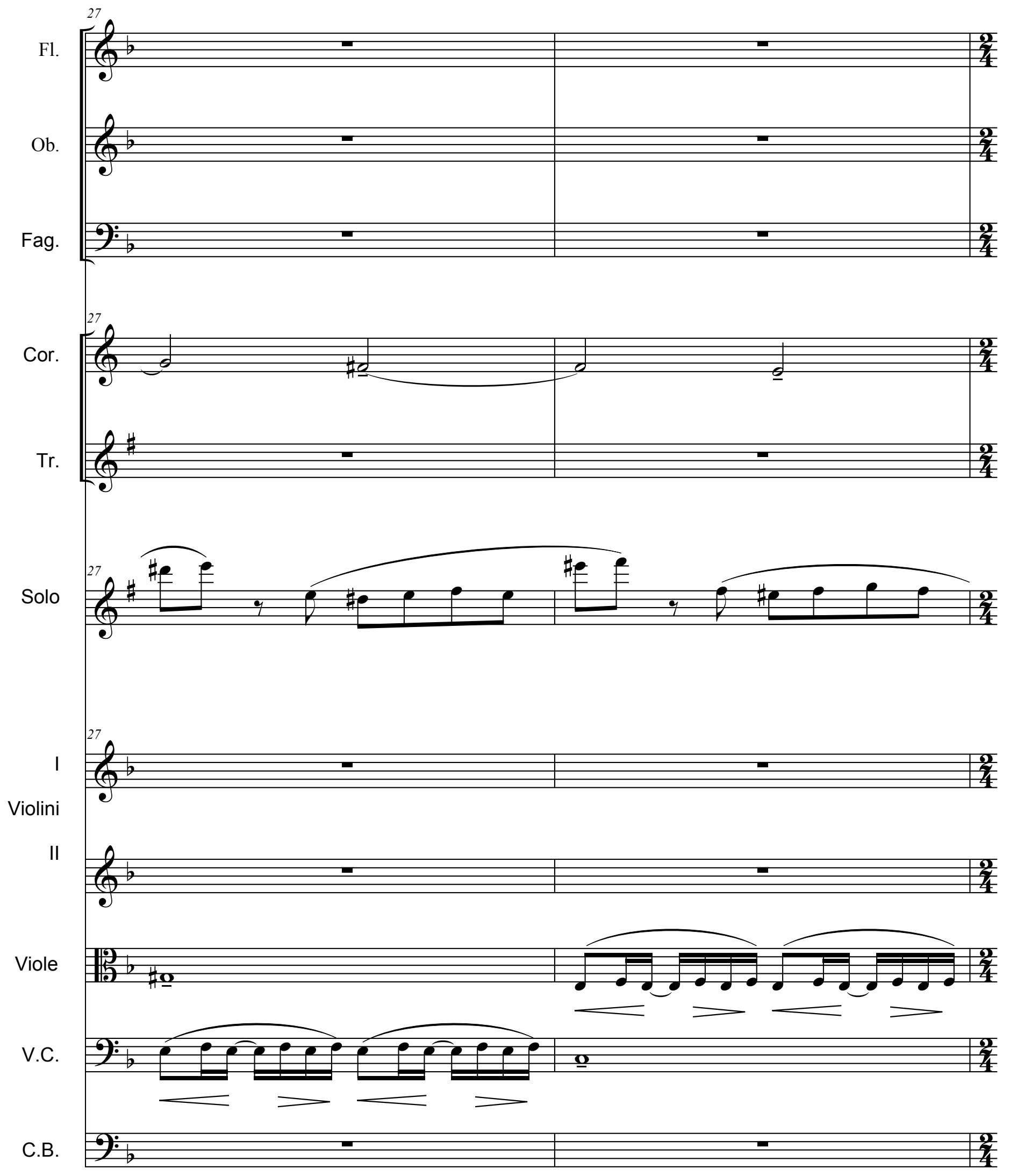


(3)

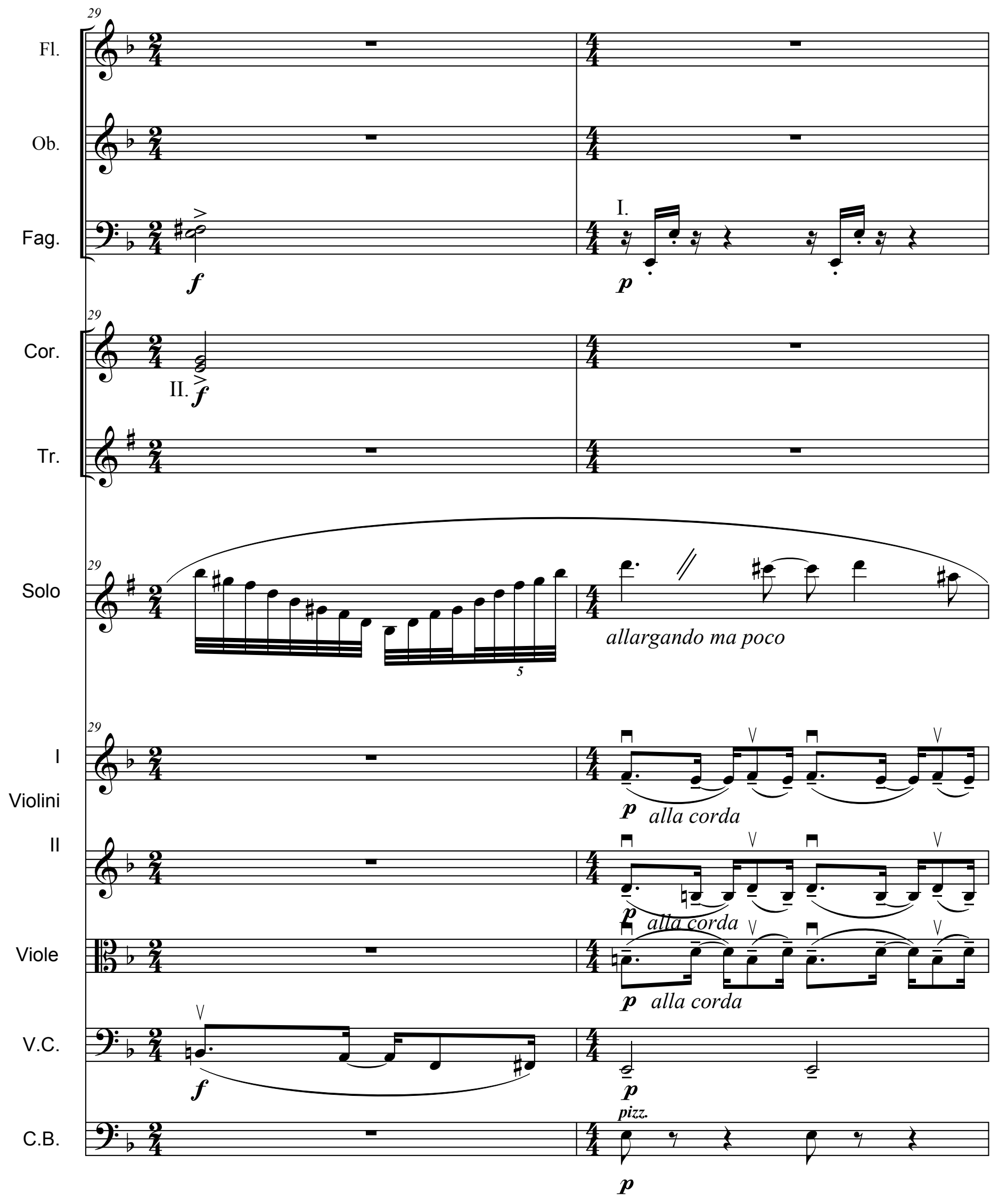



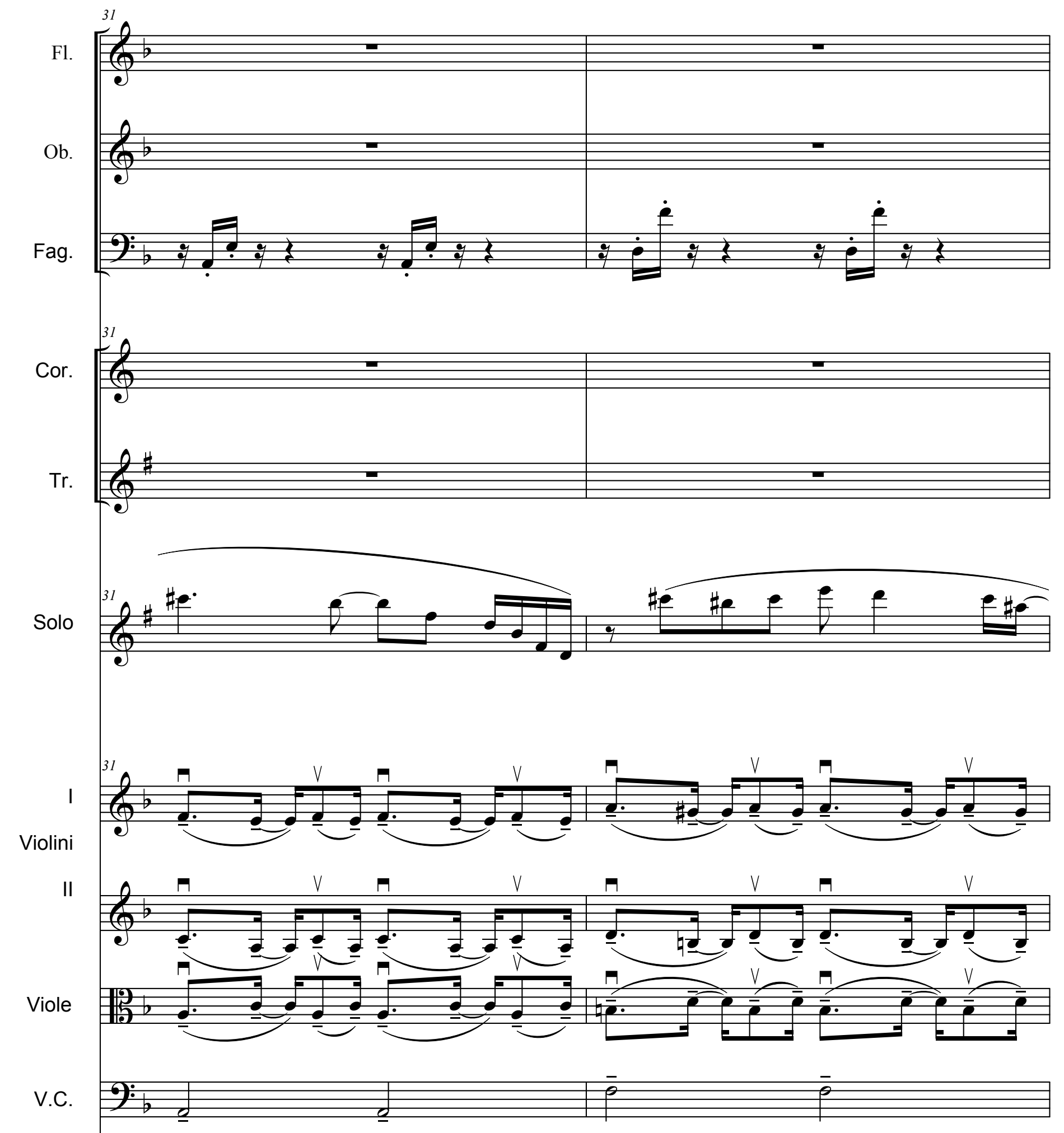

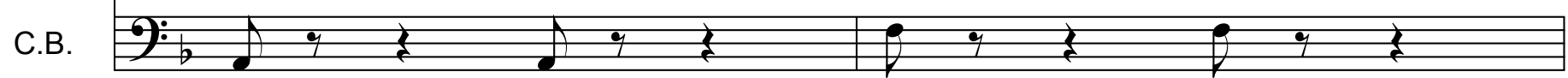



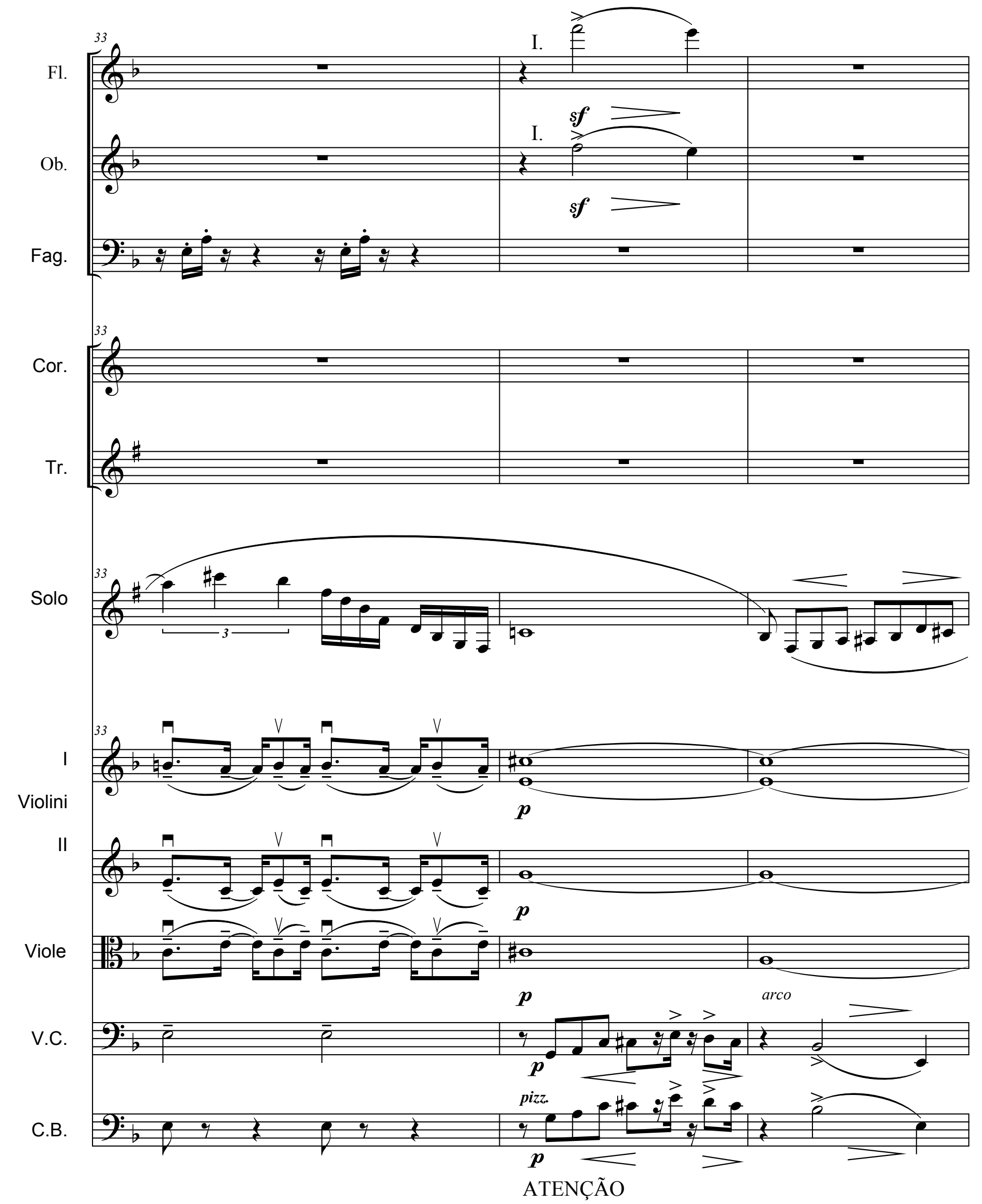


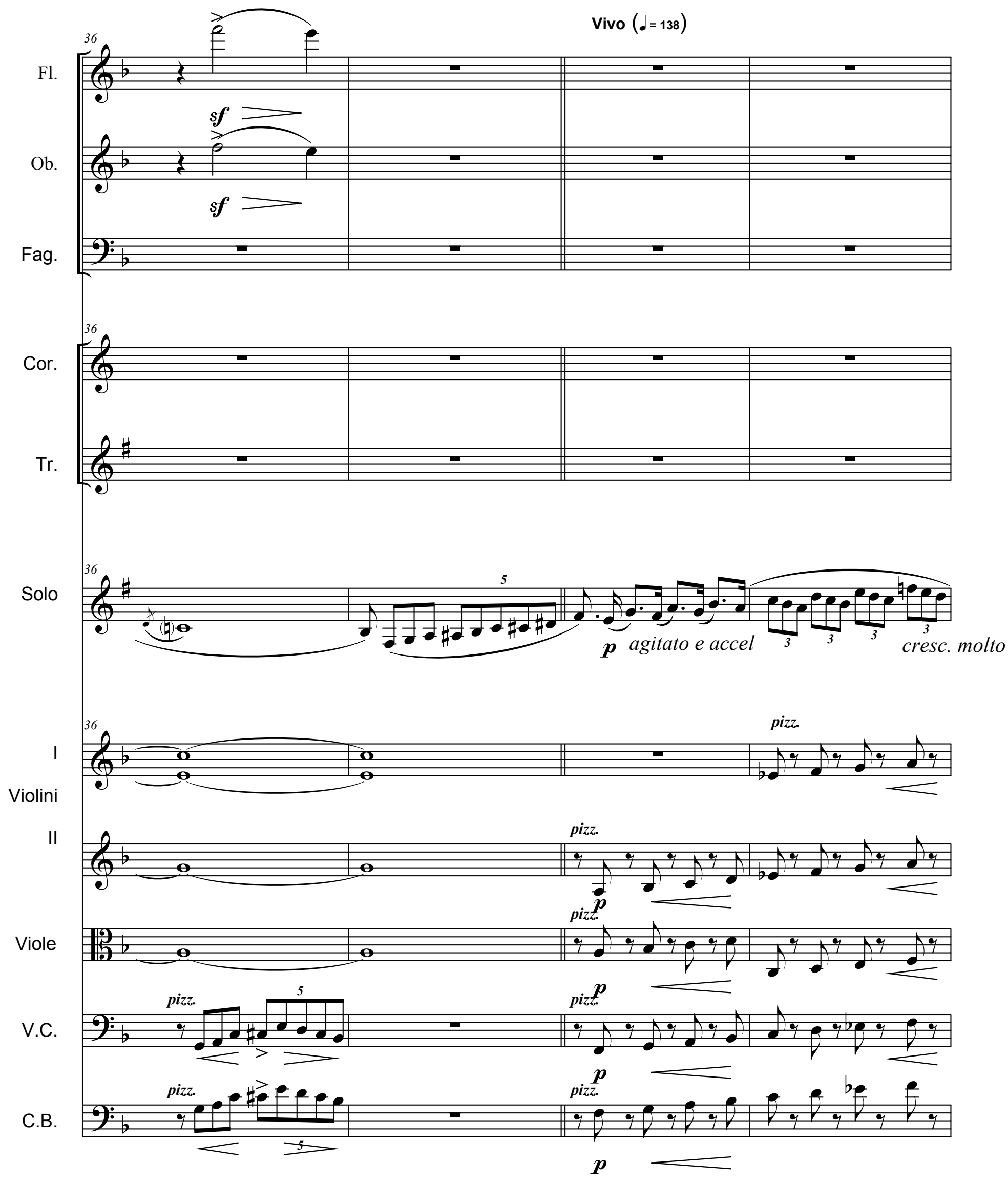




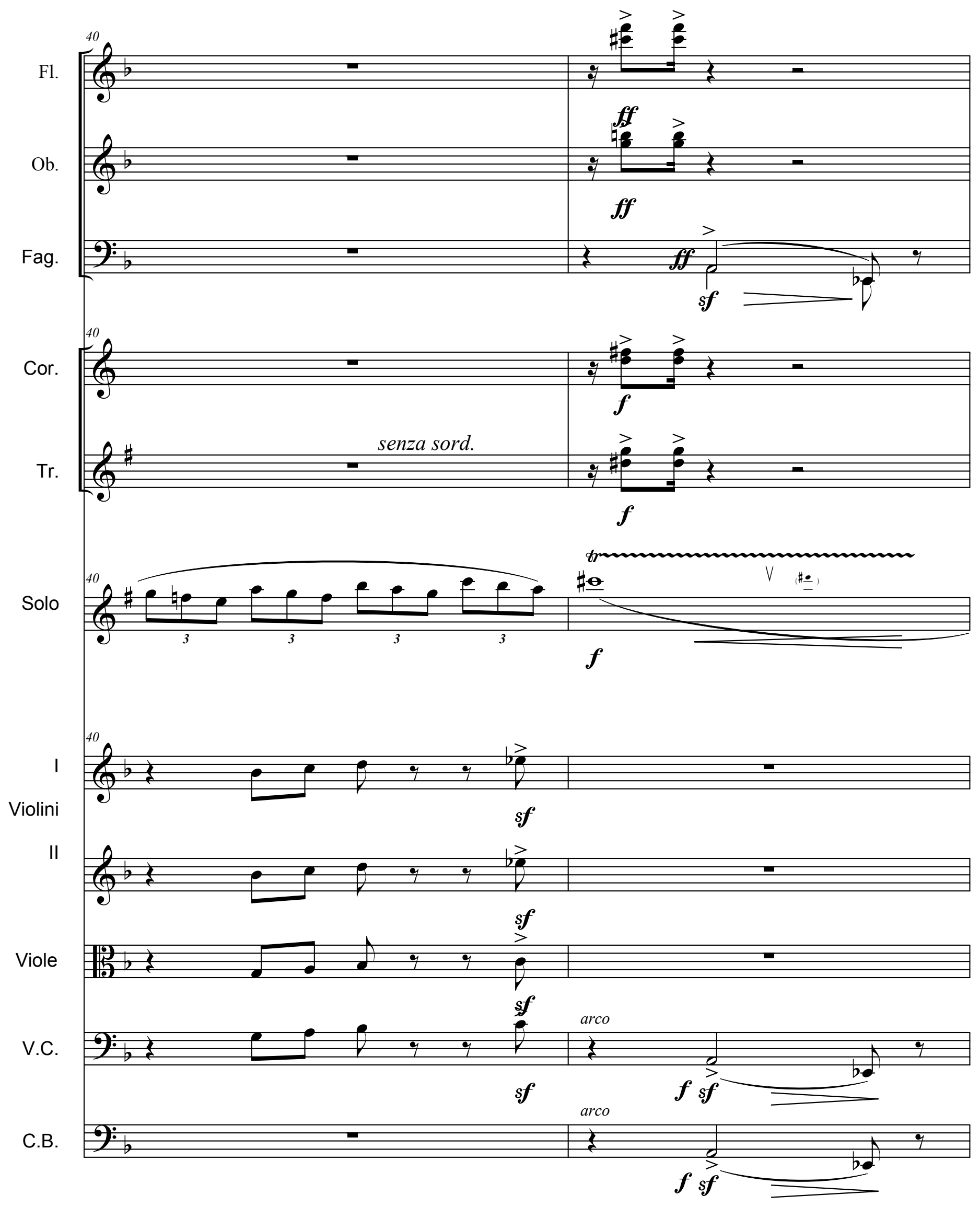


(4)
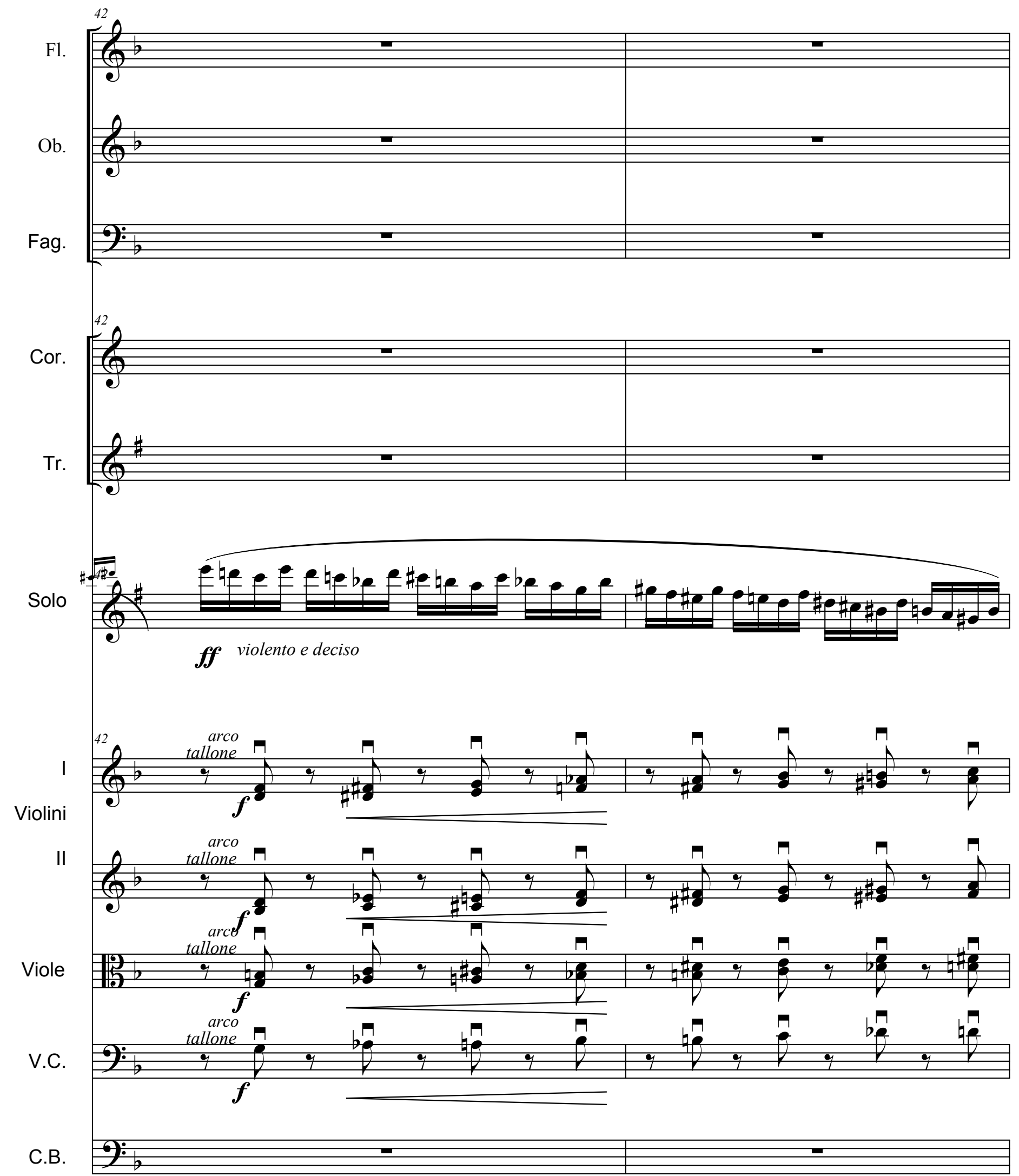


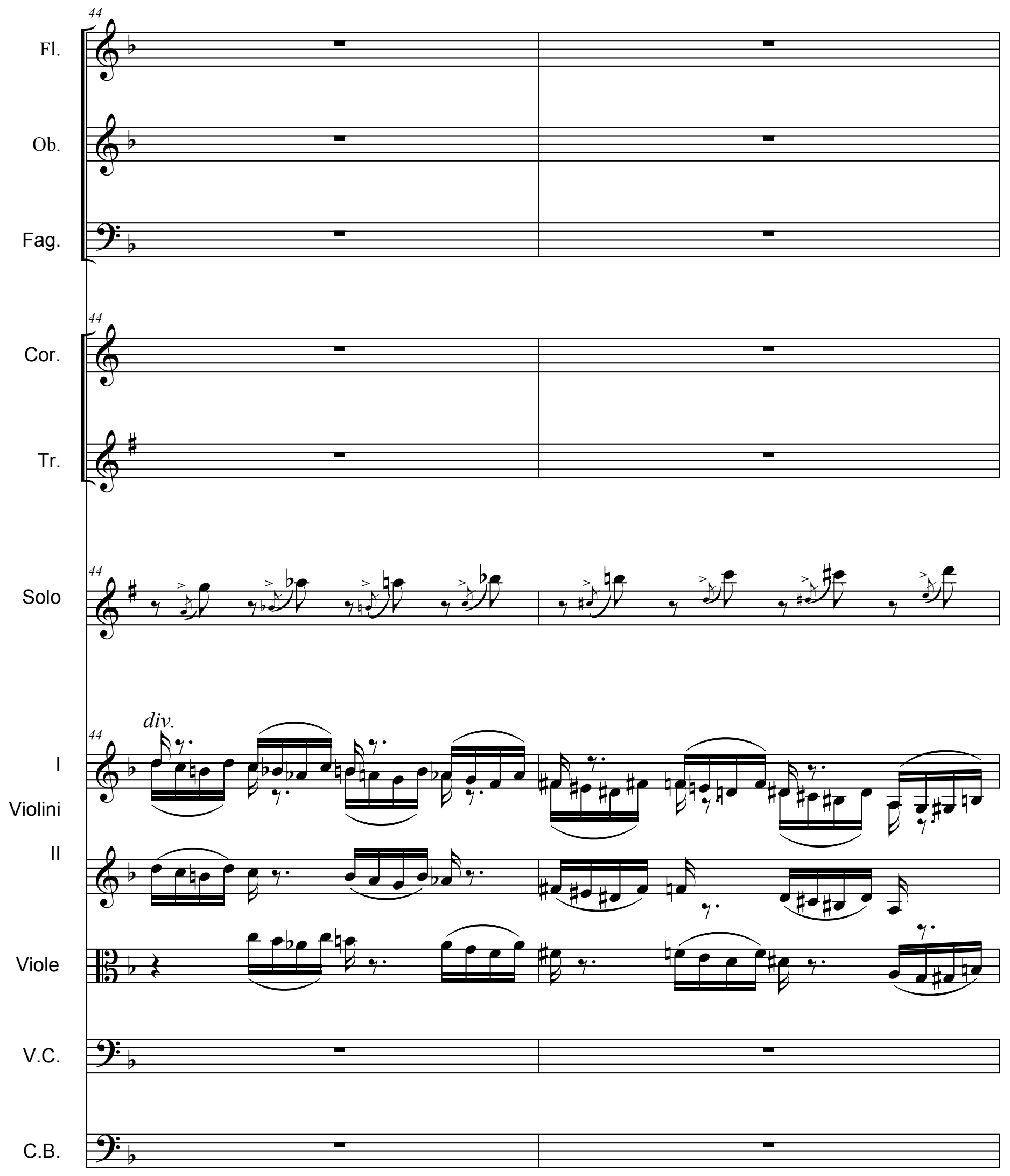


(5)

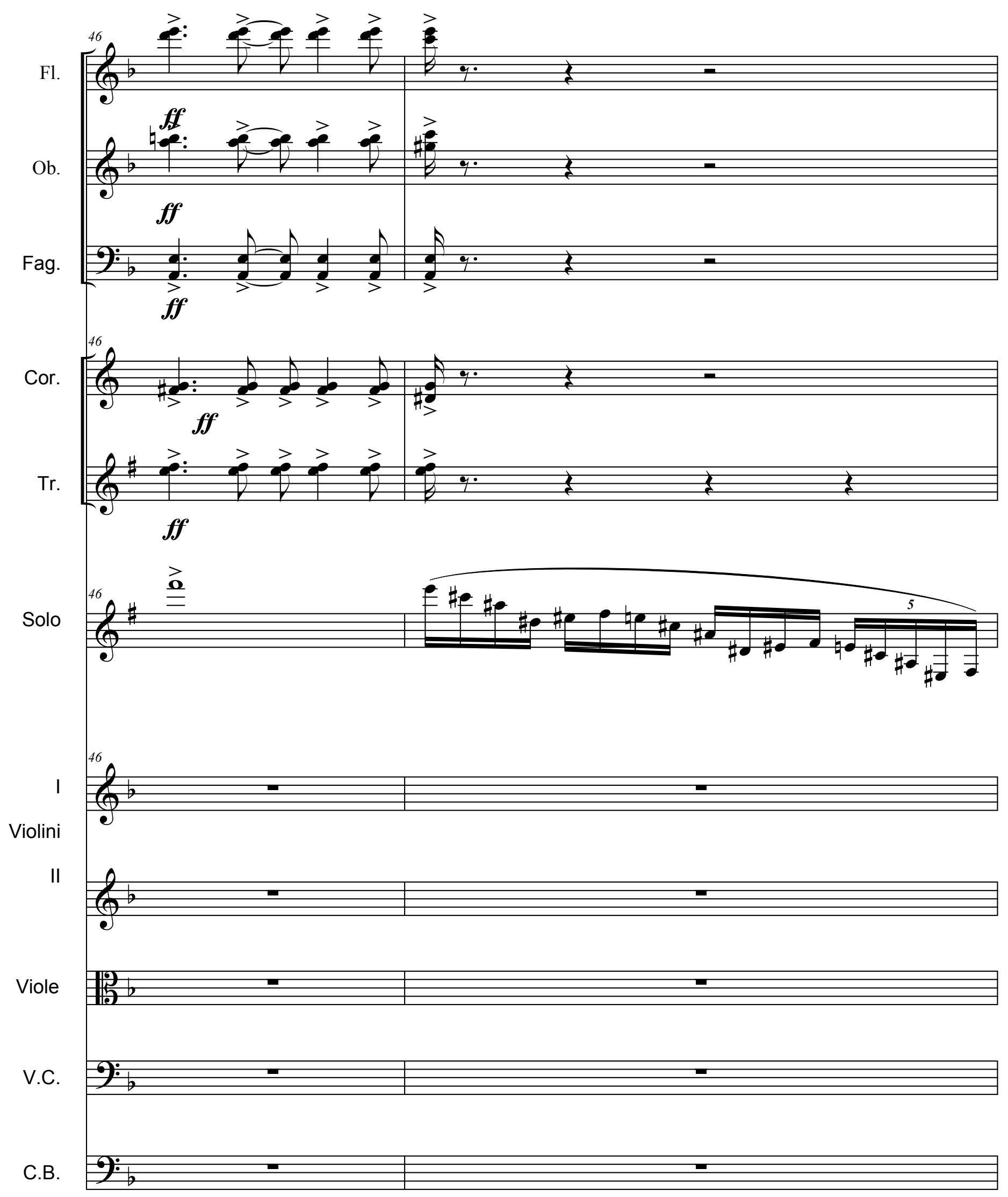



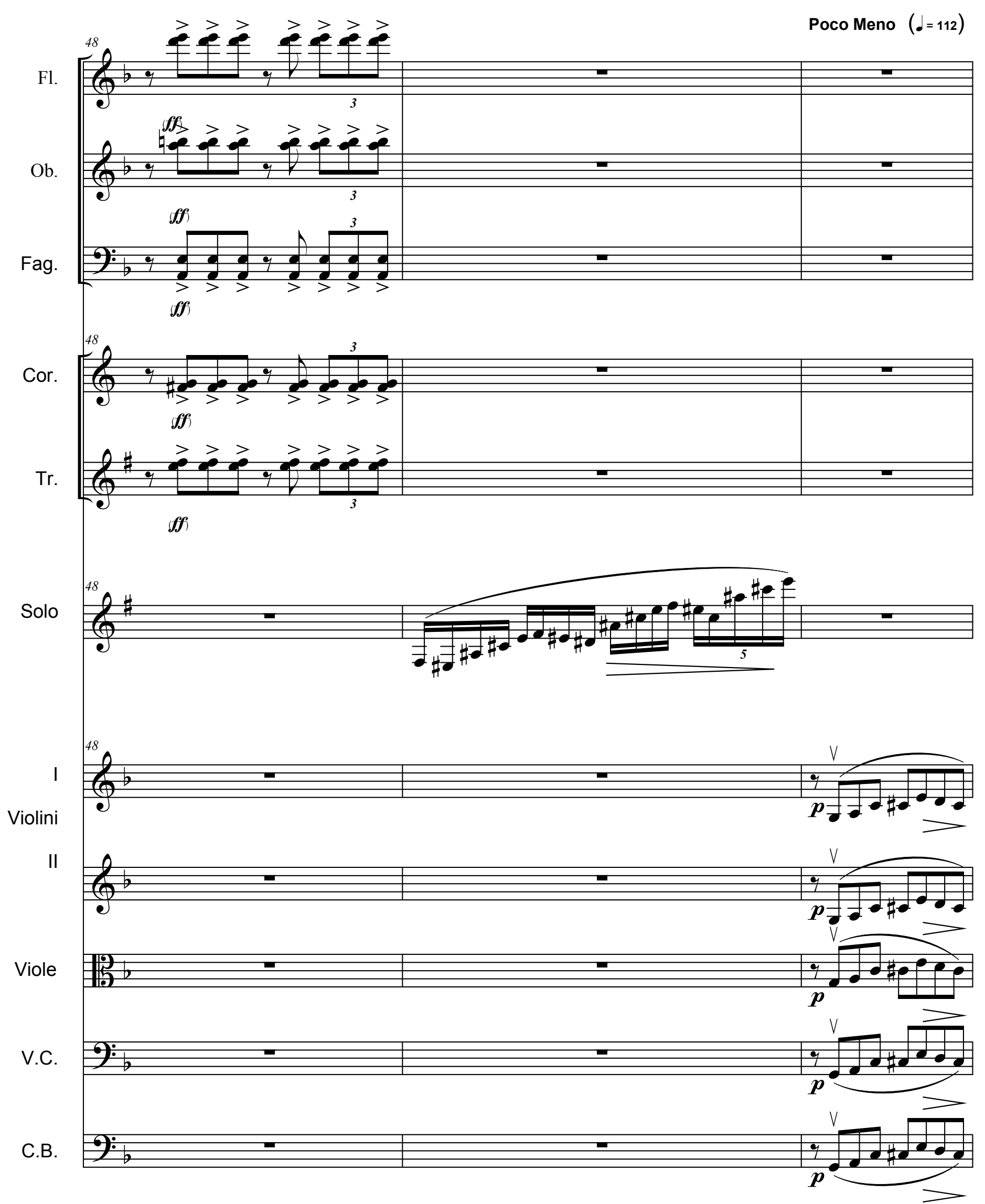


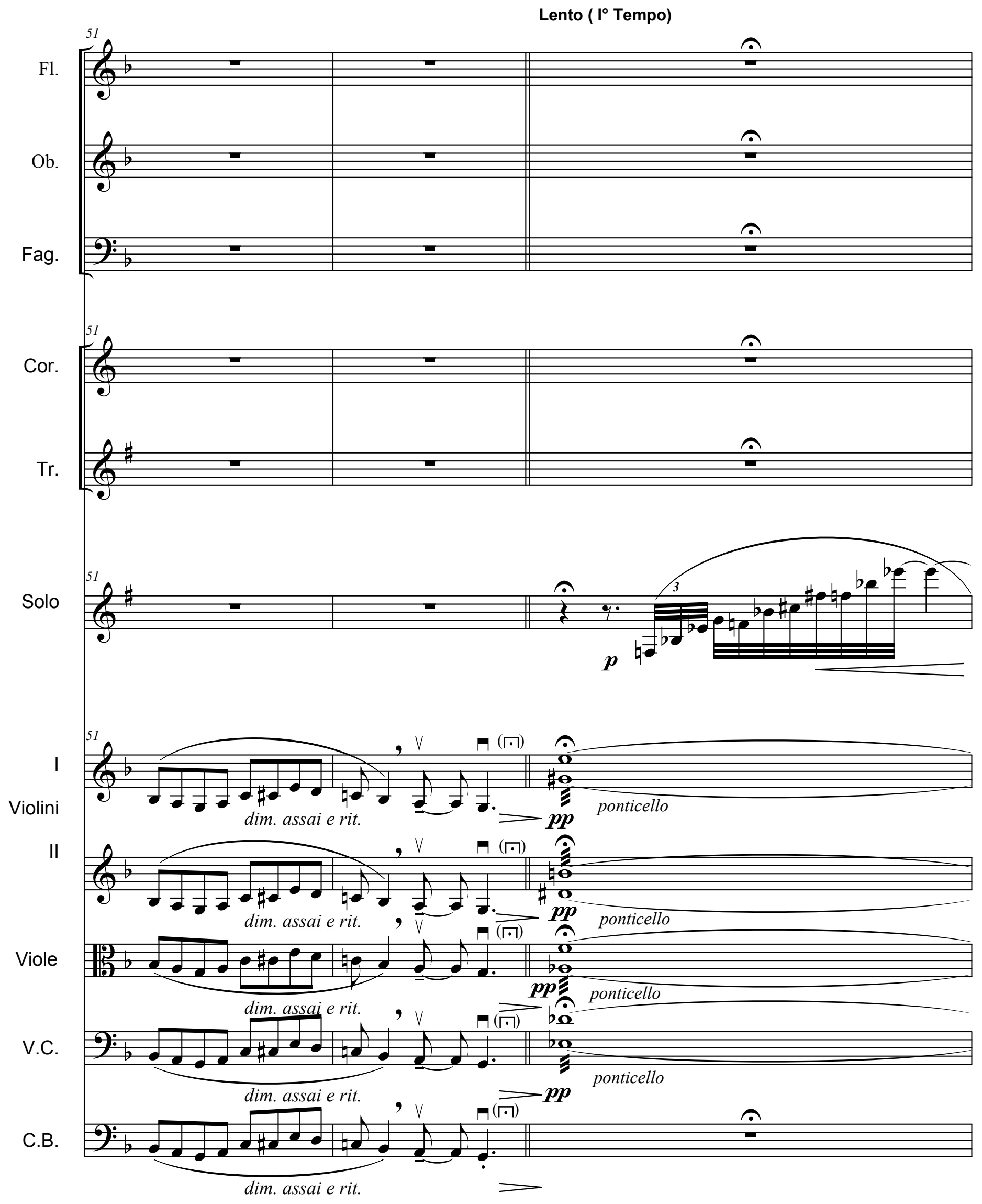


(6)

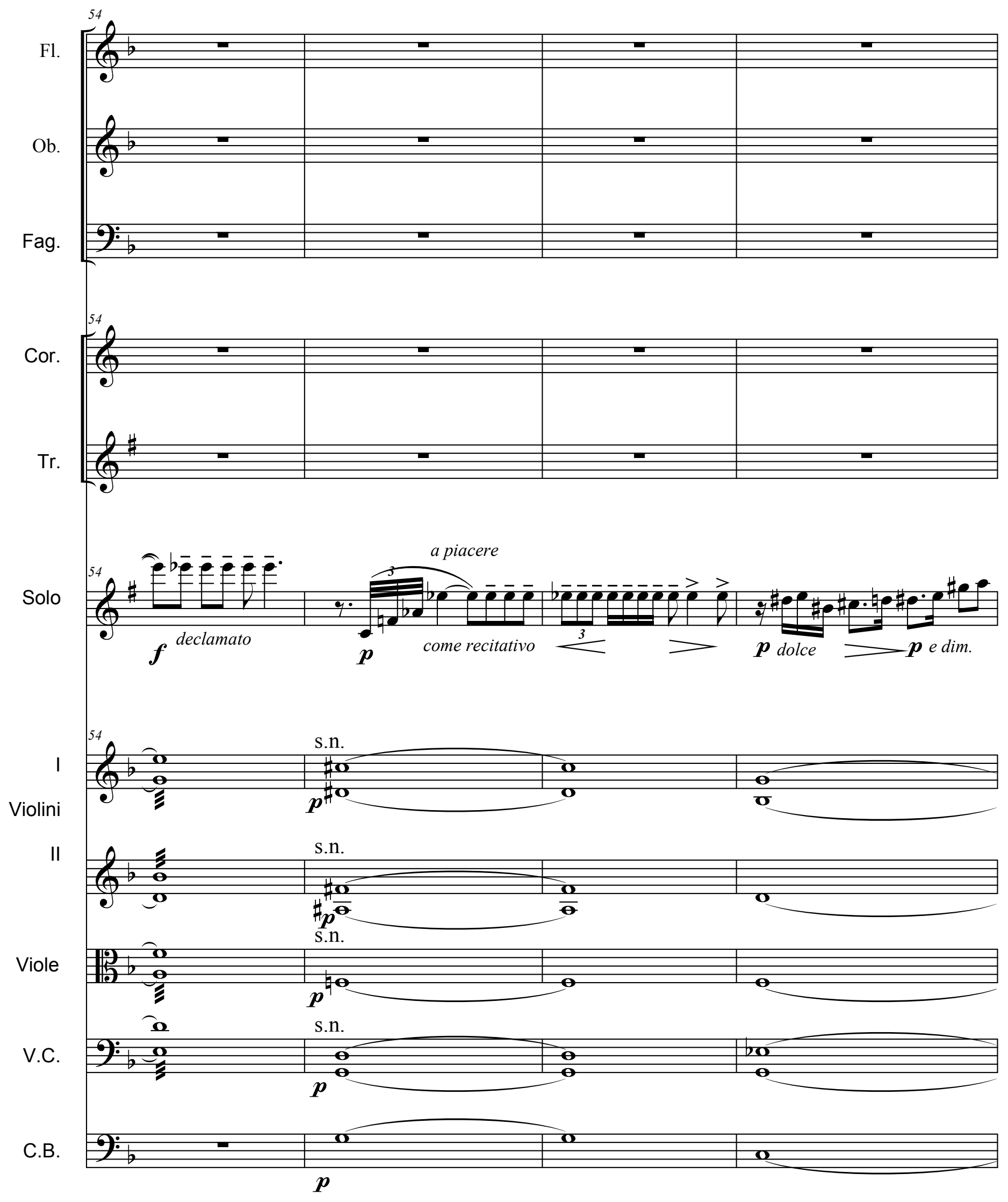



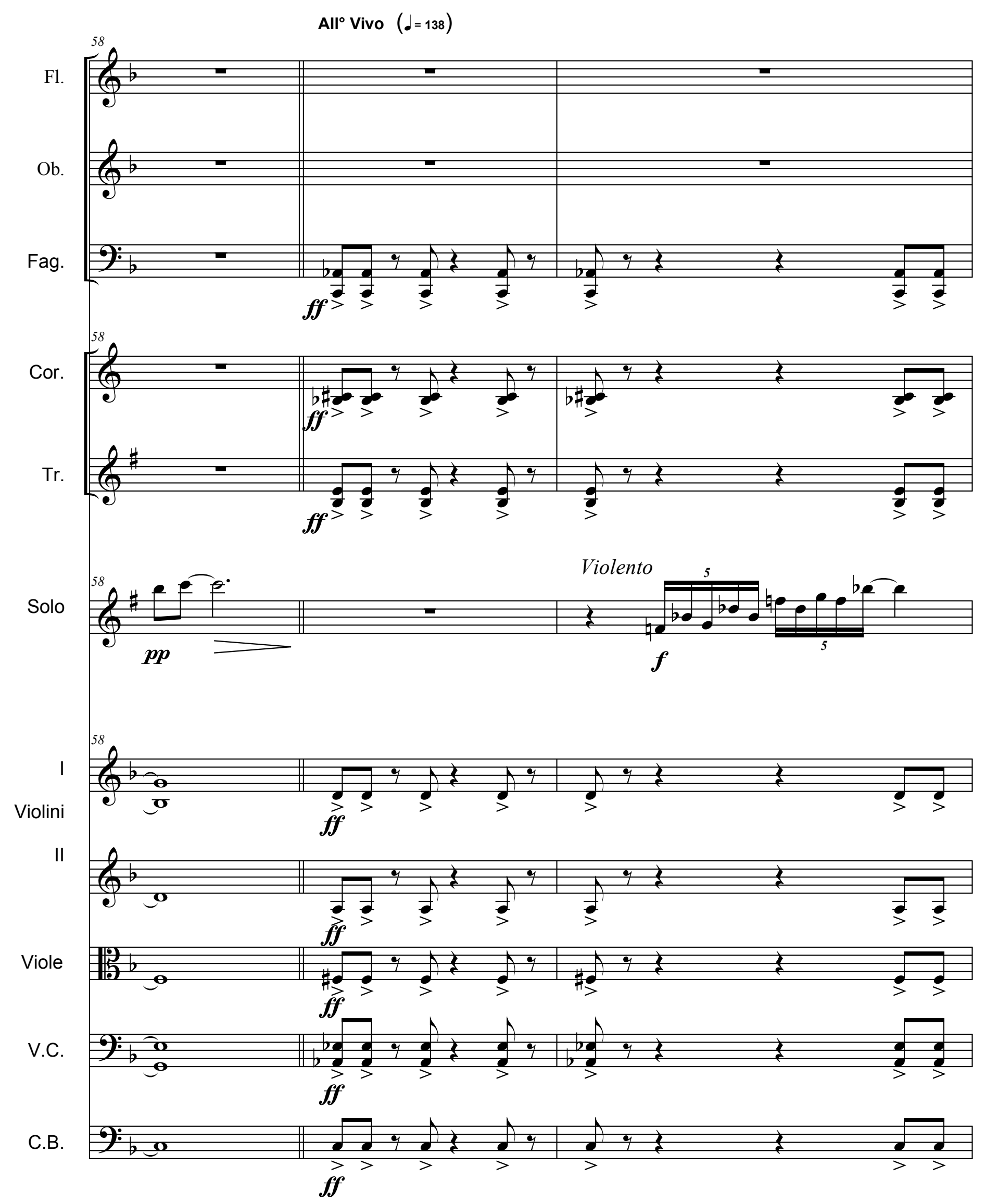

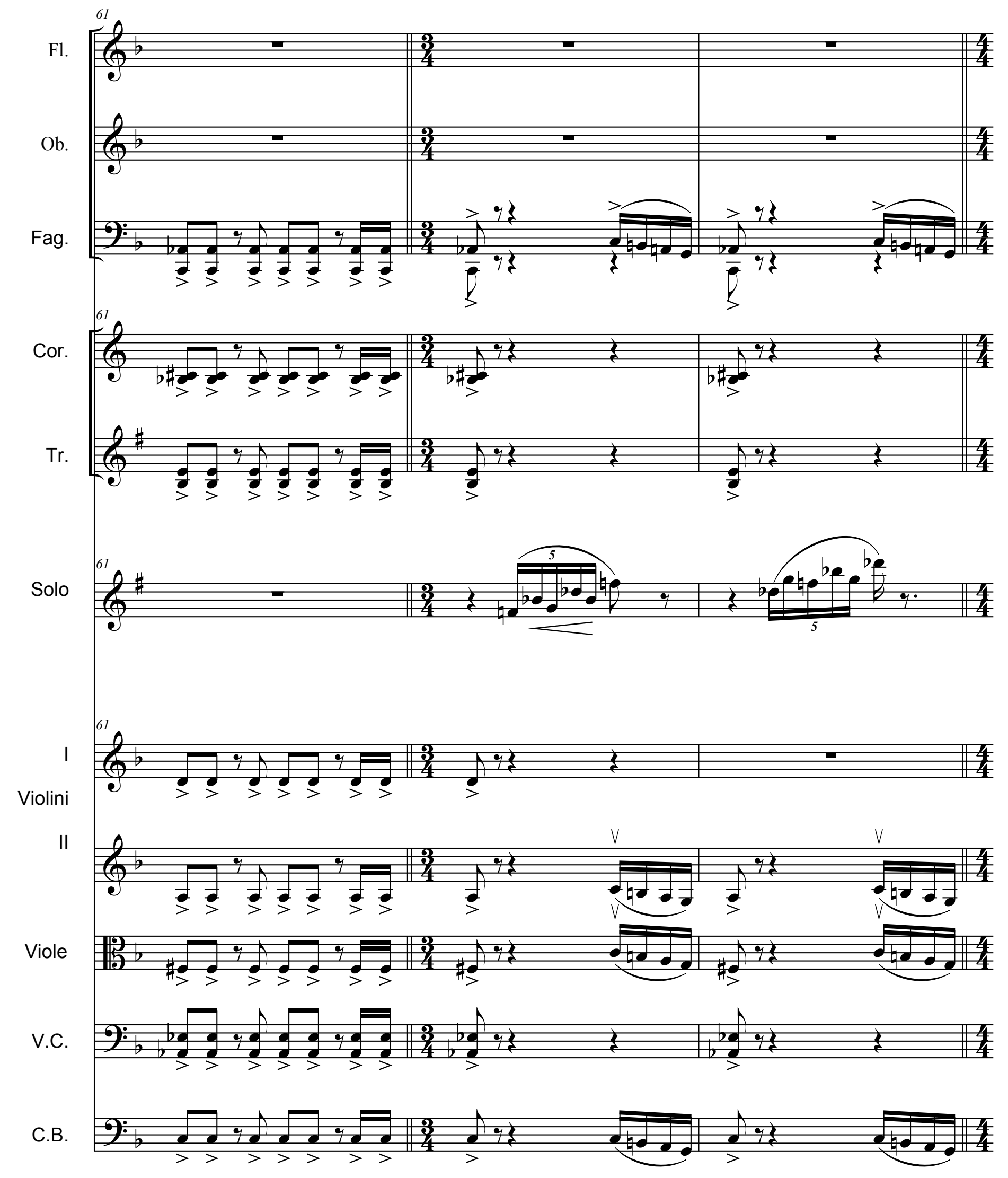
(7)
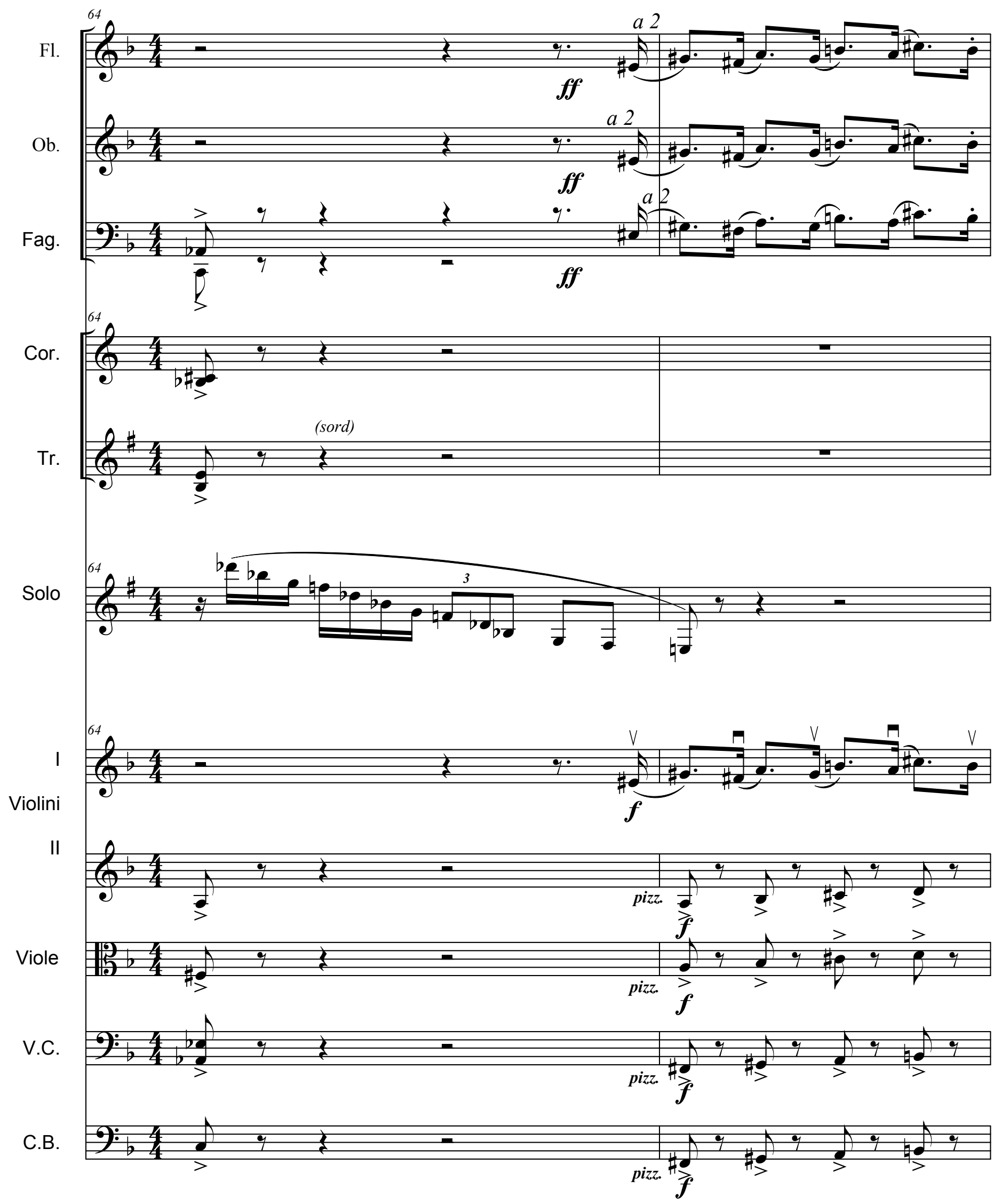

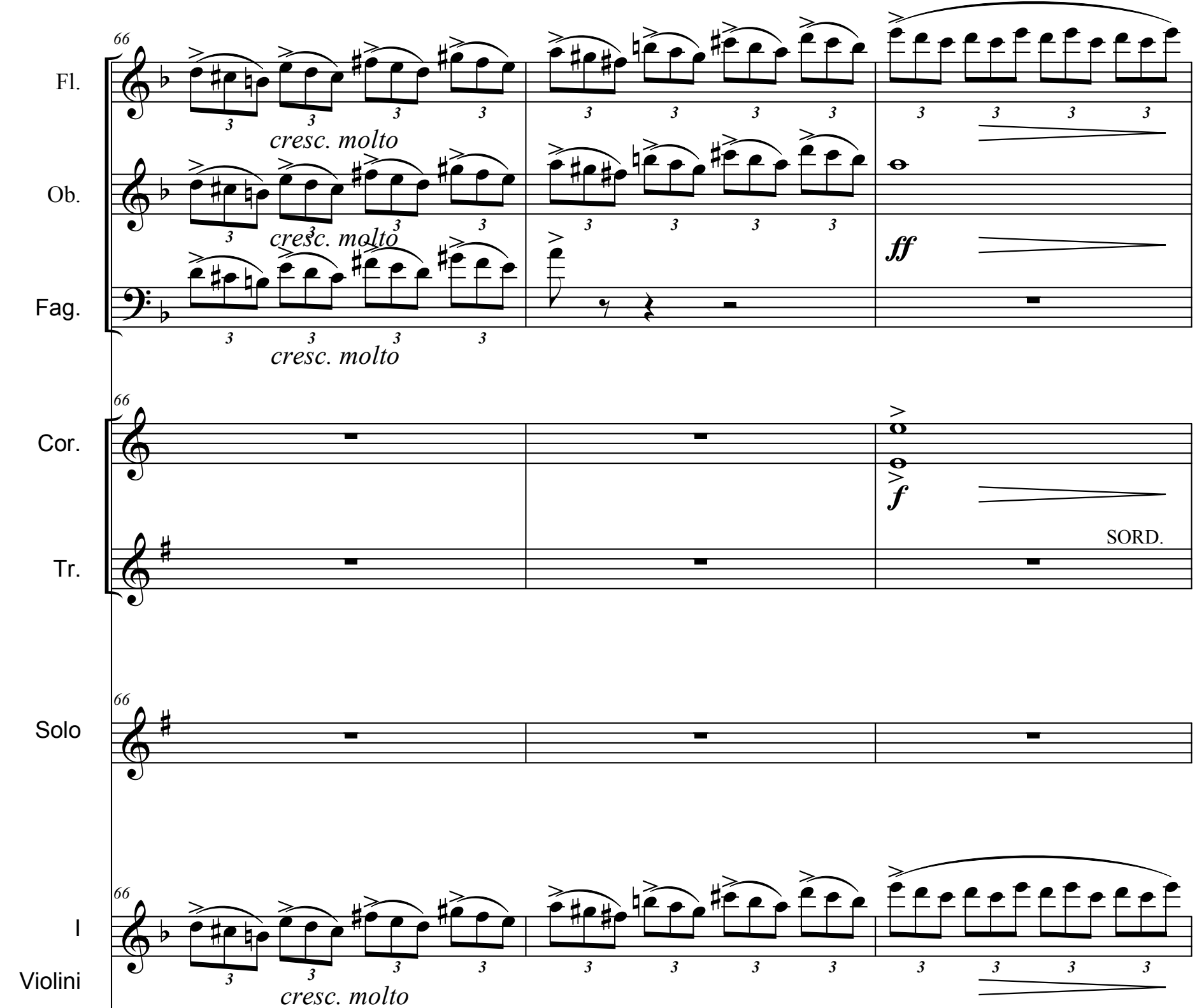

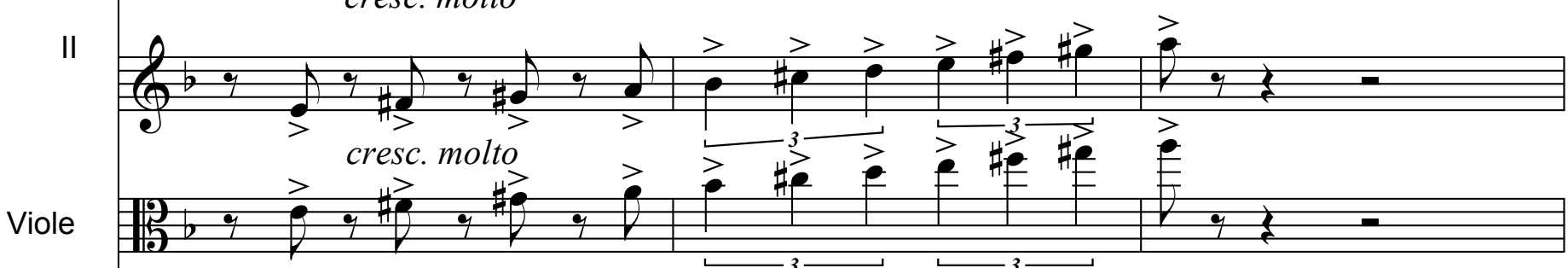

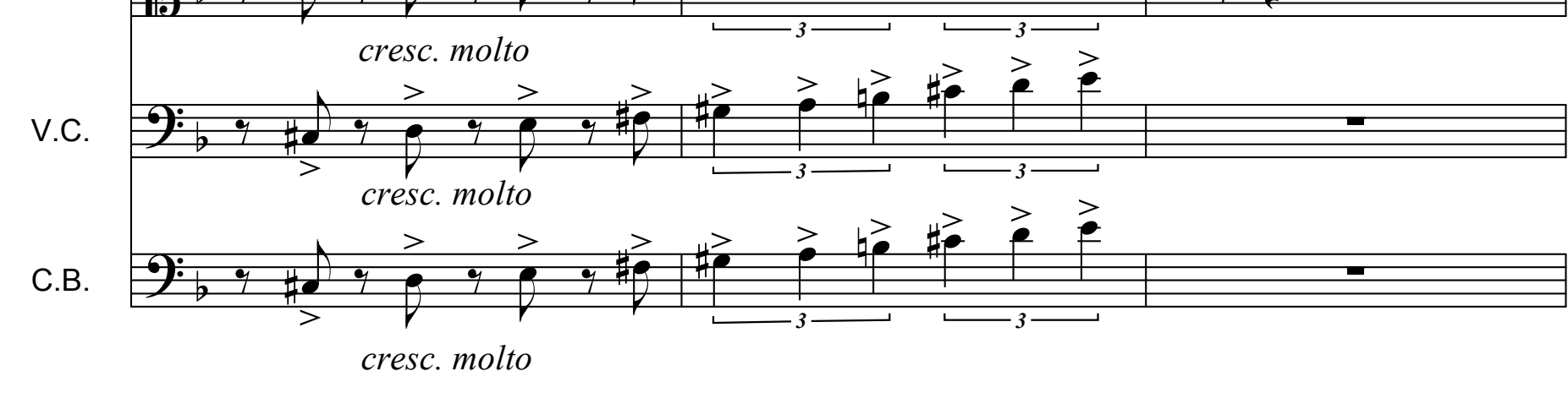




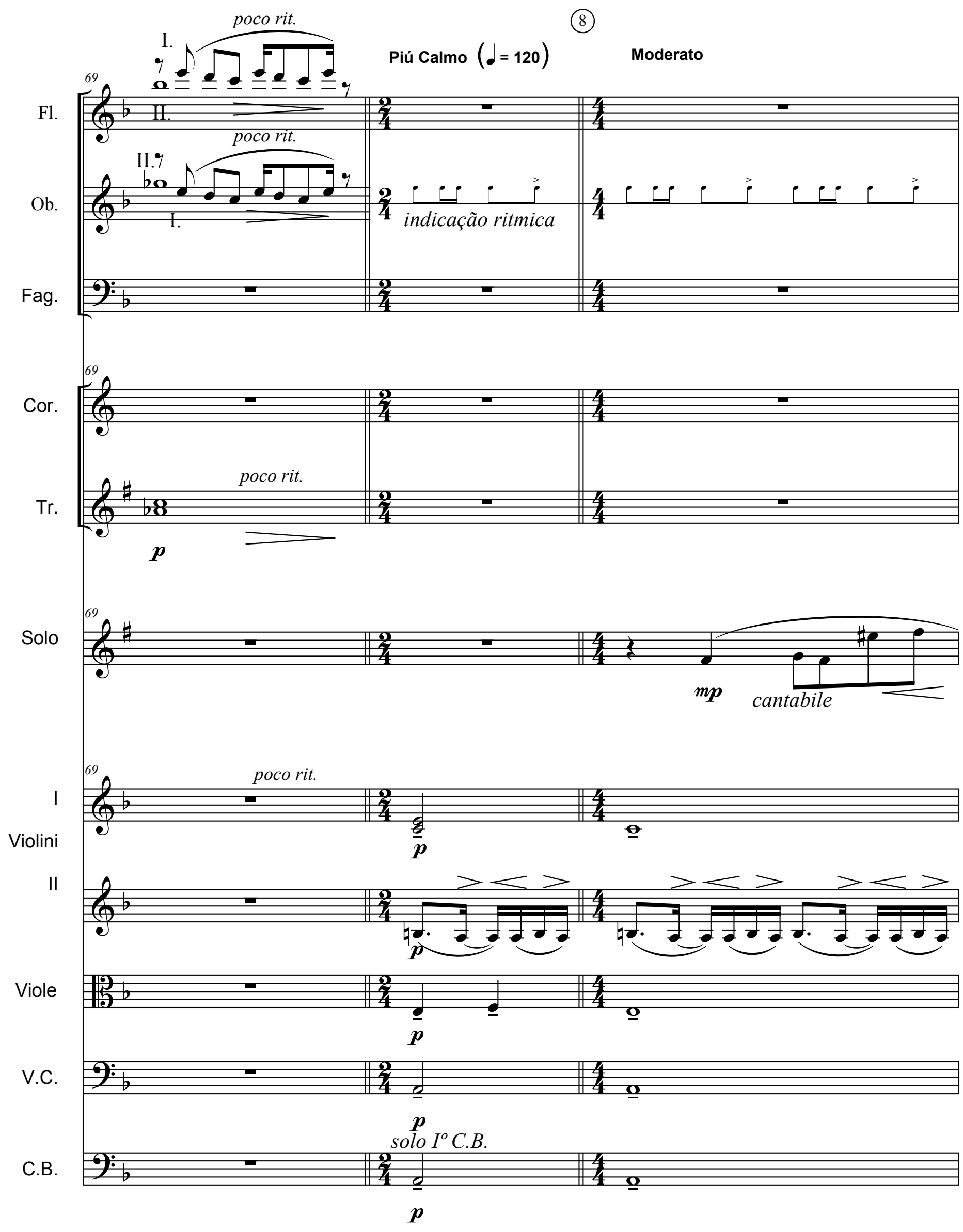




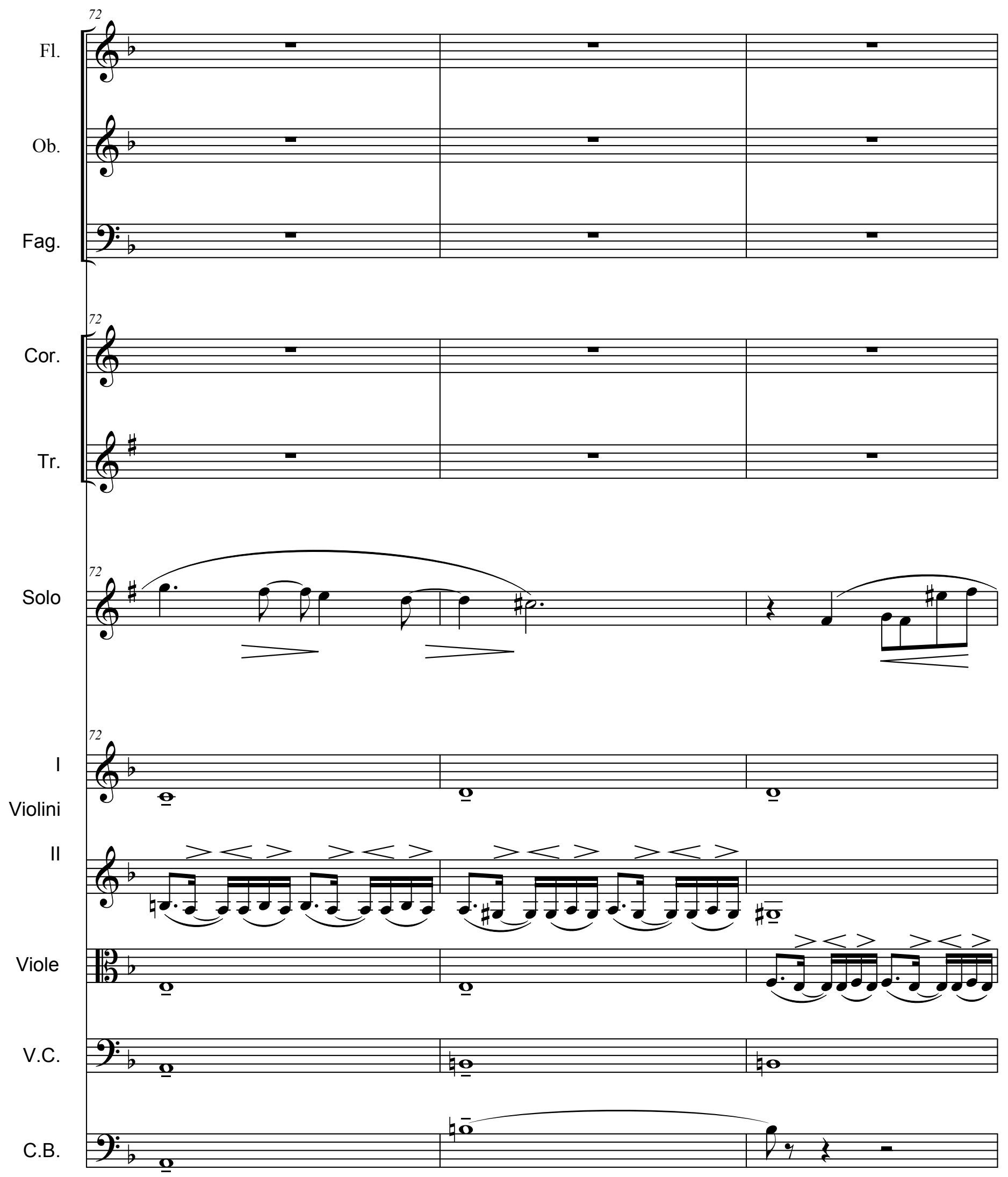




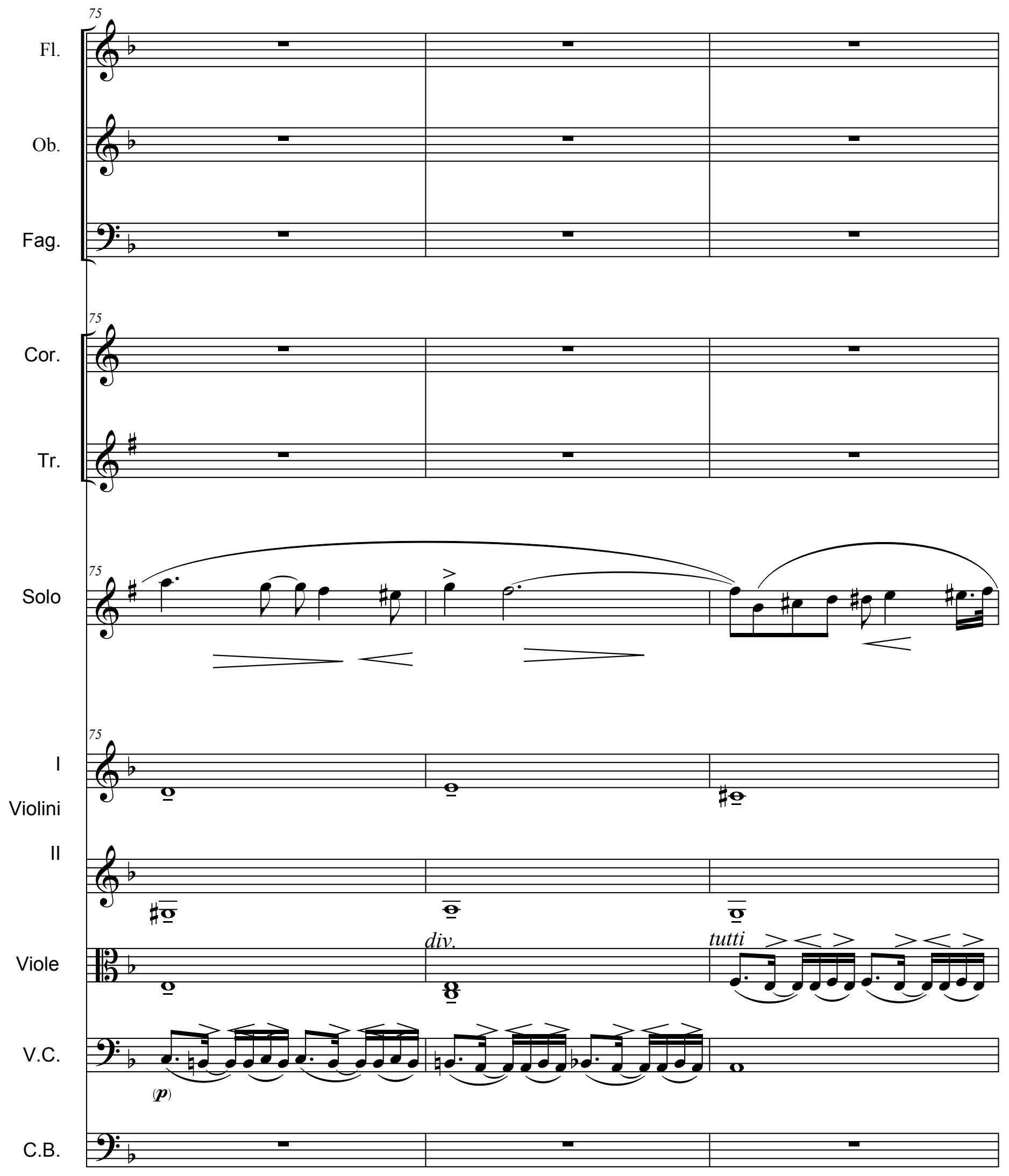




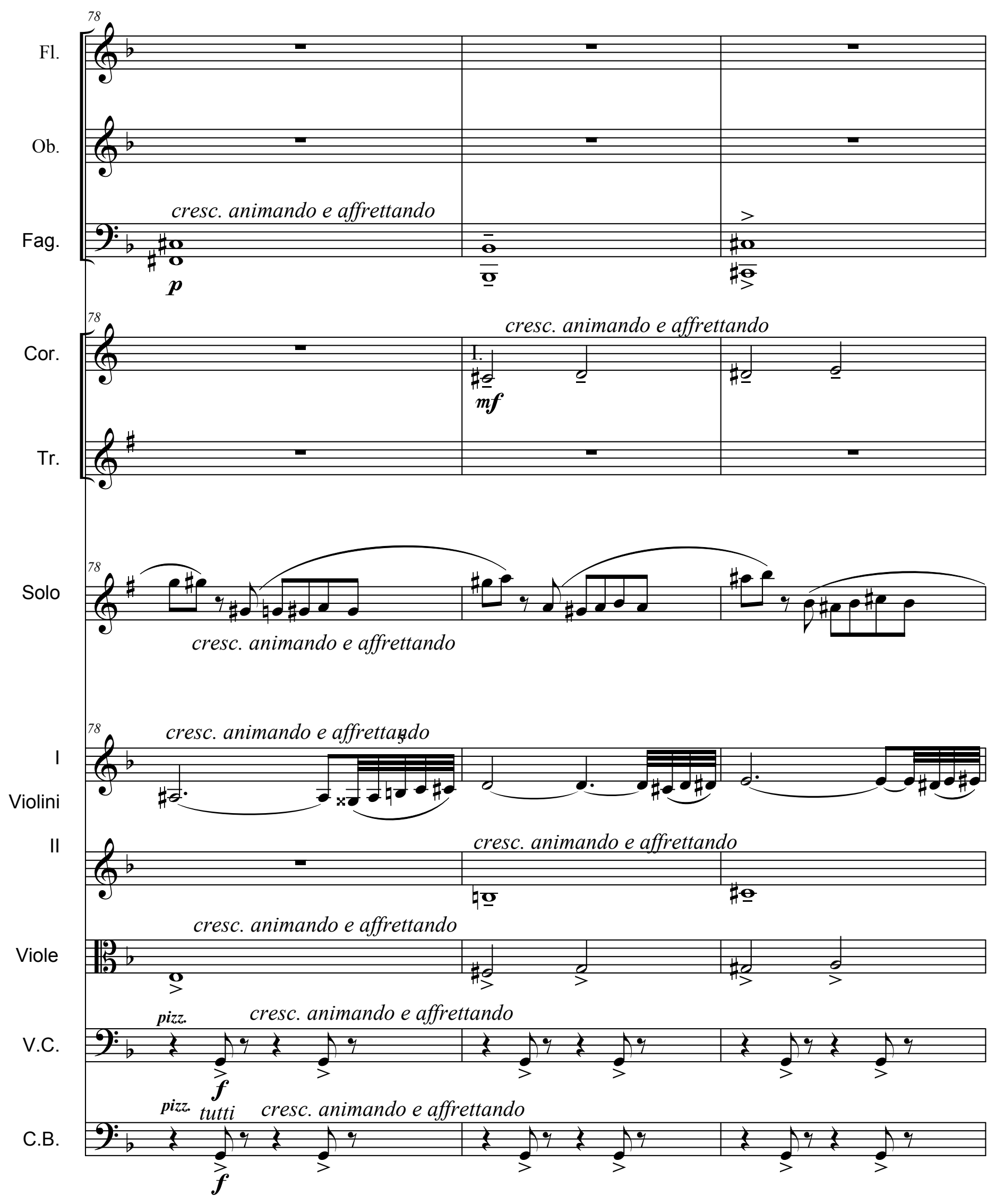



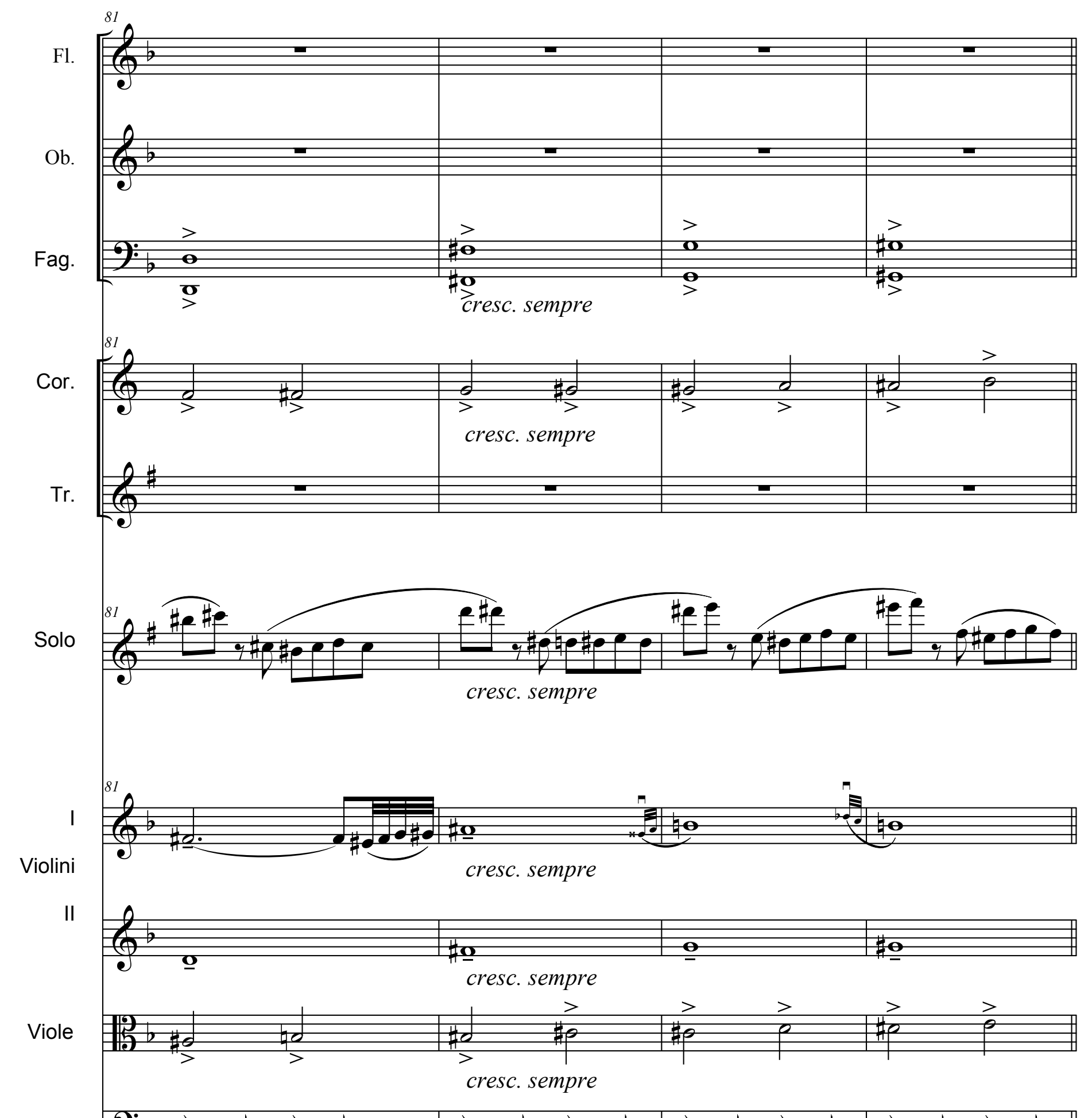

V.C.

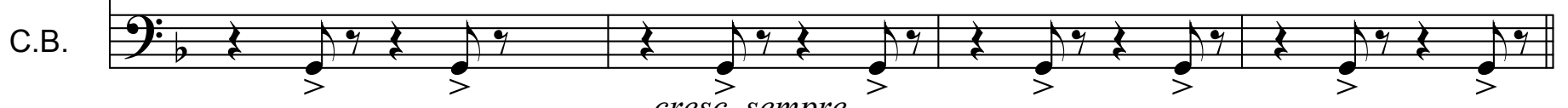
cresc. sempre 


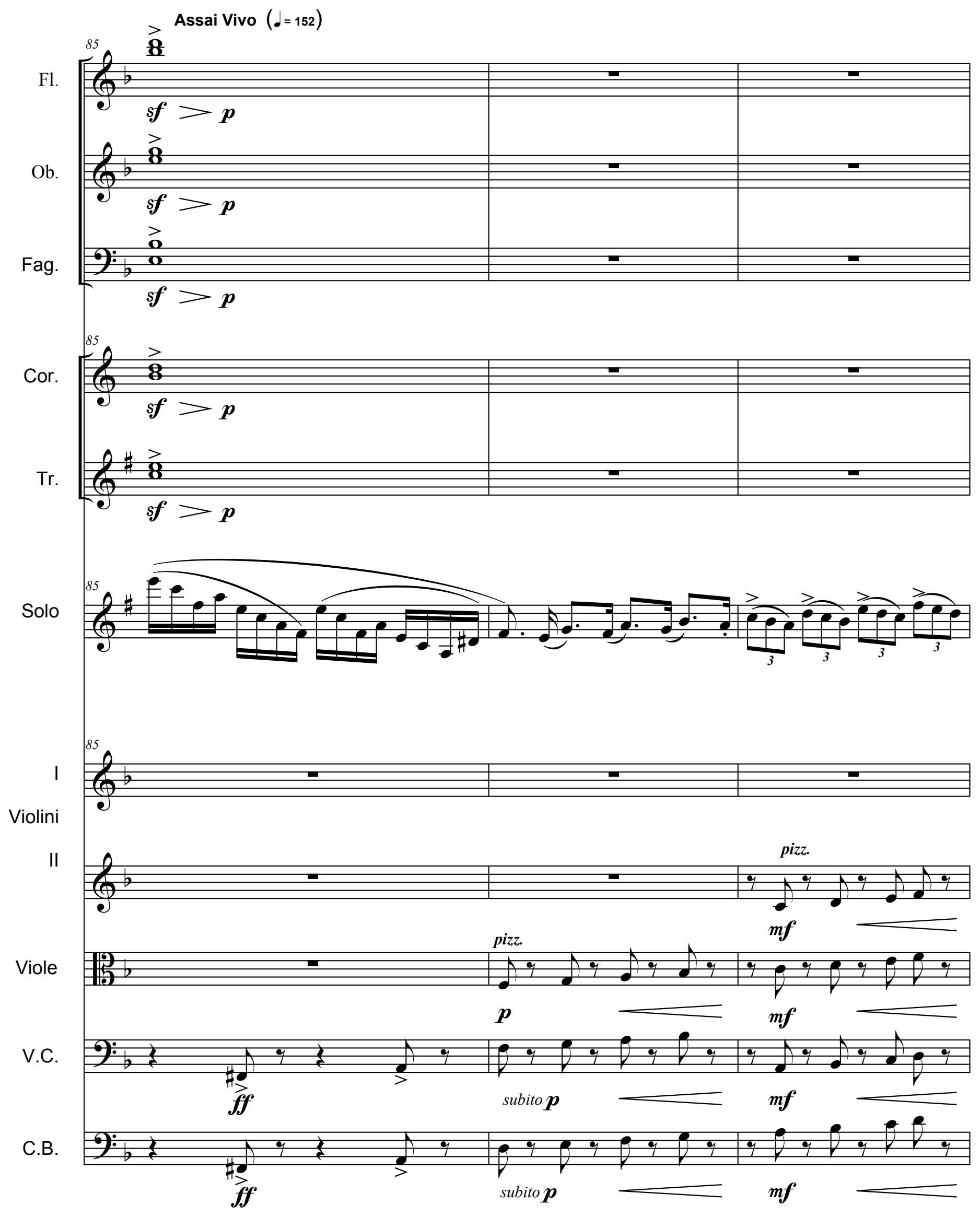


(9)
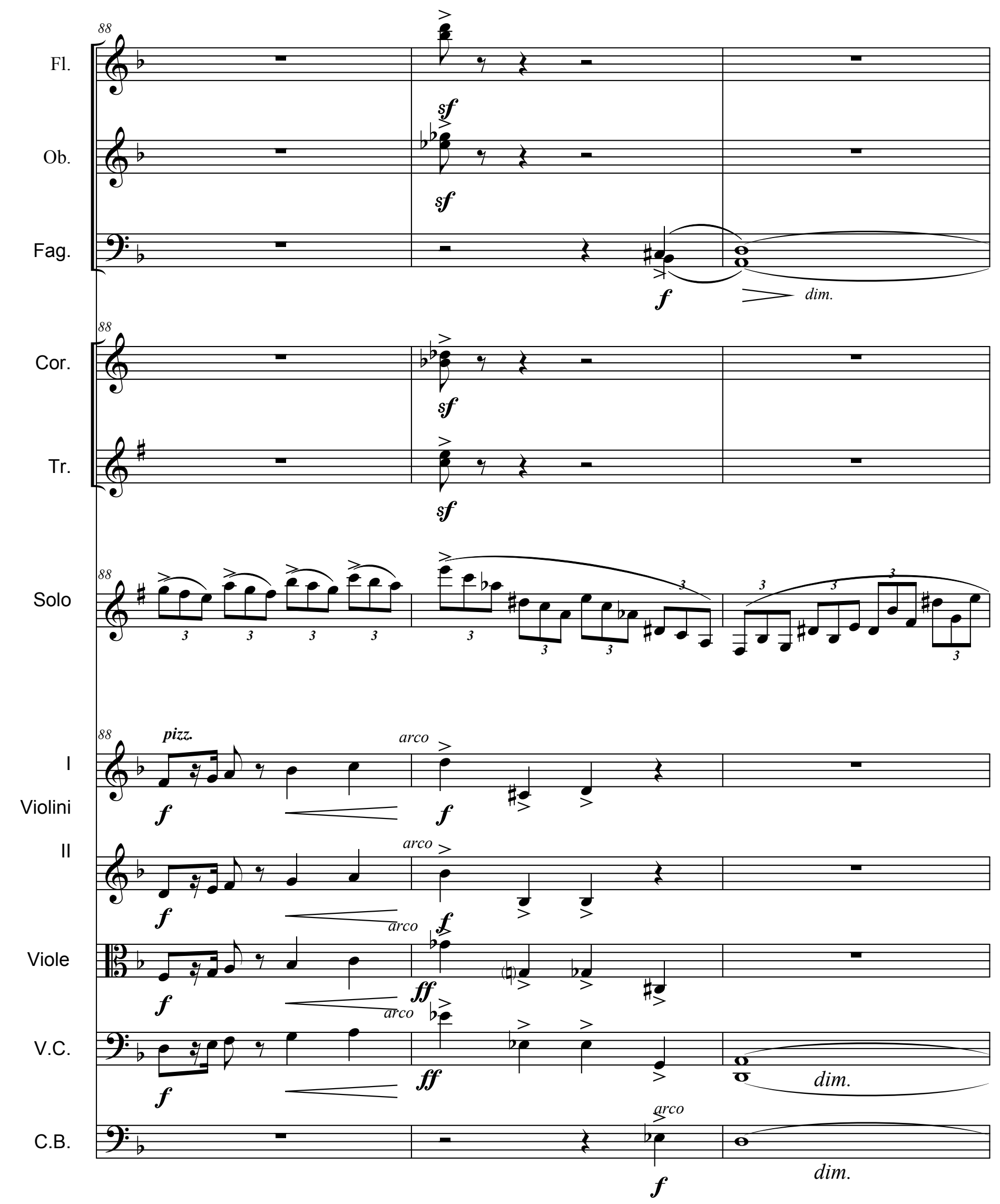


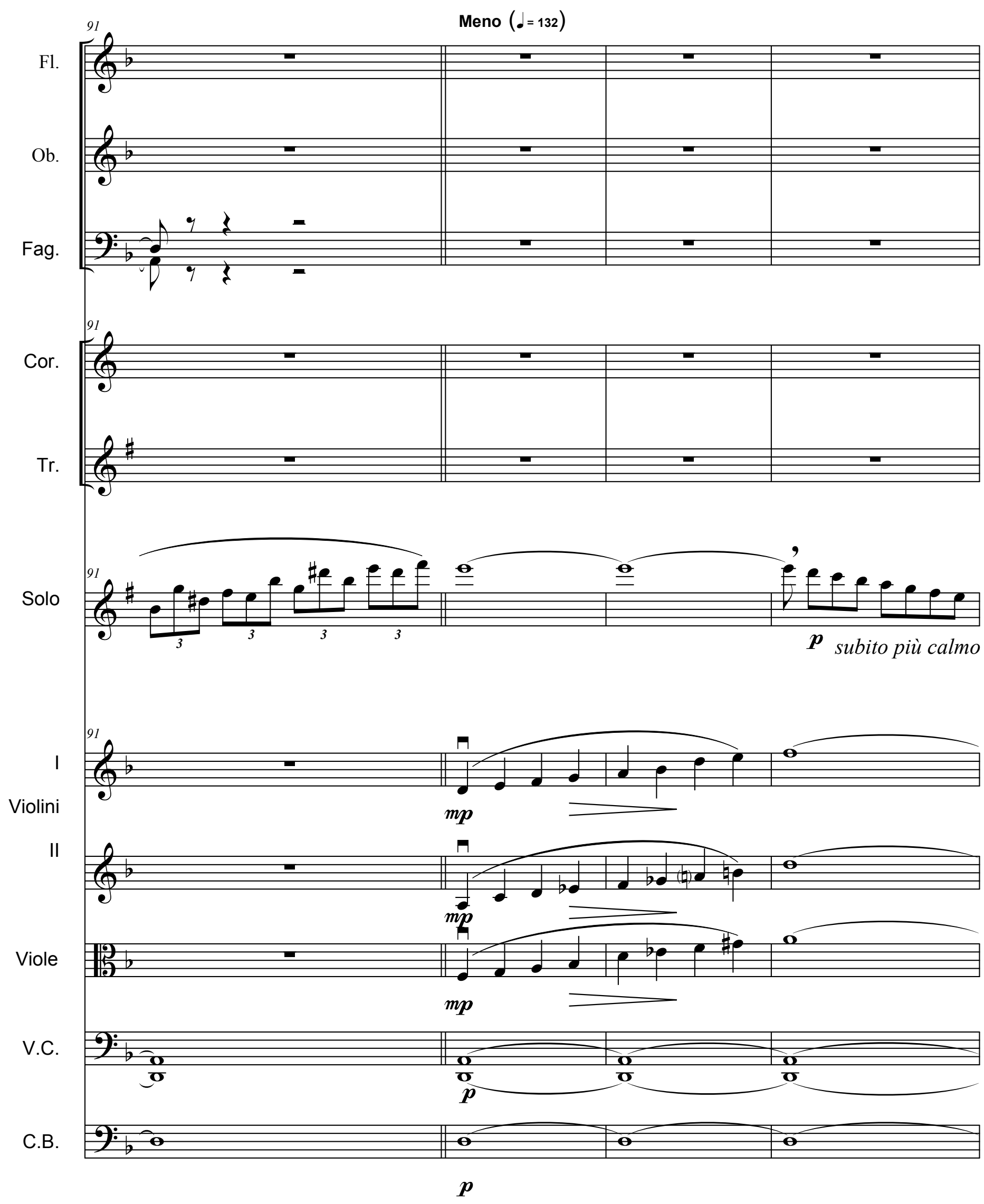




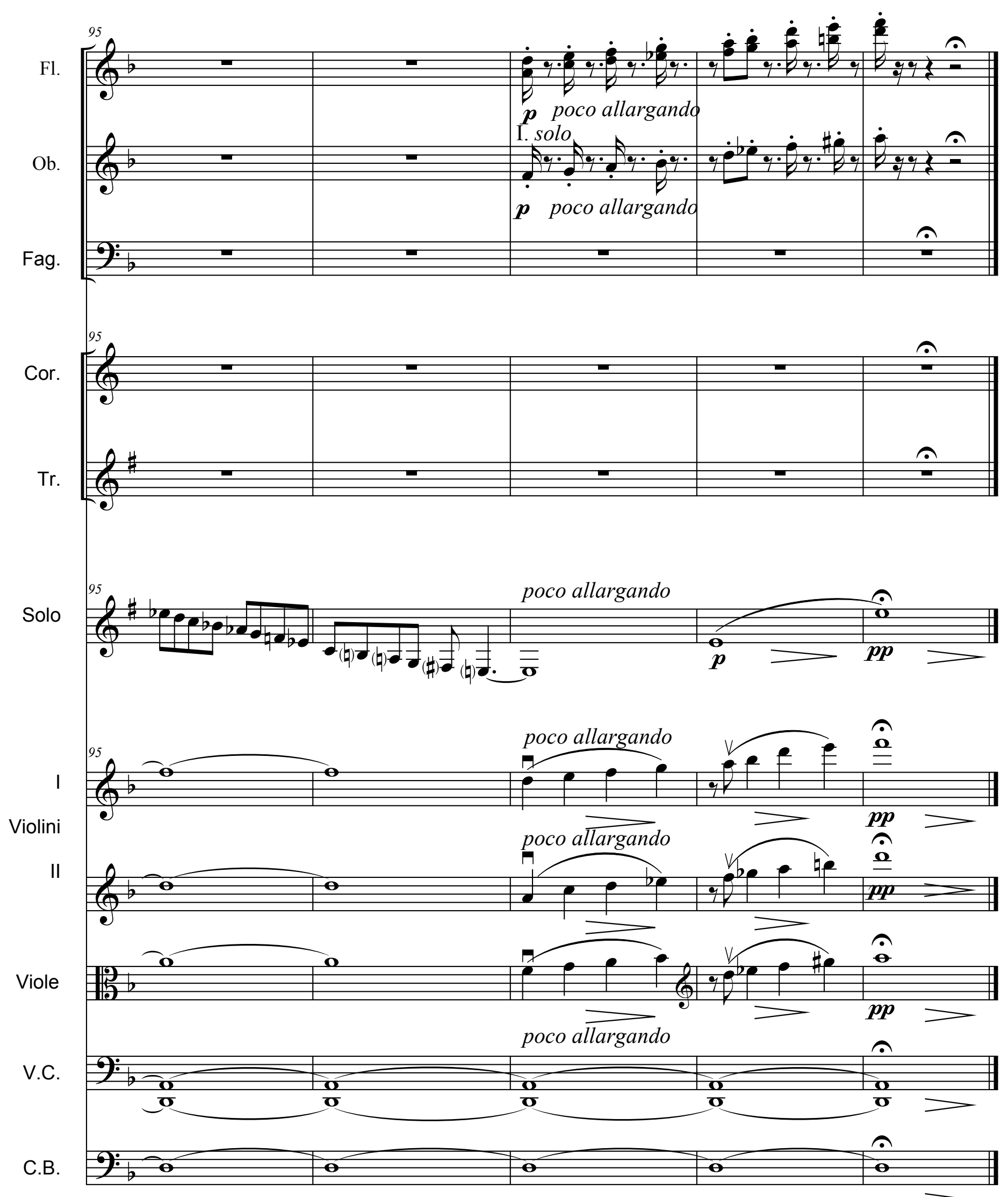




\section{II \\ TOADA}

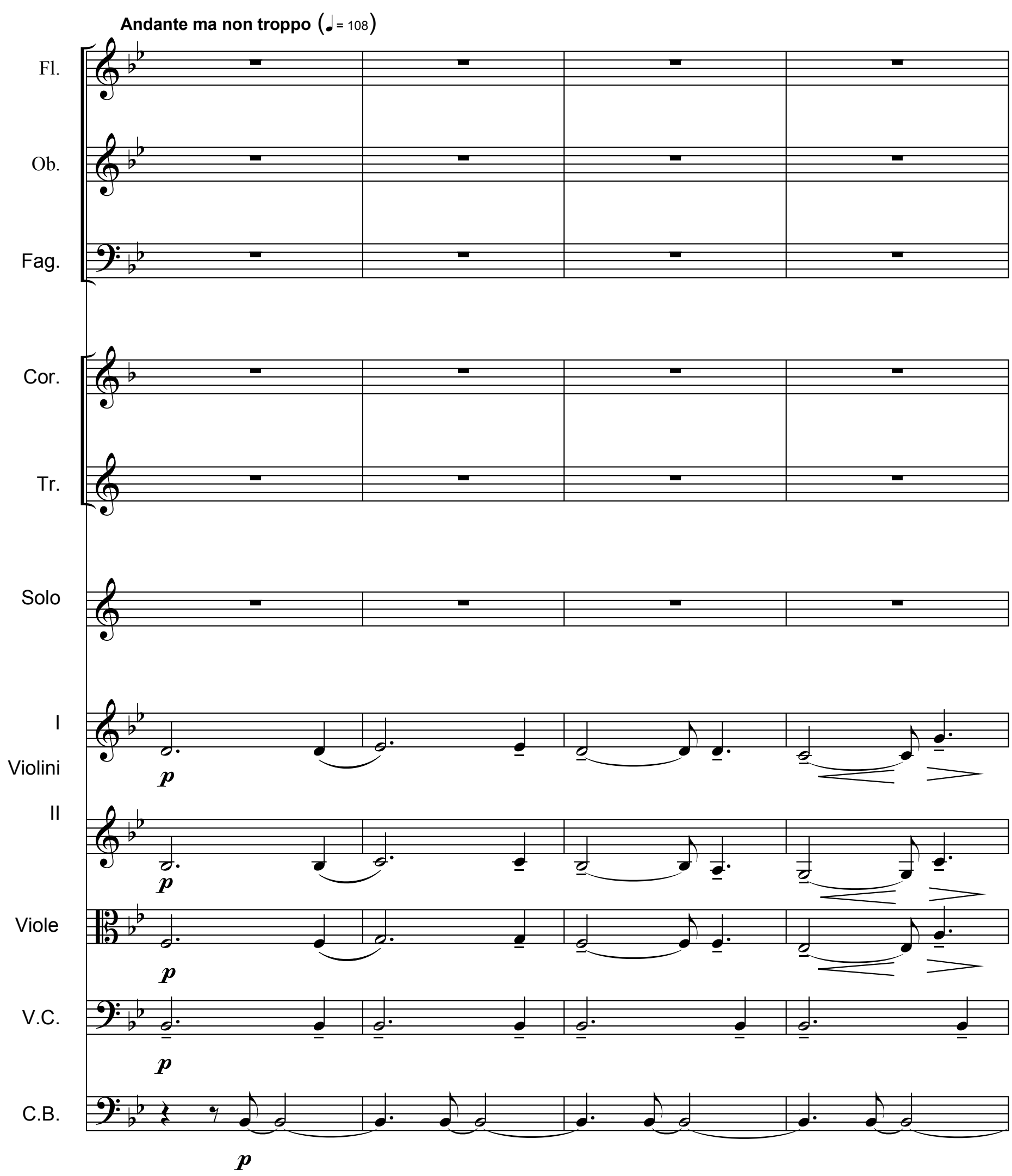



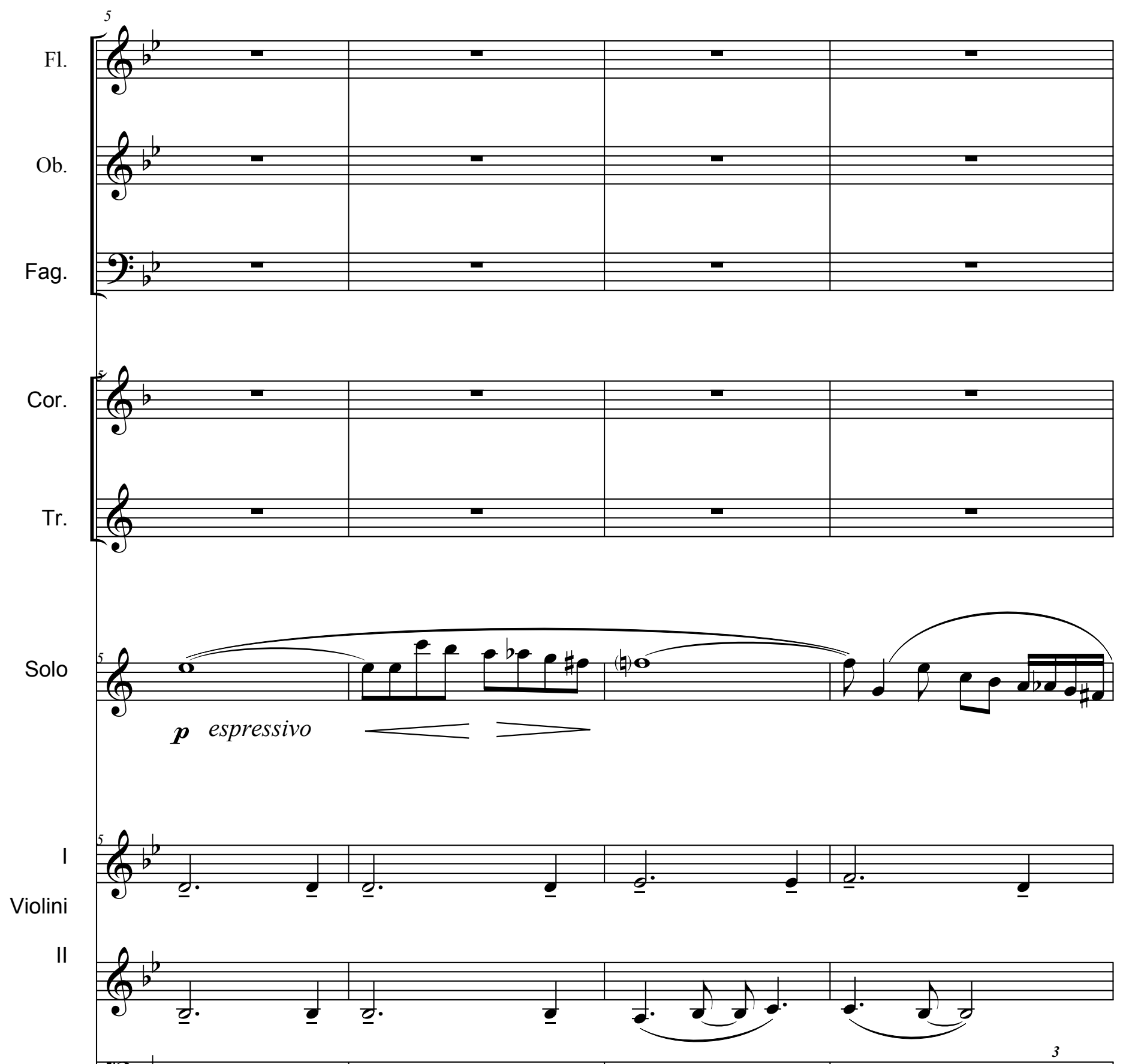

Viole
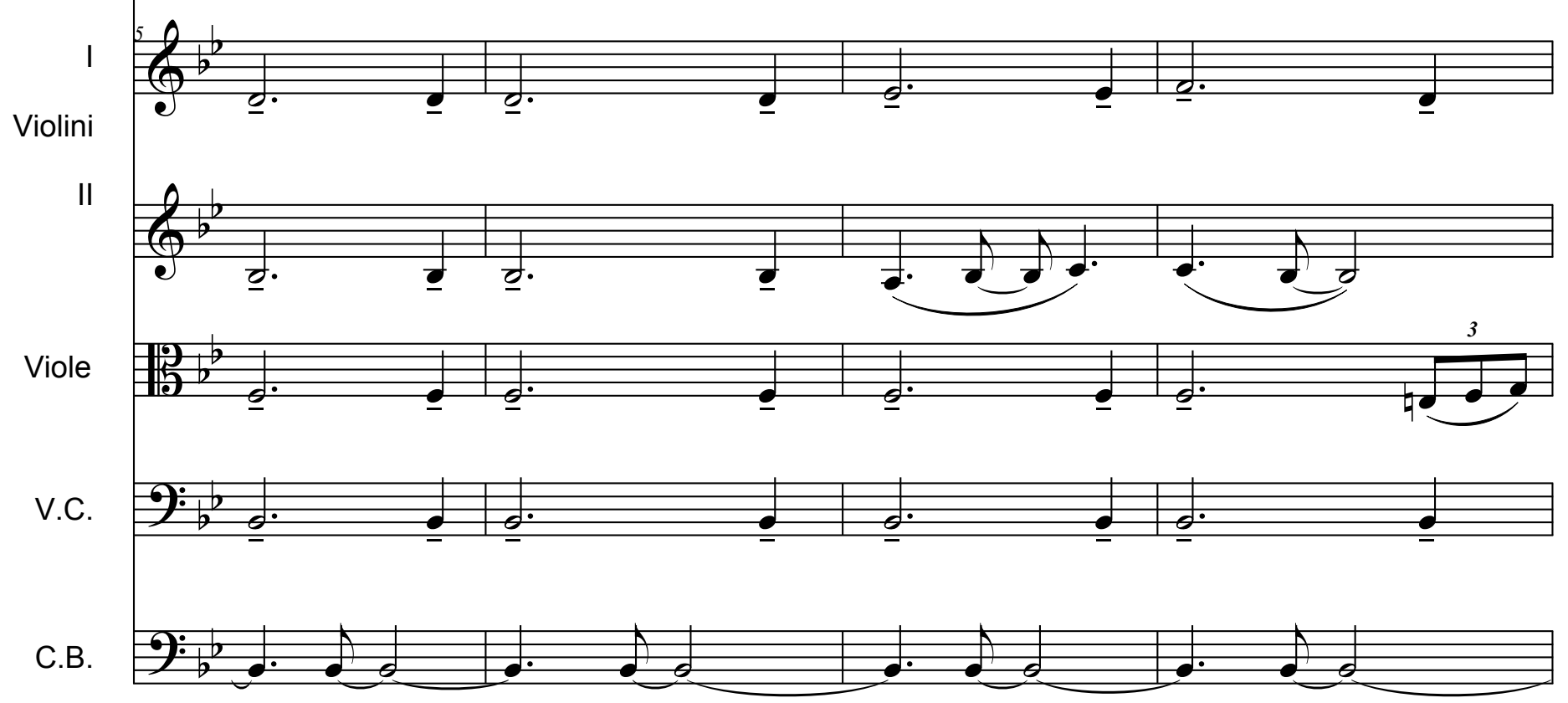

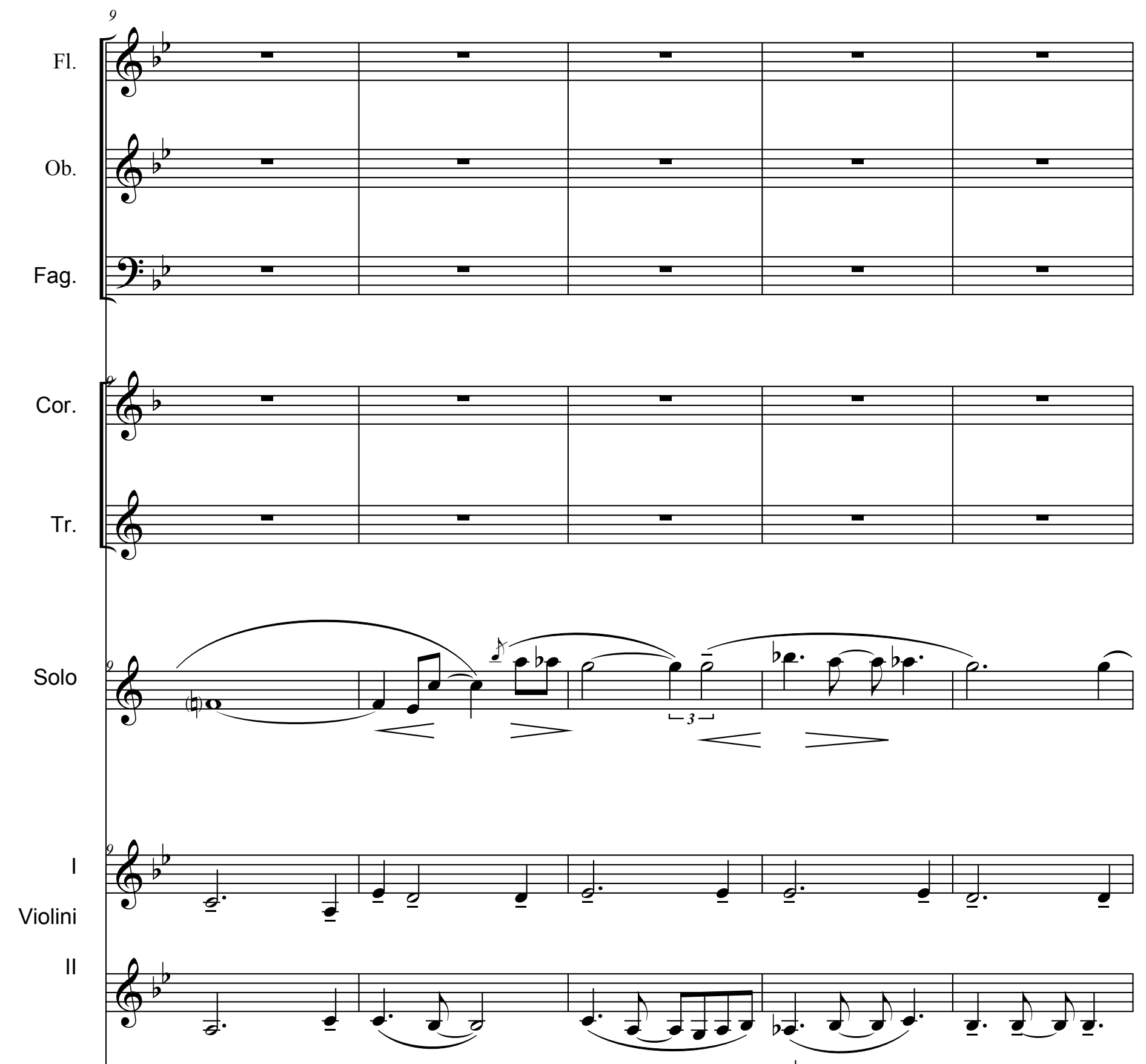

Viole

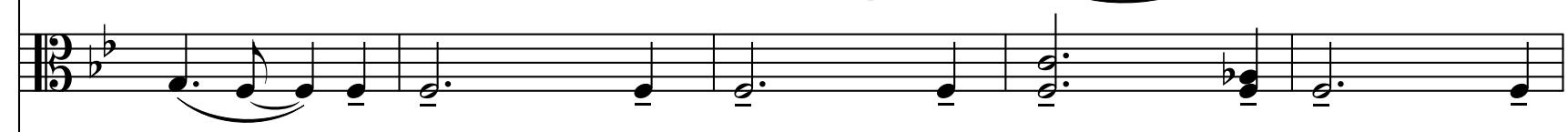

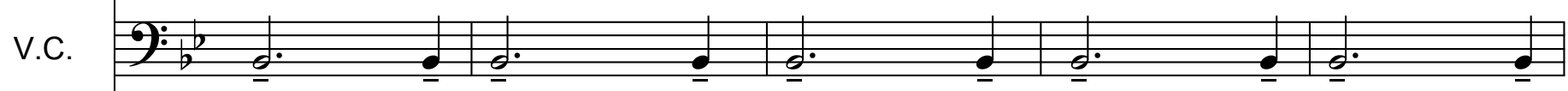

C.B. 

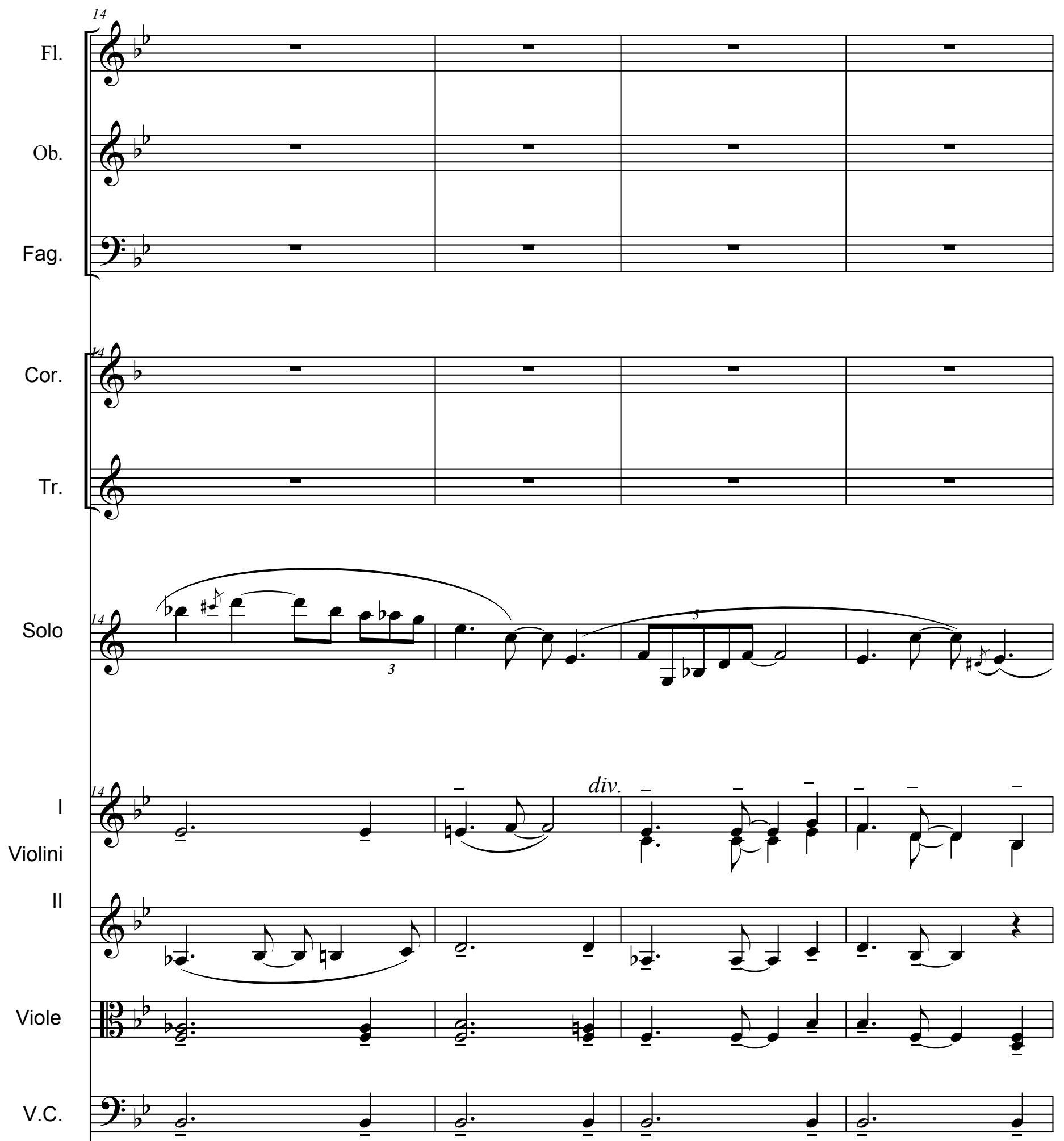

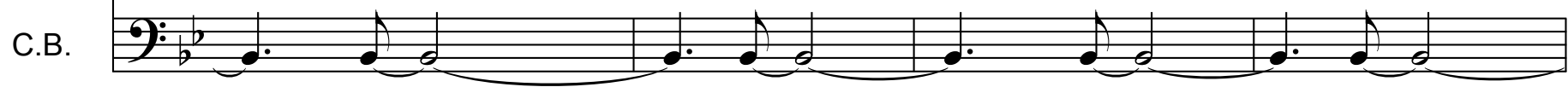


(10)
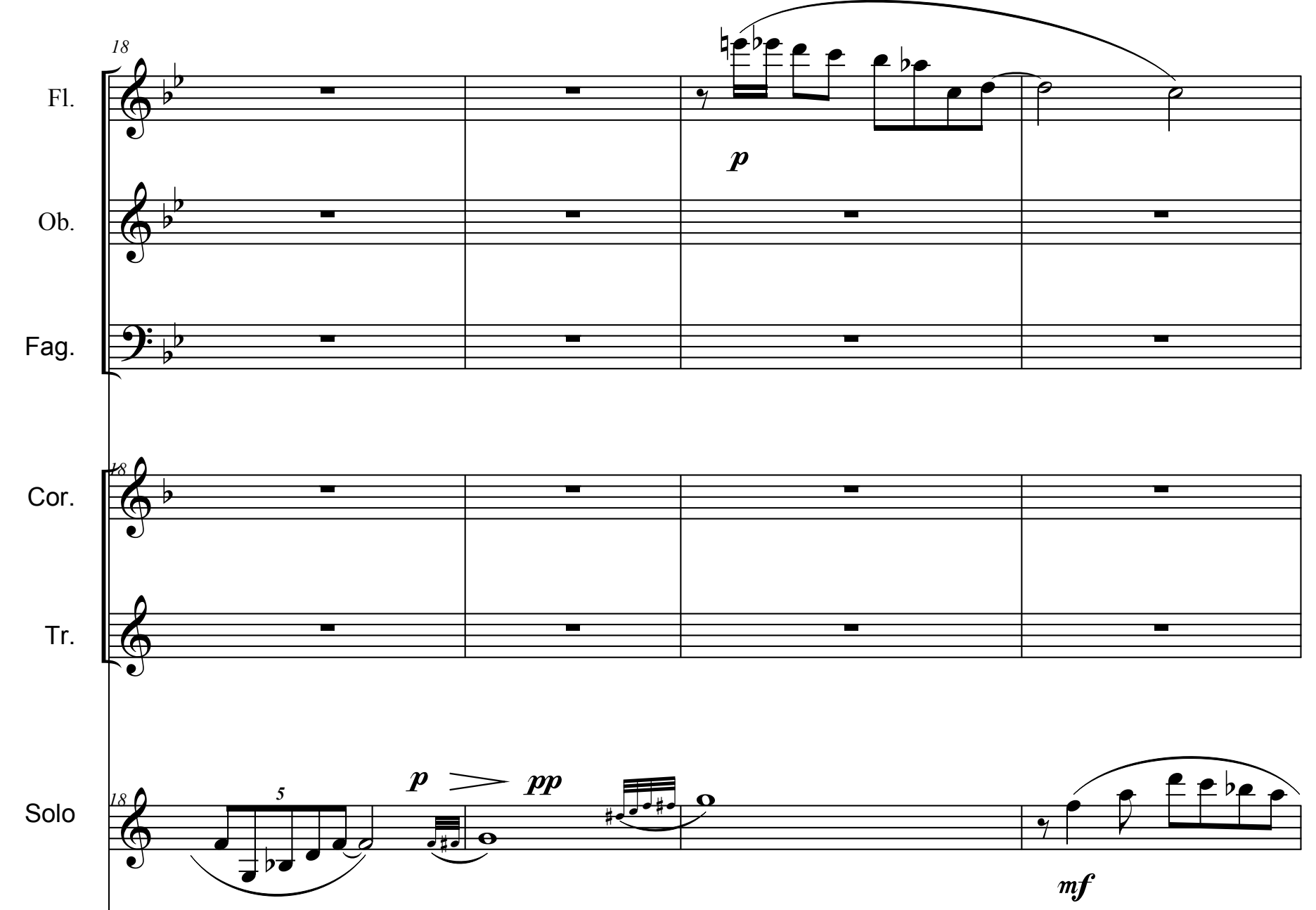

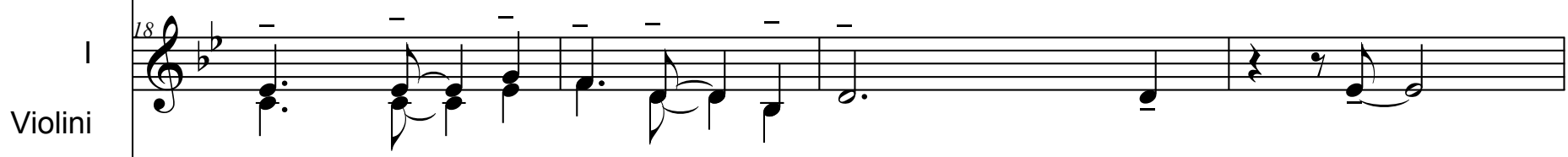

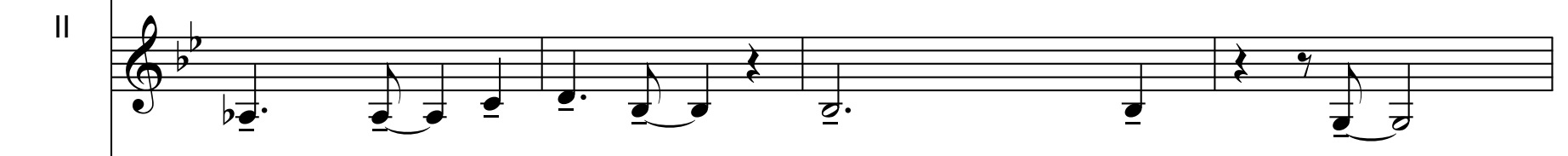

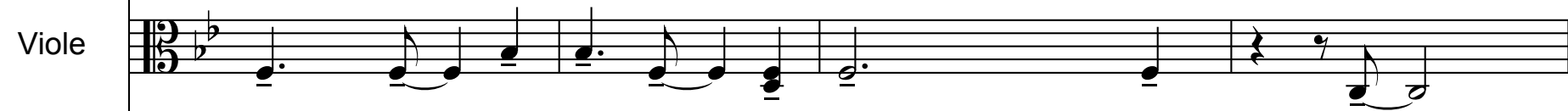

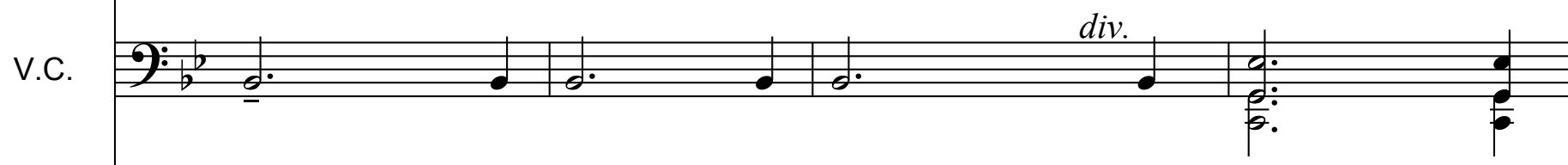

с.в. 

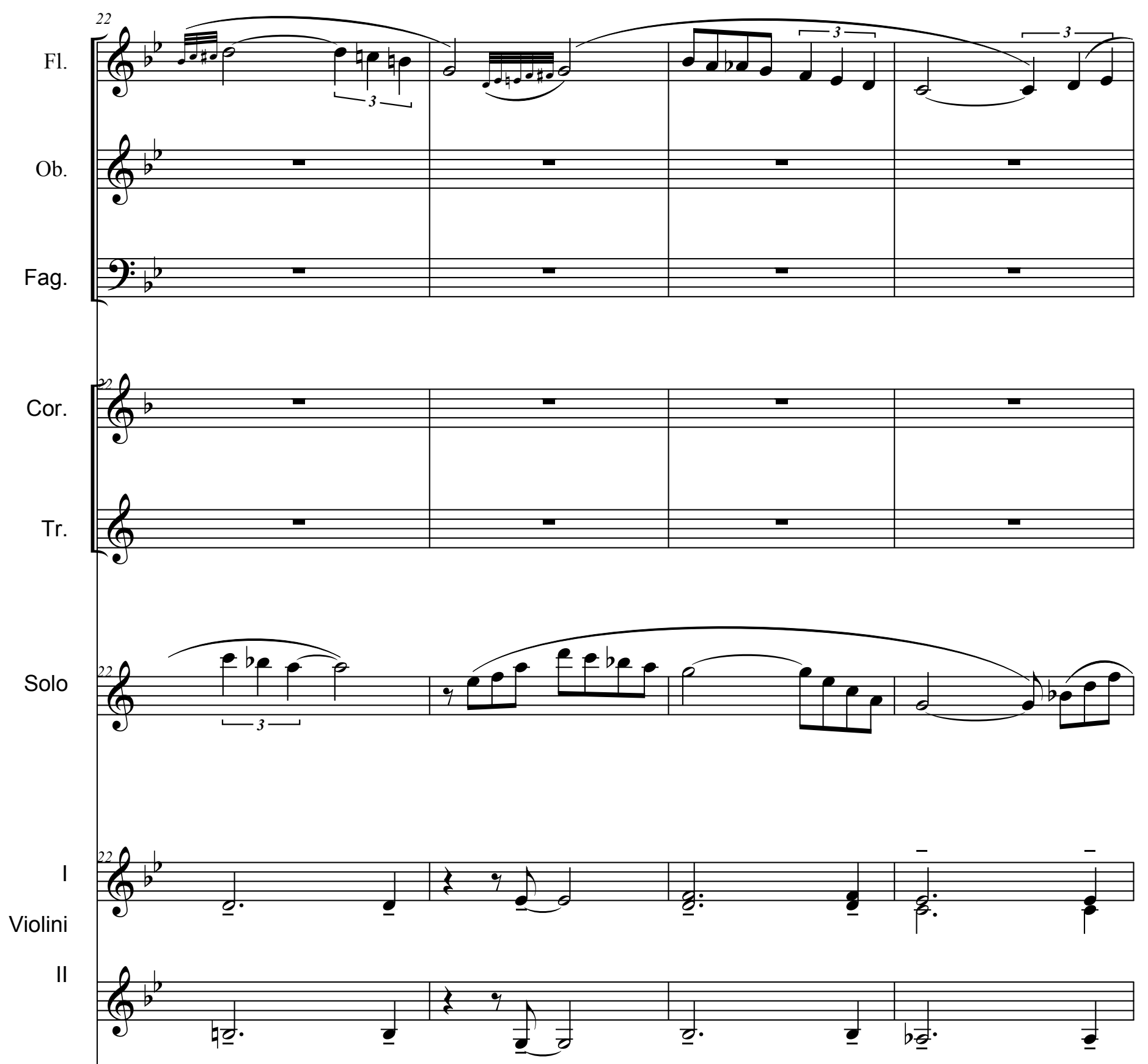

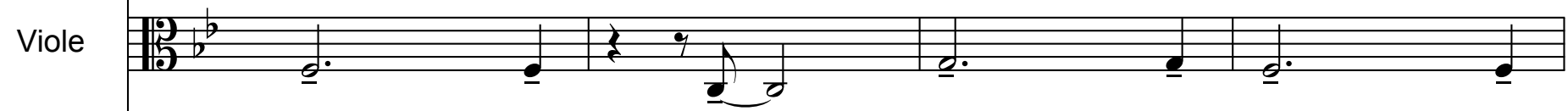

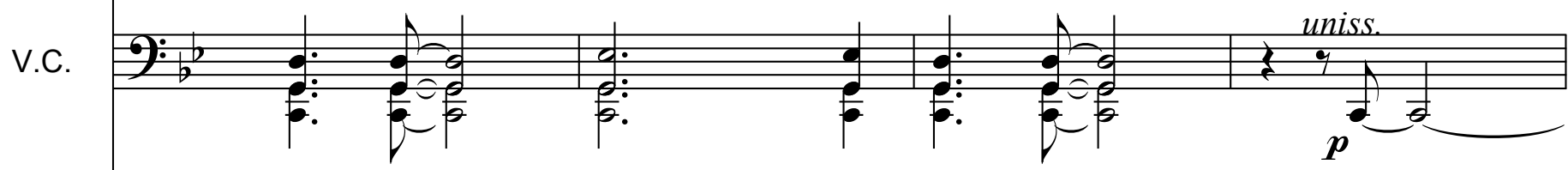

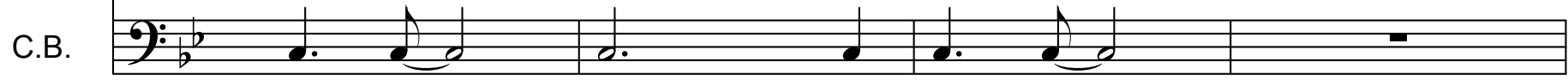



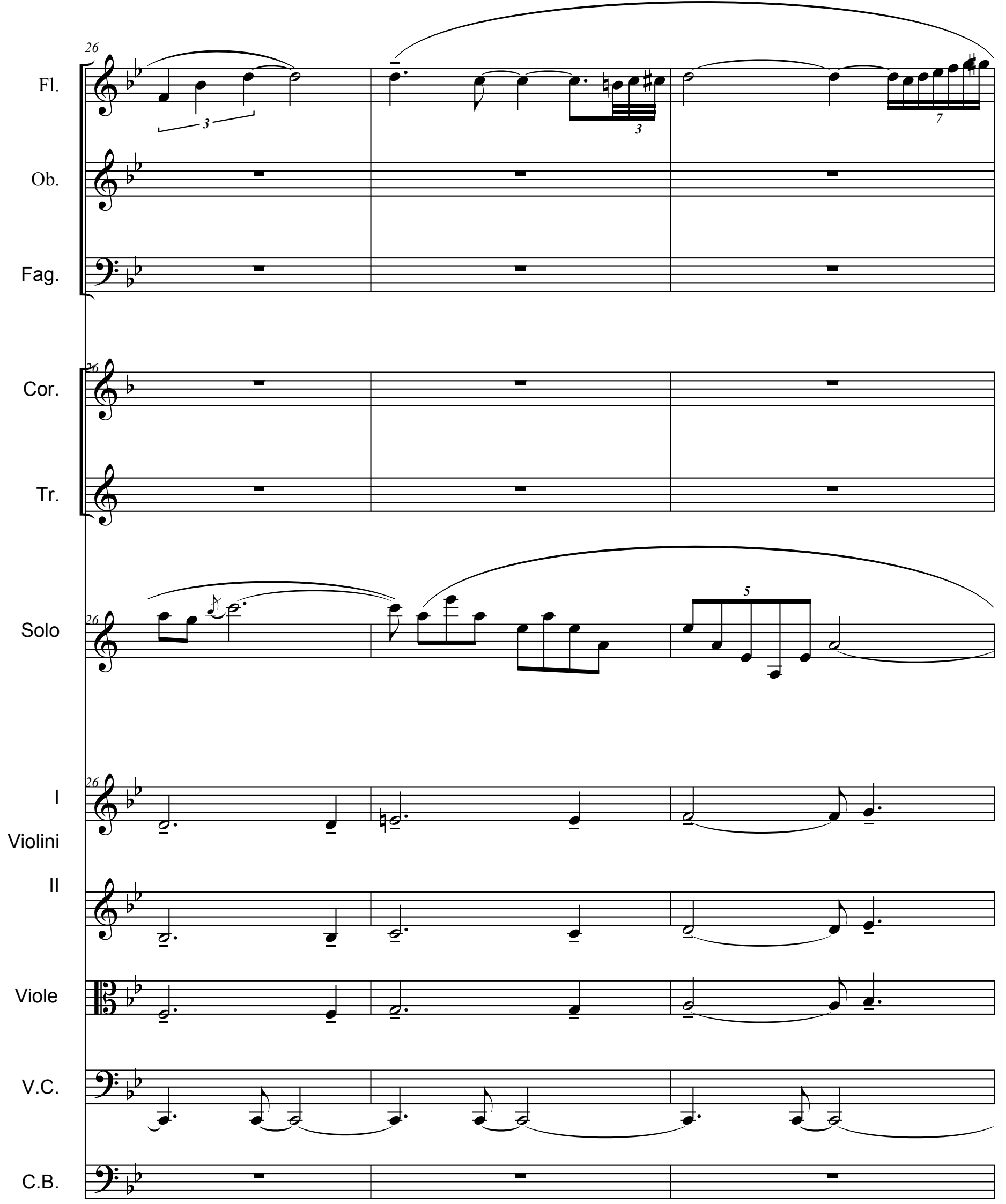
(11)
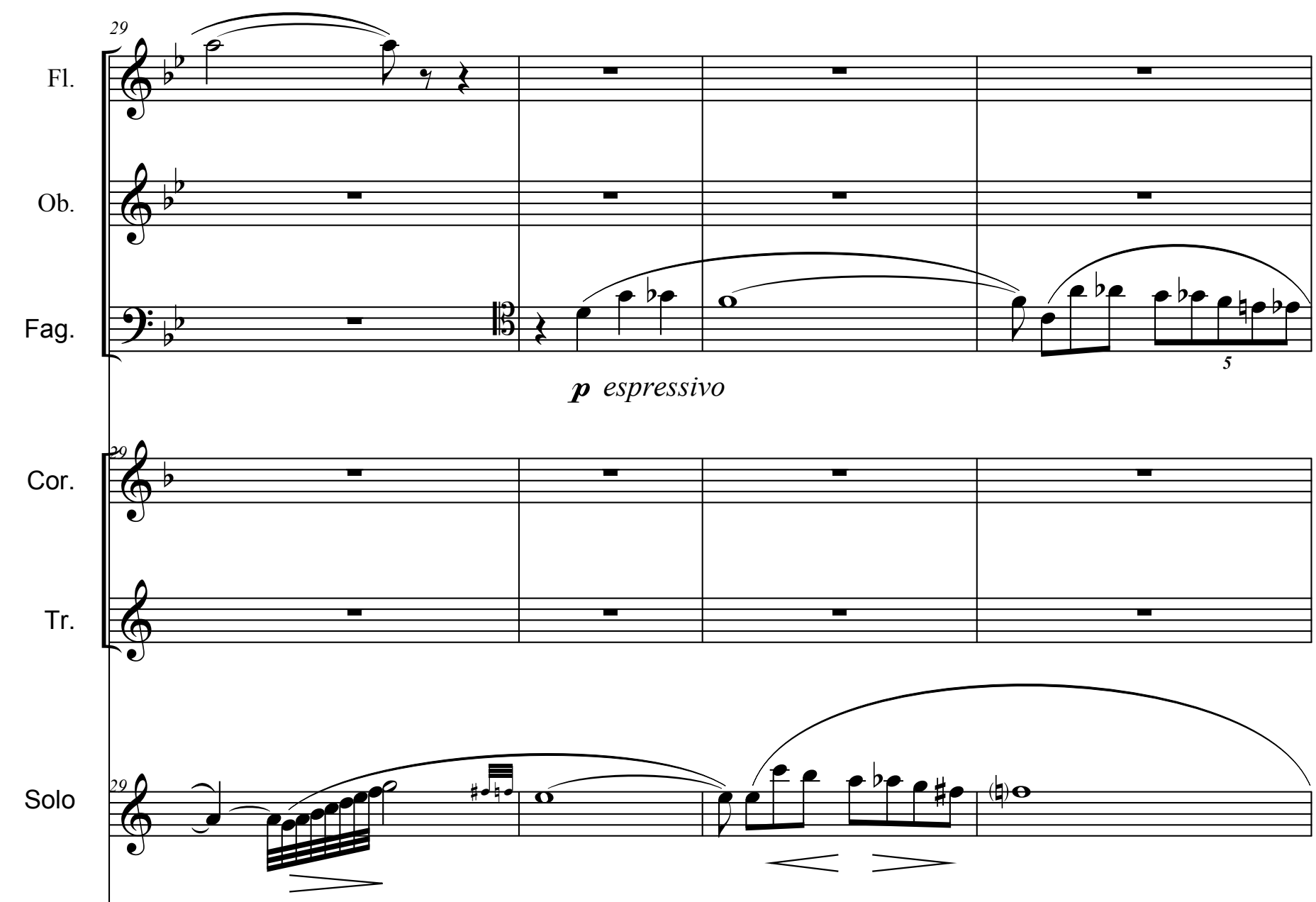

Violini
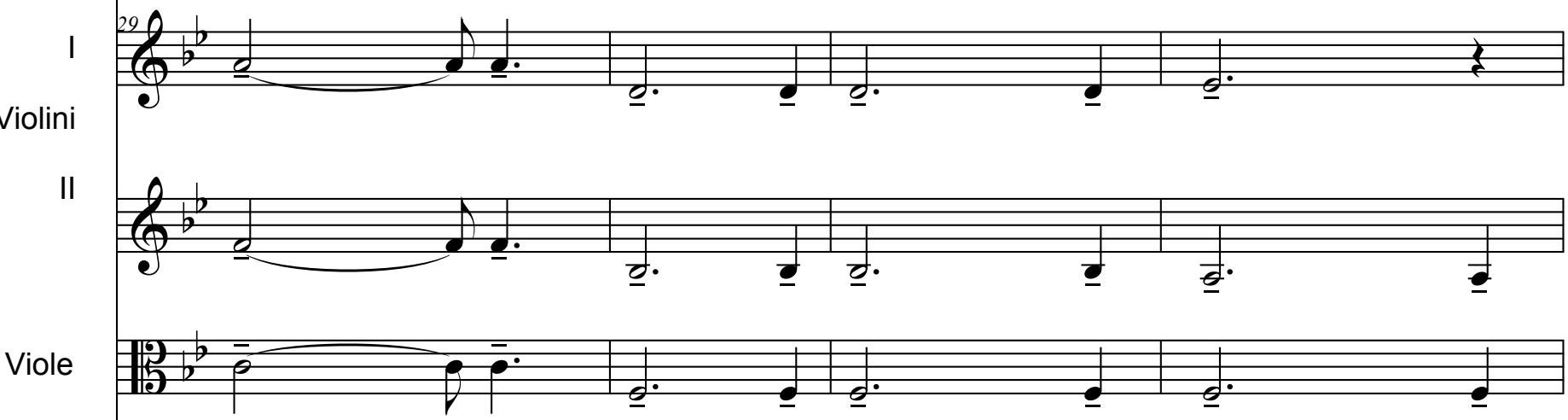

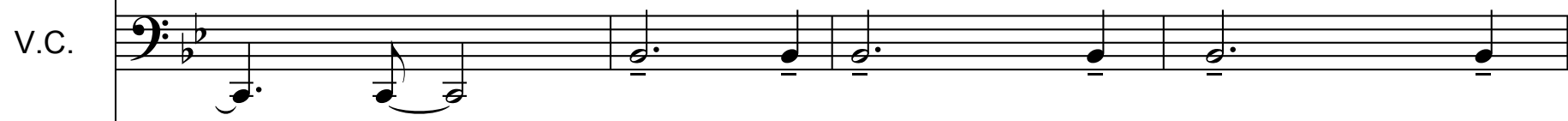

C.B. $\frac{0}{0} \frac{b}{b}$ 

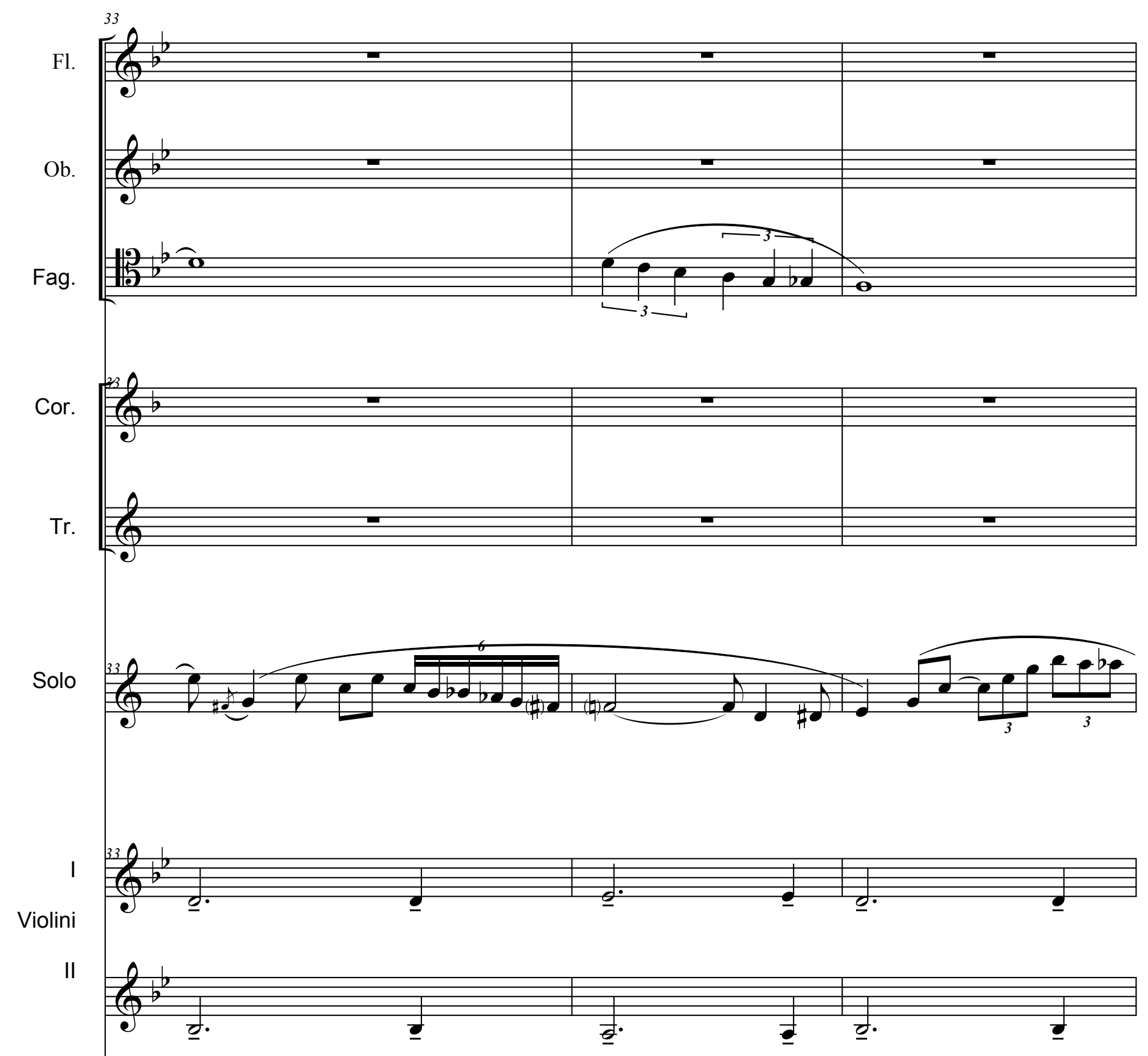

Viole

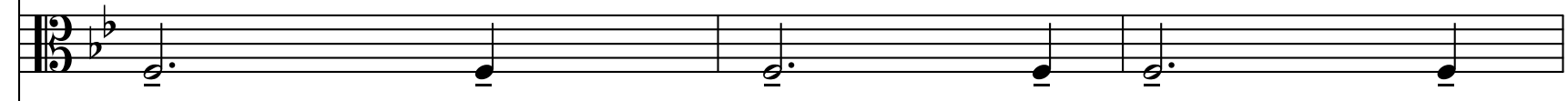

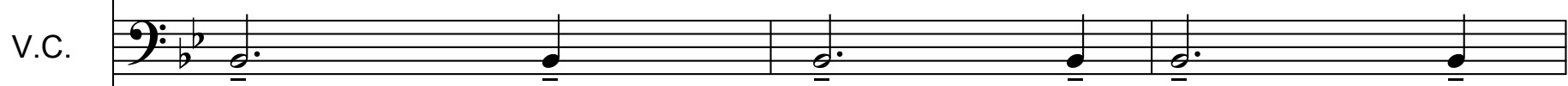

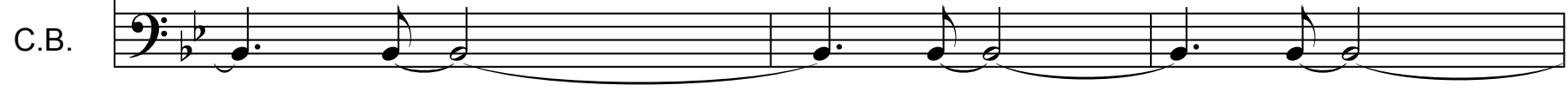



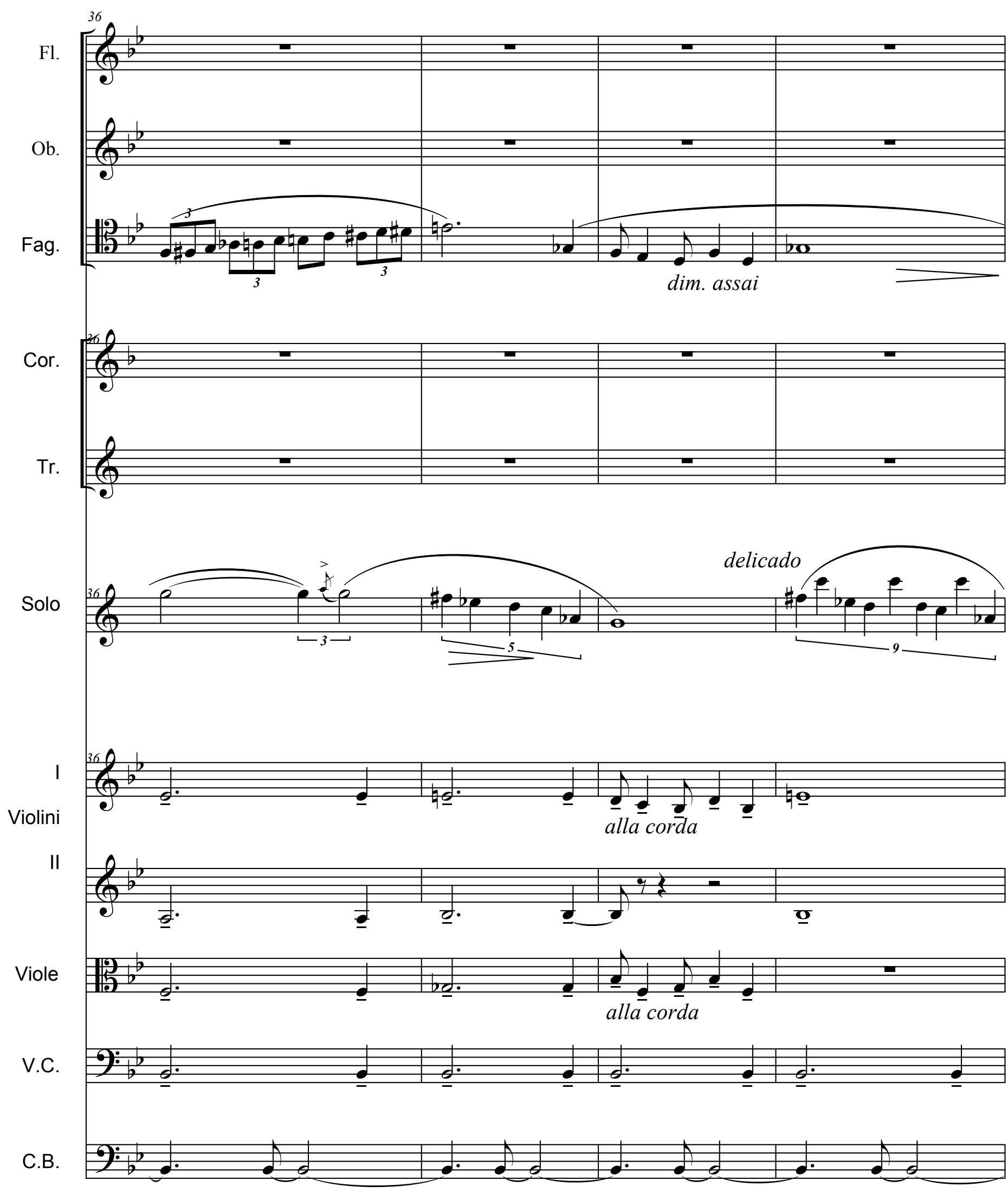

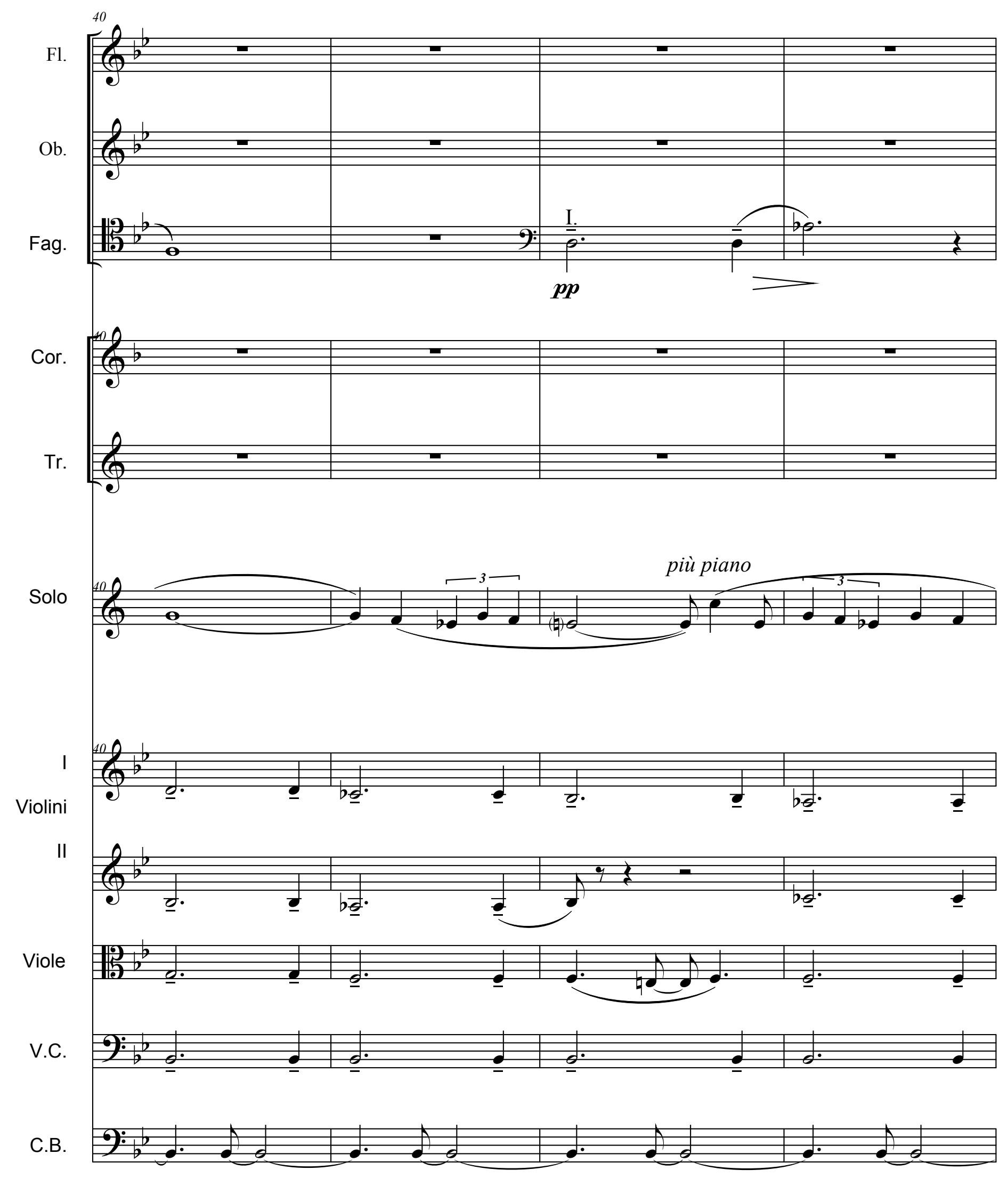
(13)
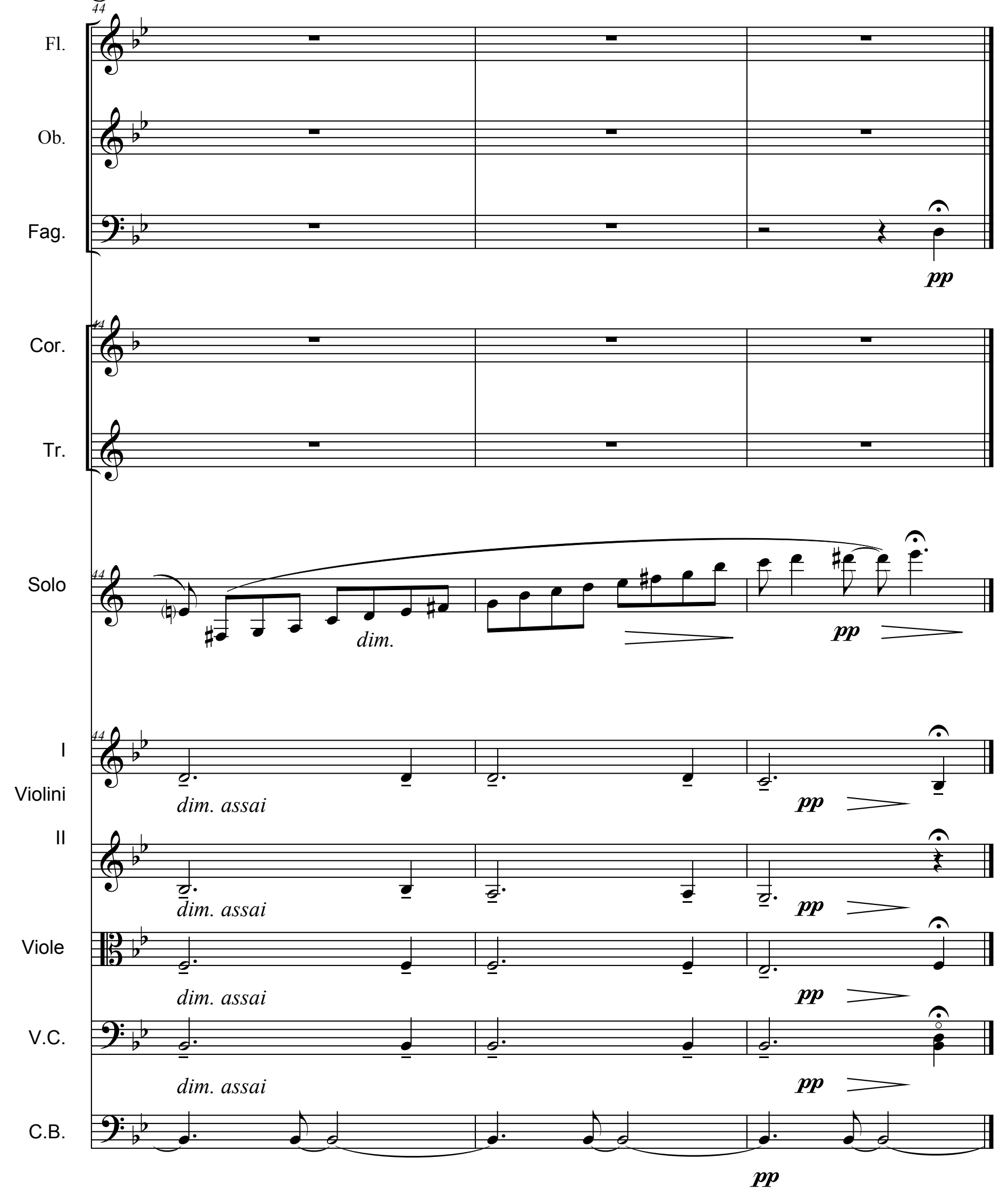
III

FINAL

Allegro $(d=138)$

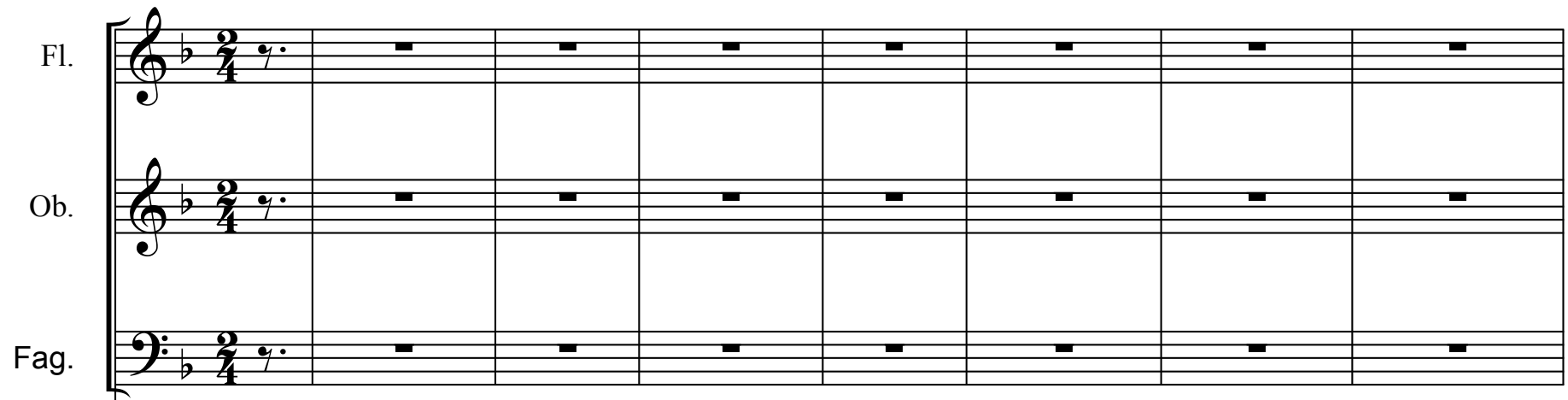

Cor.

$\operatorname{Tr}$.

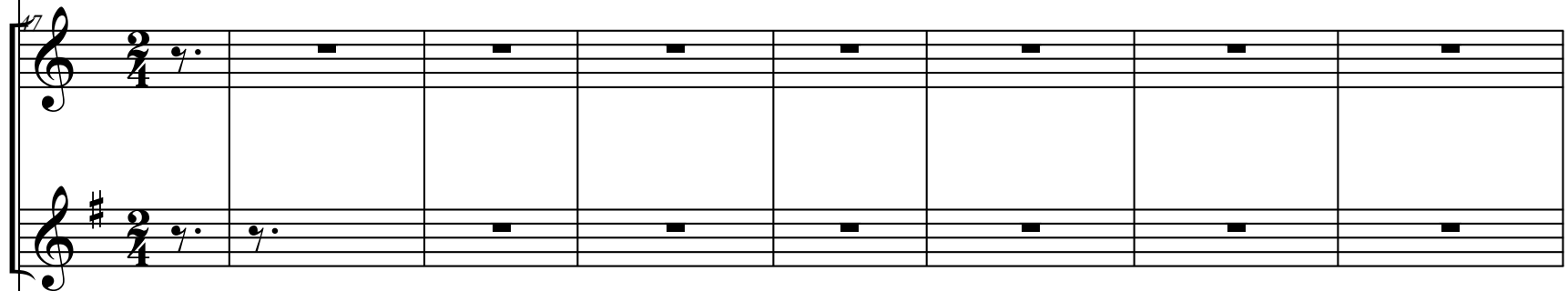

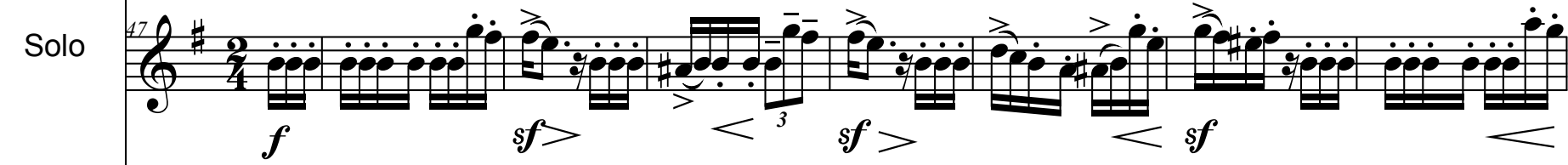

Violini

$\left(\mathrm{C}^{2}\right.$

II

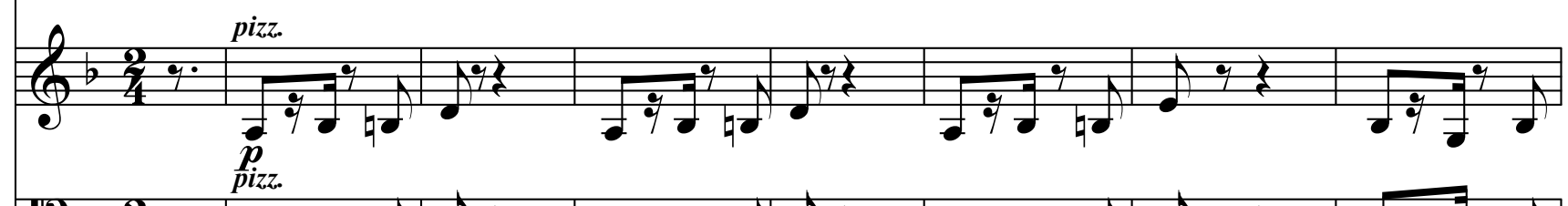

Viole

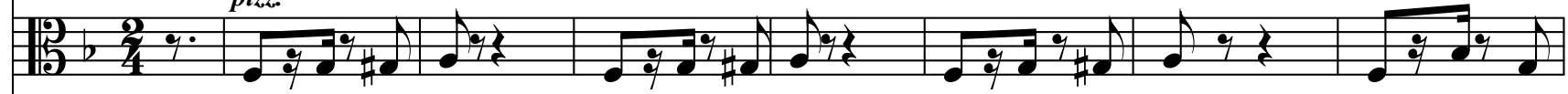

C.B.

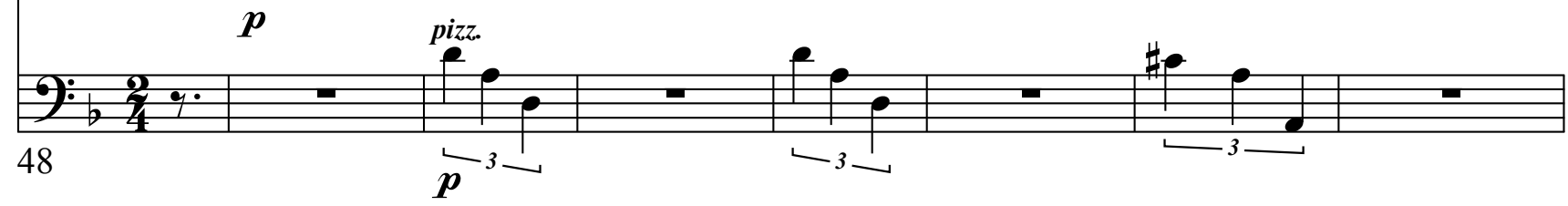



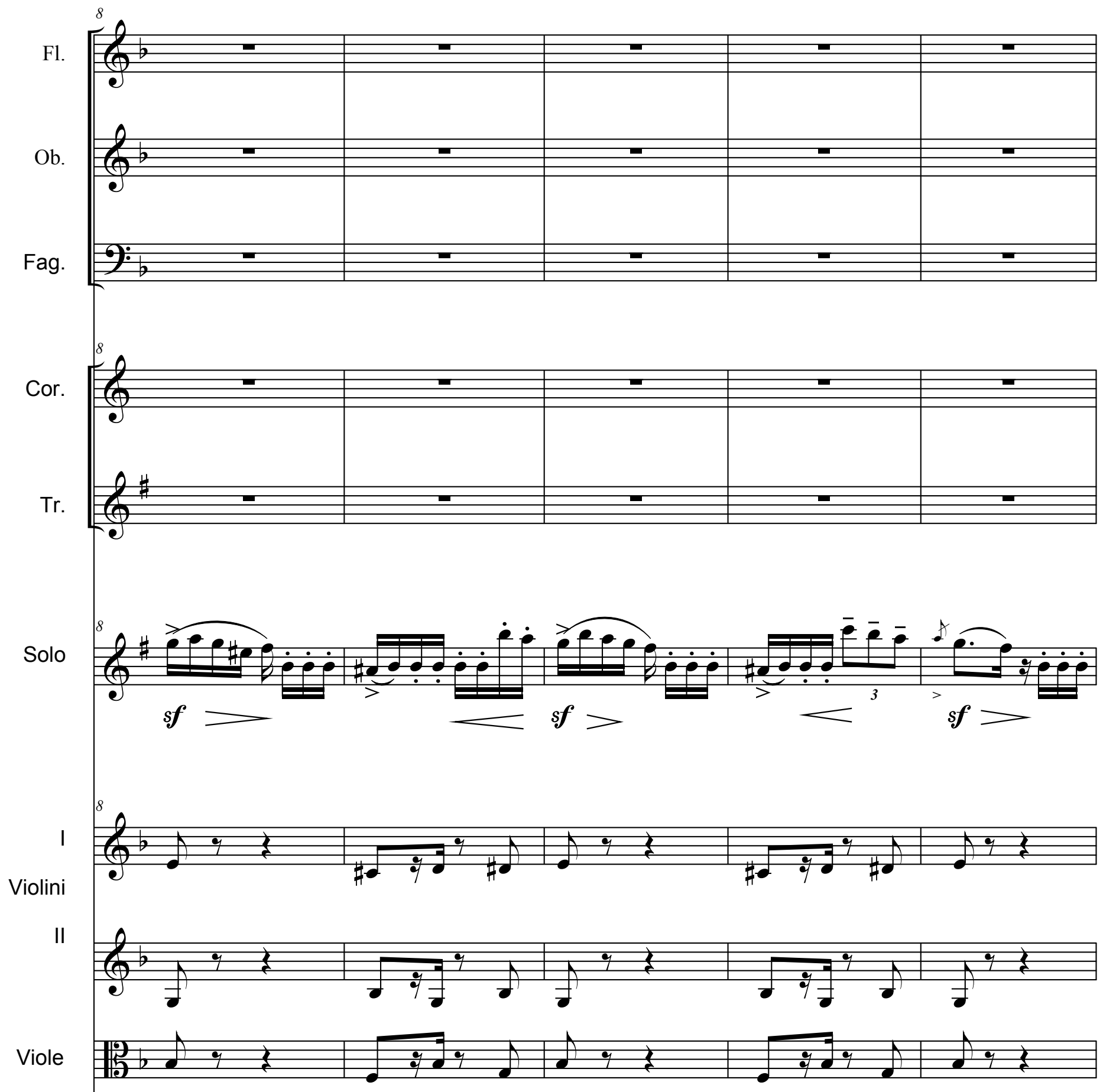

v.c.

C.B.

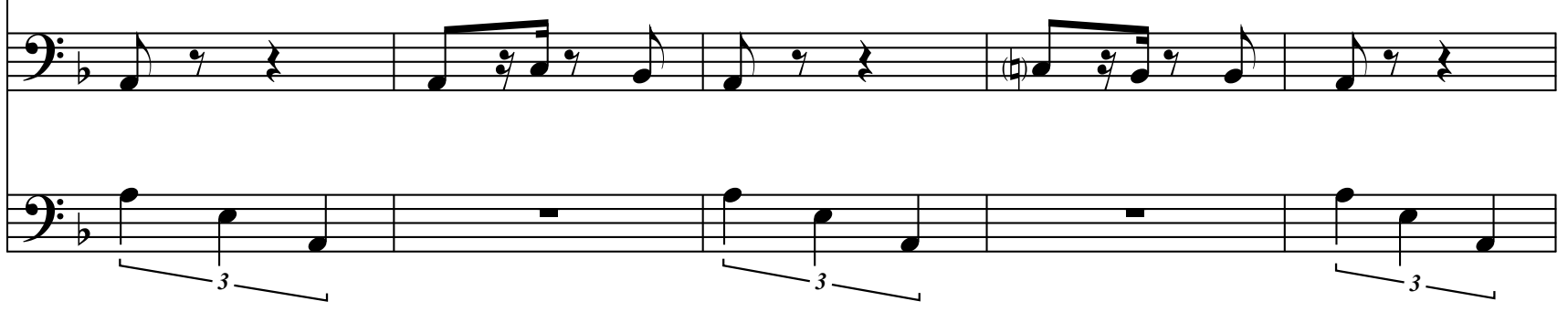

49 
(14)
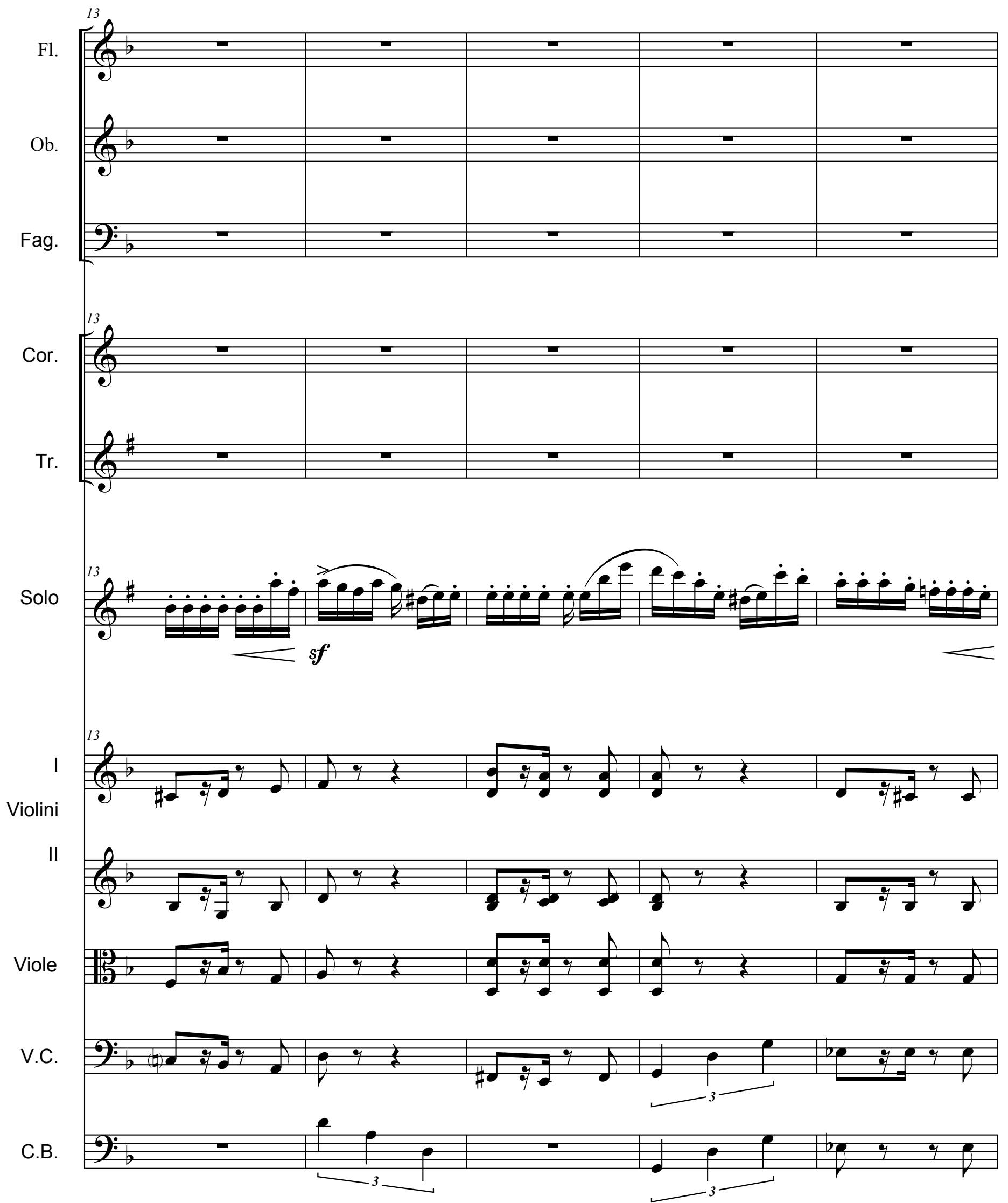

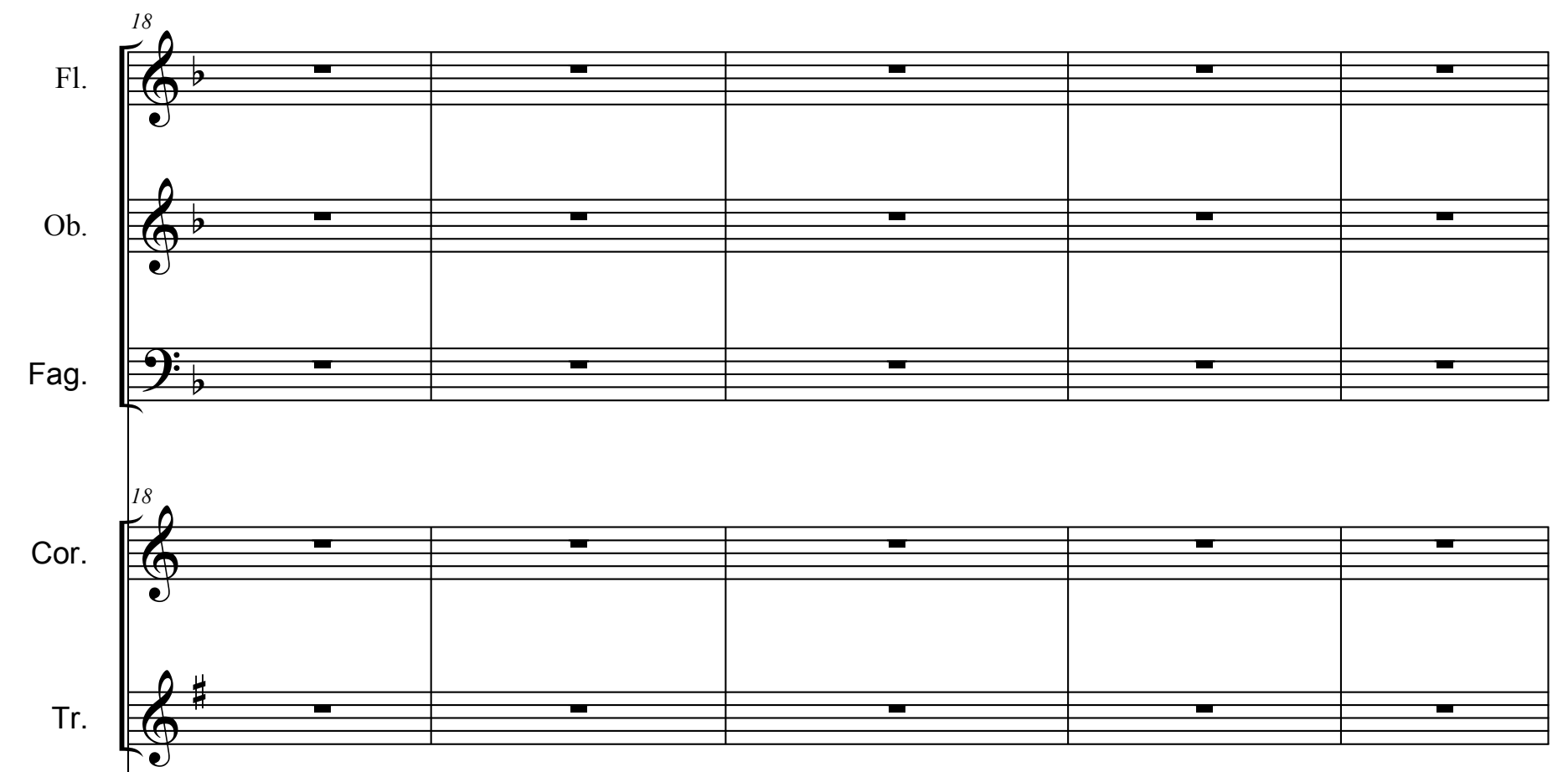

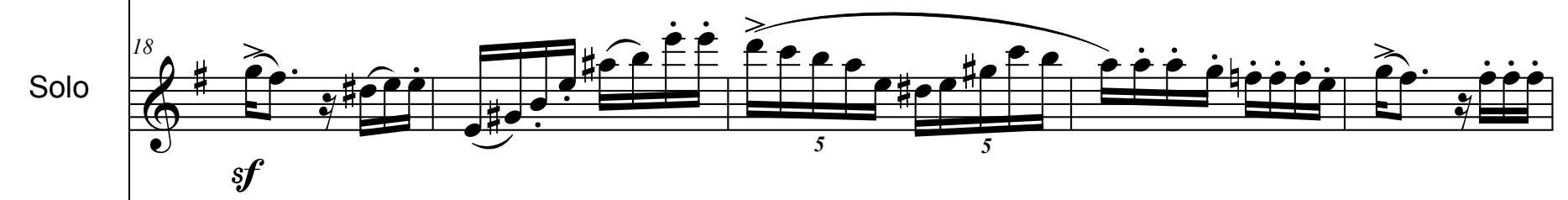

Violini

$\int^{18} \int^{\frac{1}{2}+2}$

II

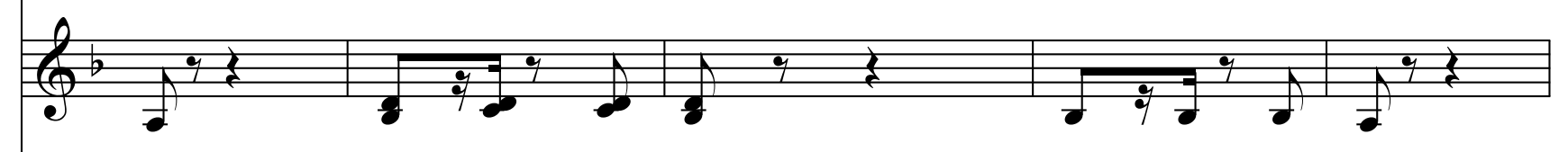

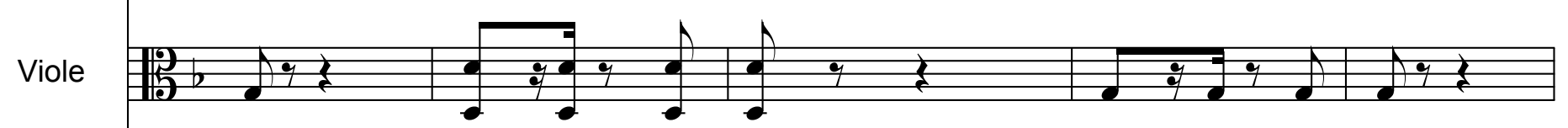

V.C. $)^{\circ}$

C.B. $)^{\circ}$ 

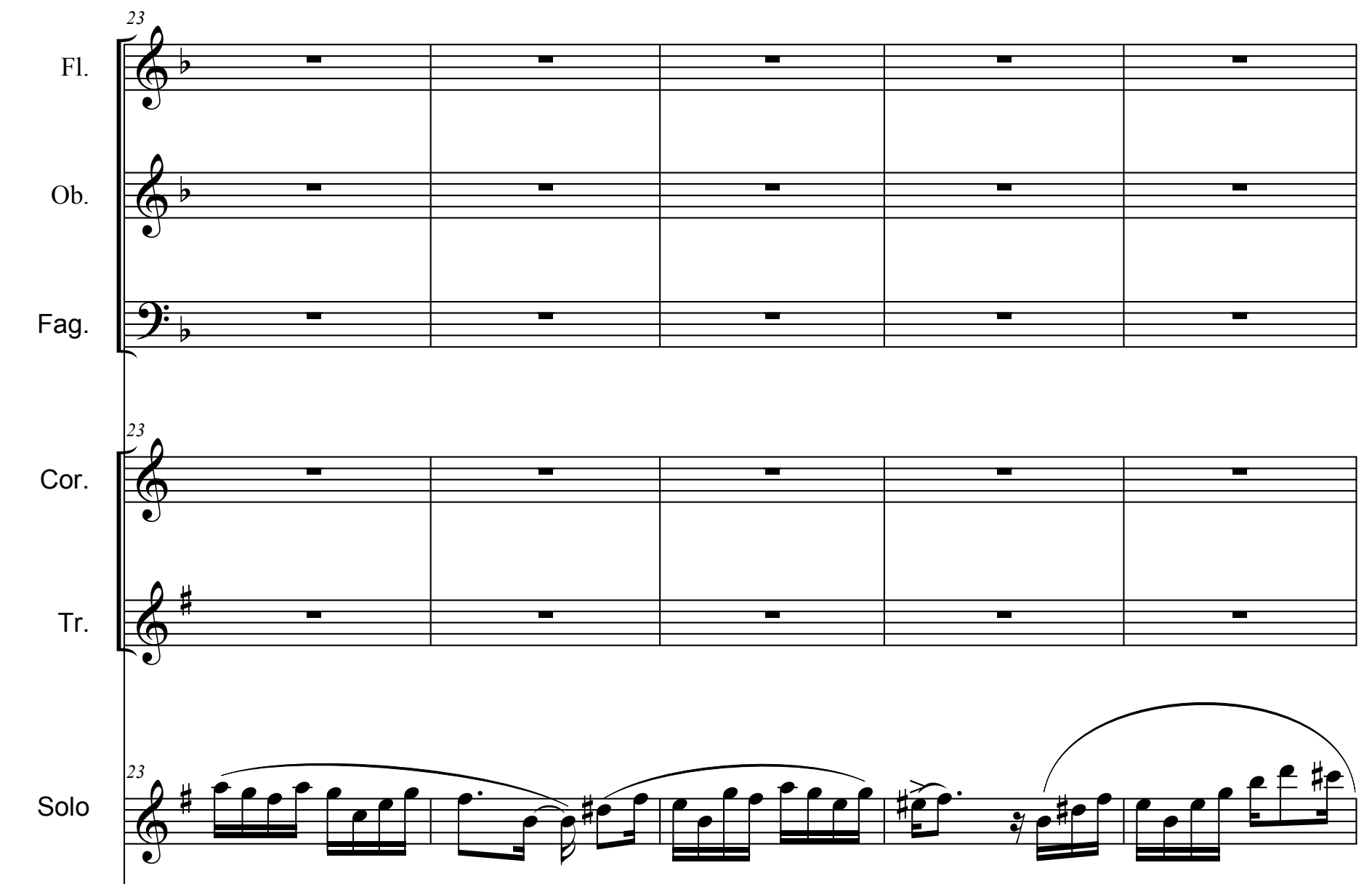

Violini

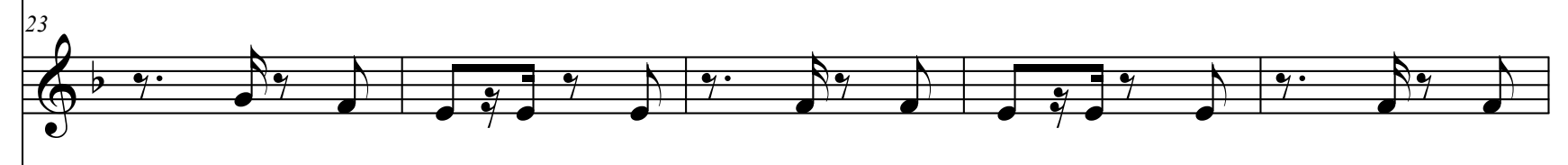

II

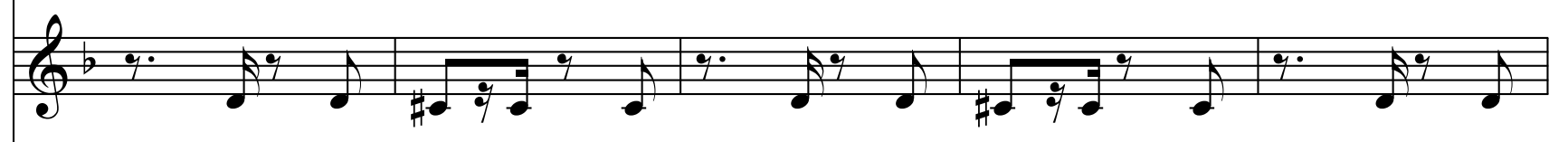

viole $1250.5 \%$

v.c. $25 \% 50.5$

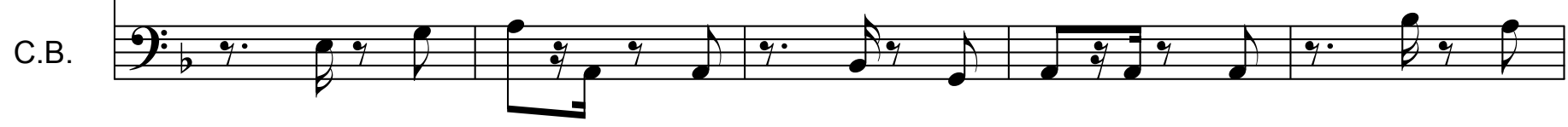




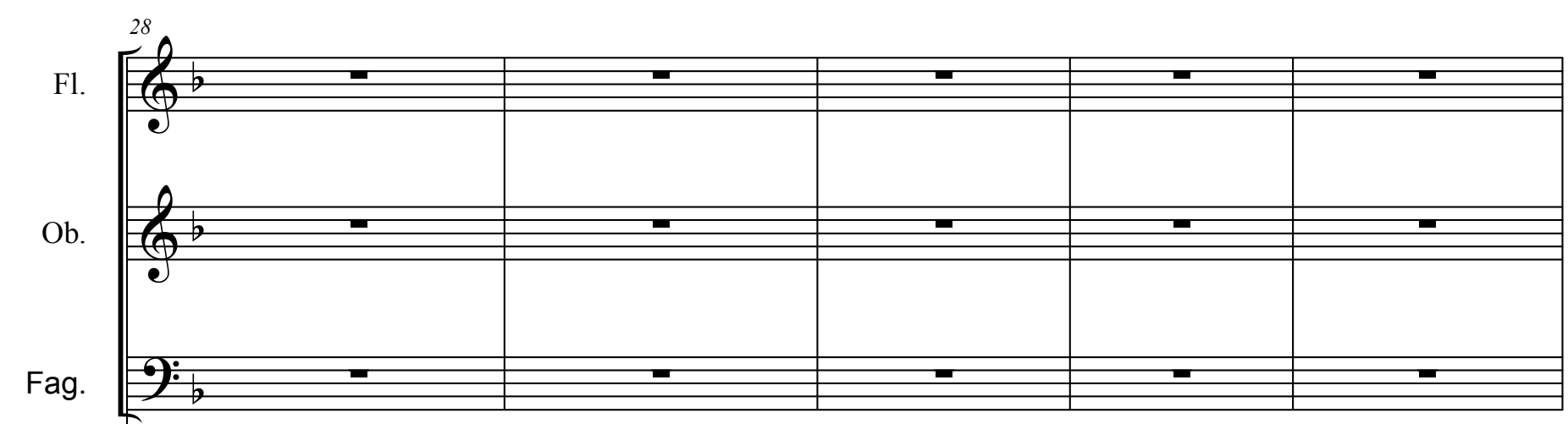

Cor

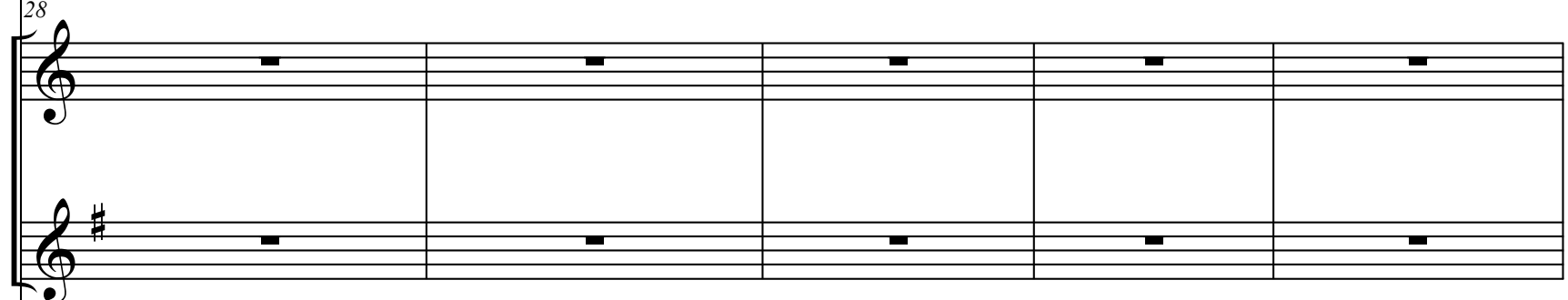

Tr.

Solo
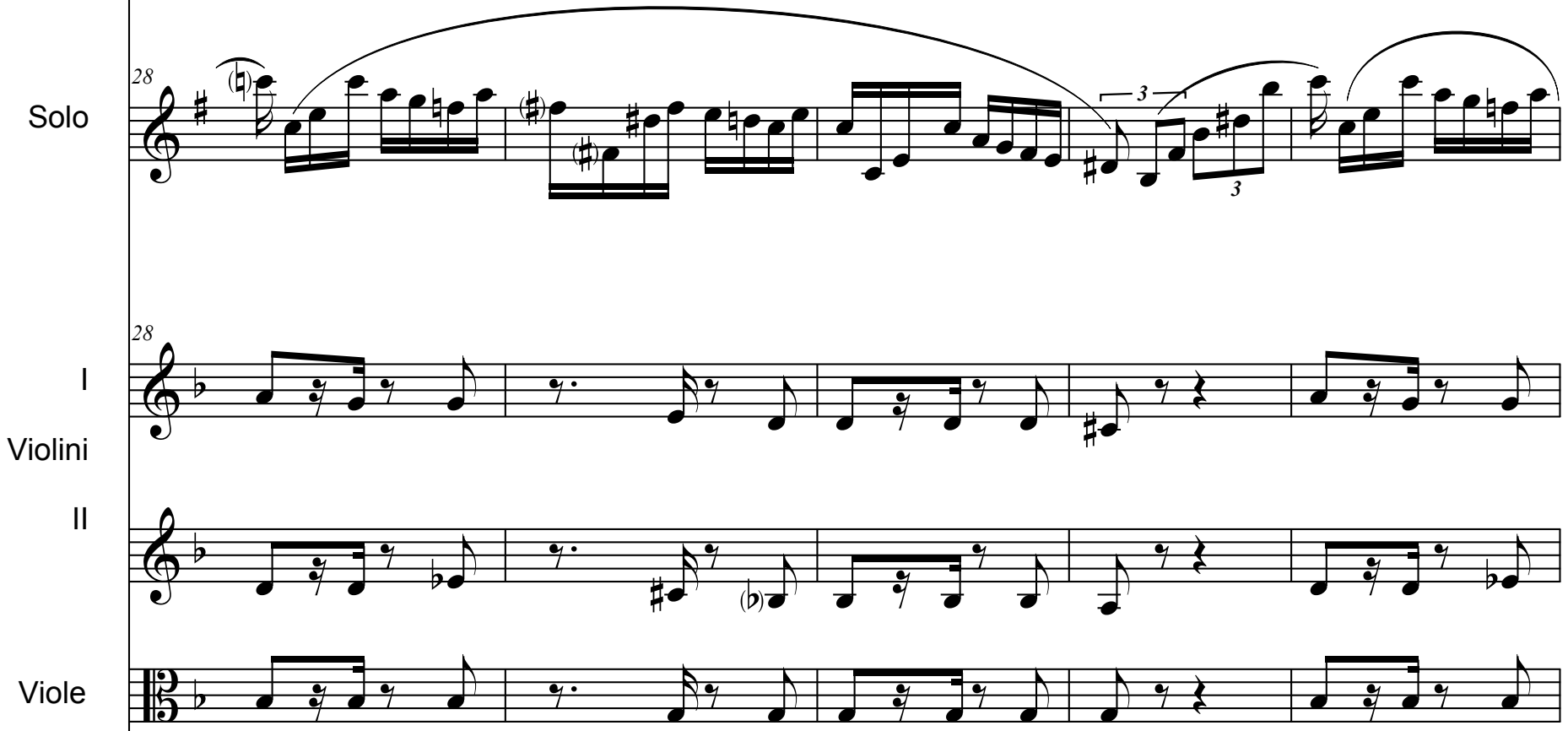

v.c.

C.B.

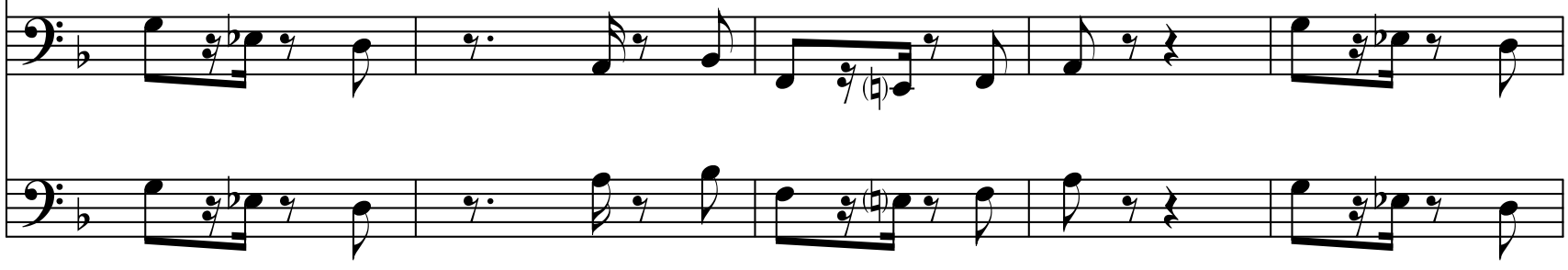

53 

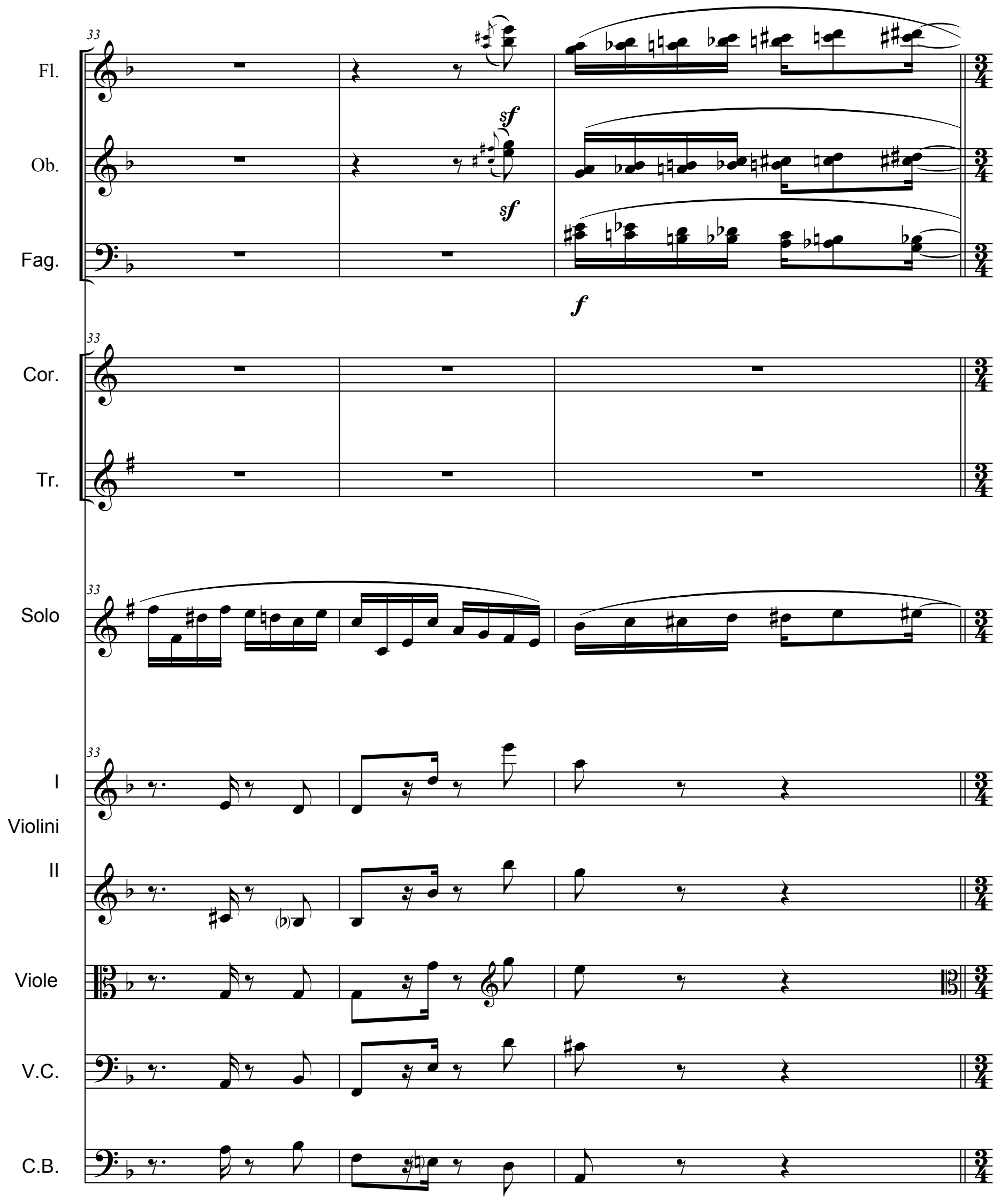
(15)
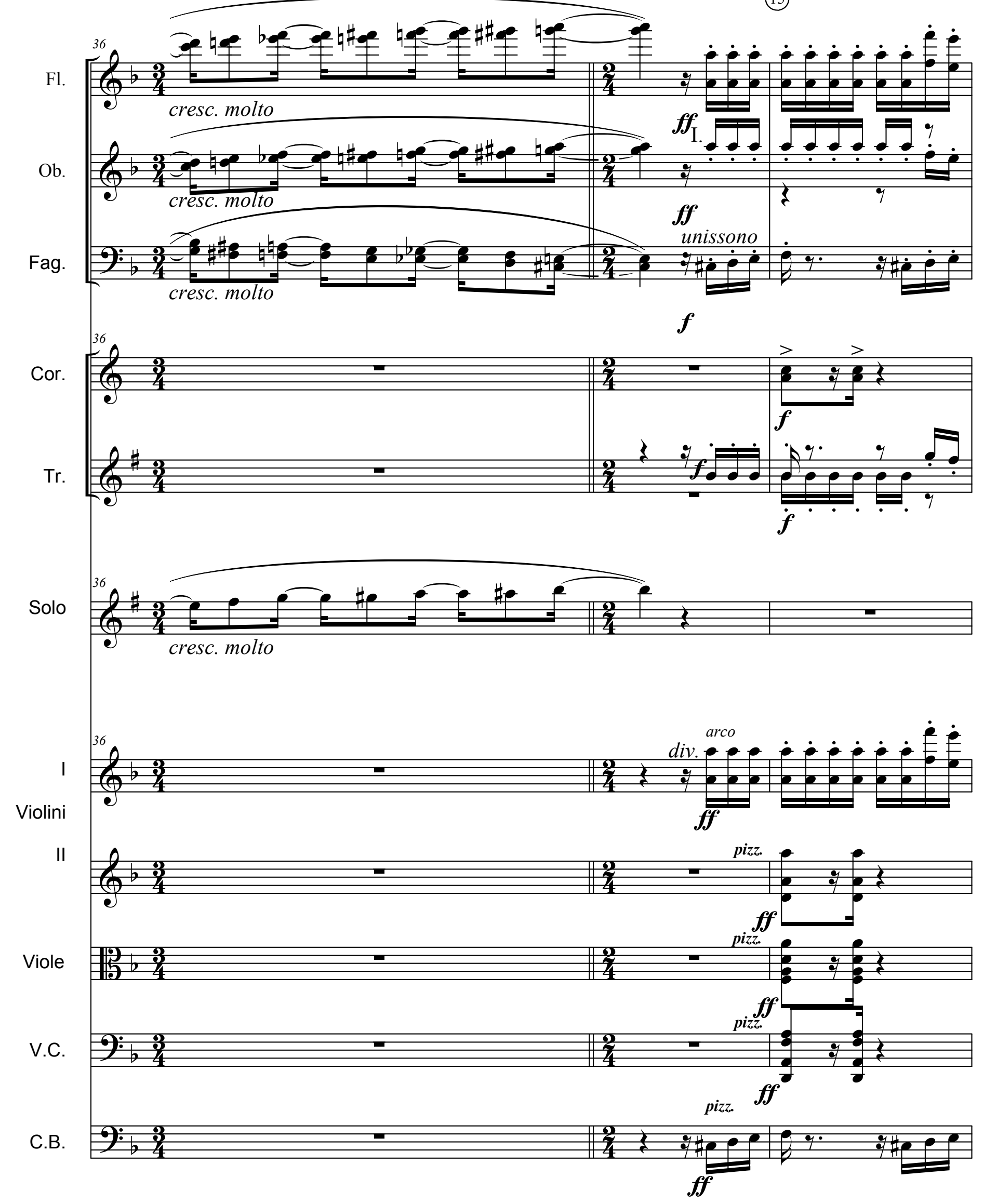

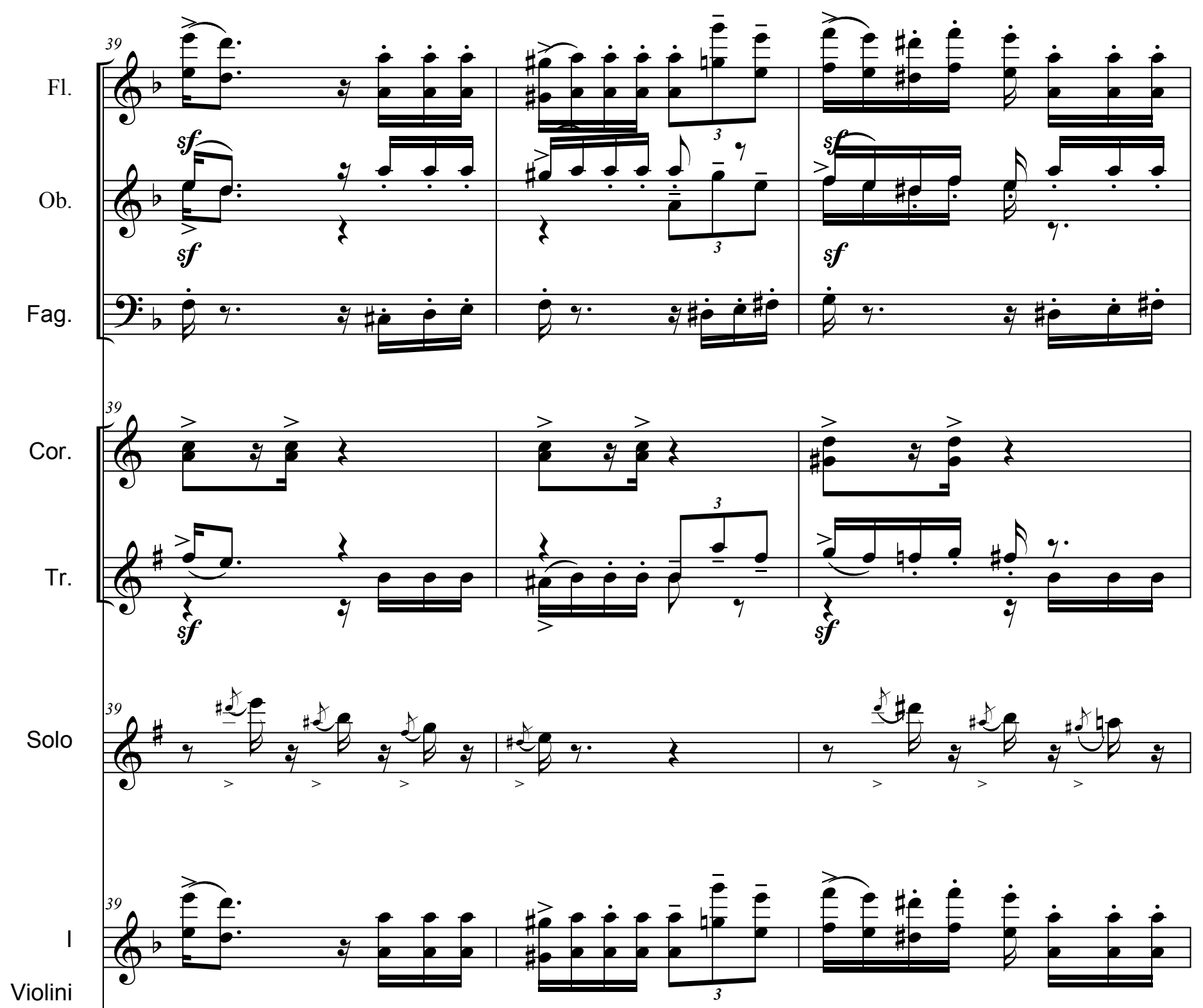

Violini

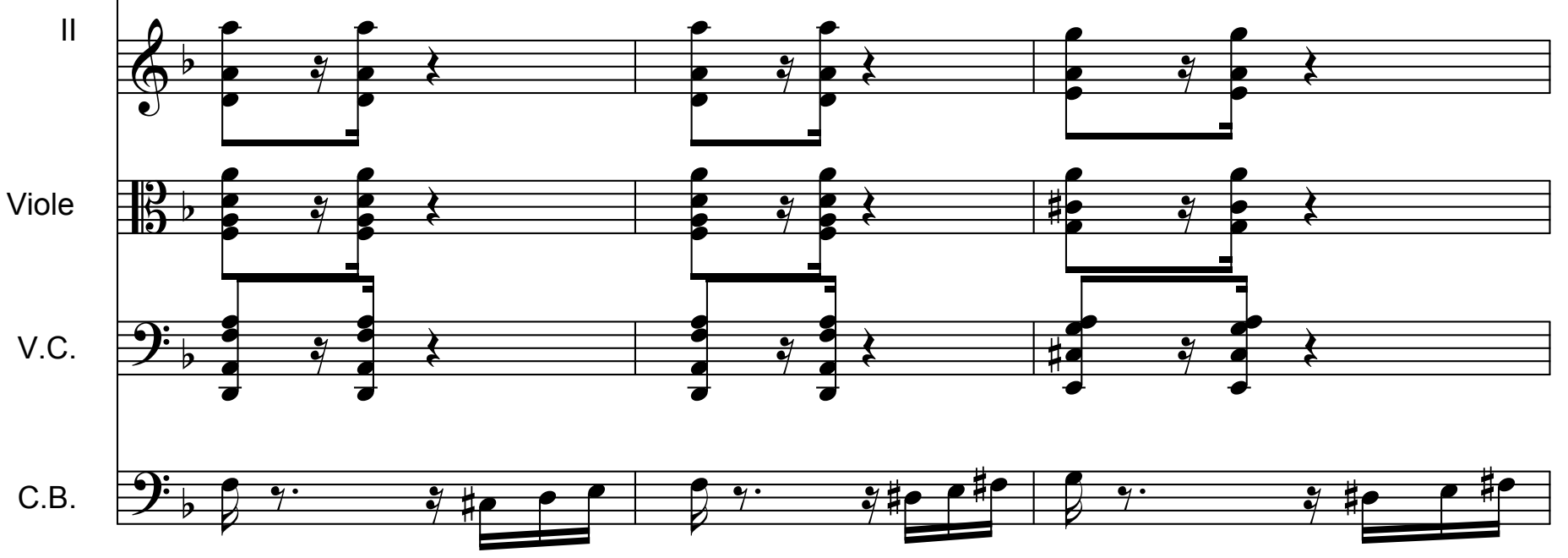




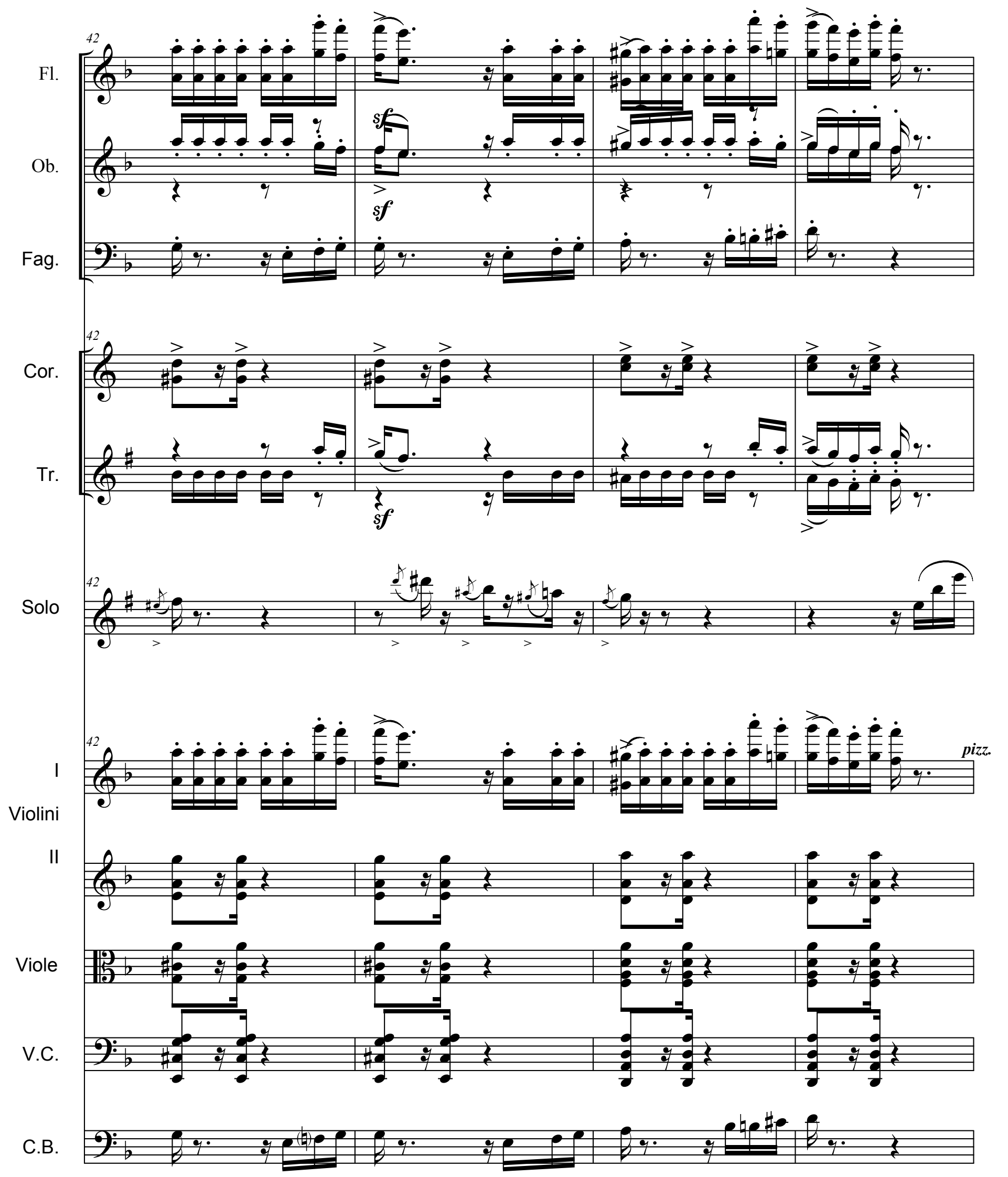


(16)
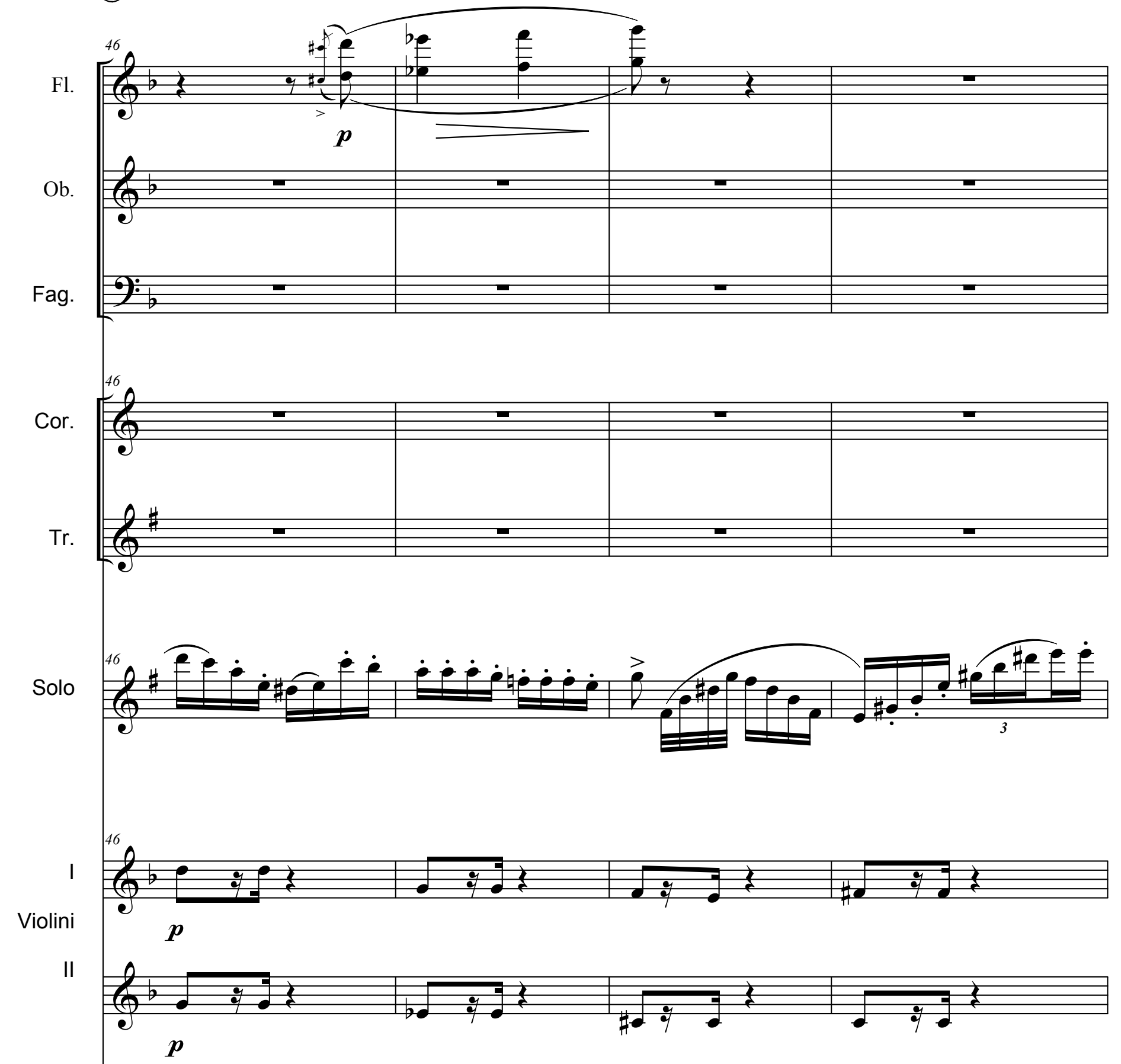

Viole

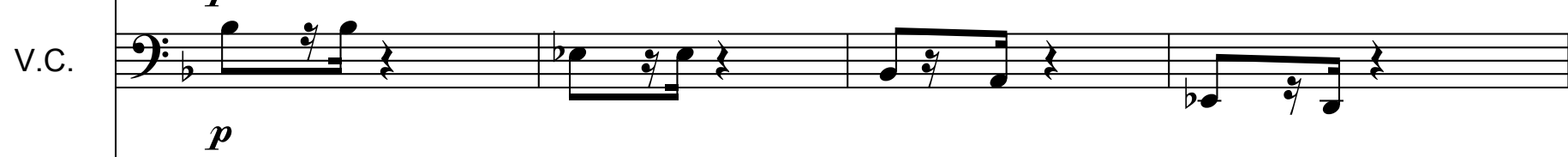

C.B.

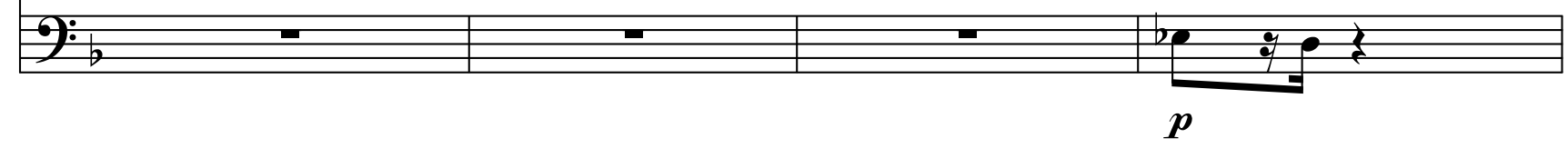



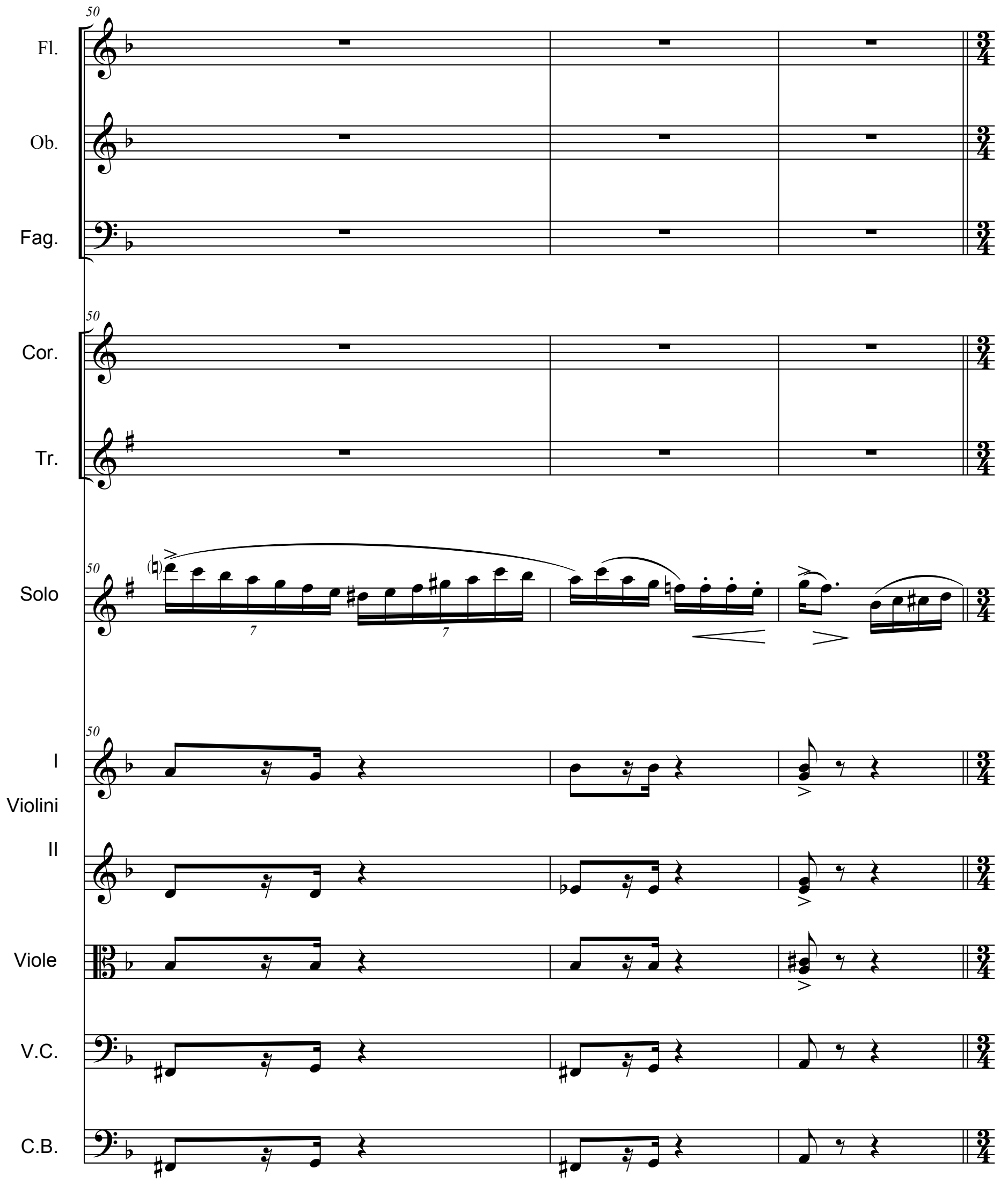
(17)
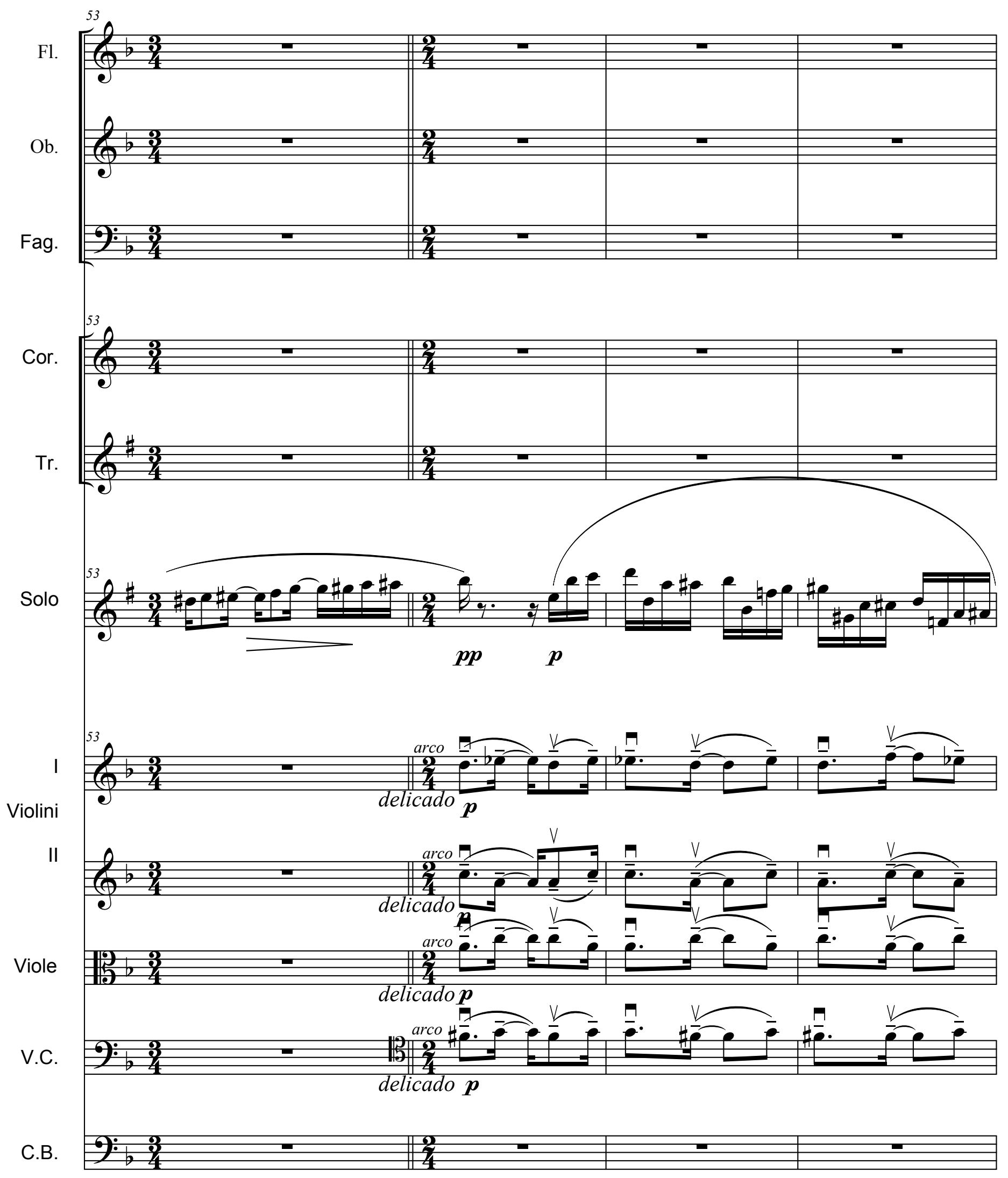

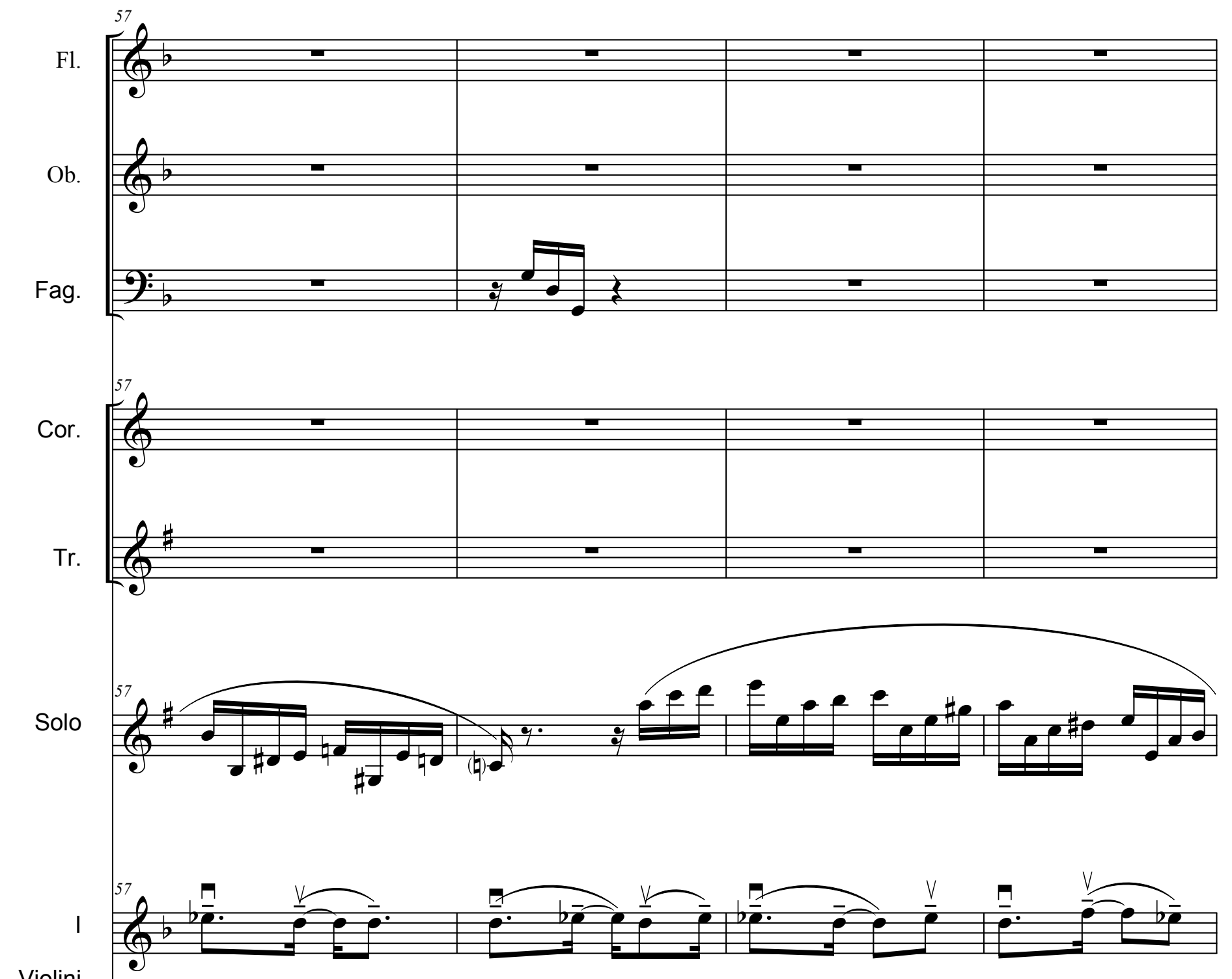

Violini
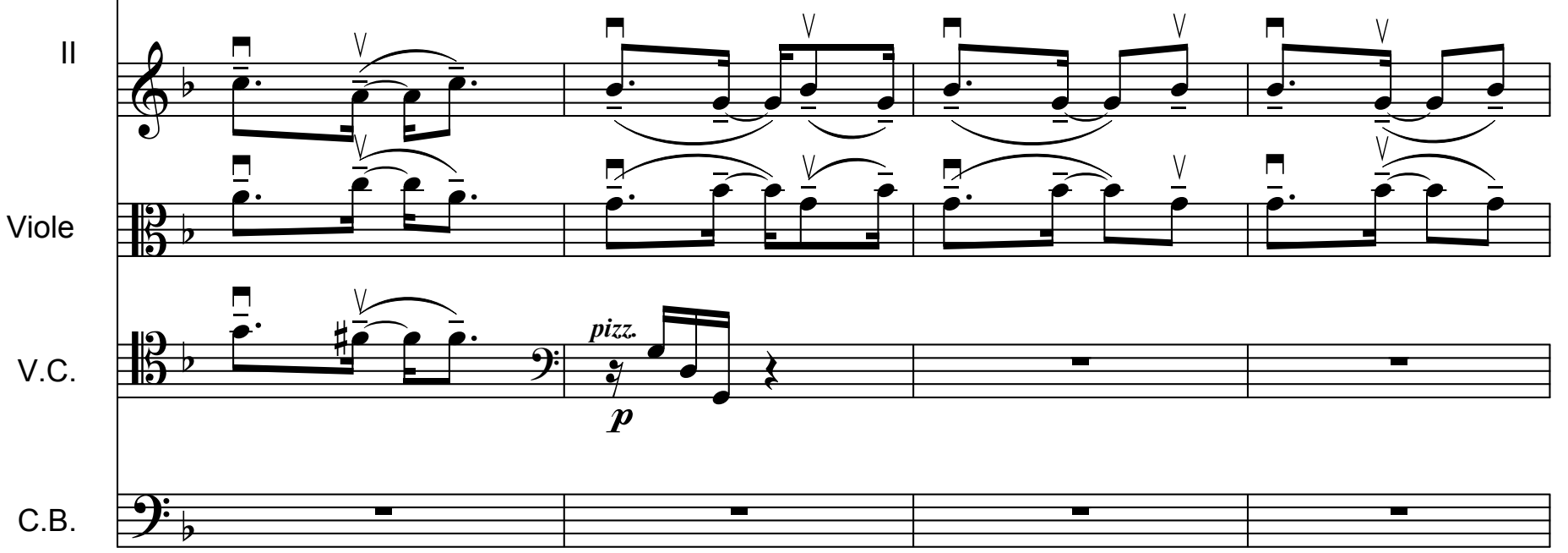


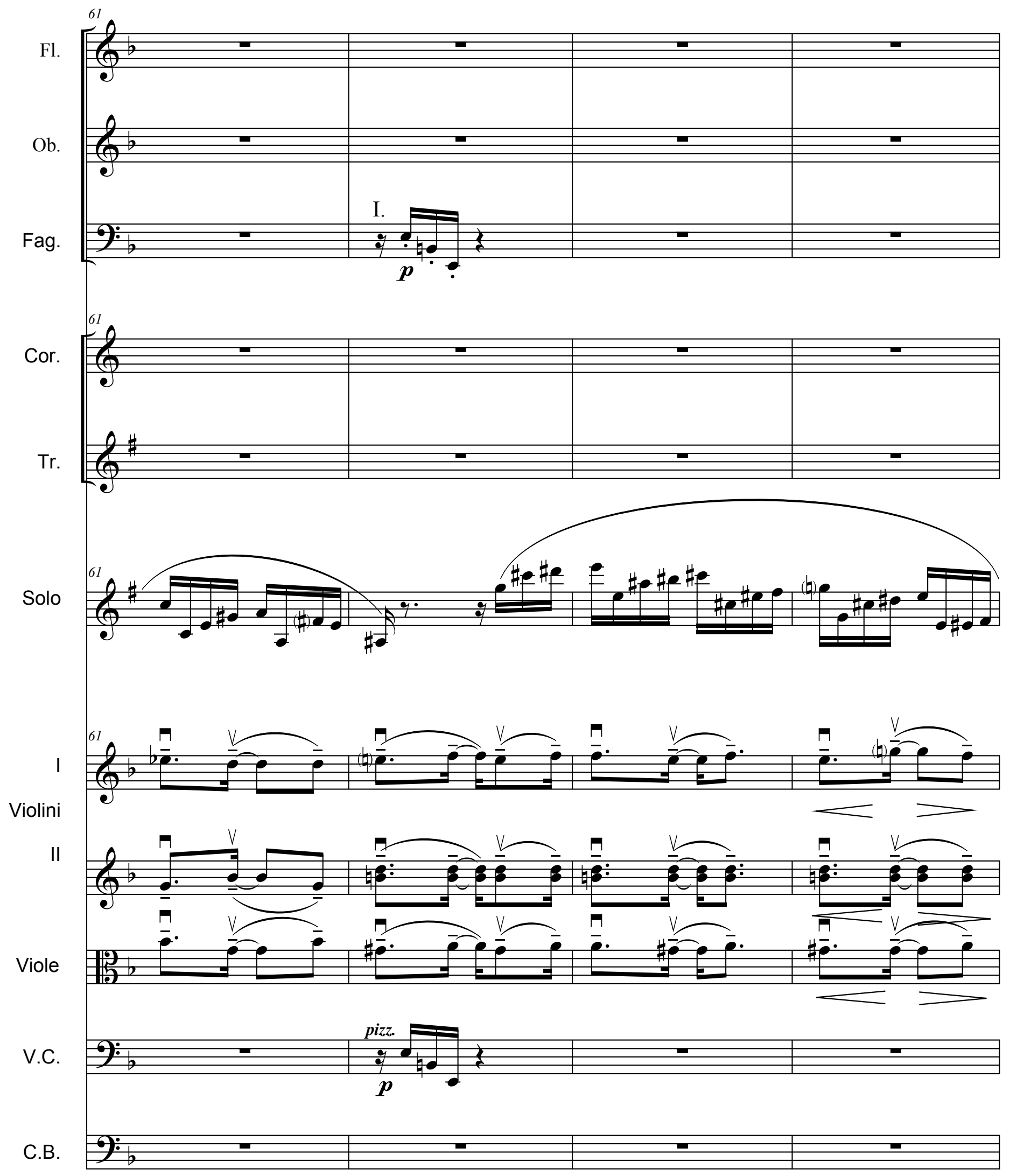




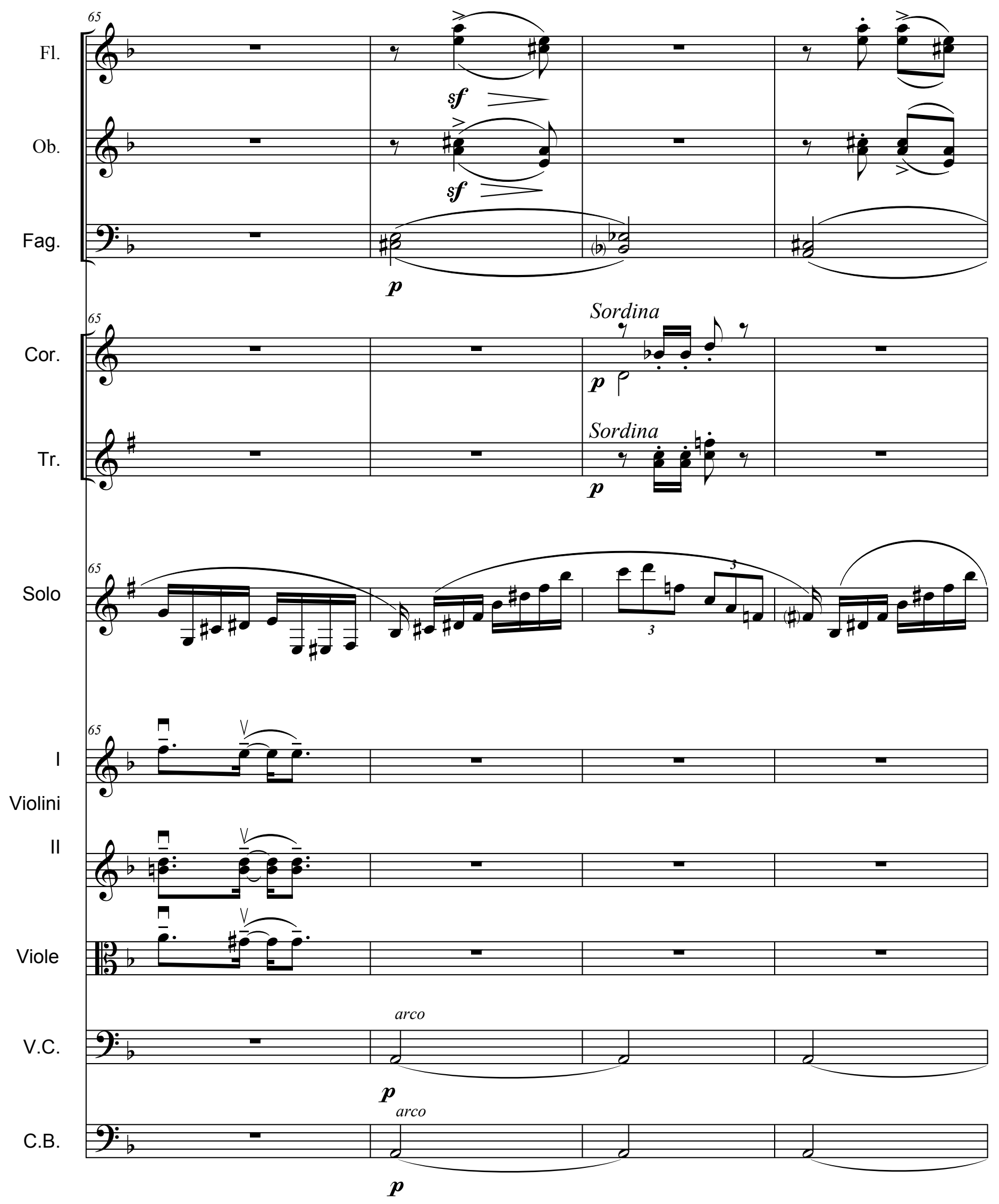


(18)

Poco Meno $(d=108$

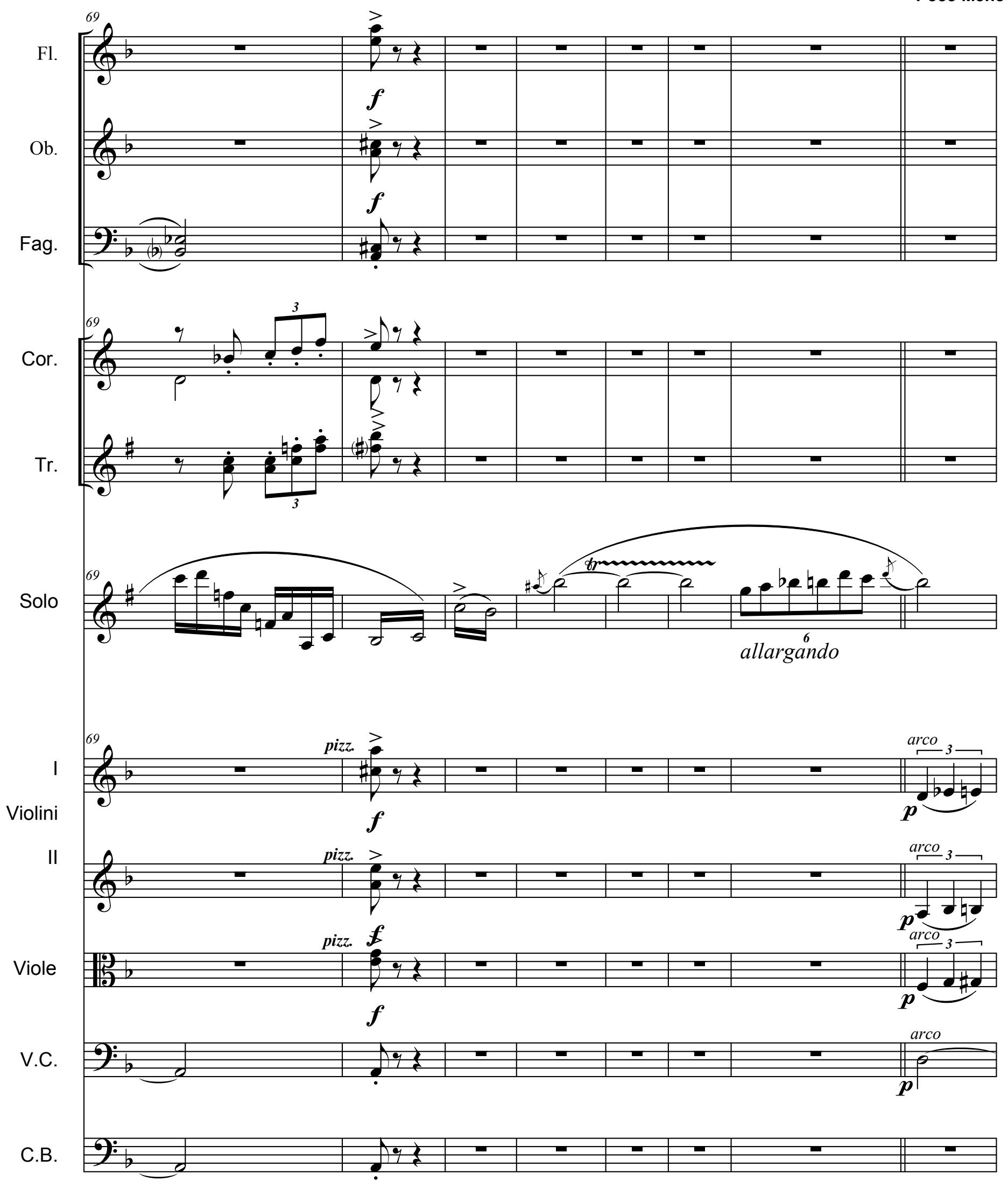



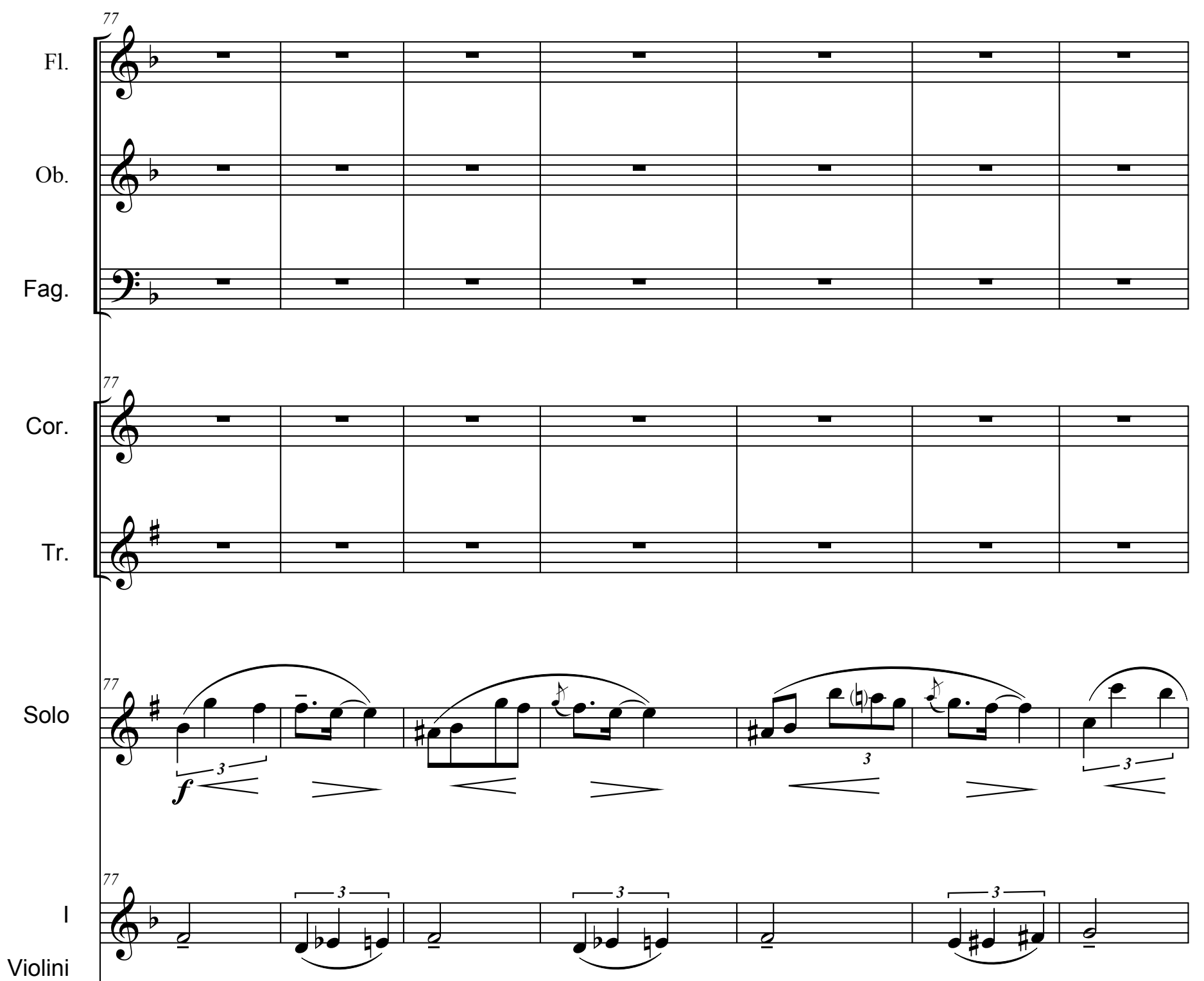

Violini

II

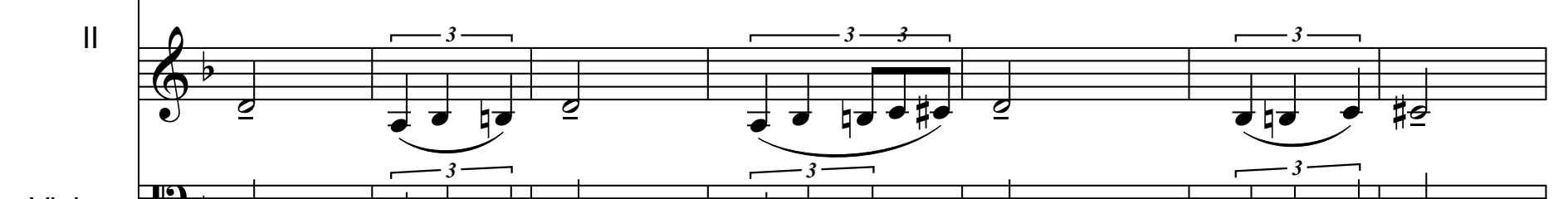

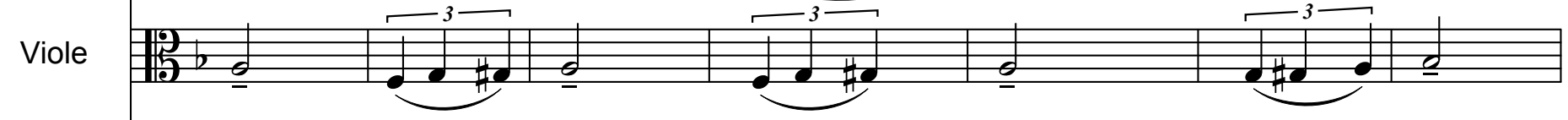

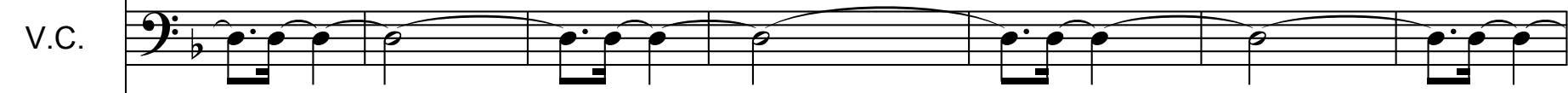

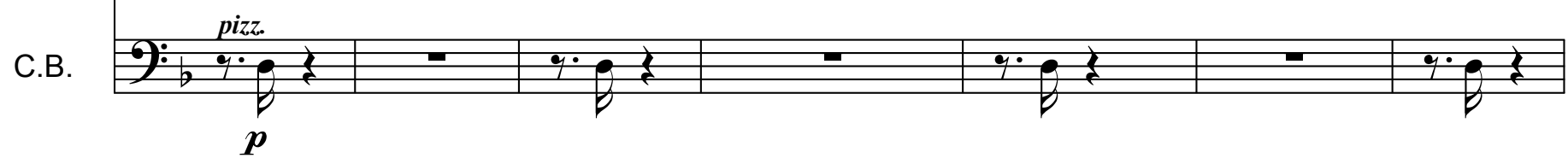



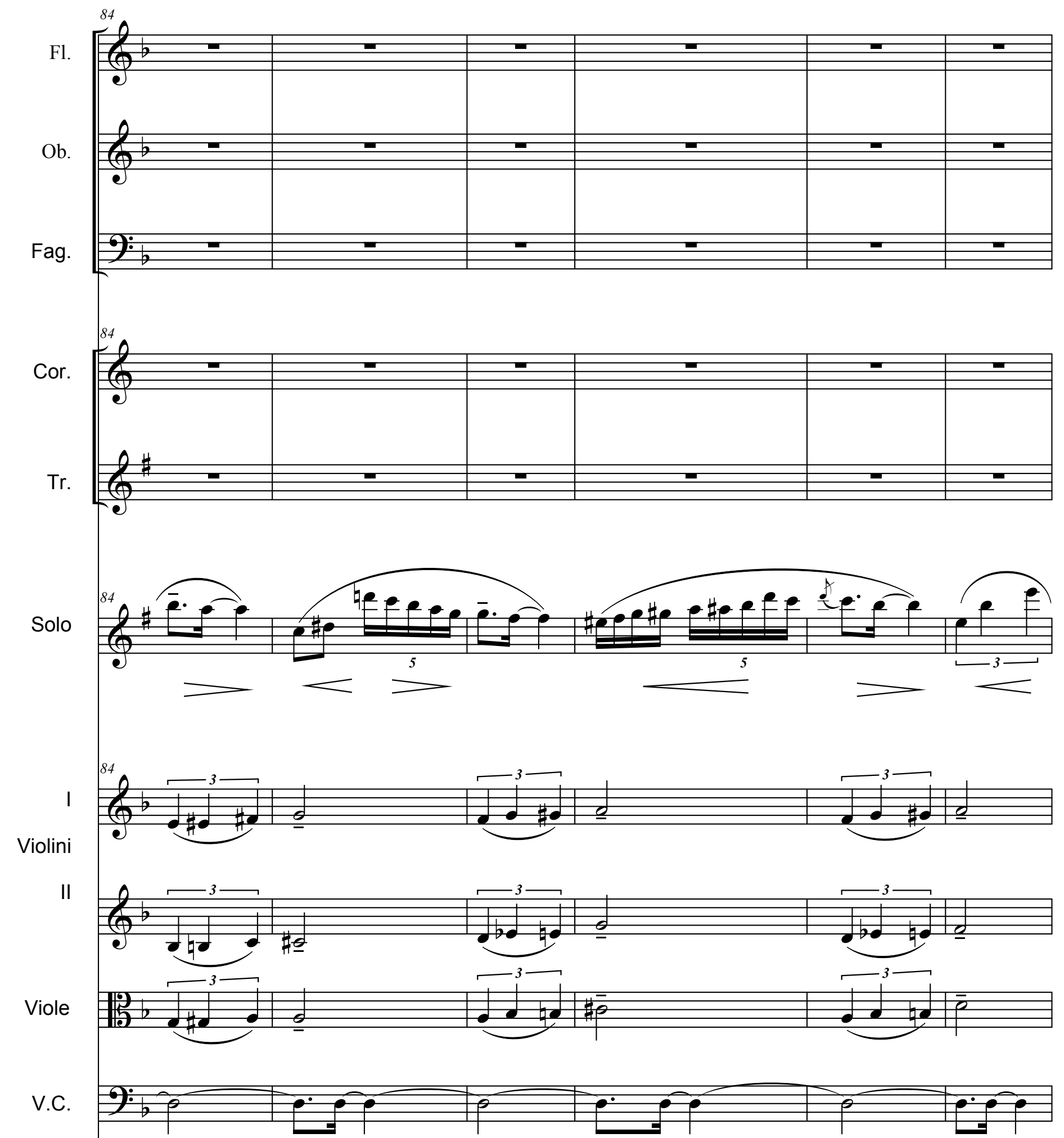

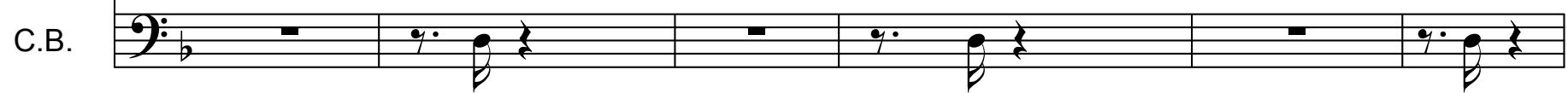



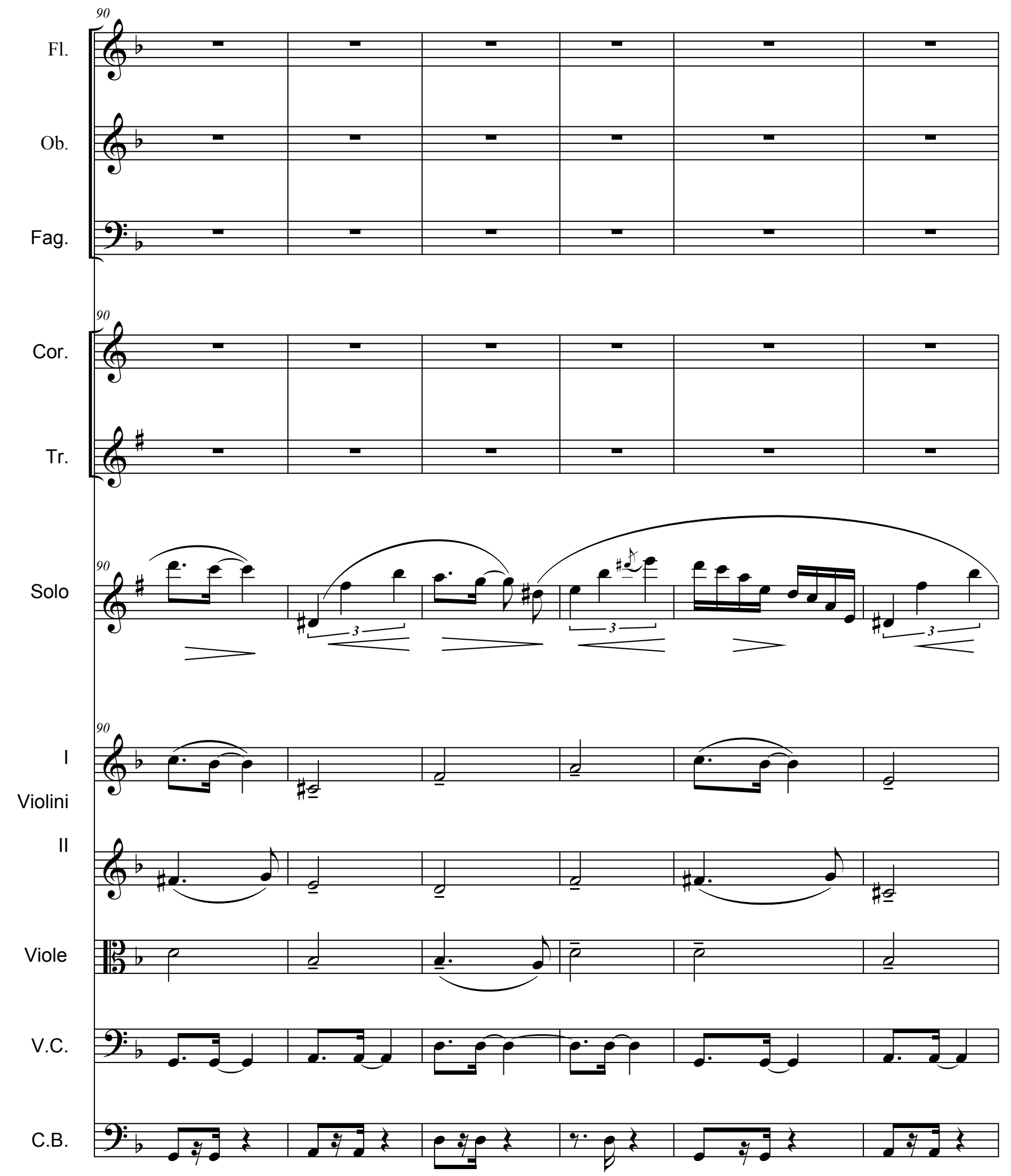
(19)
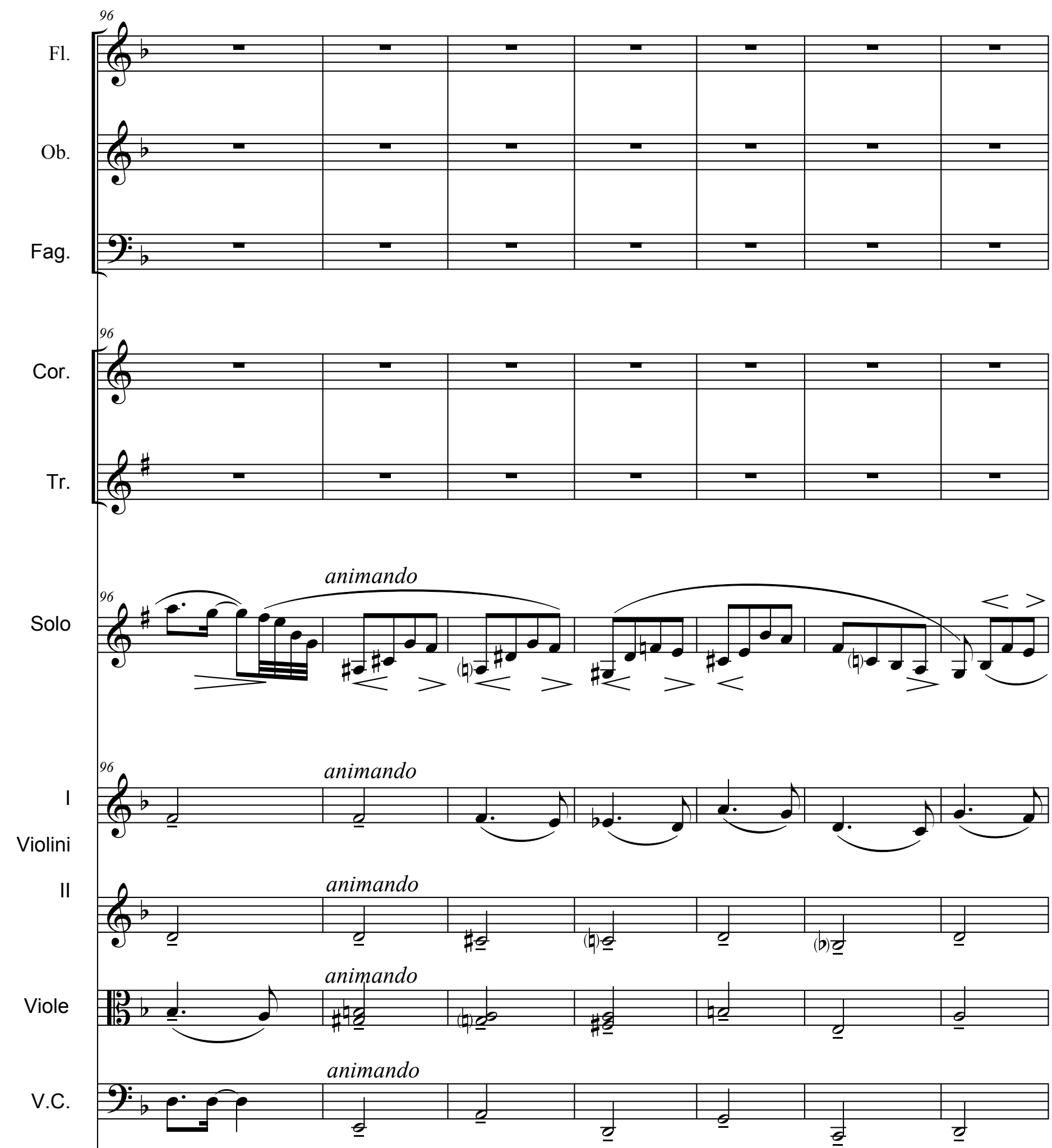

animando

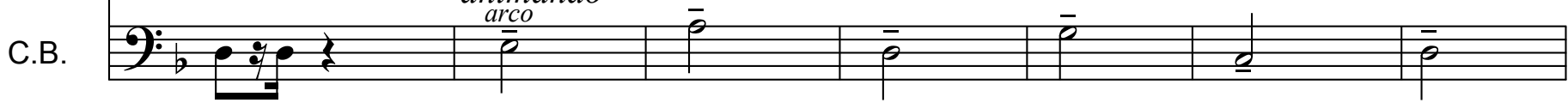



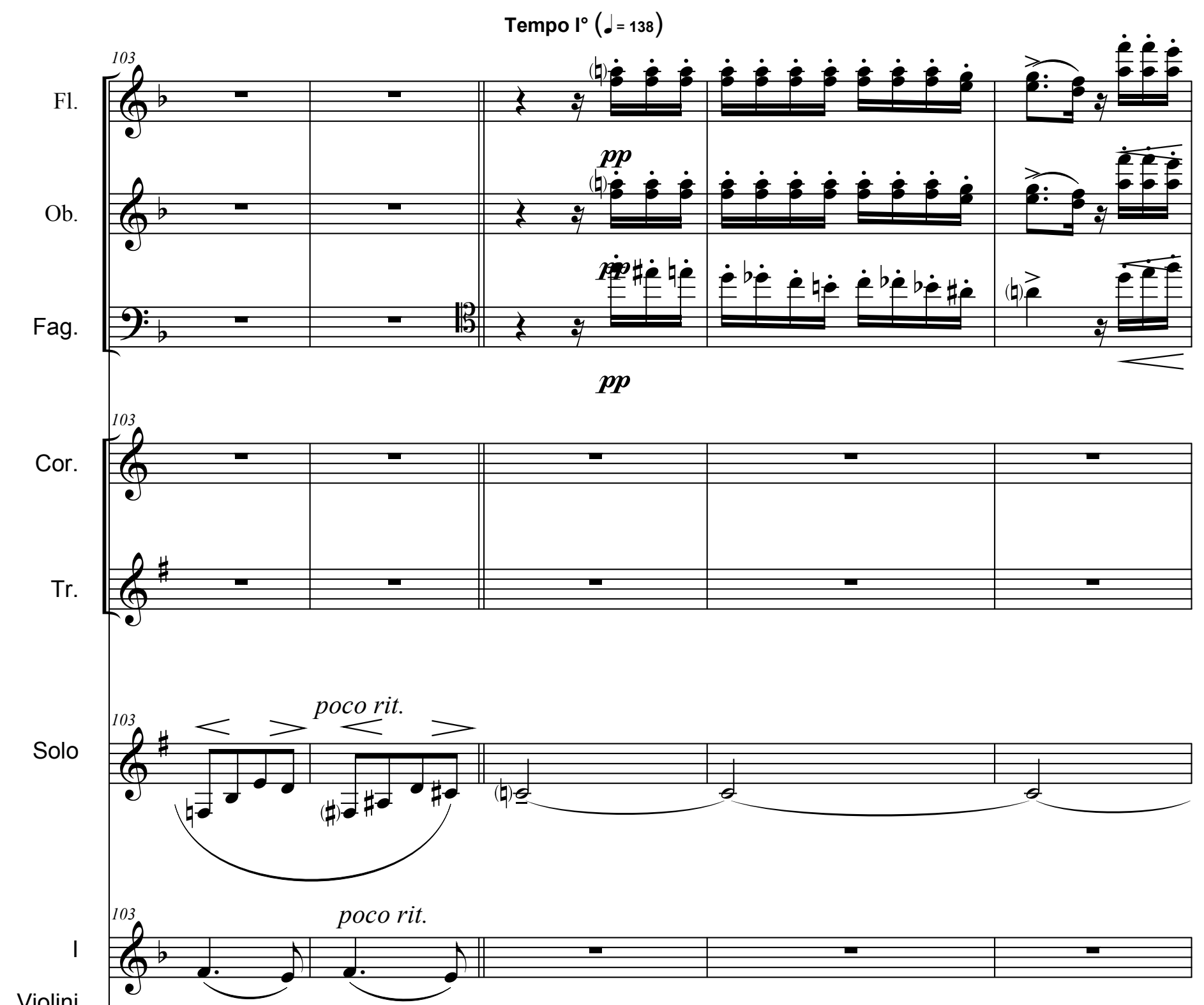

Violini

II

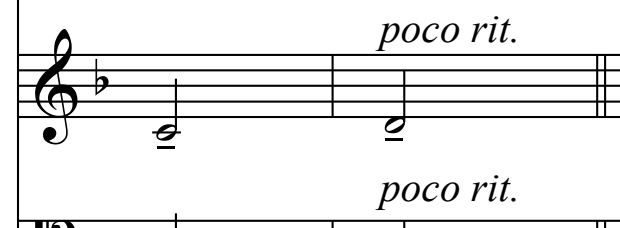

Viole

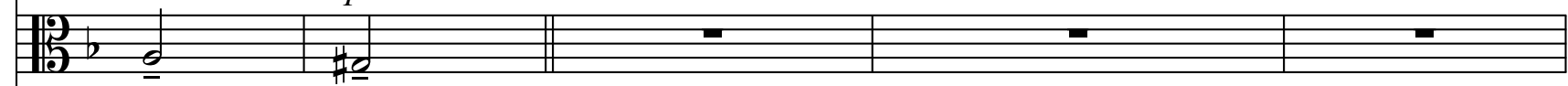

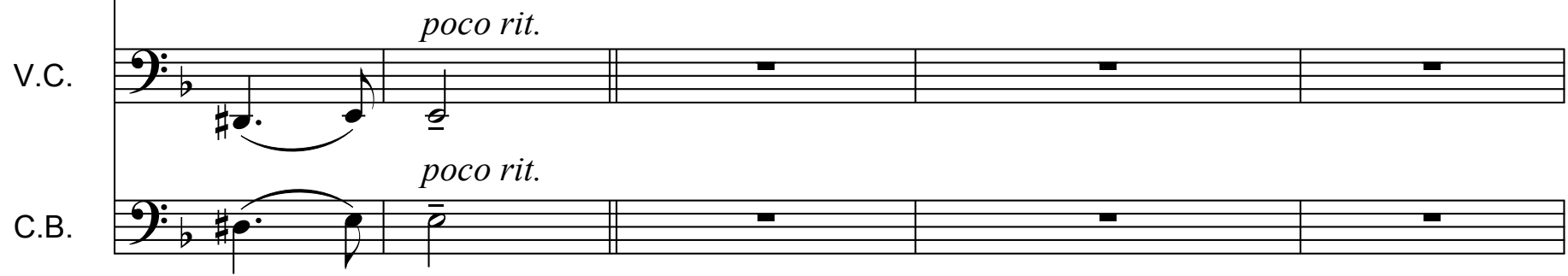




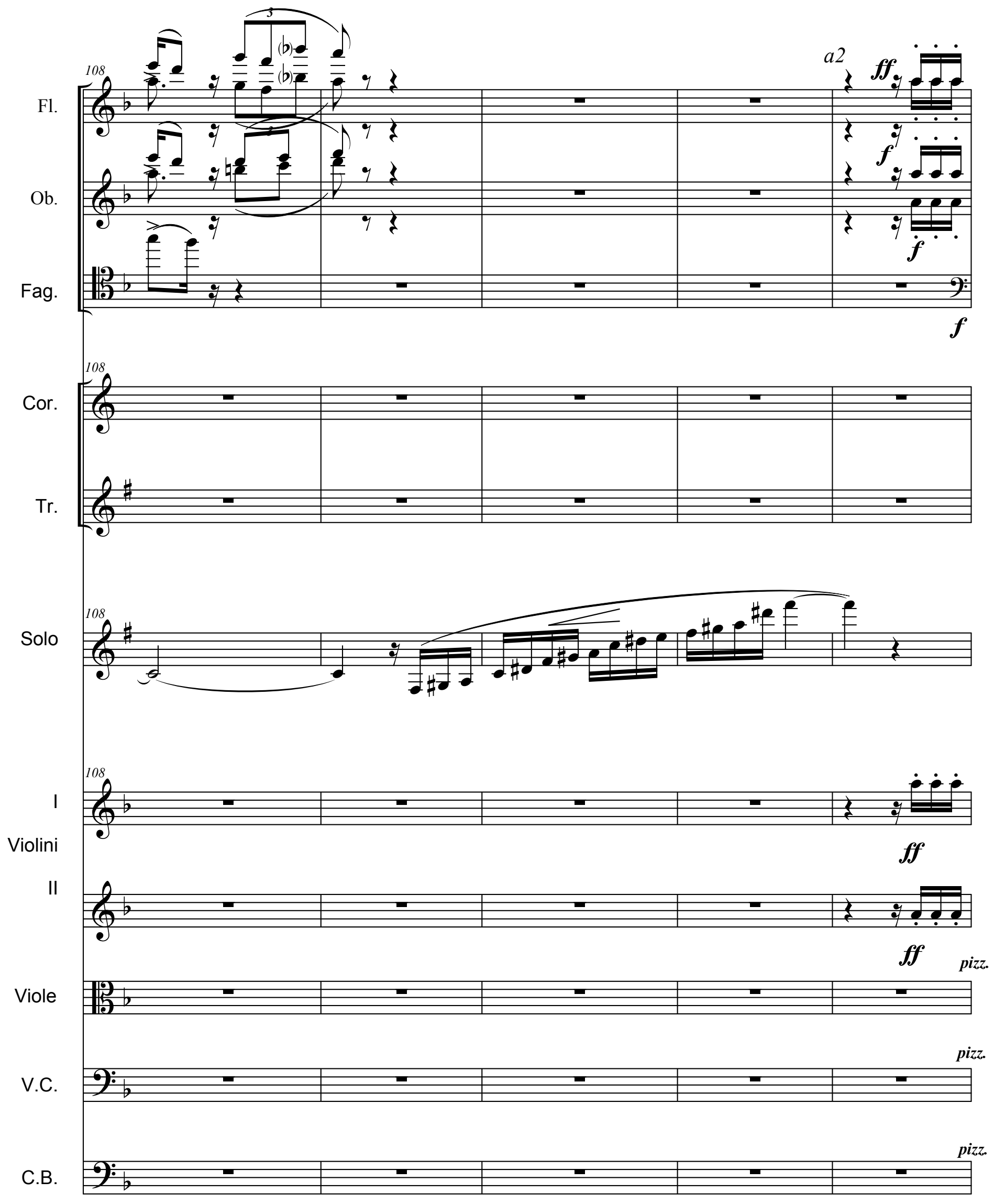


(20)

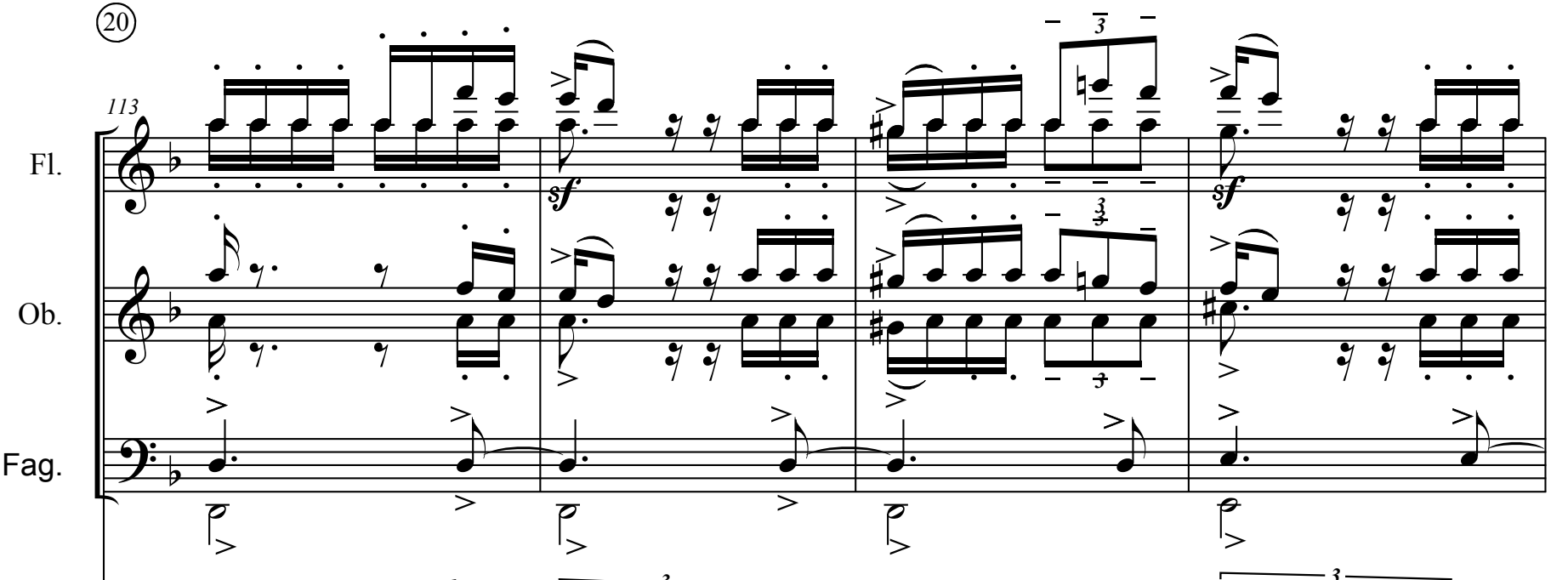

Cor.

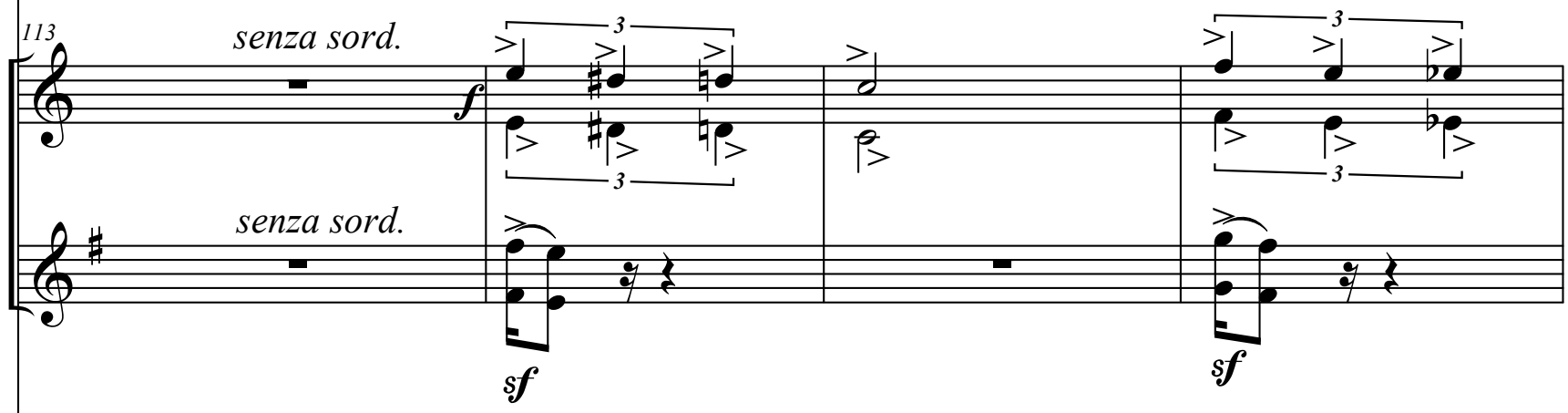

Solo

2

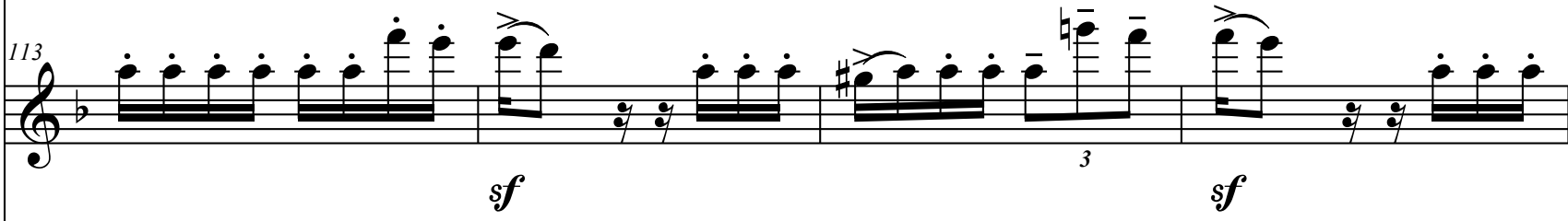

Violini

II

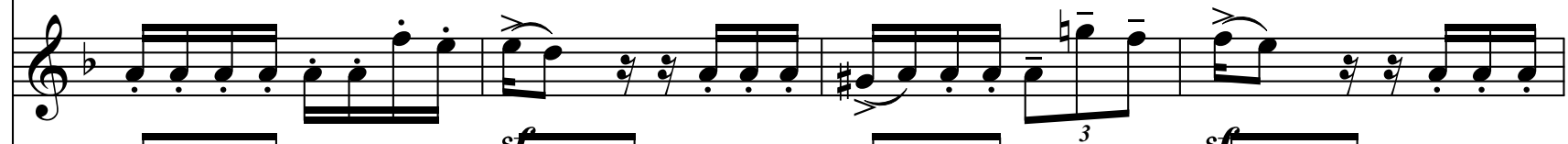

Viole
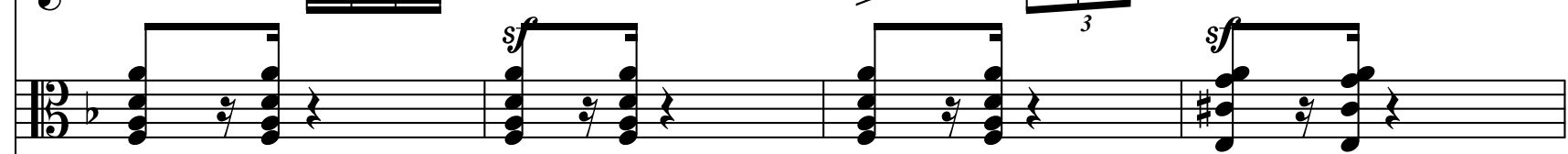

v.c.

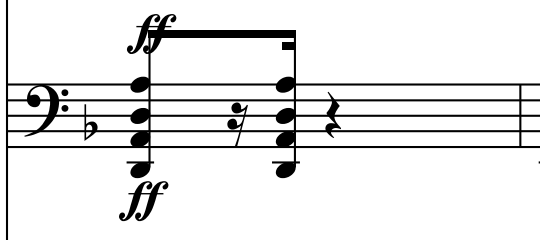

C.B.

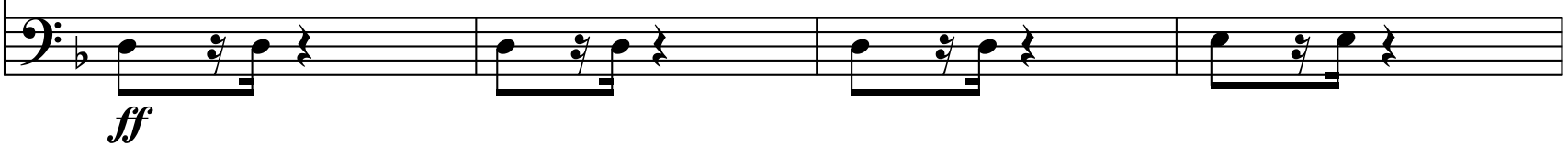




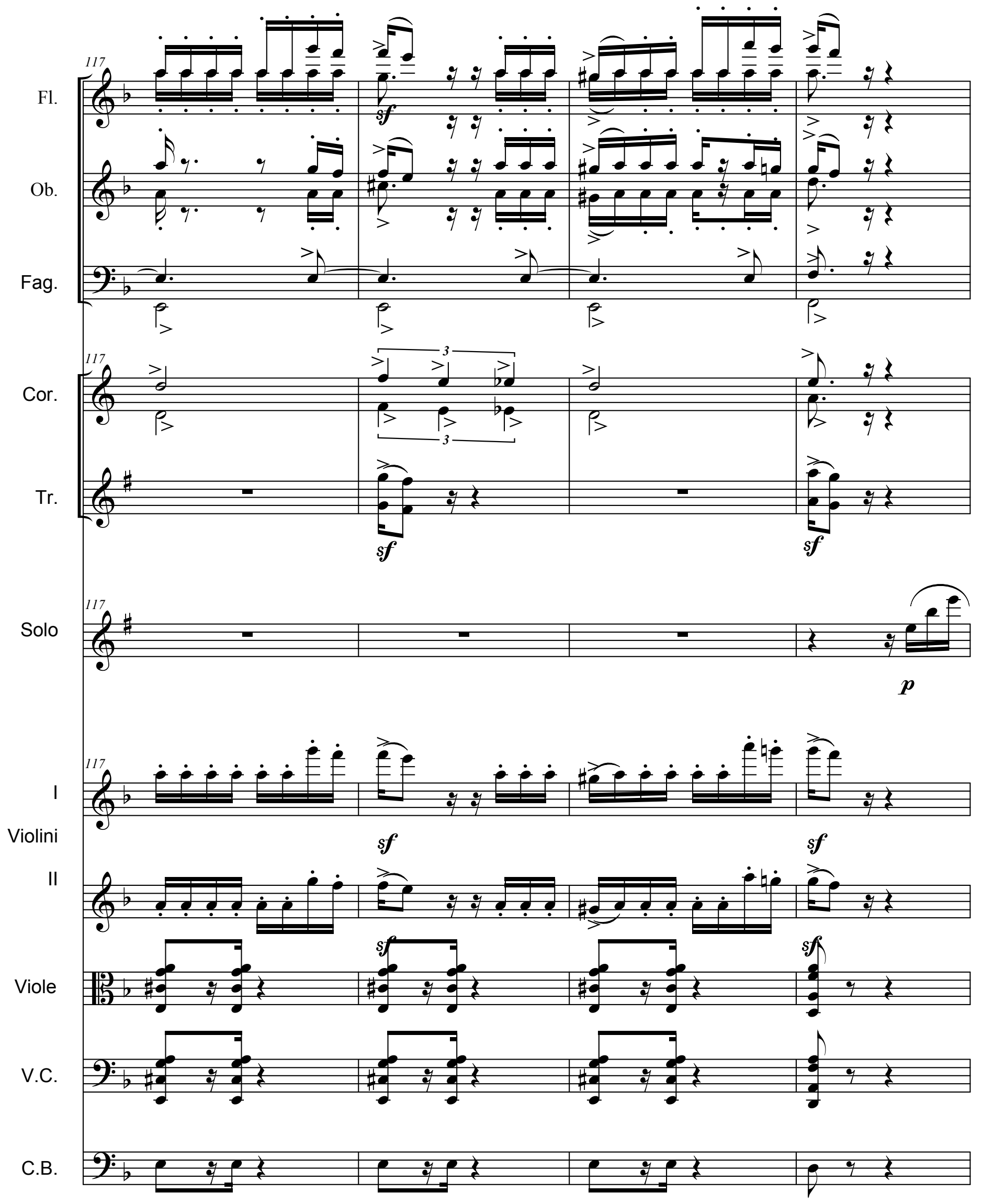




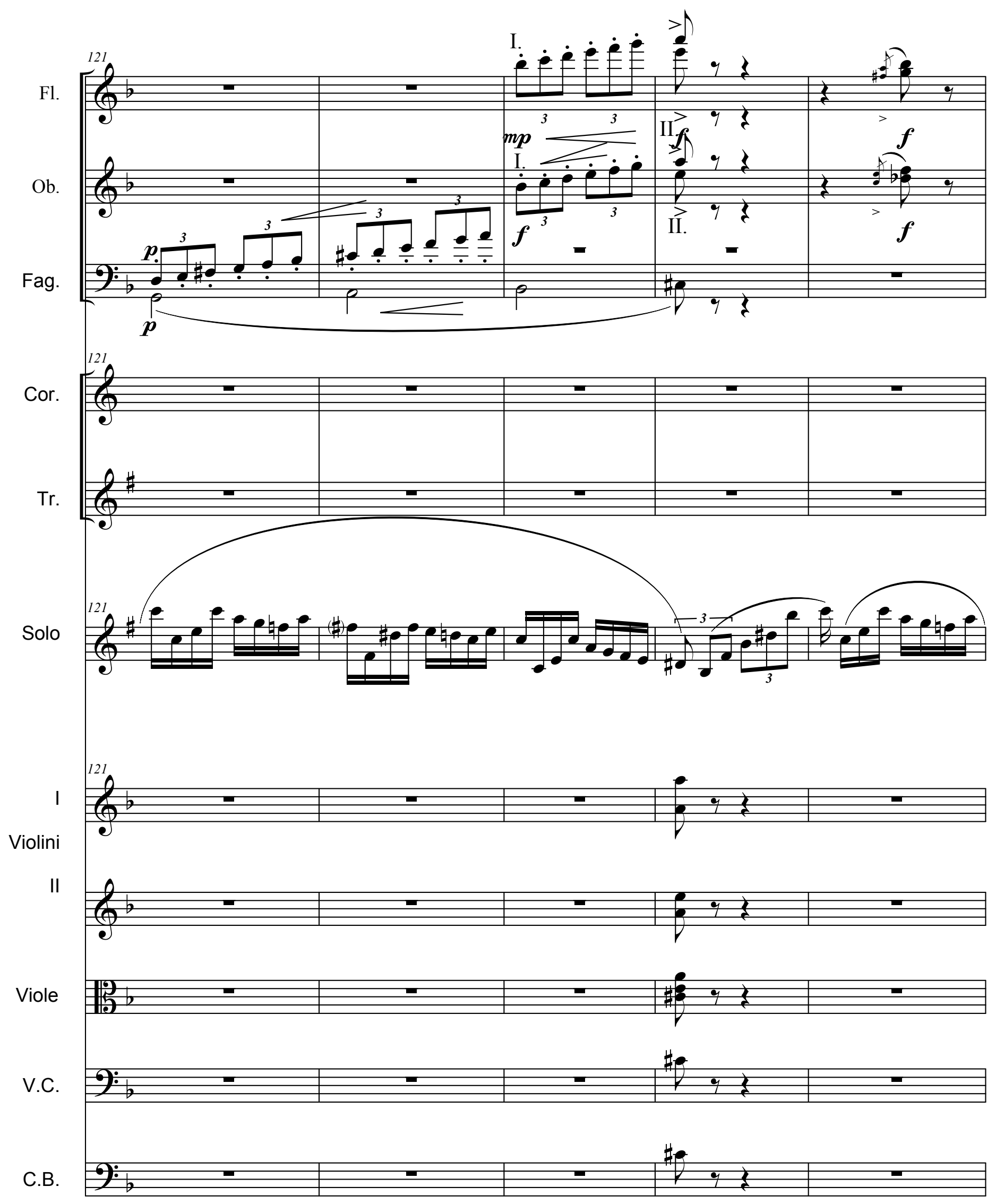




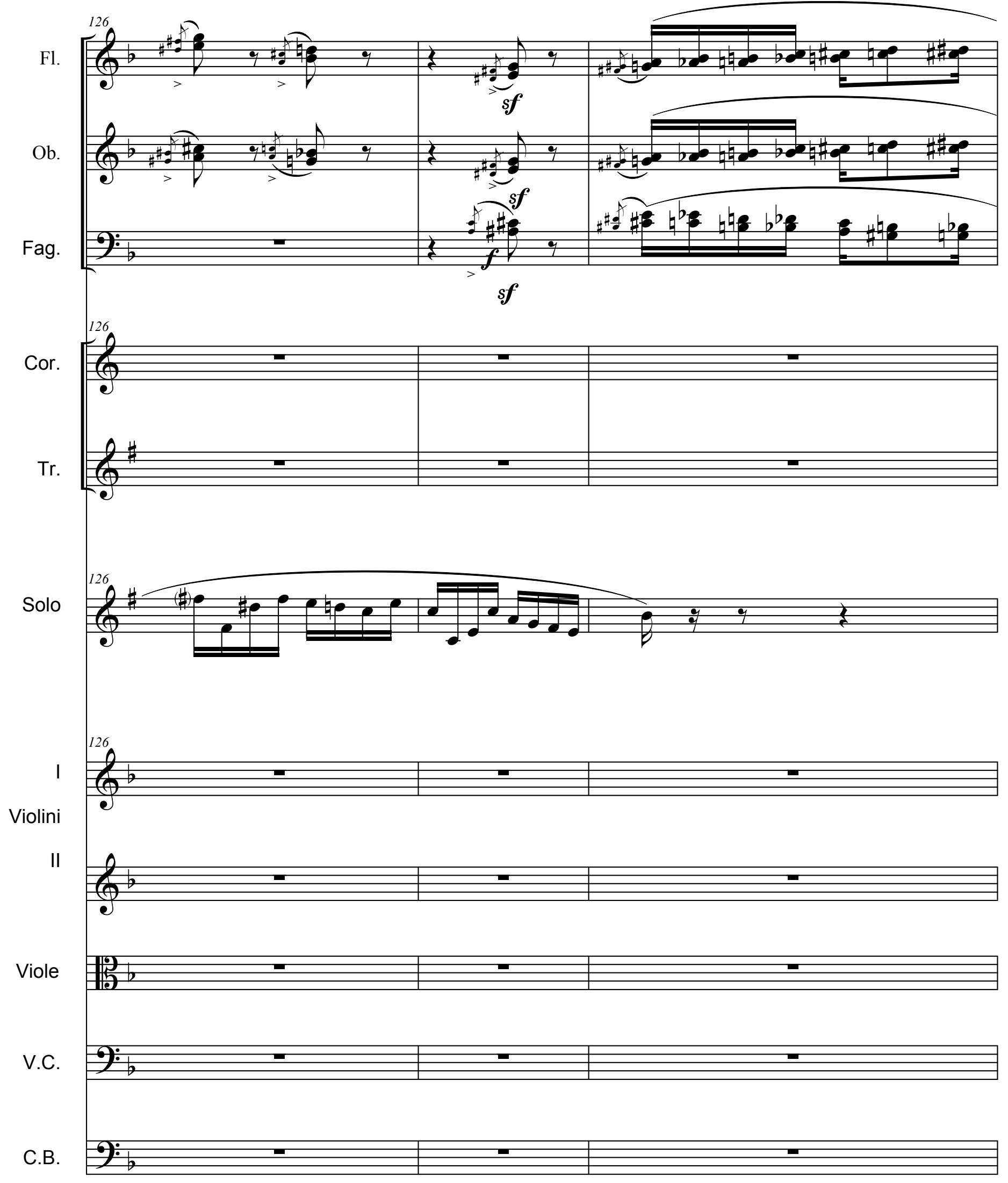


(21)

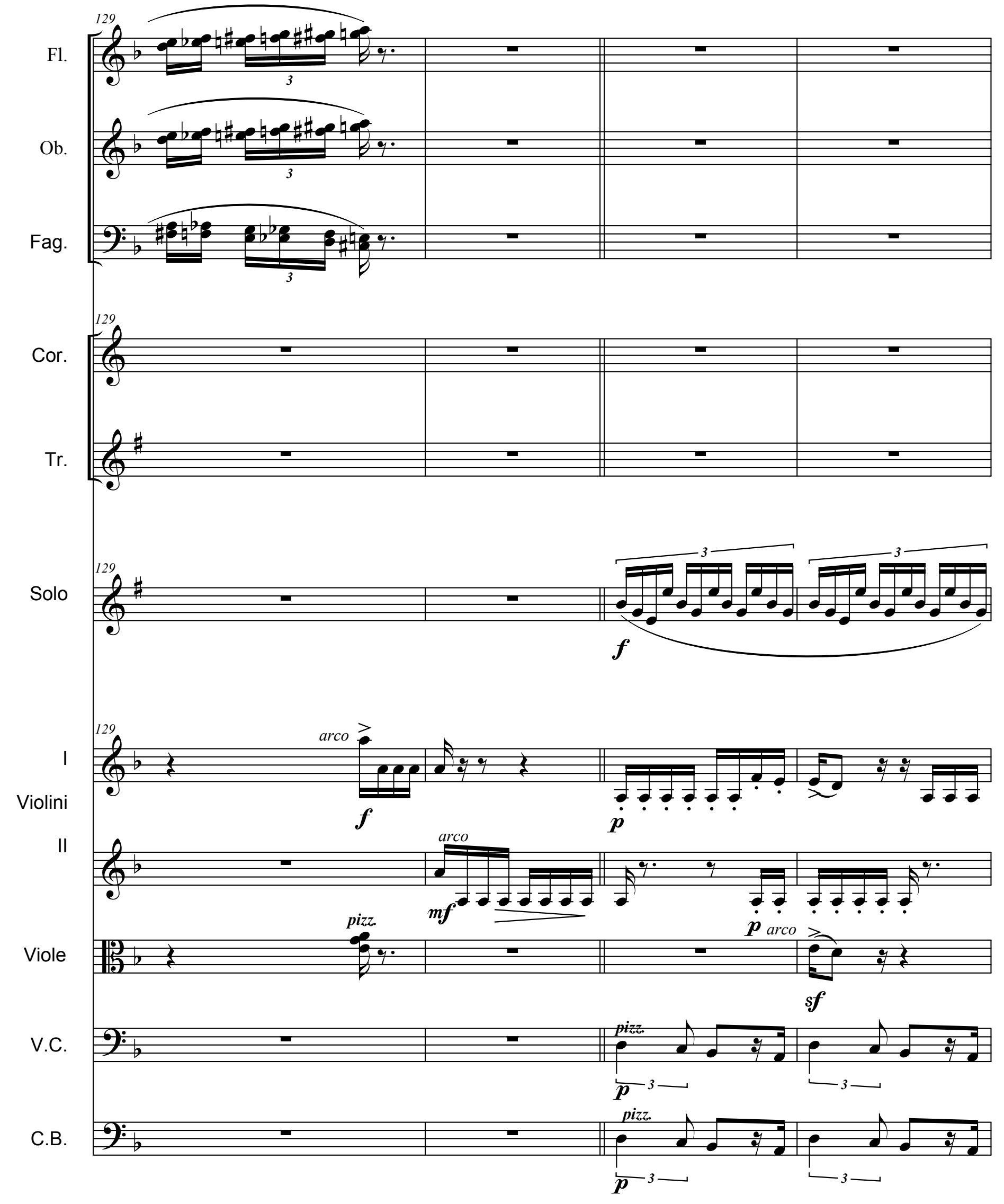



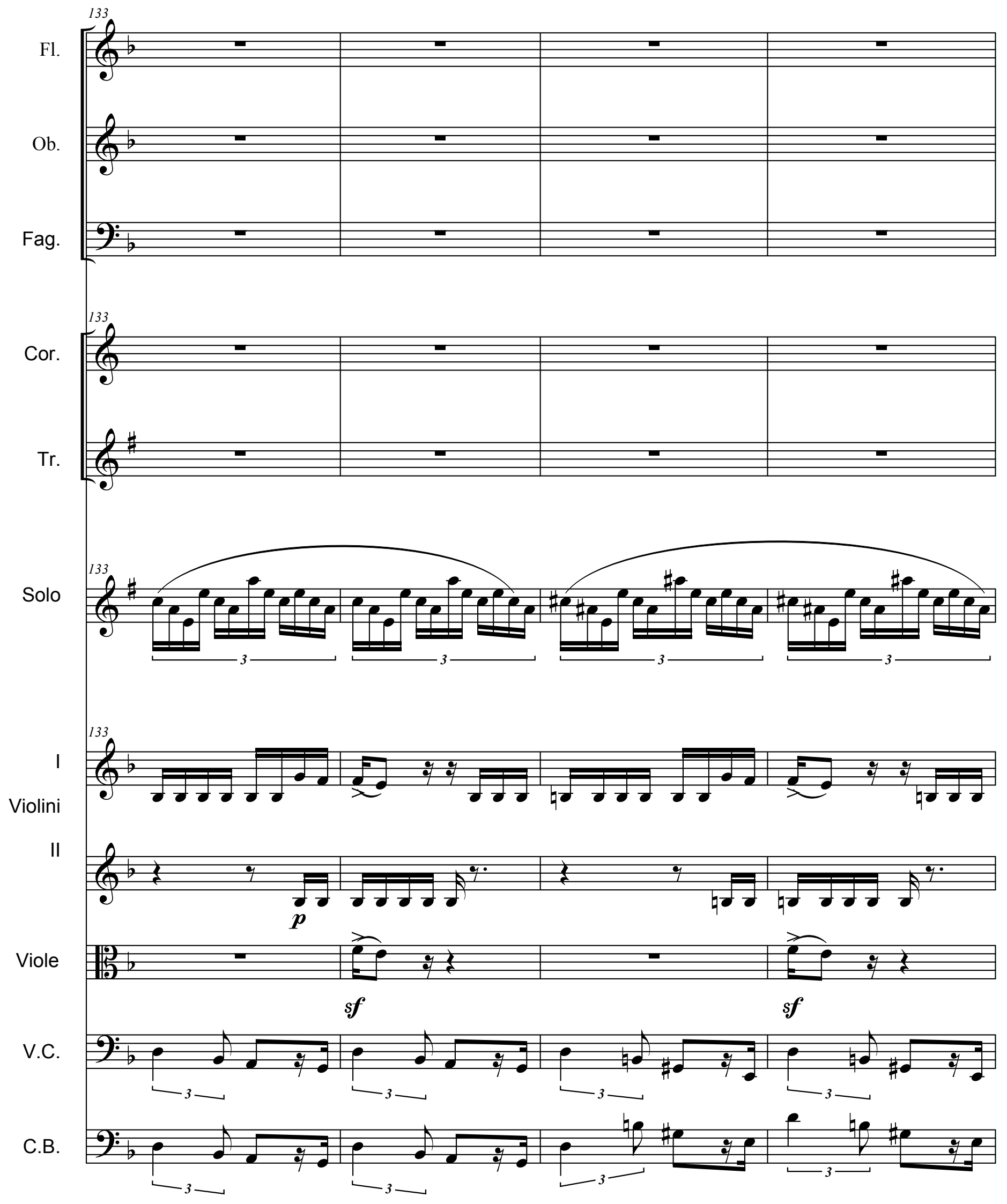

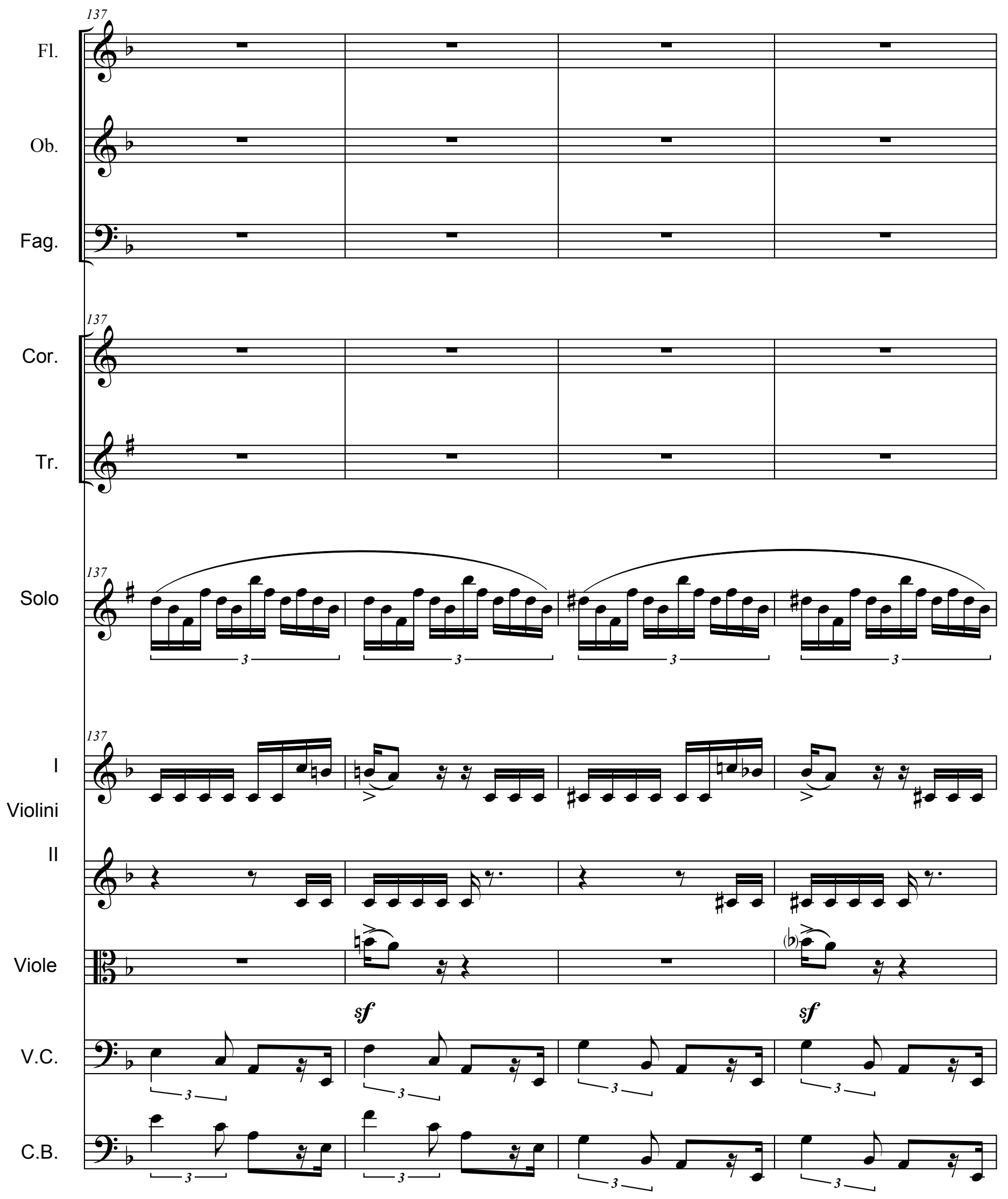

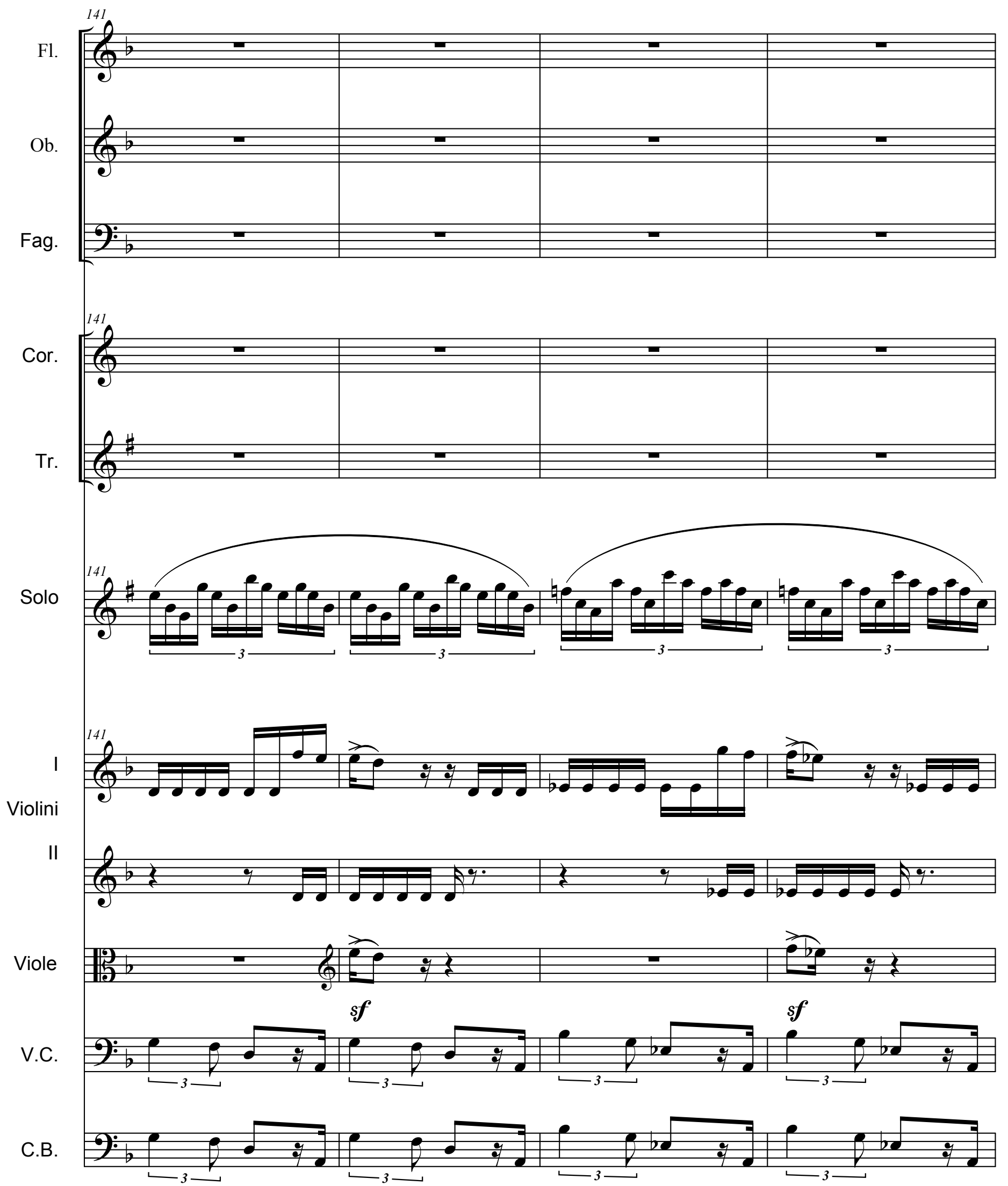

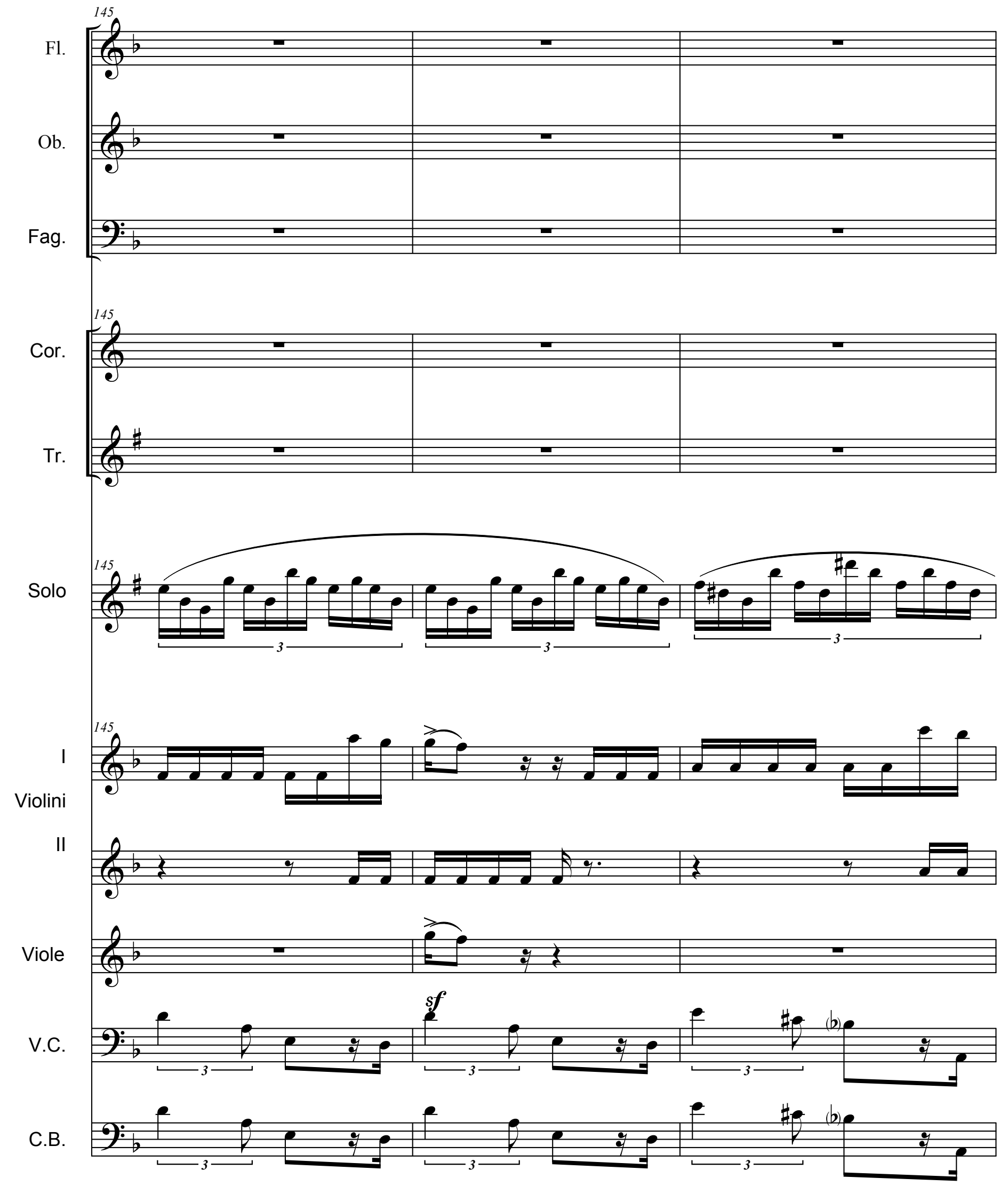
Piú Vivo $(\downarrow=144)$
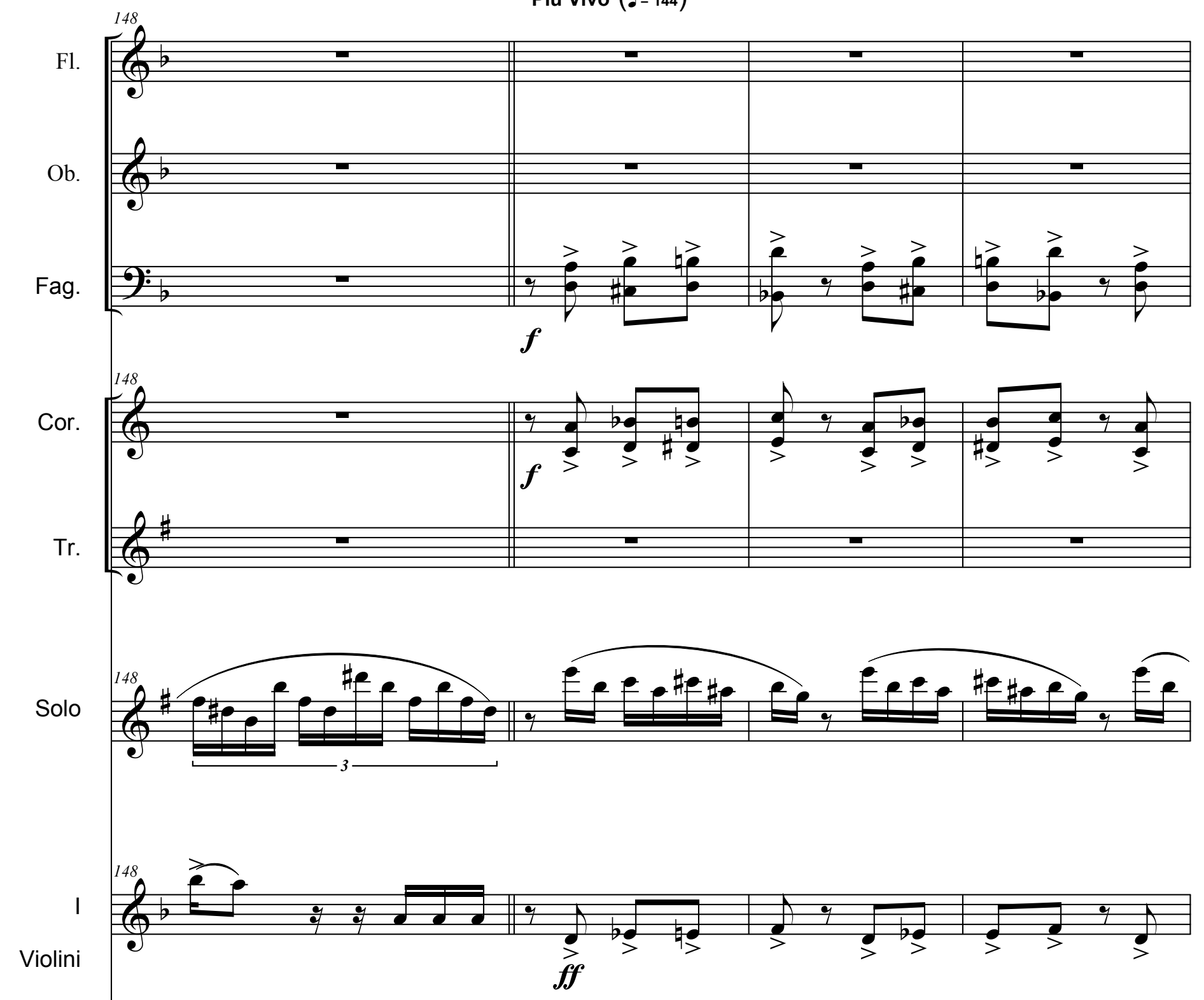

Violini

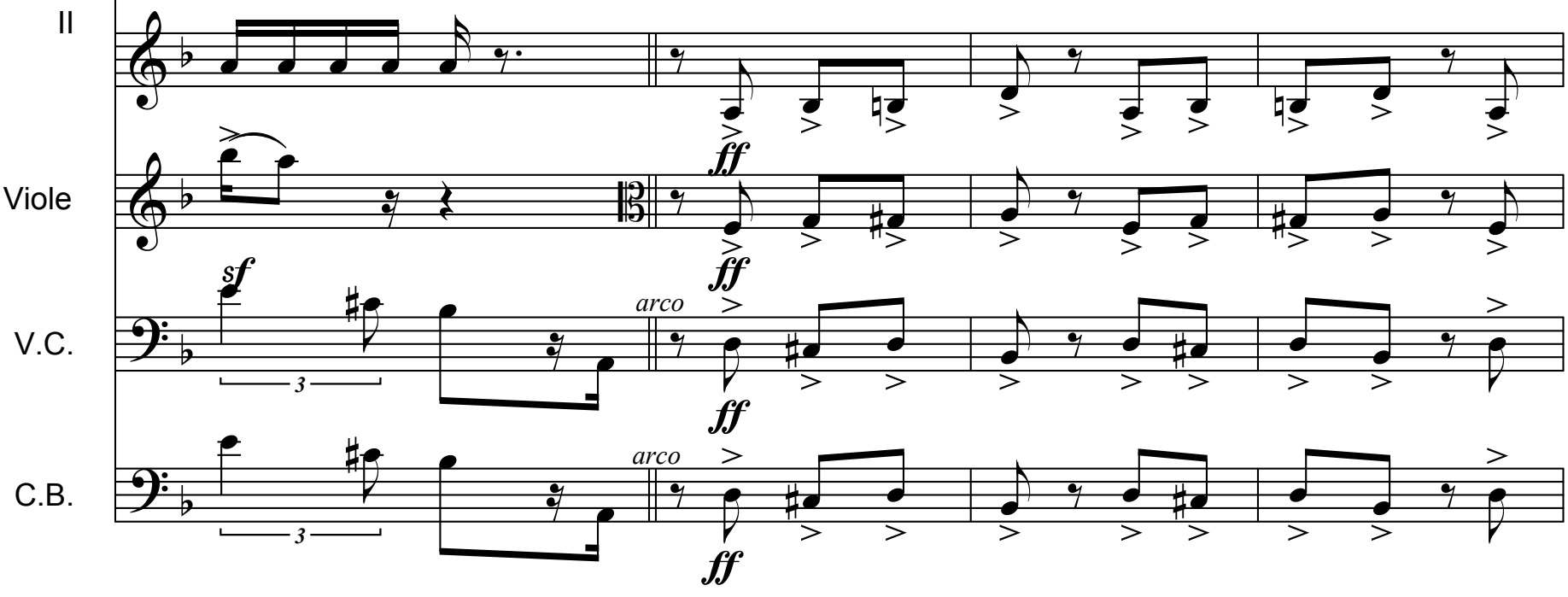


(22)
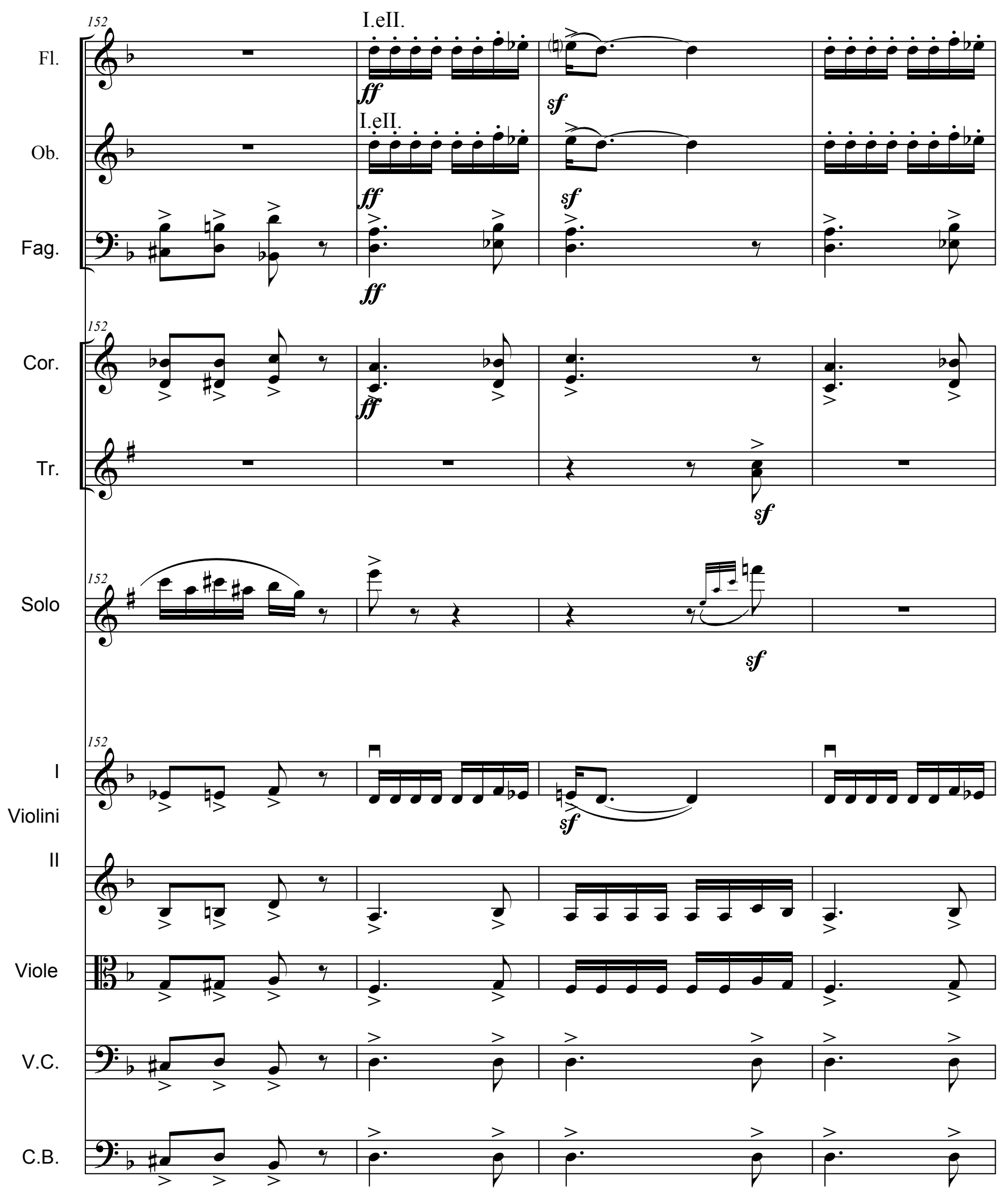


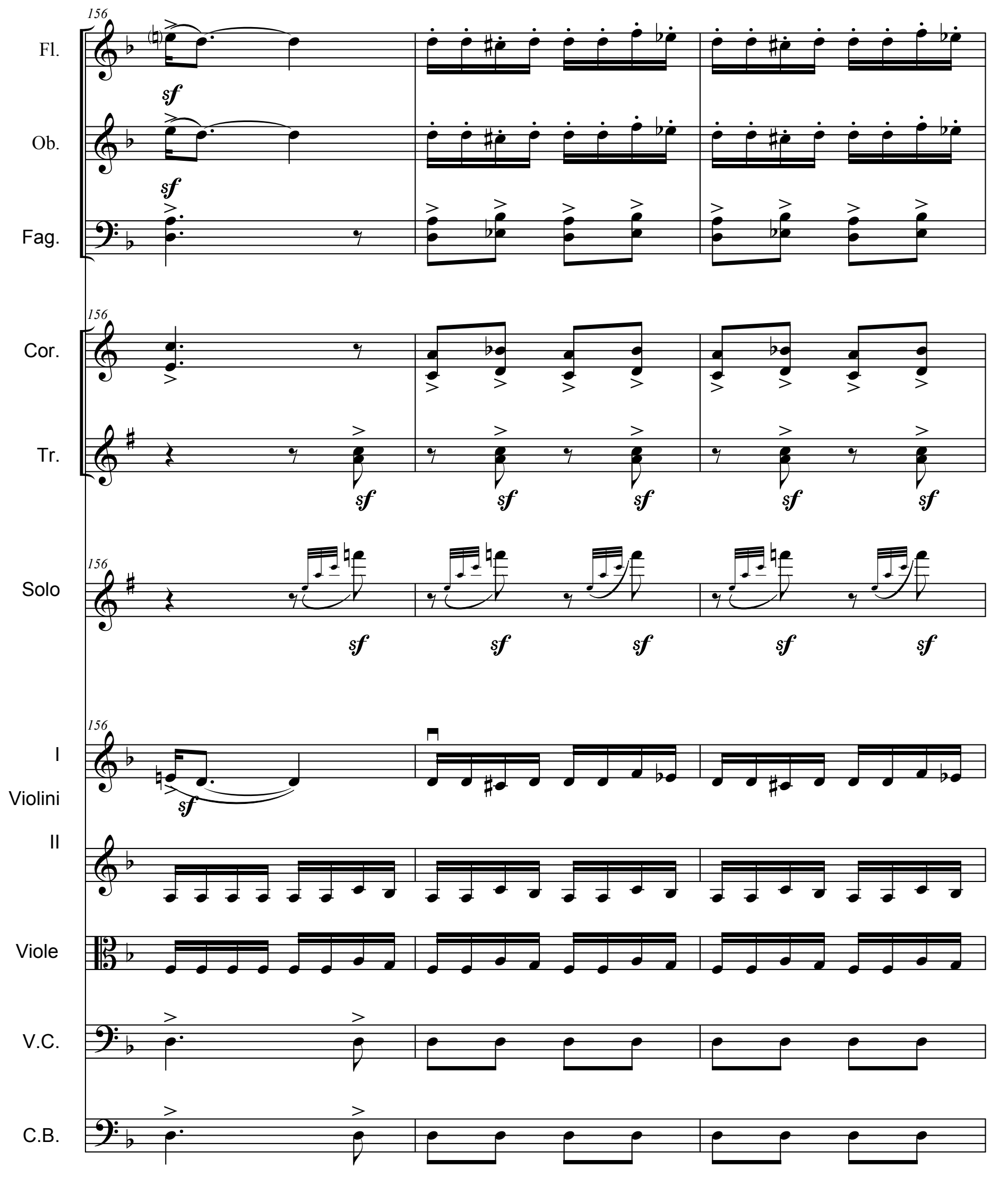




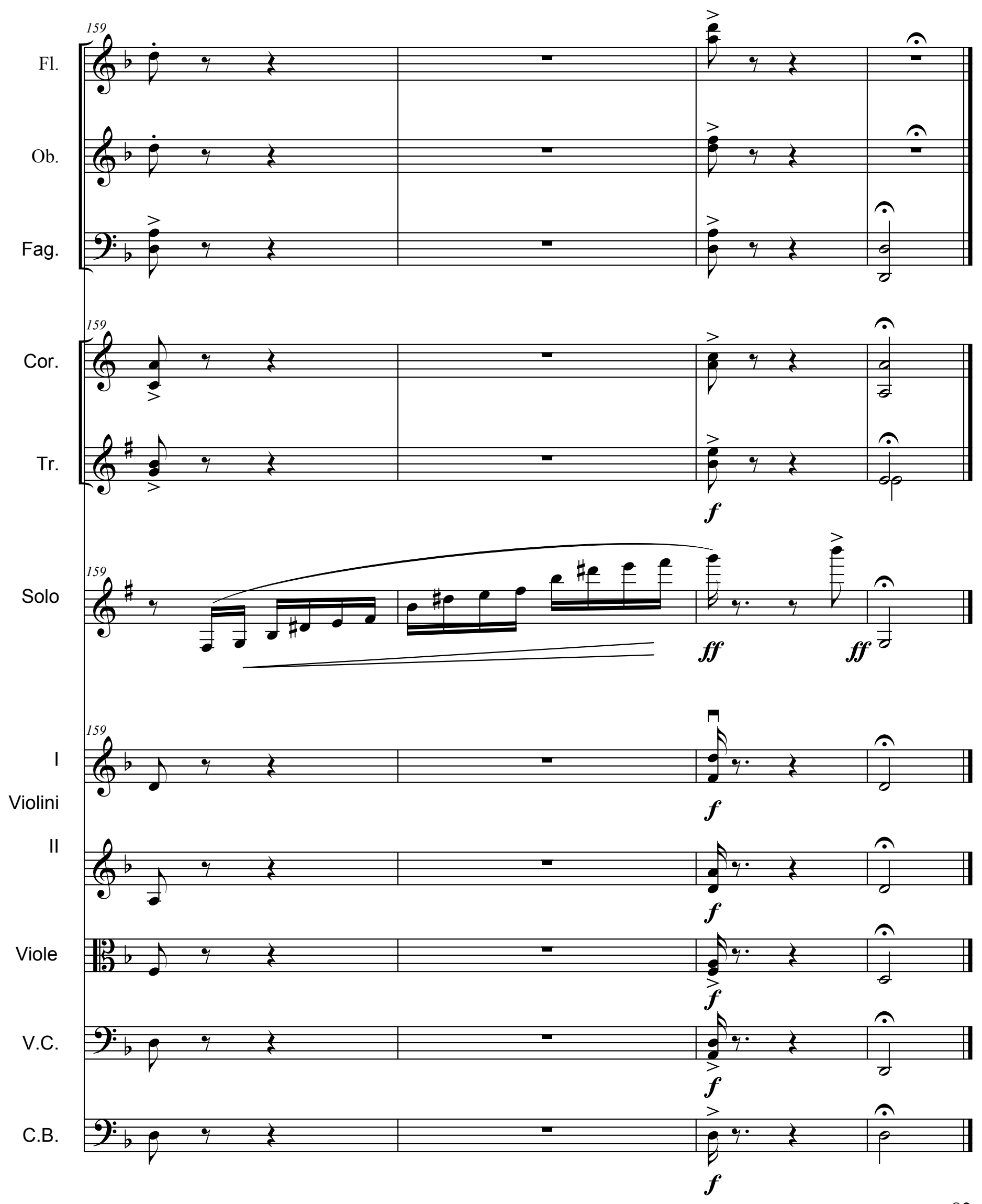

